Re-Assessing Green Building

Performance: A Post Occupancy

Evaluation of 22 GSA Buildings

KM Fowler

EM Rauch

JW Henderson

AR Kora

June 2010 - Published September 2011

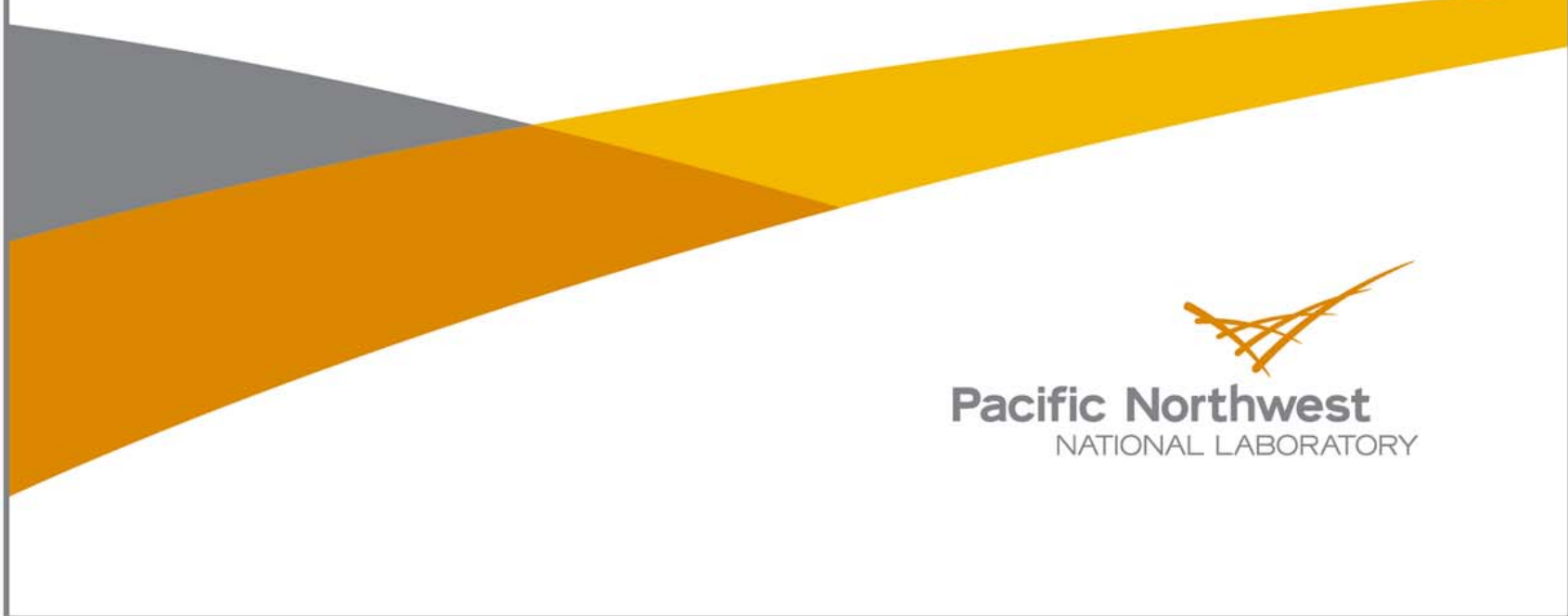




\title{
DISCLAIMER
}

This report was prepared as an account of work sponsored by an agency of the United States Government. Neither the United States Government nor any agency thereof, nor Battelle Memorial Institute, nor any of their employees, makes any warranty, express or implied, or assumes any legal liability or responsibility for the accuracy, completeness, or usefulness of any information, apparatus, product, or process disclosed, or represents that its use would not infringe privately owned rights. Reference herein to any specific commercial product, process, or service by trade name, trademark, manufacturer, or otherwise does not necessarily constitute or imply its endorsement, recommendation, or favoring by the United States Government or any agency thereof, or Battelle Memorial Institute. The views and opinions of authors expressed herein do not necessarily state or reflect those of the United States Government or any agency thereof.

\author{
PACIFIC NORTHWEST NATIONAL LABORATORY \\ operated by \\ BATTELLE MEMORIAL INSTITUTE \\ for the \\ UNITED STATES DEPARTMENT OF ENERGY \\ under Contract DE-AC05-76RL01830
}




\section{Re-Assessing Green Building Performance: A Post Occupancy Evaluation of 22 GSA Buildings}

Kim M. Fowler

Emily M. Rauch

Jordan W. Henderson

Angela R. Kora

June 2010 - Published September 2011

Prepared for the U.S. General Services Administration under Contract DE-AC05-76RLO1830 with Battelle Memorial Institute.

Pacific Northwest National Laboratory

Richland, Washington 99352 


\section{Acknowledgements}

This study was conducted under the direction of Kevin Powell with assistance from Don Horn, and Patricia Cheng of the U.S. General Services Administration, and Liz Exter, on assignment to GSA from Lawrence Berkeley National Laboratory (LBNL). Kim M. Fowler of the Pacific Northwest National Laboratory (PNNL) led the PNNL research team as the principal investigator of the study. Emily M. Rauch was co-author and the lead for the site visits, data collection and analysis. Jordan W. Henderson contributed significantly to the analysis effort and Angela Kora conducted two site visits and assisted in the analysis effort. Additional contributing PNNL staff include Steve Shankle (technical peer reviewer), Shannon Colson, Nathan Johnson, and Mike Perkins (graphics). John Goins and Nicole Walter from the Center for the Built Environment (CBE) were instrumental in administration of the survey.

Because of the need for a large quantity of data for each building, the GSA buildings' site contacts were generous with their time and data. The site contacts offered their time to host site visits, provided data for the building performance metrics, and promptly responded to our requests for clarification. Twenty-two of the buildings of the twenty-five pursued in this study lent themselves to assembling comparable data sets for analysis. The site contacts that helped make this study possible include the following (in alphabetical order)

Laura Anderson, Rockville FB

Paul Anderson, Davenport CT

Danielle Bogni, Las Vegas CT

Alex Bonaparte, Rockville FB

Jonathan Bringewatt, Lakewood FB

Jim Brown, Ogden FB

Gina Carter, Ogden FB

Steven Casey, San Francisco FB

Diana Ciryak, Cleveland CT

Chris Cockrill, Cape Girardeau CT, Manhattan FB

Pamela Coleman, Ogden FB

Scott Crews, Ogden FB

Mike Daniels, Rockville FB

Tim Essebaggers, Seattle CT

Dan Fenner, Sault Ste. Marie Port
John Garner, Omaha NPS FB and Omaha DHS FB

Christopher Grigsby, Denver CT

Angel Gonzalez, San Francisco FB

Richard Gordan, Auburn FB

Scott Hawkins, Greeneville CT and Knoxville FB

Sue Heeren, Davenport CT

Tina Hingorani, Santa Ana FB

Richard Hosey, Jacksonville FB

Jason Hunt, Fresno C'T \& FB

Nicholas Infantino, Youngstown CT \& FB

Mary Ann Kosmicki, Omaha NPS FB and Omaha DHS FB

Kristina Lee, Omaha NPS FB

Chris Litsey, Auburn FB, Eugene CT, Seattle CT 
Jill McCormick, Omaha DHS FB

Donald Murphy, Eugene CT

William Murphy, Auburn FB

Lorento Neequaye, Suitland FB

J. Michael Ortega, Denver CT

Peter Pocius, Sweetgrass Port

Sharon Schuler, Cape Girardeau CT

Wendy Schuman, Lakewood DOT FB

Warren Sitterley, San Francisco FB

Sandy Sitton, Fresno CT \& FB

C. Johnathan Sitzlar, Greeneville CT and Knoxville FB
Amy Smith, Denver FB

Don Smyth, Omaha NPS FB

Mark Stanford, Sweetgrass Port

Joni Teter, Denver FB

Tim Trubey, Manhattan FB

Steven Underhill, Las Vegas CT

Christopher Wentzell, Sweetgrass Port

Stephen West, Scowcroft FB

Ryan Wilcoxen, Denver FB

Bruce Williams, Las Vegas CT

Thank you to these and all others that contributed to this research effort. 


\section{Executive Summary}

The General Services Administration (GSA) sustainably designed buildings investigated under this study use less energy and water, cost less to maintain, and have occupants that are satisfied when compared to typical buildings. Additional findings from the building performance analysis include:

- Aggregate operations costs are 19\% lower than industry average

- Carbon dioxide equivalent emissions are 34\% lower than typical buildings

- U.S. Green Building Council Leadership in Energy and Environmental Design (LEED) Gold rated buildings generally perform better when compared to industry baselines.

Figure S1 represents the energy, water, and aggregate maintenance for each of the 22 buildings investigated. All of the Energy Star Portfolio Manager values were better than or equal to the industry baseline. Two-thirds of the water use intensity values (WUI, water use per gross square foot) and aggregate maintenance costs were better than the industry baseline. The buildings performing the best in all categories are located in the top right quadrant and have lighter colored circles.

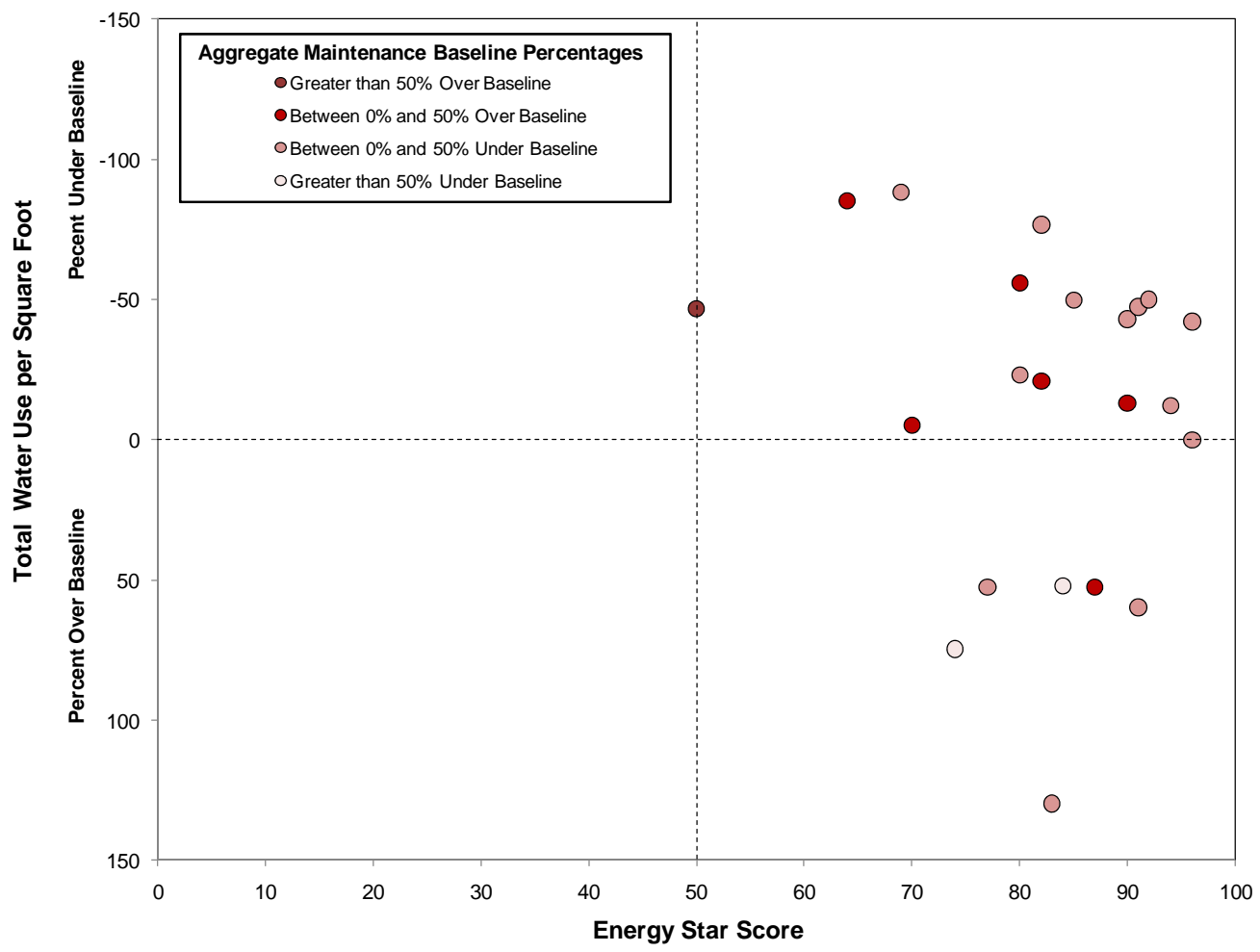

Figure S1. Energy performance is better than or equal to the baseline for all of the buildings, water performance and maintenance costs are better for two-thirds of the buildings. 
This whole building performance measurement study uses the data collected for Assessing Green Building Performance: A Post Occupancy Evaluation of 12 GSA Buildings, includes 10 additional buildings, and includes updated data for the original buildings set, resulting in measured building performance data for twenty-two GSA buildings, located in seven of its national regions (Figure S2). The intent of the analysis is to inform GSA on how its sustainably designed buildings are performing in comparison to industry and GSA baselines of typically designed buildings for energy, water, maintenance and operations, waste, recycling, occupant commute, and occupant satisfaction. Thirteen of the buildings are LEED-certified, three are LEED-registered, one won the International Facility Managers Award for Sustainable Design and Energy Efficiency, while another five buildings emphasized energy efficiency during design.

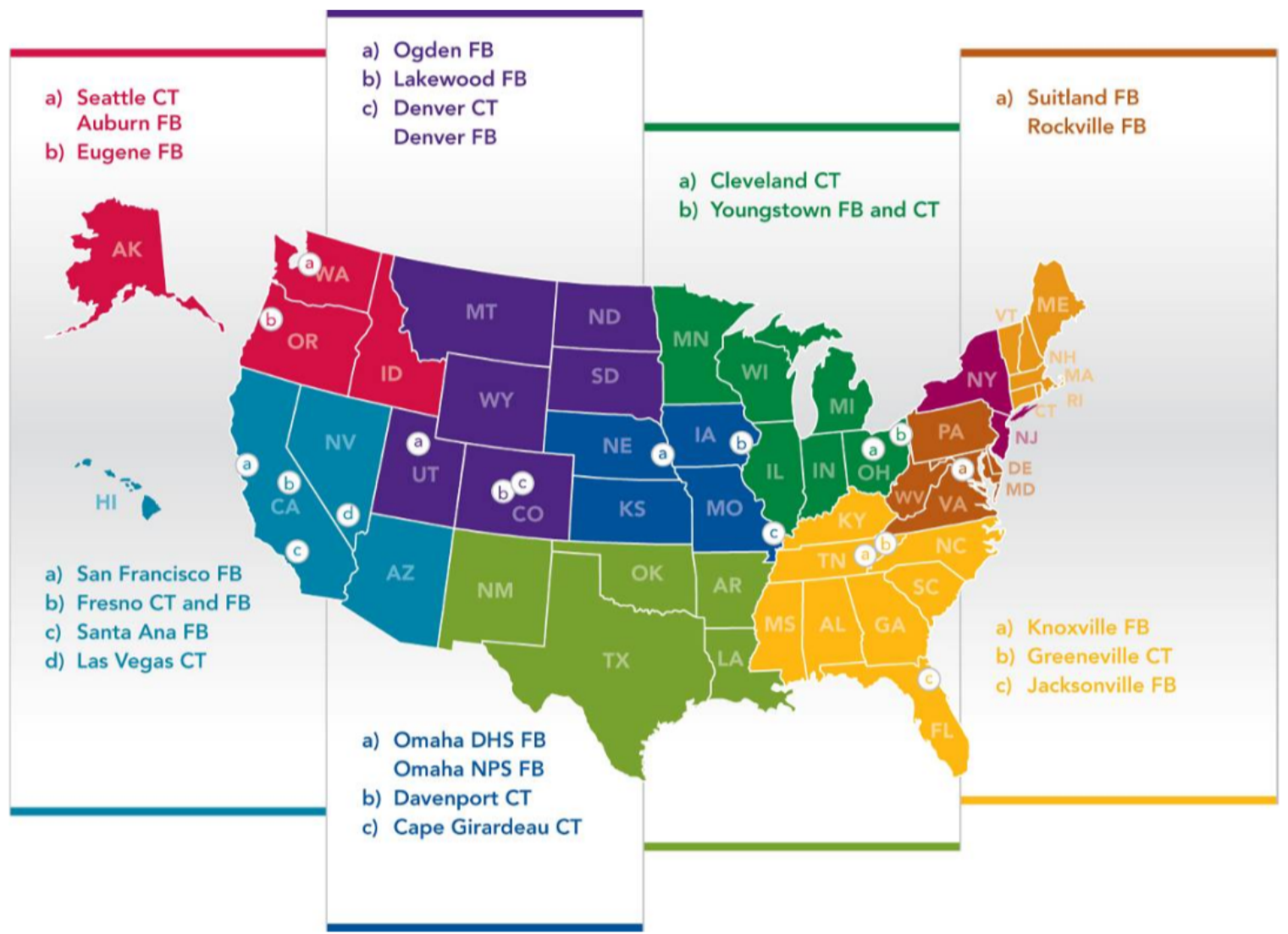

Figure S2. Twenty-two sustainably designed buildings from seven of the GSA regions are analyzed in this study.

As of the winter of 2009, GSA had 40 LEED-certified buildings. Many of these buildings are newly constructed and thus did not have performance data available for participation in the study. Although this study involved a small number of buildings, especially when considering the size of the GSA portfolio, it includes approximately one-third of GSA's LEED-certified buildings. LEED certification levels and Energy Star scores are shown in Table S1. If a building had received an official Energy Star rating, the score is in parentheses in the Certification Level column. The Energy Star Score column has unofficial scores 
calculated from the data provided by the sites. All of the buildings were at or above the $50^{\text {th }}$ percentile of the Energy Star Portfolio Manager database, and all but 4 of the buildings scored above the $75^{\text {th }}$ percentile, which means they could potentially qualify for an Energy Star rating.

Table S1. Documentation of "green-ness" of study buildings.

\begin{tabular}{|c|c|c|c|}
\hline Building Name & Certification Level & $\begin{array}{c}\text { LEED® } \\
\text { Total } \\
\text { Credits }\end{array}$ & $\begin{array}{c}\text { Energy } \\
\text { Star }{ }^{\circledR} \\
\text { Score }\end{array}$ \\
\hline Greeneville CT & Energy Star 2007 (89) & $\mathrm{N} / \mathrm{A}$ & 90 \\
\hline Jacksonville FB & Energy Star 2007 (88) & $\mathrm{N} / \mathrm{A}$ & 82 \\
\hline Knoxville FB & LEED-EB Certified, Energy Star 2007 (88) & 28 & 90 \\
\hline Cleveland CT & LEED-NC Certified & 29 & 69 \\
\hline Youngstown CT \& FB & LEED-NC Certified & 27 & 50 \\
\hline Cape Girardeau CT & LEED-NC Silver & 33 & 64 \\
\hline Davenport CT & LEED-NC Registered & $\mathrm{N} / \mathrm{A}$ & 80 \\
\hline Omaha DHS (L) FB & LEED-NC Gold & 42 & 74 \\
\hline Omaha NPS (L) FB & LEED-NC Gold & 40 & 82 \\
\hline Denver CT & Green Building Challenge, LEED-EB Silver & 33 & 70 \\
\hline Denver (L) FB & LEED-NC Gold, Energy Star 2008 (96) & 40 & 94 \\
\hline Lakewood (L) FB & LEED-NC Silver & 35 & 84 \\
\hline Ogden (L) FB & LEED-NC Silver & 34 & 83 \\
\hline Fresno CT \& FB & California Energy Standard Title 24 & $\mathrm{~N} / \mathrm{A}$ & 87 \\
\hline Las Vegas CT & Energy Star 2007 (77) & $\mathrm{N} / \mathrm{A}$ & 77 \\
\hline San Francisco FB & LEED-NC Silver & 34 & 96 \\
\hline Santa Ana FB & California Energy Standard Title 24 & $\mathrm{~N} / \mathrm{A}$ & 91 \\
\hline Auburn FB & LEED-NC Silver & 36 & 96 \\
\hline Eugene CT & LEED-NC Gold, Energy Star 2009 (94) & 39 & 92 \\
\hline Seattle CT & IFMA Sustainable Design and Energy Efficiency Award & $\mathrm{N} / \mathrm{A}$ & 85 \\
\hline Rockville (L) FB & LEED-NC Registered (Silver), Energy Star 2009 (76) & 33 & 80 \\
\hline Suitland FB & LEED-NC Registered (Gold) & 41 & 91 \\
\hline
\end{tabular}

Table Notes

FB is the abbreviation used for Federal Buildings

$\mathrm{CT}$ is the abbreviation used for Courthouses

(L) identifies the leased buildings

LEED-NC is LEED for New Construction and Major Renovations and EB is for Existing Buildings 
Performance metrics collected, normalized, and analyzed for the buildings include

- Water

- Energy

- Maintenance and operations

- Waste generation and recycling

- Occupant satisfaction

- Occupant commute.

These performance metrics were chosen to evaluate the intent of sustainable design reduced environmental impact while keeping operational costs low and occupant satisfaction high.

Building contacts provided utility bills, maintenance budgets and schedules, and supported the administration of an occupant survey. Twelve consecutive months of data were collected for each performance metric and the data were normalized using building and site characteristics. The performance data were compared to industry baselines developed from GSA building data, the U.S. Department of Energy, U.S. Environmental Protection Agency, International Facility Management Association, Building Owners and Managers Association International, University of California Berkeley's Center for the Built Environment, and the Energy Information Administration. 


\section{Aggregate Operational Cost is Lower than Baseline}

The "aggregate operating cost" metric includes water utilities, energy utilities, general maintenance, grounds maintenance, waste and recycling, and janitorial costs. On average the study buildings have an aggregate operational cost 19\% lower than the baseline. Four of the five buildings that cost more than the baseline in Figure S3 have higher general maintenance costs and two have higher energy costs.

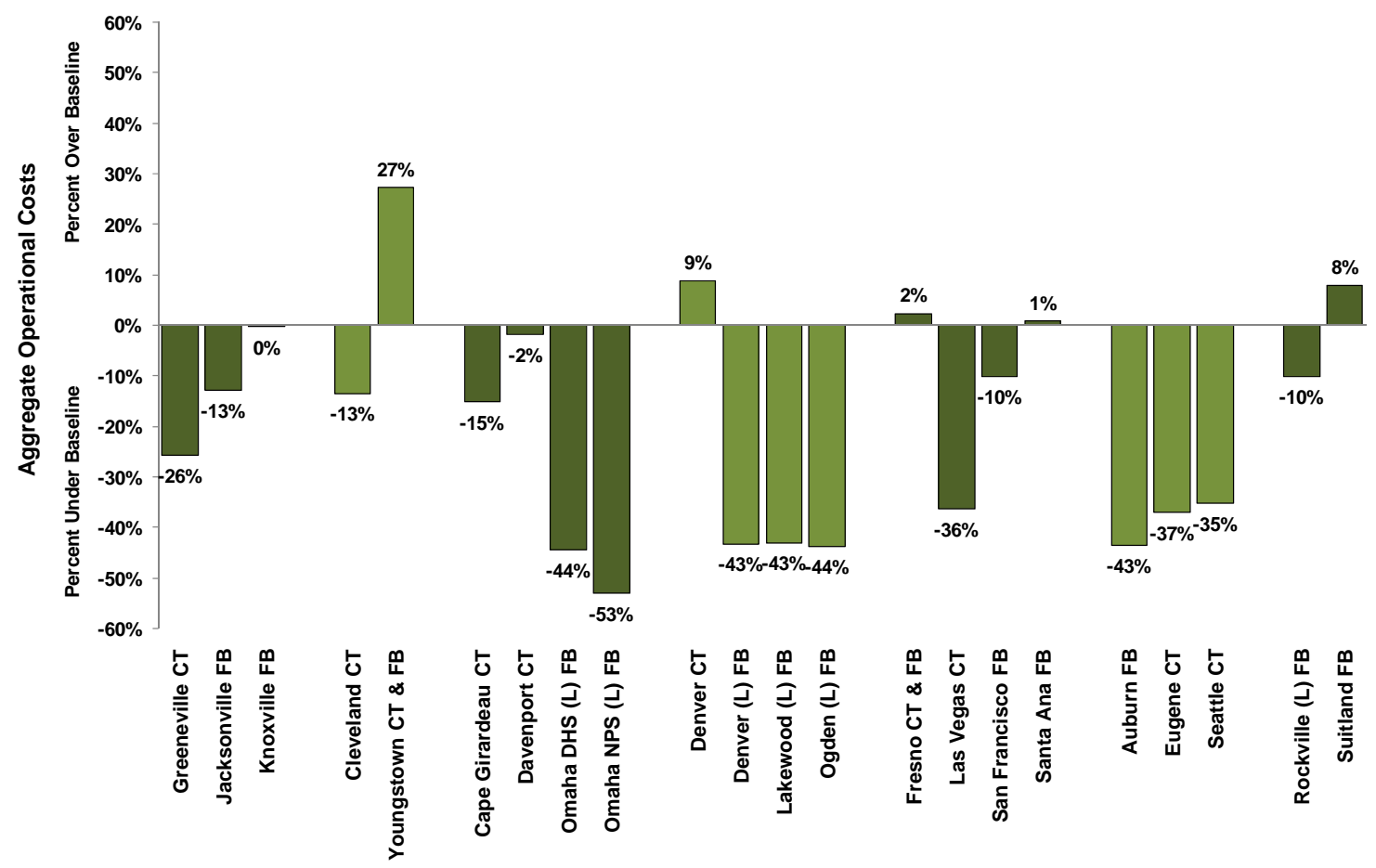

Figure S3. Aggregate operational costs are lower for most buildings.

Three different types of maintenance data were collected: general, janitorial, and grounds. Considering the calculated GSA 'general maintenance' cost baseline, half of the buildings cost less to maintain than the baseline. The janitorial maintenance costs were higher than the GSA baseline for more than half of the buildings. The grounds maintenance was within or below the normal industry baseline range for all but one building. 


\section{Energy Performance is Better than Baseline}

The buildings' energy use intensity (EUI) was compared to multiple different baselines (Figure S4), with the most commonly referenced baseline being the Commercial Building Energy Consumption Survey (CBECS) average EUI for office buildings. The energy performance average of the buildings in the study was 25\% better than CBECS, $10 \%$ better than fiscal year 2009 GSA Regional Averages, 13\% better than fiscal year 2009 GSA Target values, and 18\% better than CBECS regional averages. The CBECS national average is for office buildings built from 1990-2003, while the regional averages are for all building types. The GSA Target is the Public Buildings Service goal for energy performance across the agency.

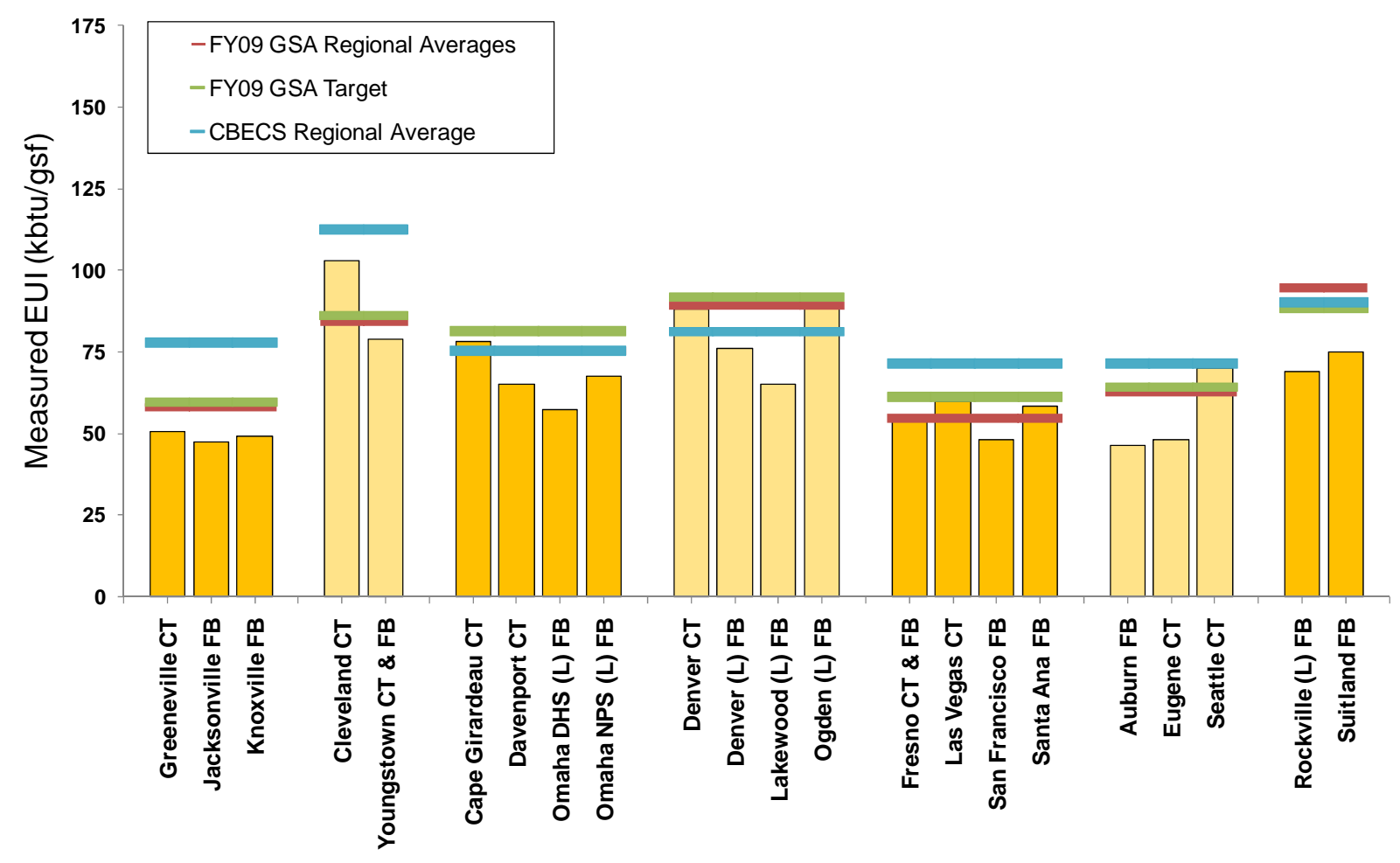

Figure S4. Energy performance of GSA buildings is strong when compared to industry averages. 


\section{Water Use is Lower than Baseline}

GSA's metric for assessing the water use of its buildings is water use per gross square foot (WUI). This metric offers a simple way to compare building water use and shows that twothirds of the buildings in this study use less water than the GSA baseline (Figure S5) with the average water use $11 \%$ below the baseline. Of the six buildings using more water than the baseline, all but one of them has cooling towers or evaporative cooling, two have exterior fountains in a hot, dry climate, and three have non-typical operating schedules.

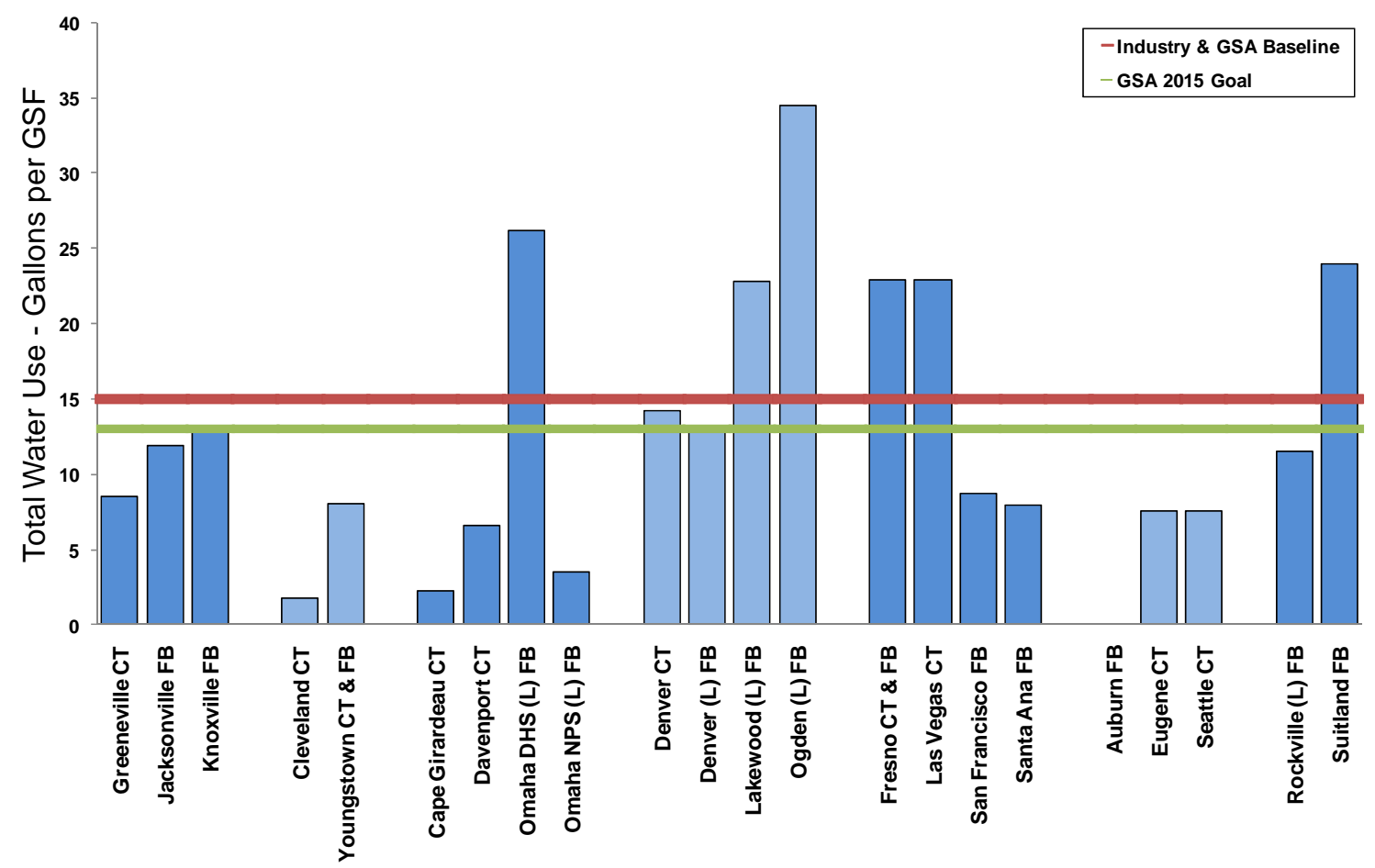

Figure S5. Two-thirds of the GSA buildings use less water than the GSA baseline.

As with energy, there are multiple baselines with which the buildings' water use can be analyzed. The water cost per rentable square foot is within or below the typical baseline range for all but one building. In the first assessment of GSA buildings the water use was analyzed as the quantity of domestic water use and the number of building occupants and visitors. This metric was examined however the comparison was erratic because of the variety of water uses in the buildings, with most buildings using more than the calculated baseline. 


\section{Occupants are Satisfied with the Buildings}

The Center for the Built Environment (CBE) indoor environmental quality survey was tailored for the study participants with the addition of a few questions, and is referred to as the Sustainable Places and Organizational Trends (SPOT) survey. The core CBE survey has been given to the occupants of over 500 buildings, which offers a valuable baseline for comparing occupant satisfaction scores. Figure S6 shows the average scores from the SPOT survey were higher than the average scores in the CBE database, except for Lighting questions where the average survey responses were essentially the same. When compared to the LEED certified buildings in the CBE database, the SPOT survey responses were better for all questions except for air quality.

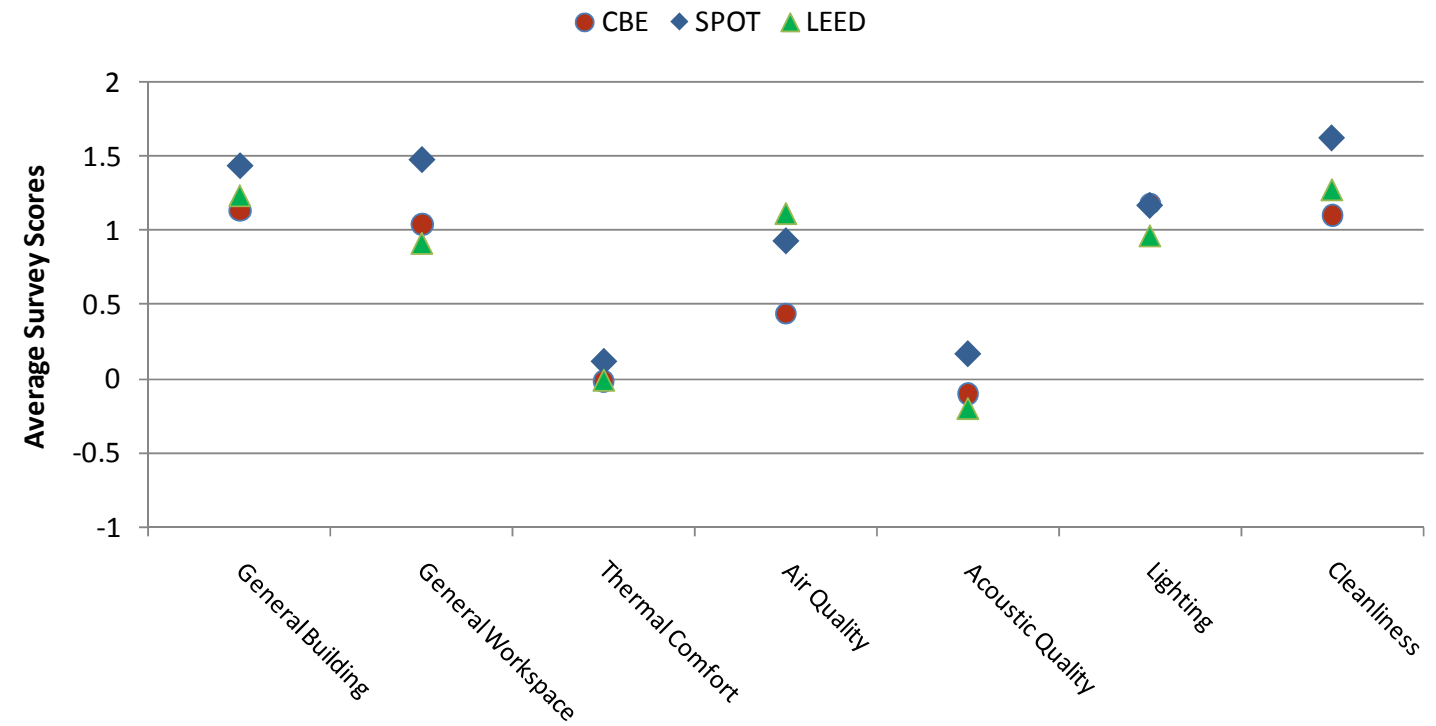

Figure S6. On average, the study building occupants are more satisfied with the buildings than those in the CBE database.

The average survey response rate was $47 \%$. All of the general building satisfaction scores are positive, however, five are below the $\mathrm{CBE}$ database $50^{\text {th }}$ percentile (i.e., below average). The average general building satisfaction levels are $27 \%$ higher than the $\mathrm{CBE}$ database $50^{\text {th }}$ percentile (Figure S7).

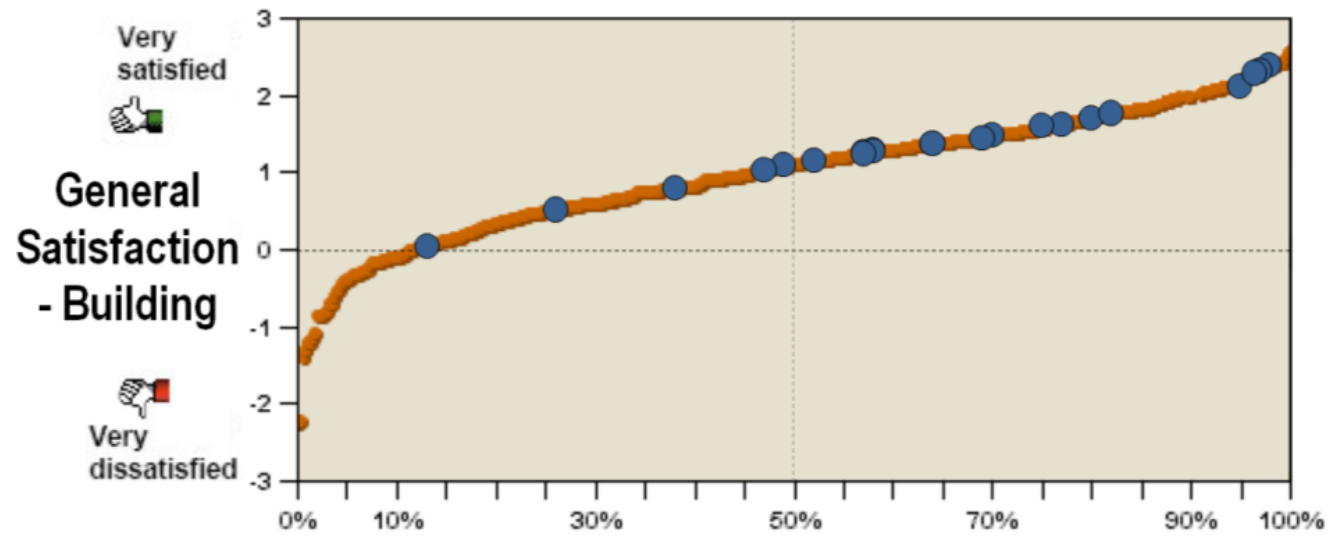

Figure S7. GSA building occupants are satisfied with their buildings overall. 


\section{Buildings and Occupants Contribute Less to Global Climate Change}

Based on the occupant response to SPOT survey commute questions, the emissions from identified transportation modes result in 29\% lower average carbon dioxide equivalent emissions when compared to the average commute (Figure S8). This could be the result of federal agency commute policies, building location, community culture, or sustainable design related decisions, such as preferred parking for carpools and alternative vehicles, showers and bike racks, or intentionally locating a building near mass-transit options.

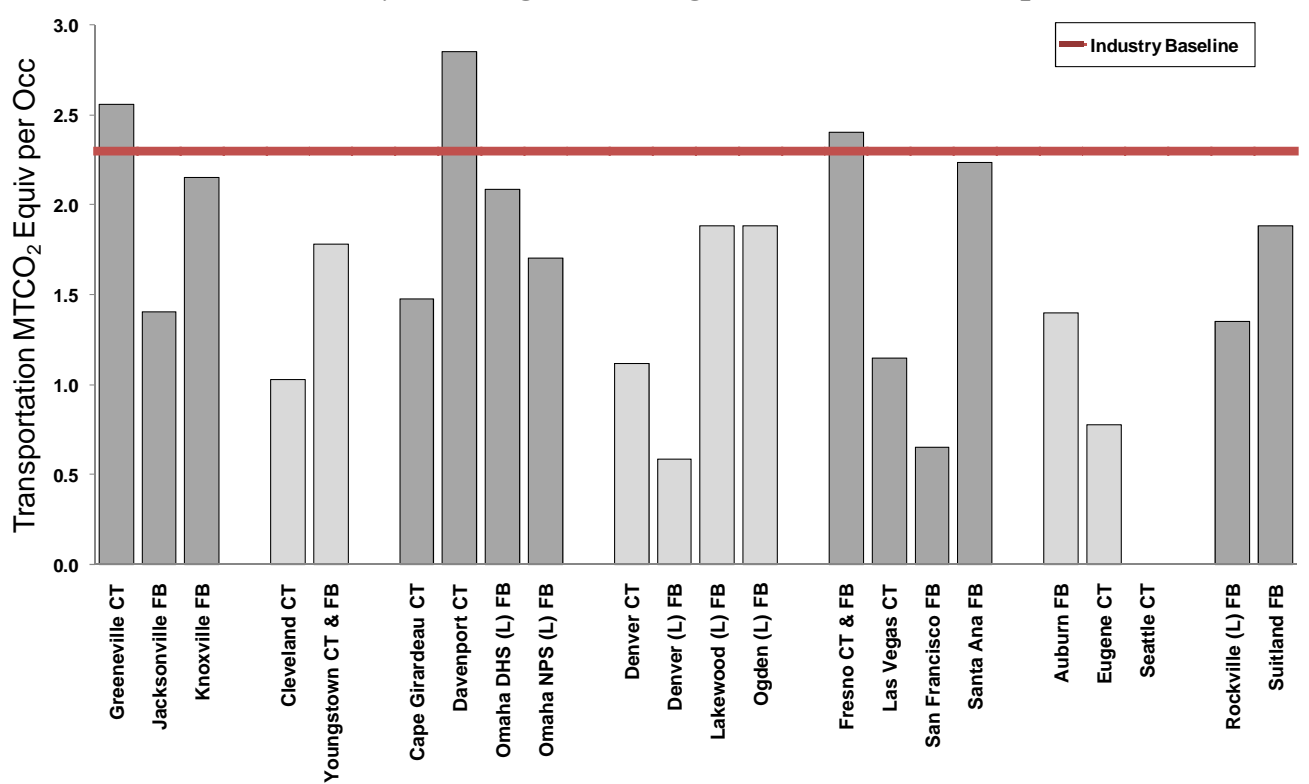

Figure S8. Lower emissions as a result of building occupant commute for most buildings.

Combining the emissions avoided from the occupant commute and the building energy performance shows that the average is $34 \%$ lower carbon dioxide-equivalent emissions than a typical building (Figure S9).

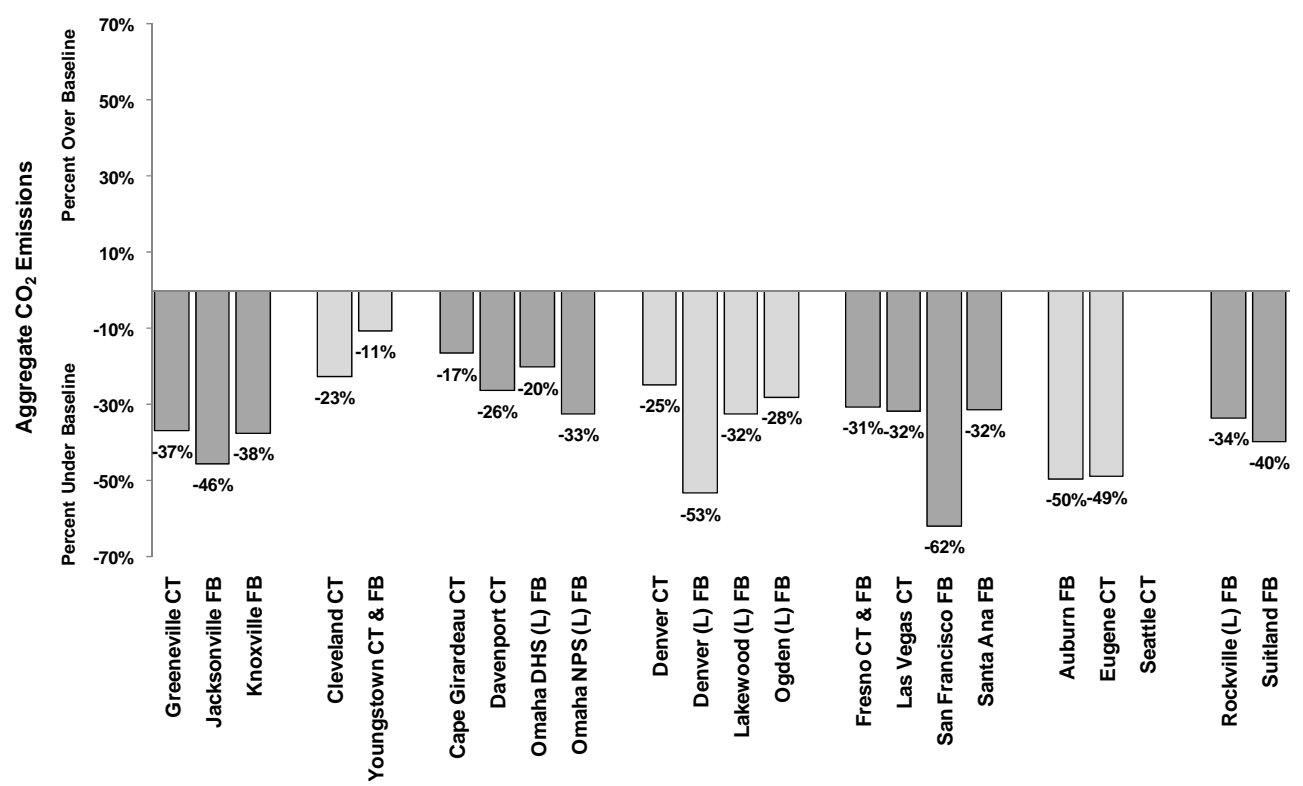

Figure S9. Emissions as a result of building energy performance and occupant commute. 


\section{LEED Gold Buildings are Top Performers}

Figure S10 shows that overall the four LEED Gold buildings in the study performed better than the industry baselines. Water use for the Omaha DHS building is not only higher than the industry baseline, but also significantly higher than it was during the first assessment of this building. This change in water use should be investigated to understand if it is a data measurement error, a leak, an unintended use, or an increase in the building occupant related water use. The waste to recycle ratio is worse than the industry baseline for both of the Omaha buildings as well.

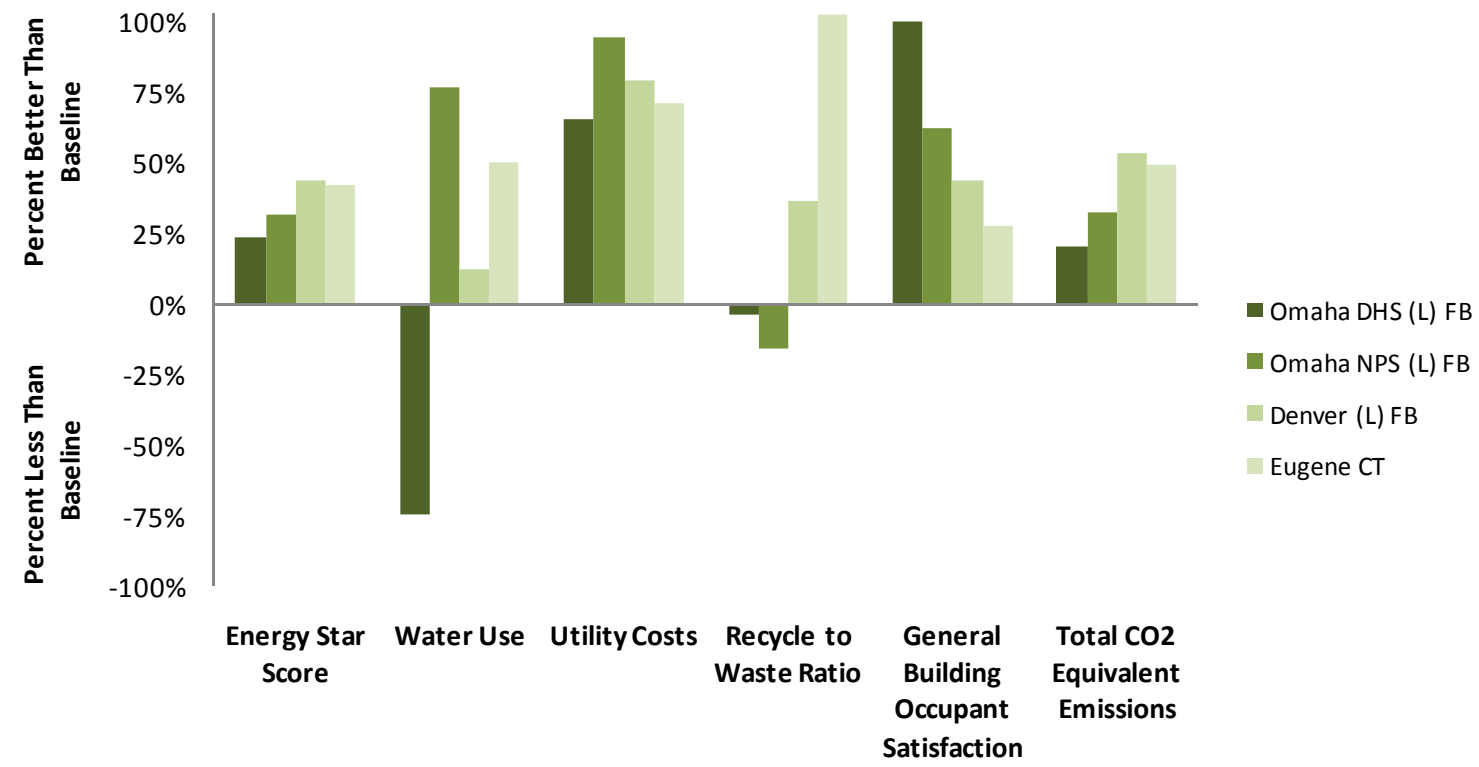

Figure S10. LEED Gold buildings show exceptional performance on all of the key performance metrics.

\section{Baselines and Operations Make a Difference}

One of the more important lessons learned with respect to whole building performance measurement and assessment is that the baselines selected for performance comparison are what define the study findings. When agency specific baselines are available, they offer a comparison of how a building meets an agency's expectations, but they make the assessment results less comparable to the general building industry. For this study GSA baselines were used whenever they were made available, however, industry baselines are also provided in order to offer another basis for comparison. 


\section{Do Sustainably Designed Buildings Perform Better?}

The results from this study of 22 buildings are generally consistent with the findings from the original study of 12 buildings. For individual buildings the response to the question "Do sustainably designed buildings perform better when compared to an industry average?" is still "it depends." The results from this study should not be assumed to represent all sustainably designed buildings. When examining the average performance values for buildings the in this study, the aggregate operational costs are 19\% lower, the energy performance is $25 \%$ better, and water performance is $11 \%$ better than comparable baselines. The LEED Gold buildings are performing well and the carbon emissions associated with the buildings are significantly lower than an average building. Given this portfolio analysis of building performance, it appears the sustainably designed buildings in the GSA portfolio are performing well and helping GSA to meet its mandated goals for reduced environmental impact.

The whole building performance measurement method used in this and the previous GSA study offers a replicable tool for assessing building performance. This portfolio analysis of 22 buildings offers an indicative assessment of building performance, identifying major strengths and weaknesses. When a diagnostic type of analysis is needed for a particular building, a detailed post occupancy evaluation or re-commissioning report may be needed to provide the necessary information on why a building is operating in a particular way. 


\section{Acronyms}

ASHRAE American Society of Heating, Refrigerating, and Air-Conditioning Engineers

BOMA Building Owners and Managers Association International

Btu British thermal unit

CBE Center for the Built Environment

CBECS Commercial Buildings Energy Consumption Survey

$\mathrm{CO}_{2} \quad$ Carbon dioxide

CT courthouse

DHS Department of Homeland Security

DOE U.S. Department of Energy

EAc1 Energy and Atmosphere Credit 1 (Optimize Energy Performance)

EMCS Energy Management Control System

EUAS Energy Usage and Analysis System

EUI energy use intensity

FB federal building

FEDS Federal Energy Decision System

FEMP Federal Energy Management Program

$\mathrm{ft}^{2} \quad$ square feet

$\mathrm{ft}^{3} \quad$ cubic feet

FY fiscal year

GSA General Services Administration

gsf or GSF gross square feet

HVAC heating, ventilation, and air-conditioning

IAQ indoor air quality

IEQ indoor environmental quality

IFMA International Facility Management Association

kBtu one thousand British thermal units

kw kilowatt

kwh kilowatt hour

L leased facilities

LBNL Lawrence Berkeley National Laboratory

LEED Leadership in Energy and Environmental Design

LEED-EB LEED for Existing Buildings

LEED-NC LEED for New Construction and Major Renovations

$\mathrm{mBtu} \quad$ one million British thermal units

$\mathrm{MTCO}_{2} \mathrm{e}$ metric tons carbon dioxide equivalent

N/A not available

NPS National Park Service

NREL National Renewable Energy Laboratory

O\&M operations and maintenance

Occ occupants

PBS Public Buildings Service 
PNNL Pacific Northwest National Laboratory

POE Post Occupancy Evaluation

R1 Round 1

rsf or RSF rentable square feet

SVOC semivolatile organic compound

SPOT Sustainable Places and Organizational Trends (survey)

UFAD Under floor air distribution

U.S. United States

Vis visitors

VOC volatile organic compound

WBPM whole building performance measurement

WEc3 Water Efficiency credit 3 (Water Use Reduction)

WUI water use intensity 


\section{Contents}

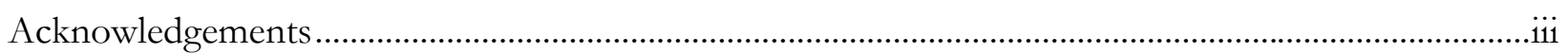

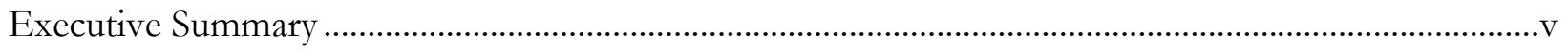

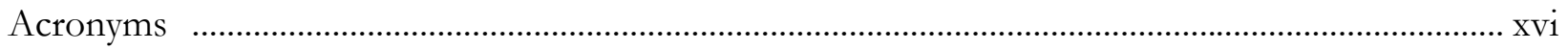

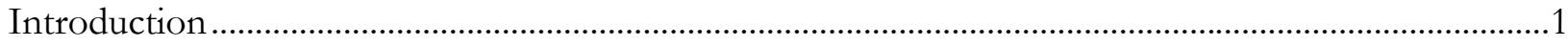

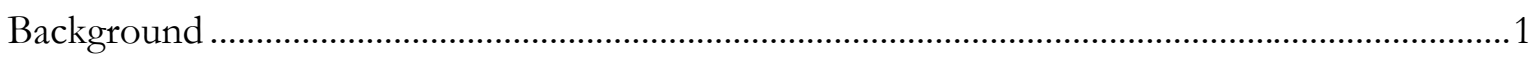

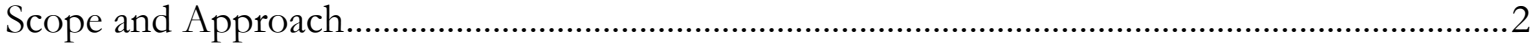

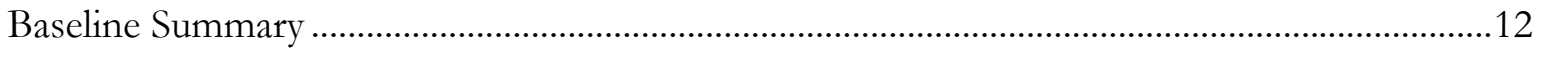

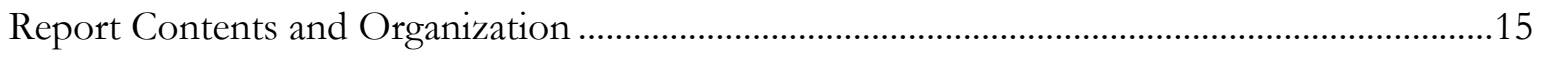

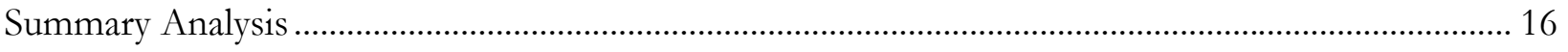

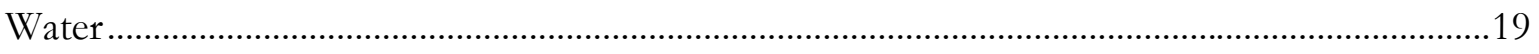

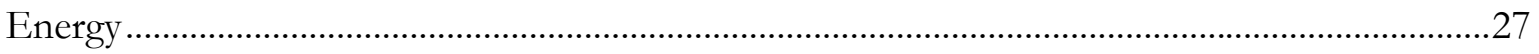

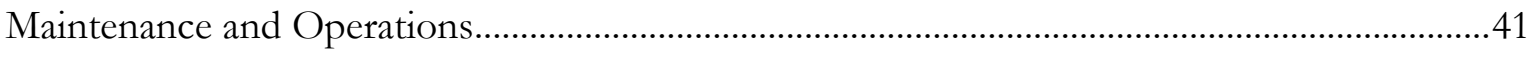

Waste Generation and Recycling ..............................................................................................50

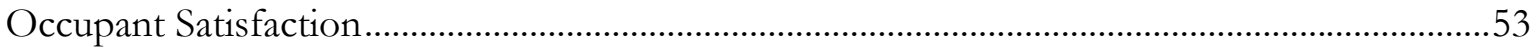

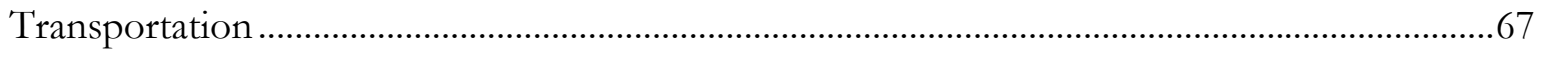

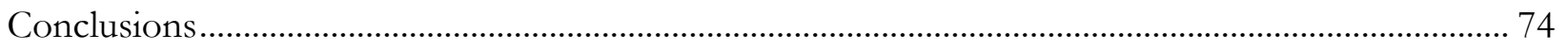

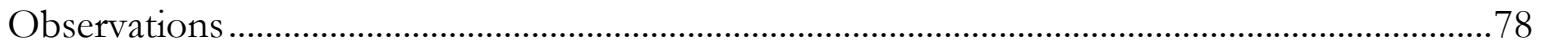

Lessons Learned and Future Research Opportunities ................................................................82

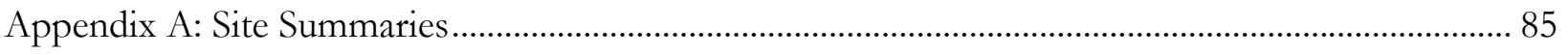

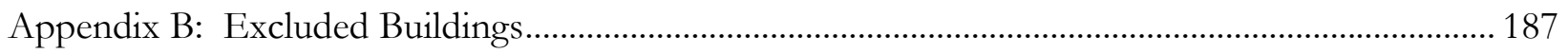

General Building Information .......................................................................................... 187

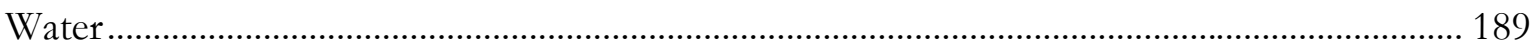

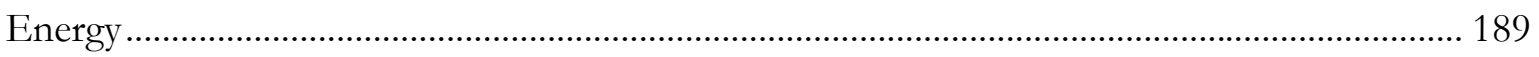

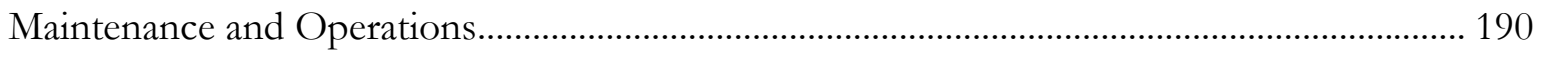

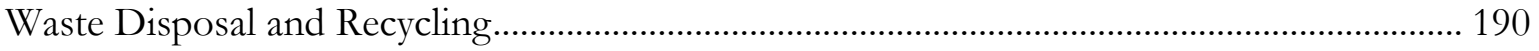

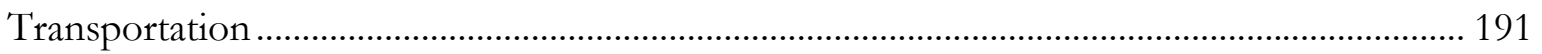

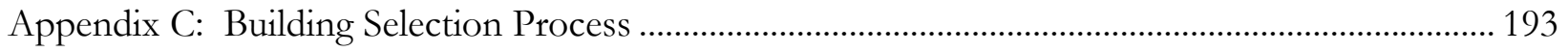

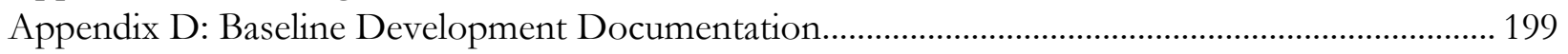

Occupant-Visitor Equivalent Calculations ………………………………………………….... 199

Water Baseline Calculations........................................................................................................ 201

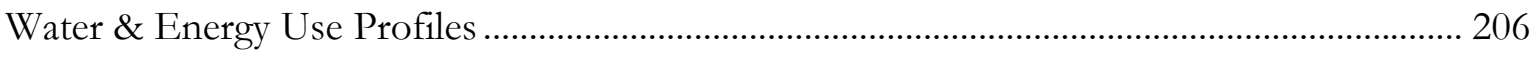

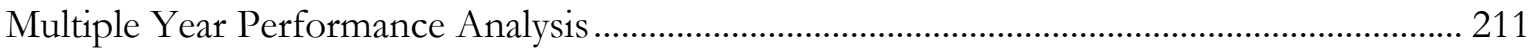

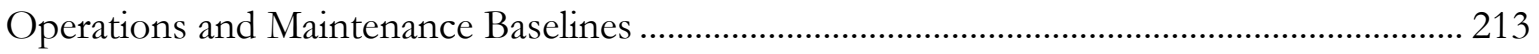

Operational Costs Baselines ……………………………………………………………..... 216

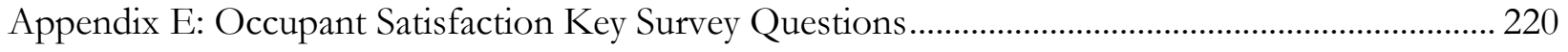

Appendix F: GSA Customer Satisfaction Survey .............................................................................. 232

Appendix G: Indoor Environmental Quality Assessment for Denver Federal Building................... 233

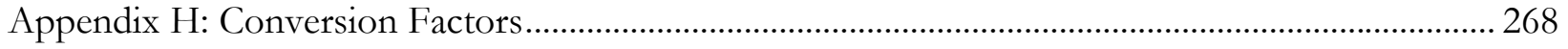

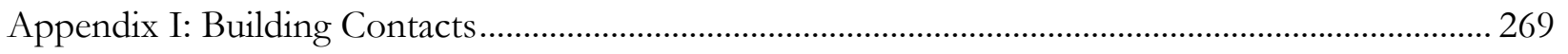

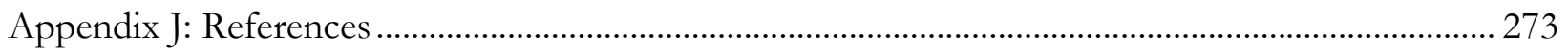




\section{Figures}

Figure S1. Energy performance is better than or equal to the baseline for all of the buildings, water performance and maintenance costs are better for two-thirds of the buildings V

Figure S2. Twenty-two sustainably designed buildings from seven of the GSA regions are analyzed in this study ..........................................................................................................

Figure S3. Aggregate operational costs are lower for most of buildings .............................................ix

Figure S4. Energy performance of GSA buildings is strong when compared to industry

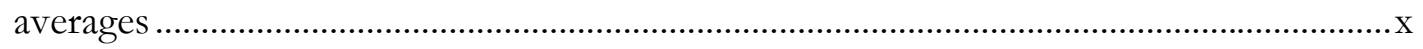

Figure S5. Two-thirds of the GSA buildings use less water than the GSA baseline.............................

Figure S6. On average, the study building occupants are more satisfied with the buildings than the occupants in the CBE database ................................................................................

Figure S7. GSA building occupants are satisfied with their building overall ........................................ii

Figure S8. Lower emissions as a result of building occupant commute for most buildings ..............xiii Figure S9. Emissions as a result of building energy performance and occupant commute ..............xiii

Figure S10. LEED Gold buildings show exceptional performance on all of the key performance metrics ........................................................................................................

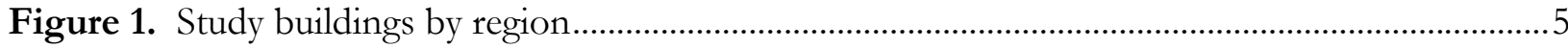

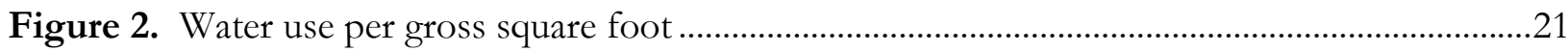

Figure 3. Water cost per rentable square foot compared to industry baseline...................................22

Figure 4. Water use per occupant compared to the water use baseline ...............................................24

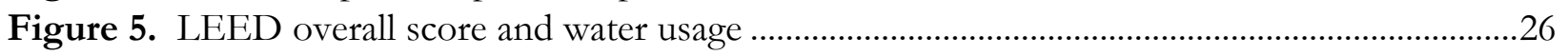

Figure 6. LEED WEc3 points and water usage .................................................................................26

Figure 7. Energy Star rating compared to energy intensity ...............................................................29

Figure 8. Study building EUIs compared to the GSA national average and CBECS national

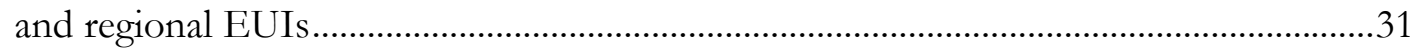

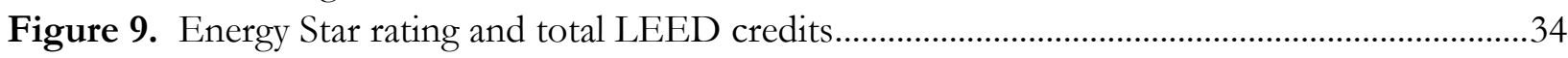

Figure 10. Energy Star rating and LEED energy credits ..................................................................34

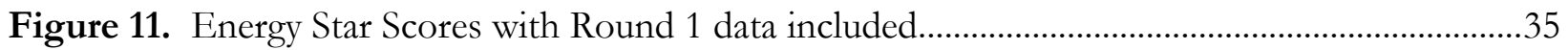

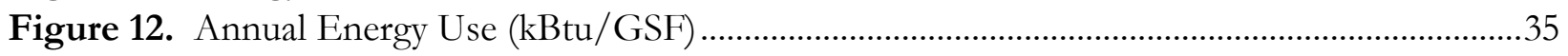

Figure 13. Energy Star score and water use per GSF performance ….................................................36

Figure 14. Energy Star score and thermal comfort with UFAD ..........................................................37

Figure 15. Energy cost per gross square foot ....................................................................................38

Figure 16. $\mathrm{CO}_{2}$ equivalents compared to Energy Star baseline ...............................................................40

Figure 17. General maintenance cost per rentable square foot ..........................................................42

Figure 18. General maintenance data source comparison................................................................43

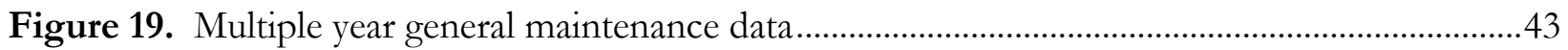

Figure 20. Grounds maintenance cost per rentable square foot .........................................................4

Figure 21. Janitorial cost per rentable square foot............................................................................

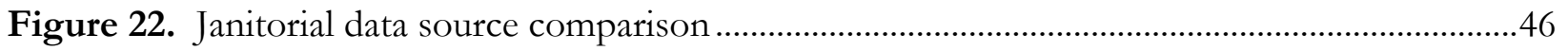

Figure 23. Multiple year janitorial maintenance cost data .......................................................................46 
Figure 24. Aggregate maintenance cost comparison.

Figure 25. Janitorial cost per rentable square foot and cleaning satisfaction compared with

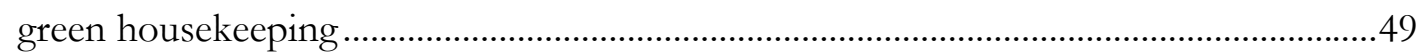

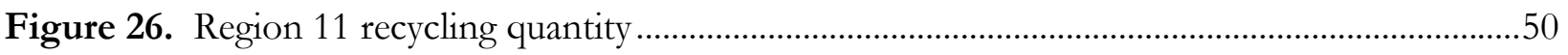

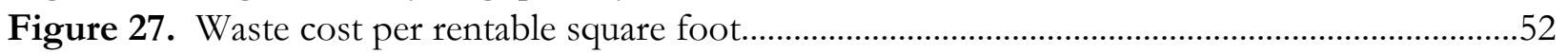

Figure 28. Region 11 recycling cost per rentable square foot...............................................................52

Figure 29. Acoustic quality rating from the occupant survey .............................................................56

Figure 30. Acoustics quality satisfaction scores for cubicle workspaces ..............................................57

Figure 31. Photographs of cubicle workspaces...................................................................................5

Figure 32. Air quality rating from the occupant survey …..............................................................58

Figure 33. Cleanliness and maintenance rating from the occupant survey..........................................59

Figure 34. Lighting quality rating from the occupant survey ...............................................................60

Figure 35. Windows and daylight satisfaction rating from the occupant survey …............................61

Figure 36. Thermal comfort rating from the occupant survey ........................................................62

Figure 37. General workplace satisfaction rating from the occupant survey ....................................63

Figure 38. Communication satisfaction rating from the occupant survey ..........................................64

Figure 39. General building satisfaction rating from the occupant survey .........................................65

Figure 40. Study building occupants are more satisfied than the building occupants in the

CBE database ................................................................................................................66

Figure 41. Occupant commute $\mathrm{CO}_{2}$ equivalent emissions compared to the baseline.......................68

Figure 42. Average commute distance and community size .................................................................69

Figure 43. $\mathrm{CO}_{2}$ equivalent emissions by community size ................................................................70

Figure 44. Aggregate $\mathrm{CO}_{2}$ equivalent emissions compared to the baseline........................................73

Figure 45. Aggregate operational costs compared to the baseline .......................................................76

Figure 46. LEED Gold building baseline comparisons ......................................................................78

Figure 47. Thermal comfort compared to Energy Star Score and maintenance costs .......................79

Figure 48. Lighting satisfaction percentile compared to Energy Star score and maintenance

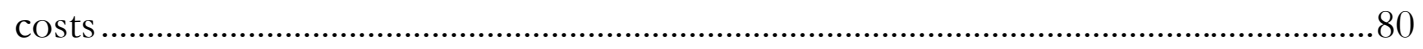

Figure 49. WUI compared to Energy Star Score and aggregate maintenance costs .........................8 81 


\section{Tables}

Table S1. Documentation of "green-ness" Scores of study buildings .................................................vii

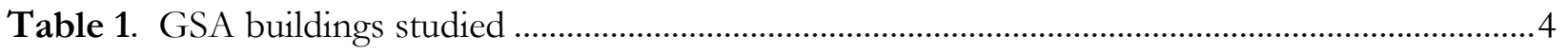

Table 2. Building and site characteristics metrics .............................................................................. 10

Table 3. Whole building performance metrics ......................................................................................11

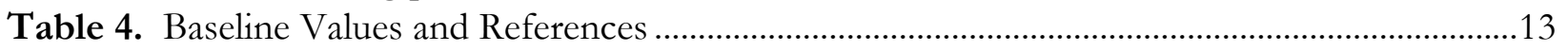

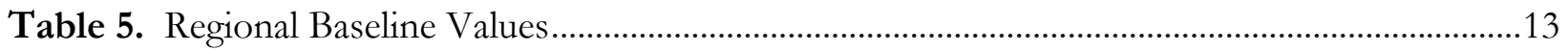

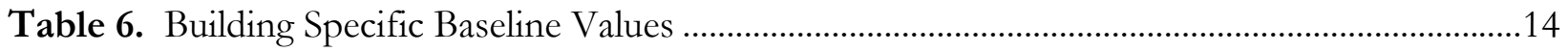

Table 7. Key building and site characteristics....................................................................................17

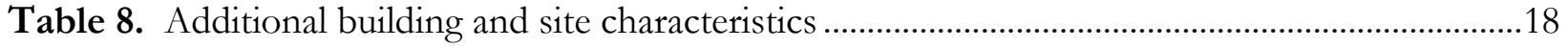

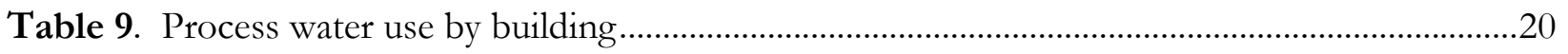

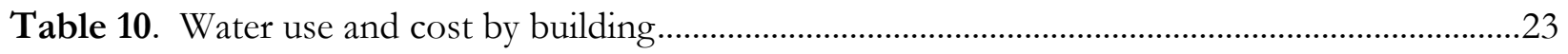

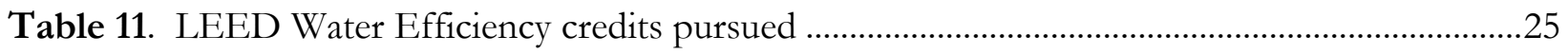

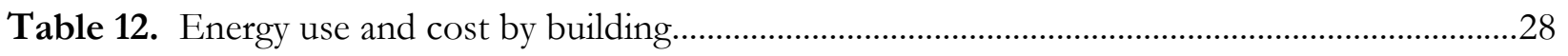

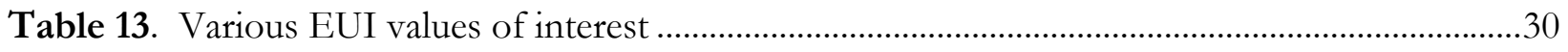

Table 14. "Green" design certification by building ................................................................................32

Table 15. LEED Energy and Atmosphere Credits pursued.....................................................................33

Table 16. Energy use, cost and $\mathrm{CO}_{2}$ equivalent performance ….........................................................39

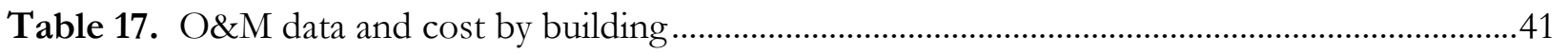

Table 18. Maintenance cost performance against baselines.................................................................47

Table 19. Waste generation and recycling data and cost by building ....................................................51

Table 20. SPOT Survey scores ranked against CBE database ..........................................................55

Table 21. Transportation data by building ..........................................................................................67

Table 22. Population density and commute distance by building .....................................................71

Table 23. Aggregate CO2 equivalent emissions for transportation and building ...............................72

Table 24. Annual costs and total project cost by building ..................................................................74

Table 25. Summary values for each performance metric .................................................................75

Table 26. Summary performance for study buildings portfolio ...........................................................77 


\section{Introduction}

The U.S. General Services Administration (GSA) has been applying sustainable design principles to its building design projects since 1999. In 2003, GSA set its target for certification at the Silver level of the U.S. Green Building Council's (USGBC) Leadership in Energy and Environmental Design for New Construction $\left(\right.$ LEED $\left.^{\circledR}-\mathrm{NC}\right)$ green building rating system for new building design starts. In 2007, GSA evaluated the performance of a dozen sustainably designed buildings with the results documented in Assessing Green Building Performance: A Post Occupancy Evaluation of 12 GSA Buildings. ${ }^{1}$ This is an updated study that involves the analysis of an additional ten GSA buildings for a total of 22 to determine the potential benefits and challenges of sustainably designed buildings.

GSA engaged several key stakeholders, including its own representatives, a research team from Pacific Northwest National Laboratory (PNNL), the University of California Berkeley's Center for the Built Environment (CBE), and site building managers and engineers to measure whole building performance in order to evaluate how well GSA's sustainably designed buildings are performing compared to industry norms and GSA comparative baselines. In contrast to LEED-NC, which is focused on the design of new construction projects; "whole building performance measurement" (WBPM) assesses how well sustainably designed buildings are actually operating. Thus, the primary intent of this WBPM study is to demonstrate the impact of investing in sustainably designed buildings, thereby enabling GSA to better document how its buildings are performing compared to a variety of building performance baselines. Ideally, the information derived from this study will be used to inform the design, construction, and operation of GSA's building portfolio.

\section{Background}

GSA buildings are typically built for a 100-year life and follow robust guidelines to enhance their asset value. The federal government owns or leases approximately 725 million square feet of office space and employs 2.7 million workers.
USGBC membership developed the $\mathrm{LEED}^{\circledR}$ green building rating system to provide a system for defining "green buildings." The rating system is organized by five aspects of building design

- Sustainable Sites

- Water Efficiency

- Energy \& Atmosphere

- Materials \& Resources, and

- Indoor Environmental Quality. LEED ratings can be achieved for new construction and major renovation (LEED-NC), existing buildings (LEEDEB), and several other building products.

Points are earned for meeting the intent of specific design criterion in each of the above categories. A LEED rating is awarded based on the total number of points earned by a building design. Prior to LEED version 3.0, LEED-NC had a total of 69 possible points and LEEDEB had a total of 85 points. LEED version 3.0 has a 110 point scale. The Buildings are rated, depending on the number of points as

- Certified

- Silver

- Gold

- Platinum 
GSA houses 1.1 million workers in 354 million square feet of office space (45\% of federal government space). ${ }^{2}$ Of the more than 4,000 LEED certified projects, $29 \%$ are owned by federal, state, or local governments. ${ }^{3}$

It is commonly recognized that a whole building, integrated design approach is essential to creating a sustainable or green building design. This design is assumed to result in optimal building performance based upon the product and equipment specifications. Several studies have documented the projected benefits of sustainably designed buildings. ${ }^{4,5,6,7,8}$ Often these studies projected savings based on design intent or measured performance of a single metric, such as occupant productivity. The measured whole building performance of sustainably designed buildings has rarely been documented. To fully measure the operational impact of sustainably designed buildings, multiple occupant and operational measures, more than energy use, need to be considered.

Although energy modeling of a building's performance is a very useful tool during the design process, it does not always accurately predict how a building will perform. Studies have shown that although modeled data can predict average, relative performance, the models do not consistently predict actual performance of an individual building. ${ }^{9,10}$ The National Renewable Energy Laboratory (NREL) technical reports have highlighted that building energy models assume the buildings will function under ideal operating conditions, which results in measured building performance being different and typically higher than modeled energy use. NREL also estimates that when an energy simulation is calibrated to the as-built design, weather, and current operating conditions, it would generally be within $12 \%$ of the measured performance. This is one reason why more measured performance data are needed to better predict the performance of design strategies, rather than design simulations.

In 2007 the New Buildings Institute led a study focused on energy performance in LEED buildings. ${ }^{11}$ This study noted that the energy performance for individual projects is highly variable and more building performance data need to be gathered and analyzed to compare design performance with design intent. It also documented that the energy performance of LEED-NC buildings in their study performed 24\% better than the Commercial Buildings Energy Consumption Survey (CBECS) average for all commercial building stock and 33\% better than the CBECS average for office buildings. ${ }^{12}$

\section{Scope and Approach}

The scope of this WBPM study is to evaluate the impact of GSA's sustainably designed buildings by collecting and analyzing actual performance data from operating buildings for comparison to industry baselines for building performance. As study collaborators, the PNNL research team was responsible for data collection, data management, data synthesis, analysis, and report development. The GSA representatives provided building and site contacts, building data derived from existing GSA systems—-such as the Energy Usage and Analysis System (EUAS), the Asset Business Plan, and Project Information Portal-and coordinated the completion of the study's version of the CBE survey to assess occupants' 
satisfaction with their buildings (also known as GSA's Sustainable Places and Organizational Trends [SPOT] survey). The CBE team was responsible for preparing, distributing, and summarizing the data from the SPOT building occupant satisfaction survey. The building managers and engineers hosted the site visit(s), provided data as requested, and deployed the SPOT survey. The quantity and quality of data were enhanced by the engagement of multiple stakeholders.

As of the end of 2009, GSA had 40 LEED-certified buildings that were either leased or owned. ${ }^{13}$ At the start of this project in the summer of 2009, there were 34 GSA LEED certified projects with many those having recently been occupied. The selection criteria for the buildings in the study included the following

- Buildings built or remodeled in the last 10 years that included sustainable design or energy efficiency as a key design consideration.

- Ability to collect a minimum of 12 months of operations data, at least 6 months after the building occupancy date and from timeframe when the building is operating without major deficiencies.

- Data availability of calendar year 2008 performance data for the key performance metrics.

- Occupants' willingness to participate in the SPOT survey.

- Building performance comparability considerations, which included

o selecting GSA building types (office and courthouse) that align with commercial building industry baselines

o co-location of buildings by region

o building ownership - leased or owned.

Using the above criteria helped to narrow the GSA portfolio of buildings to a list of 10 additional buildings for this update and 22 overall.

- $\quad$ eight are courthouses

- twelve are federal buildings

- two are courthouses and federal buildings

Three buildings were visited and performance measurement data were collected before it was understood that they did not meet all of the above criteria. Those buildings included two port of entry facilities and one federal building. The two port of entry facilities did not have comparable commercial building baselines. The federal office building was experiencing notable equipment problems that needed to be addressed before performance measurement would offer a comparable story. Site summaries for all of the buildings can be found in Appendix A. Additional detail on the excluded buildings can be found in Appendix B. A list of the buildings considered for this round of WBPM and why there were not included in the study can be found in Appendix C. 
The buildings included in the report are listed in Table 1. Throughout the report the buildings are organized by region, then alphabetically. Federal buildings (FB) are typical office buildings. For the most part, courthouses (CT), include bankruptcy and criminal courtrooms and related offices. The combined courthouse and federal building (CT \& FB) type includes significant courtroom space and significant typical office space. Six of the buildings are leased facilities, and the rest are GSA-owned.

Table 1. GSA buildings studied

\begin{tabular}{|c|c|c|}
\hline Building Type & Building Full Name & Abbreviation \\
\hline \multicolumn{3}{|l|}{ Region 4} \\
\hline Courthouse & James H. Quillen U.S. Courthouse & Greeneville CT \\
\hline Federal Building & Chas. E. Bennett Federal Building & Jacksonville FB \\
\hline Federal Building & John J. Duncan Federal Building & Knoxville FB \\
\hline \multicolumn{3}{|l|}{ Region 5} \\
\hline Courthouse & Howard M. Metzenbaum U.S. Courthouse & Cleveland CT \\
\hline Courthouse \& Federal Building & Nathaniel R. Jones Federal Building and U.S. Courthouse & Youngstown CT \& FB \\
\hline \multicolumn{3}{|c|}{ Region 6} \\
\hline Courthouse & Rush H. Limbaugh U.S. Courthouse & Cape Girardeau CT \\
\hline Courthouse & Davenport U.S. Courthouse & Davenport CT \\
\hline Federal Building & DHS Citizenship \& Immigration Services & Omaha DHS (L) FB \\
\hline Federal Building & Carl T. Curtis NPS Midwest Regional Headquarters & Omaha NPS (L) FB \\
\hline \multicolumn{3}{|l|}{ Region 8} \\
\hline Courthouse & "Alfred A. Arraj U.S. Courthouse & Denver CT \\
\hline Federal Building & EPA Region 8 Headquarters & Denver (L) FB \\
\hline Federal Building & DOT Colorado Field Office & Lakewood (L) FB \\
\hline Federal Building & Scowcroft IRS Utah Field Office & Ogden $(\mathrm{L}) \mathrm{FB}$ \\
\hline \multicolumn{3}{|l|}{ Region 9} \\
\hline Courthouse \& Federal Building & Robert E. Coyle U.S. Courthouse and Federal Building & Fresno CT \& FB \\
\hline Courthouse & Lloyd D. George U.S. Courthouse & Las Vegas CT \\
\hline Federal Building & San Francisco Federal Building & San Francisco FB \\
\hline Federal Building & Santa Ana Federal Building & Santa Ana FB \\
\hline \multicolumn{3}{|l|}{ Region 10} \\
\hline Federal Building & $\begin{array}{l}\text { Auburn SSA Teleservice Center } \\
\end{array}$ & Auburn FB \\
\hline Courthouse & Wayne L. Morse U.S. Courthouse & Eugene CT \\
\hline Courthouse & New Seattle U.S. Courthouse & Seattle CT \\
\hline \multicolumn{3}{|l|}{ Region 11} \\
\hline Federal Building & SAMSHA Metropolitan Service Center & Rockville (L) FB \\
\hline Federal Building & Census Bureau Office Complex & Suitland FB \\
\hline
\end{tabular}


The buildings were located in seven different GSA regions (Figure 1)

- three in the Southeast Region 4

- two in the Great Lakes Region 5

- four in the Heartland Region 6

- four in the Rocky Mountain Region 8

- four in the Pacific Region 9

- three in the Northwest/Arctic Region 10

- two in the National Capital Region 11.

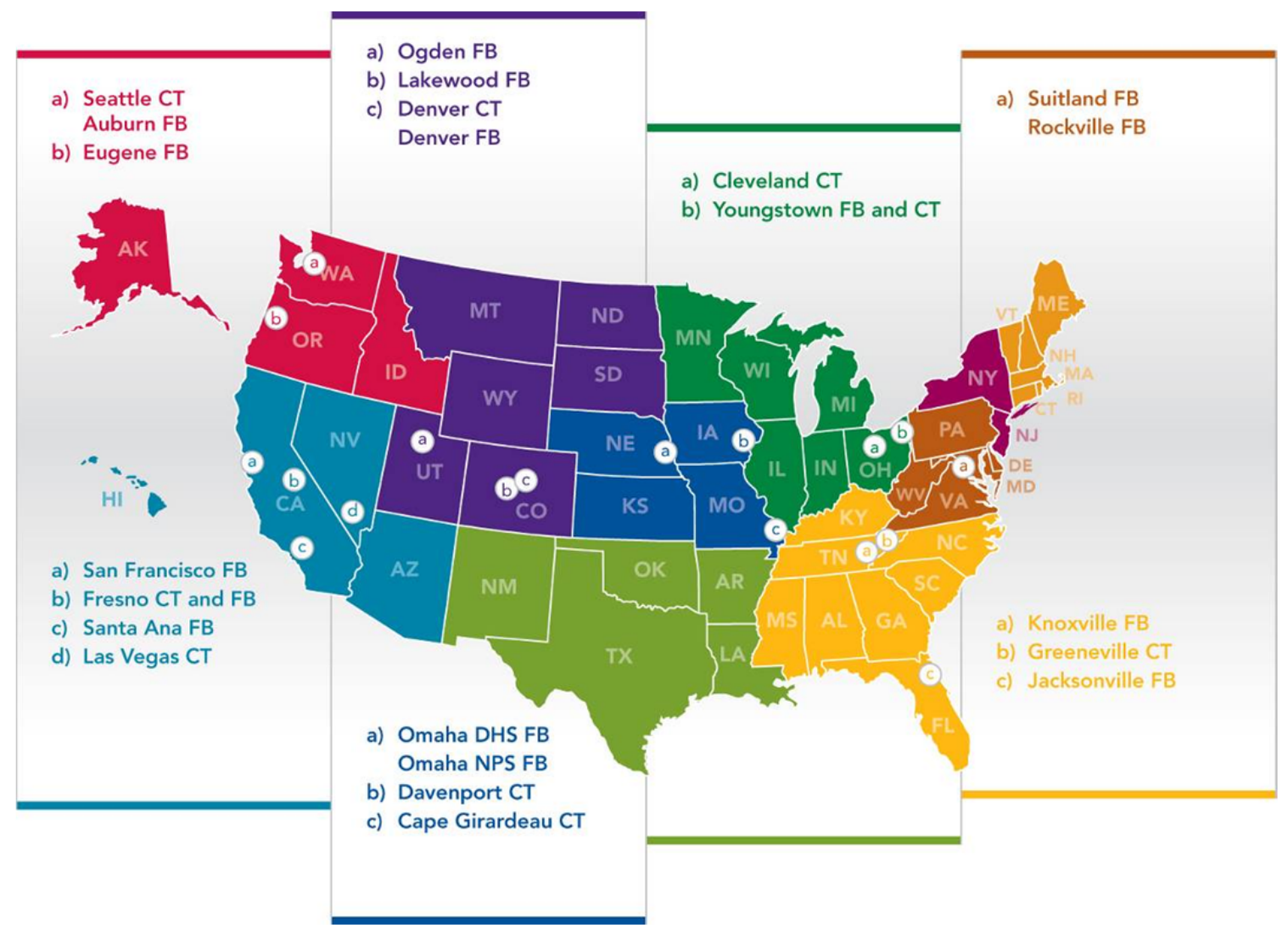

Figure 1. Study buildings by region

Many of these buildings have won sustainable design related awards, thirteen of the buildings are U.S. Green Building Council LEED-certified buildings, three are LEED registered, one won the International Facility Managers Award for Sustainable Design and Energy Efficiency, and five buildings emphasized energy efficiency during design. It is assumed GSA design expectations have resulted in a number of undocumented sustainably designed buildings. Given the number of GSA owned or leased LEED-certified buildings, LEED offers the most consistent way to track sustainably designed buildings within the agency. Brief descriptions of the buildings can be found on the next few pages. 


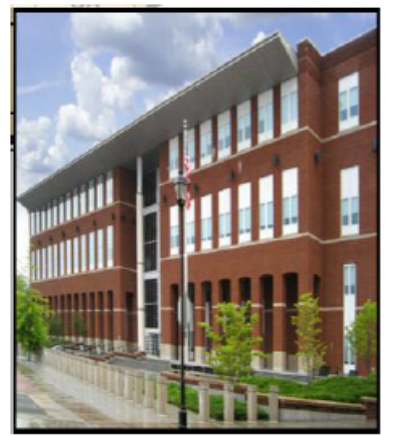

Year Built: 2001

GSF: 160,975

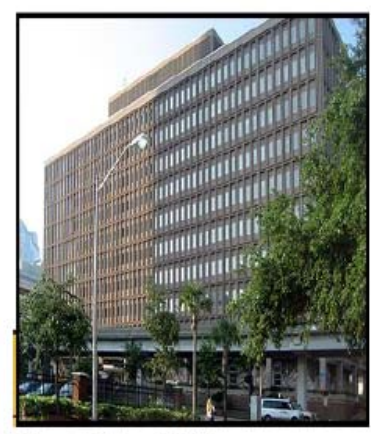

Year Built: 1967

Year Renovated: 2004

GSF: 338,008

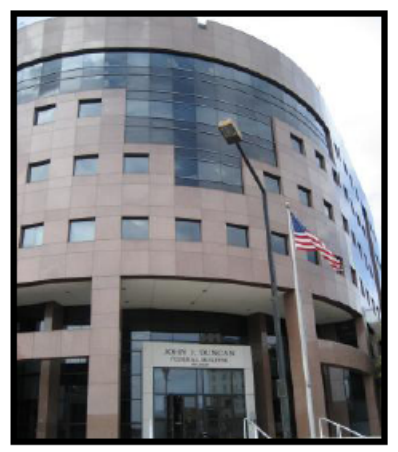

Year Built: 1986

Year Renovated: 2005

GSF: 172,684
Greeneville CT

The Quillen Courthouse replaced a smaller courthouse, from which the occupants reclaimed quality historic furniture. Some of the energyefficiency features in the building include a wellinsulated white roof and EMCS of lighting and occupancy sensors.

\section{Jacksonville FB}

Renovations to the federal building in downtown improved the function and occupant satisfaction. The building earned an Energy Star rating in 2007 and incorporates high efficiency lighting, and recycled materials in the interior.

Knoxville FB

Located in downtown, the federal building currently houses a range of services. Alterations include enhanced metering techniques, and a rainwater system. The roof reduces the heat island effect, as well as housing photovoltaic panels.

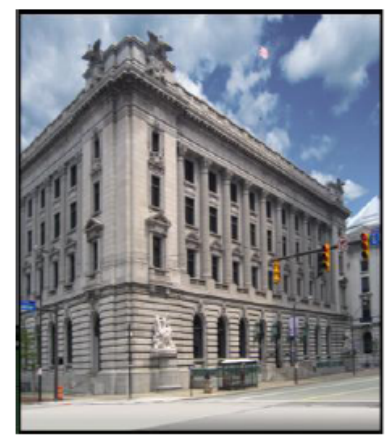

Year Built: 1910

Year Renovated: 2005

GSF: 251,314

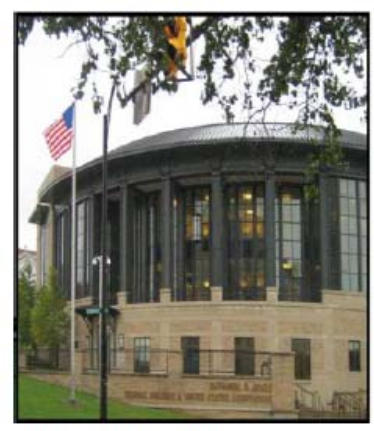

Year Built: 2002

GSF: 52,240

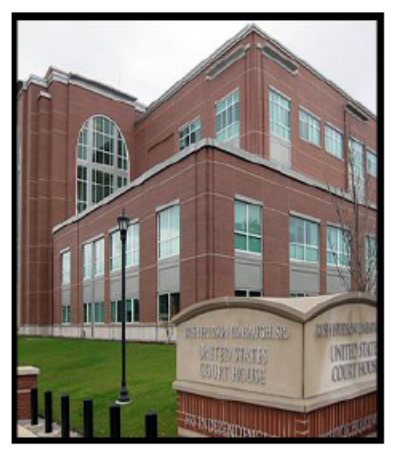

Year Built: 2008

GSF: 173,392
Cleveland CT

The courthouse is on the National Register of Historic Places. The renovation preserved $96 \%$ of the existing shell and $59 \%$ of interior elements. It won GSA's Environmental Award for recycling because of its seven-material collection system.

\section{Youngstown CT \& FB}

The building was built on a brownfield, as part of the city's urban revitalization. The facility incorporates daylighting to over $75 \%$ of occupied spaces, a stormwater management demonstration, a white membrane roof, and lightcolored pavement.

Cape Girardeau CT

This courthouse is one of the first LEED buildings in the area. The facility features building HVAC and lighting controls, irrigation rain sensors, and low-flow fixtures. Carbon dioxide sensors and low-emitting materials add to the enhanced IEQ design. 


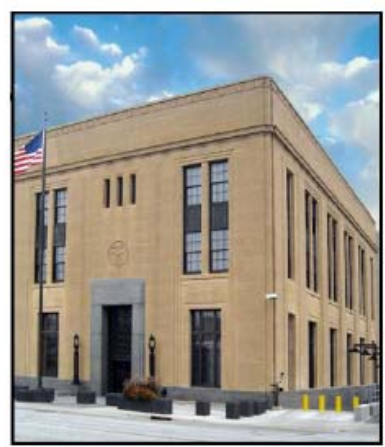

Year Built: 1933

Year Renovated: 2005

GSF: 79,872

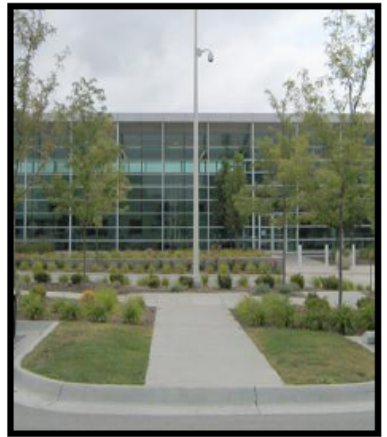

Year Built: 2005

GSF: 86,000

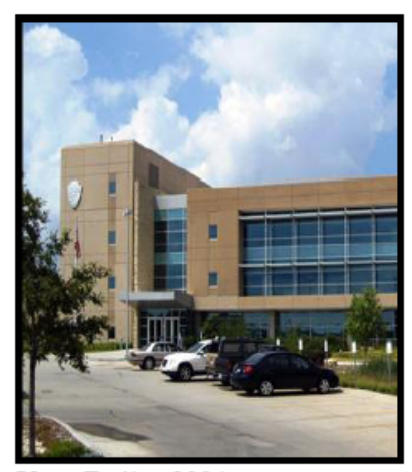

Year Built: 2004

GSF: 68,000

\section{Davenport CT}

The Davenport

Courthouse renovation maintained the integrity of the historic space, while adding more courtrooms, incorporating techniques to bring in daylight and the HVAC system utilizes high efficiency equipment.

\section{Omaha DHS FB}

This federal building recently won the 2007 American Council of Engineering Award for its design. As a LEED Gold building, the facility incorporates daylight, rainwaterharvesting systems, and a ground source heat pump system.

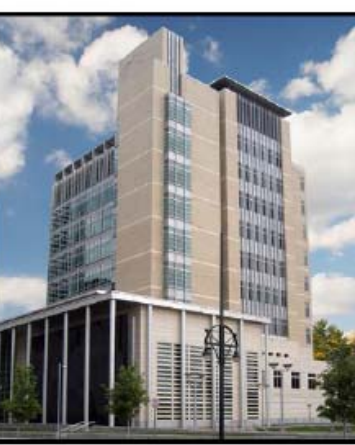

Year Built: 2002

GSF: 327,103

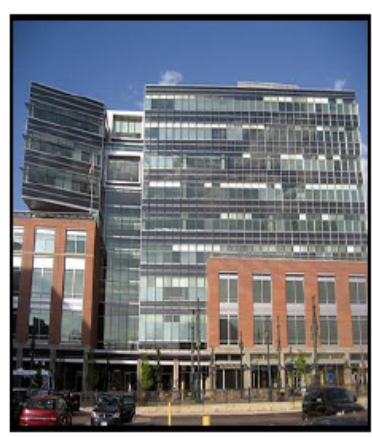

Year Built: 2006

GSF: 301,292

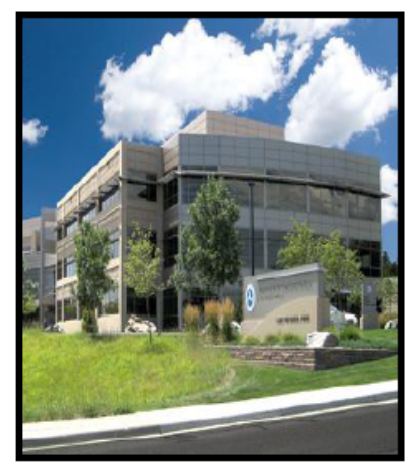

Year Built: 2004

GSF: 128,342

\section{Denver FB}

The EPA Region 8 Headquarters building located in a redeveloped area of downtown Denver is rated with LEED Gold certification. The building uses daylighting, an underfloor air distribution system, a vegetated roof, and photovoltaic panels.

\section{Omaha NPS FB}

The building was built as part of an urban redevelop-ment effort. This building showcases passive solar design, daylight harvesting, and an underfloor air distribution system. Use of adaptive vegetation eliminated the need for irrigation.

\section{nver CT}

Existing Buildings The system, lighting sens as well as photorolt panels. 


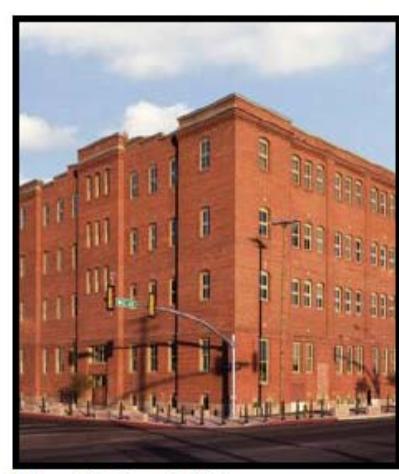

Year Built: 1900

Year Renovated: 2001

GSF: 105,000

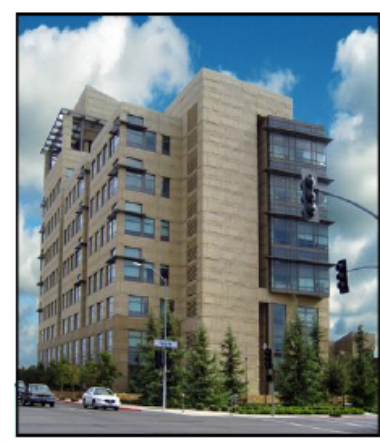

Year Built: 2005

GSF: 495,914

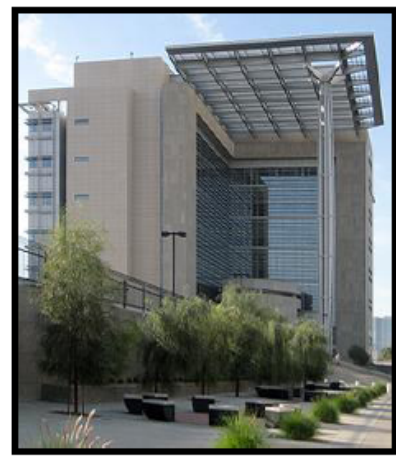

Year Built: 2000

GSF: 454,877

\section{Ogden FB}

Renovations

transformed this

historic building into

usable office space for the IRS. The design

incorporated an

underfloor air

distribution system

which was coupled with

indirect/ direct

evaporative cooling.

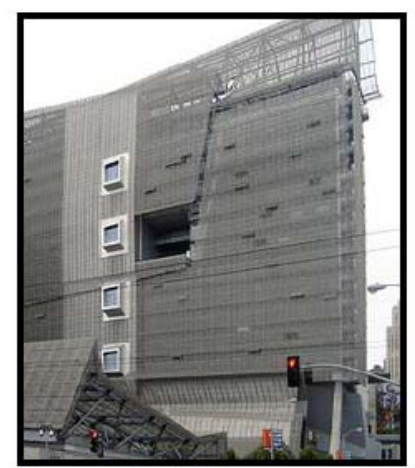

Year Built: 2007

GSF: 652,433

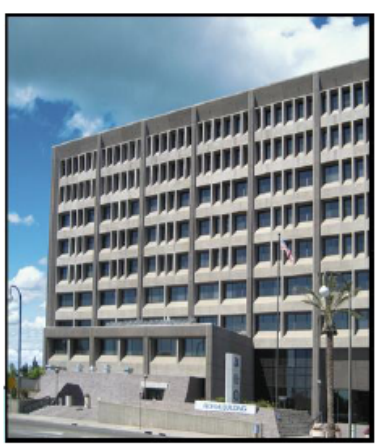

Year Built: 1975

Year Renovated: 2005

GSF: 280,365

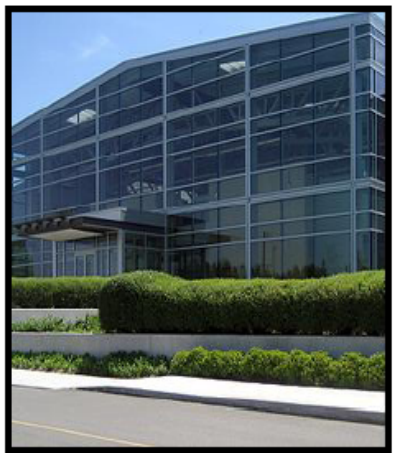

Year Built: 1944

Year Renovated: 2006

GSF: 205,354
San Francisco FB

Located in the South of

Market district, the

building was constructed

on a brownfield as part

of the city's urban

revitalization. Unique

features include naturally

ventilated and underfloor air distribution HVAC

systems, and extensive daylighting.

\section{Las Vegas CT}

The Lloyd George

Courthouse creates a

federal presence in

downtown with a large

column supporting the

sun-screen entry canopy.

The courthouse was

rated under Energy Star in 2007 and includes high-efficiency lighting and HVAC systems.

\section{Santa Ana FB}

Renovated in 2005, this Federal Building lies in the heart of the civic center and accommodates a large flow of visitors each day. This building features high-efficiency lighting and HVAC systems, occupancy temperature control, and energy efficient elevators.

\section{Auburn FB}

Renovated from a warehouse in 2006, the open plan office space earned a LEED Silver rating. Unique features include underfloor air distribution system, use of low-emitting materials, and increased ventilation. 


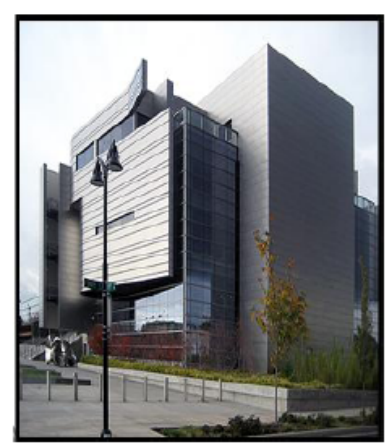

Year Built: 2006

GSF: 270,322

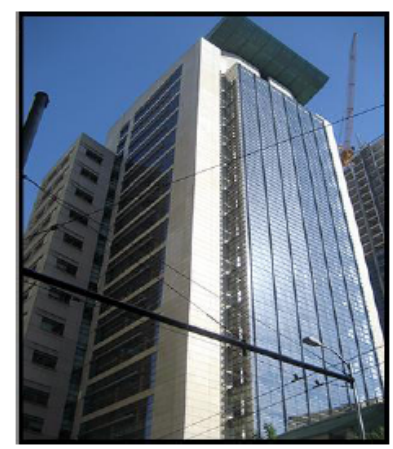

Year Built: 2004

GSF: 658,392
Eugene CT

This was the first LEED Gold

Courthouse in the US

Notable features

include underfloor air distribution system,

daylight sensors, and

low flow fixtures. IEQ

is improved through

the use of low-

emitting materials.

\section{Seattle CT}

Located in downtown Seattle, this court-

house has been

deemed one of the

safest structures ever

built. It features

radiant floor heating,

a well-utilized EMCS

system, waterless

urinals, and

photovoltaic panels.

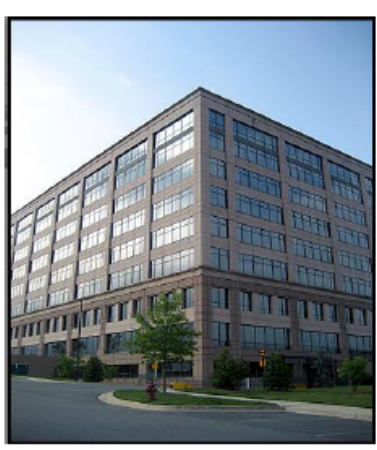

Rockville FB

This leased building

incorporates many sustainable design features including a reflective white roof, low water

landscaping, and use of renewable materials in both interior finishes and furniture.

Year Built: 2004

GSF: 232,000

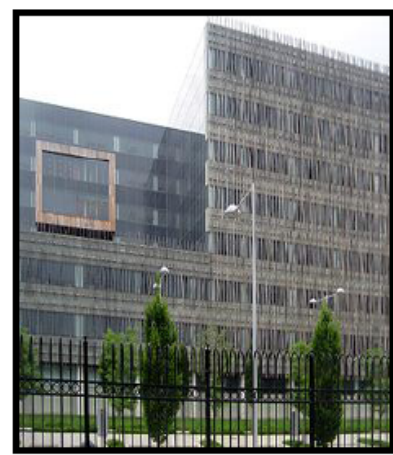

\section{Suitland FB}

The Census Bureau Headquarters building's curved rectangular shape takes advantage of natural daylighting. Other features include the underfloor air distribution system, vegetative roofs and bioswales.
Year Built: 2006

GSF: $2,340,988$

The PNNL research team collected the building and site characteristics data listed in Table 2 to normalize the building performance metrics. For example, gross interior floor area (gsf) is the total building square footage value used to estimate costs per square foot, energy use per square foot, and more. The Department of Energy (DOE) Federal Energy Management Program (FEMP) Building Cost and Performance Metrics: Data Collection Protocol ${ }^{14}$, developed by PNNL, was the tool used to identify, normalize, and analyze the performance data collected for each building. 
Table 2. Building and site characteristics metrics

\begin{tabular}{|c|c|}
\hline $\begin{array}{c}\text { Metric } \\
\text { Categories }\end{array}$ & Characteristic \\
\hline \multirow[t]{6}{*}{$\begin{array}{l}\text { Building } \\
\text { Specifications }\end{array}$} & $\begin{array}{l}\text { Building Location } \\
\text { address, city, state, zip code }\end{array}$ \\
\hline & $\begin{array}{l}\text { Building Function } \\
\text { Federal building, courthouse }\end{array}$ \\
\hline & $\begin{array}{l}\text { Key Building Features } \\
\text { LEED checklist and design highlights }\end{array}$ \\
\hline & $\begin{array}{l}\text { Building Occupancy Date } \\
\text { Year }\end{array}$ \\
\hline & $\begin{array}{l}\text { Gross Interior Floor Area (gsf) } \\
\mathrm{ft}^{2}\end{array}$ \\
\hline & $\begin{array}{l}\text { Rentable Floor Area (rsf) } \\
\mathrm{ft}^{2}\end{array}$ \\
\hline \multirow[t]{4}{*}{ Occupancy } & Hours of Operation \\
\hline & $\frac{\text { hours }}{\text { week }} \quad$ \# of Computers \\
\hline & $\begin{array}{l}\text { Total Number of Regular Occupants and Visitors } \\
\begin{array}{ll}\text { Occupant } & \text { visitors } \\
\overline{\text { work day }} & \text { work day }\end{array}\end{array}$ \\
\hline & $\begin{array}{l}\text { Occupant Gender Ratio } \\
\text { Number of female \& male occupants }\end{array}$ \\
\hline First Costs & $\begin{array}{l}\text { Total Building Cost } \\
\text { Design and Construction Cost } \\
\frac{\$}{f t 2}\end{array}$ \\
\hline
\end{tabular}

For each of the buildings, data were collected and analyzed for the key performance metrics provided in Table 3. The PNNL research team collected a minimum of 12 consecutive months of data and documented an industry baseline for each metric. When available, the study also used GSA baselines for performance analysis. Site and building contacts provided utility bills, maintenance budgets and schedules, and supported the distribution of the occupant satisfaction survey. 
Table 3. Whole building performance metrics

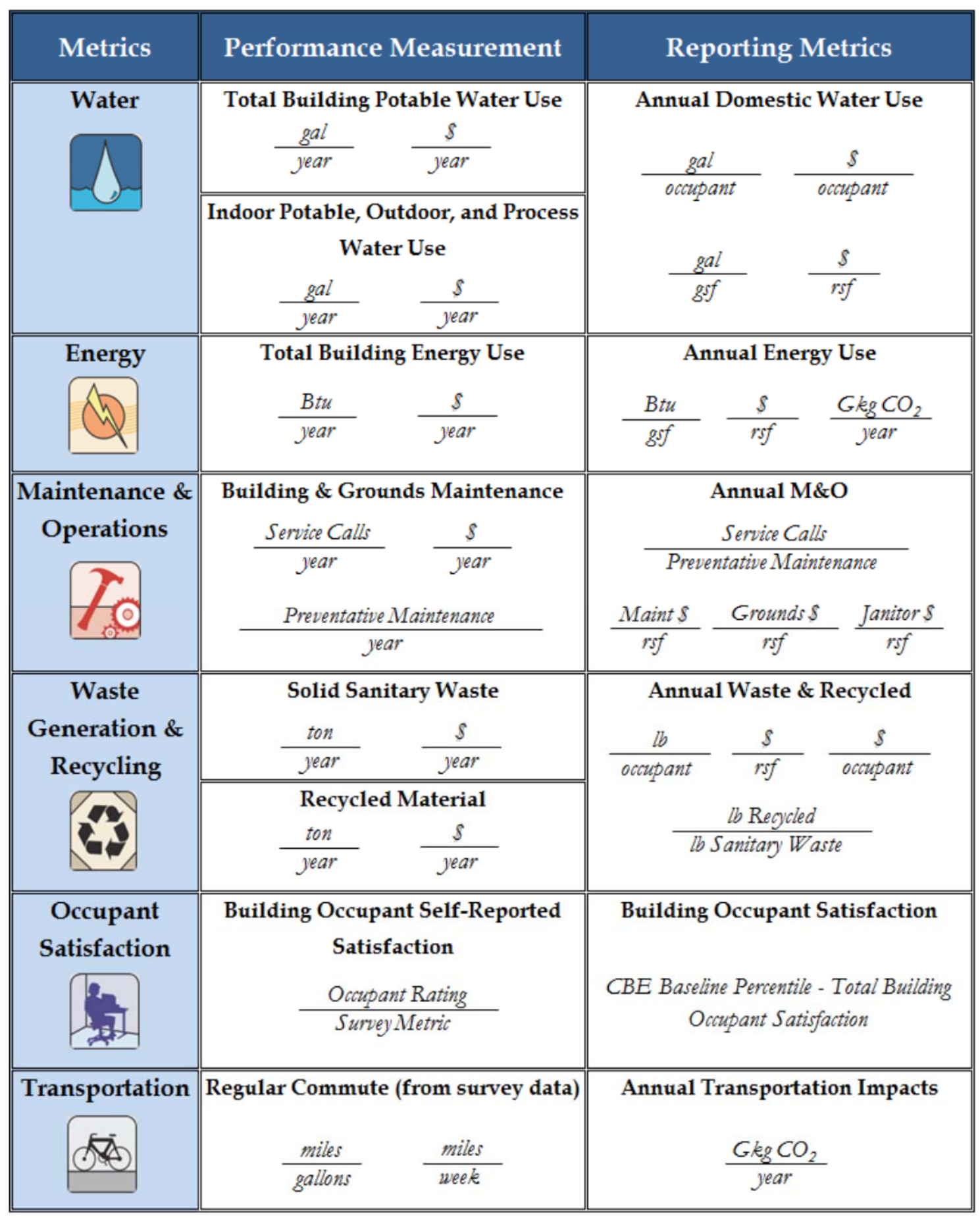




\section{Baseline Summary}

One of the more important lessons learned with respect to whole building performance measurement and assessment is that the baselines selected for performance comparison are what define the study findings. When agency specific baselines are available, they offer a comparison of how a building meets

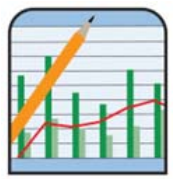
an agency's expectations, but they make the assessment results less comparable to the general building industry. Ideally performance measurement data should be compared to other measured building performance data. Comparing measured values to modeled or estimated values does not offer a valid comparison, and should be avoided whenever possible. For this study GSA baselines were used whenever they were made available, however, industry baselines are also provided in order to offer another basis for comparison.

In addition to the baselines needing consistency to make the performance measurement and assessment data useful, the buildings being studied need to be working properly to be representative of sustainably designed building performance. If a building is not operating well because it has not been properly commissioned, has had an equipment failure, or occupancy settings have not been configured, it is not useful to include in a portfolio analysis of sustainably designed buildings. In the case of a building that is not working properly, it would be difficult to parse out what aspect of the performance data is related to the design rather than the insufficient operations, and it would be more effective to perform a detailed post occupancy evaluation to identify where changes could be made in the building to improve building performance. For example, one of the buildings originally included in the study was found to have heating, ventilation and air conditioning equipment that was not functioning properly to meet the needs of the occupants. The equipment challenges were not related to the sustainable design features of the building, so the building could not be included in the study until the building was operating normally. The building managers have been working to improve the building's operations so that its equipment is performing as expected. This building could be included in future performance measurement studies when the equipment issues have been resolved.

Comparable baselines were identified for each of the metrics. Where available, GSA, regional, and industry baselines are shown together throughout the report to offer multiple points of view to assess the buildings within the study. The following tables are summaries of the baselines used in the study. Table 4 includes the baselines that apply to all of the buildings, regardless of location, size, or number of occupants. Table 5 includes baseline values that applied to specific GSA regions. Some of the baseline values were calculated specifically for the building because of occupancy and/or location. Building specific baselines are in Table 6 . Additional details regarding the baselines, especially the water baseline, are provided in Appendix D. 
Table 4. Baseline Values and References

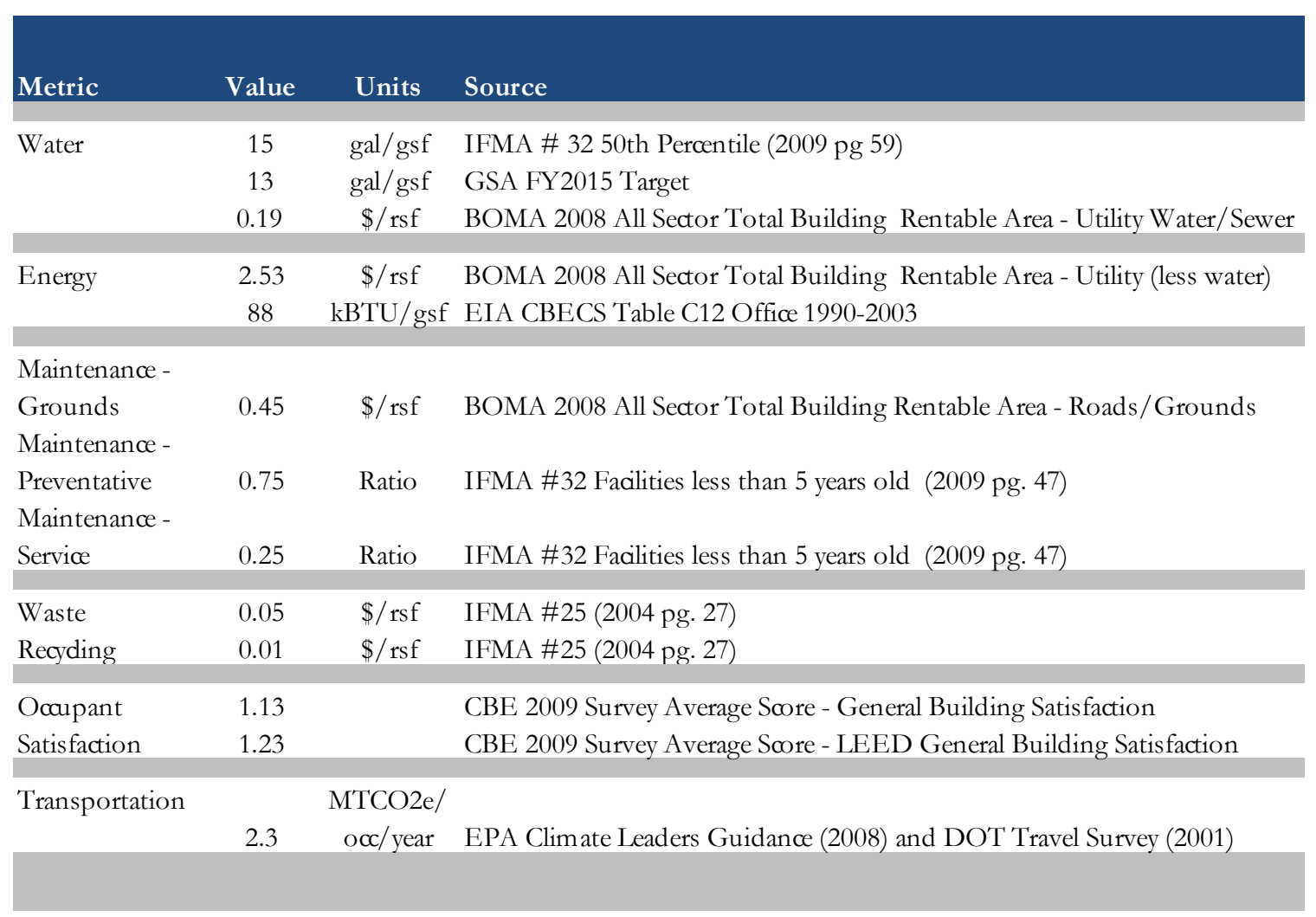

Table 5. Regional Baseline Values

\begin{tabular}{|c|c|c|c|c|c|c|c|}
\hline \multirow[b]{6}{*}{ GSA Region } & \multicolumn{6}{|c|}{ Regional Baselines } & \\
\hline & \multicolumn{3}{|c|}{ Energy kBTU/gsf } & \multicolumn{4}{|c|}{ Maintenance $\$ /$ rsf } \\
\hline & GSA & GSA & & & Adapted & & Adapted \\
\hline & FY09 & FY09 & CBECS & GSA & BOMA & GSA & BOMA \\
\hline & Regional & Regional & Regional & General & General & Janitorial & Janitoria \\
\hline & EUI & Target & EUI & Maint & Maint & Maint & Maint \\
\hline 4 & 58 & 60 & 78 & $\$ 1.25$ & $\$ 1.23$ & $\$ 1.32$ & $\$ 1.25$ \\
\hline 5 & 84 & 86 & 113 & $\$ 1.23$ & $\$ 1.81$ & $\$ 1.91$ & $\$ 1.60$ \\
\hline 6 & 75 & 81 & 75 & $\$ 1.33$ & $\$ 1.60$ & $\$ 1.55$ & $\$ 1.39$ \\
\hline 8 & 89 & 92 & 81 & $\$ 1.79$ & $\$ 1.50$ & $\$ 1.33$ & $\$ 1.32$ \\
\hline 9 & 55 & 61 & 71 & $\$ 1.83$ & $\$ 2.15$ & $\$ 1.71$ & $\$ 1.98$ \\
\hline 10 & 63 & 64 & 71 & $\$ 1.37$ & $\$ 1.80$ & $\$ 1.34$ & $\$ 1.66$ \\
\hline 11 & 95 & 88 & 90 & $\$ 2.24$ & $\$ 2.23$ & $\$ 1.93$ & $\$ 2.12$ \\
\hline
\end{tabular}


For the energy baseline in Table 6, the Energy Star Portfolio Manager energy use intensity value for the $50^{\text {th }}$ percentile is shown. This value is used to represent the industry average energy use.

Table 6. Building Specific Baseline Values

\begin{tabular}{|c|c|c|c|c|}
\hline Building Name & $\begin{array}{c}\text { Energy } \\
\text { kBTU/gsf } \\
\text { Energy Star } \\
\text { Baseline- } \\
50 \%\end{array}$ & $\begin{array}{l}\text { MTCC } \\
\text { Industry } \\
\text { Average - } \\
50 \%\end{array}$ & $\begin{array}{c}\mathrm{O}_{2} \mathrm{e} / \mathbf{g s f} \\
\text { Energy } \\
\text { Star- } 75 \%\end{array}$ & $\begin{array}{l}\text { Water } \\
\text { gal per Occ- } \\
\text { Vis Equiv } \\
\text { FEMP Water } \\
\text { Use Intensity }\end{array}$ \\
\hline Greeneville CT & 87 & 0.014 & 0.010 & 3750 \\
\hline Jacksonville FB & 93 & 0.016 & 0.012 & 3750 \\
\hline Knoxville FB & 91 & 0.015 & 0.011 & 3750 \\
\hline Cleveland CT & 129 & 0.014 & 0.010 & 3160 \\
\hline Youngstown CT \& FB & 80 & 0.012 & 0.012 & 3750 \\
\hline Cape Girardeau CT & 92 & 0.016 & 0.012 & 3645 \\
\hline Davenport CT & 96 & 0.015 & 0.011 & 3750 \\
\hline Omaha DHS (L) FB & 77 & 0.019 & 0.014 & 4323 \\
\hline Omaha NPS (L) FB & 103 & 0.017 & 0.013 & 3698 \\
\hline Denver CT & 123 & 0.016 & 0.012 & 3750 \\
\hline Denver (L) FB & 144 & 0.026 & 0.019 & 3750 \\
\hline Lakewood (L) FB & 103 & 0.021 & 0.015 & 3645 \\
\hline Ogden (L) FB & 139 & 0.014 & 0.011 & 4170 \\
\hline Fresno CT \& FB & 91 & 0.008 & 0.006 & 3750 \\
\hline Las Vegas CT & 84 & 0.014 & 0.010 & 3750 \\
\hline San Francisco FB & 112 & 0.010 & 0.007 & 3855 \\
\hline Santa Ana FB & 109 & 0.007 & 0.005 & 3791 \\
\hline Auburn FB & 108 & 0.011 & 0.008 & 3908 \\
\hline Eugene CT & 90 & 0.009 & 0.007 & 3855 \\
\hline Seattle CT & 111 & 0.010 & 0.008 & 3750 \\
\hline Rockville (L) FB & 99 & 0.016 & 0.012 & 3908 \\
\hline Suitland FB & 140 & 0.018 & 0.013 & 3960 \\
\hline
\end{tabular}




\section{Report Contents and Organization}

The observations for each of the key performance metrics addressed under this study are provided in the Summary Analysis section of this report. The values used for comparison include the following

- water use per gross square foot

- estimated domestic water use per occupant-visitor equivalent

- water cost per rentable square foot

- Energy Star rating

- energy use per gross square foot

- energy cost per rentable square foot

- general maintenance cost per rentable square foot

- grounds maintenance cost per rentable square foot

- janitorial maintenance cost per rentable square foot

- aggregate operational cost per square foot

- ratio of quantity recycled to total waste generation

- waste cost per square foot

- occupant satisfaction scores

- occupant commute greenhouse gas emissions per occupant.

General observations from the study are provided in the Conclusion section. Site-specific observations are provided in the site summaries in Appendix A. Details on excluded buildings can be found in Appendix B and Appendix $C$ has a list of buildings considered for this study and why there were not included at this time. A summary of how the comparative baselines were developed can be found in Appendix D. Appendix E is a sample Indoor Air Quality assessment performed on one of the study buildings. Example occupant satisfaction survey questions can be found in Appendices F and G. Appendix H, I, and J contain the conversion factors, site contacts, and references respectively. 


\section{Summary Analysis}

This section is organized by metric type. First, the key building and site characteristics are provided as a reference for the analysis. Next, the building performance data are analyzed for each performance metric, with the information provided in the following order

- Water

- Energy

- Maintenance and operations

- Waste generation and recycling

- Occupant satisfaction

- Transportation.

The discussion for each metric includes performance data, costs, and operational, occupant, or environmental impact, as available.

The data represented in this section were provided by GSA representatives, site contacts, and CBE. Data summarized in this study were provided in mid to late 2009 and are primarily for calendar year 2008. Where multiple years of data were available they were examined for significant differences and similarities. In the few times the differences were significant, they are noted in the text. 
The building and site characteristics data collected for each building are used to normalize the performance metrics (Table 7). The gross square footage (gsf) and rentable square footage (rsf) are the primary building geometry characteristics used for normalizing the performance metrics. The building geometry metrics are needed as part of the water, energy, and maintenance and operations metrics. The number of regular building occupants (Occ) and visitor (Vis) estimates are needed as part of the water, energy, waste and recycling, and transportation metrics. The number of computers (\# Comps) is needed as part of the energy metric.

Table 7. Key building and site characteristics

\begin{tabular}{|c|c|c|c|c|c|c|c|c|c|}
\hline Building Name & Building ID \# & Region & $\begin{array}{l}\text { Year Built/ } \\
\text { Renovated }\end{array}$ & GSF & RSF & \# Occ & $\begin{array}{l}\text { Occ-Vis } \\
\text { Equiv }\end{array}$ & $\begin{array}{c}\text { Hours/ } \\
\text { week }\end{array}$ & $\begin{array}{c}\# \\
\text { Comps }\end{array}$ \\
\hline Greeneville CT & TN0012ZZ & 4 & 2001 & 160,975 & 136,104 & 85 & 103 & 70 & 100 \\
\hline Jacksonville FB & FL0067ZZ & 4 & $1967 / 2004$ & 338,008 & 299,941 & 1,000 & 1,150 & 71 & 1,080 \\
\hline Knoxville FB & TN0076ZZ & 4 & $1986 / 2005$ & 172,684 & 120,171 & 285 & 310 & 65 & 285 \\
\hline Cleveland CT & OH0033ZZ & 5 & $1910 / 2005$ & 251,314 & 185,105 & 105 & 143 & 60 & 120 \\
\hline Youngstown CT \& FB & $\mathrm{OH} 0302 \mathrm{ZZ}$ & 5 & 2002 & 52,240 & 44,476 & 45 & 243 & 60 & 60 \\
\hline Cape Girardeau CT & MO0147ZZ & 6 & 2008 & 173,392 & 138,548 & 45 & 100 & 60 & 90 \\
\hline Davenport CT & IA0027ZZ & 6 & $1933 / 2005$ & 79,872 & 68,391 & 45 & 63 & 70 & 60 \\
\hline Omaha DHS (L) FB & NE1430ZZ & 6 & 2005 & 86,000 & 73,459 & 65 & 360 & 112 & 80 \\
\hline Omaha NPS (L) FB & NE1425ZZ & 6 & 2004 & 68,000 & 62,772 & 125 & 134 & 70 & 140 \\
\hline Denver CT & CO0061ZZ & 8 & 2002 & 327,103 & 256,718 & 170 & 370 & 70 & 185 \\
\hline Denver (L) FB & CO1977ZZ & 8 & 2006 & 301,292 & 248,849 & 922 & 993 & 68 & 1,289 \\
\hline Lakewood (L) FB & CO1923ZZ & 8 & 2004 & 128,342 & 122,225 & 318 & 336 & 70 & 383 \\
\hline Ogden (L) FB & UT1434ZZ & 8 & $1900 / 2004$ & 105,000 & 102,579 & 514 & 521 & 120 & 745 \\
\hline Fresno CT \& FB & CA0309ZZ & 9 & 2005 & 495,914 & 393,243 & 235 & 510 & 68 & 250 \\
\hline Las Vegas CT & NV0304ZZ & 9 & 2000 & 454,877 & 368,969 & 321 & 428 & 55 & 242 \\
\hline San Francisco FB & CA0305ZZ & 9 & 2007 & 652,433 & 523,208 & 1,314 & 1,444 & 70 & 1,400 \\
\hline Santa Ana FB & CA0200ZZ & 9 & $1975 / 2005$ & 280,365 & 205,378 & 409 & 459 & 70 & 424 \\
\hline Auburn FB & WA0102ZZ & 10 & $1944 / 2006$ & 205,354 & 201,003 & 675 & 675 & 70 & 675 \\
\hline Eugene CT & OR0053ZZ & 10 & 2006 & 270,322 & 237,852 & 120 & 170 & 45 & 176 \\
\hline Seattle CT & WA0831KF & 10 & 2004 & 658,392 & 557,077 & 500 & 600 & 53 & 550 \\
\hline Rockville (L) FB & MD0802ZZ & 11 & 2004 & 232,000 & 228,020 & 720 & 760 & 60 & 800 \\
\hline Suitland FB & MD0778AG & 11 & 2006 & $2,340,988$ & $1,410,988$ & 5,360 & 5,425 & 119 & 5,500 \\
\hline
\end{tabular}

In addition to the building and site characteristics, the research team also captured the following information about the buildings that was of general interest (Table 8)

- Six of the buildings are leased, sixteen are GSA-owned.

- Seven of the buildings had major renovations, fifteen are new construction.

- Eight of the buildings are 4 stories tall or fewer. 
- Ten of the buildings have GSA personnel co-located with the occupants.

- Nine buildings have underfloor air distribution systems.

- Five buildings purchase central steam.

- Three buildings purchase central chilled water.

Table 8. Additional building and site characteristics

\begin{tabular}{|c|c|c|c|c|c|c|c|}
\hline Building Name & $\begin{array}{l}\text { Owned or } \\
\text { Leased }\end{array}$ & $\begin{array}{c}\text { Project } \\
\text { Type }\end{array}$ & $\begin{array}{c}\text { \# of } \\
\text { Floors }\end{array}$ & $\begin{array}{c}\text { GSA } \\
\text { Personnel } \\
\text { On Site }\end{array}$ & $\begin{array}{l}\text { Underfloor } \\
\text { Air HVAC } \\
\text { Distribution }\end{array}$ & $\begin{array}{c}\text { Purchased } \\
\text { Steam }\end{array}$ & $\begin{array}{c}\text { Purchased } \\
\text { Chilled } \\
\text { Water }\end{array}$ \\
\hline Greeneville CT & Owned & New & 4 & No & No & No & No \\
\hline Jacksonville FB & Owned & Renovation & 11 & Yes & No & No & No \\
\hline Knoxville FB & Owned & Renovation & 8 & No & No & No & No \\
\hline Cleveland CT & Owned & Renovation & 6 & Yes & No & Yes & Yes \\
\hline Youngstown CT \& FB & Owned & New & 4 & No & No & Yes & No \\
\hline Cape Girardeau CT & Owned & New & 4 & No & No & No & No \\
\hline Davenport CT & Owned & Renovation & 4 & Yes & No & No & No \\
\hline Omaha DHS (L) FB & Leased & New & 1 & No & No & No & No \\
\hline Omaha NPS (L) FB & Leased & New & 3 & No & Yes & No & No \\
\hline Denver CT & Owned & New & 13 & Yes & Yes & Yes & Yes \\
\hline Denver (L) FB & Leased & New & 9 & No & Yes & Yes & No \\
\hline Lakewood (L) FB & Leased & New & 3 & No & No & No & No \\
\hline Ogden (L) FB & Leased & Renovation & 5 & No & Yes & No & No \\
\hline Fresno CT \& FB & Owned & New & 11 & Yes & Yes & No & No \\
\hline Las Vegas CT & Owned & New & 8 & Yes & No & No & No \\
\hline San Francisco FB & Owned & New & 18 & Yes & Yes & Yes & No \\
\hline Santa Ana FB & Owned & Renovation & 10 & No & No & Yes & Yes \\
\hline Auburn FB & Owned & Renovation & $1+$ Mezz & No & Yes & No & No \\
\hline Eugene CT & Owned & New & 6 & Yes & Yes & No & No \\
\hline Seattle CT & Owned & New & 25 & Yes & No & No & No \\
\hline Rockville (L) FB & Leased & New & 9 & No & No & No & $\mathrm{No}$ \\
\hline Suitland FB & Owned & New & 8 & Yes & Yes & No & No \\
\hline
\end{tabular}

These items of general interest were analyzed and when they offered observable trends they are discussed within the report. 


\section{Water}

Many communities periodically experience droughts and some are in the situation of an ever decreasing availability of potable water. Commercial buildings use $12 \%$ of potable water in the U.S. ${ }^{15}$ Tracking water use offers

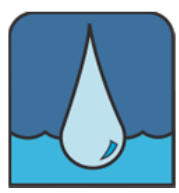
opportunities for identifying possible strategies for water use reduction. In addition to the resource management benefits, there is a monetary incentive to track and decrease water consumption.

The ideal water metric for comparing domestic water use (i.e., toilets, urinals, and faucets) is indoor potable water in gallons per year. The potable water use data for some buildings included a combination of domestic water use, landscape water use, and/or process water use. ${ }^{16}$ None of the GSA buildings had the indoor domestic water separately metered and reported, thus total building water use and cost were used. In addition to water use per square foot, water use per occupant was analyzed, using the U.S. Department of Energy's Federal Energy Management Program's water use indices. In this study, one building did not have metered water data. Sixteen of the buildings have water data that included process and/or landscape water use that needed to be excluded from the water use values in order for the buildings to be fairly compared to a water use per occupant baseline. The estimation of outdoor potable water and/or process potable water use is documented in Table 9 and described in more detail in Appendix D. In general the PNNL research team estimated the annual domestic water use for those buildings based on a review of monthly water use to

Domestic water consumption depends on human operation and fixed equipment efficiency. Therefore, typical indoor water consumption is best expressed as per occupant. identify a base water load. 
Table 9. Process water use by building

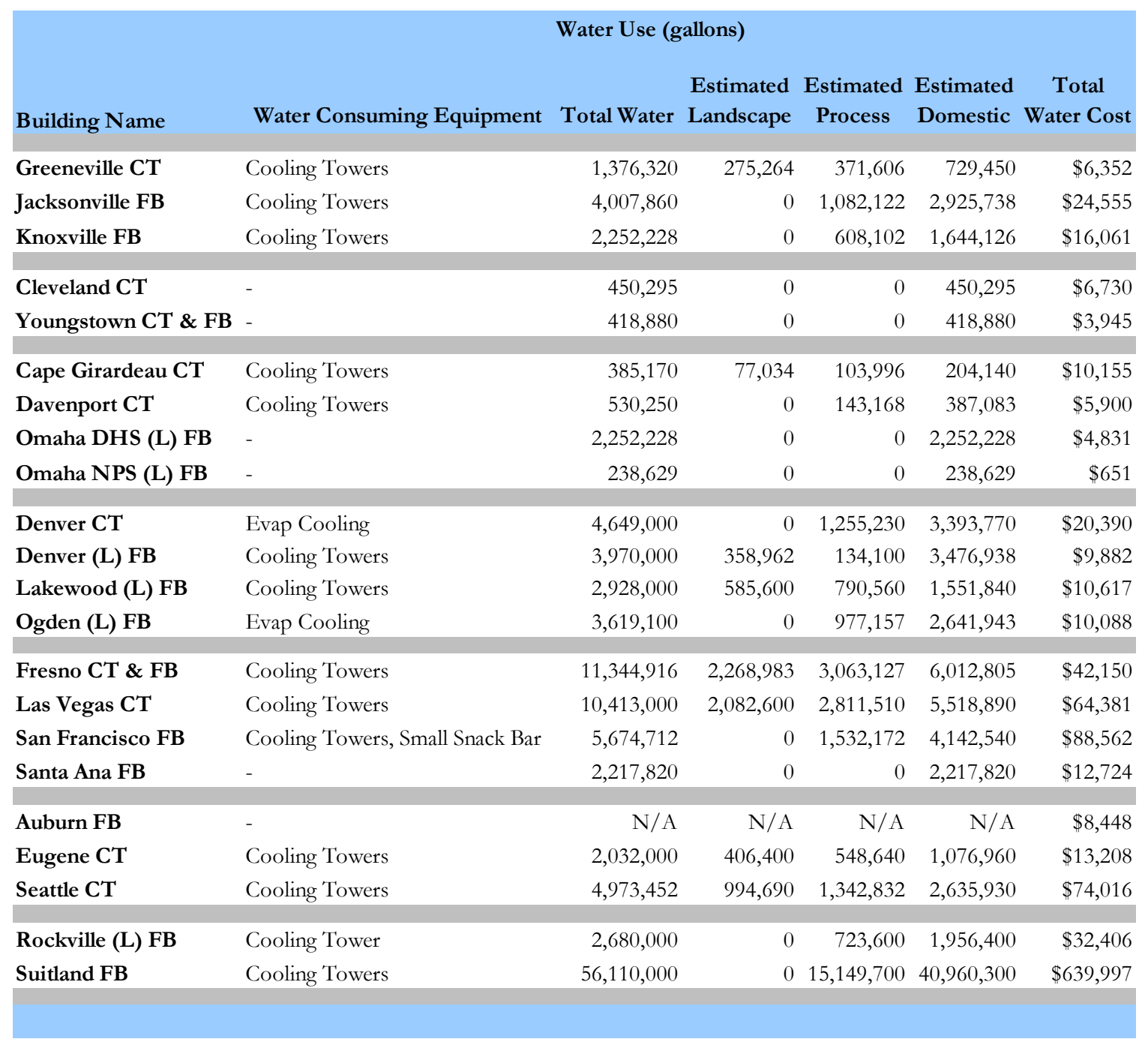


Total building water use per gross square foot includes the process water and irrigation water use. There are three different potential baselines for comparison. The GSA and industry baseline are the same value, and the GSA goal is slightly lower. Figure 2 shows six buildings use more water than the baselines, but all of those buildings have process water use, irrigation water, and/or other operational considerations that may impact water use.

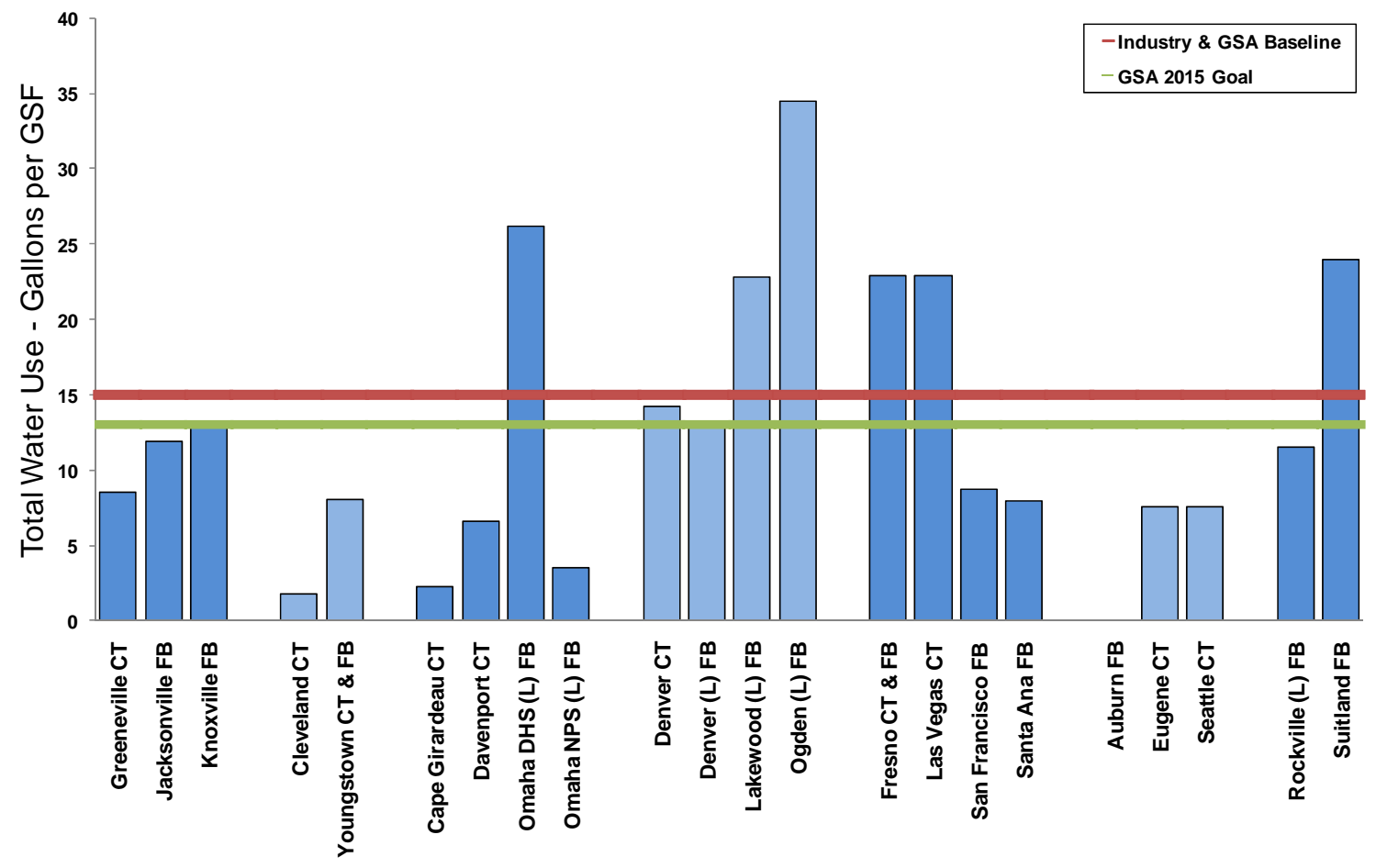

Figure 2. Water use per gross square foot

The Omaha DHS FB water use increased from the first assessment completed in 2008. It is possible this is because of an increase or change in the type of occupancy, however, given the significant increase, water use should be examined at the building to ensure there are no unexpected uses or leaks. The Fresno CT \& FB and Las Vegas CT have significant outdoor water features, which could be separately sub-metered to understand what portion of the water use is building related. Ogden FB has a high level of occupancy, which contributes to it building related water use. Suitland FB is an extremely large building with a large cafeteria and fitness center. Further investigation and measurement of the water use in the buildings above the baseline is recommended to identify operational and design opportunities to reduce water use. 
When considering the cost of water use, Figure 3 shows all but one of the buildings is within the typical range of water cost per rentable square foot. Water costs vary by location, which is especially noticeable when comparing the total water used per rentable square foot with the water cost per rentable square foot. For example, although Fresno CT \& FB and Las Vegas CT use a similar amount of water per rentable square foot, the water costs are greater in Las Vegas. Low water costs decrease the likelihood of water use being a higher priority than other building operations, such as energy use and maintenance.

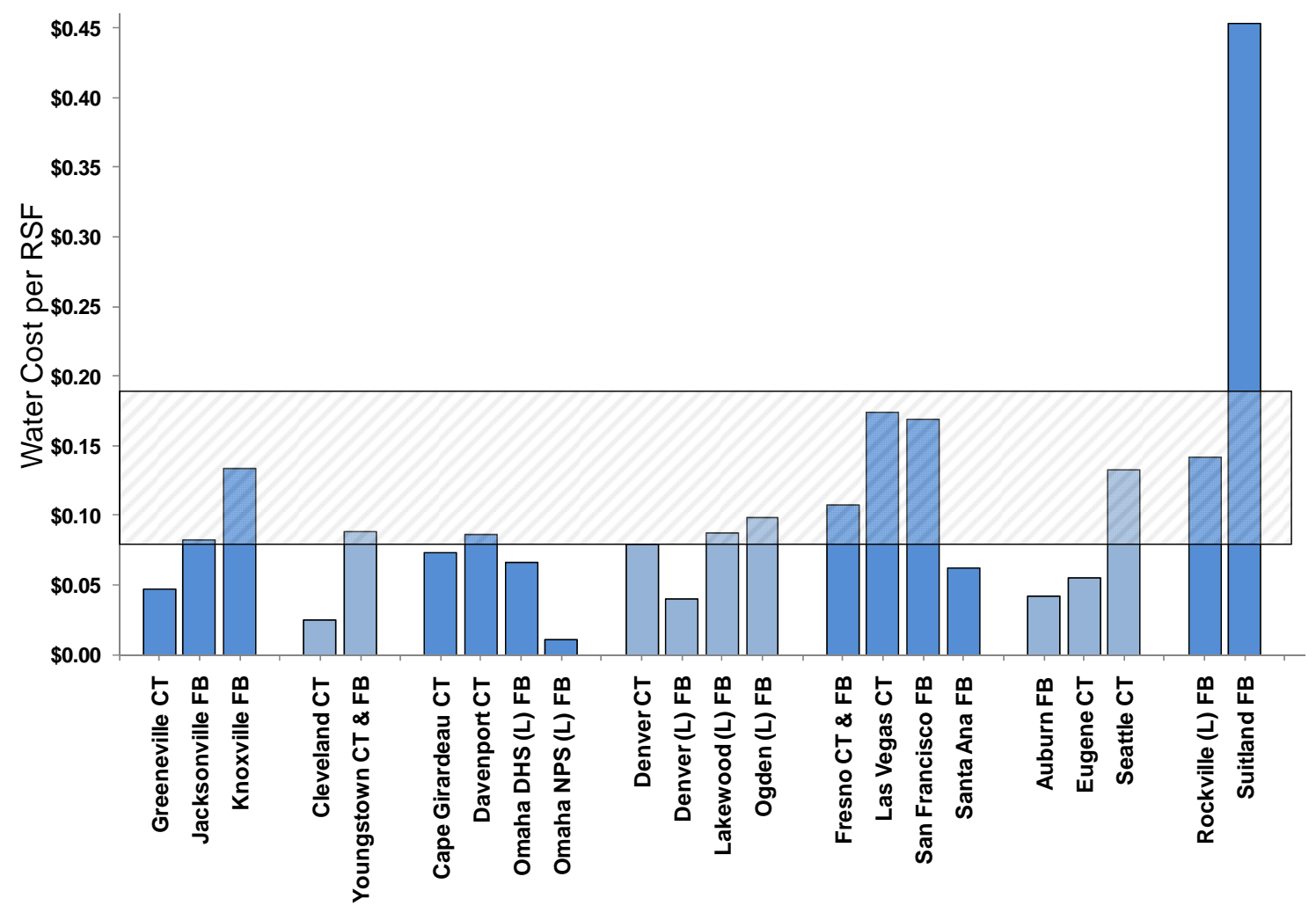

Figure 3. Water cost per rentable square foot compared to industry baseline 
Table 10 shows the values of water use and cost by building. The domestic water use was estimated given the known water uses in the buildings. The water use per occupant equivalent is unique to the building. Water use is normalized to the number of building occupants and visitors. The ratio of female-to-male occupants and the number and type of visitors provides additional detail for understanding water use.

Table 10. Water use and cost by building

\begin{tabular}{|c|c|c|c|c|c|c|}
\hline & & & Water Us & Jse (gallons/yea & & \\
\hline Building Name & $\begin{array}{c}\text { Total Water } \\
\text { Use }\end{array}$ & $\begin{array}{l}\text { Total Water } \\
\text { Use per GSF }\end{array}$ & $\begin{array}{c}\text { Total Water } \\
\text { Cost }\end{array}$ & $\begin{array}{c}\text { Total Water } \\
\text { Cost per RSF }\end{array}$ & $\begin{array}{l}\text { Estimated } \\
\text { Domestic } \\
\text { Water Use }\end{array}$ & $\begin{array}{c}\text { Estimated } \\
\text { Domestic Water } \\
\text { Use/Occupant }\end{array}$ \\
\hline Greeneville CT & $1,376,320$ & 8.5 & $\$ 6,352$ & $\$ 0.05$ & 729,450 & 7,082 \\
\hline Jacksonville FB & $4,007,860$ & 11.9 & $\$ 24,555$ & $\$ 0.08$ & $2,925,738$ & 2,544 \\
\hline Knoxville FB & $2,252,228$ & 13.0 & $\$ 16,061$ & $\$ 0.13$ & $1,644,126$ & 5,299 \\
\hline Cleveland CT & 450,295 & 1.8 & $\$ 6,730$ & $\$ 0.04$ & 450,295 & 3,160 \\
\hline Youngstown CT \& FB & 418,880 & 8.0 & $\$ 3,945$ & $\$ 0.09$ & 418,880 & 1,727 \\
\hline Cape Girardeau CT & 385,170 & 2.2 & $\$ 10,155$ & $\$ 0.07$ & 204,140 & 2,041 \\
\hline Davenport CT & 530,250 & 6.6 & $\$ 5,900$ & $\$ 0.09$ & 387,083 & 6,144 \\
\hline Omaha DHS (L) FB & $2,252,228$ & 26.2 & $\$ 4,831$ & $\$ 0.07$ & $2,252,228$ & 6,256 \\
\hline Omaha NPS (L) FB & 238,629 & 3.5 & $\$ 651$ & $\$ 0.01$ & 238,629 & 1,783 \\
\hline Denver CT & $4,649,000$ & 14.2 & $\$ 20,390$ & $\$ 0.08$ & $3,393,770$ & 9,172 \\
\hline Denver (L) FB & $3,970,000$ & 13.2 & $\$ 9,882$ & $\$ 0.04$ & $3,476,938$ & 3,500 \\
\hline Lakewood (L) FB & $2,928,000$ & 22.8 & $\$ 10,617$ & $\$ 0.09$ & $1,551,840$ & 4,625 \\
\hline Ogden (L) FB & $3,619,100$ & 34.5 & $\$ 10,088$ & $\$ 0.10$ & $2,641,943$ & 5,071 \\
\hline Fresno CT \& FB & $11,344,916$ & 22.9 & $\$ 42,150$ & $\$ 0.11$ & $6,012,805$ & 11,790 \\
\hline Las Vegas CT & $10,413,000$ & 22.9 & $\$ 64,381$ & $\$ 0.17$ & $5,518,890$ & 12,905 \\
\hline San Francisco FB & $5,674,712$ & 8.7 & $\$ 88,562$ & $\$ 0.17$ & $4,142,540$ & 2,868 \\
\hline Santa Ana FB & $2,217,820$ & 7.9 & $\$ 12,724$ & $\$ 0.06$ & $2,217,820$ & 4,832 \\
\hline Auburn FB & $\mathrm{N} / \mathrm{A}$ & $\mathrm{N} / \mathrm{A}$ & $\$ 8,448$ & $\$ 0.04$ & $\mathrm{~N} / \mathrm{A}$ & \\
\hline Eugene CT & $2,032,000$ & 7.5 & $\$ 13,208$ & $\$ 0.06$ & $1,076,960$ & 6,335 \\
\hline Seattle CT & $4,973,452$ & 7.6 & $\$ 74,016$ & $\$ 0.13$ & $2,635,930$ & 4,393 \\
\hline Rockville (L) FB & $2,680,000$ & 11.6 & $\$ 32,406$ & $\$ 0.14$ & $1,956,400$ & 2,574 \\
\hline Suitland FB & $56,110,000$ & 24.0 & $\$ 639,997$ & $\$ 0.45$ & $40,960,300$ & 7,550 \\
\hline
\end{tabular}


Although the water use values in Figure 4 were adjusted in an attempt to represent indoor potable water use only, it is clear that the commonly used end use distribution of water use is not representative for some of these buildings, such as Fresno CT \& FB and Las Vegas CT. Both of those buildings have exterior, decorative fountains and they are located in hot, dry climates. The FEMP water use indices offer the most consistently used industry baseline for water use per occupant-visitor equivalent. At the same time, the FEMP indices do not appear to work consistently with all of the buildings, and it is recognized in the area of building water use research that new values are needed. When the GSA buildings' water use is compared to the indices, at least eight of the buildings show a much greater water use per occupant than would be expected even with inefficient fixtures.

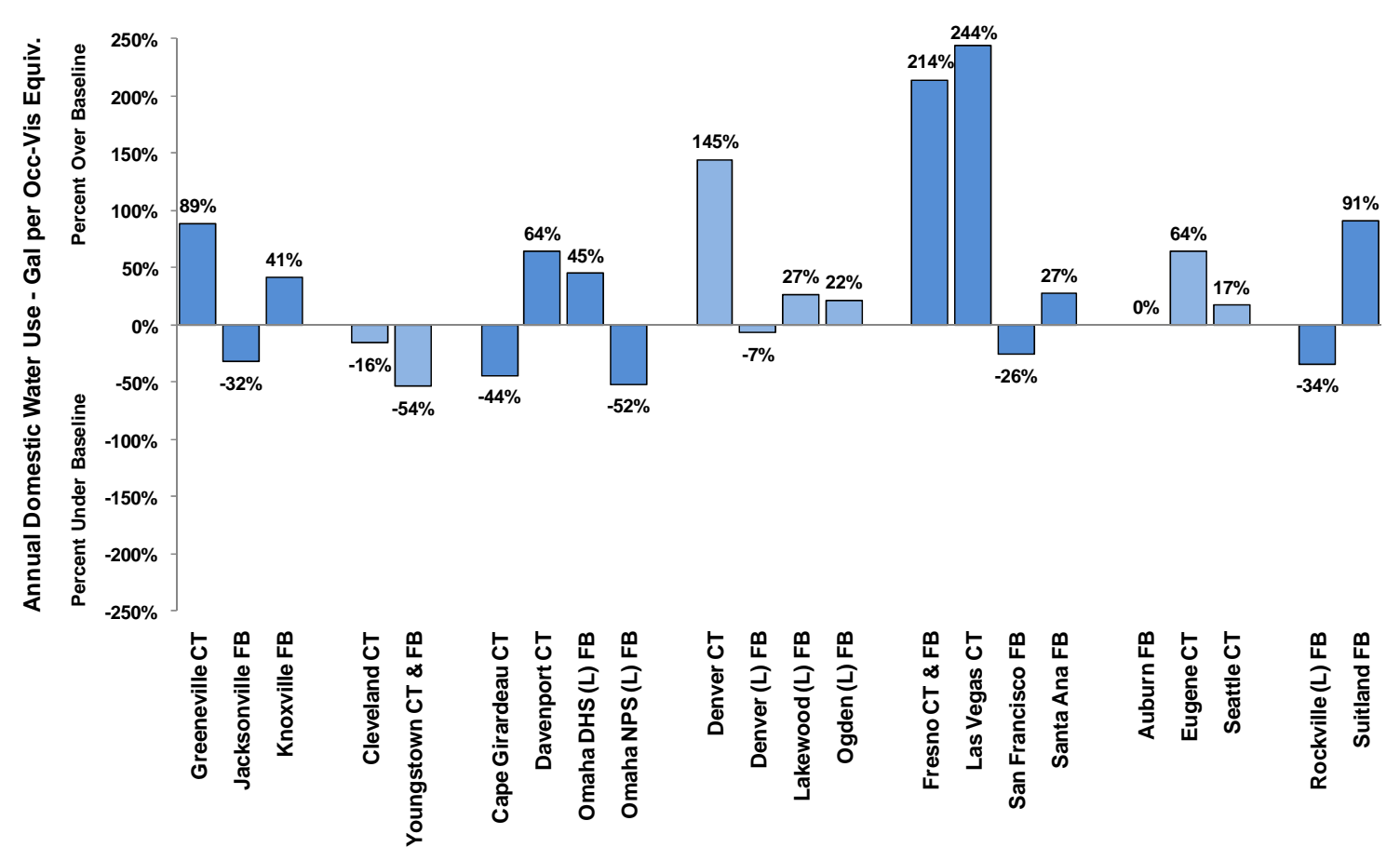

Figure 4. Water use per occupant compared to the water use baseline

The design intent of the buildings' water use can be represented by the LEED Water Efficiency credits. Table 11 shows the number of LEED points received for water efficiency credits by each building out of the five total points available. Thirteen of the buildings pursued indoor water use reduction strategies (WEc3). Twelve of the buildings attempted some water use reduction with either efficient landscape or innovative wastewater technologies.
LEED $^{\circledR}$ Water Efficiency credit 3, Water Use Reduction, is achieved by reducing potable water use by $20 \%$ or more than a baseline design. Two WEc3 points can be achieved if potable water is reduced by $30 \%$. An Innovation in Design point can be achieved for exemplary performance of potable water use reduction greater than $40 \%$.

There are additional water credits that address water efficient landscaping and innovative wastewater management strategies. 
Table 11. LEED Water Efficiency credits pursued

\begin{tabular}{|c|c|c|c|c|}
\hline & & & LEED $^{\circledR}$ Water Credit & \\
\hline Building Name & $\begin{array}{c}\text { Total WE } \\
\text { Credits }\end{array}$ & $\begin{array}{l}\text { Efficient } \\
\text { Landscaping } \\
\text { WEc1 }\end{array}$ & $\begin{array}{c}\text { Innovative Wastewater } \\
\text { Technologies } \\
\text { WEc2 }\end{array}$ & $\begin{array}{c}\text { Water Use } \\
\text { Reduction } \\
\text { WEc3 }\end{array}$ \\
\hline Greeneville CT & $\mathrm{N} / \mathrm{A}$ & $\mathrm{N} / \mathrm{A}$ & $\mathrm{N} / \mathrm{A}$ & $\mathrm{N} / \mathrm{A}$ \\
\hline Jacksonville FB & $\mathrm{N} / \mathrm{A}$ & $\mathrm{N} / \mathrm{A}$ & $\mathrm{N} / \mathrm{A}$ & $\mathrm{N} / \mathrm{A}$ \\
\hline Knoxville FB & 2 & $\mathrm{~N} / \mathrm{A}$ & $\mathrm{N} / \mathrm{A}$ & 2 \\
\hline Cleveland CT & 4 & 2 & 0 & 2 \\
\hline Youngstown CT \& FB & 2 & 2 & 0 & 0 \\
\hline Cape Girardeau CT & 2 & 1 & 0 & 1 \\
\hline Davenport CT & $\mathrm{N} / \mathrm{A}$ & $\mathrm{N} / \mathrm{A}$ & $\mathrm{N} / \mathrm{A}$ & $\mathrm{N} / \mathrm{A}$ \\
\hline Omaha DHS (L) FB & 3 & 0 & 1 & 2 \\
\hline Omaha NPS (L) FB & 4 & 2 & 0 & 2 \\
\hline Denver CT & 1 & 0 & 0 & 1 \\
\hline Denver (L) FB & 4 & 2 & 0 & 2 \\
\hline Lakewood (L) FB & 1 & 1 & 0 & 0 \\
\hline Ogden (L) FB & 2 & 1 & 0 & 1 \\
\hline Fresno CT \& FB & $\mathrm{N} / \mathrm{A}$ & $\mathrm{N} / \mathrm{A}$ & $\mathrm{N} / \mathrm{A}$ & $\mathrm{N} / \mathrm{A}$ \\
\hline Las Vegas CT & $\mathrm{N} / \mathrm{A}$ & $\mathrm{N} / \mathrm{A}$ & $\mathrm{N} / \mathrm{A}$ & $\mathrm{N} / \mathrm{A}$ \\
\hline San Francisco FB & 3 & 1 & 0 & 2 \\
\hline Santa Ana FB & $\mathrm{N} / \mathrm{A}$ & $\mathrm{N} / \mathrm{A}$ & $\mathrm{N} / \mathrm{A}$ & $\mathrm{N} / \mathrm{A}$ \\
\hline Auburn FB & 3 & 1 & 0 & 2 \\
\hline Eugene CT & 3 & 1 & 0 & 2 \\
\hline Seattle CT & $\mathrm{N} / \mathrm{A}$ & $\mathrm{N} / \mathrm{A}$ & $\mathrm{N} / \mathrm{A}$ & $\mathrm{N} / \mathrm{A}$ \\
\hline Rockville (L) FB & 3 & 2 & 0 & 1 \\
\hline Suitland FB & 4 & 2 & 0 & 2 \\
\hline
\end{tabular}


Graphically displaying the water use in comparison to the overall LEED score and the WEc3 points shows that water use is highly variable and there does not appear to be a correlation to the measured water use and the LEED credits.

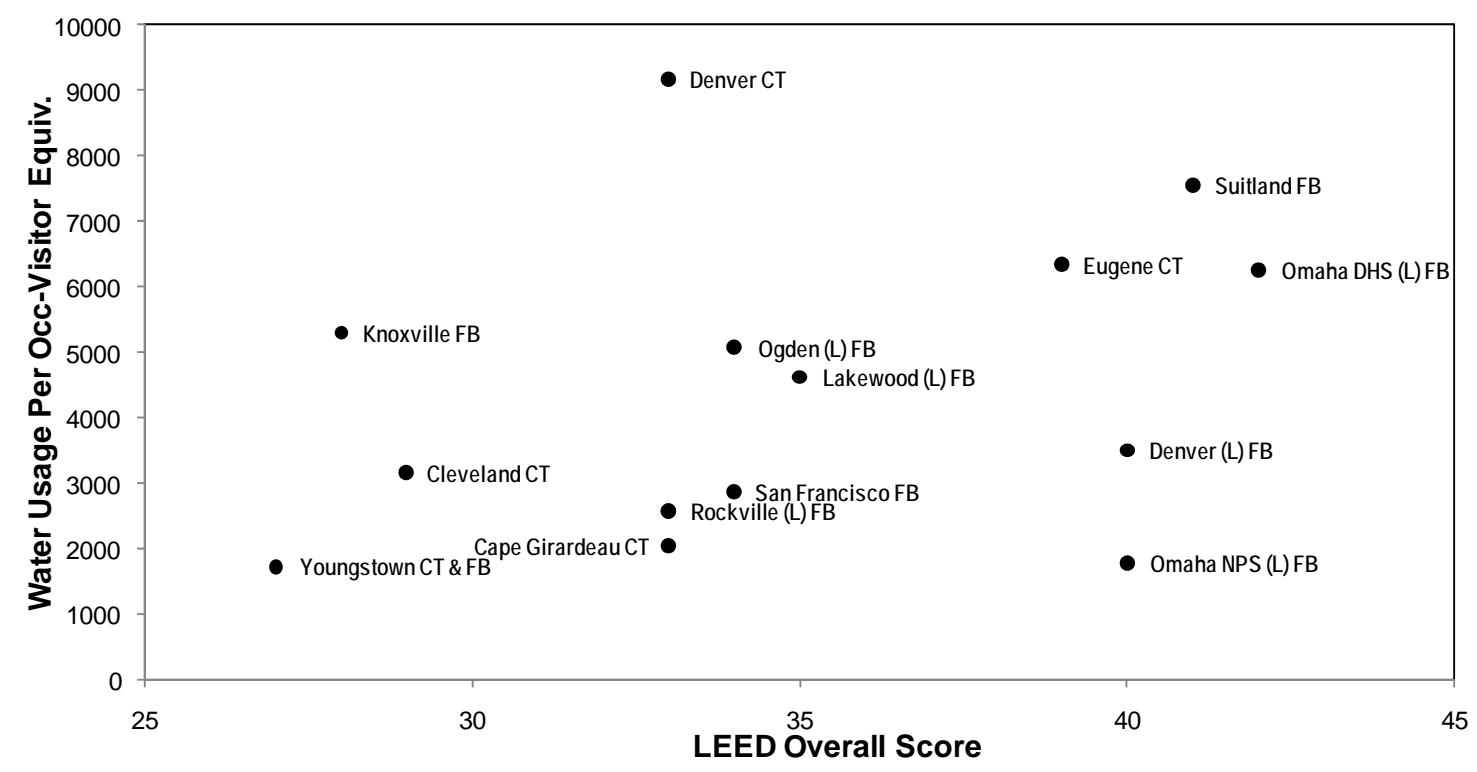

Figure 5. LEED overall score and water usage

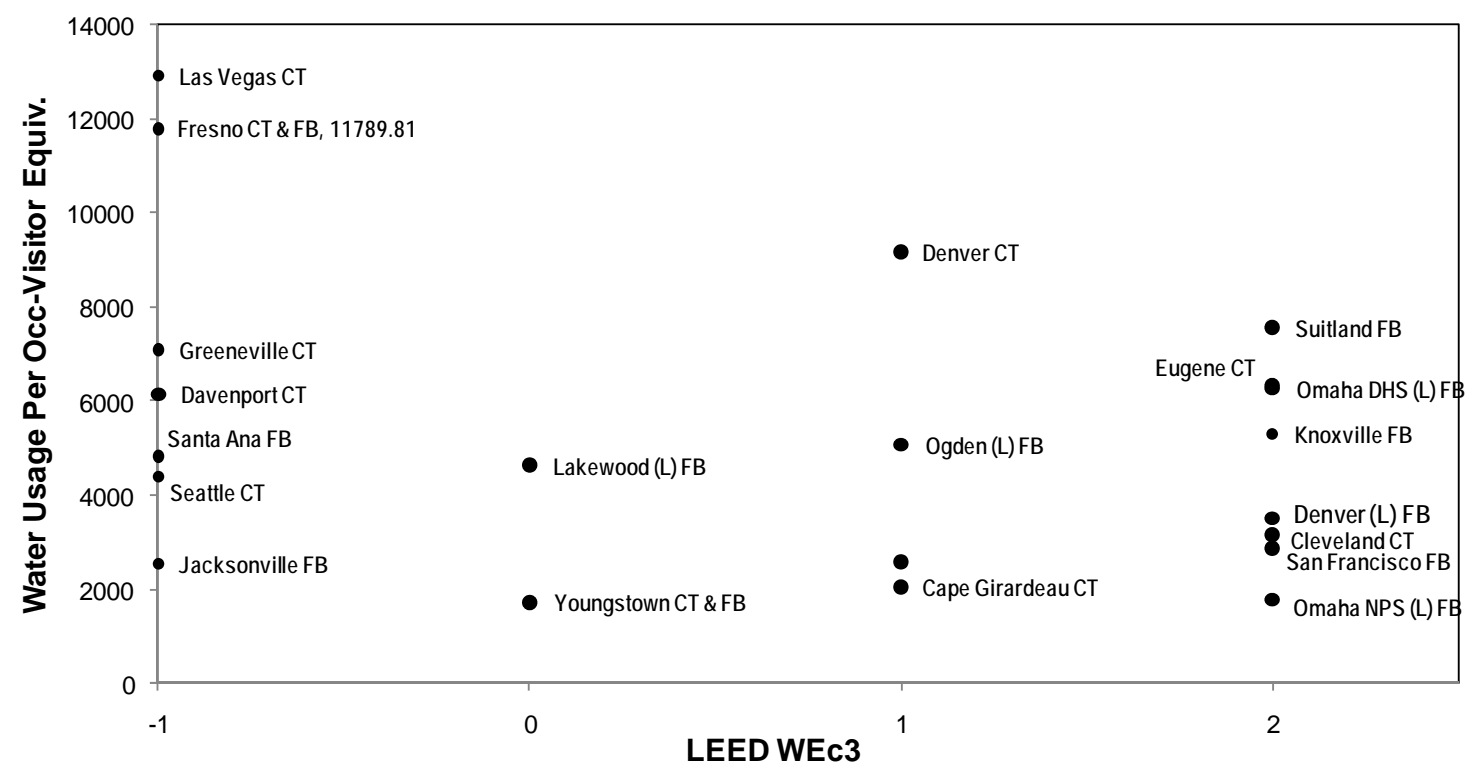

Figure 6. LEED WEc3 points and water usage

When considering all of the different ways to examine water use for a building, three buildings stand out as consistently using considerably more water and having higher water costs than the others: Fresno CT \& FB, Las Vegas CT, and Suitland FB. It is recommended the cause for higher levels of water use at those buildings is investigated in the future. 


\section{Energy}

Commercial buildings in the U.S. consume about $18 \%$ of the total energy. ${ }^{17}$ Energy costs tend to be the largest utility cost for a building and with the

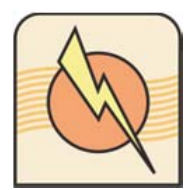
current emphasis on global climate change there is an even greater interest to reduce energy use and modify energy sources in order to reduce the building's environmental impact.

The buildings in this study were selected because they were sustainably-designed or they were designed with energy efficiency as a goal. The research team chose Energy Star as the primary mechanism for comparison because it offers an easy to understand performance compared to similar building types and geographic locations. Energy Star scores are relative to the buildings' energy use in the database, and the weather for a given time period and location. Other mechanisms for comparison include a national and regional CBECS and national GSA averages, as well as average costs from BOMA and IFMA.

The unofficial Energy Star scores for each building were calculated using the following data from each site

- building type

- building location

- 12 to 24 months of energy use data

- number of occupants

- occupancy hours

- number of computers.

Some sites have received official Energy Star ratings for recent, but not for identical time periods as the data used in this study. The Energy Star related data provided by the site was used to correlate the unofficial scores calculated for this study with the official ratings the buildings received. Table 12 provides a summary of the energy use and cost values for each building.
Energy Star ${ }^{\circledR}$ Portfolio Manager is a benchmarking tool that ranks the annual energy use of a building compared to average commercial buildings data. Each building receives a score between zero and 100. Buildings with scores above 50 can be considered better than average. Buildings with scores above 75 can receive an Energy Star Buildings Label that recognizes the building as performing in the top $25 \%$ of nationwide energy performance. 
Table 12. Energy use and cost by building

\begin{tabular}{|c|c|c|c|c|c|c|}
\hline \multirow[b]{2}{*}{ Building Name } & \multicolumn{6}{|c|}{ Energy Use } \\
\hline & $\begin{array}{c}\text { Electricity } \\
(\mathrm{MWH})\end{array}$ & $\begin{array}{l}\text { Nat Gas } \\
\left(1000 \mathrm{ft}^{3}\right)\end{array}$ & $\begin{array}{l}\text { Steam } \\
(\mathrm{kBtu})\end{array}$ & $\begin{array}{l}\text { Chilled Water } \\
\text { (Ton Hr) }\end{array}$ & $\begin{array}{l}\text { Total Energy } \\
\text { (mBtu) }\end{array}$ & $\begin{array}{c}\text { Total Energy } \\
\text { Cost }\end{array}$ \\
\hline Greeneville CT & 1,640 & 2,530 & 0 & 0 & 8,198 & $\$ 176,042$ \\
\hline Jacksonville FB & 4,578 & 396 & 0 & 0 & 16,020 & $\$ 427,075$ \\
\hline Knoxville FB & 1,928 & 1,887 & 0 & 0 & 8,489 & $\$ 198,759$ \\
\hline Cleveland CT & 1,954 & 0 & $14,052,186$ & 440,719 & 26,009 & $\$ 576,668$ \\
\hline Youngstown CT \& FB & 724 & 0 & $1,683,240$ & 0 & 4,152 & $\$ 108,647$ \\
\hline Cape Girardeau CT & 2,512 & 4,914 & 0 & 0 & 13,547 & $\$ 125,431$ \\
\hline Davenport CT & 858 & 2,236 & 0 & 0 & 5,194 & $\$ 79,627$ \\
\hline Omaha DHS (L) FB & 1,443 & 0 & 0 & 0 & 4,923 & $\$ 95,017$ \\
\hline Omaha NPS (L) FB & 821 & 1,784 & 0 & 0 & 4,586 & $\$ 73,214$ \\
\hline Denver CT & 3,584 & 0 & $11,115,858$ & 454,556 & 28,800 & $\$ 631,891$ \\
\hline Denver (L) FB & 3,834 & 0 & $9,782,442$ & 0 & 22,863 & $\$ 367,301$ \\
\hline Lakewood (L) FB & 1,832 & 2,488 & 0 & 0 & 8,810 & $\$ 213,099$ \\
\hline Ogden (L) FB & 2,053 & 2,342 & 0 & 0 & 9,348 & $\$ 150,700$ \\
\hline Fresno CT \& FB & 6,173 & 5,496 & 0 & 0 & 26,629 & $\$ 854,680$ \\
\hline Las Vegas CT & 7,545 & 1,490 & 0 & 0 & 27,255 & $\$ 720,041$ \\
\hline San Francisco FB & 6,001 & 442 & 4,973 & 0 & 31,501 & $\$ 994,770$ \\
\hline Santa Ana FB & 2,367 & 0 & $1,703,838$ & 543,812 & 16,308 & $\$ 651,182$ \\
\hline Auburn FB & 2,017 & 2,580 & 0 & 0 & 9,495 & $\$ 121,499$ \\
\hline Eugene CT & 2,581 & 4,161 & 0 & 0 & 13,020 & $\$ 213,279$ \\
\hline Seattle CT & 8,064 & 18,062 & 0 & 0 & 45,810 & $\$ 695,685$ \\
\hline Rockville (L) FB & 4,876 & 0 & 0 & 0 & 16,638 & $\$ 733,918$ \\
\hline Suitland FB & 38,384 & 44,253 & 0 & 0 & 175,795 & $\$ 4,708,207$ \\
\hline
\end{tabular}

Although energy use by fuel type and total energy use are useful information to have when considering the overall impact of a building, they do not offer a clear picture on the efficiency of a building's energy use. To assess energy efficiency, total energy use is typically normalized to building size (gross square footage or gsf) to provide an energy use intensity (EUI) value. In this study energy use was also normalized to hours of
EUI is a commonly used metric calculated when the annual energy use is divided by the total building square footage. EUI does not consider the impact of the occupants with respect to how occupant density, plug load, and operating hours may impact energy use. 
regular occupancy and the number of full-time occupant equivalents and then compared to Energy Star Portfolio Manager scores as shown in Figure 7. The figure shows that although there is a relationship between EUI and Energy Star scores, it is not a direct relationship. Note in the top graph the buildings that have Energy Star scores greater than 75 and have EUIs above the line. Other than the Seattle CT (light red box), all of those buildings have greater energy utilization per hours of occupancy and number of building occupants, meaning longer operating hours and more occupants per square foot are impacting the EUI and that is reflected as efficiency in the Energy Star scores. These graphs also show the courthouse buildings tend to have a lower number of occupants than the federal buildings.
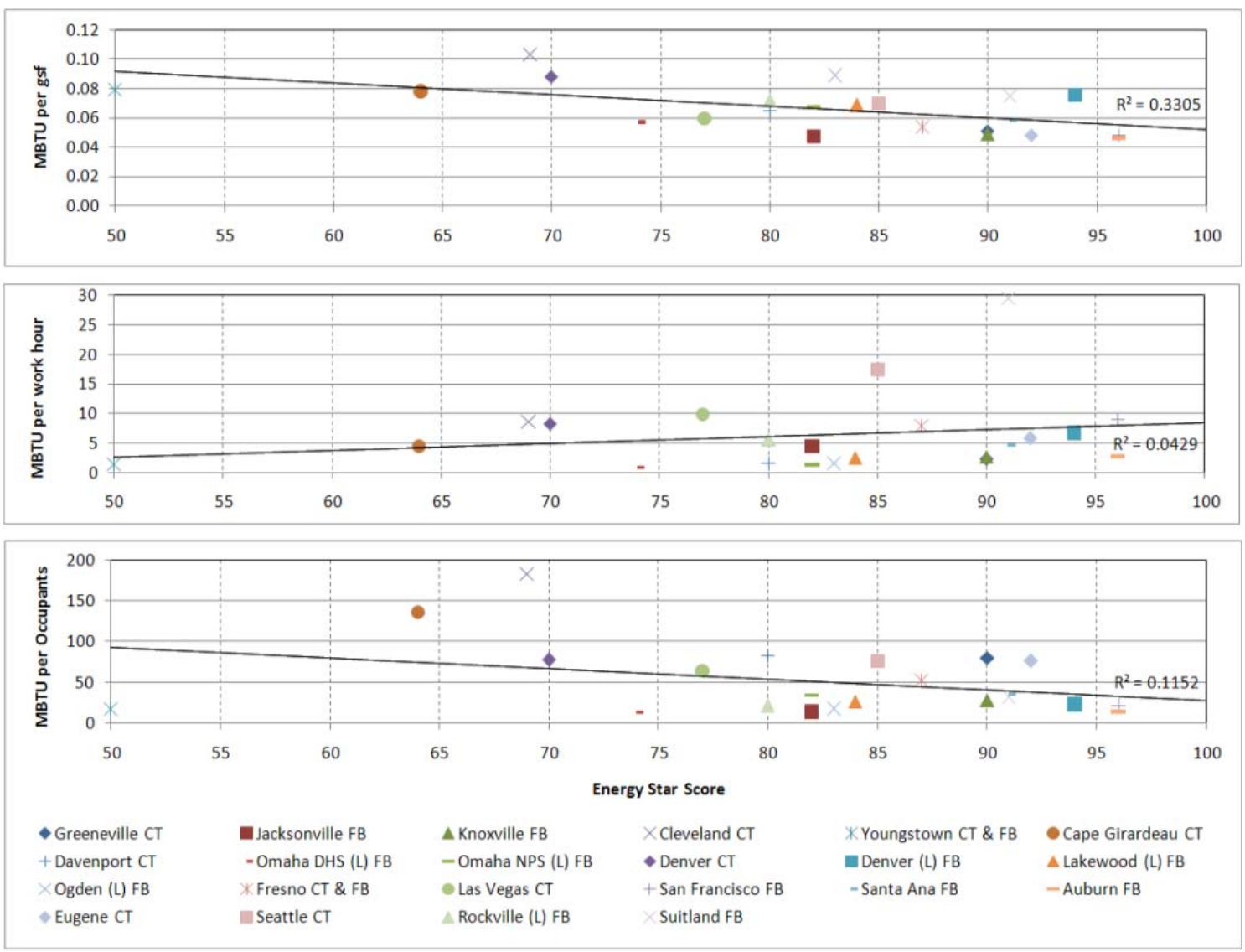

Figure 7. Energy Star rating compared to energy intensity

Table 13 summarizes the EUI data available for each building. Within the table, "Current EUI" is the EUI calculated in Energy Star from data provided by the sites and GSA's EUAS database. "FY09 GSA Regional EUI" values were provided by GSA energy professionals. "GSA FY09 Target" is the EUI goal documented in the Public Buildings Service (PBS). "Energy Star Baseline" is the

GSA has regional averages and national targets for EUI. These values are used to assess the GSA building stock's progress toward the energy and water reduction goals in Executive Order 13423 and 13514, the Energy Policy Act of 2005, and the Energy and Infrastructure Security Act of 2007. 
$50^{\text {th }}$ percentile value calculated within Energy Star. "CBECS Regional Average" includes the average EUI for all building types within specific geographic regions, correlated to GSA regions. "CBECS Office" is the national average EUI for office buildings using 2003 data for office buildings built between 1990 and $2003 .{ }^{18}$ For this analysis multiple baselines were considered in order to gain a broader comparison for how the buildings were performing.

Table 13. Various EUI values of interest

\begin{tabular}{|c|c|c|c|c|c|c|}
\hline \multirow[b]{2}{*}{ Building Name } & \multicolumn{6}{|c|}{ EUI (kBTU/gsf) } \\
\hline & $\begin{array}{c}\text { Current } \\
\text { EUI }\end{array}$ & $\begin{array}{c}\text { FY09 GSA } \\
\text { Regional } \\
\text { Averages }\end{array}$ & $\begin{array}{c}\text { FY09 GSA } \\
\text { Target }\end{array}$ & $\begin{array}{c}\text { Energy Star } \\
\text { Baseline } \\
(50 \%)\end{array}$ & $\begin{array}{c}\text { CBECS } \\
\text { Regional } \\
\text { Average }\end{array}$ & $\begin{array}{c}\text { CBECS } \\
\text { Office }\end{array}$ \\
\hline Greeneville CT & 50 & 58 & 60 & 87 & 78 & \\
\hline Jacksonville FB & 47 & 58 & 60 & 93 & 78 & 88 \\
\hline Knoxville FB & 49 & 58 & 60 & 91 & 78 & 88 \\
\hline Cleveland CT & 103 & 84 & 86 & 129 & 113 & \\
\hline Youngstown CT \& FB & 79 & 84 & 86 & 80 & 113 & \\
\hline Cape Girardeau CT & 78 & 75 & 81 & 92 & 75 & \\
\hline Davenport CT & 65 & 75 & 81 & 96 & 75 & \\
\hline Omaha DHS (L) FB & 57 & 75 & 81 & 77 & 75 & 88 \\
\hline Omaha NPS (L) FB & 67 & 75 & 81 & 103 & 75 & 88 \\
\hline Denver CT & 98 & 89 & 92 & 123 & 81 & \\
\hline Denver (L) FB & 76 & 89 & 92 & 144 & 81 & 88 \\
\hline Lakewood (L) FB & 65 & 89 & 92 & 103 & 81 & 88 \\
\hline Ogden (L) FB & 89 & 89 & 92 & 139 & 81 & 88 \\
\hline Fresno CT \& FB & 54 & 55 & 61 & 91 & 71 & 88 \\
\hline Las Vegas CT & 60 & 55 & 61 & 84 & 71 & \\
\hline San Francisco FB & 48 & 55 & 61 & 112 & 71 & 88 \\
\hline Santa Ana FB & 58 & 55 & 61 & 109 & 71 & 88 \\
\hline Auburn FB & 46 & 63 & 64 & 108 & 71 & 88 \\
\hline Eugene CT & 48 & 63 & 64 & 90 & 71 & \\
\hline Seattle CT & 70 & 63 & 64 & 111 & 71 & \\
\hline Rockville (L) FB & 69 & 95 & 88 & 99 & 90 & 88 \\
\hline Suitland FB & 75 & 95 & 88 & 140 & 90 & 88 \\
\hline
\end{tabular}


In Figure 8 the buildings' EUIs were compared to the different potential baselines including the CBECS national average for office buildings built from 1990-2003, CBECS regional averages for all building types, and GSA's regional averages and targets. All of GSA's buildings in this study perform better than or equivalent to the CBECS

CBECS is a publicly available database comprised of national survey data on U.S. commercial building energy consumption. CBECS data can be sorted by building type, age, region, size, fuel type, and various other parameters.

averages. Both of the buildings that are not performing better than the GSA's FY09 target are courthouses. Only one of the buildings in the Pacific Region, the San Francisco FB, is performing better than the GSA regional average. Outside of the Pacific Region, the only buildings that are not meeting the regional averages are three courthouses (note that in the Heartland Region the GSA regional average is the same as the CBECS regional average, so you cannot see the 'blue line' in the graph).

The energy performance average of the buildings in the study was $25 \%$ better than CBECS office building national average, 10\% better than fiscal year 2009 GSA Regional Averages, 13\% better than fiscal year 2009 GSA Target values, 18\% better than CBECS regional averages, and $37 \%$ better than the Energy Star Portfolio Manager $50^{\text {th }}$ percentile buildings.

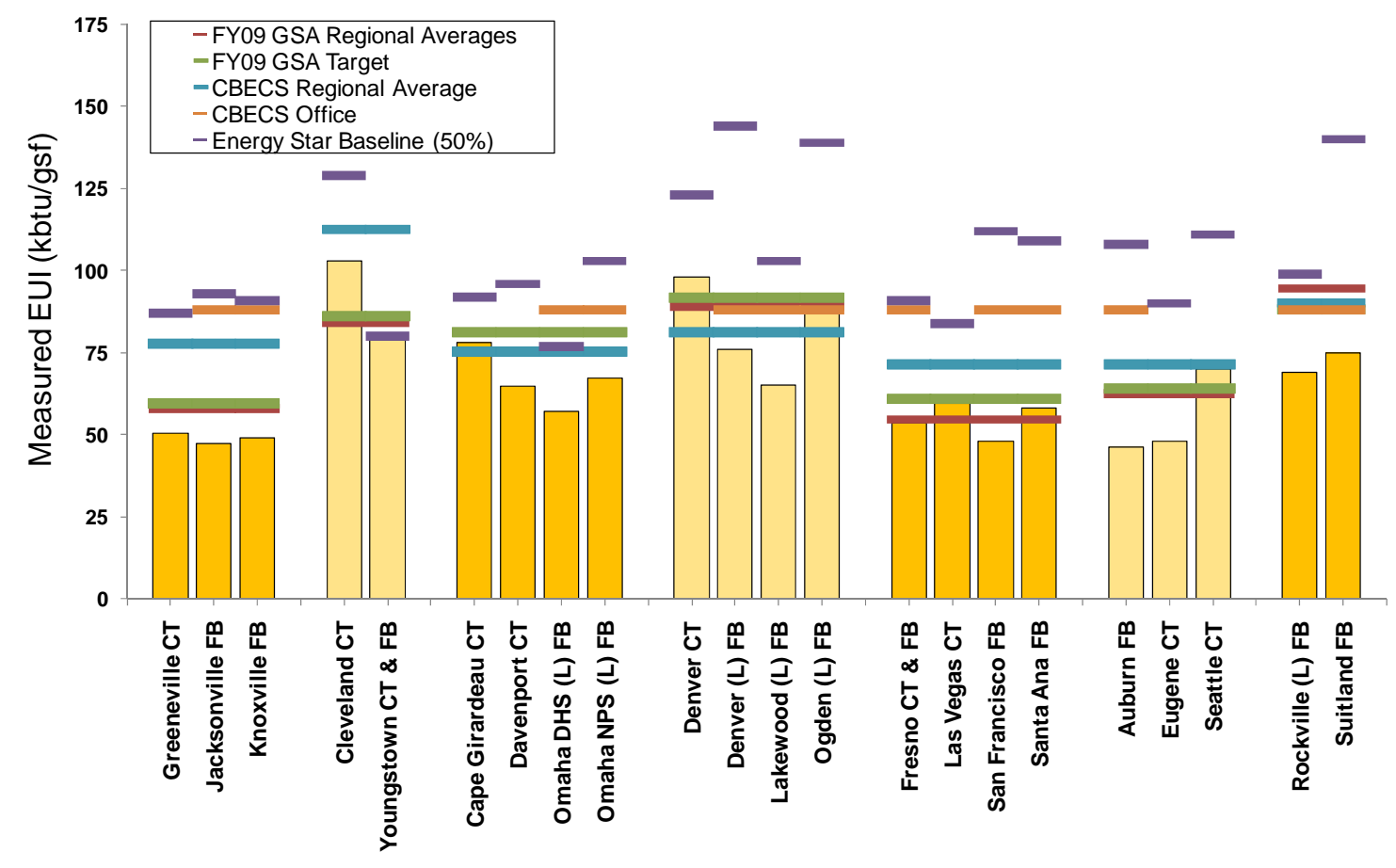

Figure 8. Study building EUIs compared to the GSA national average and CBECS national and regional EUIs 
Table 14 provides the LEED total credits, EAc1 points, WEc3 points, and the calculated Energy Star scores. For the buildings that have earned an Energy Star rating, the official Energy Star value is

LEED $^{\circledR}$ Energy and Atmosphere credit 1 (EAc1), Optimize Energy Performance, allows for up to 10 points for reducing energy consumption by $42 \%$ or more. provided in parentheses next to the certification level. The official values may be different from the values calculated for this study because of different timeframes for the assessment.

Table 14. "Green" design certification by building

\begin{tabular}{|c|c|c|c|c|c|}
\hline Building Name & Certification Level & $\begin{array}{c}\text { LEED }^{\circledR} \\
\text { Total } \\
\text { Credits }\end{array}$ & $\begin{array}{c}\text { LEED® } \\
\text { EAc1 } \\
\text { Credits }\end{array}$ & $\begin{array}{c}\text { LEED® } \\
\text { WEc3 } \\
\text { Credits }\end{array}$ & $\begin{array}{c}\text { Energy } \\
\text { Star }{ }^{\circledR} \\
\text { Score }\end{array}$ \\
\hline Greeneville CT & Energy Star 2007 (89) & $\mathrm{N} / \mathrm{A}$ & $\mathrm{N} / \mathrm{A}$ & $\mathrm{N} / \mathrm{A}$ & 90 \\
\hline Jacksonville FB & Energy Star 2007 (88) & $\mathrm{N} / \mathrm{A}$ & $\mathrm{N} / \mathrm{A}$ & $\mathrm{N} / \mathrm{A}$ & 82 \\
\hline Knoxville FB & LEED-EB Certified, Energy Star 2007 (88) & 28 & 8 & 2 & 90 \\
\hline Cleveland CT & LEED-NC Certified & 29 & 3 & 2 & 69 \\
\hline Youngstown CT \& FB & LEED-NC Certified & 27 & 0 & 0 & 50 \\
\hline Cape Girardeau CT & LEED-NC Silver & 33 & 4 & 1 & 64 \\
\hline Davenport CT & LEED-NC Registered & $\mathrm{N} / \mathrm{A}$ & $\mathrm{N} / \mathrm{A}$ & $\mathrm{N} / \mathrm{A}$ & 80 \\
\hline Omaha DHS (L) FB & LEED-NC Gold & 42 & 10 & 2 & 74 \\
\hline Omaha NPS (L) FB & LEED-NC Gold & 40 & 3 & 2 & 82 \\
\hline Denver CT & Green Building Challenge, LEED-EB Silver & 33 & 2 & 1 & 70 \\
\hline Denver (L) FB & LEED-NC Gold, Energy Star 2008 (96) & 40 & 5 & 2 & 94 \\
\hline Lakewood (L) FB & LEED-NC Silver & 35 & 4 & 0 & 84 \\
\hline Ogden (L) FB & LEED-NC Silver & 34 & 5 & 1 & 83 \\
\hline Fresno CT \& FB & California Energy Standard Title 24 & $\mathrm{~N} / \mathrm{A}$ & $\mathrm{N} / \mathrm{A}$ & $\mathrm{N} / \mathrm{A}$ & 87 \\
\hline Las Vegas CT & Energy Star 2007 (77) & $\mathrm{N} / \mathrm{A}$ & $\mathrm{N} / \mathrm{A}$ & $\mathrm{N} / \mathrm{A}$ & 77 \\
\hline San Francisco FB & LEED-NC Silver & 34 & 2 & 2 & 96 \\
\hline Santa Ana FB & California Energy Standard Title 24 & $\mathrm{~N} / \mathrm{A}$ & $\mathrm{N} / \mathrm{A}$ & $\mathrm{N} / \mathrm{A}$ & 91 \\
\hline Auburn FB & LEED-NC Silver & 36 & 5 & 2 & 96 \\
\hline Eugene $\mathrm{CT}$ & LEED-NC Gold, Energy Star 2009 (94) & 39 & 4 & 2 & 92 \\
\hline Seattle CT & IFMA Sustainable Design and Energy Efficiency Award & $\mathrm{N} / \mathrm{A}$ & $\mathrm{N} / \mathrm{A}$ & $\mathrm{N} / \mathrm{A}$ & 85 \\
\hline Rockville (L) FB & LEED-NC Registered (Silver), Energy Star 2009 (76) & 33 & 2 & 1 & 80 \\
\hline Suitland FB & LEED-NC Registered (Gold) & 41 & 1 & 2 & 91 \\
\hline
\end{tabular}


In addition to the LEED Optimize Energy Performance credits, key energy management credits are documented in Table 15. Note that the Youngstown FB \& CT has zero optimize energy performance credits. Youngstown was designed to an early version of LEED that did not require points in this category.

Table 15. LEED Energy and Atmosphere Credits pursued

\begin{tabular}{|c|c|c|c|c|c|}
\hline & & LEE & $D^{\circledR}$ Energy Credit & & \\
\hline Building Name & $\begin{array}{c}\text { Total EA } \\
\text { Credits }\end{array}$ & $\begin{array}{c}\text { Optimize Energy } \\
\text { Performance } \\
\text { EAc1 }\end{array}$ & $\begin{array}{c}\text { Additional } \\
\text { Commissioning } \\
\text { EAc3 }\end{array}$ & $\begin{array}{c}\text { Measurement \& } \\
\text { Verification } \\
\text { EAc5 }\end{array}$ & $\begin{array}{c}\text { Green Power } \\
\text { EAc6 }\end{array}$ \\
\hline Greeneville CT & $\mathrm{N} / \mathrm{A}$ & $\mathrm{N} / \mathrm{A}$ & $\mathrm{N} / \mathrm{A}$ & $\mathrm{N} / \mathrm{A}$ & $\mathrm{N} / \mathrm{A}$ \\
\hline Jacksonville FB & $\mathrm{N} / \mathrm{A}$ & $\mathrm{N} / \mathrm{A}$ & $\mathrm{N} / \mathrm{A}$ & $\mathrm{N} / \mathrm{A}$ & $\mathrm{N} / \mathrm{A}$ \\
\hline Knoxville FB & 11 & 8 & $\mathrm{~N} / \mathrm{A}$ & $\mathrm{N} / \mathrm{A}$ & $\mathrm{N} / \mathrm{A}$ \\
\hline Cleveland CT & 3 & 3 & 0 & 0 & 0 \\
\hline Youngstown CT \& FB & 1 & 0 & 0 & 0 & 0 \\
\hline Cape Girardeau CT & 6 & 4 & 0 & 1 & 0 \\
\hline Davenport CT & $\mathrm{N} / \mathrm{A}$ & $\mathrm{N} / \mathrm{A}$ & $\mathrm{N} / \mathrm{A}$ & $\mathrm{N} / \mathrm{A}$ & $\mathrm{N} / \mathrm{A}$ \\
\hline Omaha DHS (L) FB & 13 & 10 & 0 & 1 & 1 \\
\hline Omaha NPS (L) FB & 6 & 3 & 1 & 1 & 1 \\
\hline Denver CT & 8 & 2 & - & - & - \\
\hline Denver (L) FB & 9 & 5 & 1 & 1 & 1 \\
\hline Lakewood (L) FB & 8 & 4 & 1 & 1 & 1 \\
\hline Ogden (L) FB & 7 & 5 & 0 & 1 & 1 \\
\hline Fresno CT \& FB & $\mathrm{N} / \mathrm{A}$ & $\mathrm{N} / \mathrm{A}$ & $\mathrm{N} / \mathrm{A}$ & $\mathrm{N} / \mathrm{A}$ & $\mathrm{N} / \mathrm{A}$ \\
\hline Las Vegas CT & $\mathrm{N} / \mathrm{A}$ & $\mathrm{N} / \mathrm{A}$ & $\mathrm{N} / \mathrm{A}$ & $\mathrm{N} / \mathrm{A}$ & $\mathrm{N} / \mathrm{A}$ \\
\hline San Francisco FB & 4 & 2 & 1 & 1 & 0 \\
\hline Santa Ana FB & $\mathrm{N} / \mathrm{A}$ & $\mathrm{N} / \mathrm{A}$ & $\mathrm{N} / \mathrm{A}$ & $\mathrm{N} / \mathrm{A}$ & $\mathrm{N} / \mathrm{A}$ \\
\hline Auburn FB & 9 & 5 & 1 & 1 & 1 \\
\hline Eugene CT & 8 & 4 & 1 & 1 & 1 \\
\hline Seattle CT & $\mathrm{N} / \mathrm{A}$ & $\mathrm{N} / \mathrm{A}$ & $\mathrm{N} / \mathrm{A}$ & $\mathrm{N} / \mathrm{A}$ & $\mathrm{N} / \mathrm{A}$ \\
\hline Rockville (L) FB & 4 & 2 & 0 & 1 & 0 \\
\hline Suitland FB & 4 & 1 & 1 & 0 & 1 \\
\hline
\end{tabular}


Comparing the Energy Star scores to the overall LEED score does not appear to offer a correlation between the measured energy use and the LEED scores.

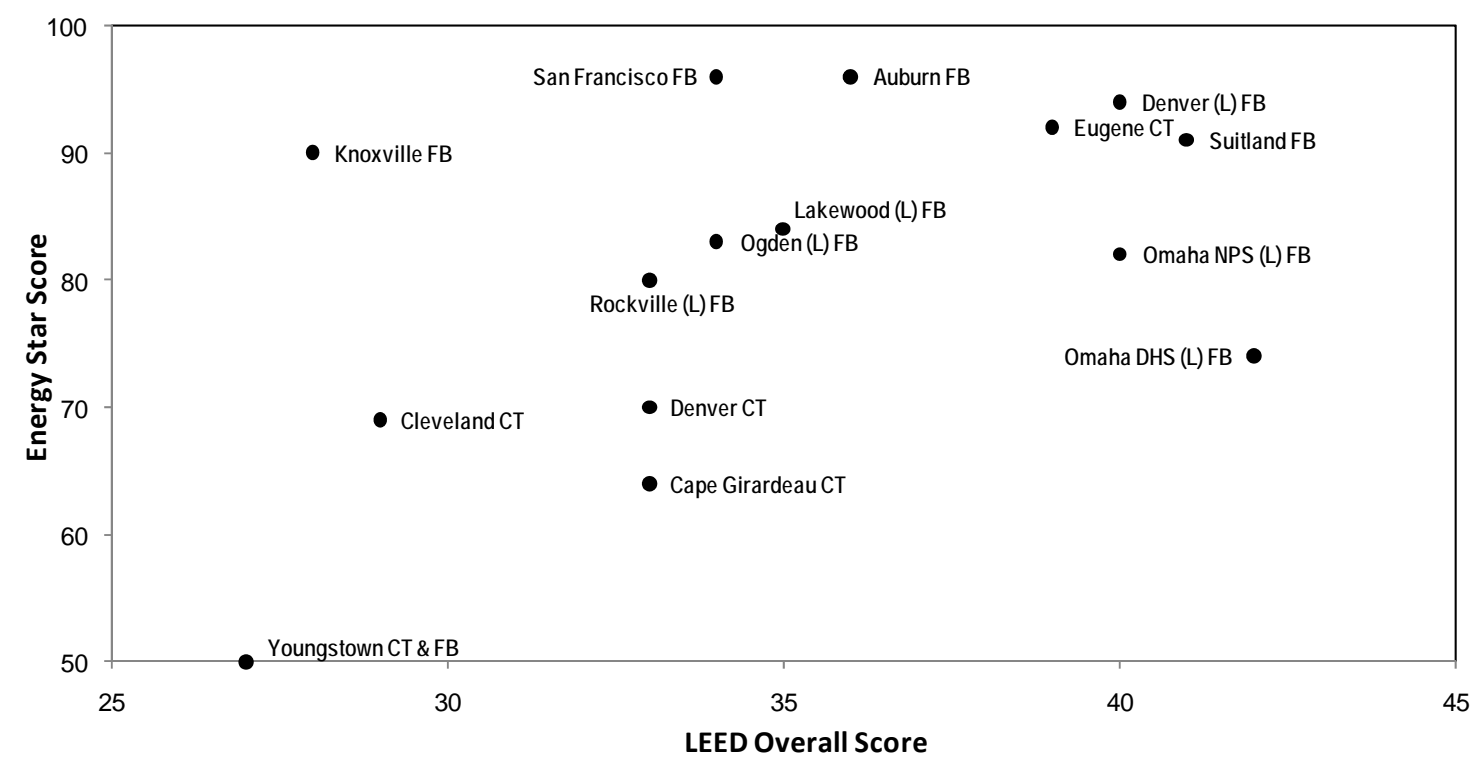

Figure 9. Energy Star rating and total LEED credits

Comparing Energy Star scores with the EAc1 points shows that 4 of the 5 buildings that had five or more EAc1 points had Energy Star scores above 80, with only $50 \%$ of the buildings with three points or less scoring 80 or above.

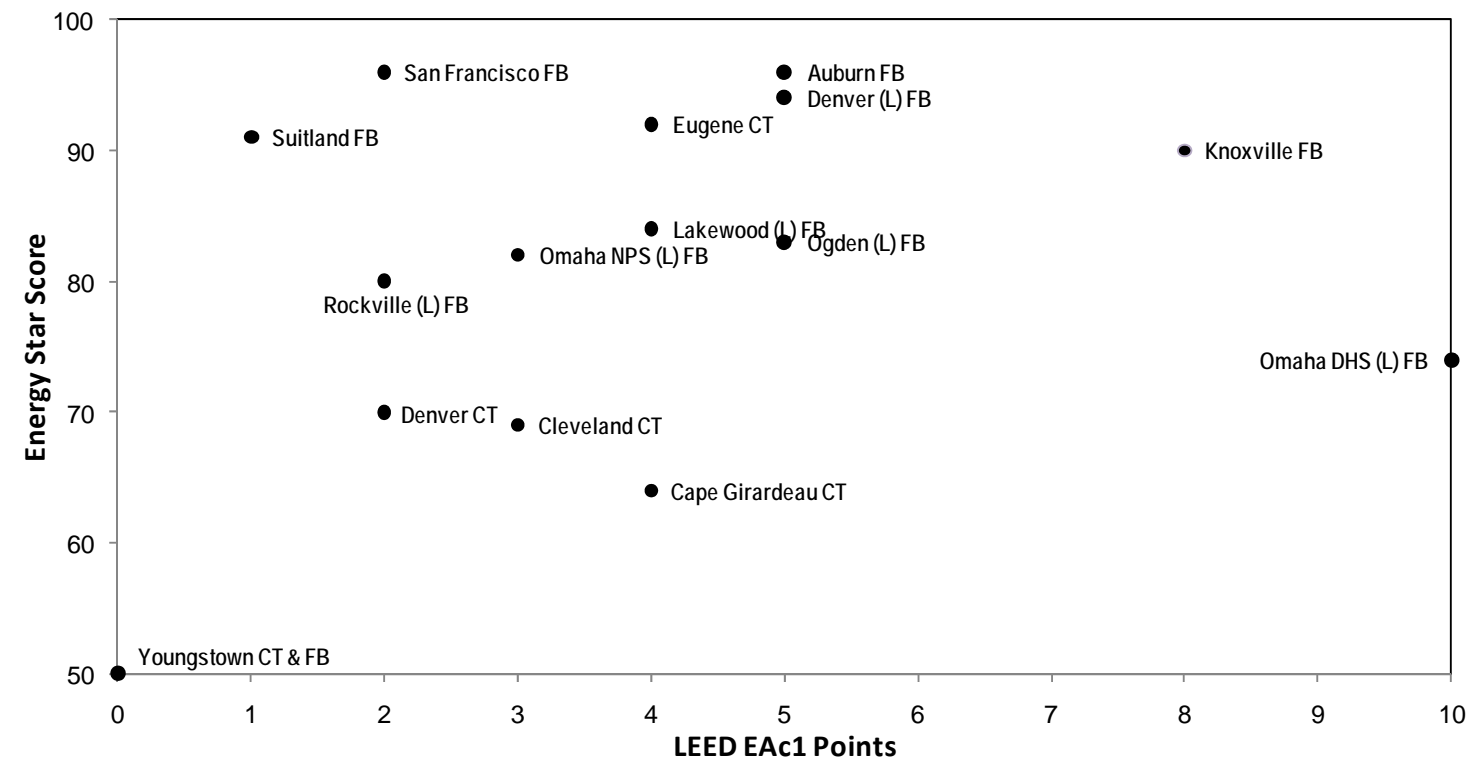

Figure 10. Energy Star rating and LEED energy credits 
Eight of the twelve buildings included in the first round of performance measurement (Round 1, or R1) had lower Energy Star scores during timeframe of this assessment (Figure 11). Some of the changes were minor and could be because of an increase in building information in the Energy Star Portfolio Manager database. However three of those buildings had noticeable increases in energy consumption from the first assessment (Figure 12). It is recommended the changes in energy use are investigated at the Cleveland CT, Youngstown CT \& FB, and the Omaha DHS FB.

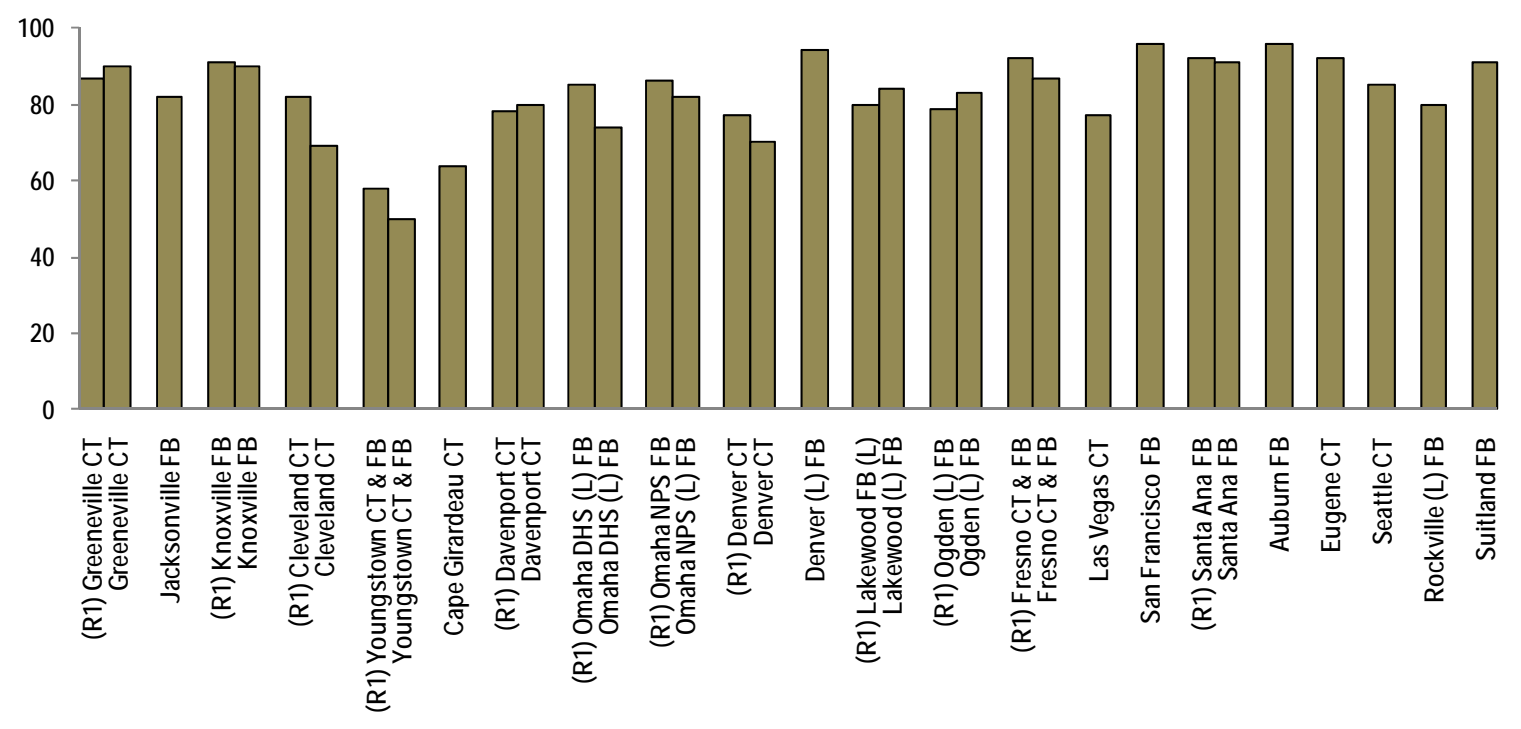

Figure 11. Energy Star Scores with Round 1 data included

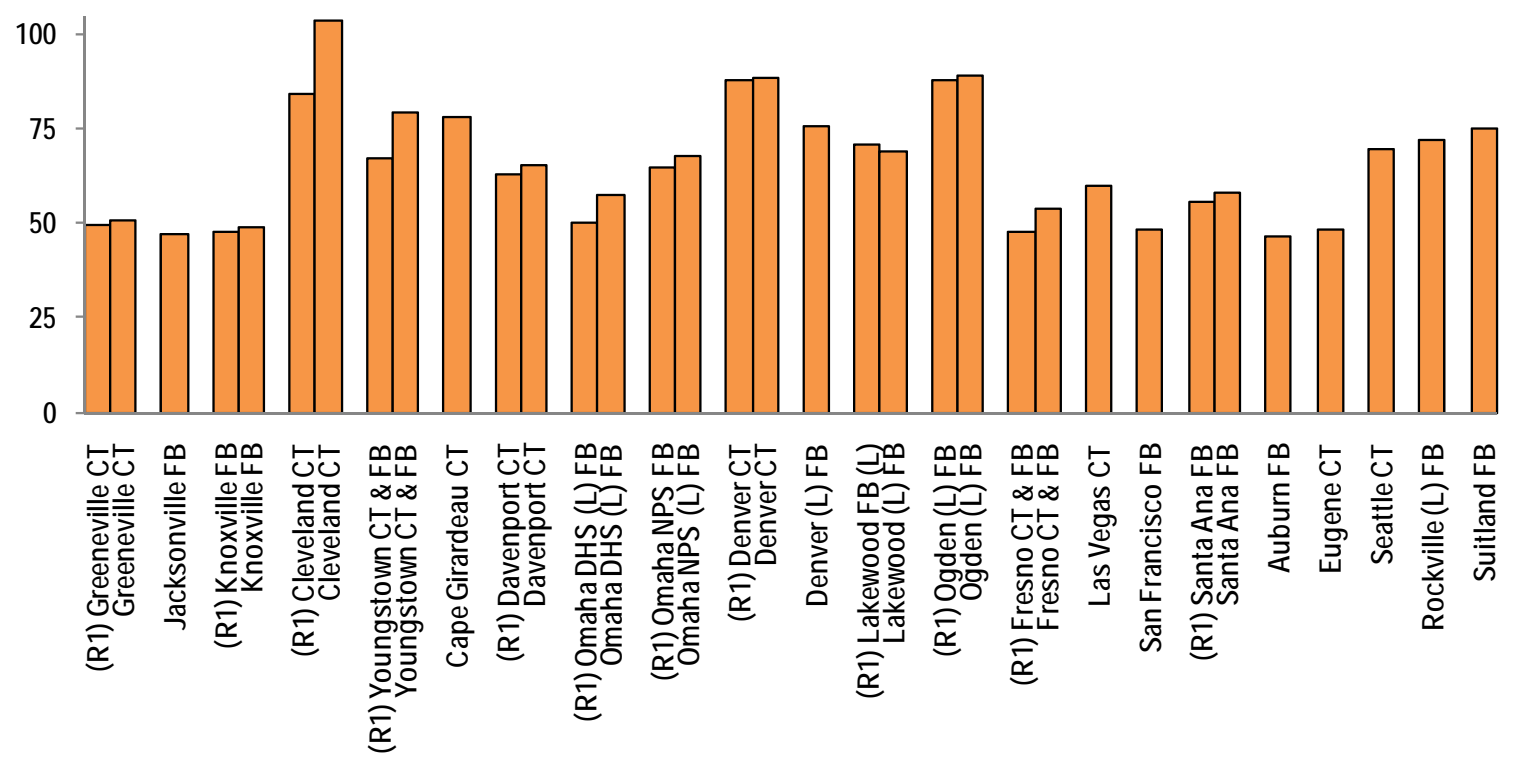

Figure 12. Annual Energy Use (kBtu/GSF) 
Figure 13 shows the Energy Star Portfolio Manager scores in relationship to the water use per gross square foot. The energy performance for all of the buildings in this study is equal to or better than the industry average. Water use per gross square foot is better than the industry average for 15 of the 21 buildings with water data (buildings in the top right quadrant). Five of the buildings provided water use data for the indoor, domestic water use only (triangles), while the remaining buildings had a combination of process and irrigation water use included in the total building water use values. Thus, in sixteen of the buildings the water performance contributes to the energy efficiency of the buildings. Note that all but two of the buildings with an Energy Star Score of 80 and above use process water, while the building with the lowest Energy Star score is not using water to augment its energy performance.

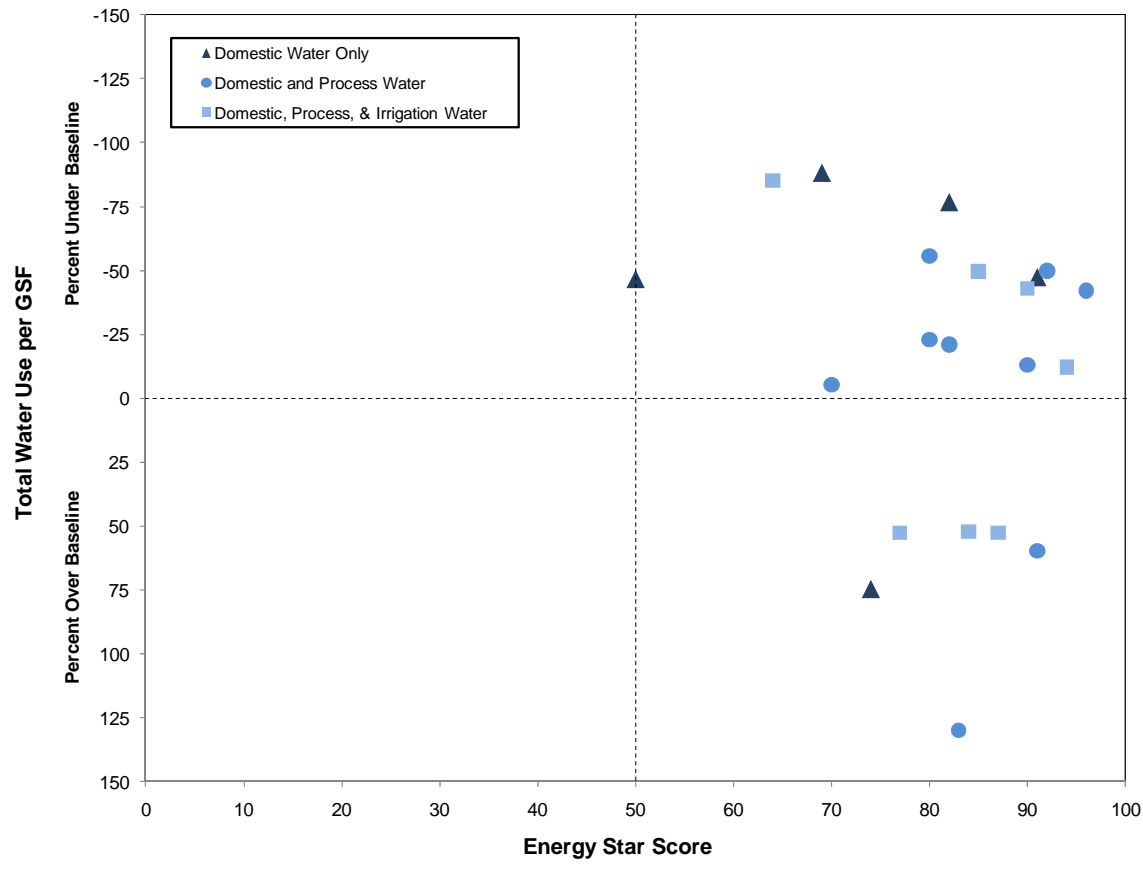

Figure 13. Energy Star score and water use per GSF performance 
When examining energy use and thermal comfort, the subset of buildings that had under floor air distribution (UFAD) systems appeared to have better energy performance and lower thermal comfort scores. However, the buildings with UFAD systems have them only in part of the building. In contrast to the whole building data shown in Figure 14, the Center for the Built Environment survey results were examined by location within one building, and the space in the building that had the UFAD system had the highest thermal comfort scores in the building, with the other spaces scoring low, resulting in a low number for the whole building. Although it is interesting that this subset of buildings has better overall energy performance and lower thermal comfort scores, this is a very small sample and even a meta-analysis within this building set showed there is evidence that the whole building satisfaction levels are not representative of all UFAD spaces.

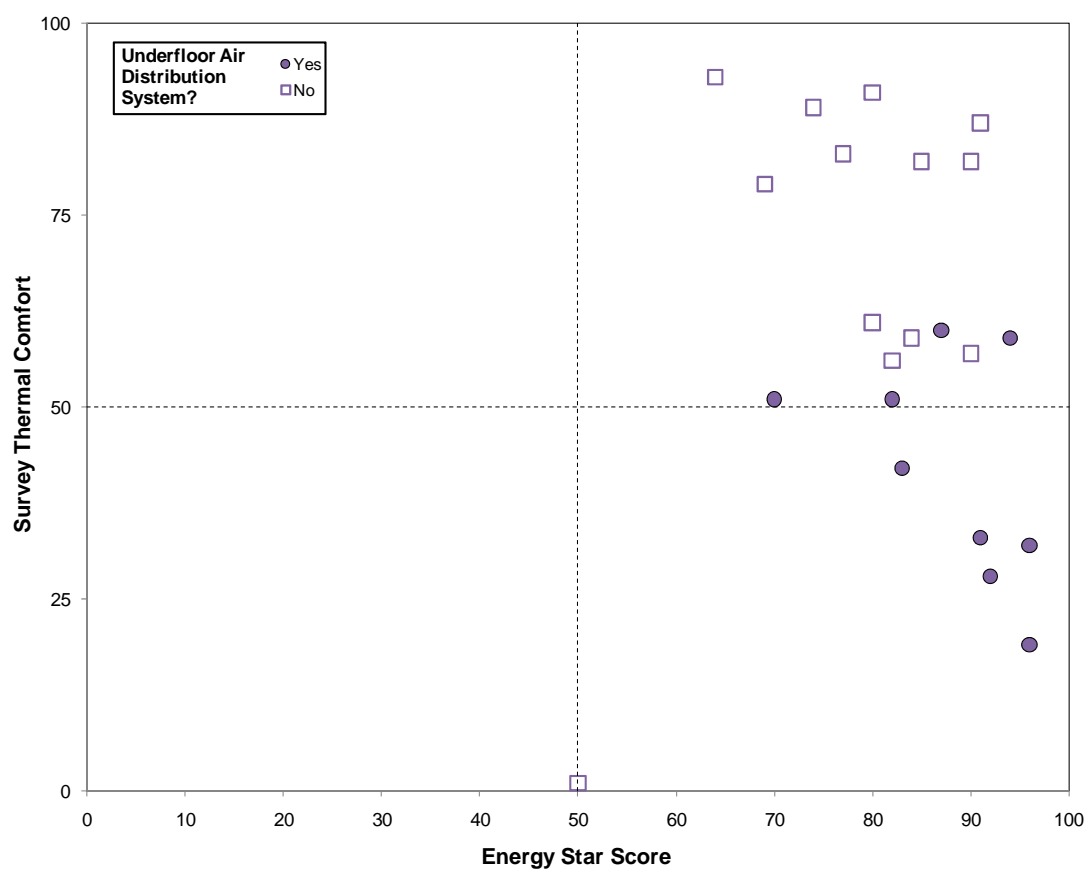

Figure 14. Energy Star score and thermal comfort with UFAD

Although there is value in high-level, whole building performance analysis, Figure 14 is an example of how summary data can be misleading if not carefully examined. The whole building performance data provided in this study is intended only for a summary analysis of the portfolio and to identify areas where further investigation may be needed. 
The energy-related utility costs tend to be a significant portion of a building's operating costs. Energy costs are typically expressed as cost per rentable square foot (RSF). The baseline value for energy costs per gross square foot is based on office building values from IFMA and BOMA. ${ }^{19,20,21,22}$ The baseline range shown in Figure 15 are national averages, thus location related differences in energy costs may explain some of the buildings outside of the range. For example, the states in the Heartland and Northwest/Arctic regions have lower than the U.S. average electricity costs, and states in National Capital region have higher than average electricity costs. ${ }^{23}$ California is the only other state with buildings in the study that had electricity costs higher than the national average, which may explain the higher costs at the Santa Ana FB, especially given it has an Energy Star score of 91. Regardless of regional differences, the buildings with higher than average costs are worth investigating further in order to ensure everything possible is being done to reduce operating costs.

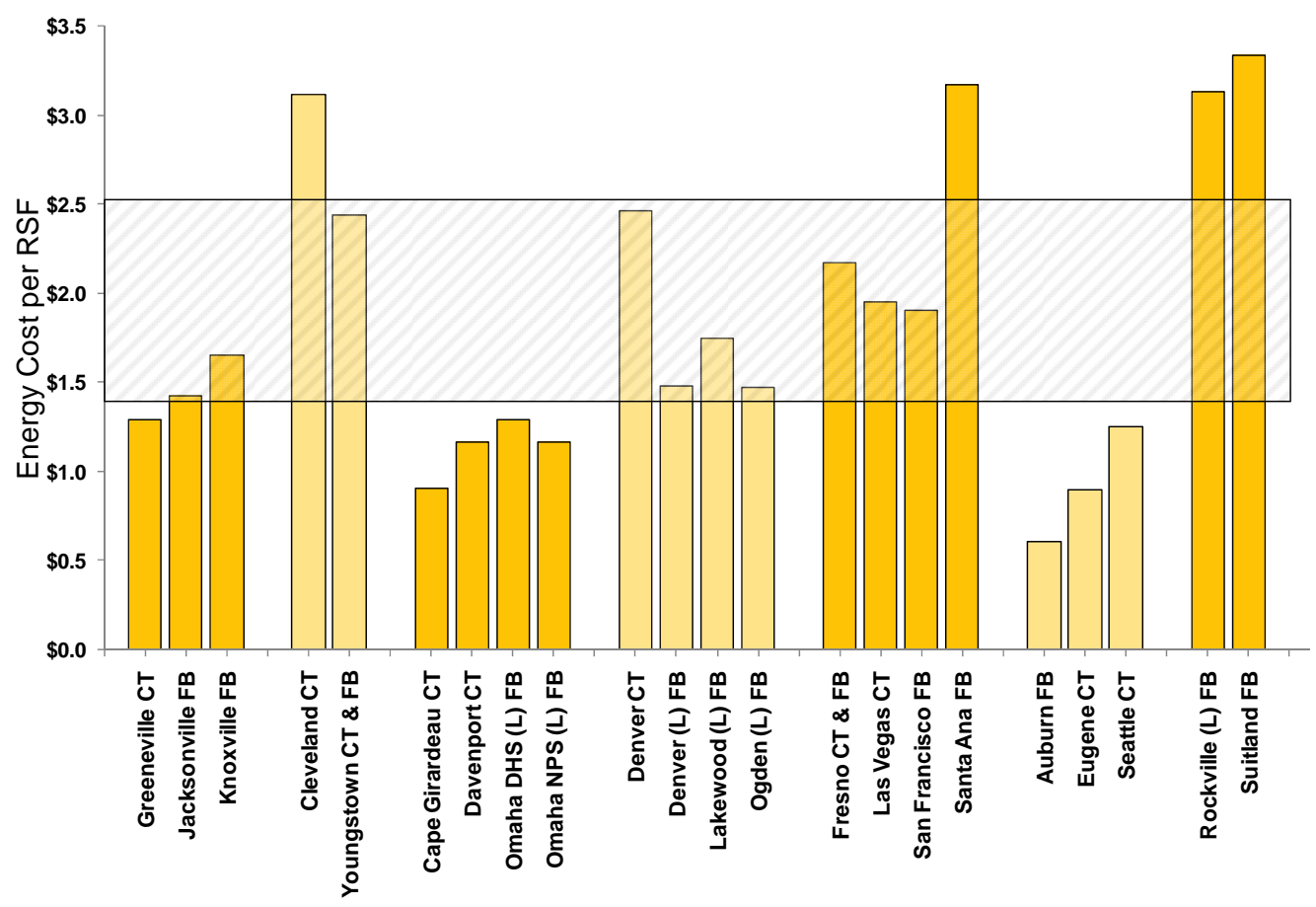

Figure 15. Energy cost per gross square foot

Note that the Cleveland CT and the Santa Ana FB buildings were evaluated in the previous round of GSA's whole building performance assessment. Both buildings' energy costs are noticeably higher than they were in the first round. The Cleveland CT energy use increased, but the Santa Ana FB energy remained relatively constant. 
A key environmental impact of energy use is greenhouse gas emissions. Greenhouse gas emissions are represented as carbon dioxide $\left(\mathrm{CO}_{2}\right)$ equivalents. The $\mathrm{CO}_{2}$ equivalents related to source energy use for the buildings in the study are calculated through the Energy Star Portfolio Manager and summarized in Table 16.

Table 16. Energy use, cost and $\mathrm{CO}_{2}$ equivalent performance

\begin{tabular}{|c|c|c|c|}
\hline & Energy Use Emis & ssions & \\
\hline Building Name & $\begin{array}{c}\text { Energy Use } \\
\text { (kBTU) per } \\
\text { GSF }\end{array}$ & $\begin{array}{c}\text { Energy Cost per } \\
\text { RSF }\end{array}$ & $\begin{array}{c}\text { Building } \mathrm{CO}_{2} \\
\text { Equivalent per } \\
\text { GSF (Metric } \\
\text { Tons) }\end{array}$ \\
\hline Greeneville CT & 50 & $\$ 1.29$ & 0.0078 \\
\hline Jacksonville FB & 47 & $\$ 1.42$ & 0.0082 \\
\hline Knoxville FB & 49 & $\$ 1.65$ & 0.0083 \\
\hline Cleveland CT & 103 & $\$ 3.12$ & 0.0109 \\
\hline Youngstown CT \& FB & 79 & $\$ 2.44$ & 0.0123 \\
\hline Cape Girardeau CT & 78 & $\$ 0.91$ & 0.0136 \\
\hline Davenport CT & 65 & $\$ 1.16$ & 0.0104 \\
\hline Omaha DHS (L) FB & 57 & $\$ 1.29$ & 0.0139 \\
\hline Omaha NPS (L) FB & 67 & $\$ 1.17$ & 0.0114 \\
\hline Denver CT & 98 & $\$ 2.46$ & 0.0131 \\
\hline Denver (L) FB & 76 & $\$ 1.48$ & 0.0135 \\
\hline Lakewood (L) FB & 65 & $\$ 1.74$ & 0.0131 \\
\hline Ogden (L) FB & 89 & $\$ 1.47$ & 0.0092 \\
\hline Fresno CT \& FB & 54 & $\$ 2.17$ & 0.0047 \\
\hline Las Vegas CT & 60 & $\$ 1.95$ & 0.0101 \\
\hline San Francisco FB & 48 & $\$ 1.90$ & 0.0043 \\
\hline Santa Ana FB & 58 & $\$ 3.17$ & 0.0038 \\
\hline Auburn FB & 46 & $\$ 0.60$ & 0.0047 \\
\hline Eugene CT & 48 & $\$ 0.90$ & 0.0048 \\
\hline Seattle CT & 70 & $\$ 1.25$ & 0.0065 \\
\hline Rockville (L) FB & 69 & $\$ 3.22$ & 0.0109 \\
\hline Suitland FB & 75 & $\$ 3.34$ & 0.0095 \\
\hline
\end{tabular}


Figure 16 shows the relative baselines for each building given the energy use and utility. All of the buildings studied are below the industry average $\mathrm{CO}_{2}$ equivalent emissions. Eight of the buildings also have contracts to purchase green power (Table 15, EAc6), which would result in lower emissions. Emissions reductions from green power purchases are not represented in this graphic.

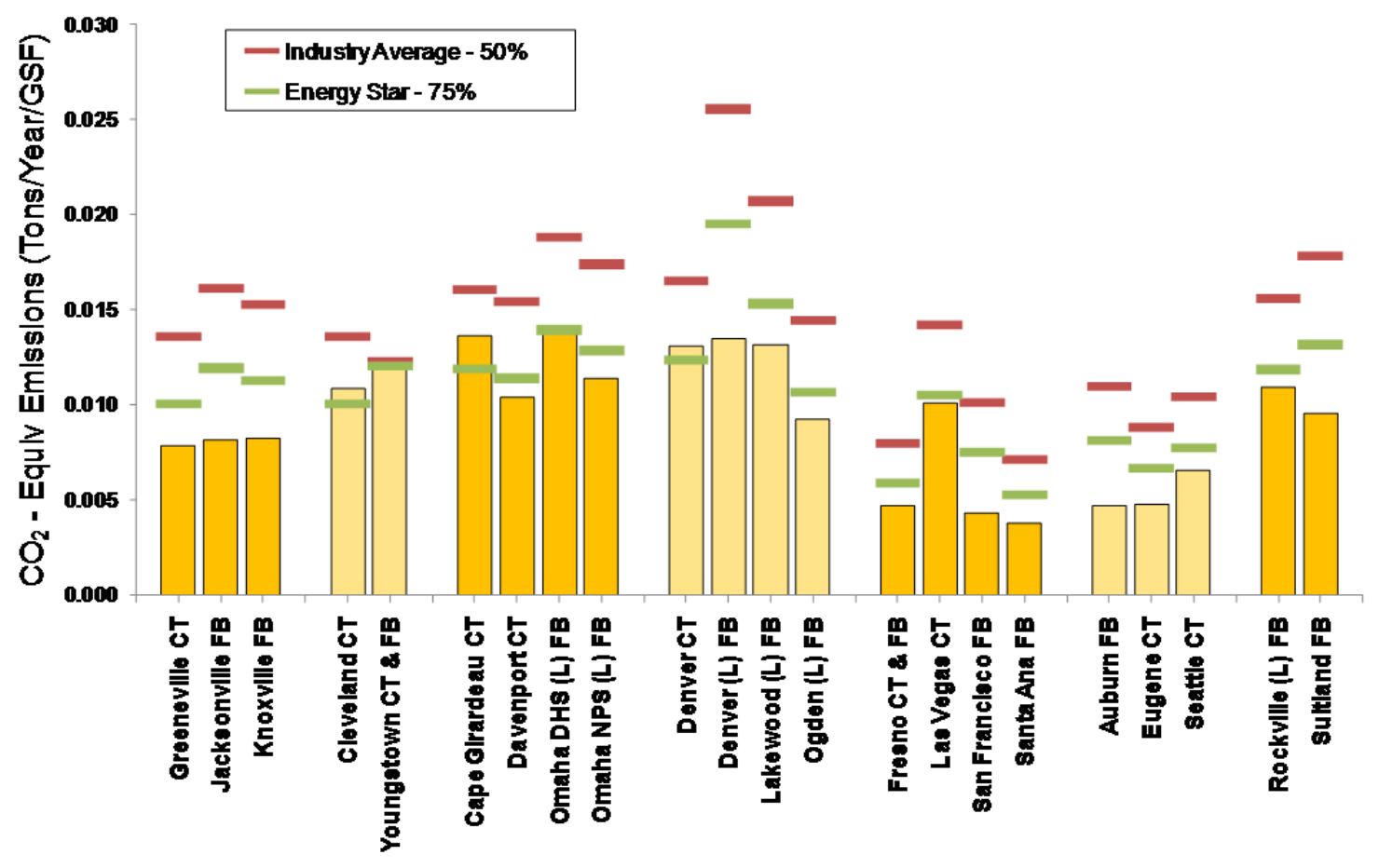

Figure 16. $\mathrm{CO}_{2}$ equivalents compared to Energy Star baseline

On average, the buildings in the study use less energy, have lower energy costs, and have lower carbon emissions. Three of the buildings that were assessed in the first round of whole building performance measurement had increases in energy use. It is recommended those buildings be further investigated to better understand the change in energy use. 


\section{Maintenance and Operations}

Interdependence in building systems means that a cost effective and highperforming operations and maintenance $(\mathrm{O} \& \mathrm{M})$ program may cost more in

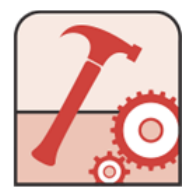
training, monitoring, and preventative maintenance, but reduces the costs of occupant satisfaction and productivity, energy, water, materials, and repair costs. The details provided for each building's maintenance records varied and thus, when details were not available, it was assumed that the maintenance costs represented equivalent activities to other buildings. The O\&M data available for each building are summarized in Table 17.

Table 17. O\&M data and cost by building

\begin{tabular}{|c|c|c|c|c|c|c|}
\hline Building Name & $\begin{array}{l}\text { Green House- } \\
\text { keeping }\end{array}$ & $\begin{array}{c}\text { Maint Calls / } \\
\text { Total Maint }\end{array}$ & $\begin{array}{l}\text { Prev Maint / } \\
\text { Total Maint }\end{array}$ & $\begin{array}{c}\text { General } \\
\text { Maint Cost }\end{array}$ & $\begin{array}{l}\text { Janitorial } \\
\text { Maint Cost }\end{array}$ & $\begin{array}{l}\text { Grounds } \\
\text { Maint Cost }\end{array}$ \\
\hline Greeneville CT & Some & $14 \%$ & $86 \%$ & $\$ 163,419$ & $\$ 227,517$ & $\$ 4,000$ \\
\hline Jacksonville FB & Yes & $27 \%$ & $73 \%$ & $\$ 523,958$ & $\$ 499,906$ & $\$ 2,148$ \\
\hline Knoxville FB & Some & $16 \%$ & $84 \%$ & $\$ 237,836$ & $\$ 220,948$ & $\$ 5,300$ \\
\hline Cleveland CT & Yes & $46 \%$ & $54 \%$ & $\$ 176,320$ & $\$ 297,728$ & $\$ 3,100$ \\
\hline Youngstown CT \& FB & Yes & $29 \%$ & $71 \%$ & $\$ 124,875$ & $\$ 99,267$ & $\$ 37,300$ \\
\hline Cape Girardeau CT & Yes & $\mathrm{N} / \mathrm{A}$ & $\mathrm{N} / \mathrm{A}$ & $\$ 411,651$ & $\$ 172,282$ & $\$ 11,318$ \\
\hline Davenport CT & Some & $31 \%$ & $69 \%$ & $\$ 179,011$ & $\$ 145,990$ & $\$ 6,421$ \\
\hline Omaha DHS (L) FB & Some & $35 \%$ & $65 \%$ & $\$ 72,632$ & $\$ 70,800$ & $\$ 8,200$ \\
\hline Omaha NPS (L) FB & Yes & $62 \%$ & $38 \%$ & $\$ 41,600$ & $\$ 56,400$ & $\$ 9,050$ \\
\hline Denver CT & No & $44 \%$ & $56 \%$ & $\$ 643,227$ & $\$ 349,560$ & $\$ 29,791$ \\
\hline Denver (L) FB & Yes & $85 \%$ & $15 \%$ & $\$ 184,607$ & $\$ 258,120$ & $\$ 16,833$ \\
\hline Lakewood (L) FB & No & $5 \%$ & $95 \%$ & $\$ 103,644$ & $\$ 83,220$ & $\$ 7,394$ \\
\hline Ogden (L) FB & Some & $\mathrm{N} / \mathrm{A}$ & $\mathrm{N} / \mathrm{A}$ & $\$ 39,068$ & $\$ 125,892$ & $\$ 3,584$ \\
\hline Fresno CT \& FB & No & $20 \%$ & $80 \%$ & $\$ 1,194,365$ & $\$ 821,414$ & $\$ 24,236$ \\
\hline Las Vegas CT & Yes & $40 \%$ & $60 \%$ & $\$ 616,845$ & $\$ 174,441$ & $\$ 126,328$ \\
\hline San Francisco FB & Yes & $77 \%$ & $23 \%$ & $\$ 1,152,725$ & $\$ 1,169,249$ & $\$ 25,000$ \\
\hline Santa Ana FB & No & $43 \%$ & $57 \%$ & $\$ 478,557$ & $\$ 345,401$ & $\$ 15,018$ \\
\hline Auburn FB & Yes & $17 \%$ & $83 \%$ & $\$ 233,367$ & $\$ 370,864$ & $\$ 22,497$ \\
\hline Eugene CT & Yes & $\mathrm{N} / \mathrm{A}$ & $\mathrm{N} / \mathrm{A}$ & $\$ 381,904$ & $\$ 339,996$ & $\$ 51,808$ \\
\hline Seattle CT & Yes & $\mathrm{N} / \mathrm{A}$ & $\mathrm{N} / \mathrm{A}$ & $\$ 597,755$ & $\$ 1,016,574$ & $\$ 29,635$ \\
\hline Rockville (L) FB & Yes & $84 \%$ & $16 \%$ & $\$ 370,782$ & $\$ 301,832$ & $\$ 91,858$ \\
\hline Suitland FB & Yes & $54 \%$ & $46 \%$ & $\$ 2,730,589$ & $\$ 3,213,210$ & $\$ 149,239$ \\
\hline
\end{tabular}


Figure 17 shows general maintenance costs per rentable square foot. The baseline values for the general, grounds, and janitorial maintenance costs were provided by GSA or collected from IFMA and BOMA resources. ${ }^{24,25,26,27}$ For some of the buildings GSA provided maintenance values that included only the specific O\&M data used in the GSA baseline and those that matched the BOMA baselines. These standardized values were different from the values provided by the building operators (Figure 18). Using the adapted general maintenance values, eleven of the buildings had general maintenance costs equal to or greater than the GSA baseline, with nine buildings costing more than the industry baseline.

The International Facilities Management Association (IFMA) and the Building Owners and Managers Association (BOMA) provide the main source of statistics on the state of commercial buildings.

Each organization publishes benchmarking reports on a variety of development, operations and maintenance topics. Their data are obtained primarily through surveys of their members, which exceed 15,000 in each organization.

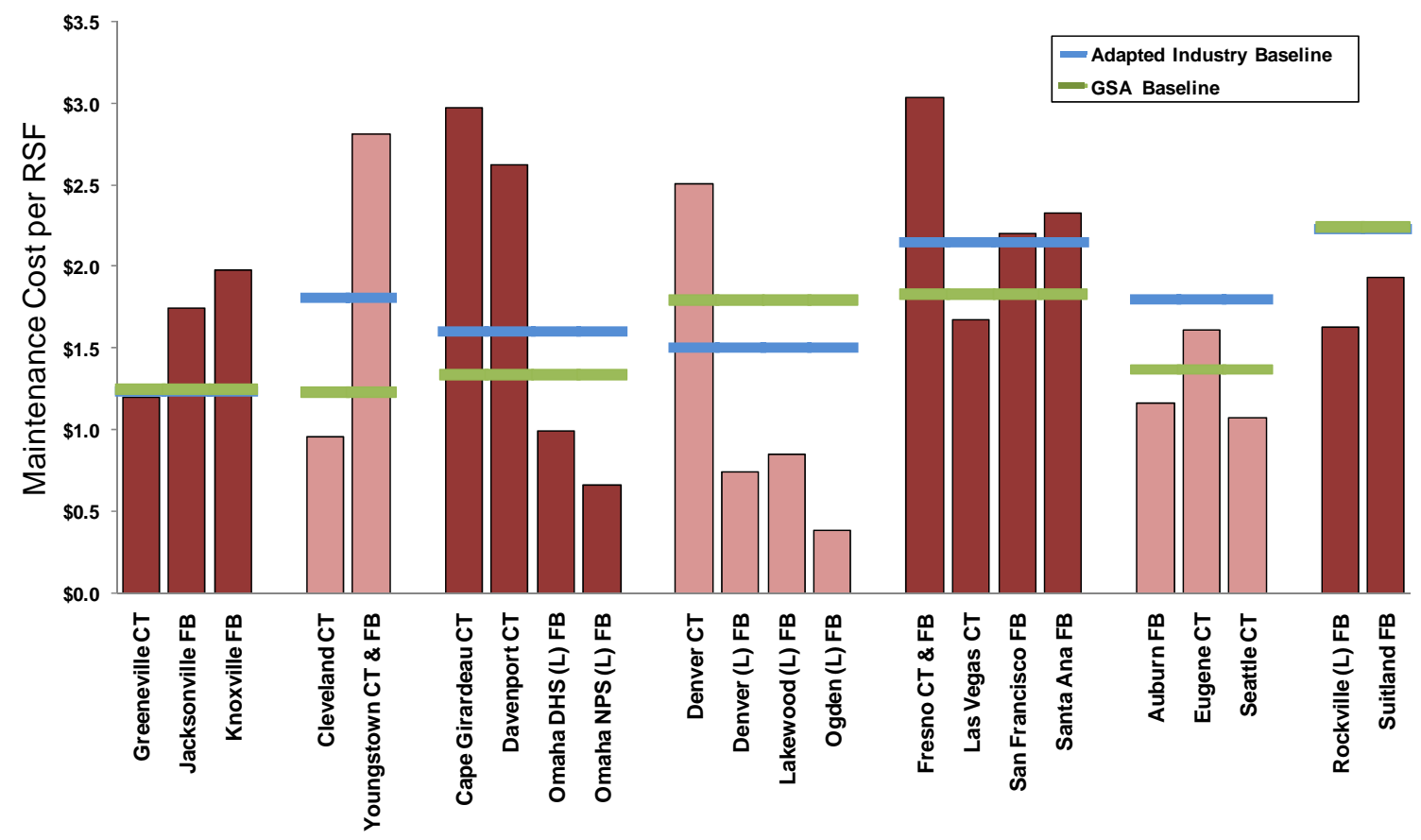

Figure 17. General maintenance cost per rentable square foot 
Generally speaking the data provided by the building managers was lower than the adjusted data provided by GSA, except for Las Vegas CT and the Eugene CT.

Figure 18. General maintenance data source comparison

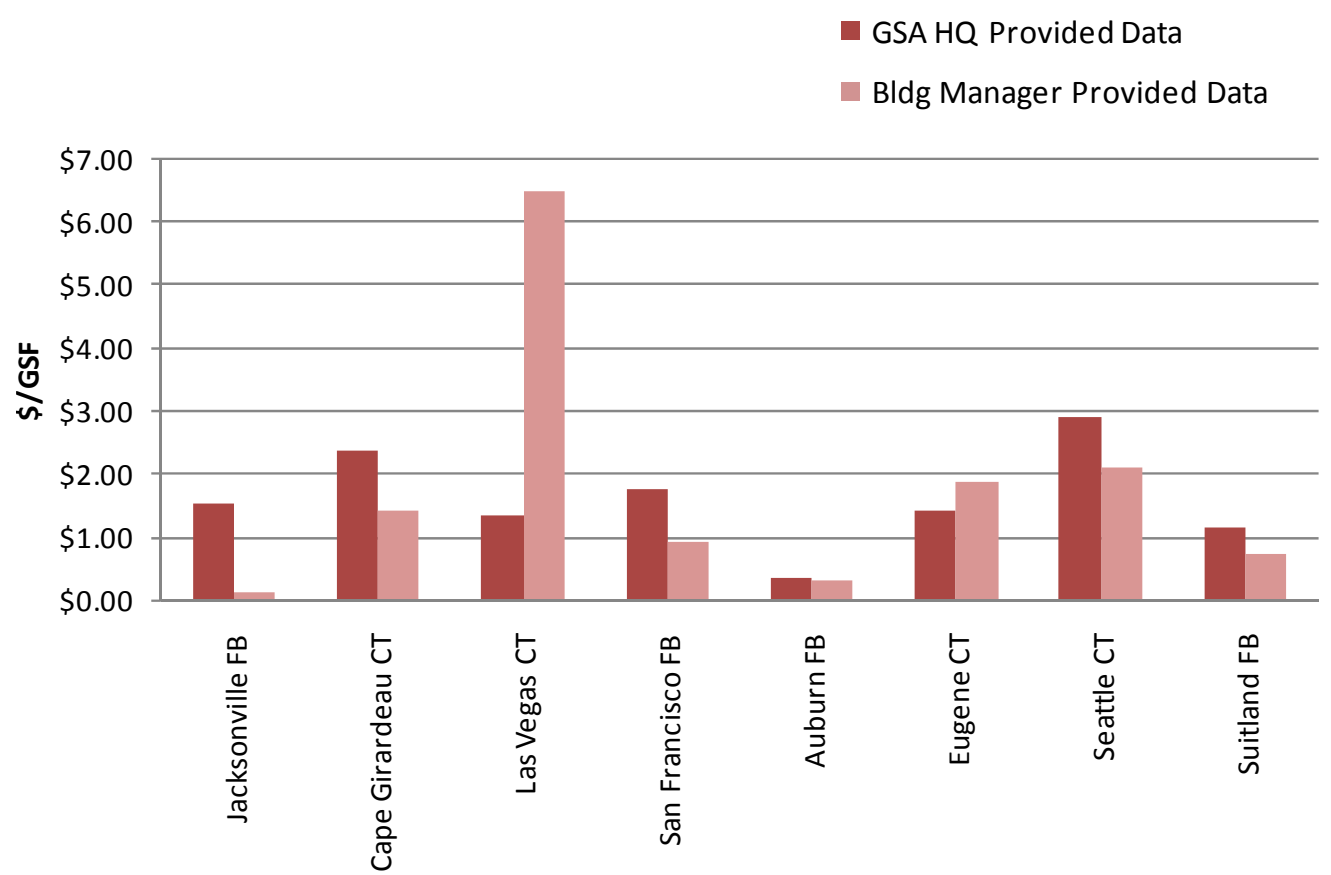

For some buildings we have multiple years of maintenance data (Figure 19). General maintenance costs are virtually the same for some buildings, higher, or lower for other buildings, with no obvious reason for the changes in costs. Thus, given that the data displayed in Figure 17 only represents one year of building O\&M costs, the data should not be assumed to represent an average or expected cost for a building.

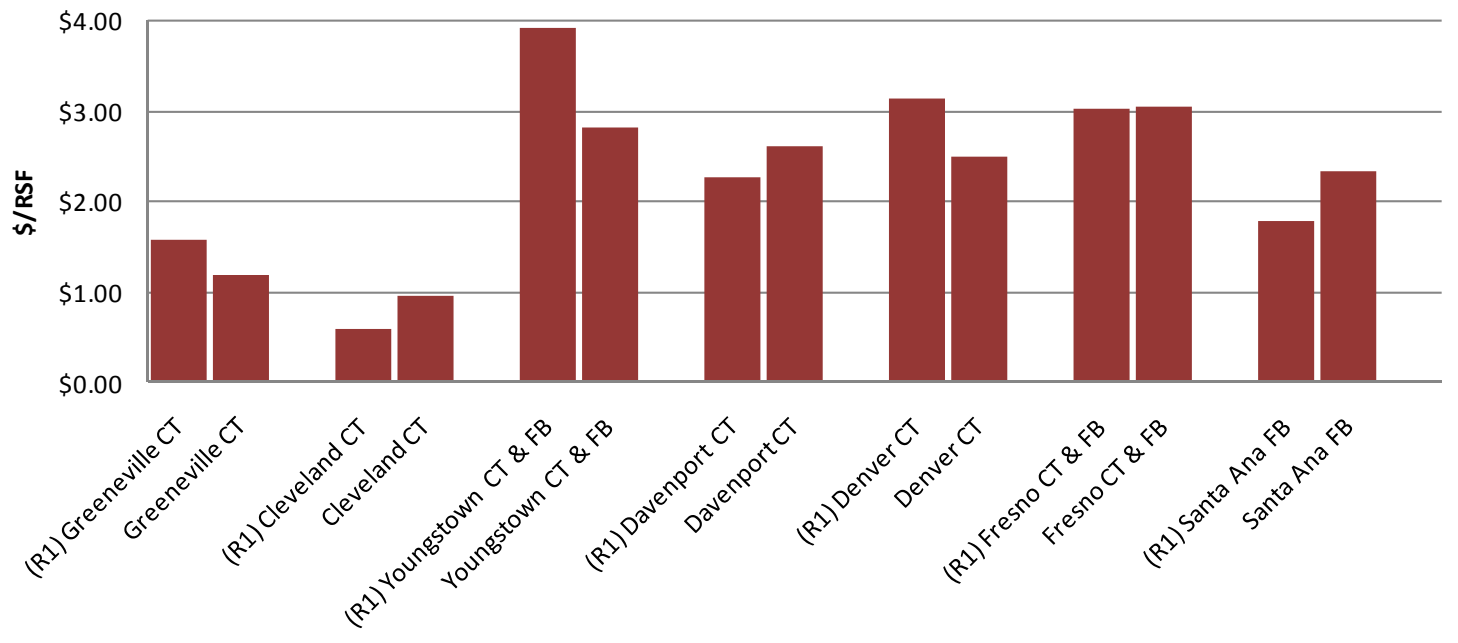

Figure 19. Multiple year general maintenance data 
Figure 20 shows grounds maintenance costs per rentable square foot. All but one of the buildings fell within or below the baseline range. The building significantly above the baseline has manually weeded native prairie grass for landscaping, which may contribute to the higher grounds maintenance costs.

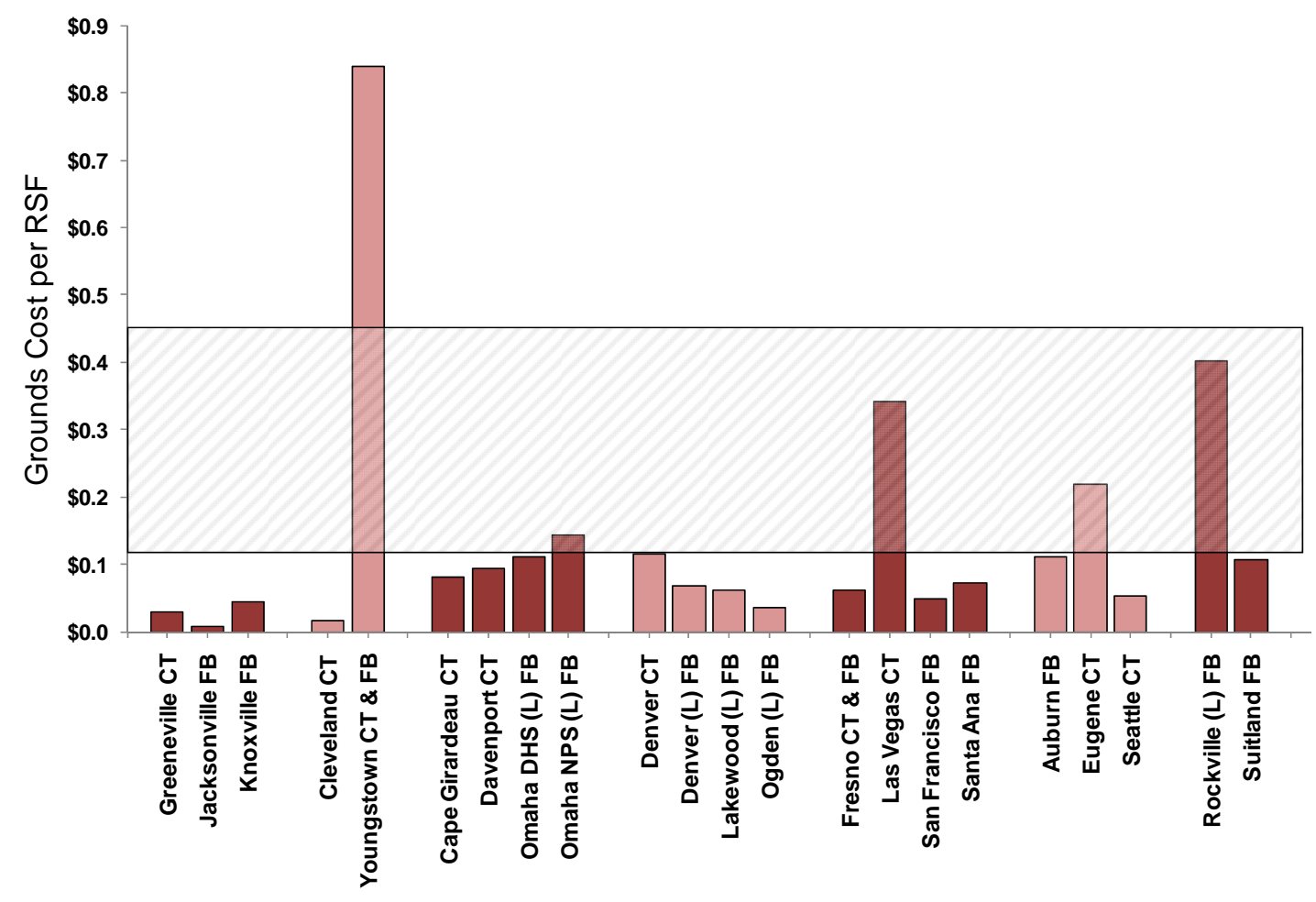

Figure 20. Grounds maintenance cost per rentable square foot 
The janitorial maintenance costs for half of the buildings were above the baseline costs (Figure 21). As mentioned with general maintenance costs, the one year of costs provided in this study does not address the quality of work, potential regional cost differences, or the uniqueness of the year's janitorial needs.

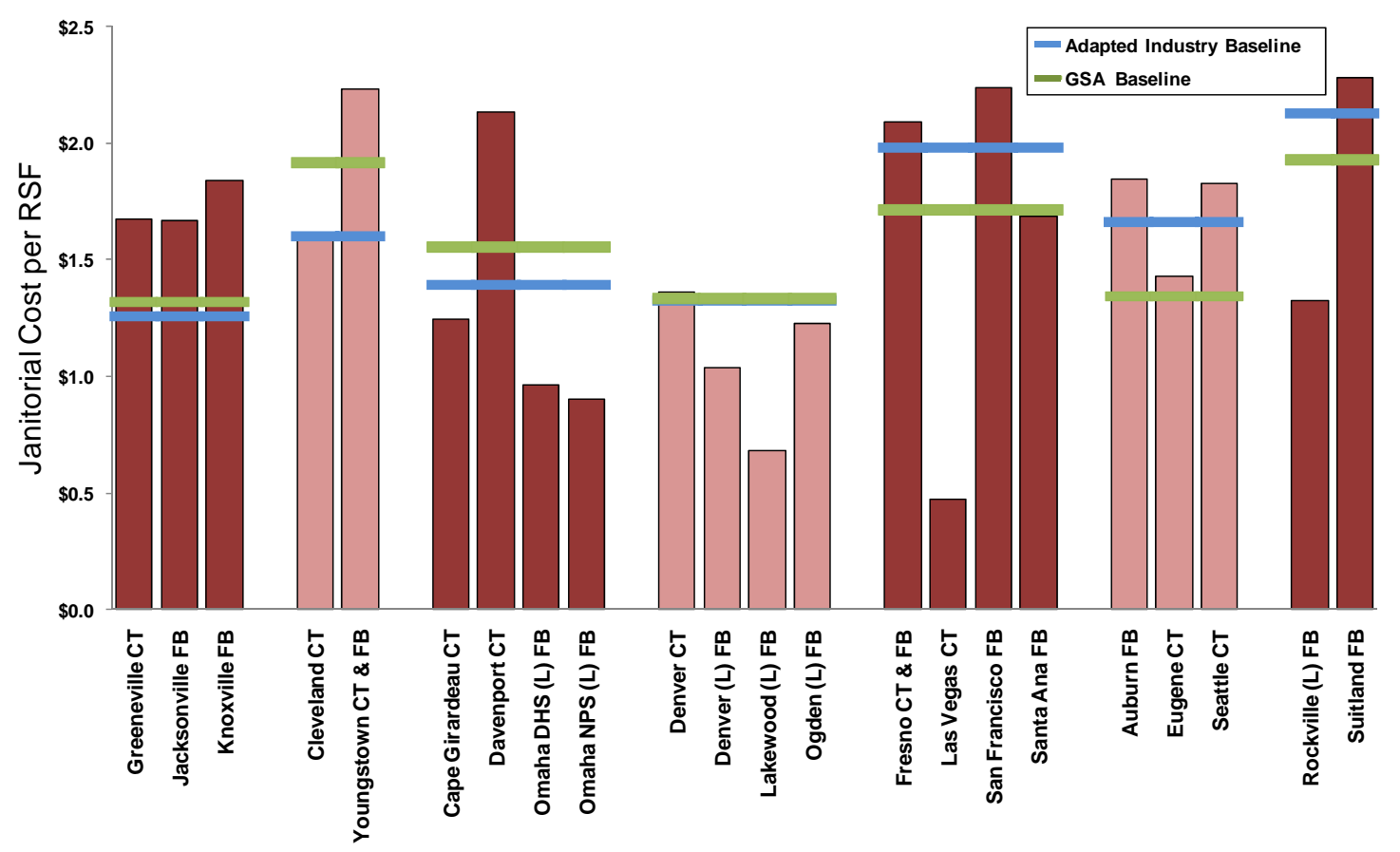

Figure 21. Janitorial cost per rentable square foot 
The janitorial data provided by the building owners varied from what was in the GSA standard reporting system. The janitorial values were more similar to each other than the general maintenance values (Figure 22).

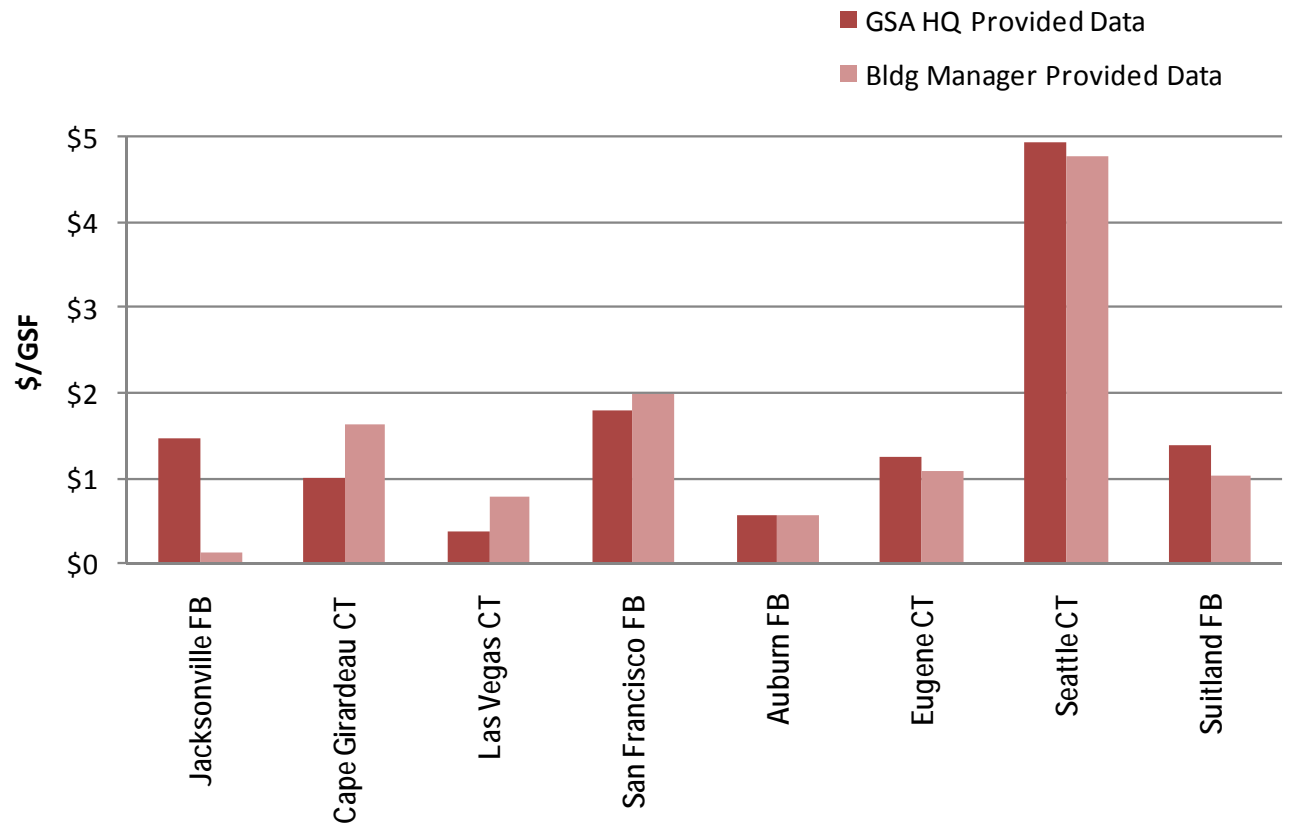

Figure 22. Janitorial data source comparison

Multiple years of janitorial maintenance cost data were available for some buildings (Figure 23). Similar to general maintenance, there is no consistency from one year to the next for these buildings. These data emphasize the importance of continuously monitoring a building's performance to fully understand whether it is performing well.

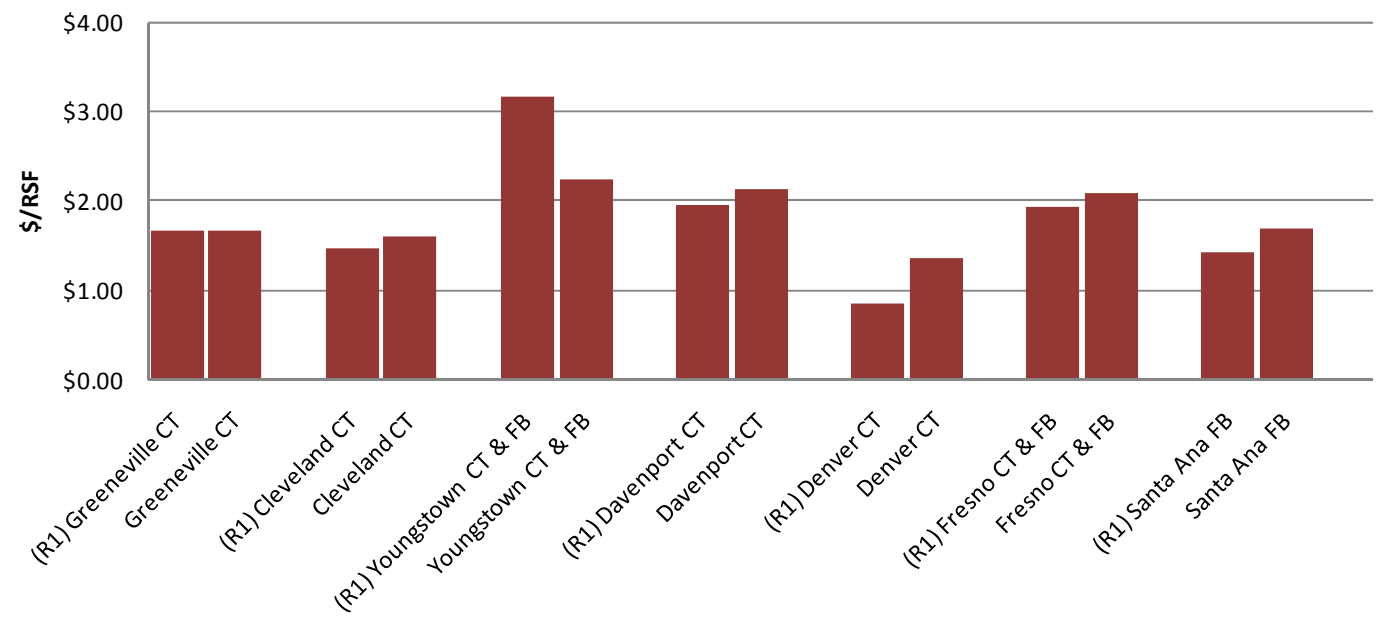

Figure 23. Multiple year janitorial maintenance cost data 
Multiple baselines were used to compare the maintenance costs (Table 18). GSA has regional baselines addressing specific general and janitorial maintenance activities. A regional baseline value is available that was adapted from BOMA values to address the key areas identified by GSA. The grounds maintenance baseline was available through BOMA and represented as a range of 12-45 cents per rentable square foot. Depending on the location and type of landscape there will be varying grounds maintenance needs, which is the likely reason for the wide range in costs.

Table 18. Maintenance cost performance against baselines

\begin{tabular}{|c|c|c|c|c|c|c|c|c|c|}
\hline \multirow[b]{2}{*}{ Building Name } & \multicolumn{3}{|c|}{ General Maint (\$/rsf) } & \multicolumn{3}{|c|}{ Janitorial Maint (\$/rsf) } & \multicolumn{3}{|c|}{ Grounds Maint (\$/rsf) } \\
\hline & $\begin{array}{l}\text { Bldg } \\
\text { Maint }\end{array}$ & $\begin{array}{c}\text { GSA } \\
\text { Baseline }\end{array}$ & $\begin{array}{l}\text { Adapted } \\
\text { Industry } \\
\text { Baseline }\end{array}$ & $\begin{array}{l}\text { Bldg } \\
\text { Maint }\end{array}$ & $\begin{array}{c}\text { GSA } \\
\text { Baseline }\end{array}$ & $\begin{array}{l}\text { Adapted } \\
\text { Industry } \\
\text { Baseline }\end{array}$ & $\begin{array}{l}\text { Bldg } \\
\text { Maint }\end{array}$ & $\begin{array}{c}\text { BOMA } \\
\text { Industry } \\
\text { Baseline } \\
\text { (Low) }\end{array}$ & $\begin{array}{c}\text { BOMA } \\
\text { Industry } \\
\text { Baseline } \\
\text { (High) }\end{array}$ \\
\hline Greeneville CT & $\$ 1.20$ & $\$ 1.25$ & $\$ 1.23$ & $\$ 1.67$ & $\$ 1.32$ & $\$ 1.25$ & $\$ 0.03$ & $\$ 0.12$ & $\$ 0.45$ \\
\hline Jacksonville FB & $\$ 1.75$ & $\$ 1.25$ & $\$ 1.23$ & $\$ 1.67$ & $\$ 1.32$ & $\$ 1.25$ & $\$ 0.01$ & $\$ 0.12$ & $\$ 0.45$ \\
\hline Knoxville FB & $\$ 1.98$ & $\$ 1.25$ & $\$ 1.23$ & $\$ 1.84$ & $\$ 1.32$ & $\$ 1.25$ & $\$ 0.04$ & $\$ 0.12$ & $\$ 0.45$ \\
\hline Cleveland CT & $\$ 0.95$ & $\$ 1.23$ & $\$ 1.81$ & $\$ 1.61$ & $\$ 1.91$ & $\$ 1.60$ & $\$ 0.02$ & $\$ 0.12$ & $\$ 0.45$ \\
\hline Youngstown CT \& FB & $\$ 2.81$ & $\$ 1.23$ & $\$ 1.81$ & $\$ 2.23$ & $\$ 1.91$ & $\$ 1.60$ & $\$ 0.84$ & $\$ 0.12$ & $\$ 0.45$ \\
\hline Cape Girardeau CT & $\$ 2.97$ & $\$ 1.33$ & $\$ 1.60$ & $\$ 1.24$ & $\$ 1.55$ & $\$ 1.39$ & $\$ 0.08$ & $\$ 0.12$ & $\$ 0.45$ \\
\hline Davenport CT & $\$ 2.62$ & $\$ 1.33$ & $\$ 1.60$ & $\$ 2.13$ & $\$ 1.55$ & $\$ 1.39$ & $\$ 0.09$ & $\$ 0.12$ & $\$ 0.45$ \\
\hline Omaha DHS (L) FB & $\$ 0.99$ & $\$ 1.33$ & $\$ 1.60$ & $\$ 0.96$ & $\$ 1.55$ & $\$ 1.39$ & $\$ 0.11$ & $\$ 0.12$ & $\$ 0.45$ \\
\hline Omaha NPS (L) FB & $\$ 0.66$ & $\$ 1.33$ & $\$ 1.60$ & $\$ 0.90$ & $\$ 1.55$ & $\$ 1.39$ & $\$ 0.14$ & $\$ 0.12$ & $\$ 0.45$ \\
\hline Denver CT & $\$ 2.51$ & $\$ 1.79$ & $\$ 1.50$ & $\$ 1.36$ & $\$ 1.33$ & $\$ 1.32$ & $\$ 0.12$ & $\$ 0.12$ & $\$ 0.45$ \\
\hline Denver (L) FB & $\$ 0.74$ & $\$ 1.79$ & $\$ 1.50$ & $\$ 1.04$ & $\$ 1.33$ & $\$ 1.32$ & $\$ 0.07$ & $\$ 0.12$ & $\$ 0.45$ \\
\hline Lakewood (L) FB & $\$ 0.85$ & $\$ 1.79$ & $\$ 1.50$ & $\$ 0.68$ & $\$ 1.33$ & $\$ 1.32$ & $\$ 0.06$ & $\$ 0.12$ & $\$ 0.45$ \\
\hline Ogden (L) FB & $\$ 0.38$ & $\$ 1.79$ & $\$ 1.50$ & $\$ 1.23$ & $\$ 1.33$ & $\$ 1.32$ & $\$ 0.03$ & $\$ 0.12$ & $\$ 0.45$ \\
\hline Fresno CT \& FB & $\$ 3.04$ & $\$ 1.83$ & $\$ 2.15$ & $\$ 2.09$ & $\$ 1.71$ & $\$ 1.98$ & $\$ 0.06$ & $\$ 0.12$ & $\$ 0.45$ \\
\hline Las Vegas CT & $\$ 1.67$ & $\$ 1.83$ & $\$ 2.15$ & $\$ 0.47$ & $\$ 1.71$ & $\$ 1.98$ & $\$ 0.34$ & $\$ 0.12$ & $\$ 0.45$ \\
\hline San Francisco FB & $\$ 2.20$ & $\$ 1.83$ & $\$ 2.15$ & $\$ 2.23$ & $\$ 1.71$ & $\$ 1.98$ & $\$ 0.05$ & $\$ 0.12$ & $\$ 0.45$ \\
\hline Santa Ana FB & $\$ 2.33$ & $\$ 1.83$ & $\$ 2.15$ & $\$ 1.68$ & $\$ 1.71$ & $\$ 1.98$ & $\$ 0.07$ & $\$ 0.12$ & $\$ 0.45$ \\
\hline Auburn FB & $\$ 1.16$ & $\$ 1.37$ & $\$ 1.80$ & $\$ 1.85$ & $\$ 1.34$ & $\$ 1.66$ & $\$ 0.11$ & $\$ 0.12$ & $\$ 0.45$ \\
\hline Eugene $\mathrm{CT}$ & $\$ 1.61$ & $\$ 1.37$ & $\$ 1.80$ & $\$ 1.43$ & $\$ 1.34$ & $\$ 1.66$ & $\$ 0.22$ & $\$ 0.12$ & $\$ 0.45$ \\
\hline Seattle CT & $\$ 1.07$ & $\$ 1.37$ & $\$ 1.80$ & $\$ 1.82$ & $\$ 1.34$ & $\$ 1.66$ & $\$ 0.05$ & $\$ 0.12$ & $\$ 0.45$ \\
\hline Rockville (L) FB & $\$ 1.63$ & $\$ 2.24$ & $\$ 2.23$ & $\$ 1.32$ & $\$ 1.93$ & $\$ 2.12$ & $\$ 0.40$ & $\$ 0.12$ & $\$ 0.45$ \\
\hline Suitland FB & $\$ 1.94$ & $\$ 2.24$ & $\$ 2.23$ & $\$ 2.28$ & $\$ 1.93$ & $\$ 2.12$ & $\$ 0.11$ & $\$ 0.12$ & $\$ 0.45$ \\
\hline
\end{tabular}


Fifteen of the 22 buildings had aggregate maintenance costs below baseline (Figure 24). Aggregate maintenance is the summation of the general, janitorial, and grounds maintenance values. Of the buildings with higher aggregate maintenance costs, all of their general maintenance costs were higher than baseline.

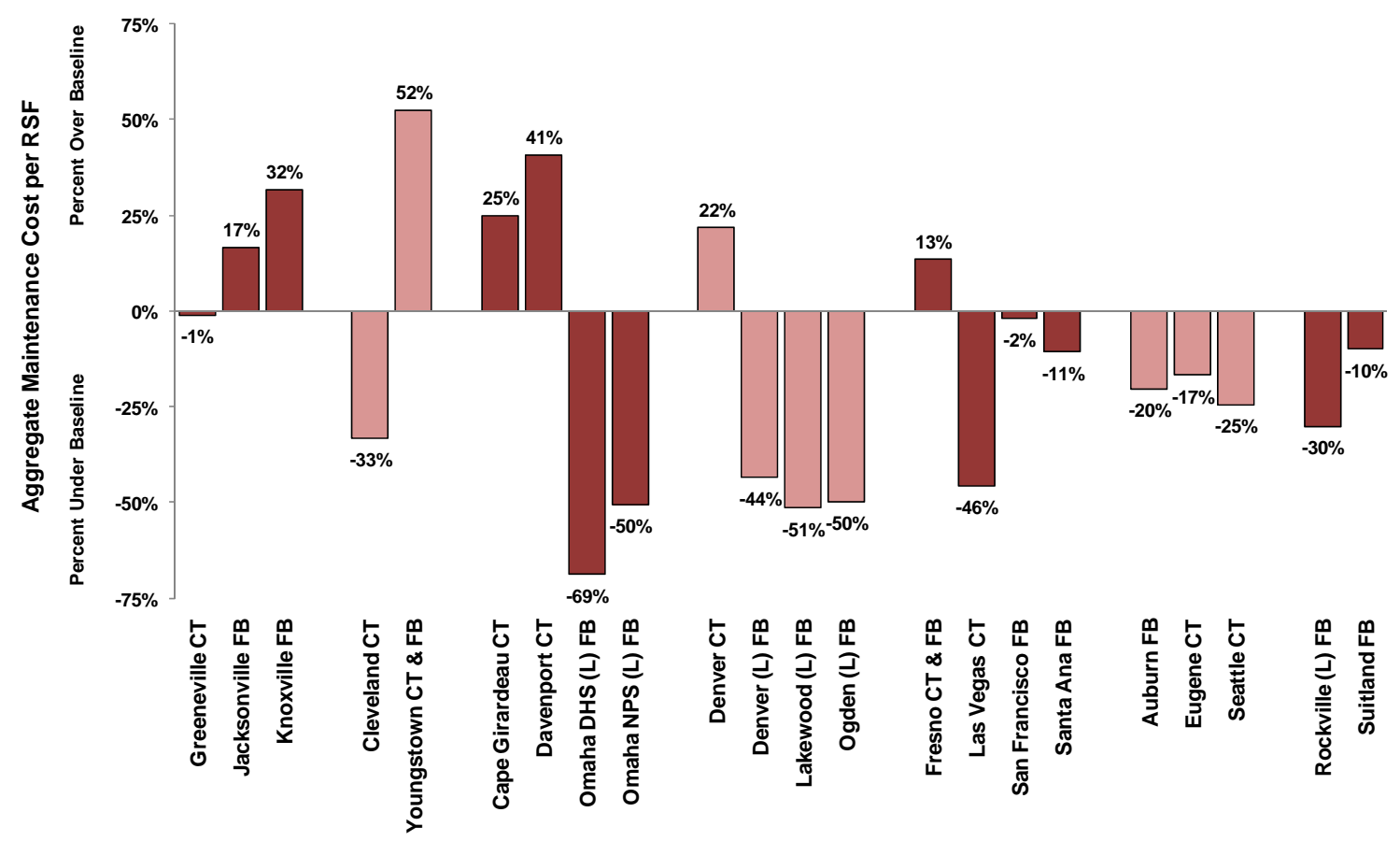

Figure 24. Aggregate maintenance cost comparison 
Consistent with the first round of building assessments, the occupants appear satisfied with the cleanliness and maintenance of the buildings, with all of the satisfaction scores above zero. Note that although the buildings have positive satisfaction scores, five buildings have scores below the CBE survey $50^{\text {th }}$ percentile.

Green housekeeping is a sustainable design and operations strategy used to provide a healthy, clean work environment. Figure 25 displays the relative occupant satisfaction with cleaning and maintenance compared to janitorial maintenance costs and aggregate maintenance costs. During site visits, the research team observed that some of the buildings with green cleaning policies had products that implied different operating practices. Buildings with green housekeeping policies that offered evidence of different operational practices are identified as "some" green housekeeping practices. There are buildings with green cleaning programs on both sides of the janitorial cost baseline.

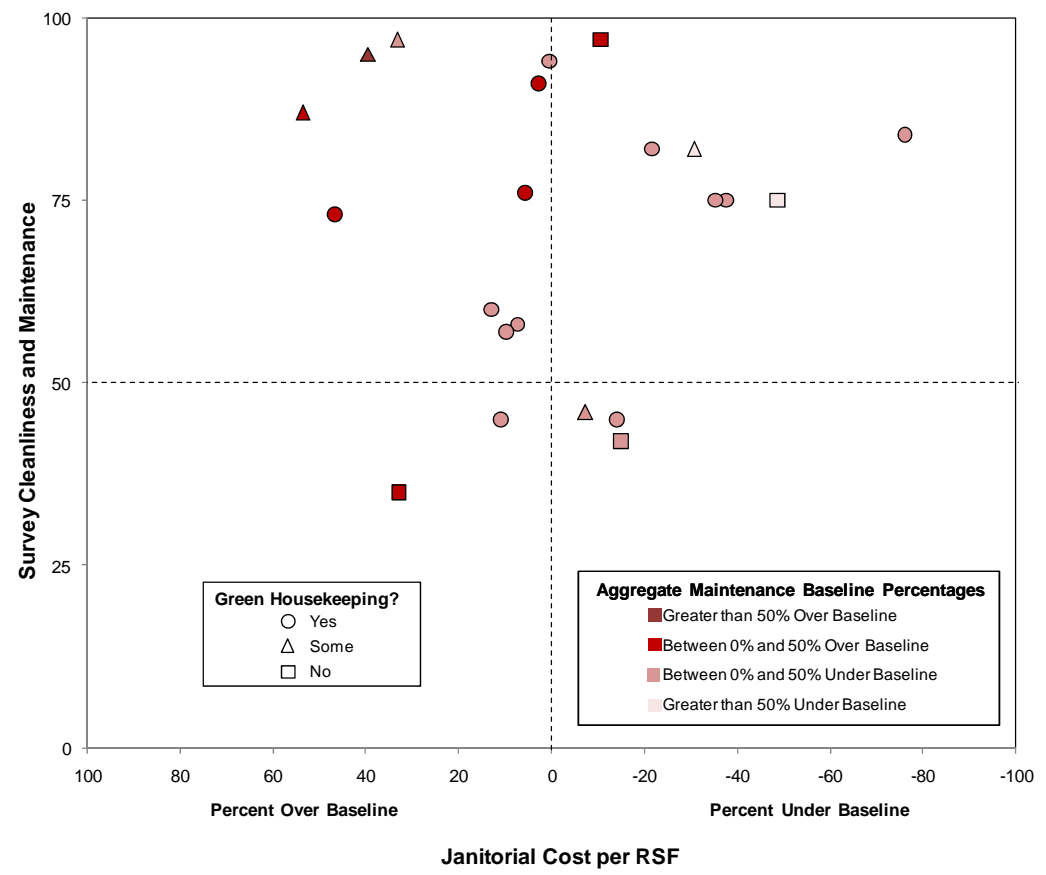

Figure 25. Janitorial cost per rentable square foot and cleaning satisfaction compared with green housekeeping

According to IFMA research, a building less than 5 years old would spend $75 \%$ of its maintenance funds on preventative maintenance and $27 \%$ on service call related maintenance. For buildings 5 to 10 years old the ratio changes to $63 \%$ and $37 \%{ }^{28}$ The Denver FB, San Francisco FB, and Rockville FB had three to four times as many service calls as preventative maintenance tasks, which is significantly different from the IFMA baseline for buildings less than 5 years old. Two of those buildings had lower costs and one had higher costs than baseline. Excluding those buildings, the averaged ratio of preventative maintenance to service calls is $68 \%$ and $32 \%$ respectively, which is comparable to the IFMA baseline. 


\section{Waste Generation and Recycling}

Waste disposal is a utility cost incurred by buildings that is an indicator of resource use by the building occupants. Although occupant waste generation

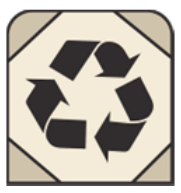
is not typically seen as having a connection to a building, LEED requires recycle bins as part of the building design. This performance metric is being used to investigate whether the occupants of green buildings recycle at a greater rate than an industry baseline.

Although a building designer, manager and/or owner can offer space, services, and encouragement to recycle, recycling programs are more commonly successful when they are promoted by the building occupant's employer. In other words, recycling goals and/or incentives offered by the federal agencies that occupy these buildings, and coordinated with the building management would offer the greatest opportunity to reduce solid sanitary waste. Although some buildings had exemplary recycling programs, the research team did not observe a consistent emphasis to reduce solid sanitary waste or to increase recycling at the buildings in the study.

There are few useful baselines available for waste and recycling values. GSA's National Capitol Region (Region 11) has been collecting recycling data for over 40 buildings for the last 10 years, which offers a relevant point of reference for the buildings in this study. The average recycling value for the buildings in this study is just under half a pound per rentable square foot, which is higher than the average recycling quantity for every year Region 11 has been collecting the data (Figure 26).

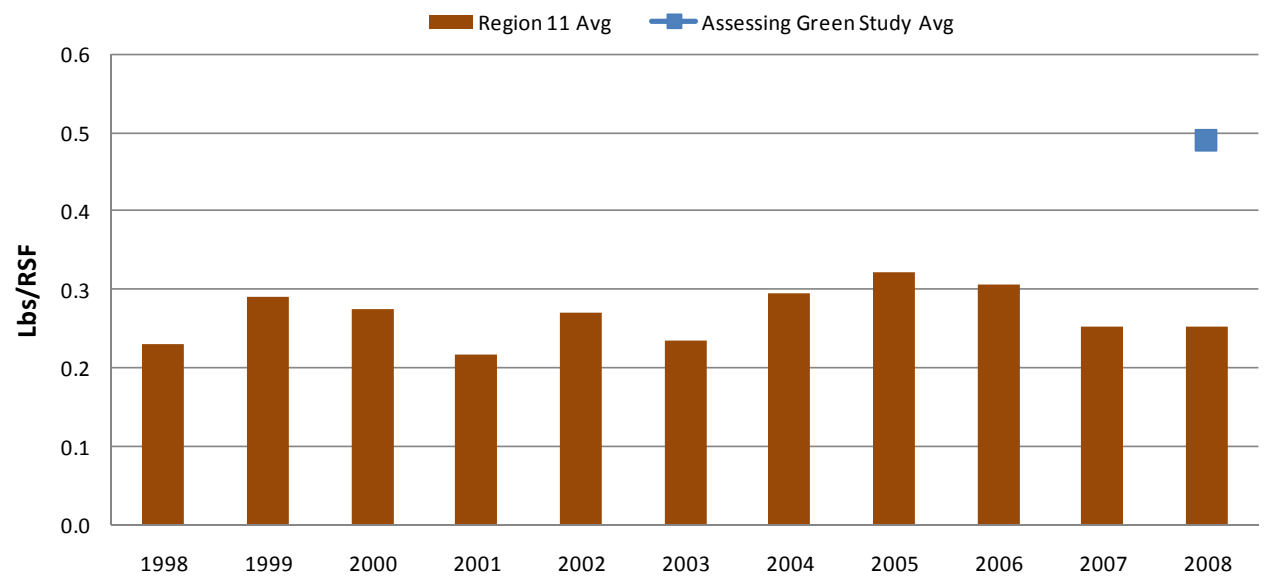

Figure 26. Region 11 recycling quantity

GSA's Recycling Guide has an average waste generation rate of 1.6 pounds of solid waste per building occupant per day. When considering the waste per occupant rate, Greeneville CT, Davenport CT, Omaha DHS FB, Omaha NPS FB, Denver FB, Lakewood FB, Ogden FB, and Santa Ana FB all generate quite a bit more waste per occupant (from 2.3 to 9.8 pounds per occupant per day). 
Table 19 provides a summary of the waste and recycling quantity and cost data available for each building.

Table 19. Waste generation and recycling data and cost by building

\begin{tabular}{|c|c|c|c|c|c|c|}
\hline Building Name & $\begin{array}{l}\text { Waste } \\
\text { per Year } \\
\text { (Tons) }\end{array}$ & $\begin{array}{c}\text { Waste } \\
\text { Cost }\end{array}$ & Recycled Material & $\begin{array}{l}\text { Recycle per } \\
\text { year (Tons) }\end{array}$ & $\begin{array}{c}\text { Recycle } \\
\text { Cost }\end{array}$ & $\begin{array}{c}\% \text { Recycle of } \\
\text { Total Waste } \\
\text { Generation }\end{array}$ \\
\hline Greeneville CT & 39 & $\$ 900$ & Paper & 2 & $-\$ 71$ & $6 \%$ \\
\hline Jacksonville FB & 14 & $\mathrm{~N} / \mathrm{A}$ & Paper (mixed \& cardboard), wood pallets, & 3 & $\mathrm{~N} / \mathrm{A}$ & $16 \%$ \\
\hline Knoxville FB & 41 & $\$ 4,380$ & Paper \& Metal & 20 & $\mathrm{~N} / \mathrm{A}$ & $33 \%$ \\
\hline Cleveland CT & 24 & $\$ 3,067$ & Paper \& Metal & 3 & $-\$ 101$ & $10 \%$ \\
\hline Youngstown CT \& FB & 17 & $\$ 1,530$ & Paper & 29 & $\$ 0$ & $63 \%$ \\
\hline Cape Girardeau CT & 2 & $\$ 325$ & Paper & 0 & $\$ 144$ & $12 \%$ \\
\hline Davenport CT & 59 & $\$ 907$ & Paper & 2 & $\$ 0$ & $4 \%$ \\
\hline Omaha DHS (L) FB & 113 & $\$ 2,400$ & Paper & 24 & $\$ 0$ & $17 \%$ \\
\hline Omaha NPS (L) FB & 130 & $\$ 1,500$ & Paper \& Cardboard & 11 & $\$ 1,020$ & $8 \%$ \\
\hline Denver CT & 38 & $\mathrm{~N} / \mathrm{A}$ & Paper & $\mathrm{N} / \mathrm{A}$ & $\mathrm{N} / \mathrm{A}$ & $\mathrm{N} / \mathrm{A}$ \\
\hline Denver (L) FB & 290 & $\$ 15,862$ & Comingled recycling & 177 & $\$ 3,228$ & $38 \%$ \\
\hline Lakewood (L) FB & 374 & $\$ 3,600$ & Paper & 204 & $\$ 0$ & $35 \%$ \\
\hline Ogden (L) FB & 220 & $\$ 3,940$ & Paper \& Cardboard & 67 & $\$ 16,081$ & $23 \%$ \\
\hline Fresno CT \& FB & 16 & $\$ 24,236$ & Paper & 18 & $\$ 0$ & $53 \%$ \\
\hline Las Vegas CT & $\mathrm{N} / \mathrm{A}$ & $\$ 25,266$ & Paper & 24 & $\$ 0$ & $\mathrm{~N} / \mathrm{A}$ \\
\hline San Francisco FB & 94 & $\$ 31,970$ & Bottles, Cans, Paper, Compost and & 45 & $-\$ 880$ & $32 \%$ \\
\hline Santa Ana FB & 562 & $\$ 18,360$ & Paper & 11 & $\$ 1,600$ & $2 \%$ \\
\hline Auburn FB & 75 & $\$ 2,184$ & Plastic, aluminum, paper - mixed & 7 & $\mathrm{~N} / \mathrm{A}$ & $9 \%$ \\
\hline Eugene CT & 5 & Included & Comingled recycling & 6 & $\mathrm{~N} / \mathrm{A}$ & $56 \%$ \\
\hline Seattle CT & 59 & Included & Aluminum, pastic, glass, mixed paper, & 38 & $-\$ 533$ & $39 \%$ \\
\hline Rockville (L) FB & $\mathrm{N} / \mathrm{A}$ & $\$ 22,056$ & Paper, tone, batteries, cell phones, & $\mathrm{N} / \mathrm{A}$ & Included & $\mathrm{N} / \mathrm{A}$ \\
\hline Suitland FB & 560 & $\$ 107,871$ & Paper, cans (aluminum), bottles & 129 & $-\$ 2,480$ & $19 \%$ \\
\hline
\end{tabular}

Analysis was performed comparing the recycling to waste ratio for each building. Eight of the buildings in the study recycled more than the national average. However, the waste and recycling data were not consistently available for each building. Some buildings shared services with other buildings and some estimated the quantity of waste or recycled material based on the frequency of service rather than measured quantities. Based on the site visits it was clear that recycling was not a strong expectation of the building occupants for at least some of the buildings. Although paper was recycled in all of the buildings, other commonly recycled items - glass, aluminum, and cardboard - were not consistently collected. In at least one building the PNNL research team was told how the building management gave up on recycling anything but paper because the occupants used the recycle bins as trash cans. 
Figure 27 shows the waste cost per rentable square foot. Seven of the buildings are above the industry baseline.

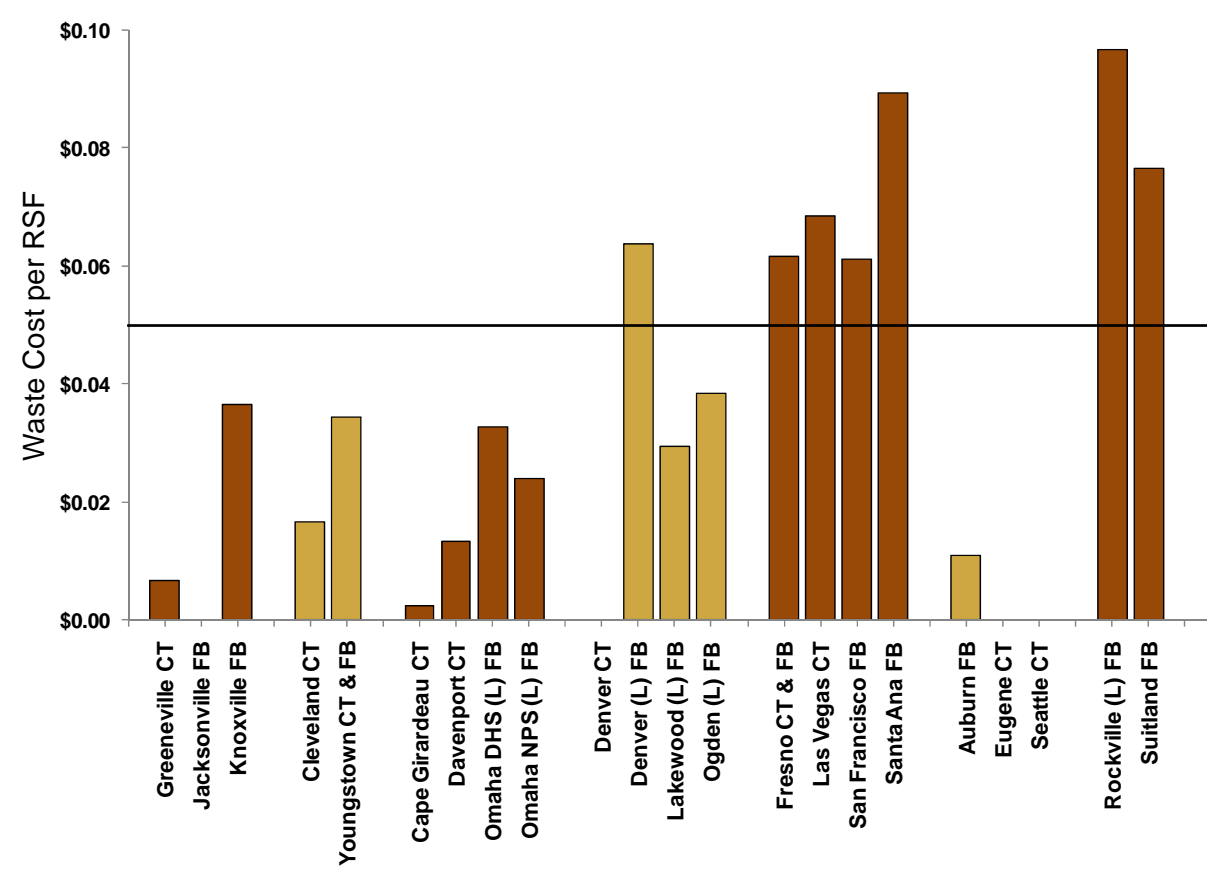

Figure 27. Waste cost per rentable square foot

Using the Region 11 average recycling cost, Figure 28 shows the average costs for the buildings in this study are higher for most years. Keep in mind the average quantity of waste was higher for the study buildings, which can impact the cost of recycling services.

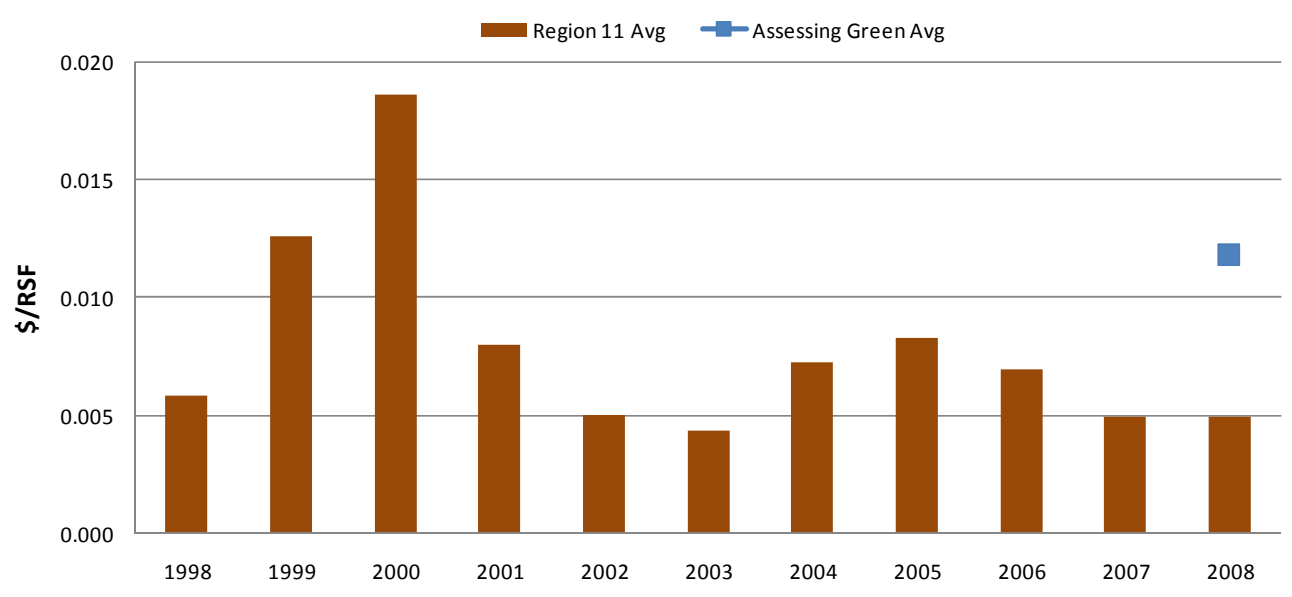

Figure 28. Region 11 recycling cost per rentable square foot

To better understand the impact the building design and operation have on the quantity of materials recycled, the building occupant employer programs would need to be equivalent. Additionally, the cost and availability of recycling programs in the community and the willingness of the building manager to manage a recycling program might impact the ability of building occupants to recycle. 


\section{Occupant Satisfaction}

A primary aim of sustainable design is maximizing the occupant comfort and satisfaction, while minimizing the environmental impact and costs. Indoor environmental quality (IEQ) is the commonly used term to describe the

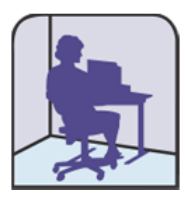
building features that directly impact the occupants. The IEQ of a workplace reflects the interaction of air, lighting, and surroundings with occupants in a holistic sense. IEQ effects include occupant health, productivity, and satisfaction. Occupant satisfaction is crucial to staff retention. Studies have shown that employees planning to leave an organization were $25 \%$ less satisfied with their physical workplace than those that planned to stay. ${ }^{29}$

Occupant surveys are the typical mechanism used to gather occupant satisfaction data. This study used the Center for the Built Environment's (CBE) occupant satisfaction survey. The $\mathrm{CBE}$ core survey questions fit within the following categories

- Office Layout

- Office Furnishings

- Thermal Comfort

- Air Quality

- Lighting

- Acoustic Quality

- Cleanliness and Maintenance

- General Comments.

The University of California Berkeley's Center for the Built Environment (CBE) has developed an occupant satisfaction survey that has had over 48,000 survey responses. Occupants in 506 buildings have taken the CBE survey, with over 320 office buildings and 66 are LEEDcertified. GSA has over 225 buildings in the database. The survey is distributed via the internet, takes approximately 10 minutes to complete, and protects the confidentiality of the respondents.

CBE allows for customization of the core survey. Previously, GSA has used a modified version of the CBE survey. This project started with the GSA modified survey and then added questions related to occupant commute. The additional questions increased the estimated time to complete the survey to 20 minutes. The survey tool used to measure building occupant satisfaction for this study is called SPOT (Sustainable Places and Organizational Trends). This survey is a GSA modified version of the CBE core survey that removes the office furnishings and office layout questions and adds occupant commute questions. The SPOT survey was distributed to building occupants electronically in 2008 through 2010. For a few buildings the electronic distribution, via an internet site, was unsuccessful because of limited access to the internet. In those cases, a paper version of the survey was distributed, collected, and the resulting data were entered into the electronic survey. A copy of the key questions provided in the survey can be found in Appendix E.

The industry baseline for the occupant satisfaction metrics is the CBE core survey responses. The survey questions offer a numerical response of between -3 and 3 . CBE prepares building specific survey summary reports. These reports provide the average scores for each of the key elements addressed in the survey. The average response score and the 
average responses within the CBE database are compared. For example, if a building scored at the $50^{\text {th }}$ percentile, $50 \%$ of the buildings in the database would have a lower score and $50 \%$ would have a higher score.

The percentiles for the surveys performed during the first round of this study were recalculated against the current CBE database, which resulted in the percentiles for specific buildings changing.

The $\mathrm{CBE}$ preferred response rate for the survey is greater than $50 \%$. More than half of the buildings in the study had response rates lower than desired. The Seattle CT was the only building that did not take the SPOT survey. Alternatively, the standard GSA survey administered in 2006 was used to compare occupant satisfaction. The scores were translated from a 5 point scale to the 7 point $\mathrm{CBE}$ scale using methods created by $\mathrm{CBE}{ }^{30}$ Forty-three questions regarding the building features, its services, security, and management staff are included. The survey was completed either on-line or hard-copy and mailed. A copy of the survey can be found in Appendix F.

In addition to the CBE survey a rapid indoor air quality (IAQ) assessment was performed on one building, the Denver FB (Appendix G). The one day assessment involved five indoor and one outdoor location, and included measurements of temperature, relative humidity, atmospheric pressure, sound level, carbon dioxide, ozone, particulate matter, fungal spores, volatile organic compounds, and semivolatile organics. When the rapid IAQ assessment results were compared to available standards, there were no acute hazards identified and temperature and relative humidity measurements were within the American Society of Heating, Refrigerating, and Air-Conditioning Engineers (ASHRAE) Standard 55-2004 acceptable range.

Table 20 provides an individual building summary of the SPOT survey response rates and the percentile ranking in each IEQ category for each building as provided by CBE. 
Table 20. SPOT Survey scores ranked against CBE database

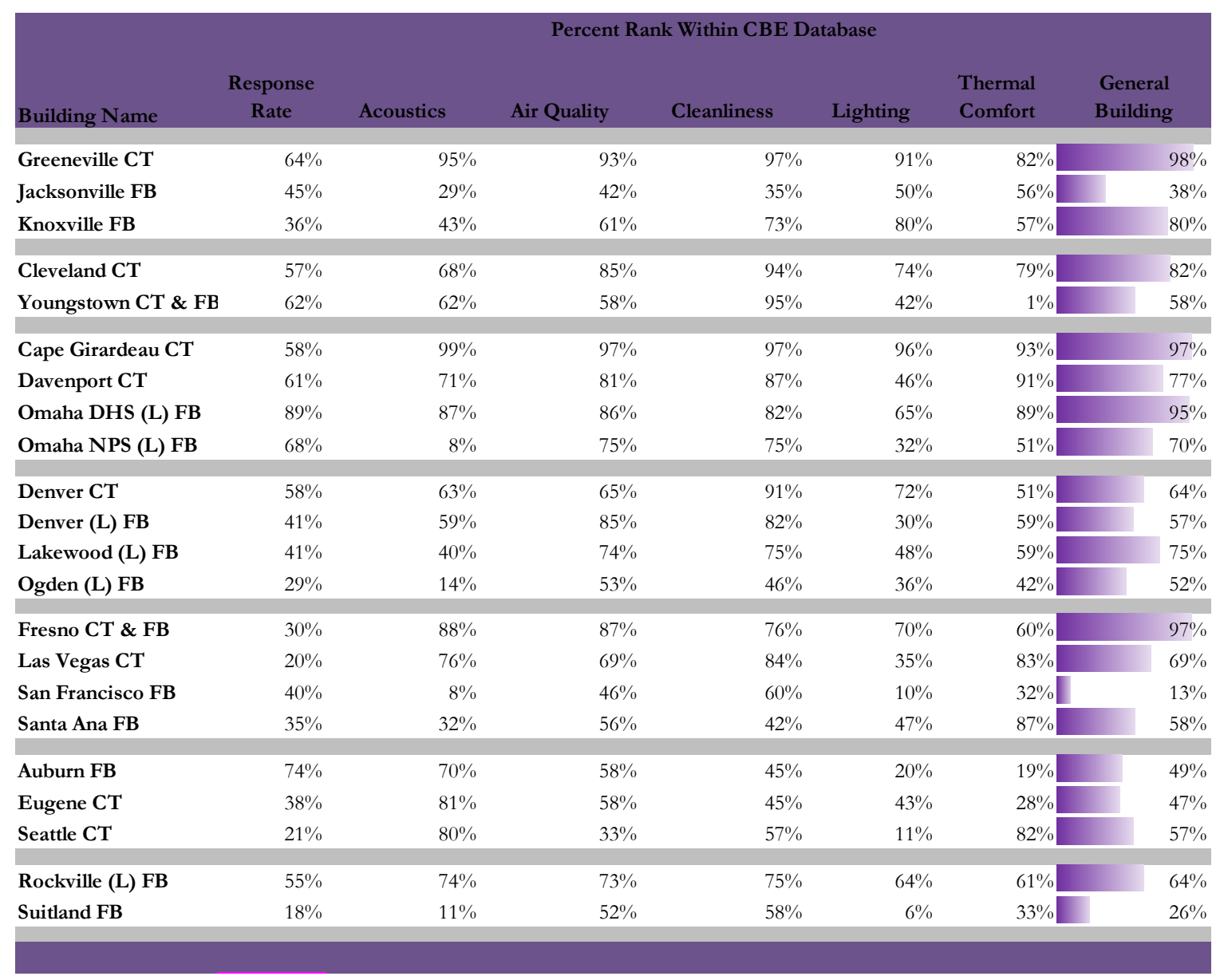


The building results for key summary survey questions have been compared to the full $\mathrm{CBE}$ survey database. Figure 29 shows that the occupants of more than two-thirds of the buildings in the study were more satisfied with their acoustical quality than the $50^{\text {th }}$ percentile of those surveyed by CBE.

In the next set of figures, the orange line represents the average survey responses by question category in the $\mathrm{CBE}$ database and the blue dots are the average scores for the 22 buildings in this study.

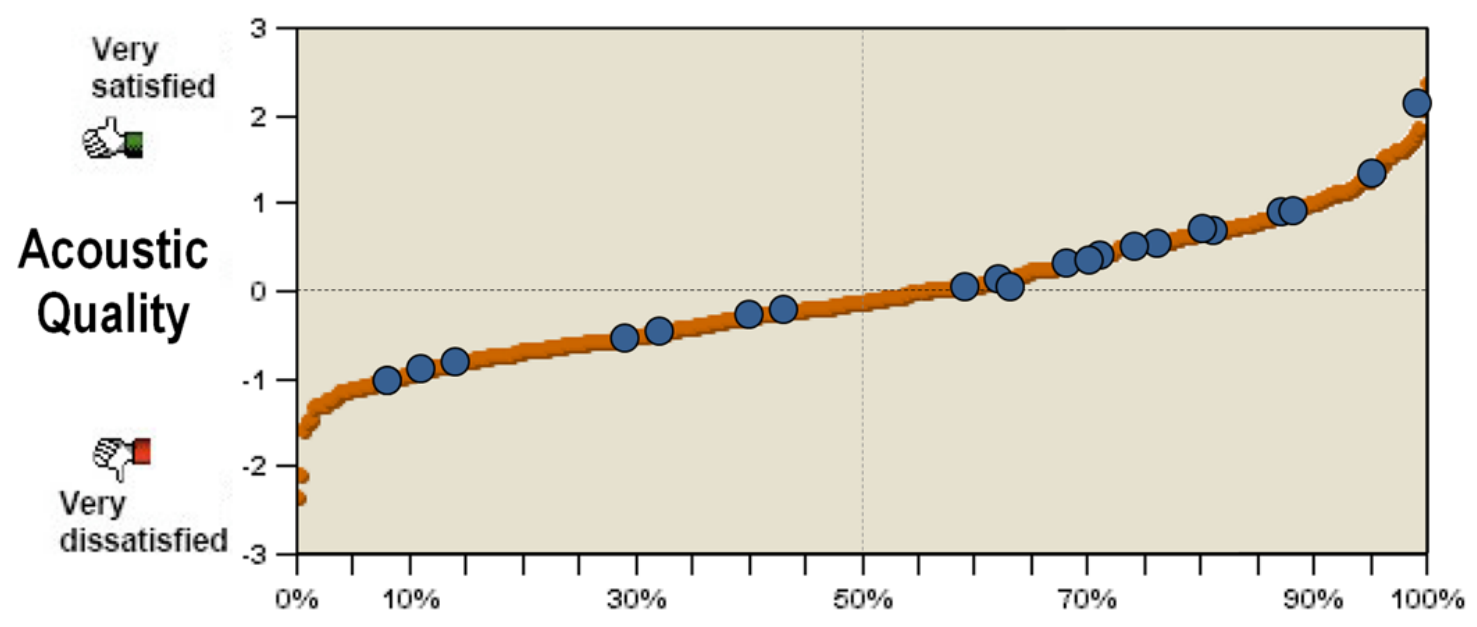

Acoustic Quality Percentiles

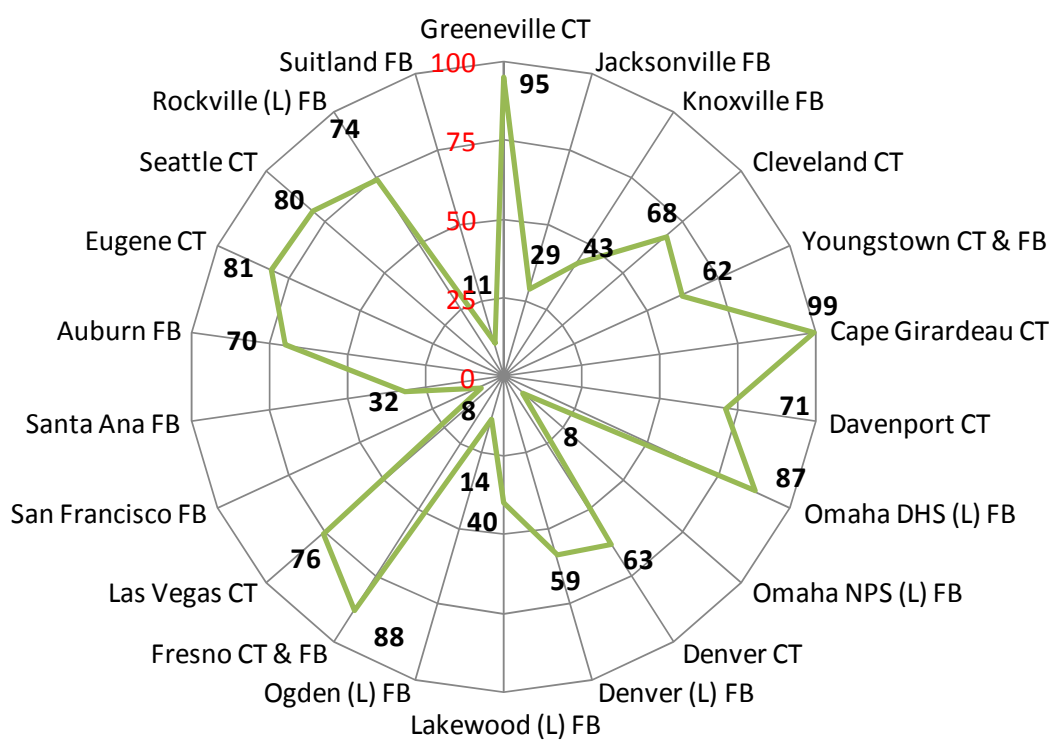

Figure 29. Acoustic quality rating from the occupant survey

Data presented by CBE have the average acoustics satisfaction score for LEED buildings at 0.45 with the average score of typical buildings in the CBE database at -0.16 . The responses to sound privacy were lower than noise level. Thus it is CBE's conclusion that the 
information content of the noise causes distraction and dissatisfaction. CBE also compared the acoustic satisfaction levels to the type of office space. Not surprisingly, the highest levels of satisfaction are in private offices and the lowest are in open office spaces and cubicles. ${ }^{31}$ For the buildings in this study where cubicle workspaces were predominant the acoustic satisfaction scores are shown in Figure 30. Two of the five buildings with cubicle style workspace, Denver FB and Auburn FB, have a positive acoustic satisfaction scores.

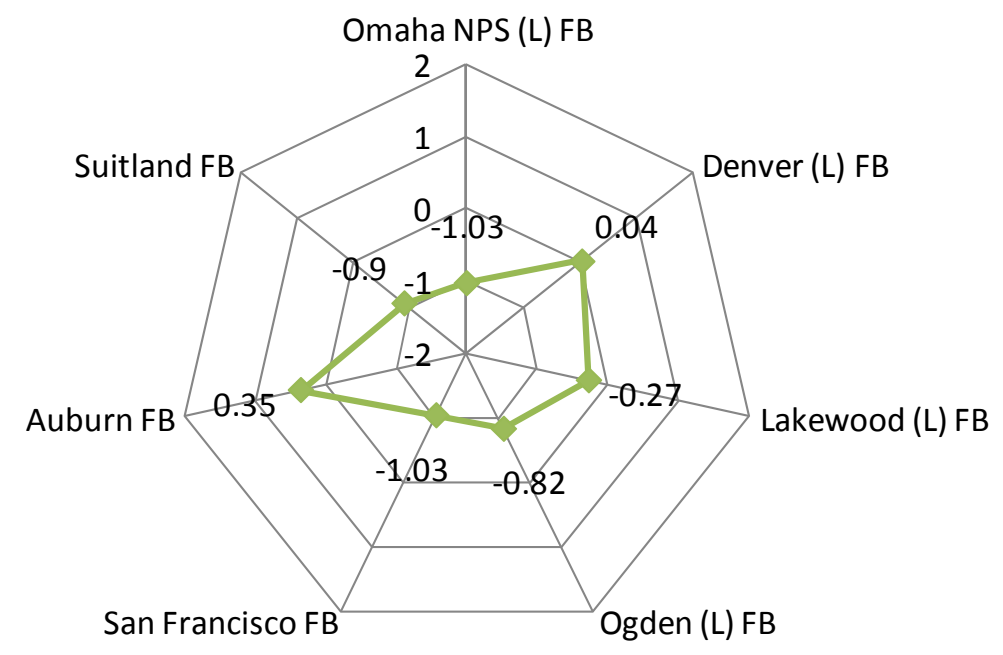

Figure 30. Acoustics quality satisfaction scores for cubicle workspaces

Photographs of the building workspaces show a variety of cubicle heights and types, which do not offer a consistent reason for the different acoustic satisfaction scores.

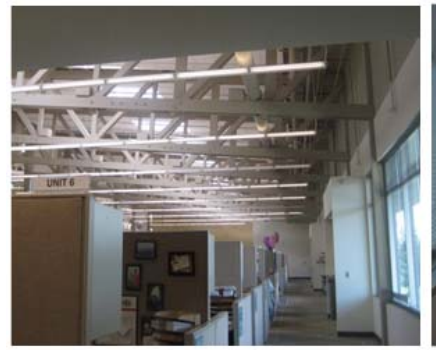

Auburn FB

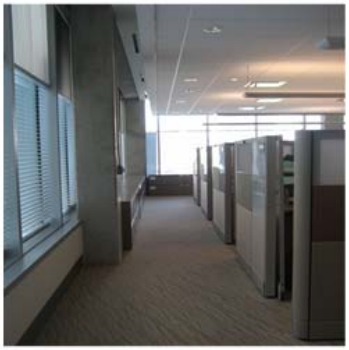

Denver FB

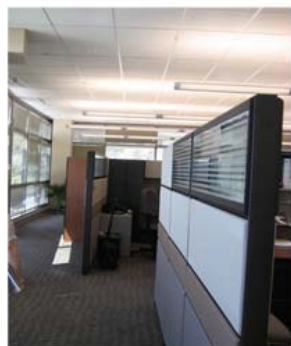

Lakewood FB

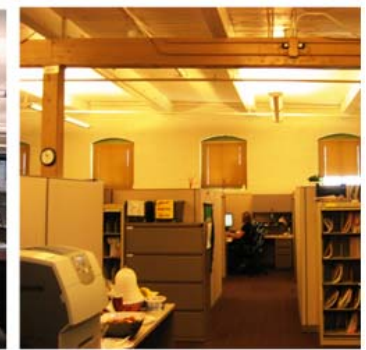

Ogden FB

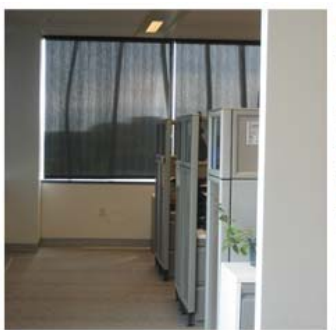

Suitland FB

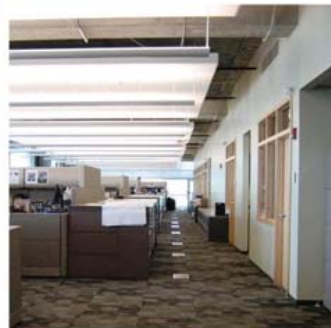

Omaha NPB FB

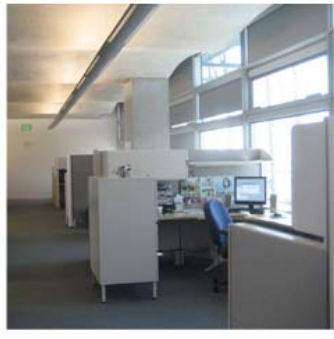

San Francisco FB

Figure 31. Photographs of cubicle workspaces 
Figure 32 illustrates that occupants of all the buildings in the study were satisfied with building air quality. Occupants from all but three of the buildings were more satisfied with the air quality than the $50^{\text {th }}$ percentile of those surveyed by CBE.

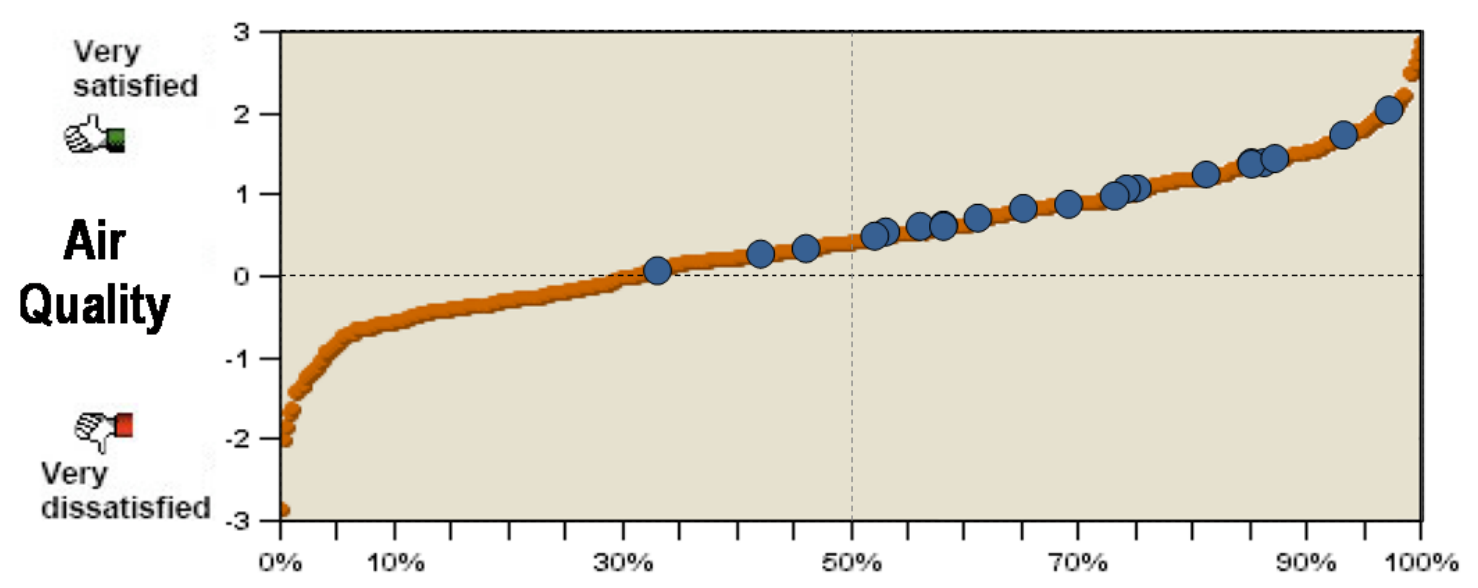

Air Quality Percentiles

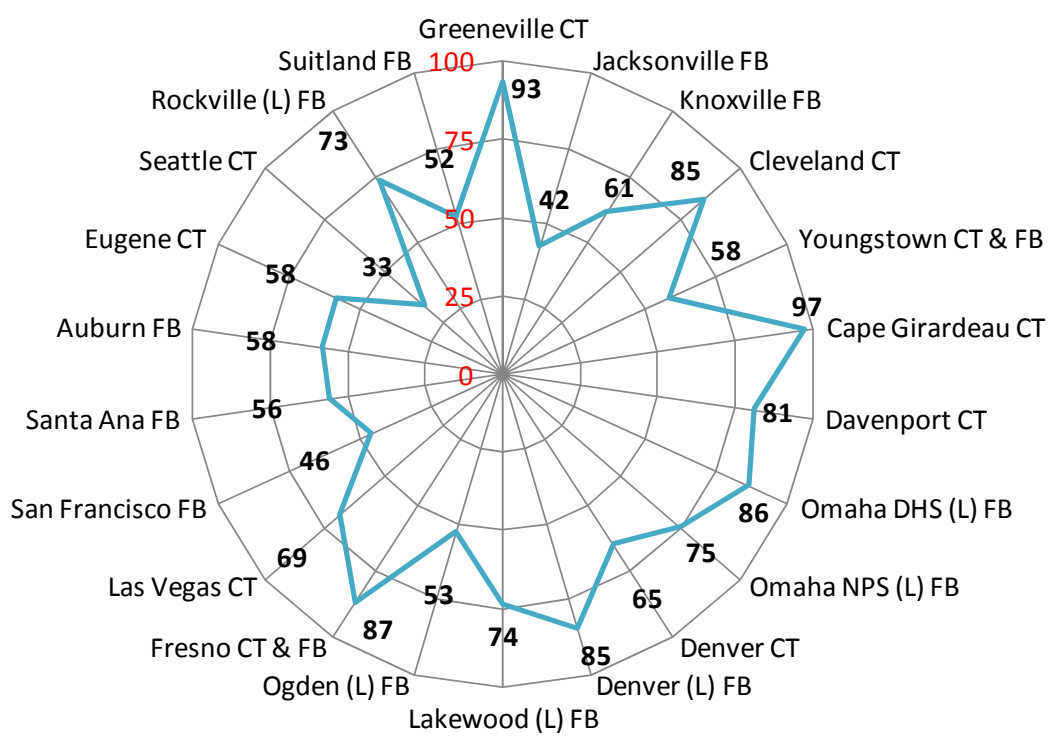

Figure 32. Air quality rating from the occupant survey 
Figure 33 illustrates that occupants in all but four of the buildings in the study identified cleanliness and maintenance as being better than the $50^{\text {th }}$ percentile of the CBE database. More than half of the buildings scored at the $75^{\text {th }}$ percentile and above. When considering the cost data, the maintenance costs of some of the buildings in the study are high, yet the building occupants are pleased with the service they are receiving.

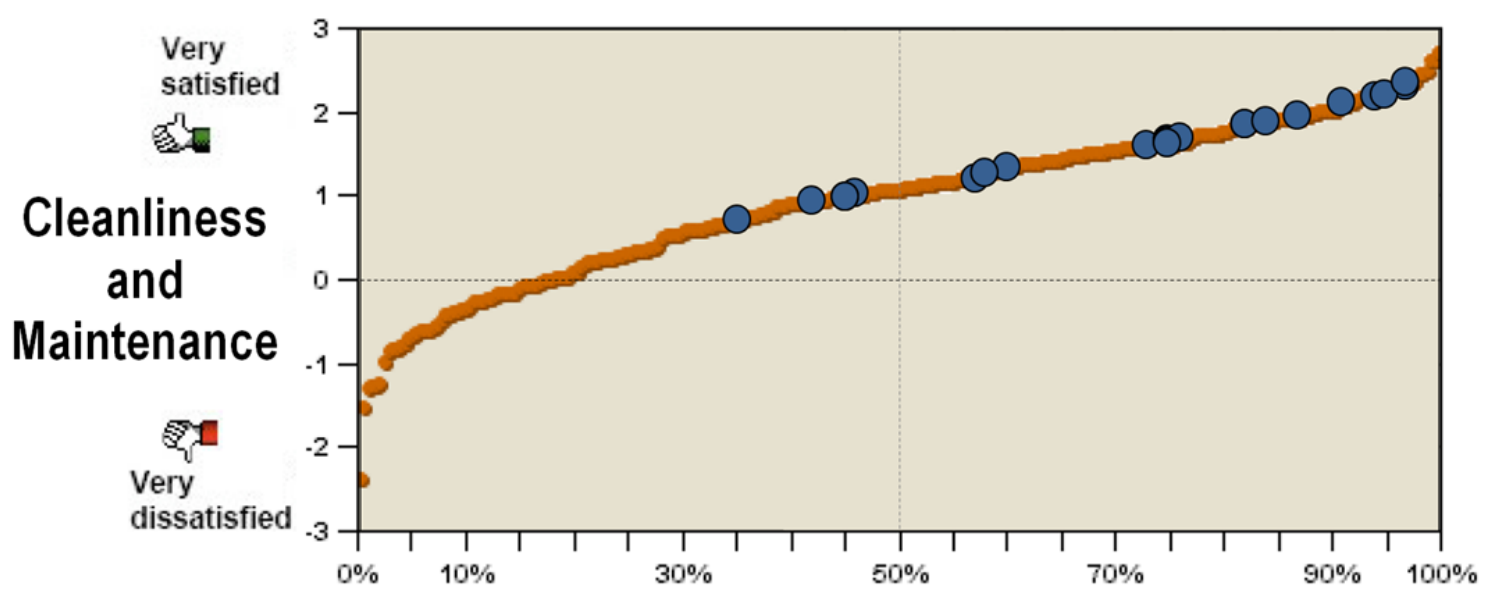

\section{Cleanliness and Maintenance Percentiles}

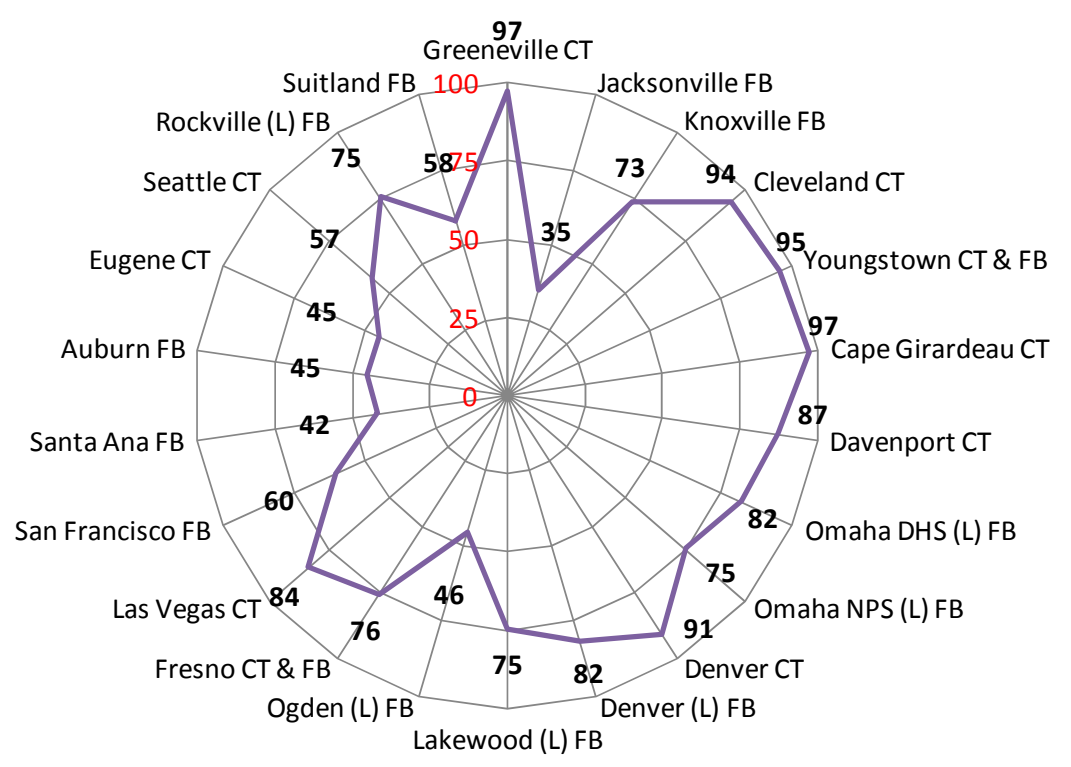

Figure 33. Cleanliness and maintenance rating from the occupant survey 
Figure 34 illustrates that although all of the occupants scored the lighting as satisfactory (above zero), more than half of the buildings in the study identified lighting as being worse than the $50^{\text {th }}$ percentile, with a quarter below the $30^{\text {th }}$ percentile. The lighting occupant satisfaction rating needs to be considered in context with energy use. The primary questions that make up the lighting satisfaction level are

- How satisfied are you with the amount of light in your workspace?

- How satisfied are you with the visual comfort of the lighting?

- How satisfied are you with the degree of control you have over the lighting in your workspace?

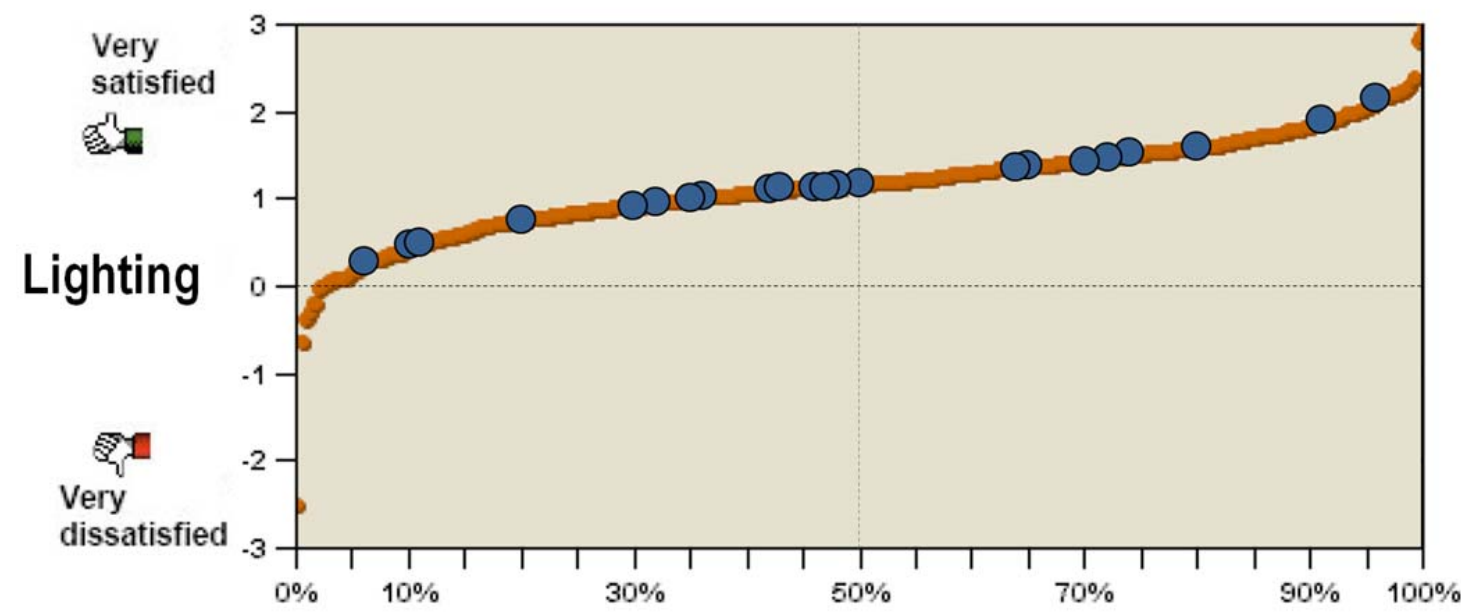

\section{Lighting Percentiles}

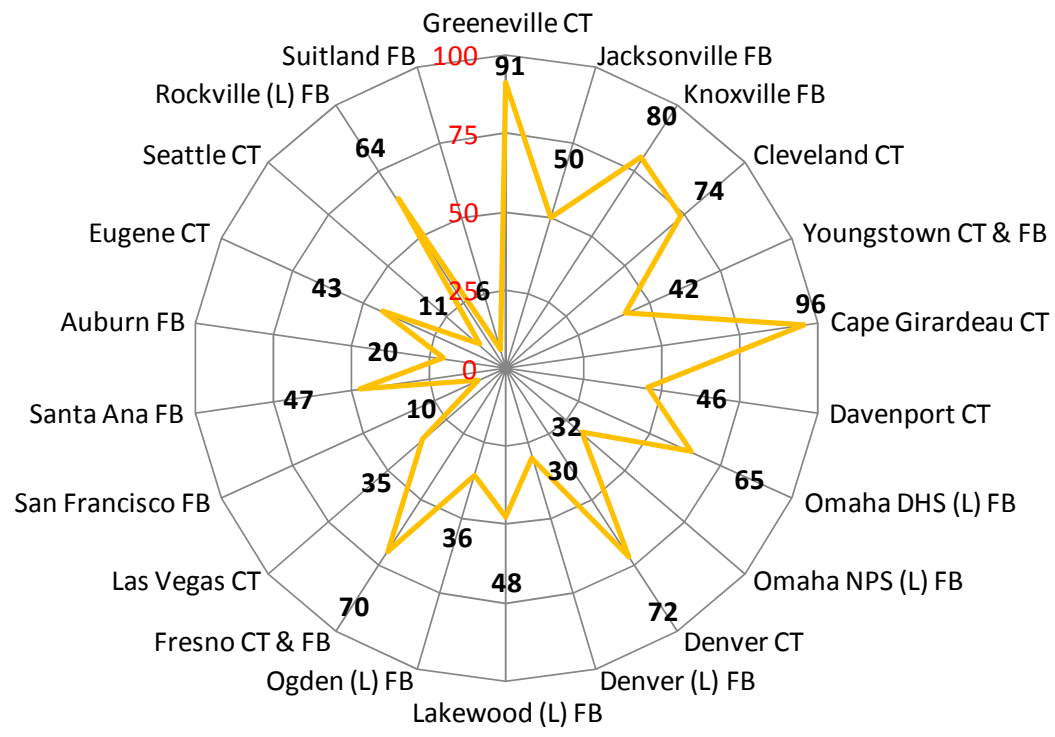

Figure 34. Lighting quality rating from the occupant survey 
Figure 35 shows the satisfaction scores for the windows and daylight questions. The majority of the GSA buildings in the study scored above the $50^{\text {th }}$ percentile, but note that the CBE database does not have many buildings in the database that have responded to these questions. The primary questions that make up the windows and daylight satisfaction level are

- How satisfied are you with the amount of daylight in your general office area?

- How satisfied are you with your access to a window view?

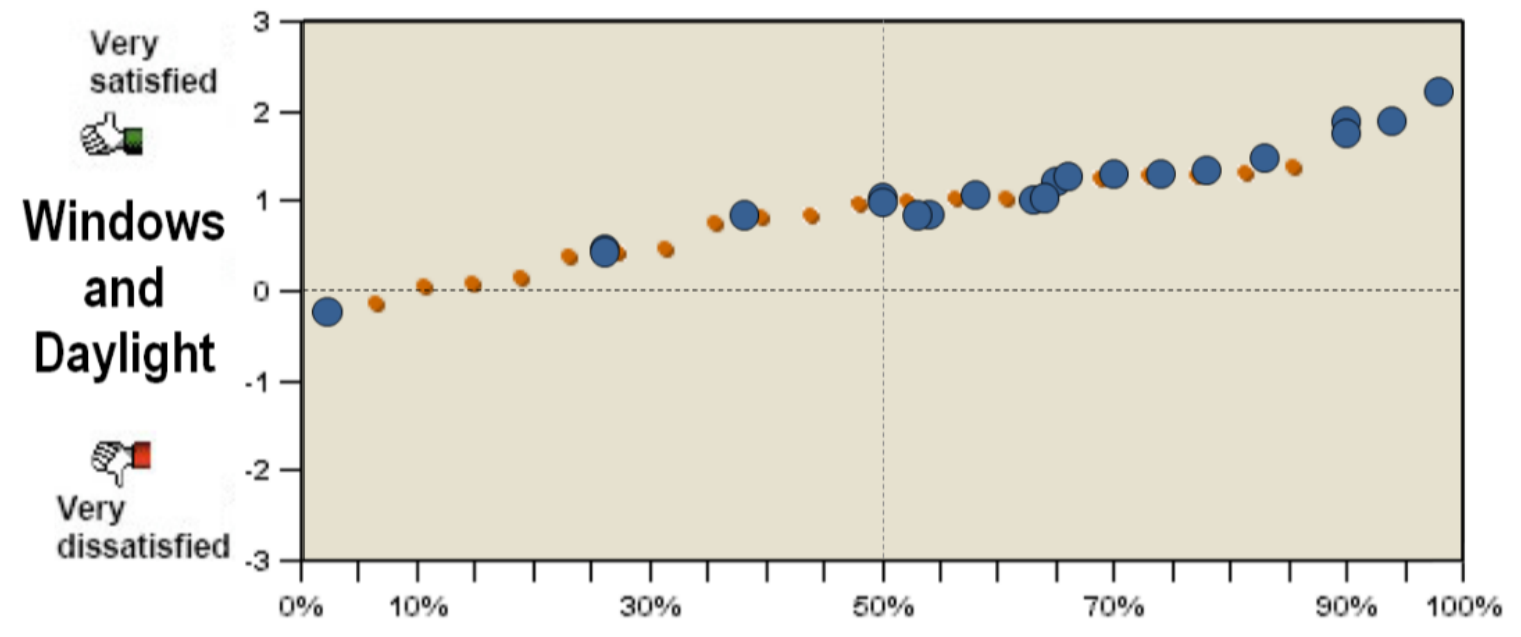

\section{Windows and Daylight Percentiles}

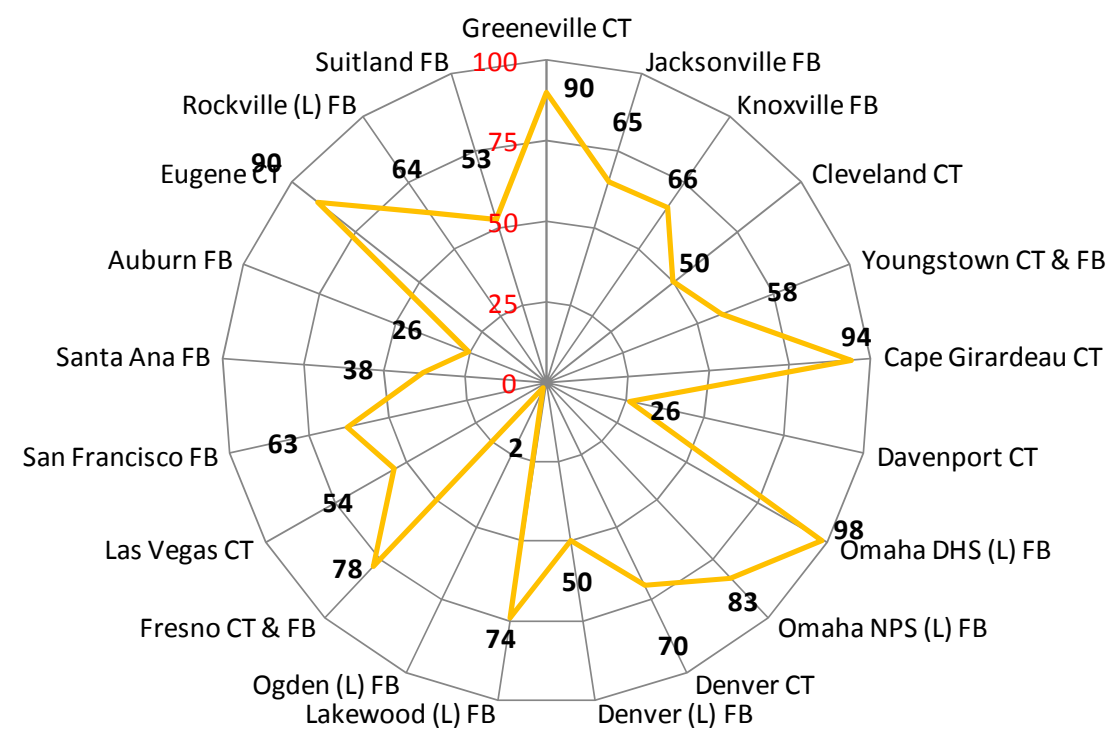

Figure 35. Windows and daylight satisfaction rating from the occupant survey 
For thermal comfort, most of the buildings scored above the $50^{\text {th }}$ percentile (Figure 36). One of the buildings whose occupants stated they were very dissatisfied with the thermal comfort has additional workspaces have been created from spaces that were not originally designed to be occupied. The building manager of this building commented that the additional occupant spaces negatively impacted ventilation.

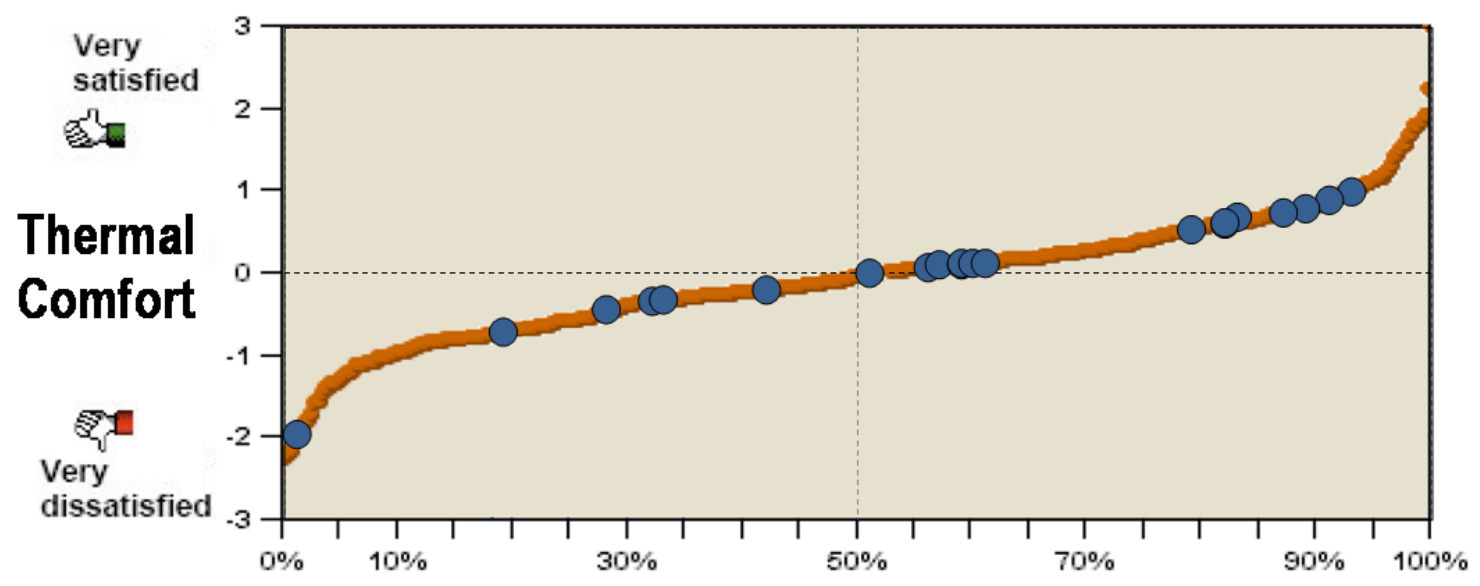

Thermal Comfort Percentiles

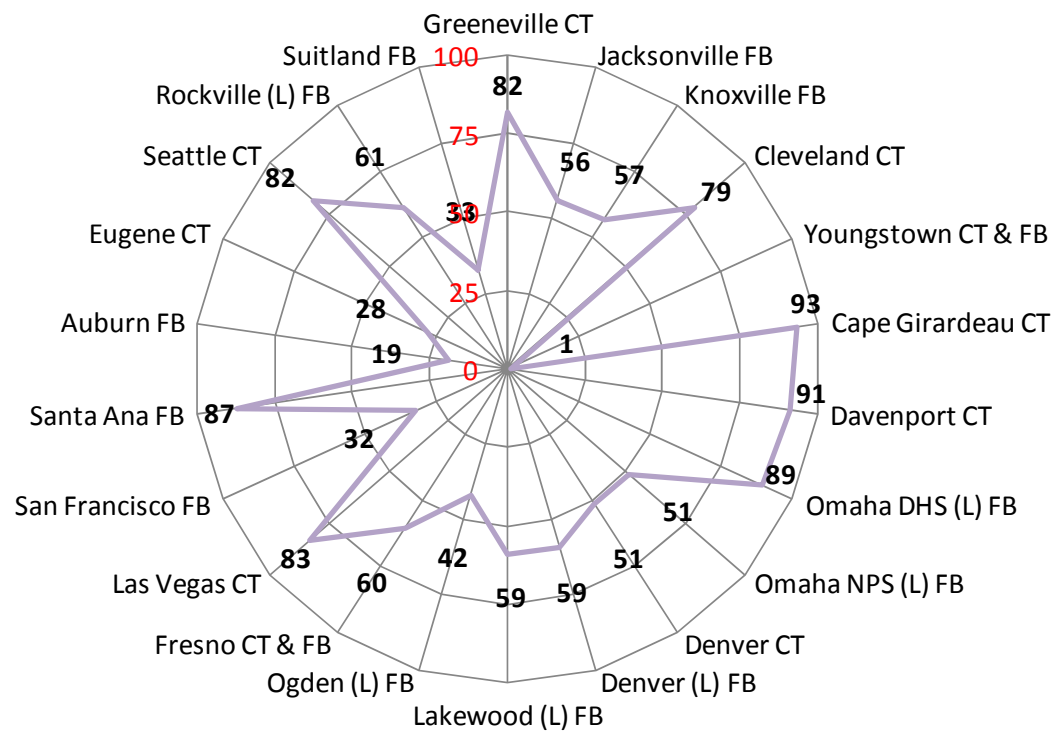

Figure 36. Thermal comfort rating from the occupant survey 
Overall, the general satisfaction with the individual workspace was positive (above zero) and the majority of the buildings had average satisfaction scores above the $50^{\text {th }}$ percentile (Figure $37)$.

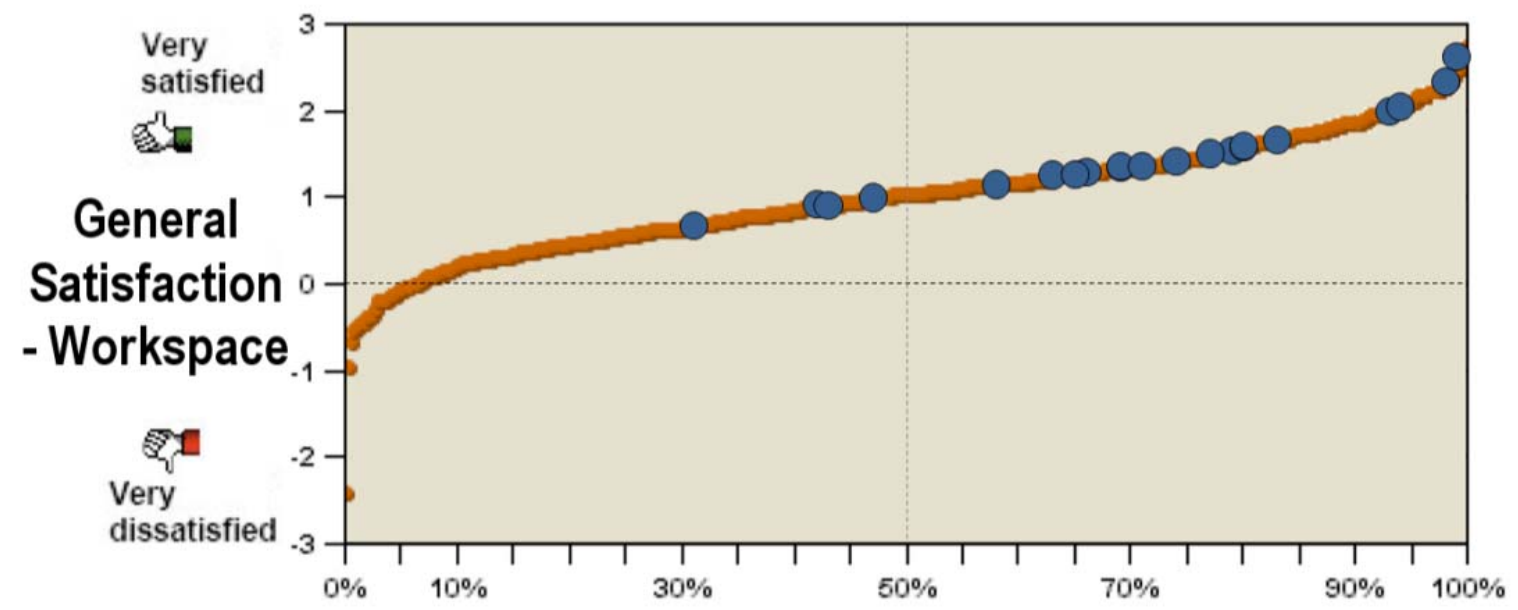

\section{General Satisfaction - Workplace Percentiles}

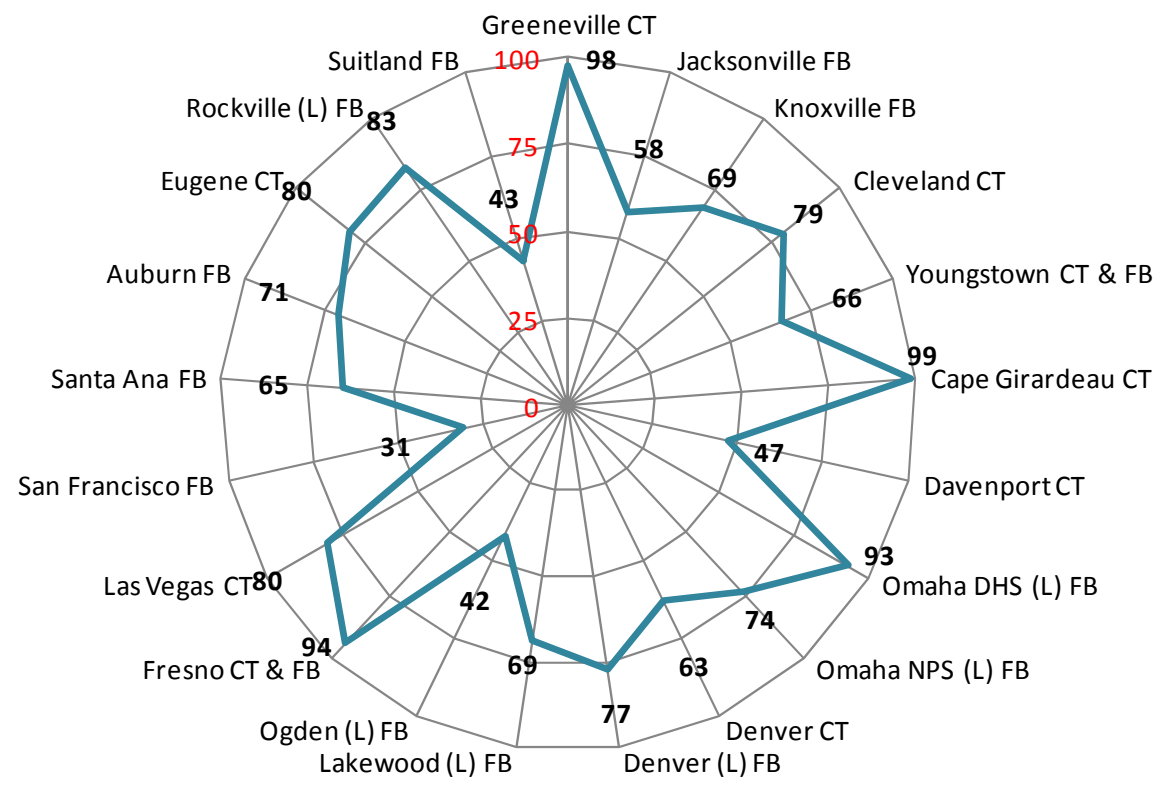

Figure 37. General workplace satisfaction rating from the occupant survey 
Very few buildings have used the communication satisfaction survey question, thus the baseline comparison is limited. All of the buildings were satisfied with communication (above zero). Buildings with the lowest communication survey scores, Suitland FB and San Francisco FB, also have the lowest acoustic quality, thermal comfort, lighting, and general building satisfaction scores. The questions for the communication satisfaction level are

- How satisfied are you with your ability to communicate with co-workers in person?

- How satisfied are you with the ease of interaction with co-workers?

- How satisfied are you with your ability to communicate in privacy?

- How satisfied are you with the availability of space where you and your colleagues can talk into a speaker phone together.

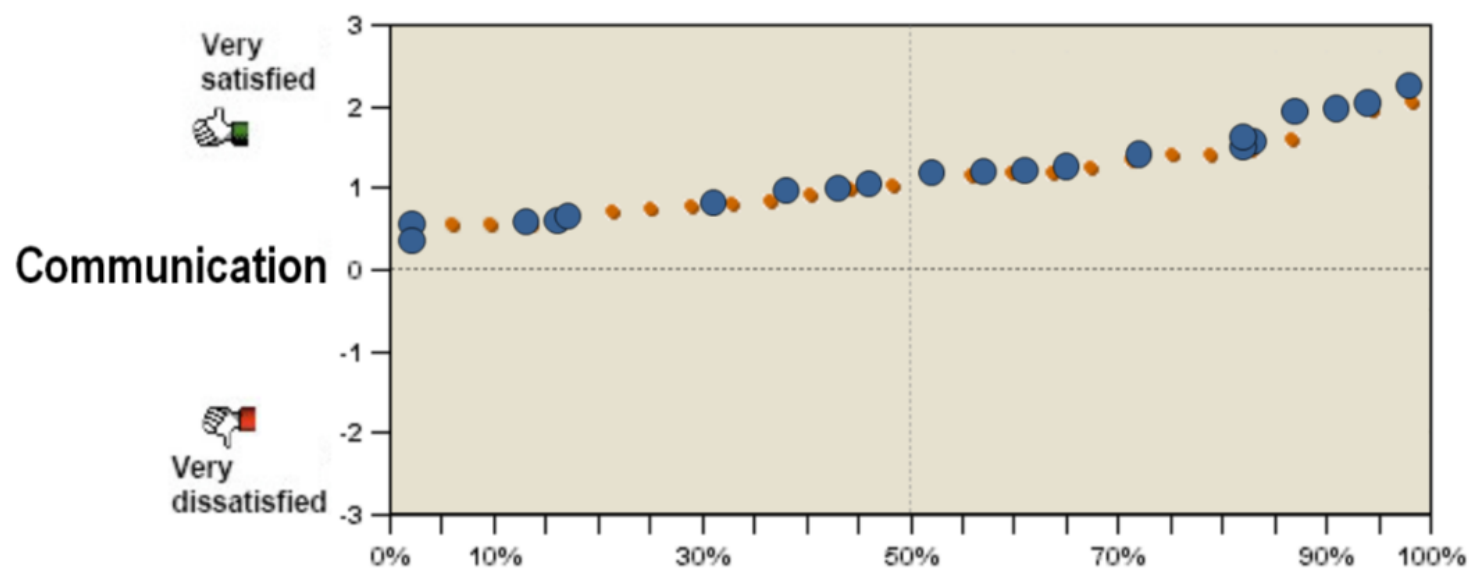

Communication Percentiles

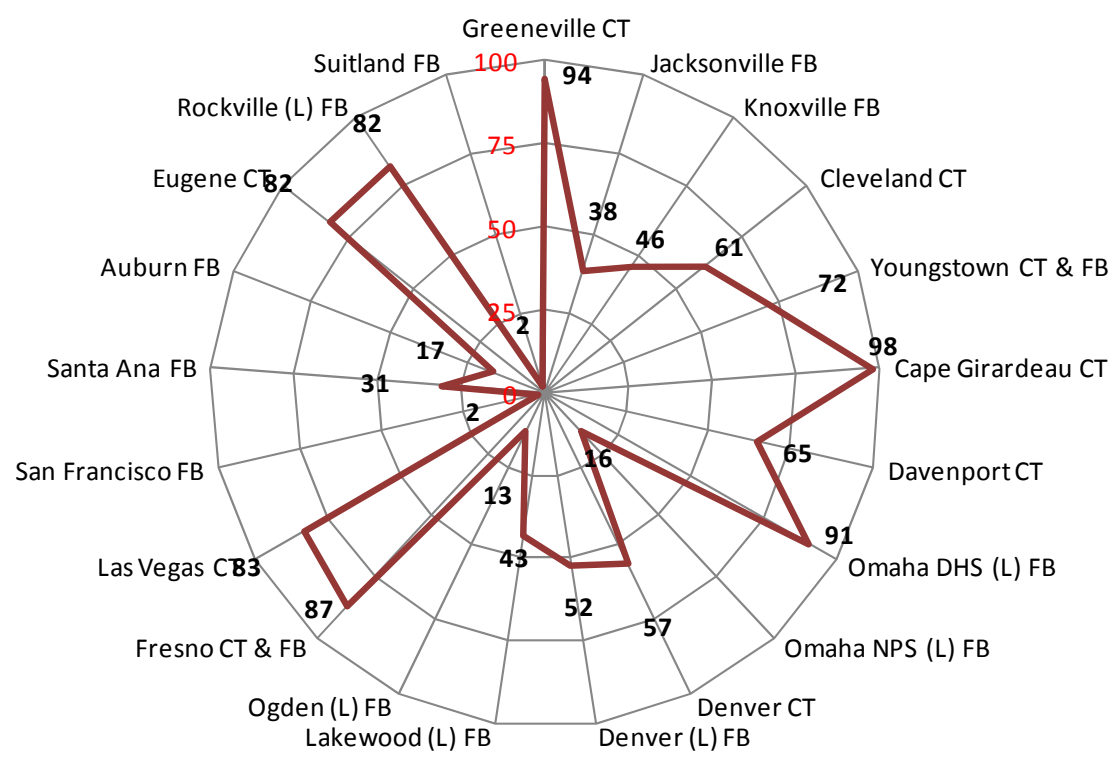

Figure 38. Communication satisfaction rating from the occupant survey 
All of the GSA buildings in the study had positive general satisfaction scores (above zero) and two-thirds of the buildings scored above the $50^{\text {th }}$ percentile (Figure 39).

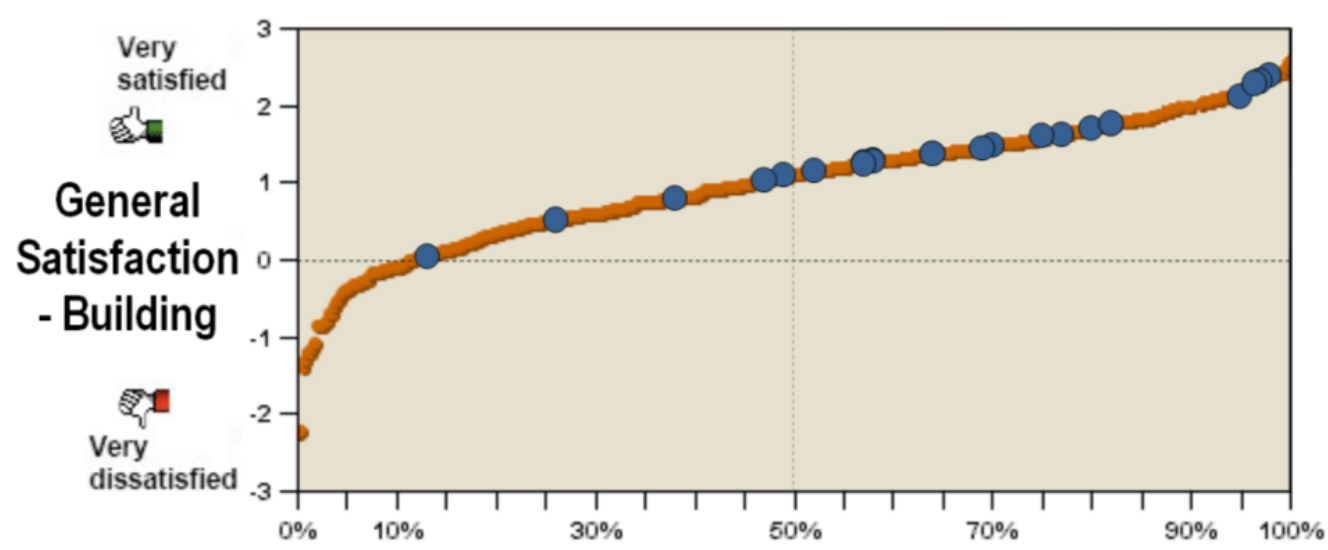

\section{General Satisfaction - Building Percentiles}

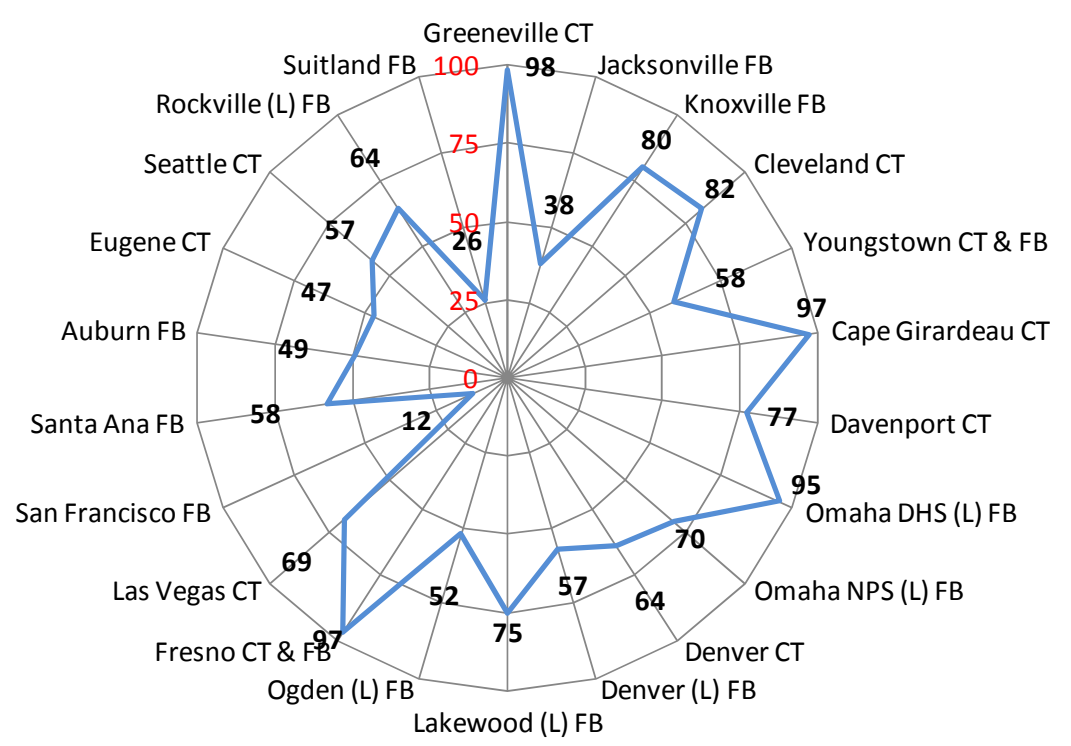

Figure 39. General building satisfaction rating from the occupant survey 
Figure 40 shows that the average scores from the SPOT survey were higher than the average scores in the CBE database, except for lighting satisfaction questions, where the average survey responses were essentially the same. When compared to the LEED certified buildings in the CBE database, the SPOT survey responses were better for all questions except for air quality.

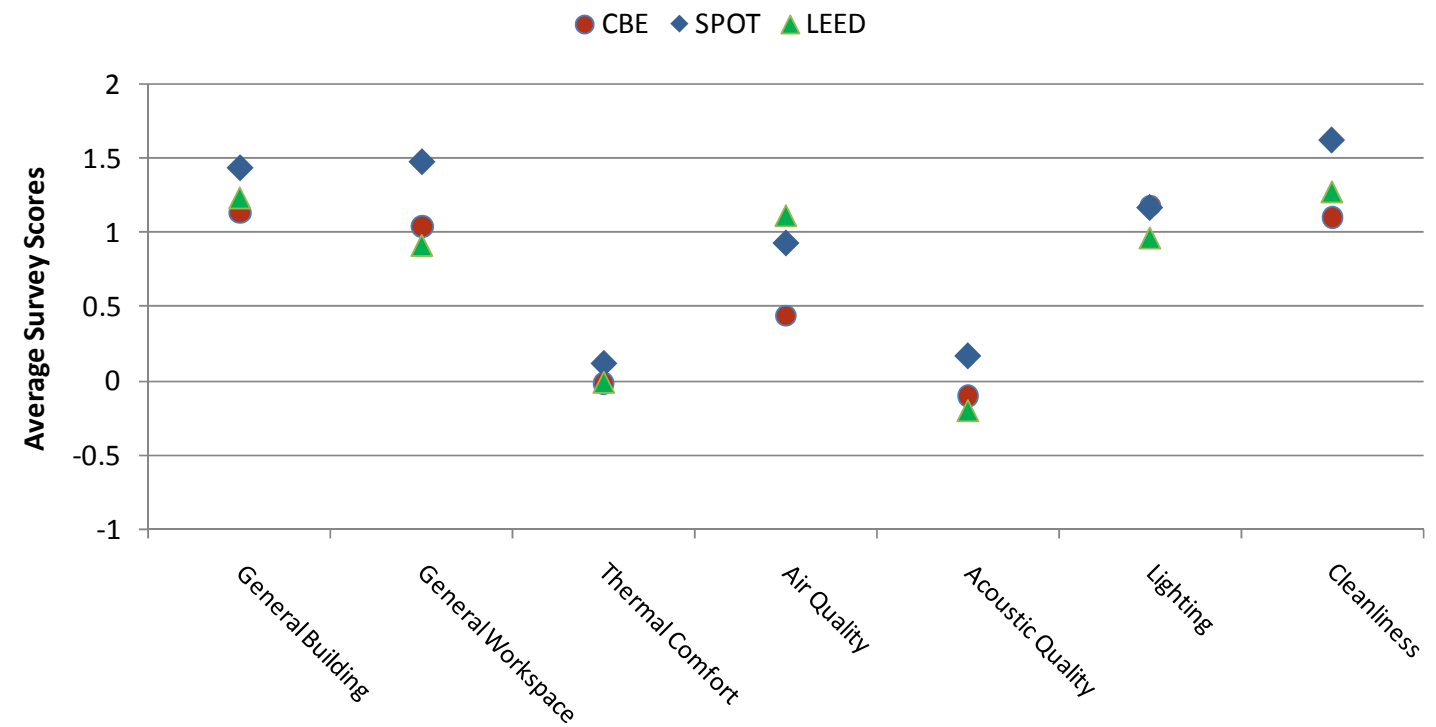

Figure 40. Study building occupants are more satisfied than the building occupants in the CBE database.

The occupant satisfaction information compared to the CBE baseline offers a snapshot of the relative satisfaction of these buildings' occupants at this point in time. More detailed building studies of why building occupants are responding as they are would offer additional insight. These data connect with the other building metrics, such as maintenance and janitorial costs compared to cleanliness and maintenance satisfaction scores and thermal comfort compared to EUI. Additional analysis across the metrics can be found in the conclusion section. 


\section{Transportation}

The occupant commute to a building reflects the impact of siting, agency incentives, and the environmental ethic of the building occupants. The

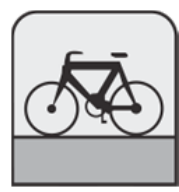
information for the transportation metric was collected using the SPOT survey. The impact of the occupant transportation choices is represented by the average distance traveled and the carbon dioxide $\left(\mathrm{CO}_{2}\right)$ equivalents. Table 21 shows the summary transportation data and $\mathrm{CO}_{2}$ equivalents based on responses to the questions about occupant commute distance and vehicle type questions.

Table 21. Transportation data by building

\begin{tabular}{|c|c|c|c|c|c|c|c|}
\hline Building Name & $\begin{array}{c}\text { Survey N- } \\
\text { Value }\end{array}$ & \# Occ & $\begin{array}{l}\% \text { of Occupants } \\
\text { who commute } \\
\text { using mass transit, } \\
\text { biking and/or } \\
\text { walking }\end{array}$ & $\begin{array}{l}\text { Avg Daily } \\
\text { Roundtrip } \\
\text { Miles } \\
\text { Traveled/Occ }\end{array}$ & $\begin{array}{c}\text { Transportation } \\
\mathrm{CO}_{2} \text { Equiv/Occ } \\
\text { (metric tons) }\end{array}$ & $\begin{array}{c}\text { Baseline } \\
\text { Transportation } \\
\mathrm{CO}_{2} \text { Equiv/Occ } \\
\text { (metric tons) }\end{array}$ & $\begin{array}{c}\text { Bldg } \\
\text { Transportation } \\
\text { Performance }\end{array}$ \\
\hline Greeneville CT & 55 & 85 & $0 \%$ & 22.4 & 2.6 & 2.3 & $11 \%$ \\
\hline Jacksonville FB & 393 & 1,000 & $25 \%$ & 32.5 & 1.4 & 2.3 & $-39 \%$ \\
\hline Knoxville FB & 98 & 285 & $0 \%$ & 28.9 & 2.2 & 2.3 & $-6 \%$ \\
\hline Cleveland CT & 55 & 105 & $56 \%$ & 25.8 & 1.0 & 2.3 & $-55 \%$ \\
\hline Youngstown CT \& FB & 28 & 45 & $0 \%$ & 28.8 & 1.8 & 2.3 & $-23 \%$ \\
\hline Cape Girardeau CT & 26 & 45 & $8 \%$ & 41.0 & 1.5 & 2.3 & $-36 \%$ \\
\hline Davenport CT & 22 & 45 & $0 \%$ & 26.5 & 2.9 & 2.3 & $24 \%$ \\
\hline Omaha DHS (L) FB & 16 & 65 & $0 \%$ & 29.7 & 2.1 & 2.3 & $-9 \%$ \\
\hline Omaha NPS (L) FB & 82 & 125 & $0 \%$ & 21.4 & 1.7 & 2.3 & $-26 \%$ \\
\hline Denver CT & 58 & 170 & $53 \%$ & 24.4 & 1.1 & 2.3 & $-51 \%$ \\
\hline Denver (L) FB & 339 & 922 & $87 \%$ & 25.6 & 0.6 & 2.3 & $-75 \%$ \\
\hline Lakewood (L) FB & 103 & 318 & $9 \%$ & 23.1 & 1.9 & 2.3 & $-18 \%$ \\
\hline Ogden (L) FB & 151 & 514 & $3 \%$ & 19.6 & 1.9 & 2.3 & $-18 \%$ \\
\hline Fresno CT \& FB & 64 & 235 & $0 \%$ & 25.7 & 2.4 & 2.3 & $4 \%$ \\
\hline Las Vegas CT & 62 & 321 & $5 \%$ & 24.9 & 1.1 & 2.3 & $-50 \%$ \\
\hline San Francisco FB & 485 & 1,314 & $94 \%$ & 32.1 & 0.6 & 2.3 & $-72 \%$ \\
\hline Santa Ana FB & 118 & 409 & $12 \%$ & 29.7 & 2.2 & 2.3 & $-3 \%$ \\
\hline Auburn FB & 427 & 675 & $7 \%$ & 31.6 & 1.4 & 2.3 & $-39 \%$ \\
\hline Eugene CT & 48 & 120 & $19 \%$ & 18.2 & 0.8 & 2.3 & $-66 \%$ \\
\hline Seattle CT & $\mathrm{N} / \mathrm{A}$ & 500 & $\mathrm{~N} / \mathrm{A}$ & $\mathrm{N} / \mathrm{A}$ & N/A & 2.3 & $\mathrm{~N} / \mathrm{A}$ \\
\hline Rockville (L) FB & 230 & 720 & $18 \%$ & 30.5 & 1.4 & 2.3 & $-41 \%$ \\
\hline Suitland FB & 945 & 5,360 & $22 \%$ & 39.4 & 1.9 & 2.3 & $-18 \%$ \\
\hline
\end{tabular}

Although occupant commute is not typically seen as having a connection to a building, LEED encourages the consideration of the occupant commute during the building design. LEED points can be earned for siting the building near public transportation, providing preferred parking for carpools and alternative vehicles, and offering space and services for bicycle riders. This performance measure is being used to investigate whether the roundtrip 
commute of green building occupants has a lower environmental impact than the industry baseline.

In addition to the strategies used during building design, the building manager and/or owner can offer space, services and encouragement to alter commute practices. For example, the cost and availability of parking and/or public transportation may have a greater impact on occupant commute choices than preferential parking spaces for carpoolers. Other incentives provided by the occupant's employer, such as public transportation vouchers or the ability to telecommute, will also have an impact on occupant transportation decisions. Of course there is also the personal decision of vehicle type, and housing location that is not being addressed in this study. The rate of single occupant vehicle transportation changes by location, and the current economic and/or political situation. All but three of the buildings in the study have occupant commute emissions lower than industry baseline (Figure 41).

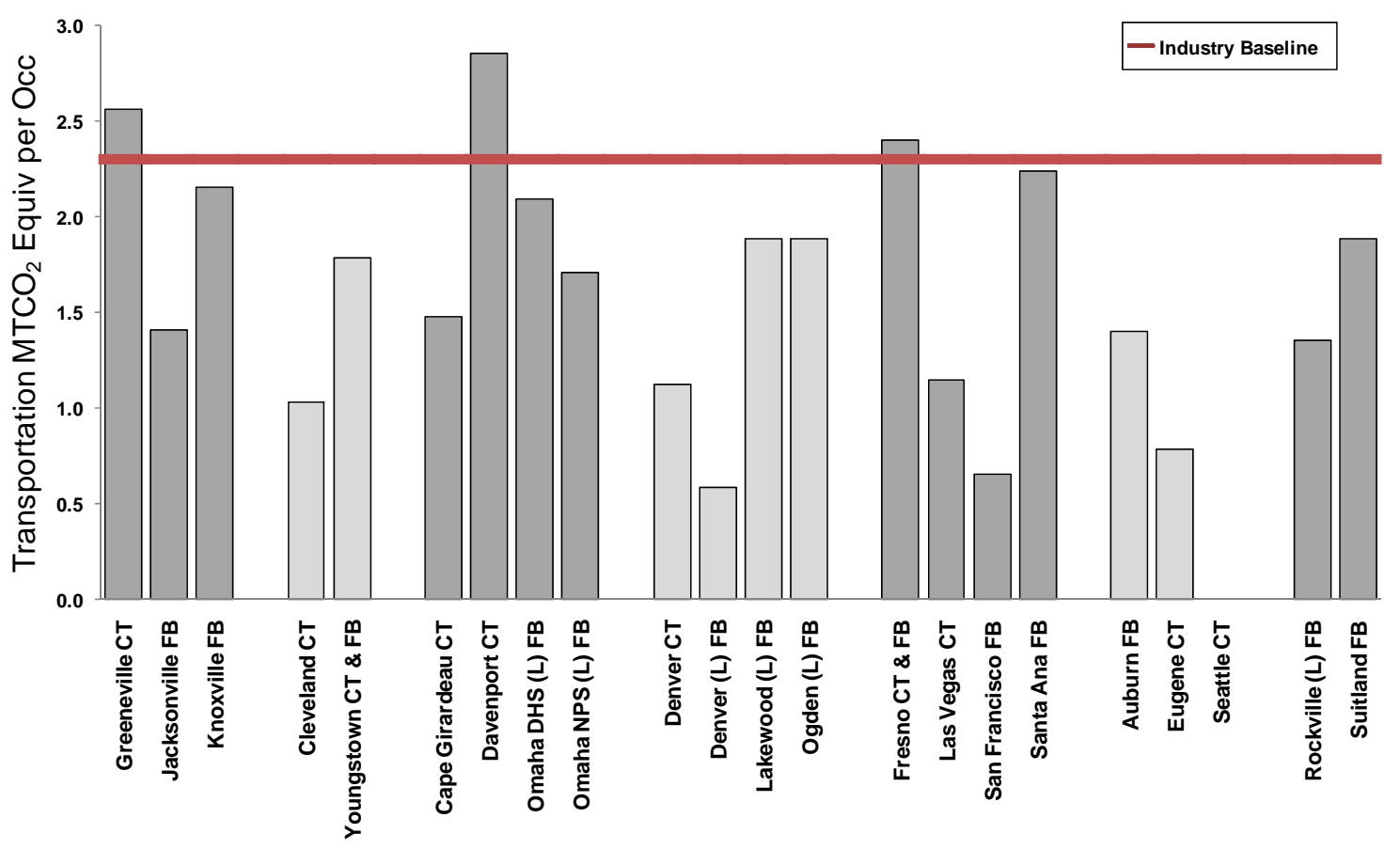

Figure 41. Occupant commute $\mathrm{CO}_{2}$ equivalent emissions compared to the baseline 
Per an Environmental Building News article, key factors associated with reducing occupant commute impact are the density of the building location, and distance to mass transit. ${ }^{32}$ The industry average roundtrip is a little less than 24 miles per day. In this study, there is no correlation between the size of the community and the average length of commute. Most of the buildings in the study have longer commutes than baseline (Figure 42). Sustainable design siting considerations would ideally show a decrease in commute distance traveled, but there would also be a $\mathrm{CO}_{2}$ emission shift because of preferential parking incentives to carpool and access to public transportation.

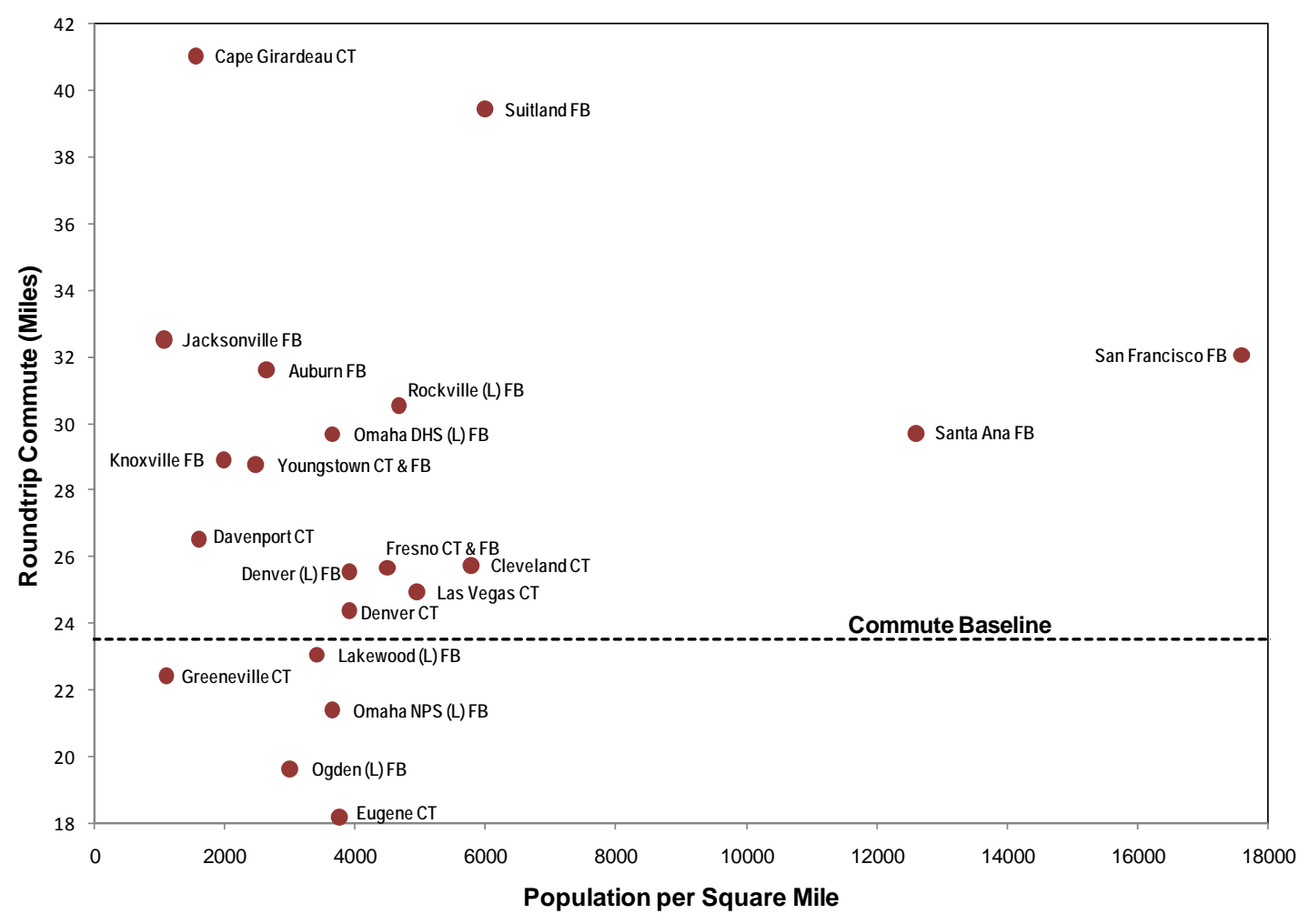

Figure 42. Average commute distance and community size 
Given the average commute is longer than baseline, Figure 43 shows the occupants are choosing commute options with a lower emissions impact. One of the buildings that is higher than baseline is the only one located in a "town" as designated by the Census Bureau. The other two buildings are located in cities with limited access to mass transit.

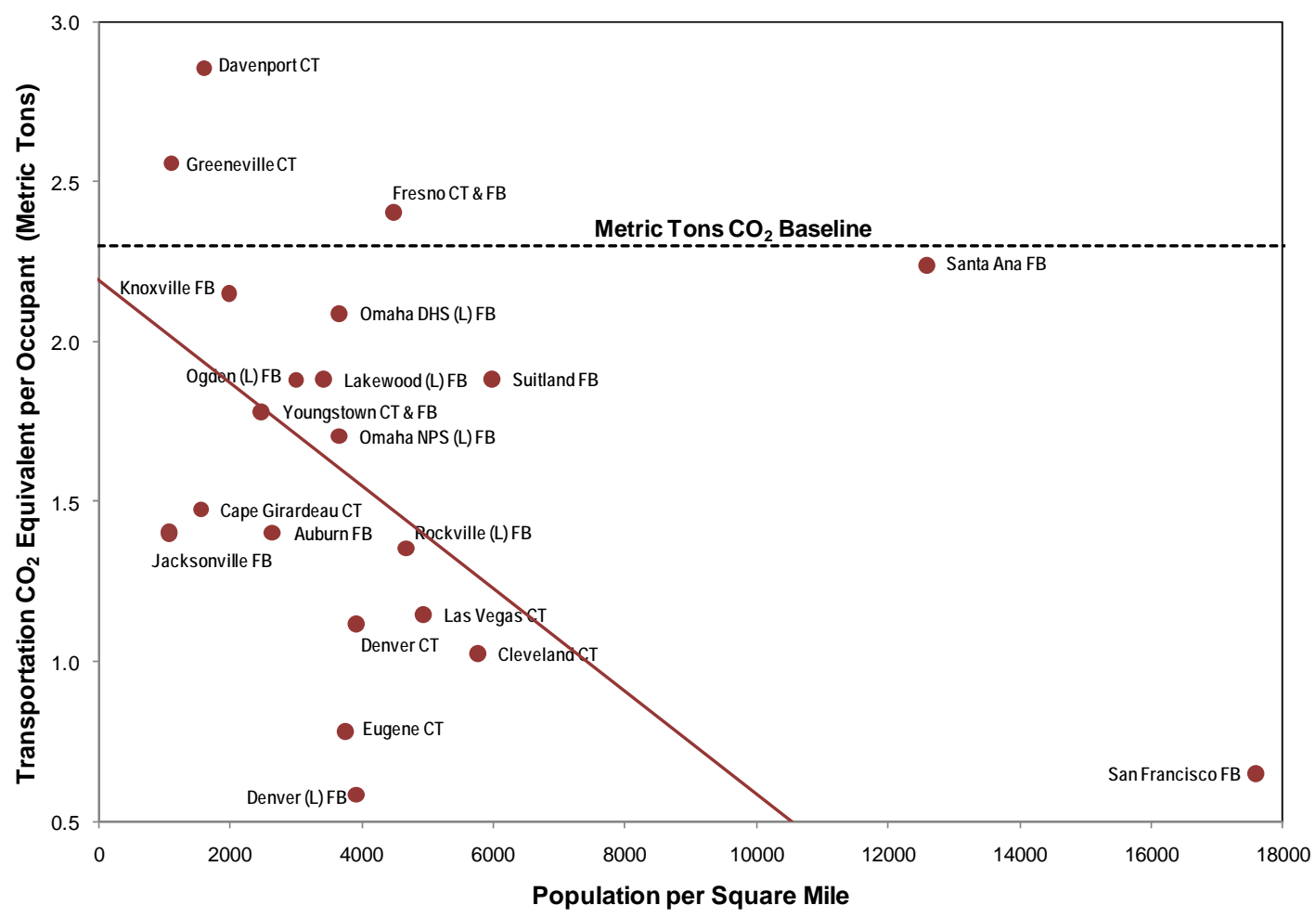

Figure 43. $\mathrm{CO}_{2}$ equivalent emissions by community size 
Table 22 shows the size of the cities with the calculated $\mathrm{CO}_{2}$ equivalent emissions per occupant.

Table 22. Population density and commute distance by building

\begin{tabular}{|c|c|c|c|c|c|c|}
\hline & & & & Population D & Density & \\
\hline Building Name & $\begin{array}{l}\text { Census } \\
\text { Designation }\end{array}$ & Population & $\begin{array}{l}\text { Square } \\
\text { miles }\end{array}$ & $\begin{array}{l}\text { people per } \\
\text { sq mile }\end{array}$ & $\begin{array}{l}\text { Roundtrip } \\
\text { Commute } \\
\text { distance }\end{array}$ & $\begin{array}{c}\text { Transportation } \\
\mathrm{CO}_{2} \text { Equiv/Occ } \\
\text { (metric tons) }\end{array}$ \\
\hline Greeneville CT & Town & 15,537 & 14 & 1,107 & 22.4 & 2.56 \\
\hline Jacksonville FB & City & 807,815 & 757 & 1,067 & 32.5 & 1.40 \\
\hline Knoxville FB & City & 182,337 & 92 & 1,982 & 28.9 & 2.15 \\
\hline Cleveland CT & City & 444,313 & 77 & 5,770 & 25.8 & 1.03 \\
\hline Youngstown CT \& FB & City & 81,520 & 33 & 2,470 & 28.8 & 1.78 \\
\hline Cape Girardeau CT & City & 37,370 & 24 & 1,557 & 41.0 & 1.47 \\
\hline Davenport CT & City & 99,514 & 62 & 1,605 & 26.5 & 2.85 \\
\hline Omaha DHS (L) FB & City & 419,545 & 115 & 3,648 & 29.7 & 2.09 \\
\hline Omaha NPS (L) FB & City & 419,545 & 115 & 3,648 & 21.4 & 1.70 \\
\hline Denver CT & City & 598,707 & 153 & 3,913 & 24.4 & 1.12 \\
\hline Denver (L) FB & City & 598,707 & 153 & 3,913 & 25.6 & 0.58 \\
\hline Lakewood (L) FB & City & 140,024 & 41 & 3,415 & 23.1 & 1.88 \\
\hline Ogden (L) FB & City & 78,086 & 26 & 3,003 & 19.6 & 1.88 \\
\hline Fresno CT \& FB & City & 466,714 & 104 & 4,488 & 25.7 & 2.40 \\
\hline Las Vegas CT & City & 558,383 & 113 & 4,941 & 24.9 & 1.15 \\
\hline San Francisco FB & City & 808,976 & 46 & 17,586 & 32.1 & 0.65 \\
\hline Santa Ana FB & City & 340,024 & 27 & 12,593 & 29.7 & 2.24 \\
\hline Auburn FB & City & 55,426 & 21 & 2,639 & 31.6 & 1.40 \\
\hline Eugene CT & City & 150,104 & 40 & 3,753 & 18.2 & 0.78 \\
\hline Seattle CT & City & 598,541 & 83 & 7,211 & $\mathrm{~N} / \mathrm{A}$ & $\mathrm{N} / \mathrm{A}$ \\
\hline Rockville (L) FB & City & 60,734 & 13 & 4,672 & 30.5 & 1.35 \\
\hline Suitland FB & City & 33,515 & 6 & 5,985 & 39.4 & 1.88 \\
\hline
\end{tabular}


Table 23 and Figure 44 show the aggregate $\mathrm{CO}_{2}$ equivalent emissions for occupant commute and building energy use. When the values are combined, all of the buildings perform better than baseline.

Table 23. Aggregate $\mathrm{CO} 2$ equivalent emissions for transportation and building

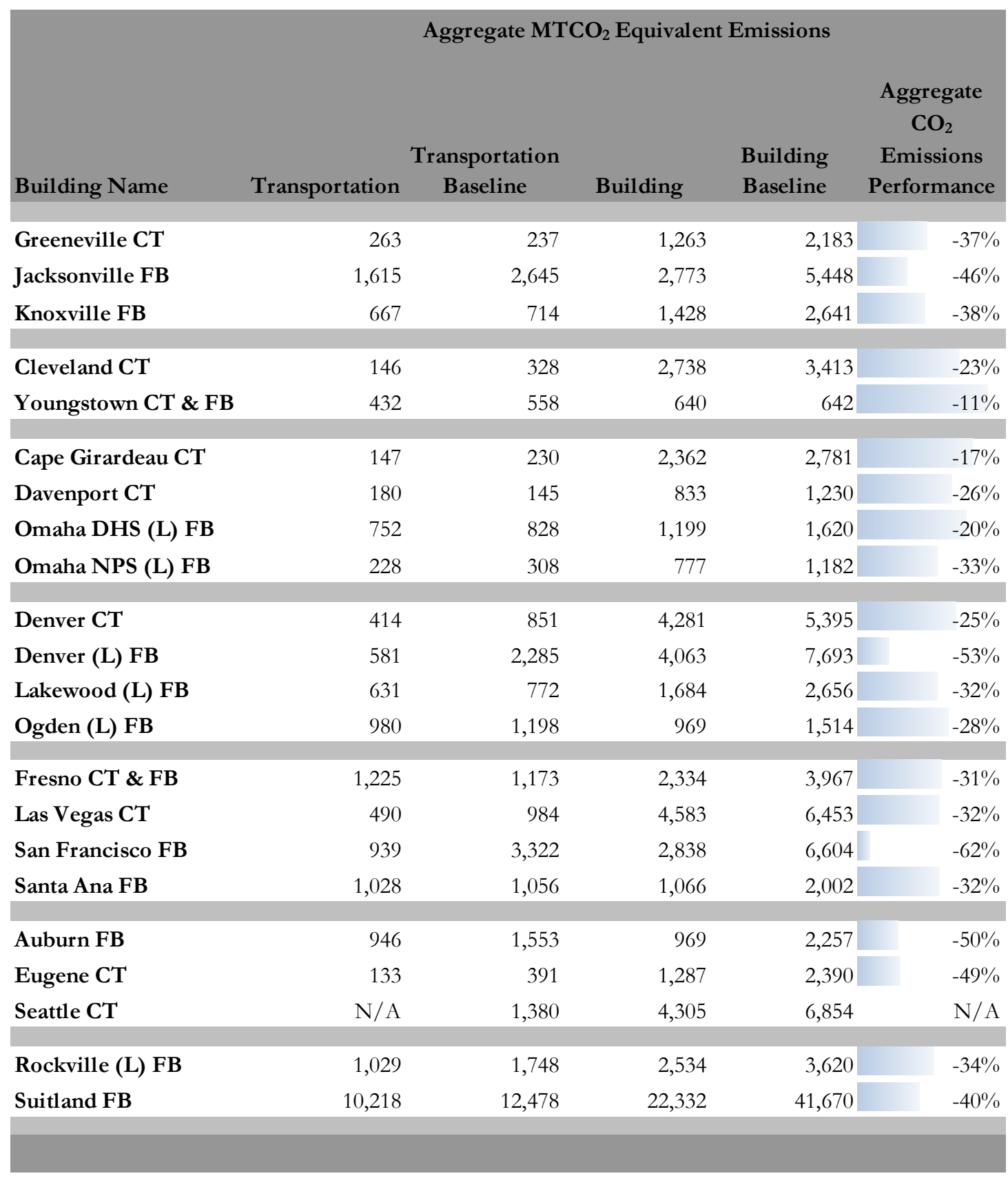




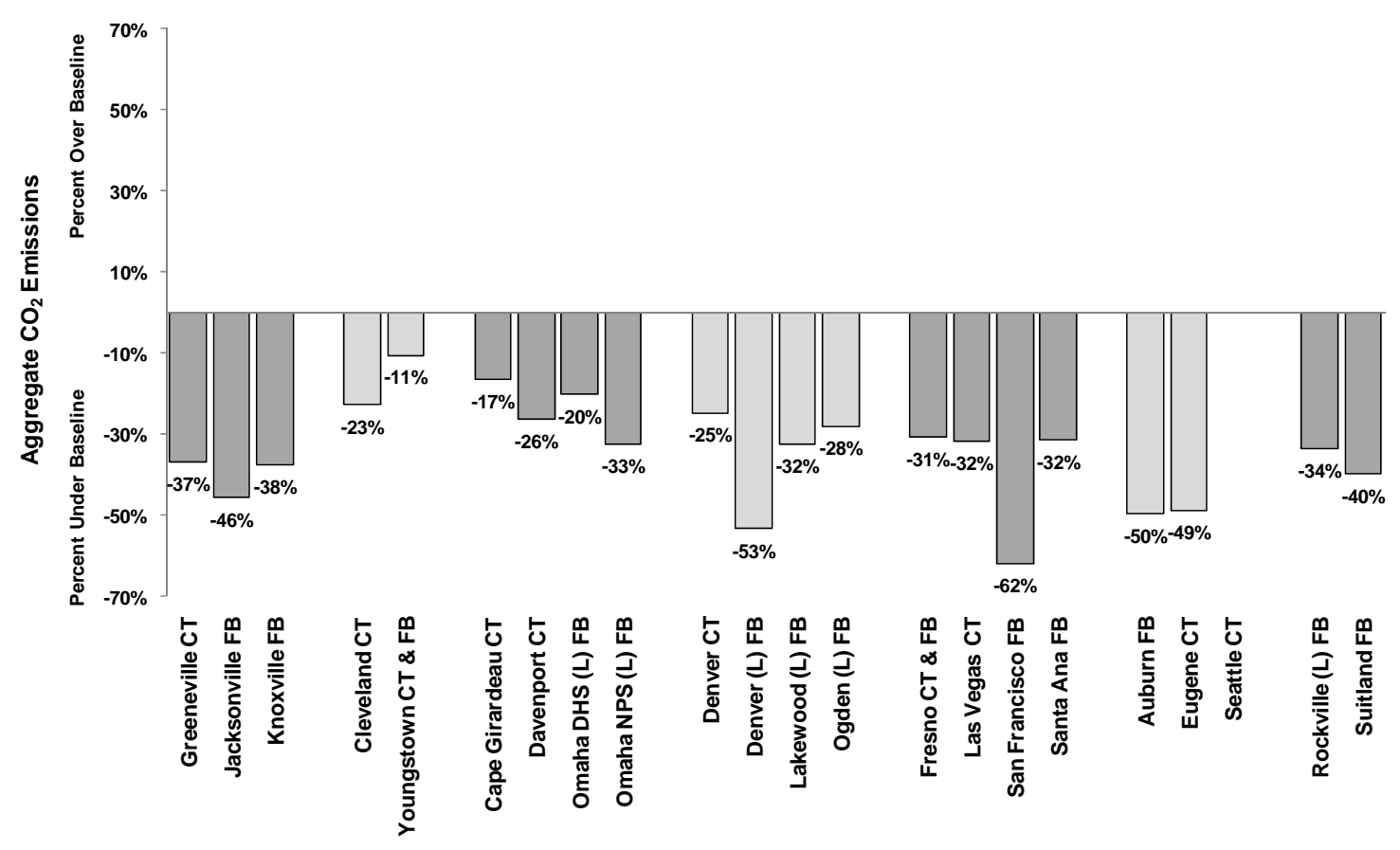

Figure 44. Aggregate $\mathrm{CO}_{2}$ equivalent emissions compared to the baseline

When considering the $\mathrm{CO}_{2}$ equivalent emissions impact of the buildings in this study, the occupant commute played a small part. Most of the buildings had a roundtrip commute longer than the industry average and the emissions were generally lower than industry average, it appears the occupants are choosing to walk, bike or use mass transit more than the general population. It is not clear whether this can be attributed to sustainable design siting practices or if it is just a coincidence. More detailed analysis on the mass transit options available in each location, cost of living, driving, and parking, and the incentives provided to occupants would be useful information to consider in building specific post occupancy evaluations. 


\section{Conclusions}

The purpose of this study was to provide an overview of measured whole building performance as it compares to GSA and industry baselines. The PNNL research team found the data analysis illuminated strengths and weaknesses of individual buildings as well as the portfolio of buildings. This section includes summary data, observations that cross multiple performance metrics, discussion of lessons learned from this research, and opportunities for future research. Table 24 provides the cost data for each whole building performance metric.

Table 24. Annual costs and total project cost by building

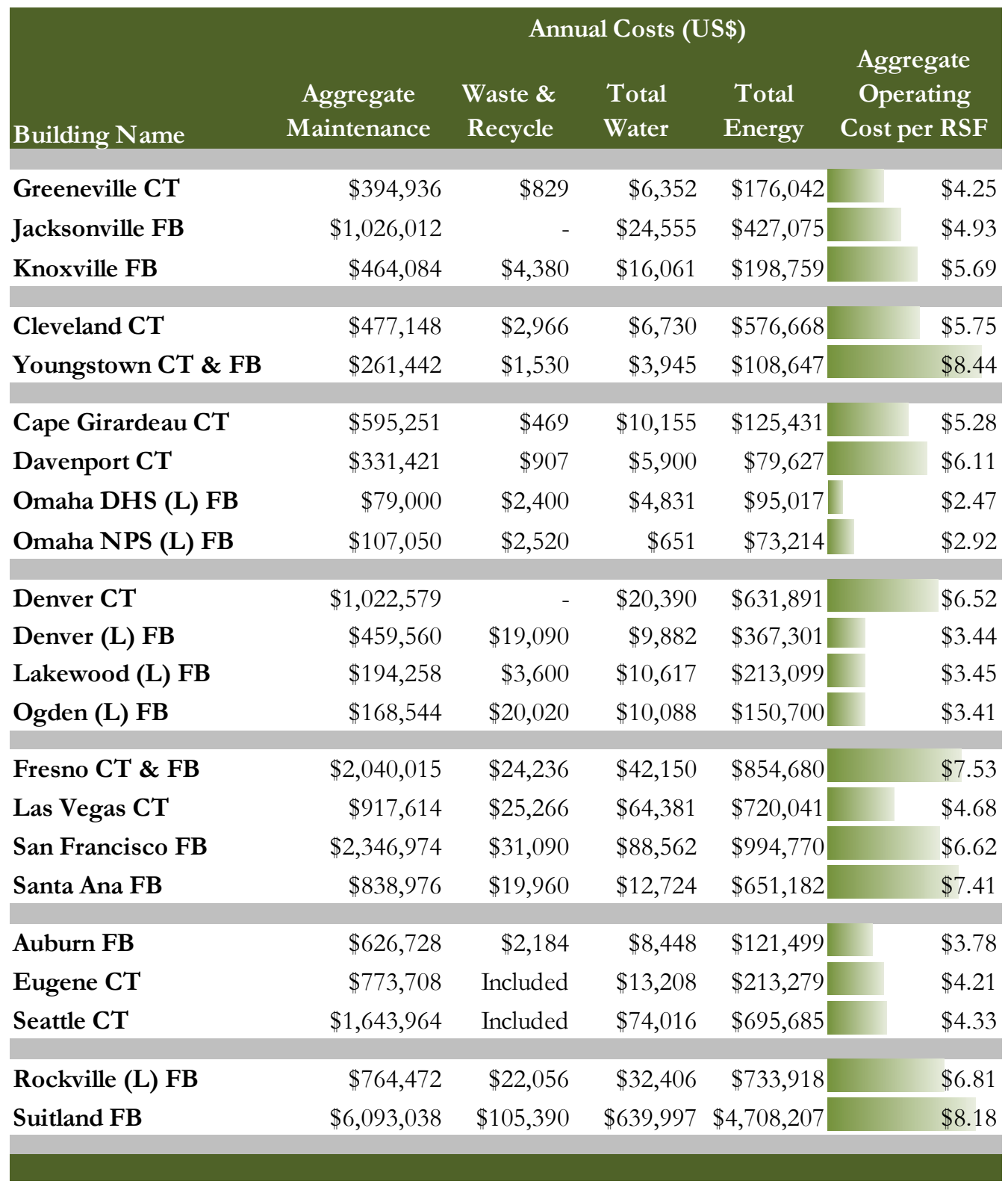


The summary of annual data for each of the performance metrics is provided in Table 25. The data represent 1 year of measurements and are not associated with any specific design features or strategies. Where available, multiple years of data were examined and there were minimal significant differences between the years. Individually focused post occupancy evaluation (POEs) would allow for more detailed analysis of the buildings. Examining building performance over multiple years could potentially offer a useful diagnostic tool for identifying building operations that are in need of operational changes. Investigating what the connection is between the building performance and the design intent would offer potential design guidance and possible insight into building operation strategies.

Table 25. Summary values for each performance metric

\begin{tabular}{|c|c|c|c|c|c|c|c|}
\hline Building Name & GSF & $\begin{array}{l}\text { Energy } \\
\text { Star }{ }^{\circledR} \\
\text { Score }\end{array}$ & $\begin{array}{c}\text { Total } \\
\text { Water } \\
(1000 \text { gal })\end{array}$ & $\begin{array}{l}\text { Aggregate } \\
\text { Maintenance } \\
\text { Cost }\end{array}$ & $\begin{array}{l}\text { Waste } \\
\text { Cost }\end{array}$ & $\begin{array}{c}\text { General } \\
\text { B1dg \% } \\
\text { Satisfaction }\end{array}$ & $\begin{array}{l}\text { Metric Tons of } \\
\mathrm{CO}_{2} \text { equiv/Occ }\end{array}$ \\
\hline Greeneville CT & 160,975 & 90 & 1,376 & $\$ 394,936$ & $\$ 900$ & $98 \%$ & 14.8 \\
\hline Jacksonville FB & 338,008 & 82 & 4,008 & $\$ 1,026,012$ & $\mathrm{~N} / \mathrm{A}$ & $59 \%$ & 3.8 \\
\hline Knoxville FB & 172,684 & 90 & 2,252 & $\$ 464,084$ & $\$ 4,380$ & $89 \%$ & 6.8 \\
\hline Cleveland CT & 251,314 & 69 & 450 & $\$ 477,148$ & $\$ 3,067$ & $89 \%$ & 20.2 \\
\hline Youngstown CT \& FB & 52,240 & 50 & 419 & $\$ 261,442$ & $\$ 1,530$ & $70 \%$ & 4.4 \\
\hline Cape Girardeau CT & 173,392 & 64 & 385 & $\$ 595,251$ & $\$ 325$ & $92 \%$ & 25.1 \\
\hline Davenport CT & 79,872 & 80 & 530 & $\$ 331,421$ & $\$ 907$ & $89 \%$ & 16.1 \\
\hline Omaha DHS (L) FB & 86,000 & 74 & 2,252 & $\$ 79,000$ & $\$ 2,400$ & $100 \%$ & 5.4 \\
\hline Omaha NPS (L) FB & 68,000 & 82 & 239 & $\$ 107,050$ & $\$ 1,500$ & $81 \%$ & 7.5 \\
\hline Denver CT & 327,103 & 70 & 4,649 & $\$ 1,022,579$ & $\mathrm{~N} / \mathrm{A}$ & $74 \%$ & 12.7 \\
\hline Denver (L) FB & 301,292 & 94 & 3,970 & $\$ 459,560$ & $\$ 15,862$ & $72 \%$ & 4.7 \\
\hline Lakewood (L) FB & 128,342 & 84 & 2,928 & $\$ 194,258$ & $\$ 3,600$ & $82 \%$ & 6.9 \\
\hline Ogden (L) FB & 105,000 & 83 & 3,619 & $\$ 168,544$ & $\$ 3,940$ & $72 \%$ & 3.7 \\
\hline Fresno CT \& FB & 495,914 & 87 & 11,345 & $\$ 2,040,015$ & $\$ 24,236$ & $92 \%$ & 7.0 \\
\hline Las Vegas CT & 454,877 & 77 & 10,413 & $\$ 917,614$ & $\$ 25,266$ & $74 \%$ & 11.9 \\
\hline San Francisco FB & 652,433 & 96 & 5,675 & $\$ 2,346,974$ & $\$ 31,970$ & $48 \%$ & 2.6 \\
\hline Santa Ana FB & 280,365 & 91 & 2,218 & $\$ 838,976$ & $\$ 18,360$ & $72 \%$ & 4.6 \\
\hline Auburn FB & 205,354 & 96 & - & $\$ 626,728$ & $\$ 2,184$ & $67 \%$ & 2.8 \\
\hline Eugene CT & 270,322 & 92 & 2,032 & $\$ 773,708$ & Induded & $64 \%$ & 8.3 \\
\hline Seattle CT & 658,392 & 85 & 4,973 & $\$ 1,643,964$ & Induded & $70 \%$ & $\mathrm{~N} / \mathrm{A}$ \\
\hline Rockville (L) FB & 232,000 & 80 & 2,680 & $\$ 764,472$ & $\$ 22,056$ & $75 \%$ & 4.7 \\
\hline Suitland FB & $2,340,988$ & 91 & 56,110 & $\$ 6,093,038$ & $\$ 107,871$ & $52 \%$ & 6.0 \\
\hline
\end{tabular}


The "aggregate operating cost" metric used in this study represents the costs that were available for developing a comparative industry baseline for office buildings. The costs include water utilities, energy utilities, general maintenance, grounds maintenance, waste and recycling, and janitorial costs. Three of the buildings that cost more than the baseline in Figure 45 have higher maintenance costs than the baseline, and one has higher energy costs.

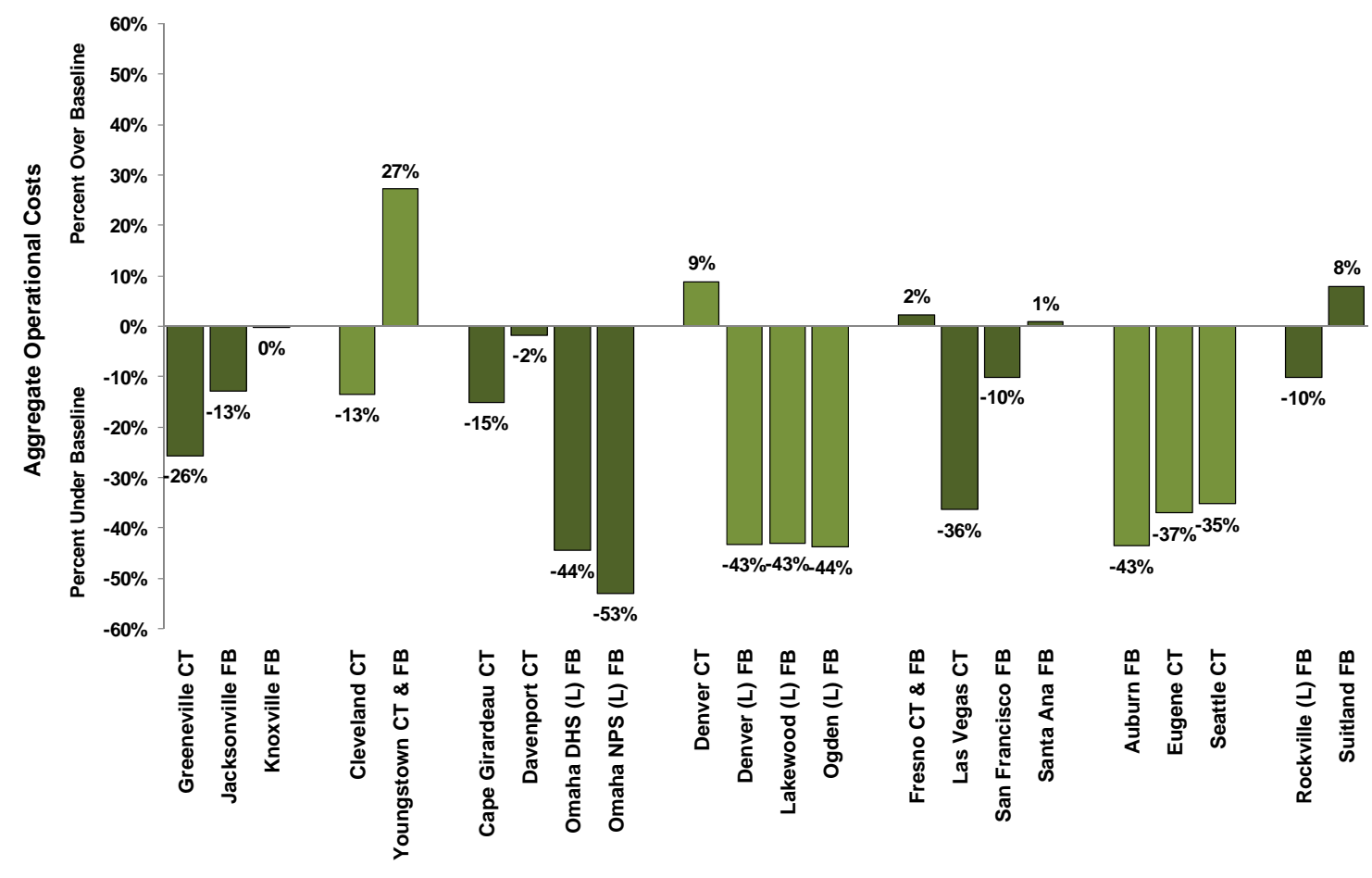

Figure 45. Aggregate operational costs compared to the baseline 
Given the volume of data collected and analyzed for this study, the inevitable request is for a simple answer with respect to sustainably designed building performance. As previously stated, compiling the individual building values into single metrics is not statistically valid given the small number of buildings, but it has been done to provide a cursory view of this portfolio of sustainably designed buildings (Table 26). For all metrics except recycling cost per rentable square foot and CBE survey response rate, the averaged building performance was better than the baseline for the GSA buildings in this study.

Table 26. Summary performance for study buildings portfolio

\begin{tabular}{|c|c|c|}
\hline Metric Description & Performance & Performance Description \\
\hline Water Use & $-11 \%$ & $\begin{array}{l}\text { Average WUI (13.3 gallons/gsf) as compared to IFMA Industry average (15 } \\
\text { gallons/gsf) }\end{array}$ \\
\hline Energy Use & $-25 \%$ & Average EUI (66 kBtu/gsf) as compared to CBECS office $(88 \mathrm{kBtu} / \mathrm{gsf})$ \\
\hline Aggregate Operations Cost & $-19 \%$ & $\begin{array}{l}\text { Average percent better than baseline for Water, Energy, Maintenance, Janitoral, } \\
\text { Grounds, Waste, and Recycling costs per RSF as compared to BOMA industry } \\
\text { baselines }\end{array}$ \\
\hline Aggregate Maintenance Cost & $-12 \%$ & $\begin{array}{l}\text { Average General, Janitorial and Grounds Maintenance Cost per RSF as } \\
\text { compared to GSA adapted industry baselines for General and Janitorial, and } \\
\text { BOMA for Grounds }\end{array}$ \\
\hline $\mathrm{CO} 2$ Buildings + Transportation & $-34 \%$ & $\begin{array}{l}\text { Calculated } \mathrm{CO}_{2} \text { for each building as compared to Energy Star Baseline and } \\
\text { emissions for the occupant commute as compared to EPA commute emissions } \\
\text { baseline }\end{array}$ \\
\hline Occupant Satisfaction & $-27 \%$ & $\begin{array}{l}\text { Average SPOT survey score (1.43) as compared to CBE Database average (1.13) } \\
\text { for General Building Satisfaction }\end{array}$ \\
\hline Average Survey Response Rate & $47 \%$ & Average SPOT response rate \\
\hline Water Cost & $-46 \%$ & Average Water Cost per RSF ( $\$ 0.10)$ as compared to BOMA baseline $(\$ 0.19)$ \\
\hline Energy Cost & $-28 \%$ & Average Energy Cost per RSF ( $\$ 1.82)$ as compared to BOMA baseline ( $\$ 2.53)$ \\
\hline General Maintenance Cost & $-2 \%$ & $\begin{array}{l}\text { Average General Maintenance Cost per RSF as compared to GSA Adapted } \\
\text { BOMA industry averages }\end{array}$ \\
\hline Janitorial Maintenance Cost & $-2 \%$ & $\begin{array}{l}\text { Average Janitorial Maintenance Cost per RSF as compared to GSA Adapted } \\
\text { BOMA industry averages }\end{array}$ \\
\hline Grounds Maintenance Cost & $-69 \%$ & $\begin{array}{l}\text { Average Grounds Maintenance Cost per RSF (\$0.14) as compared to BOMA } \\
\text { high average }(\$ 0.45)\end{array}$ \\
\hline Waste Disposal Cost & $-15 \%$ & $\begin{array}{l}\text { Average Waste Disposal Cost per RSF as compared to BOMA industry average } \\
\text { for Offices }\end{array}$ \\
\hline Recycling Cost & $17 \%$ & $\begin{array}{l}\text { Average Recycling Cost per RSF as compared to BOMA industry average for } \\
\text { Offices }\end{array}$ \\
\hline CO2 Building & $-36 \%$ & Average $\mathrm{CO}_{2}$ difference from Energy Star building baseline \\
\hline CO2 Transportation & $-29 \%$ & $\begin{array}{l}\text { Average } \mathrm{CO}_{2} \text { difference from EPA and Department of Transportation calucated } \\
\text { baseline }\end{array}$ \\
\hline
\end{tabular}




\section{Observations}

Whole building performance measurement involves the analysis of the interaction between different metrics. Many comparisons can be made between energy, water, maintenance, and occupant satisfaction. Additional comparisons could include waste generation and commute data, but for those metrics no significant findings were evident.

Based on the LEED credits and Energy Star ratings, it was observed that when projects had incorporated sustainable design principles from the start and had included energy savings goals, the overall performance of the building was better than the industry standard. Additionally, the LEED Gold buildings performed consistently well in each metric (Figure 46).

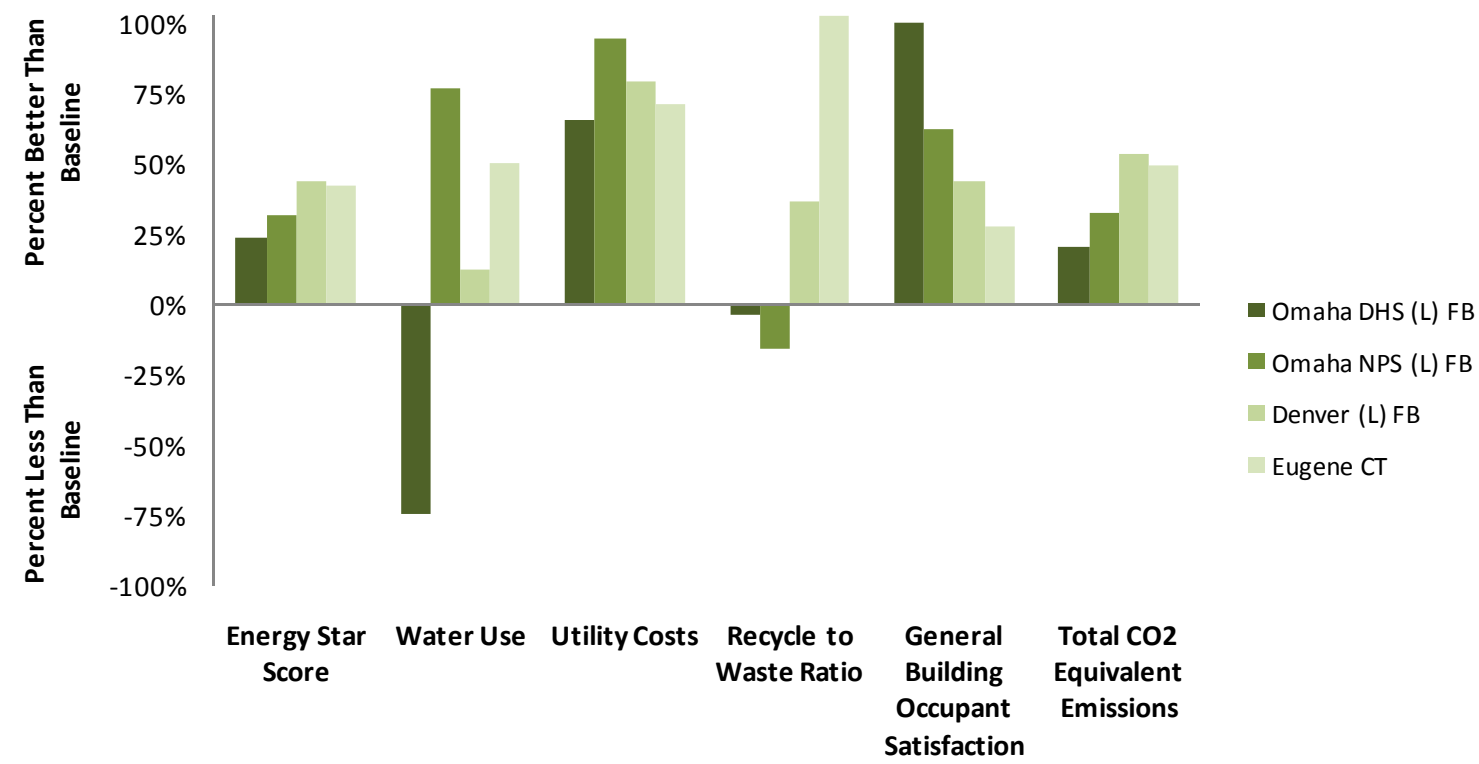

Figure 46. LEED Gold building baseline comparisons 
Looking at the detailed SPOT survey results we have already discussed how almost all of the buildings have better than average thermal satisfaction and all of the buildings' energy performance were at or above the baseline. Figure 47 shows that the building with the lowest thermal comfort satisfaction is the one with the lowest EUI and with maintenance costs more than $50 \%$ greater than the baseline. This quad chart also shows the two least expensive buildings to

The next set of figures is referred to as "quad charts." Performance better than the baseline by the metrics on the $\mathrm{x}$ and $y$ axis are placed to the right and above the baseline lines, that is, the top right quadrant. The color of the dot represents the aggregate maintenance cost. maintain are in the top quadrant.

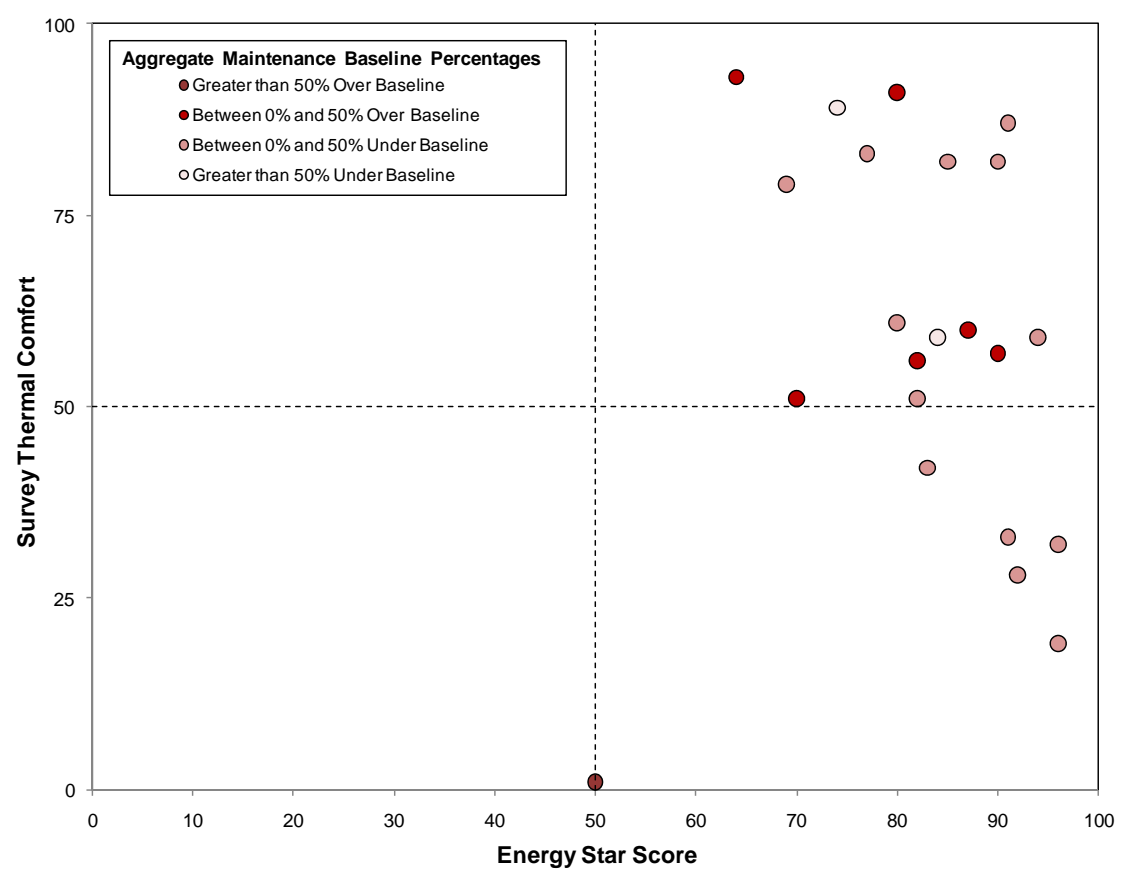

Figure 47. Thermal comfort compared to Energy Star Score and maintenance costs 
All of the buildings had lighting satisfaction survey responses above zero, meaning the occupants were satisfied with the lighting. However, as mentioned previously, when the lighting satisfaction levels were compared to the CBE database baseline responses, more than half of the buildings are below the $50^{\text {th }}$ percentile. There does not appear to be a correlation between the Energy Star Portfolio Manager scores and the lighting satisfaction levels, but it does appear that buildings that had lower maintenance costs were less satisfied with the lighting (Figure 48).

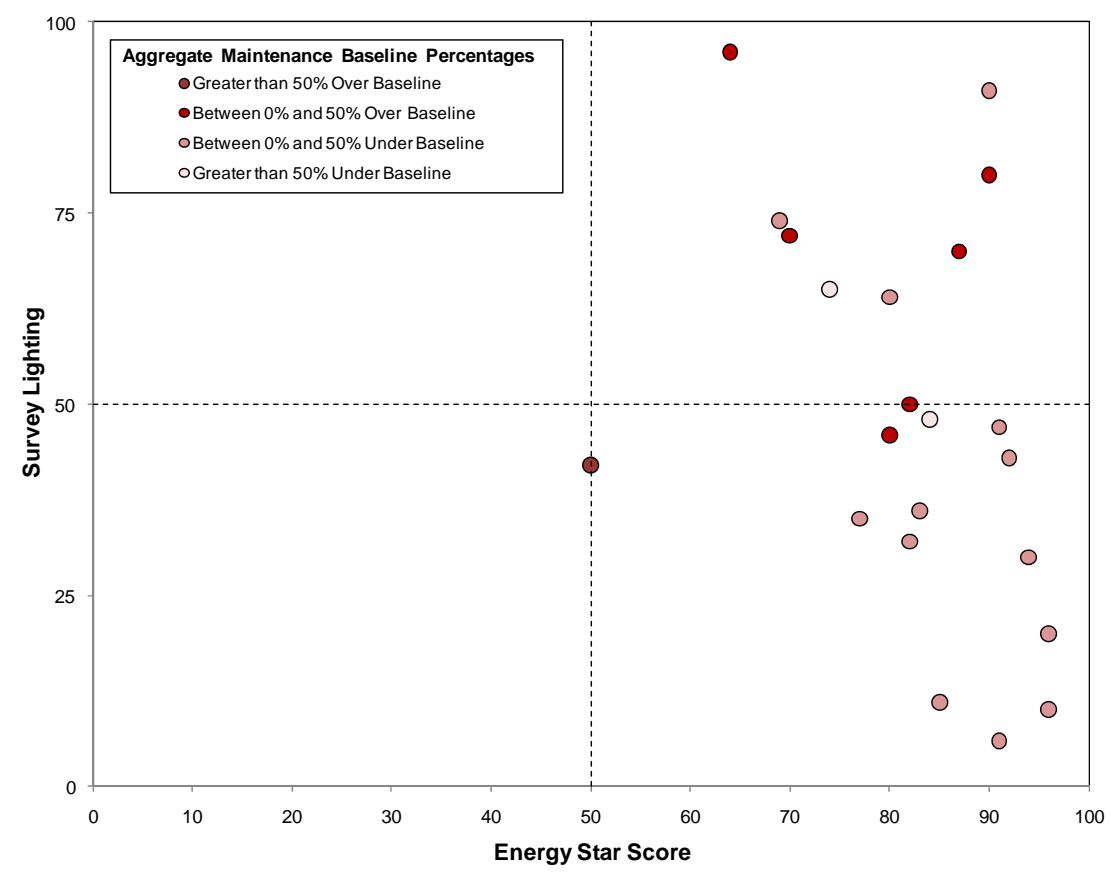

Figure 48. Lighting satisfaction percentile compared to Energy Star score and maintenance costs 
Figure 49 offers a summary representation of the energy, water, occupant satisfaction, and aggregate maintenance costs for each of the buildings investigated. All of the Energy Star Portfolio Manager values were better than the baseline typical building, two-thirds of the water use intensity (WUI, gallons/occupant) values were better than or at the baseline, all of the occupant satisfaction scores were higher than the $50^{\text {th }}$ percentile, and more than half of the buildings have aggregate maintenance costs that are below the baseline.

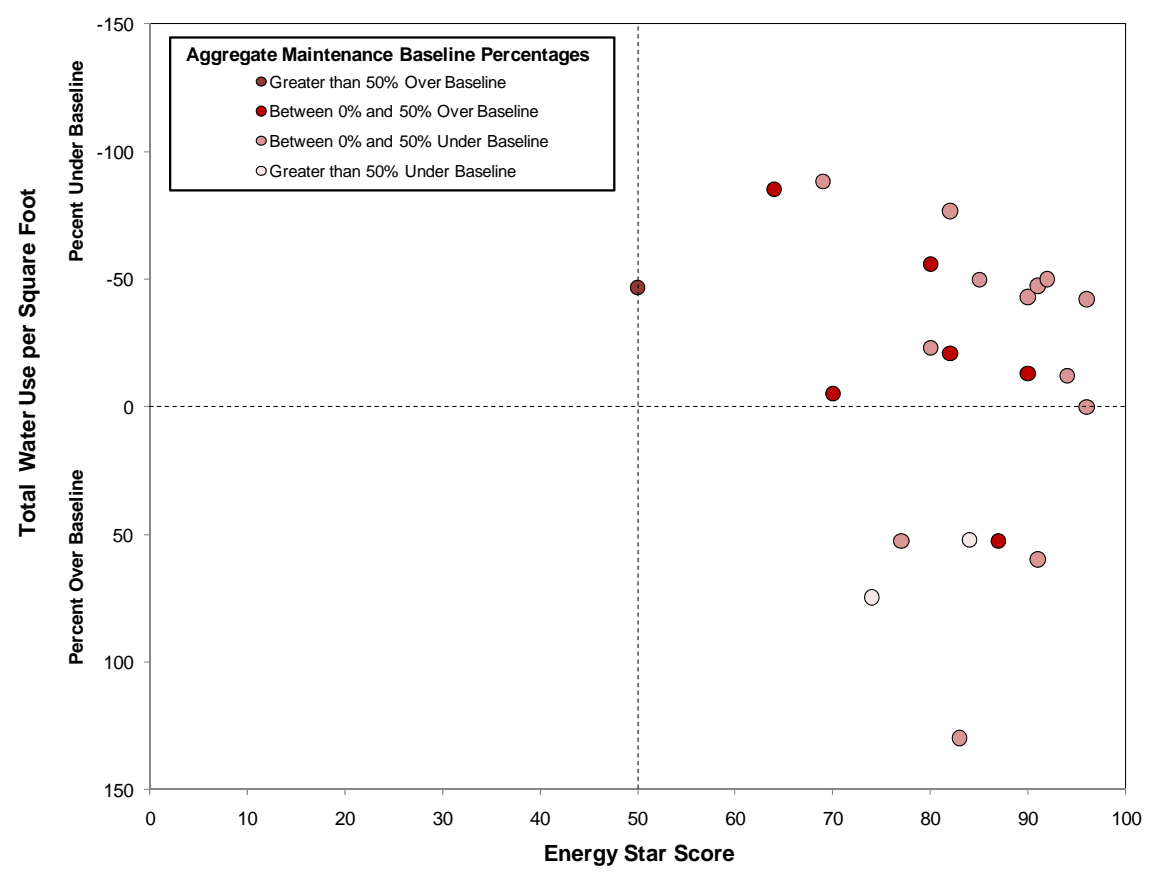

Figure 49. WUI compared to Energy Star Score and aggregate maintenance costs 


\section{Lessons Learned and Future Research Opportunities}

This study includes almost half of GSA's LEED buildings. Although this is a respectable representation of the buildings that have been officially identified as being sustainably designed, the sample size is small, so it does not lend itself to broader inferences for the entire GSA building stock. Nevertheless, the lessons learned may be helpful for future design, construction, and operation of GSA buildings. Measuring the performance of more buildings will allow for a greater understanding of how sustainably designed buildings perform as a group. Based on the data collection and analysis experiences the following includes future research opportunities and observations of the current data set.

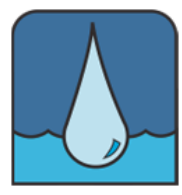

A detailed investigation into the water use for each building is needed to determine, with any confidence, an accurate understanding of water use within sustainably designed buildings. Design estimates focus on bathroom and kitchenette fixture specifications. How much water building occupants actually use is not well understood. Plus, many buildings use water for irrigation, process water, food service, and other activities without separately metering the water use. The impact of that "other" water use is also not well understood.

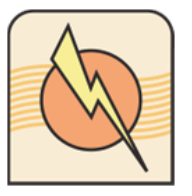

Energy use and cost are the metric that is most easily and commonly examined in a more detailed fashion. Sub-metered energy use data can provide insights into what aspects of the building operations are impacting energy use most significantly. In many buildings, the miscellaneous electric load is a significant portion of the energy use, but is not well understood since it is driven by the occupants. Large electric loads associated with computing equipment, in the form of small data centers, are a growing portion of building energy use. Additional data collection and research related to the miscellaneous electric load in buildings would identify potential opportunities for conservation and efficiency.

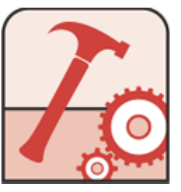

Operations and maintenance data are being tracked by more building managers, but the quality of the data varies by building. Additionally, there is no consistent level of detail collected at each building because of the flexibility of the tracking systems. This variability of data makes comparisons between buildings a challenge. Inferences from the regular maintenance and preventative maintenance ratio should be considered speculative unless the more consistent data and details are provided by all of the buildings for each metric. The ability to collect consistent data from each site is critical for building-to-building comparisons to industry baselines and for building to building comparisons.

Employer or community programs for recycling and occupant commute may impact the performance values of these metrics. Therefore, ideally, employer and community programs would be accounted for in the analysis. Additionally, the availability and cost of recycling programs and mass transit within a specific 
community have an impact on the occupants' willingness and ability to use those services. A consistent mechanism for comparing sanitary waste, recycling, and mass transit is needed.

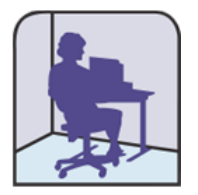

When there are occupancy changes and/or unplanned uses of the buildings, the impact on building performance needs to be accounted when conducting a detailed performance measurement analysis. Additionally, a better understanding of response rate expectations is needed, especially given CBE's goal of a $50 \%$ response rate and the study's inability to meet that goal for many of its buildings. Many of the buildings in the study that had low response rates also had very high building occupancy. Survey response rate research data could not be found to define acceptable response rates or number of responses on a given survey.

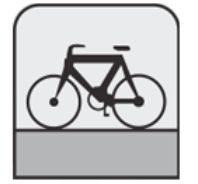

Currently the transportation metric involves the calculation of $\mathrm{CO}_{2}$ equivalent emissions based on building occupant responses to a survey regarding their daily commute. Although a survey is the method being used by national and internal greenhouse gas emission calculators, additional techniques might offer a better understanding as to why building occupants choose one mode of transportation over another. As mentioned above, different municipalities and employers have different resources and cultures related to occupant commute that could impact occupant choices.

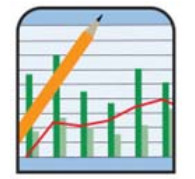

One of the more important lessons learned with respect to whole building performance measurement and assessment is that the baselines selected for performance comparison are what define the study findings. When agency specific baselines are available they offer a comparison of how a building meets an agency's expectations, but they make the assessment results less comparable to the general building industry. Ideally performance measurement data should be compared to other measured building performance data. Comparing measured values to modeled or estimated values does not offer a valid comparison, and should be avoided whenever possible. For this study GSA baselines were used whenever they were made available, however, industry baselines are also provided in order to offer another basis for comparison.

In addition to the baselines needing consistency to make the performance measurement and assessment data useful, the buildings being studied need to be working properly to be representative of sustainably designed building performance. If a building is not operating well because it has not been properly commissioned, has had an equipment failure, or occupancy settings have not been optimized, it is not useful to include in a portfolio analysis of sustainably designed buildings. In the case of a building that is not working properly, it would be difficult to parse out what aspect of the performance data is related to the design rather than the insufficient operations, and it would be more effective to perform a detailed post occupancy evaluation to identify where changes could be made in the building to improve building performance. 
A more detailed study of individual buildings could be used to determine which design features offer the best value. This type of investigation may be able to show the difference between early design expectations, as-built expectations, and operations. For example, with energy, compare design modeled data, number of LEED credits received, measured energy data, and Energy Star score. Additionally, multiple years of data would be useful in understanding whether the performance will be maintained or if it was a 'good' or 'bad' year for the building.

The snapshot view of these sustainably designed buildings provides a valuable picture of the overall performance. Continued work to assess more buildings and to include multiple years of whole building performance data could improve the accuracy and depth of this assessment. Of course, individual buildings had higher and lower performance in various metrics, as the performance of every building whether sustainably designed or typically designed depends on many factors, especially the building occupants. Nonetheless, as a portfolio of buildings, the average performance of the buildings in this study was better than the GSA and industry baselines for almost all of the performance metrics. 


\section{Appendix A: Site Summaries}

Data were collected and site visits were performed for twenty-five buildings under the scope of this study. The site summaries in this appendix provide an overview for each building and offer site-specific observations. Each site summary includes the following

- building photo

- general building description

- table listing building and site characteristics data

- certification information

- operation costs compared to baseline costs

- occupant satisfaction survey summary results

- table summarizing building performance data.

The site summaries are presented in the following order

\begin{tabular}{|c|c|c|}
\hline Building Type & Building Full Name & Abbreviation \\
\hline \multicolumn{3}{|l|}{ Region 4} \\
\hline Courthouse & James H. Quillen U.S. Courthouse & "Greeneville CT \\
\hline Federal Building & Chas. E. Bennett Federal Building & Jacksonville FB \\
\hline Federal Building & John J. Duncan Federal Building & Knoxville FB \\
\hline \multicolumn{3}{|l|}{ Region 5} \\
\hline Courthouse & Howard M. Metzenbaum U.S. Courthouse & Cleveland CT \\
\hline Courthouse \& Federal Building & Nathaniel R. Jones Federal Building and U.S. Courthouse & Youngstown CT \& FB \\
\hline \multicolumn{3}{|l|}{ Region 6} \\
\hline Courthouse & Rush H. Limbaugh U.S. Courthouse & Cape Girardeau CT \\
\hline Courthouse & Davenport U.S. Courthouse & Davenport CT \\
\hline Federal Building & DHS Citizenship \& Immigration Services & Omaha DHS (L) FB \\
\hline Federal Building & Carl T. Curtis NPS Midwest Regional Headquarters & Omaha NPS (L) FB \\
\hline \multicolumn{3}{|l|}{ Region 8} \\
\hline Courthouse & Alfred A. Arraj U.S. Courthouse & Denver CT \\
\hline Federal Building & EPA Region 8 Headquarters & Denver (L) FB \\
\hline Federal Building & DOT Colorado Field Office & Lakewood (L) FB \\
\hline Federal Building & Scowcroft IRS Utah Field Office & Ogden (L) FB \\
\hline \multicolumn{3}{|l|}{ Region 9} \\
\hline Courthouse \& Federal Building & "Robert E. Coyle U.S. Courthouse and Federal Building & Fresno CT \& FB \\
\hline Courthouse & Lloyd D. George U.S. Courthouse & Las Vegas CT \\
\hline Federal Building & San Francisco Federal Building & San Francisco FB \\
\hline Federal Building & Santa Ana Federal Building & Santa Ana FB \\
\hline \multicolumn{3}{|l|}{ Region 10} \\
\hline Federal Building & " Auburn SSA Teleservice Center & "Auburn FB \\
\hline Courthouse & Wayne L. Morse U.S. Courthouse & Eugene CT \\
\hline Courthouse & New Seattle U.S. Courthouse & Seattle CT \\
\hline \multicolumn{3}{|l|}{ Region 11} \\
\hline Federal Building & " SAMSHA Metropolitan Service Center & Rockville (L) FB \\
\hline Federal Building & Census Bureau Office Complex & Suitland FB \\
\hline
\end{tabular}

The table above shows both the official building name and the name used within the body of this report, which includes building location and type. In this appendix, each site 
summary is titled using the same name as the body of the report and then the official building name is used throughout the text so that the site is recognizable to those who occupy each building.

The research team derived the majority of the information summarized in this appendix from site or other General Services Administration (GSA) contacts and databases. For each site, the general building characteristics are summarized in the first table, and the operational data are summarized in the final table.

The costs associated with whole building performance are represented as a percentage above or below the baseline for each metric. The baseline is the industry standard for each metric's cost per square foot. The aggregate operational cost compares the summation of the building's costs to the aggregate baseline costs. "Below the baseline" suggests it costs less to operate the building than the industry standard. The different colors for different buildings are the same colors used in the body of the report.

GSA representatives modified the University of California Berkeley's Center for the Built Environment's (CBE's) occupant satisfaction survey to address the occupant commute questions and GSA specific interests. The survey for this study was called the GSA Sustainable Places and Organizational Trends (SPOT) survey. GSA representatives distributed the survey to building occupants electronically, providing an internet link, and provided a hard copy of the SPOT survey at a few of the buildings where electronic distribution was not available to all occupants. GSA representatives manually entered the hard copy SPOT survey responses into the CBE database so that a summary report could be generated.

The SPOT survey questions offer a numerical response of between -3 and 3. CBE prepares building-specific survey summary reports. These reports provide the average scores for each of the key elements addressed in the survey. In this appendix, the average scores for each key element are provided. 


\section{Greeneville Courthouse}

\section{Description}

The James H. Quillen U.S. Courthouse was completed in 2001 and received Energy Star recognition in 2007. The Quillen Courthouse replaced a smaller, historic courthouse, from which the occupants reclaimed the quality furniture. Some of the energy-efficiency features in

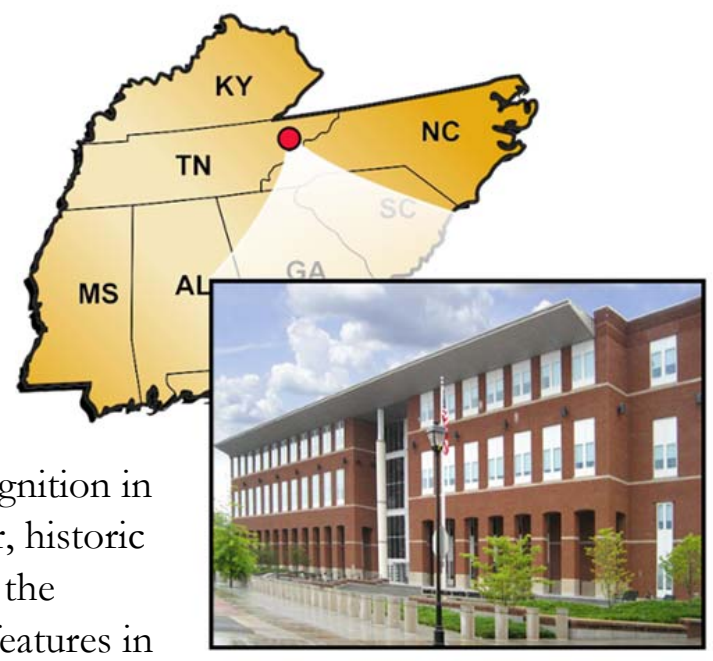
the building include use a well-insulated white roof, and Energy Management Control System (EMCS) control of lighting and occupancy sensors. During the site visit, researchers noticed that occupants had their office lights turned off if they had sufficient daylight from a window.

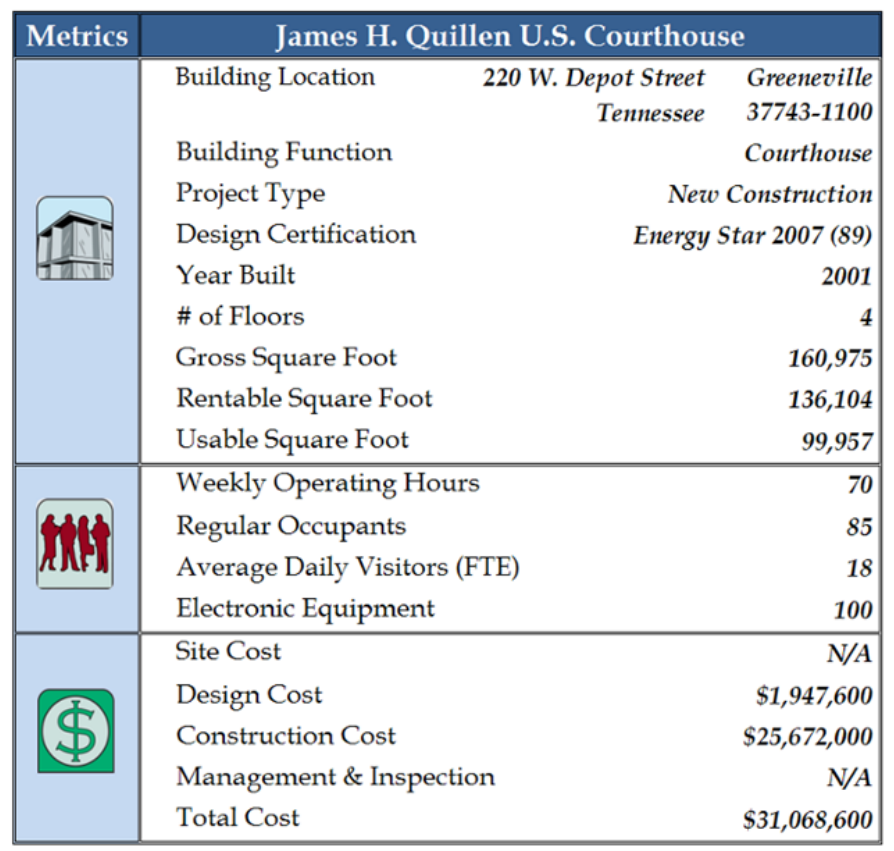

The landscape includes a large grassy area. Some green cleaning products are being used, but not all products would have been considered "green." The building has auto-flush toilets, but the building engineer wants them removed because of the maintenance challenges of this technology.

The building houses four courtrooms and sees a significant fluctuation in visitors depending on the need for those courtrooms.

Each building in the study had operational highlights and potential opportunities for improvement. Although it was not the focus of this study to investigate and/or document operational highlights and opportunities, the research team observed:

- Consider pursuing LEED for Existing Buildings Certification. 


\section{Certifications}

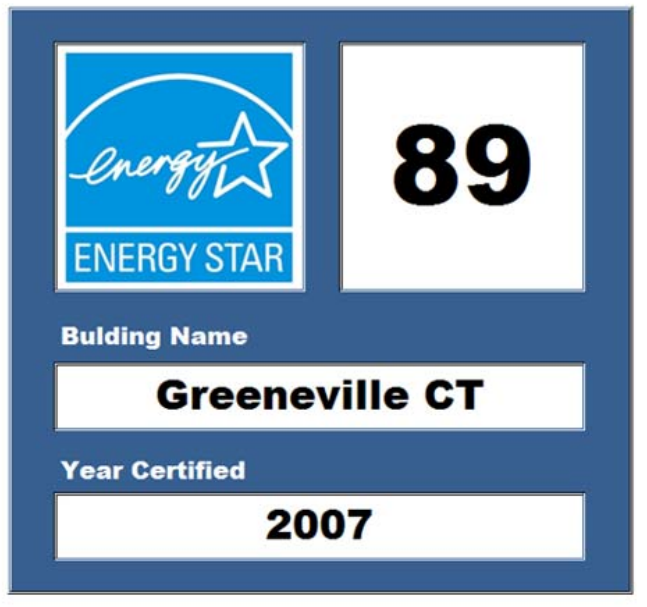

\section{Whole Building Performance}

The Quillen Courthouse operating costs are lower than the industry baseline for water, energy, general maintenance, grounds maintenance, waste, and recycling costs. The janitorial costs are higher than the industry baseline. Overall, the building costs less to operate than a baseline building.

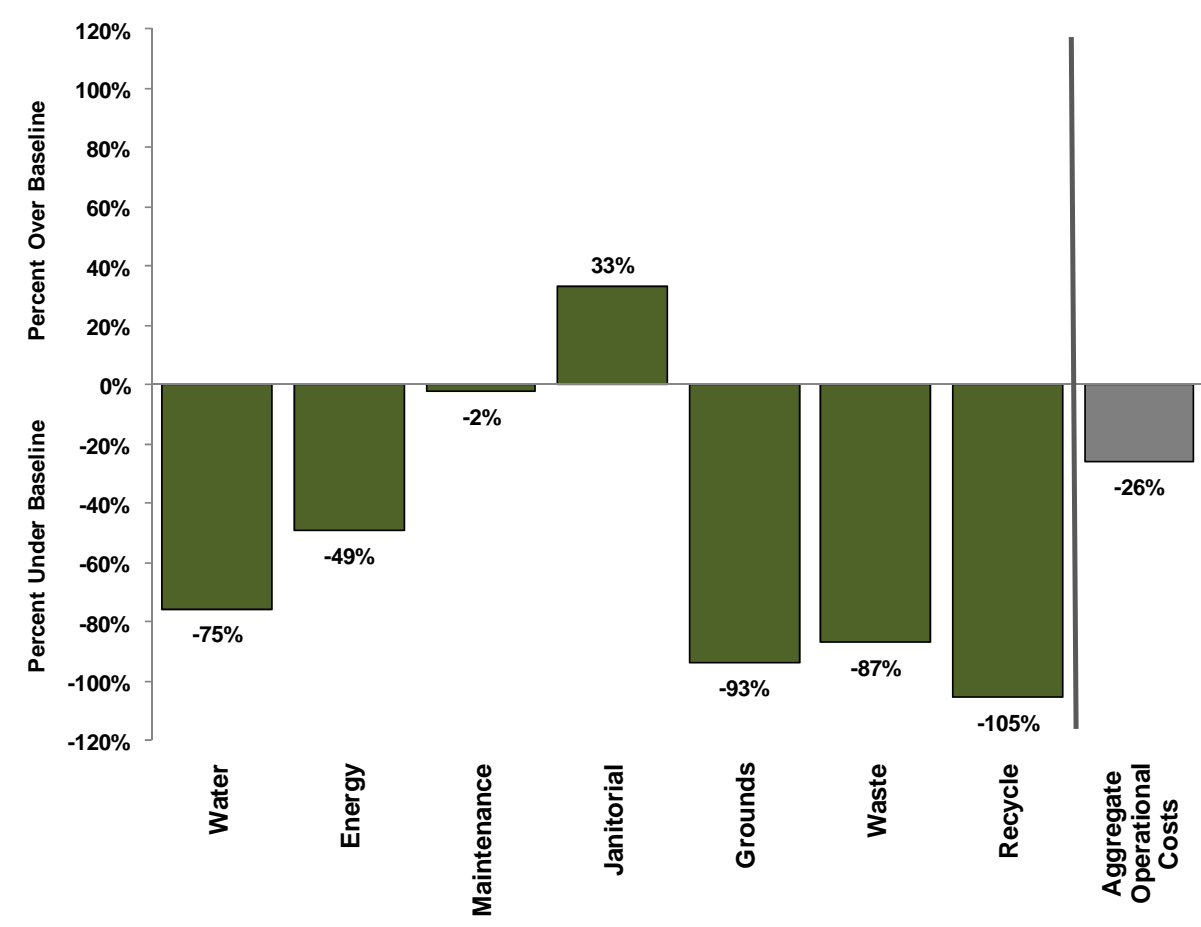




\section{Occupant Satisfaction Survey}

All 85 of the Quillen Courthouse occupants were surveyed and 54 responded. In addition to the electronic survey, GSA representatives issued the survey in hardcopy form as many staff did not have electronic access to the survey.

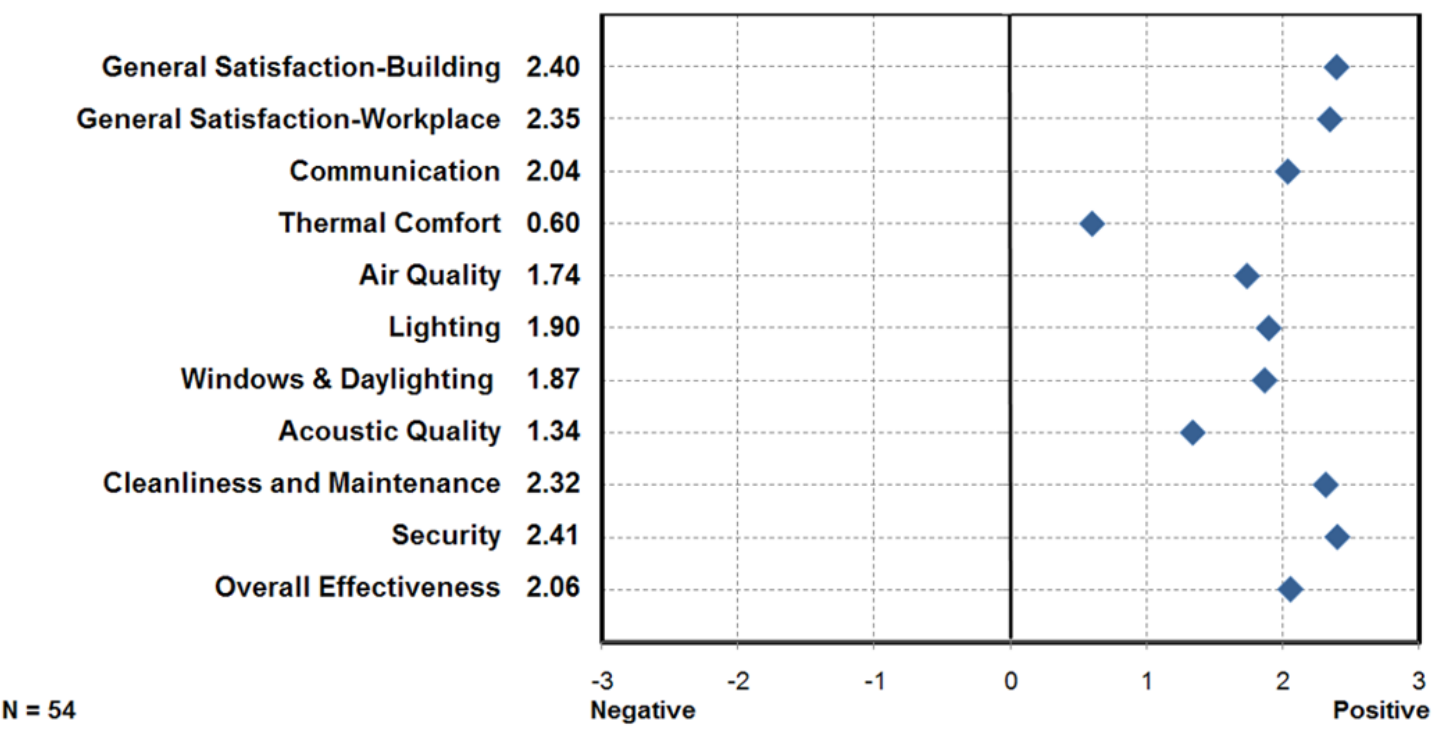

The results indicated that occupants of the Quillen Courthouse are significantly more satisfied with their building than occupants in the CBE baseline $\left(98^{\text {th }}\right.$ percentile), with the highest occupant satisfaction score for all of the buildings in the study. The Quillen Courthouse also had some of the highest occupant satisfaction scores in the study for acoustic quality, air quality, cleanliness and maintenance, and lighting. Thermal comfort was the lowest scored occupancy metric, yet it scored in the $82^{\text {th }}$ percentile when compared to the $\mathrm{CBE}$ building database.

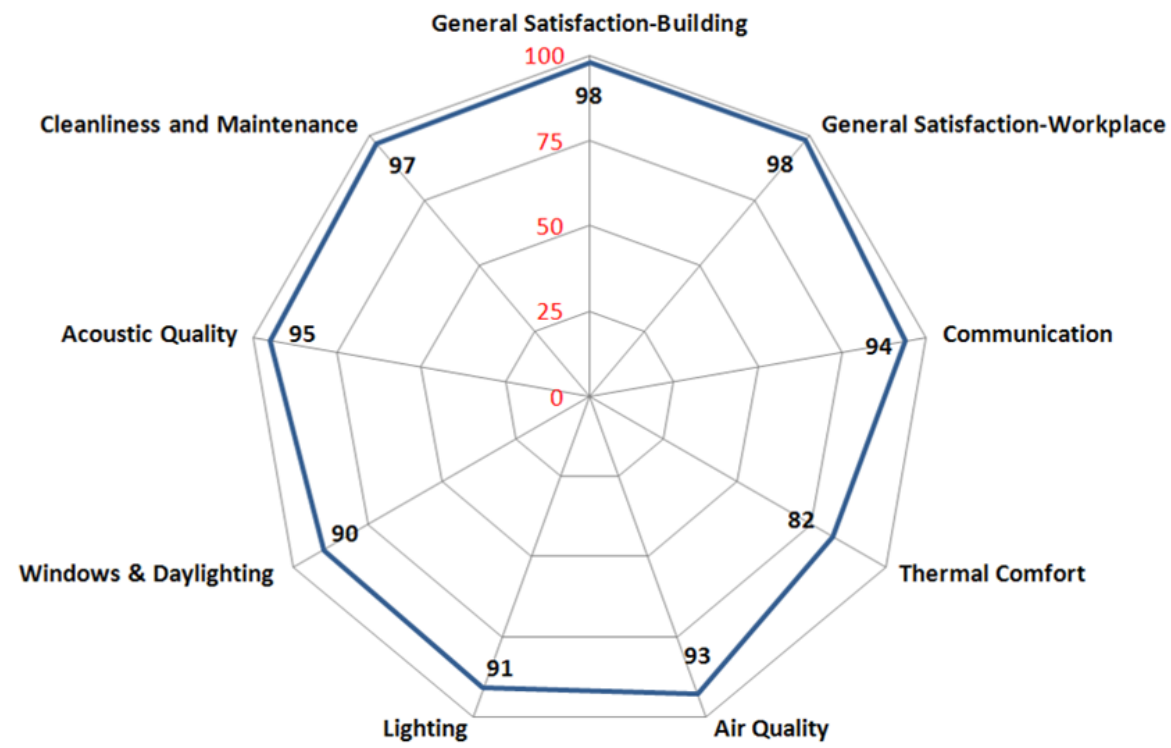




\section{Performance Data Summary}

The research team collected, normalized, and compared whole building performance data for the Quillen Courthouse to industry baselines. The following table summarizes the annual performance data collected and normalized. The facility uses water-cooled chillers for its air-conditioning system; therefore, the cooling tower water use was estimated using the "rule-of-thumb" that $27 \%$ of total water use is process water. Outdoor water use was estimated using the "rule-of-thumb" that $20 \%$ of total water use for landscaping.

\begin{tabular}{|c|c|c|c|c|}
\hline Metrics & \multicolumn{2}{|c|}{ Annual Performance Measurements } & \multicolumn{2}{|l|}{ Annual Performance Metrics } \\
\hline & Water Use (gal) & $1,376,320$ & Gallons per occupant & 7,082 \\
\hline & Process Water Use (gal) & 371,606 & Water Cost per occupant & $\$ 61.67$ \\
\hline & Outdoor Water Use (gal) & 275,264 & Gallons per GSF & 8.55 \\
\hline & Water Cost & $\$ 6,352$ & Water Cost per RSF & $\$ 0.05$ \\
\hline & Energy Star Score & 90 & \multirow{3}{*}{$\begin{array}{l}\text { Energy Use (kBTU) per GSF } \\
\text { Energy Cost per RSF } \\
\text { Building Emissions per Occupant }\left(\mathrm{MTCO}_{2} \mathrm{e}\right)\end{array}$} & 50 \\
\hline & Total Energy Use (kBtu) & $8,198,162$ & & $\$ 1.29$ \\
\hline & Energy Cost & $\$ 176,042$ & & 12.27 \\
\hline \multirow{5}{*}{10} & General Maintenance Cost & $\$ 163,419$ & \multirow{5}{*}{$\begin{array}{l}\text { General Maint Cost per RSF } \\
\text { Janitorial Services Cost per RSF } \\
\text { Grounds Maint Cost per RSF } \\
\text { Ratio of Maint Requests to Total Maint Jobs }\end{array}$} & \multirow{5}{*}{$\begin{array}{r}\$ 1.20 \\
\$ 1.67 \\
\$ 0.03 \\
0.14\end{array}$} \\
\hline & Janitorial Services Cost & $\$ 227,517$ & & \\
\hline & Grounds Maintenance Cost & $\$ 4,000$ & & \\
\hline & Quantity of Maint Requests & 180 & & \\
\hline & Quantity of Prev Maint Jobs & 1,078 & & \\
\hline \multirow{4}{*}{8} & Solid Waste Generated (tons) & 39 & \multirow{4}{*}{$\begin{array}{l}\text { Solid Waste (lb) per occupant } \\
\text { Solid Waste Cost per RSF } \\
\text { Solid Waste Cost per occupant } \\
\% \text { Recycle of Total Waste Generation }\end{array}$} & \multirow{4}{*}{$\begin{array}{r}757 \\
\$ 0.01 \\
\$ 8.74 \\
6 \% \\
\end{array}$} \\
\hline & Solid Waste Cost & $\$ 900$ & & \\
\hline & Quantity Recycled (tons) & 2.37 & & \\
\hline & Recycling Cost & $-\$ 71$ & & \\
\hline 2] & Survey \# of Respondents (n) & 54 & Survey Return Rate & $64 \%$ \\
\hline \multirow{3}{*}{ c8) } & Commute Miles per occ (avg) & 22 & \multirow{3}{*}{$\begin{array}{l}\text { Commute Emmisions per occ }\left(\mathrm{MTCO}_{2} \mathrm{e}\right) \\
\% \text { of Occupants who commute using mass } \\
\text { transit, biking and/or walking }\end{array}$} & 2.56 \\
\hline & \# of Occupants using mass transit/walk/bike & 0 & & \multirow{2}{*}{$0 \%$} \\
\hline & \# of Respondents to Commute Question & 55 & & \\
\hline
\end{tabular}




\section{J acksonville Federal Building}

\section{Description}

The Chas E. Bennett Federal Building was renovated in 2004 and received Energy Star recognition in 2007. The building was completely gutted during renovation and all of the plumbing, electrical and mechanical systems were replaced. Some of the flooring and finishes used recycled materials.

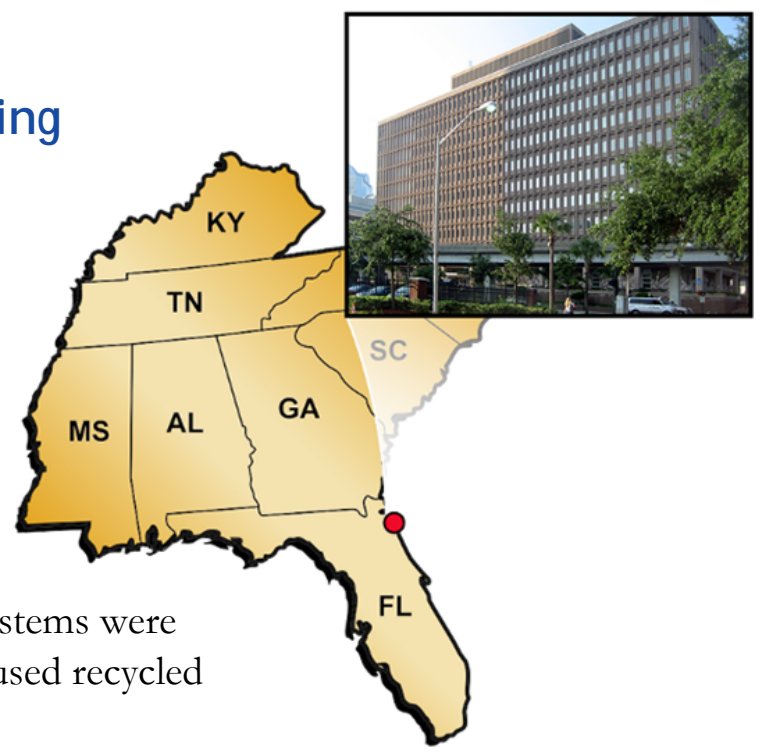

The energy use intensity has reduced by $60 \%$ from a pre-renovation energy use intensity of $120 \mathrm{kBtu} / \mathrm{SF}$. The renovation included envelope improvements including better insulation and low-E windows. A smaller "pony" chiller was added during the renovation to cool the

\begin{tabular}{|c|c|c|}
\hline \multirow{4}{*}{ Metrics } & \multicolumn{2}{|c|}{ Chas. E. Bennett Federal Building } \\
\hline & Building Location & $\begin{array}{rr}400 \text { West Bay St } & \text { Jacksonville } \\
\text { Florida } & 32202-4410\end{array}$ \\
\hline & Building Function & Federal Building \\
\hline & Project Type & Renovation \\
\hline & Design Certification & Energy Star 2007 (88) \\
\hline and & Year Built & 1967 \\
\hline & \# of Floors & 11 \\
\hline & Gross Square Foot & 338,008 \\
\hline & Rentable Square Foot & 299,941 \\
\hline & Usable Square Foot & 238,471 \\
\hline & Weekly Operating Hours & 71 \\
\hline & Regular Occupants & 1,000 \\
\hline & Average Daily Visitors (FTE & 150 \\
\hline & Electronic Equipment & 1,080 \\
\hline & Site Cost & $N / A$ \\
\hline & Design Cost & $\$ 1,930,000$ \\
\hline & Construction Cost & $\$ 25,762,323$ \\
\hline & Management \& Inspection & $\$ 1,851,000$ \\
\hline & Total Cost & $\$ 29,543,323$ \\
\hline
\end{tabular}

spaces that require conditioning and humidity control during unoccupied hours. The EMCS system utilize computerized lighting controls that operate on time clocks that align with occupants schedules and housekeeping.

The landscaping was also included in the renovation and the amount of landscaping was decreased. Moisture sensors and rain sensors were installed with the irrigation system to minimize the water use and decrease the amount of grounds maintenance needed.

The building houses training space and sees a significant fluctuation in visitors depending on the training schedule.

Each building in the study had operational highlights and potential opportunities for improvement. Although it was not the focus of this study to investigate and/or document operational highlights and opportunities, the research team observed:

- Consider pursuing LEED for Existing Buildings Certification. 


\section{Certifications}

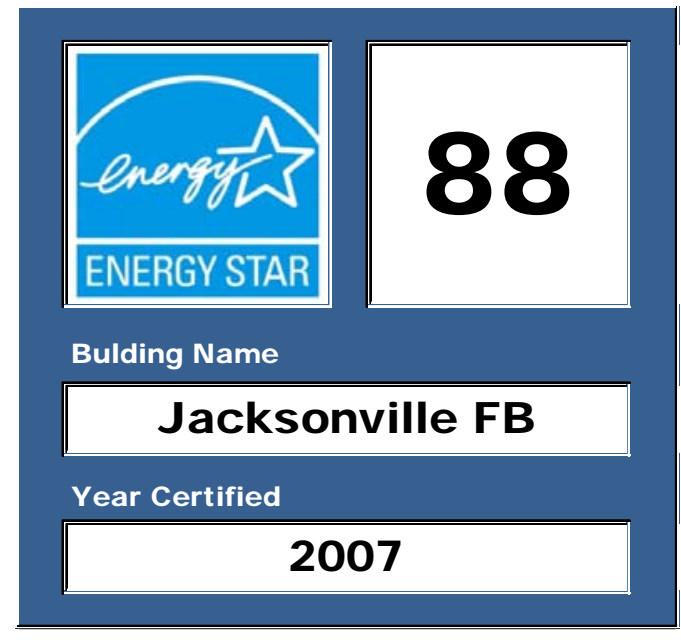

\section{Whole Building Performance}

The Bennett Federal Building operating costs are lower than the industry baseline for water, energy, and grounds maintenance. The janitorial costs are higher than the industry baseline; however the waste and recycling costs are included in the janitorial reporting and were not reported separately. The general maintenance costs are also above baseline. Overall, the building costs less to operate than a baseline building.

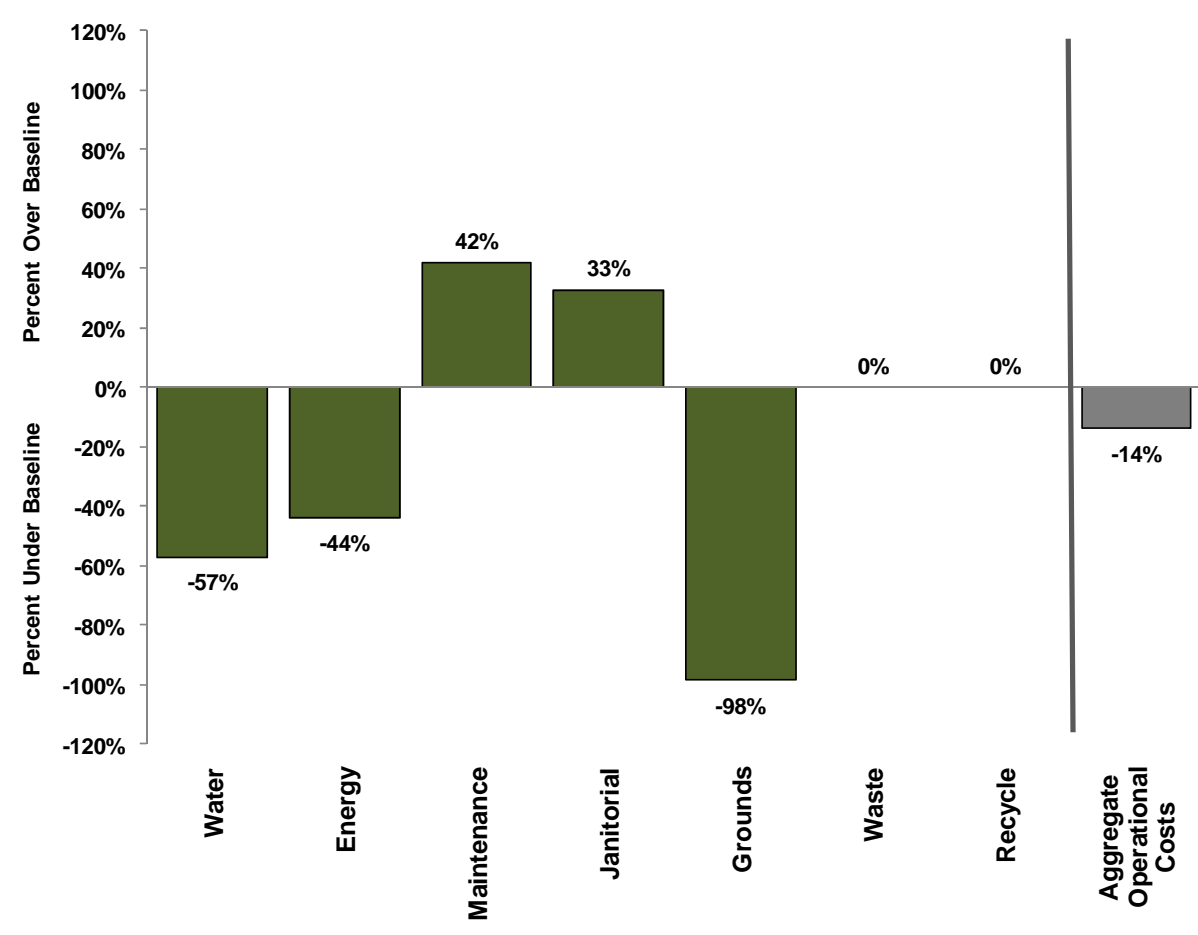




\section{Occupant Satisfaction Survey}

All 1,000 of the Bennett Federal Building occupants were surveyed and 393 responded. All of the main survey categories except acoustic quality had positive average scores.

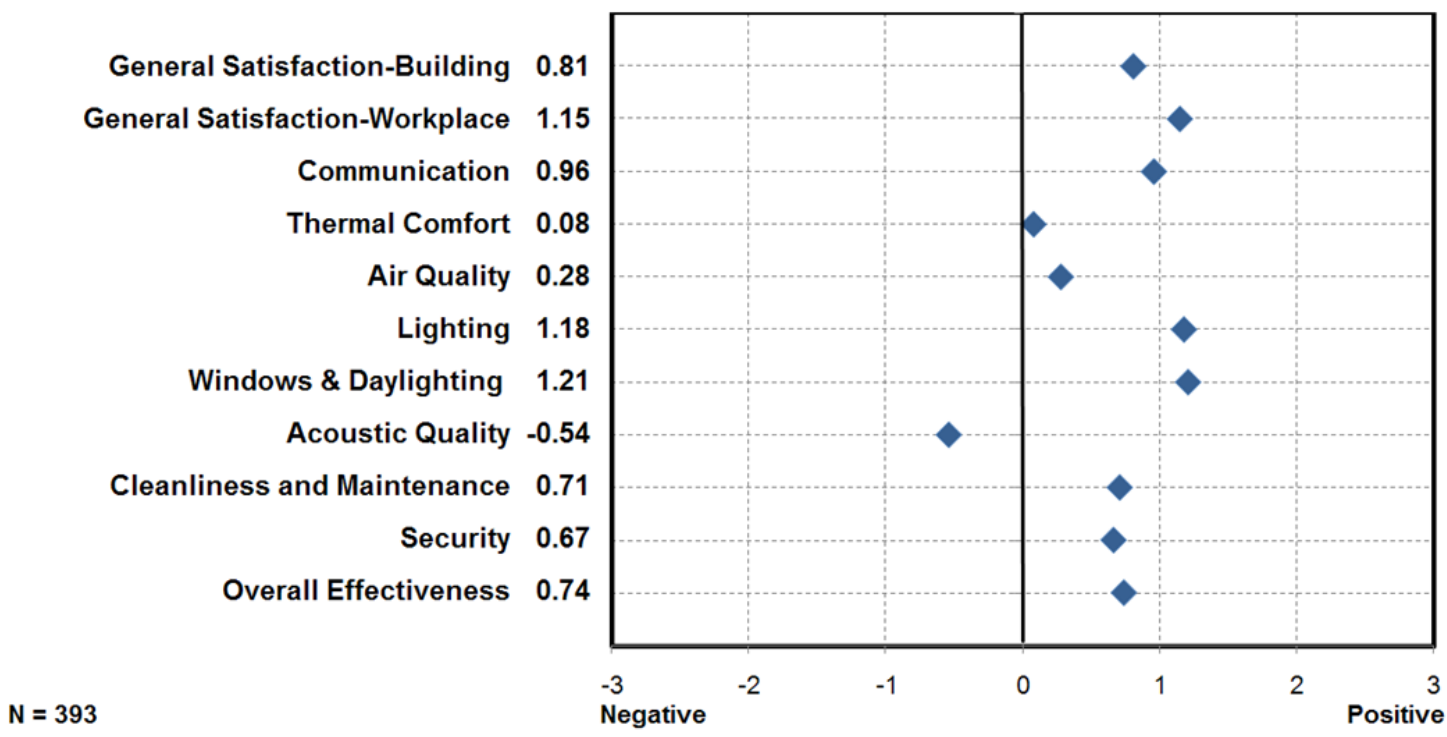

The results indicated that occupants of the Bennett Federal Building are less satisfied with their building than occupants in the CBE baseline $\left(38^{\text {th }}\right.$ percentile). General workspace satisfaction, thermal comfort, lighting, windows and daylighting scored at or above the $50^{\text {th }}$ percentile when compared to the CBE building database.

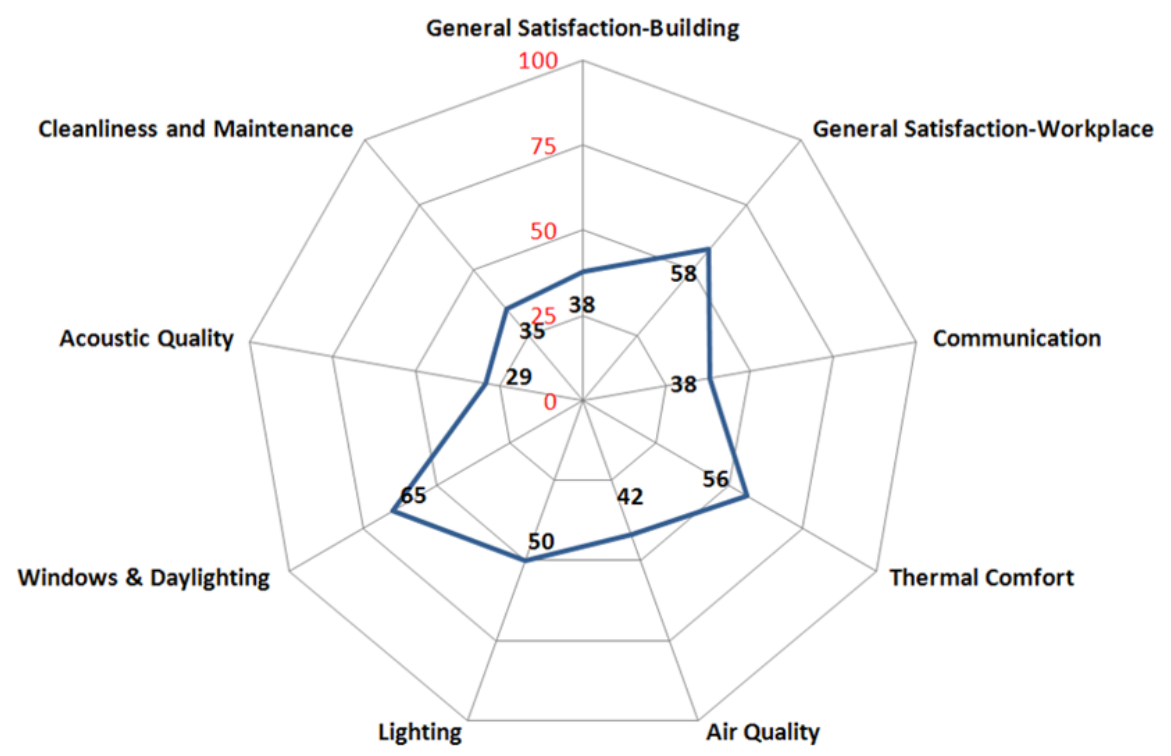




\section{Performance Data Summary}

The research team collected, normalized, and compared whole building performance data for the Bennett Federal Building to industry baselines. The following table summarizes the annual performance data collected and normalized. The facility uses water-cooled chillers for its air-conditioning system; therefore, the cooling tower water use was estimated using the "rule-of-thumb" that $27 \%$ of total water use is process water.

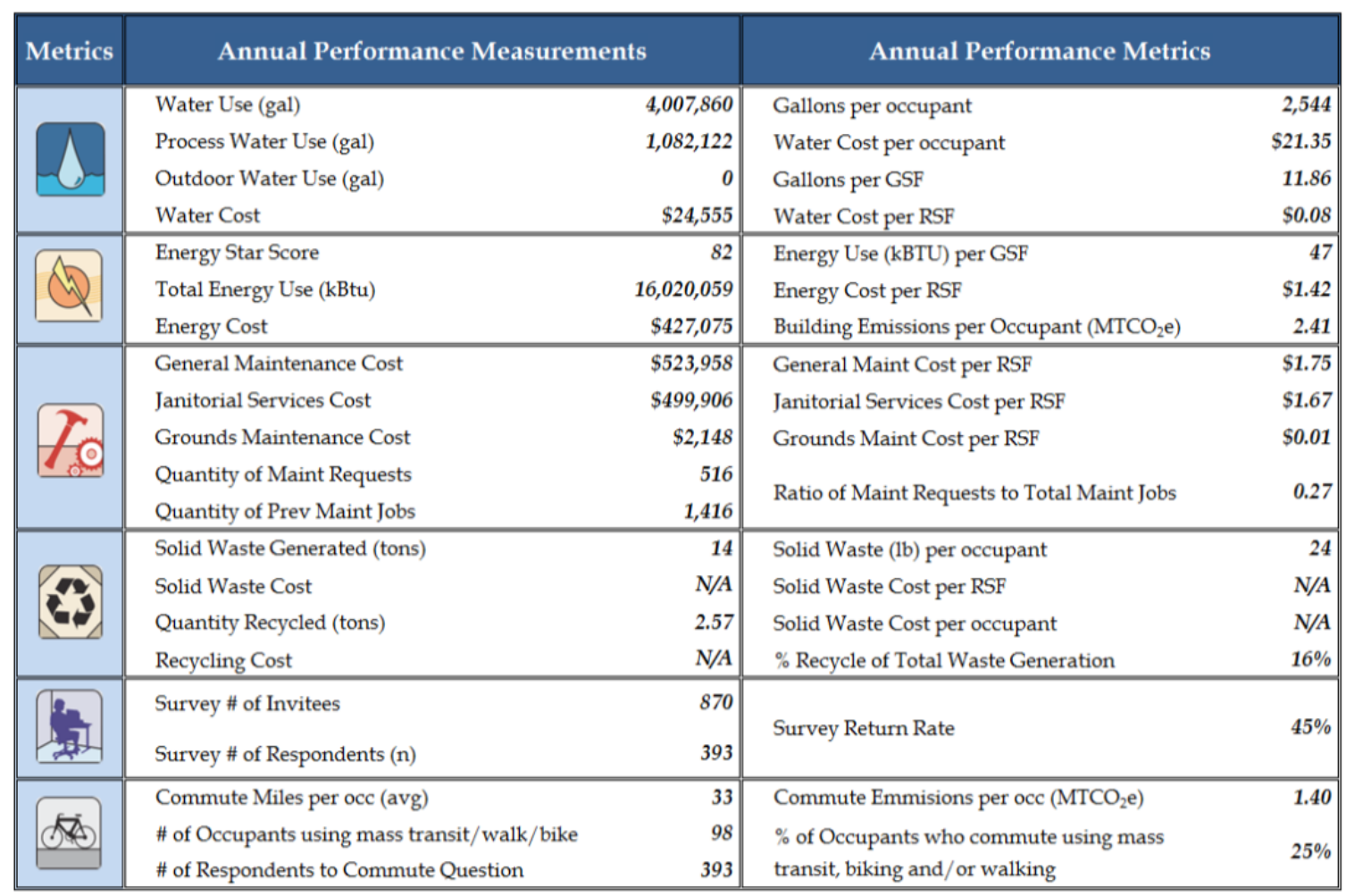




\section{Knoxville Federal Building}

\section{Description}

The John J. Duncan Federal Building was remodeled in 2005, incorporating a new energy management system, high-efficiency lighting, motion sensors, variable frequency drives, enhanced metering, low-flow fixtures, and a 1400-gallon rainwater catchment system to increase both energy and water efficiency in the

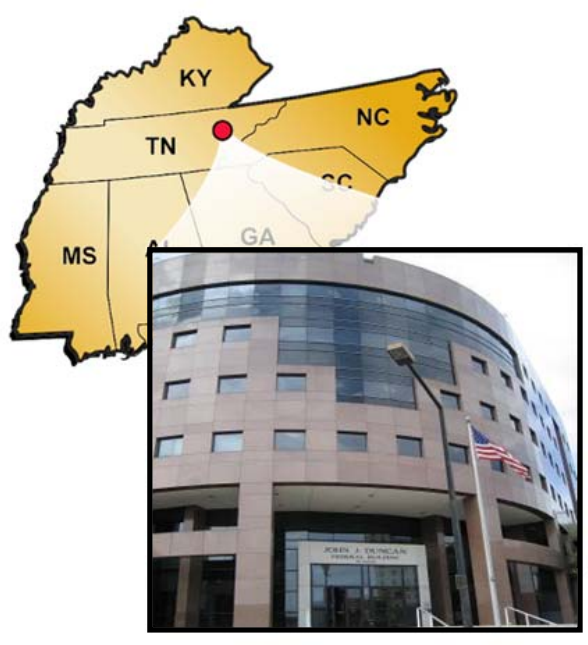
facility. The roof meets emissivity requirements to reduce heat the island effect, and houses solar lighting panels to power the roof lights. The steel-framed building has a curved front that includes a generous amount of glass in and above the entrance. The interior has an acoustic-tile ceiling and recessed fluorescent lighting, marble floors in the public areas and carpet in the private offices.

\begin{tabular}{|c|c|c|}
\hline \multirow[t]{2}{*}{ Metrics } & \multicolumn{2}{|c|}{ John J. Duncan Federal Building } \\
\hline & Building Location & $\begin{array}{rr}710 \text { Locust Street } & \text { Knoxville } \\
\text { Tennessee } & 37902-2540\end{array}$ \\
\hline & Building Function & Federal Building \\
\hline & Project Type & Renovation \\
\hline & Design Certification & B Certified, Energy Star 2007 (88) \\
\hline Git & Year Built & 1986 \\
\hline & \# of Floors & 8 \\
\hline & Gross Square Foot & 172,684 \\
\hline & Rentable Square Foot & 120,171 \\
\hline & Usable Square Foot & 93,040 \\
\hline & Weekly Operating Hours & 65 \\
\hline & Regular Occupants & 285 \\
\hline & Average Daily Visitors (FTE) & 25 \\
\hline & Electronic Equipment & 285 \\
\hline & Site Cost & N/A \\
\hline & Design Cost & $N / A$ \\
\hline & Construction Cost & $N / A$ \\
\hline & Management \& Inspection & $N / A$ \\
\hline & Total Cost & $\$ 269,000$ \\
\hline
\end{tabular}

The facility is located in downtown Knoxville and currently houses eight federal agencies. A small café is on the first floor and is used by many of the tenants..

Each building in the study had operational highlights and potential opportunities for improvement. Although it was not the focus of this study to investigate and/or document operational highlights and opportunities, the research team observed:

stop to the building offers staff an opportunity not seen at many of the other buildings in this study: an easy commute via public transportation. Only 4\% of those responding to the survey claimed they use the public transportation system. The availability of underground parking may have an impact on the incentive to use public transportation.

- The fact that many of the building occupants are not in the building every day may offer energy-management opportunities for the unoccupied spaces. Investigating whether occupant computers can be turned off when occupants are not present could reduce plug load and heat gain within the building. 


\section{Certifications}

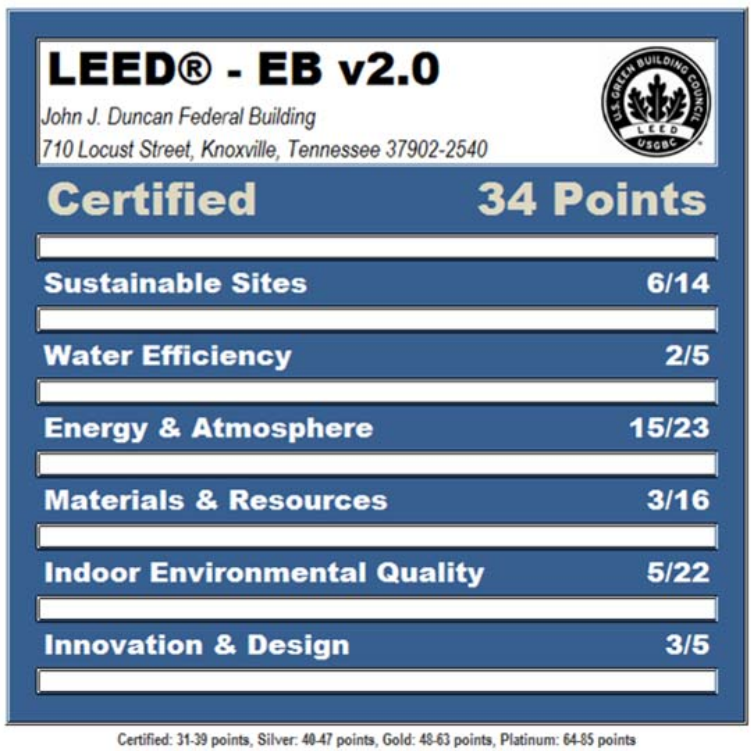

\section{Whole Building Performance}

The Duncan Federal Building operating costs are lower than the industry baseline for energy, water, and waste costs, and slightly higher for general maintenance and janitorial costs. When personnel from the Office of Surface Mines are working in the field and returning to the building, there are increased janitorial responsibilities because of dirty floors. There is no cost for operating the recycling program. Overall, the building costs less to operate than a baseline building.

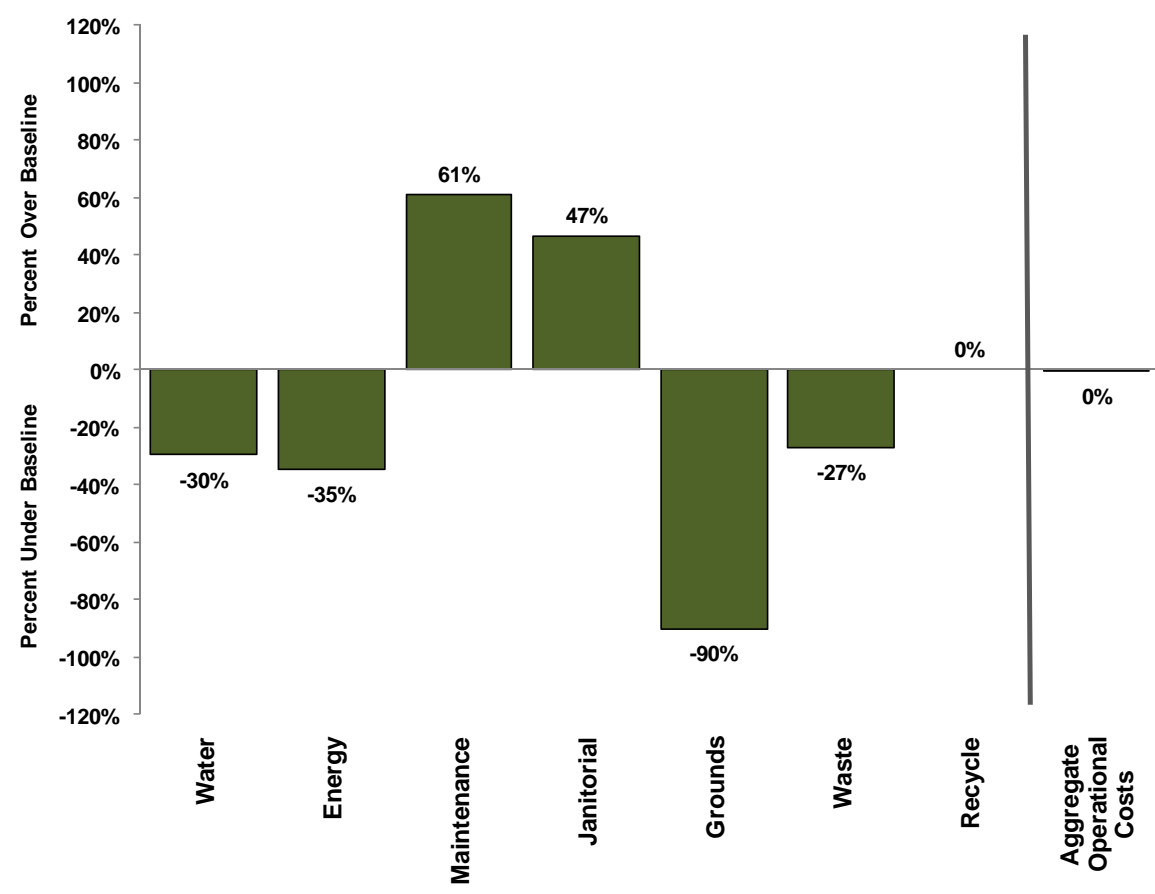




\section{Occupant Satisfaction Survey}

Of the 285 occupants in the Duncan Federal Building, 275 were surveyed and 98 responded. In addition to the electronic survey, GSA representatives issued the survey in hard-copy form to increase the response rate.

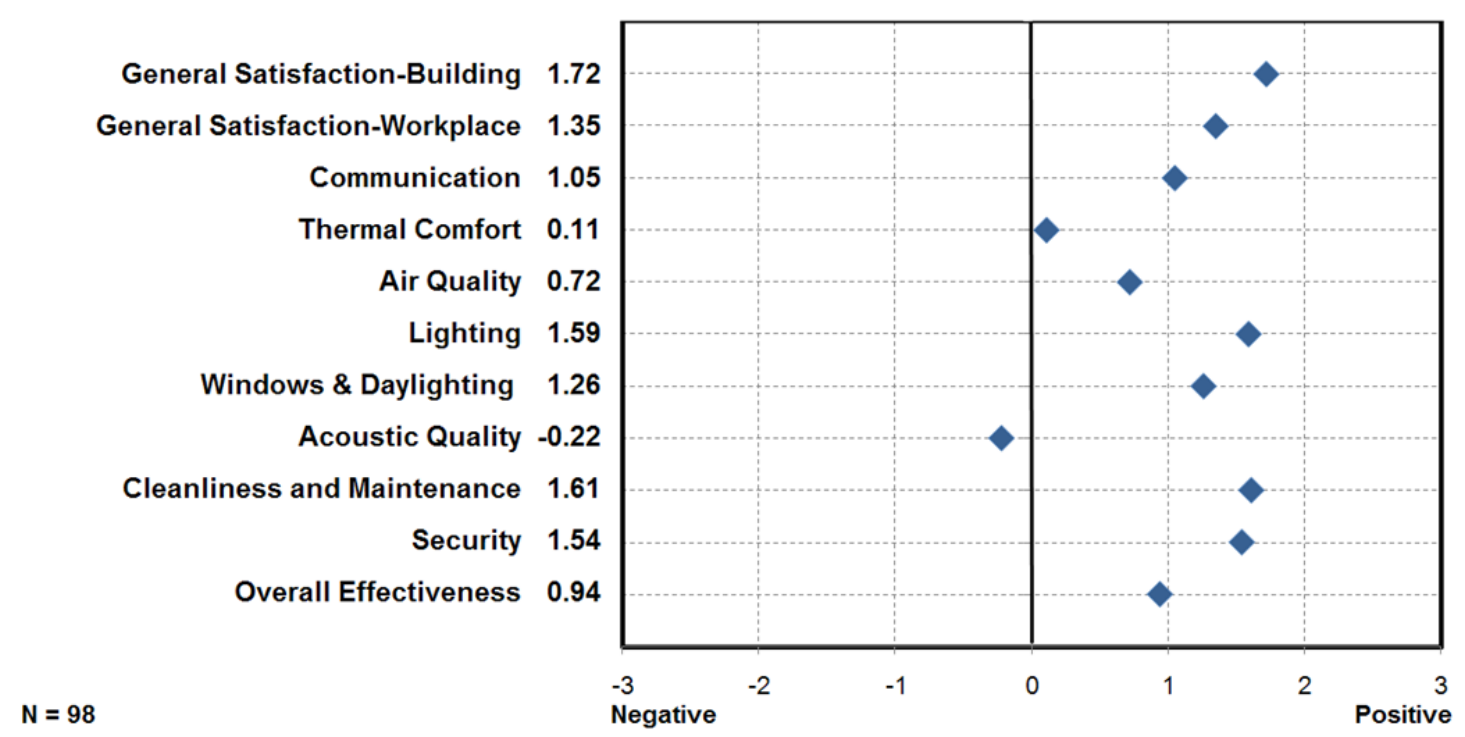

Survey results indicated that the occupants of the Duncan Federal Building are more satisfied with their building than occupants in the CBE baseline $\left(84^{\text {th }}\right.$ percentile). The acoustic quality score is at the $50^{\text {th }}$ percentile of all buildings surveyed by CBE. In the remainder of the categories, the Duncan Federal Building rated above the buildings in the CBE database.

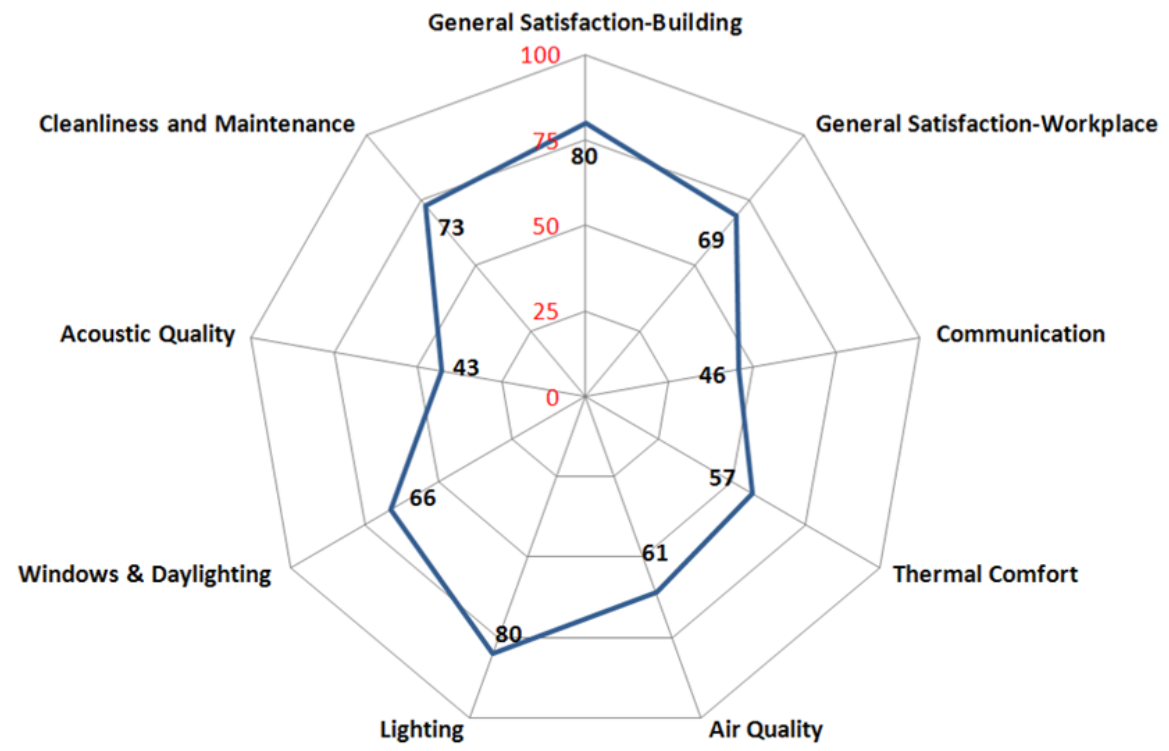




\section{Performance Data Summary}

The research team collected, normalized, and compared whole building performance data for the Duncan Federal Building to industry baselines. The following table summarizes the annual performance data collected and normalized. The facility uses water-cooled chillers for its air-conditioning system; therefore, the cooling tower water use was estimated using the "rule-of-thumb" that $27 \%$ of total water use is process water. ${ }^{33}$

\begin{tabular}{|c|c|c|c|c|}
\hline Metrics & \multicolumn{2}{|c|}{ Annual Performance Measurements } & \multicolumn{2}{|l|}{ Annual Performance Metrics } \\
\hline & Water Use (gal) & $2,252,228$ & Gallons per occupant & 5,299 \\
\hline & Process Water Use (gal) & 608,102 & Water Cost per occupant & $\$ 51.77$ \\
\hline & Outdoor Water Use (gal) & 0 & Gallons per GSF & 13.04 \\
\hline & Water Cost & $\$ 16,061$ & Water Cost per RSF & $\$ 0.13$ \\
\hline & Energy Star Score & 90 & Energy Use (kBTU) per GSF & 49 \\
\hline & Total Energy Use (kBtu) & $8,488,914$ & Energy Cost per RSF & $\$ 1.65$ \\
\hline & Energy Cost & $\$ 198,759$ & Building Emissions per Occupant $\left(\mathrm{MTCO}_{2} \mathrm{e}\right)$ & 4.60 \\
\hline & General Maintenance Cost & $\$ 237,836$ & General Maint Cost per RSF & $\$ 1.98$ \\
\hline & Janitorial Services Cost & $\$ 220,948$ & Janitorial Services Cost per RSF & $\$ 1.84$ \\
\hline & Grounds Maintenance Cost & $\$ 5,300$ & Grounds Maint Cost per RSF & $\$ 0.04$ \\
\hline & Quantity of Maint Requests & 660 & Ratio of Maint Requests to Total Maint Jobs & 0.16 \\
\hline & Quantity of Prev Maint Jobs & 3,541 & 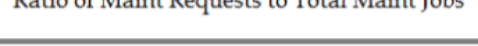 & 0.10 \\
\hline & Solid Waste Generated (tons) & 41 & Solid Waste (lb) per occupant & 261 \\
\hline & Solid Waste Cost & $\$ 4,380$ & Solid Waste Cost per RSF & $\$ 0.03$ \\
\hline & Quantity Recycled (tons) & 20.35 & Solid Waste Cost per occupant & $\$ 14.12$ \\
\hline & Recycling Cost & N/A & $\%$ Recycle of Total Waste Generation & $33 \%$ \\
\hline & $\begin{array}{l}\text { Survey \# of Invitees } \\
\text { Survey \# of Respondents (n) }\end{array}$ & $\begin{array}{r}275 \\
98\end{array}$ & Survey Return Rate & $36 \%$ \\
\hline & Commute Miles per occ (avg) & 29 & Commute Emmisions per occ $\left(\mathrm{MTCO}_{2} \mathrm{e}\right)$ & 2.15 \\
\hline & $\begin{array}{l}\text { \# of Occupants using mass transit/walk/bike } \\
\text { \# of Respondents to Commute Question }\end{array}$ & $\begin{array}{r}0 \\
98\end{array}$ & $\begin{array}{l}\% \text { of Occupants who commute using mass } \\
\text { transit, biking and/or walking }\end{array}$ & $0 \%$ \\
\hline
\end{tabular}




\section{Cleveland Courthouse}

\section{Description}

The Howard M. Metzenbaum U.S.

Courthouse is located in the hub of

Cleveland's central business district. This

LEED Certified facility maintained $96 \%$ of

the existing shell and $59 \%$ of interior

elements during its renovation.

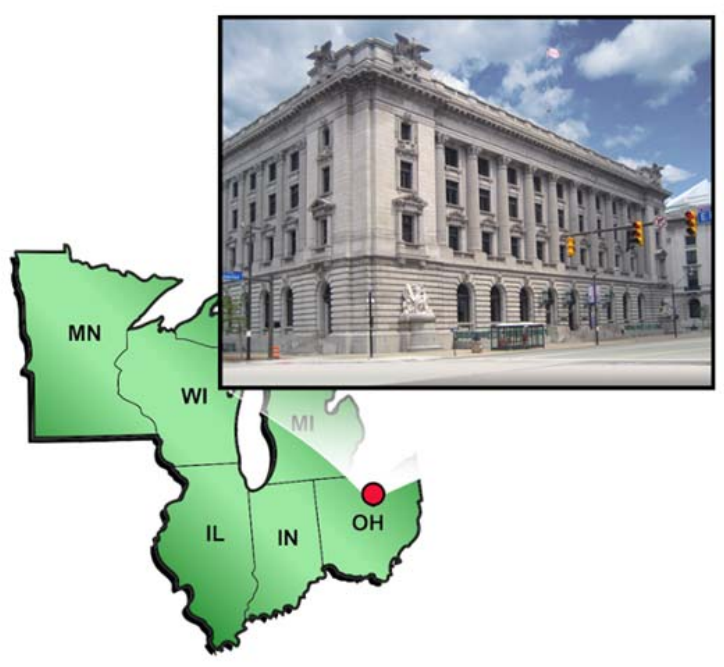

Due to its urban location, alternative transportation is used widely and encouraged by management. No new landscaping was added during the building renovation. The existing trees do not require irrigation, and the building's low-flow fixtures increase its water

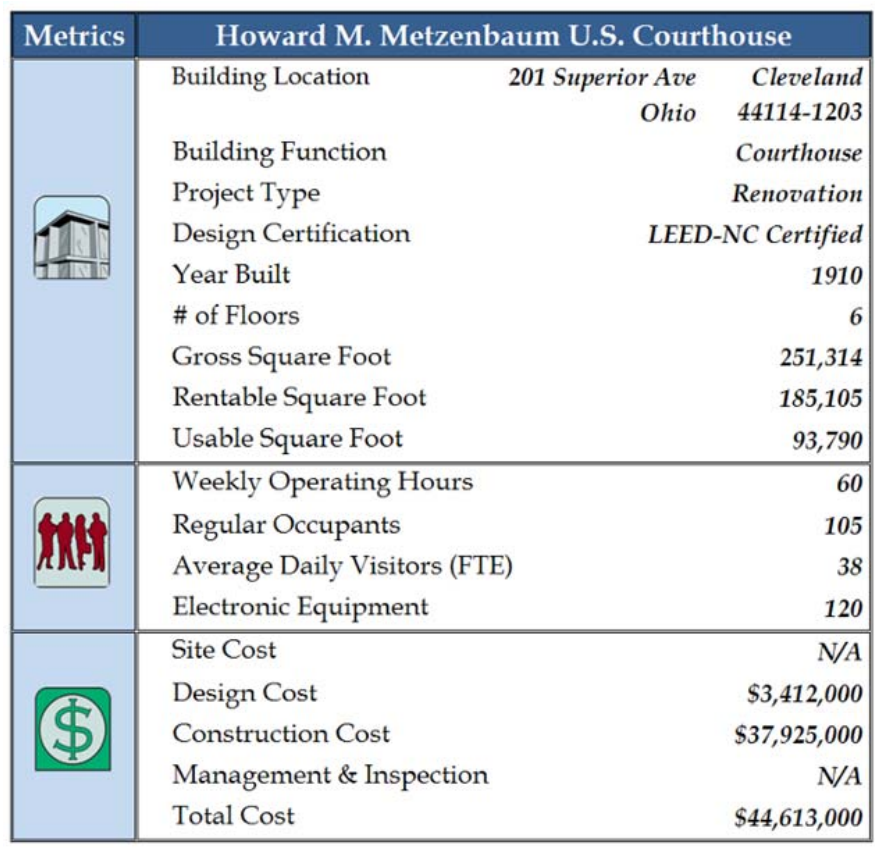
efficiency.

The Metzenbaum Courthouse won GSA's Environmental Award for Recycling because of its sevenmaterial collection system. The building has low-emitting carpets, $\mathrm{CO}_{2}$ sensors, and practices green housekeeping to maintain high indoor environmental quality standards for its occupants.

Each building in the study had operational highlights and potential opportunities for improvement. Although it was not the focus of this study to investigate and/or

document operational highlights and opportunities, the research team observed:

- During one of the site visits, researchers observed rust on new mechanical equipment caused by water leaking into the basement from the sidewalk. Addressing the leak will minimize maintenance costs in the future.

- The high level of occupant satisfaction on all categories implies that Metzenbaum's building systems are working well. Identifying and communicating the causes of these operational successes offers successful building operations strategies for other Federal buildings and courthouses. 


\section{Certifications}

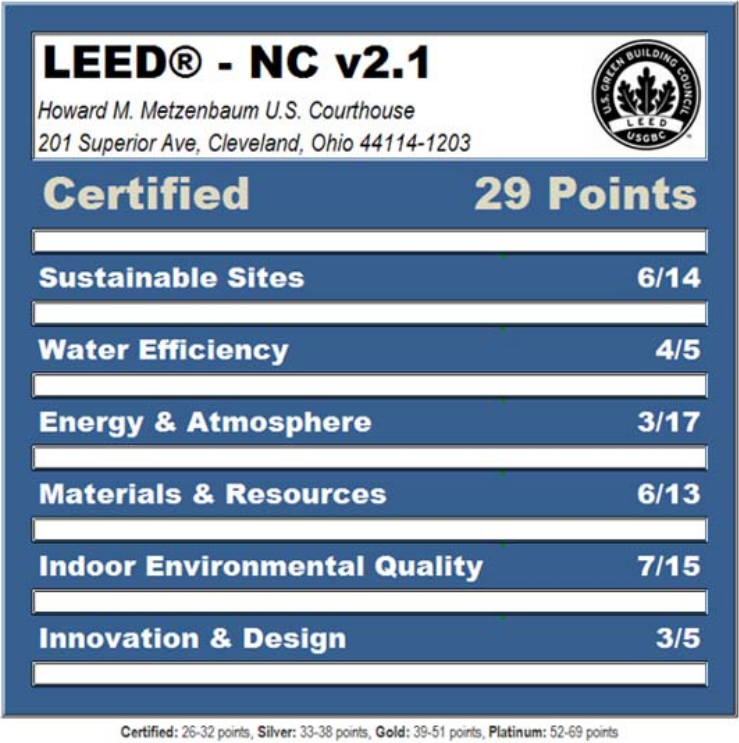

\section{Whole Building Performance}

The Metzenbaum Courthouse operating costs are lower than the industry baseline for all metrics other than energy. Overall, the building costs less to operate than a baseline building.

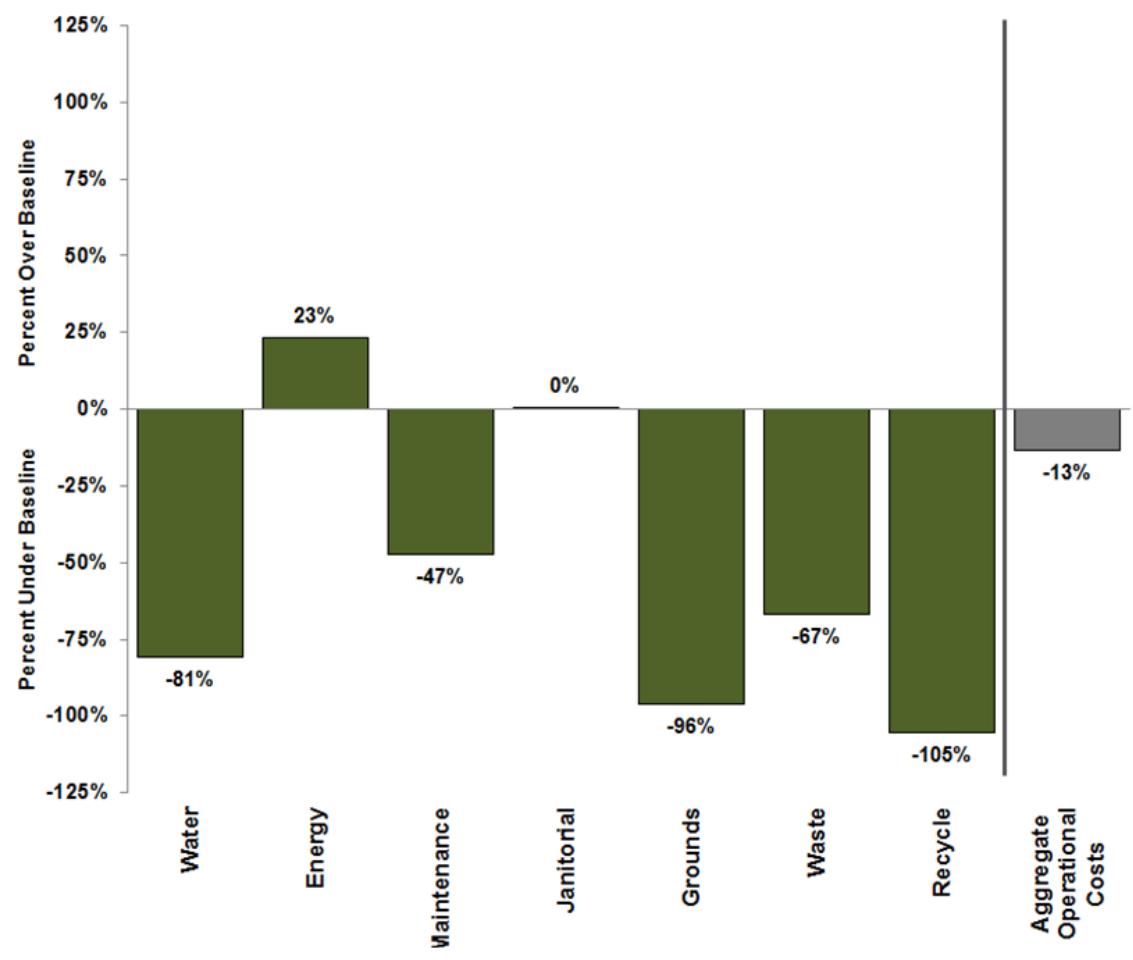




\section{Occupant Satisfaction Survey}

Of the 105 occupants in the building, 95 were surveyed and 54 responded. All of the main survey categories had positive average scores.

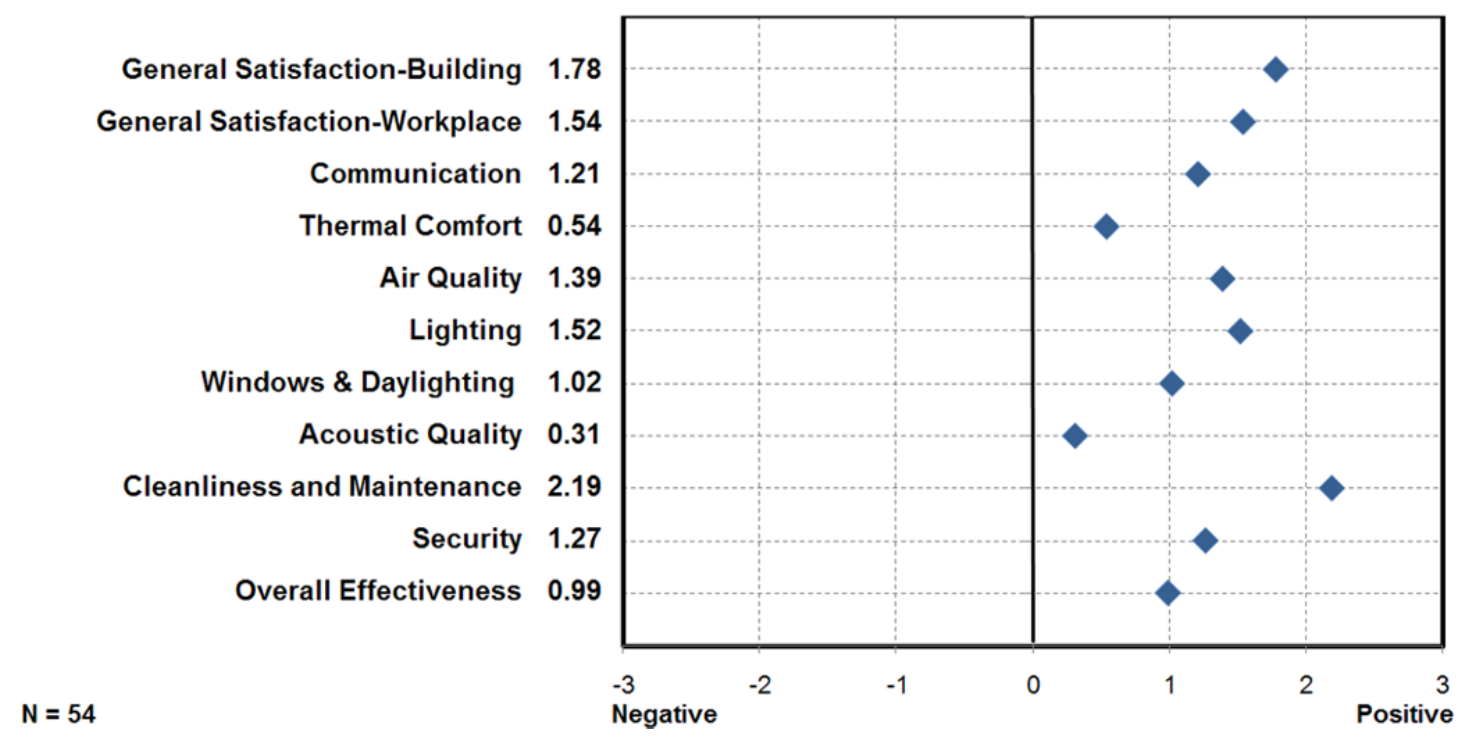

The results indicated that occupants of the Metzenbaum Courthouse are more satisfied with their building than occupants in the CBE baseline ( $82^{\text {nd }}$ percentile). In all of the key measurements - acoustic quality, air quality, cleanliness and maintenance, thermal comfort and lighting-Metzenbaum occupants scored above the $50^{\text {th }}$ percentile of the CBE buildings surveyed.

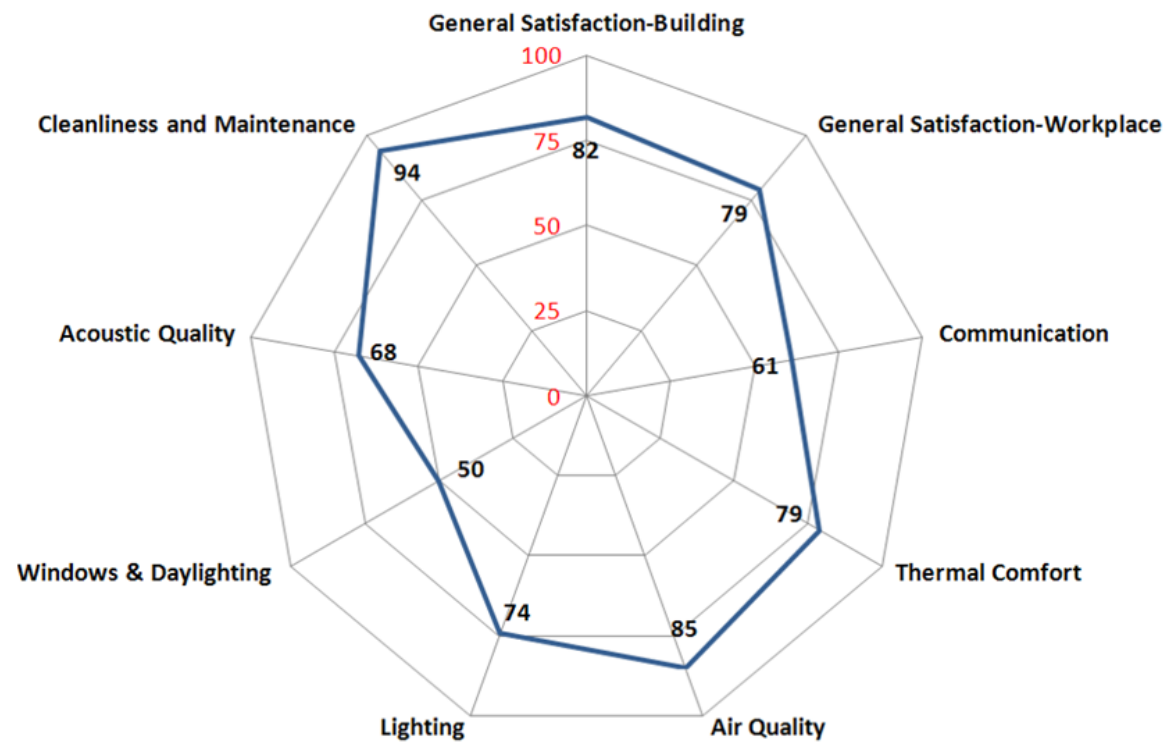




\section{Performance Data Summary}

The research team collected, normalized, and compared whole building performance data for the Metzenbaum Courthouse to industry baselines. The following table summarizes the annual performance data collected and normalized.

\begin{tabular}{|c|c|c|c|c|}
\hline Metrics & \multicolumn{2}{|c|}{ Annual Performance Measurements } & \multicolumn{2}{|l|}{ Annual Performance Metrics } \\
\hline & Water Use (gal) & 450,295 & Gallons per occupant & 3,160 \\
\hline & Process Water Use (gal) & 0 & Water Cost per occupant & $\$ 47.23$ \\
\hline & Outdoor Water Use (gal) & 0 & Gallons per GSF & 1.79 \\
\hline & Water Cost & $\$ 6,730$ & Water Cost per RSF & $\$ 0.04$ \\
\hline & Energy Star Score & 69 & Energy Use (kBTU) per GSF & 103 \\
\hline & Total Energy Use (kBtu) & $26,009,475$ & Energy Cost per RSF & $\$ 3.12$ \\
\hline & Energy Cost & $\$ 576,668$ & Building Emissions per Occupant $\left(\mathrm{MTCO}_{2} \mathrm{e}\right)$ & 19.21 \\
\hline & General Maintenance Cost & $\$ 176,320$ & General Maint Cost per RSF & $\$ 0.95$ \\
\hline & Janitorial Services Cost & $\$ 297,728$ & Janitorial Services Cost per RSF & $\$ 1.61$ \\
\hline & Grounds Maintenance Cost & $\$ 3,100$ & Grounds Maint Cost per RSF & $\$ 0.02$ \\
\hline & Quantity of Maint Requests & 684 & & 0.46 \\
\hline & Quantity of Prev Maint Jobs & 805 & Ratio or Maint Requests to lotal Maint Jobs & 0.40 \\
\hline & Solid Waste Generated (tons) & 24 & Solid Waste (lb) per occupant & 337 \\
\hline & Solid Waste Cost & $\$ 3,067$ & Solid Waste Cost per RSF & $\$ 0.01$ \\
\hline & Quantity Recycled (tons) & 2.80 & Solid Waste Cost per occupant & $\$ 21.52$ \\
\hline & Recycling Cost & $-\$ 101$ & $\%$ Recycle of Total Waste Generation & $10 \%$ \\
\hline & $\begin{array}{l}\text { Survey \# of Invitees } \\
\text { Survey \# of Respondents (n) }\end{array}$ & $\begin{array}{l}95 \\
54\end{array}$ & Survey Return Rate & $57 \%$ \\
\hline & Commute Miles per occ (avg) & 26 & Commute Emmisions per occ $\left(\mathrm{MTCO}_{2} \mathrm{e}\right)$ & 1.03 \\
\hline & $\begin{array}{l}\text { \# of Occupants using mass transit/walk/bike } \\
\text { \# of Respondents to Commute Question }\end{array}$ & $\begin{array}{l}31 \\
55\end{array}$ & $\begin{array}{l}\% \text { of Occupants who commute using mass } \\
\text { transit, biking and/or walking }\end{array}$ & $56 \%$ \\
\hline
\end{tabular}




\section{Sault Ste. Marie Port}

\section{Description}

The Sault Ste. Marie Port-of-Entry is located on the U.S. side of the northern international border and operates 24 hours a day, 365 days a year. The building has primary and secondary vehicle inspection bays and two commercial truck lanes and three car lanes

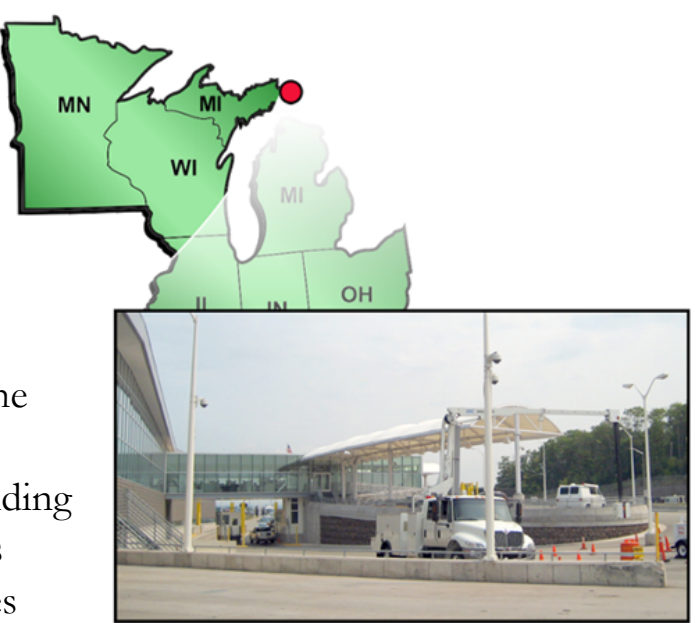
for in-bound inspections.

The facility's steel-frame construction with glass curtainwall offers daylighting to the interior space, and the facility sits on top of an at-grade parking garage.

\begin{tabular}{|c|c|c|}
\hline Metrics & \multicolumn{2}{|l|}{ Sault Sainte Marie Border Station } \\
\hline & $\begin{array}{r}\text { Building Location } \quad 989 \text { W. Portage Ave } \\
\text { Michiga }\end{array}$ & $\begin{array}{r}\text { Sault Sainte } \\
49783-0000\end{array}$ \\
\hline & Building Function & order Station \\
\hline & Project Type & Construction \\
\hline & Design Certification & VC Registered \\
\hline ant & Year Built & 2005 \\
\hline & \# of Floors & 2 \\
\hline & Gross Square Foot & 63,874 \\
\hline & Rentable Square Foot & 39,709 \\
\hline & Usable Square Foot & 29,263 \\
\hline & Weekly Operating Hours & 168 \\
\hline & Regular Occupants & 74 \\
\hline & Average Daily Visitors (FTE) & 10 \\
\hline & Electronic Equipment & 80 \\
\hline & Site Cost & N/A \\
\hline & Design Cost & $\$ 700,000$ \\
\hline & Construction Cost & $\$ 10,653,500$ \\
\hline & Management \& Inspection & $N / A$ \\
\hline & Total Cost & $\$ 13,711,500$ \\
\hline
\end{tabular}

The facility houses an indoor firing range, a fitness room and locker facilities, holding cells and customs related laboratories. The multipitched roof features vegetative cover. The facility operates three boilers, a chiller, and three airhandling units. Lighting is controlled by both occupancy and daylight sensors.

Because of the facility's security function, the space houses various types of monitors, screening machines, and cameras. The screening booths and inspection bays are mostly open to the outside and pose a challenge for temperature control during the winter months.

Each building in the study had operational highlights and potential opportunities for improvement. Although it was not the focus of this study to investigate and/or document operational highlights and opportunities, the research team observed:

- For both the Sault Ste. Marie and Sweetgrass Port facilities, this study used an office building baseline, because there is nothing equivalent to a Port in the publically available industry baseline data. To fairly assess the performance of these buildings, an alternative baseline is needed. 
- The vegetative roof has been a challenge to keep up due to potential installation flaws and the less-than-average annual rainfall over the past two years. Maintenance personnel training on upkeep of this feature may improve the health of the roof.

- Based on the CBE survey results, issues appear to exist with thermal comfort, daylighting, lighting, and acoustics. Interviews of occupants regarding these issues may result in a more detailed understanding of how operations might be adjusted to improve occupant satisfaction.

\section{Certifications}

\section{LEED-NC Registered}

\section{Whole Building Performance}

The Sault Ste. Marie Port's operating costs are higher than the industry baseline for general maintenance, janitorial, and grounds costs. The water, energy and waste costs are lower than the industry baseline. Overall, the building costs more to operate than a baseline building. The baseline used for this analysis was an office building, because there is no equivalent to Ports available for comparison. Significant consideration must be given to the building's operational function when reviewing these costs.

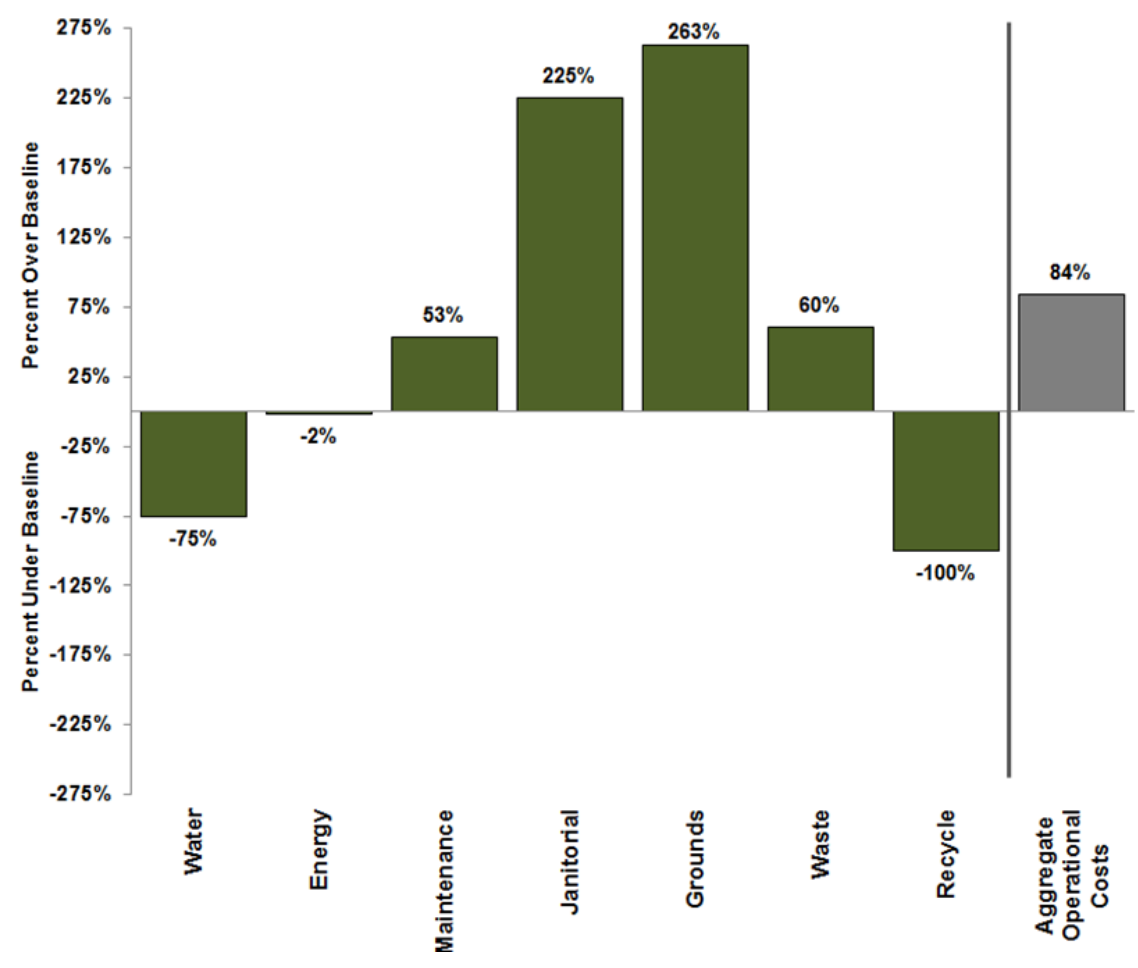




\section{Occupant Satisfaction Survey}

All 74 of the Sault Ste. Marie Port occupants were surveyed and 16 responded.

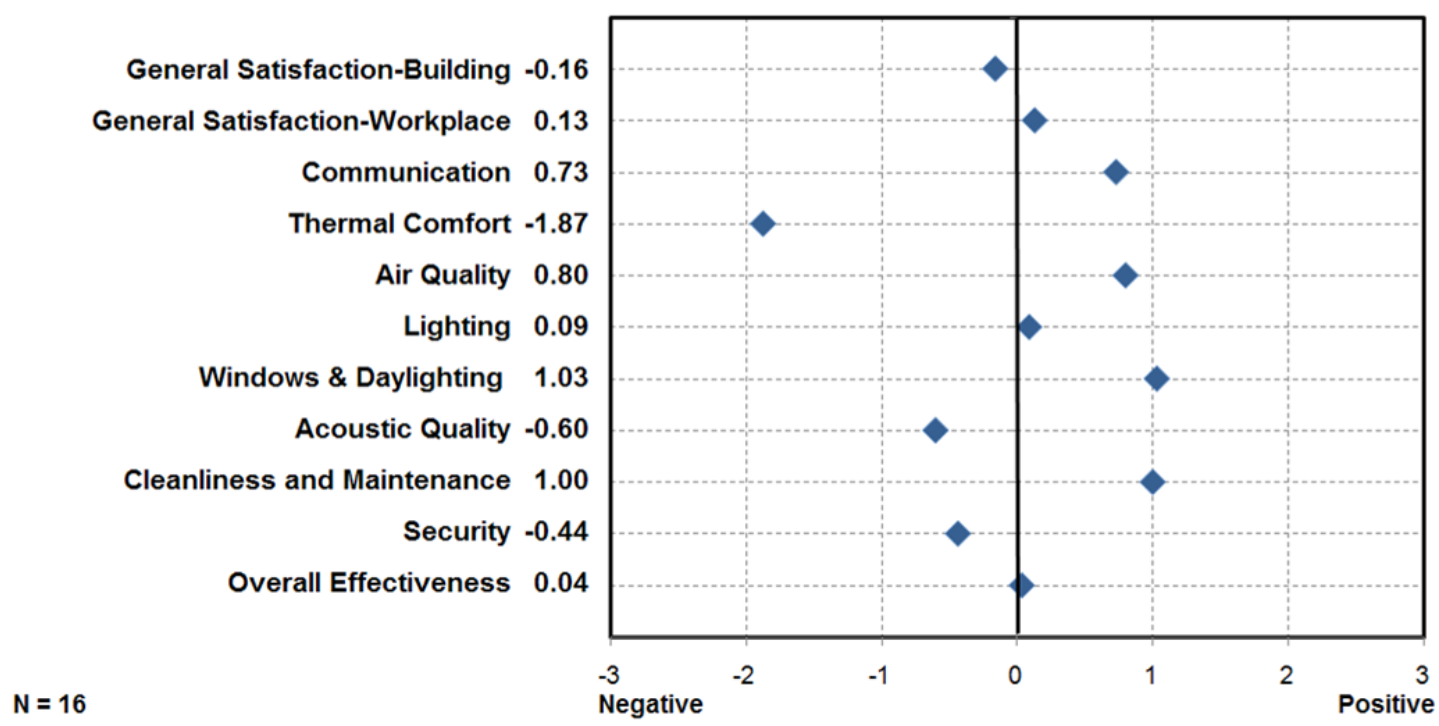

The results indicated that occupants of the Sault Ste. Marie Port are generally less satisfied with their building than occupants in the CBE baseline ( $2^{\text {nd }}$ percentile), and the building scored the lowest of all of the GSA buildings surveyed in this study. The acoustic quality, thermal comfort, cleanliness and maintenance, and lighting all scored below the $50^{\text {th }}$ percentile of the CBE buildings surveyed. Satisfaction with windows and daylighting and air quality scored above the $50^{\text {th }}$ percentile. Problems with glare and temperature due to the daylighting were identified as a persistent lighting and thermal comfort issue.

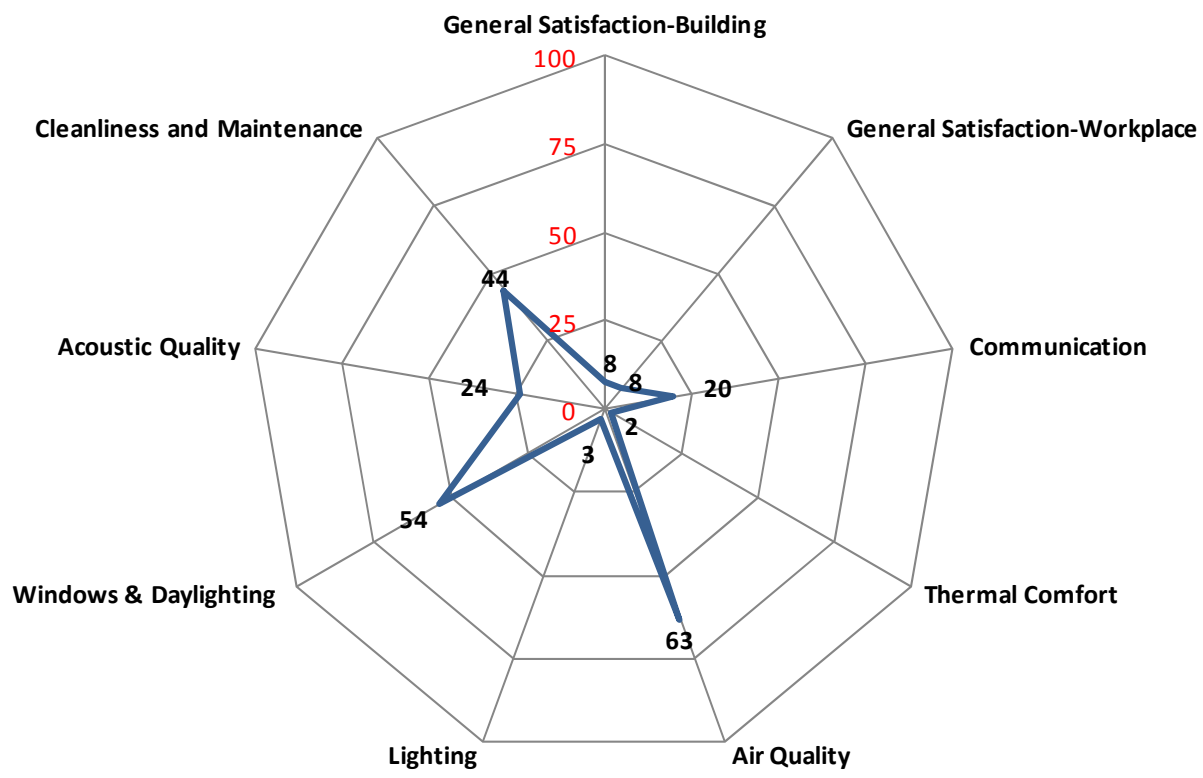




\section{Performance Data Summary}

The research team collected, normalized, and compared whole building performance data for the Sault Sainte Marie Port to industry baselines. The following table summarizes the annual performance data collected and normalized.

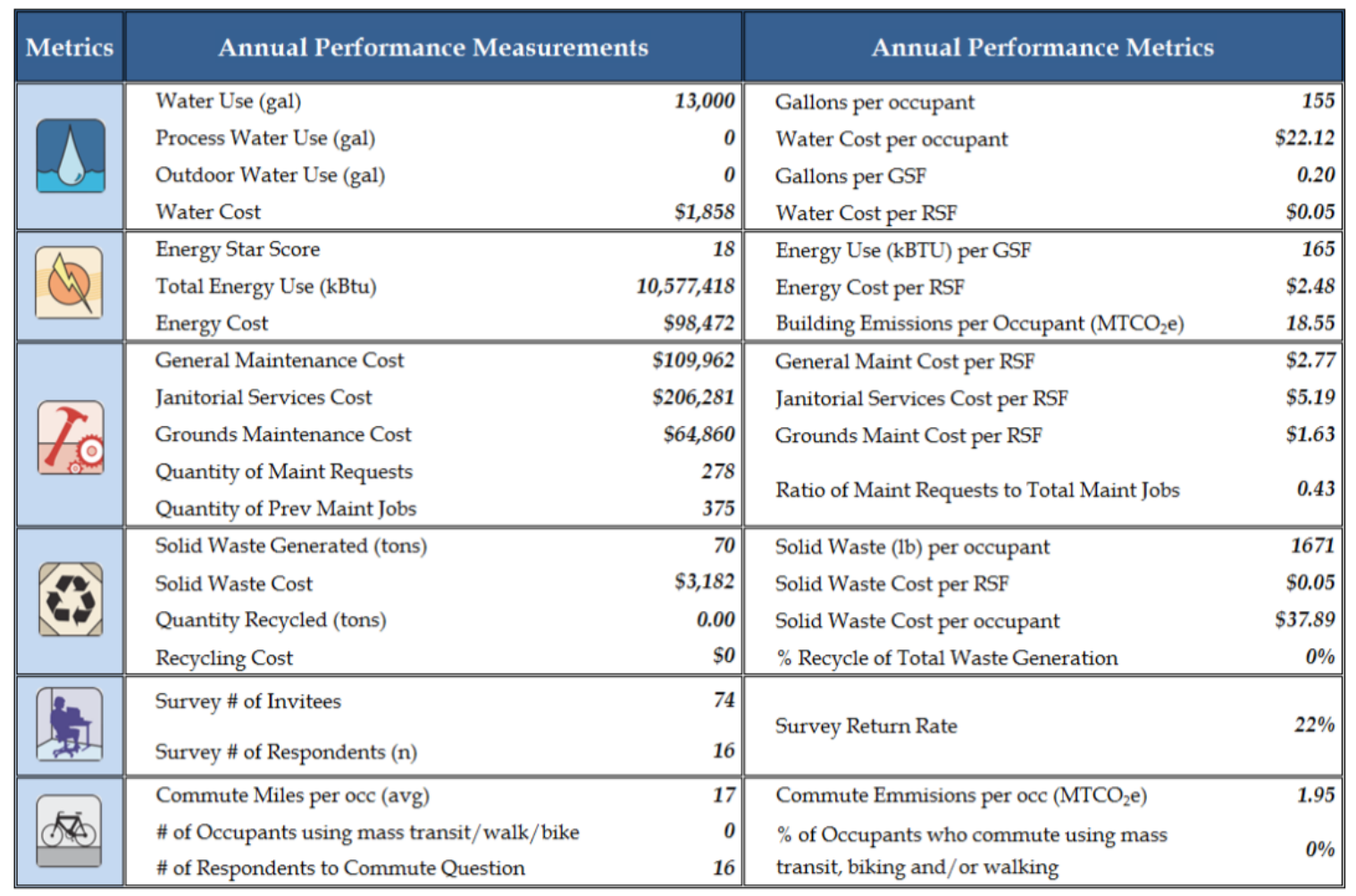




\section{Youngstown Courthouse and Federal Building}

\section{Description}

The Nathaniel R. Jones Federal Building and United States Courthouse (Youngstown CT \& FB) is a part of the urban revitalization of the city's downtown district. The building houses one bankruptcy courtroom and various types of office space to accommodate a variety of tenants.

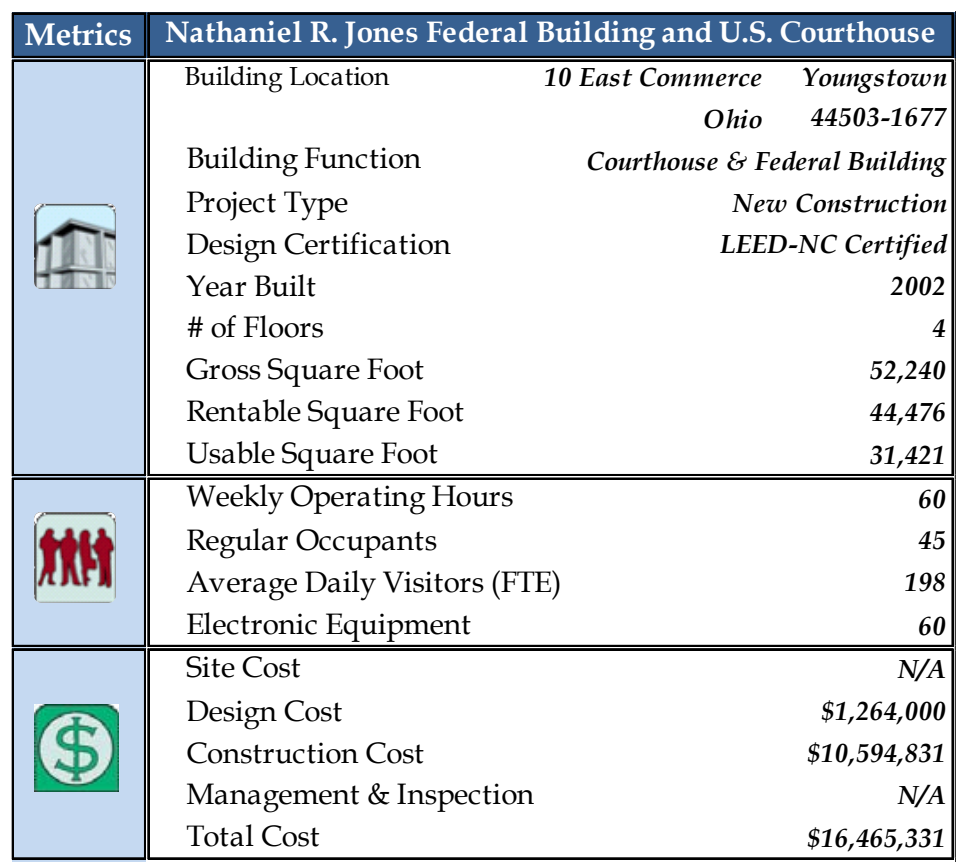

The facility is GSA's first courthouse to achieve LEED certification. The facility was built on a brownfield and incorporates building controls, combined with air-cooled chillers and municipal utility steam, and daylighting to over $75 \%$ of occupied spaces into building operations.

Unique features of the Youngstown CT \& FB include a native landscape and stormwater management demonstration adjacent to the building, and use of a white

membrane roof and light-colored pavement to reduce the heat island effect.

Each building in the study had operational highlights and potential opportunities for improvement. Although it was not the focus of this study to investigate and/or document operational highlights and opportunities, the research team observed:

- The Youngstown CT \& FB was the lowest scoring in the thermal comfort category of the CBE survey ( $1^{\text {st }}$ percentile). Building management is aware of problems with its cooling system and plans exist to upgrade the system.

- Native prairie grass landscaping is manually weeded, which may contribute to the higher grounds maintenance costs. 


\section{Certifications}

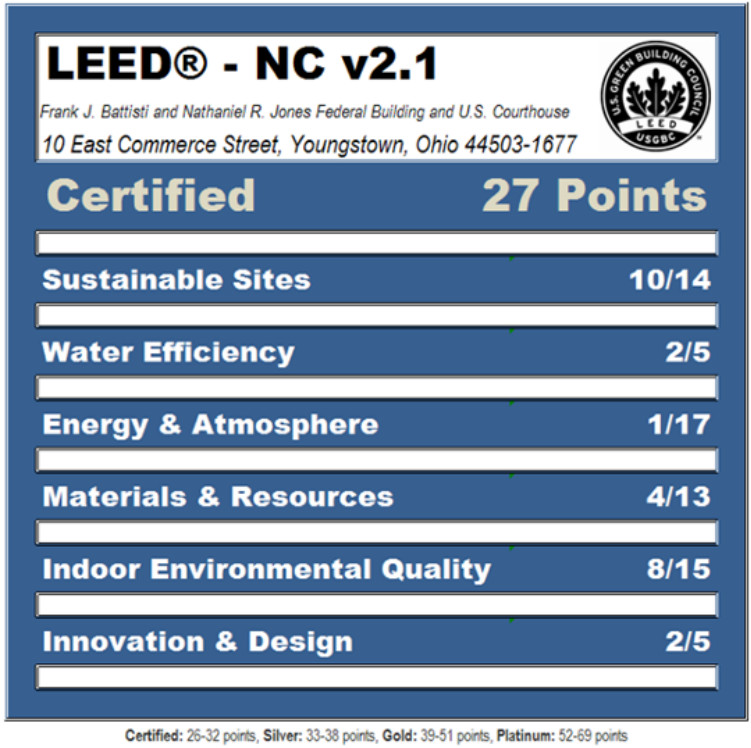

\section{Whole Building Performance}

The costs of operating the Youngstown CT \& FB are lower than the industry baseline for water, energy and waste costs. The general maintenance, janitorial, and grounds maintenance costs were higher than the industry baseline, and overall the building costs more to operate than the baseline. Note that the building's mechanical systems have been malfunctioning, and the basement has flooded five times since its commissioning, potentially affecting the maintenance and janitorial costs.

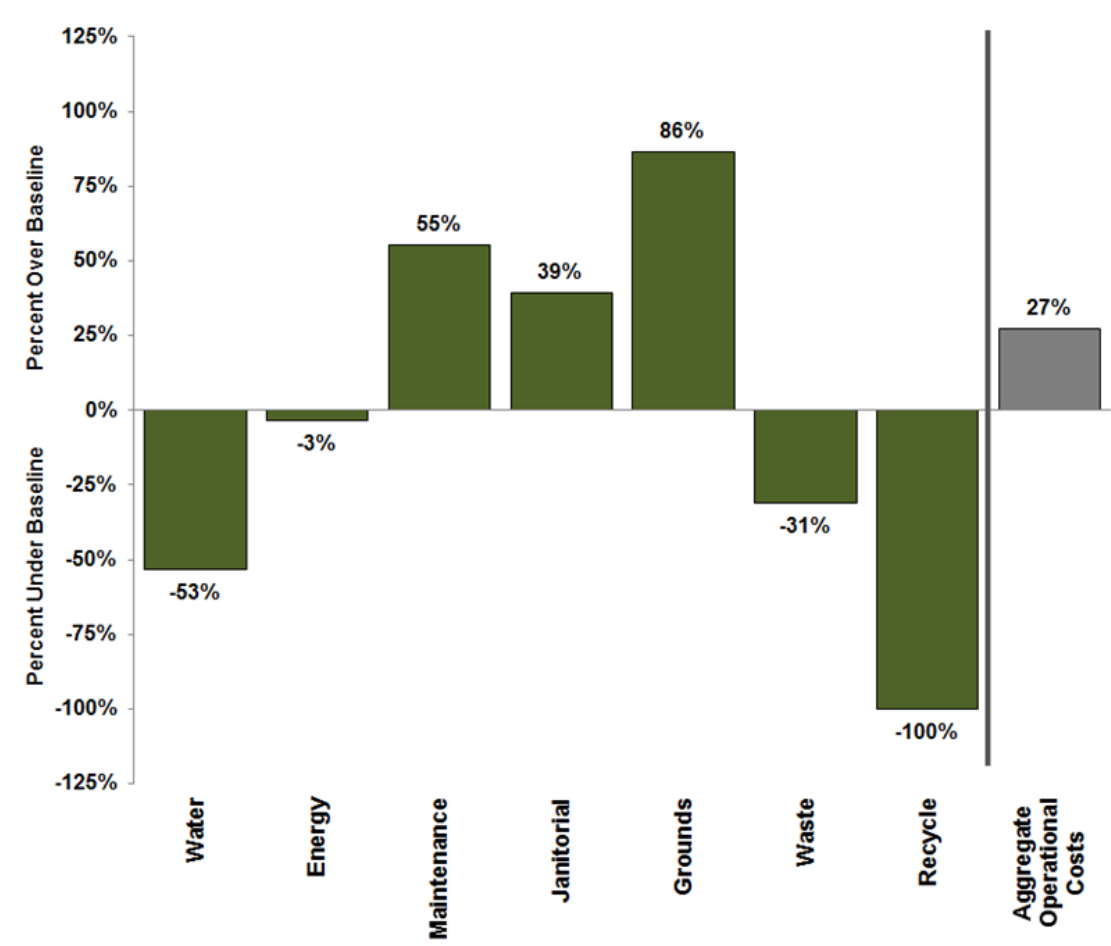




\section{Occupant Satisfaction Survey}

All 45 of the Youngstown CT \& FB occupants were surveyed and 28 responded. All of the main survey categories except thermal comfort had positive average scores.

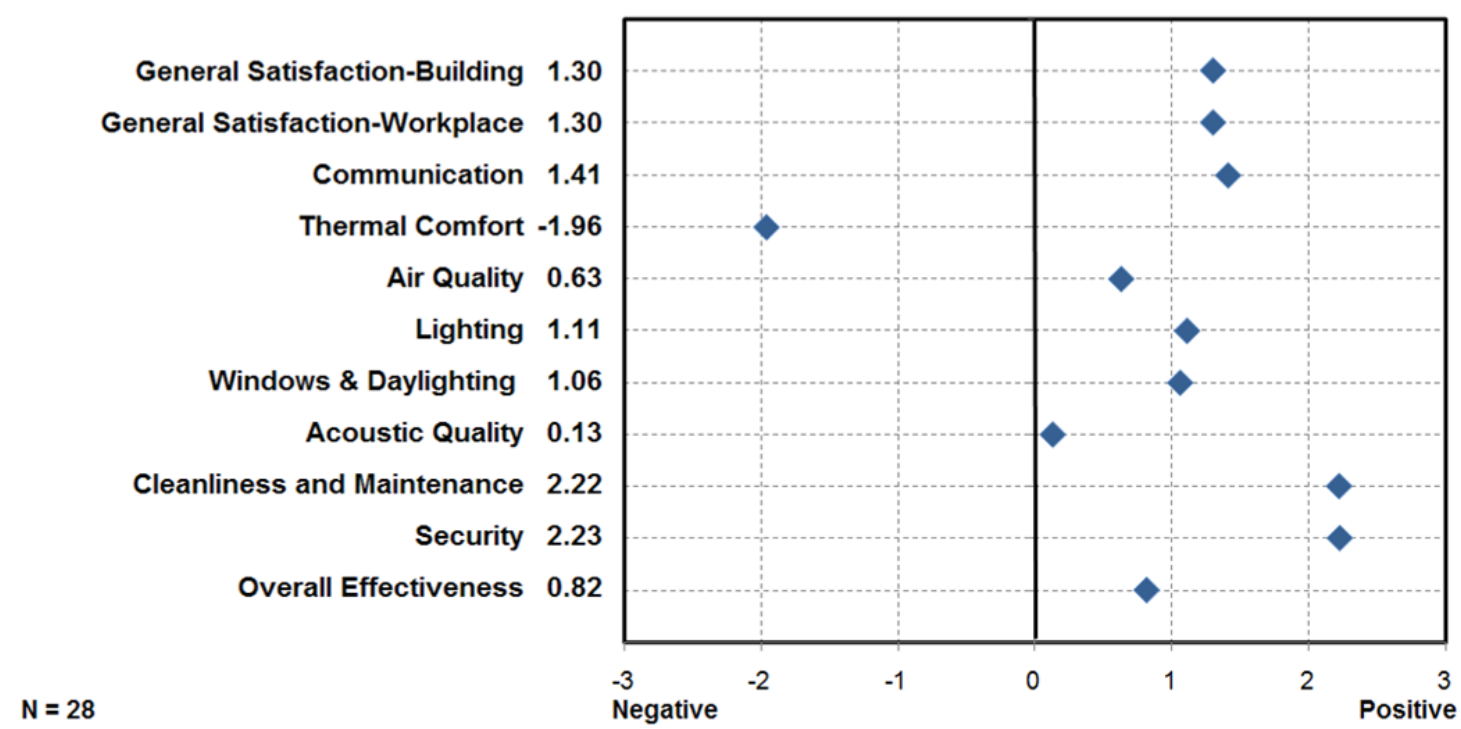

The results indicated that occupants of the Youngstown CT \& FB are generally more satisfied with their building than occupants in the CBE baseline ( $58^{\text {th }}$ percentile). Thermal comfort and lighting quality scored below the $50^{\text {th }}$ percentile of the CBE buildings surveyed. Acoustics, air quality, and cleanliness and maintenance all scored above the $50^{\text {th }}$ percentile.

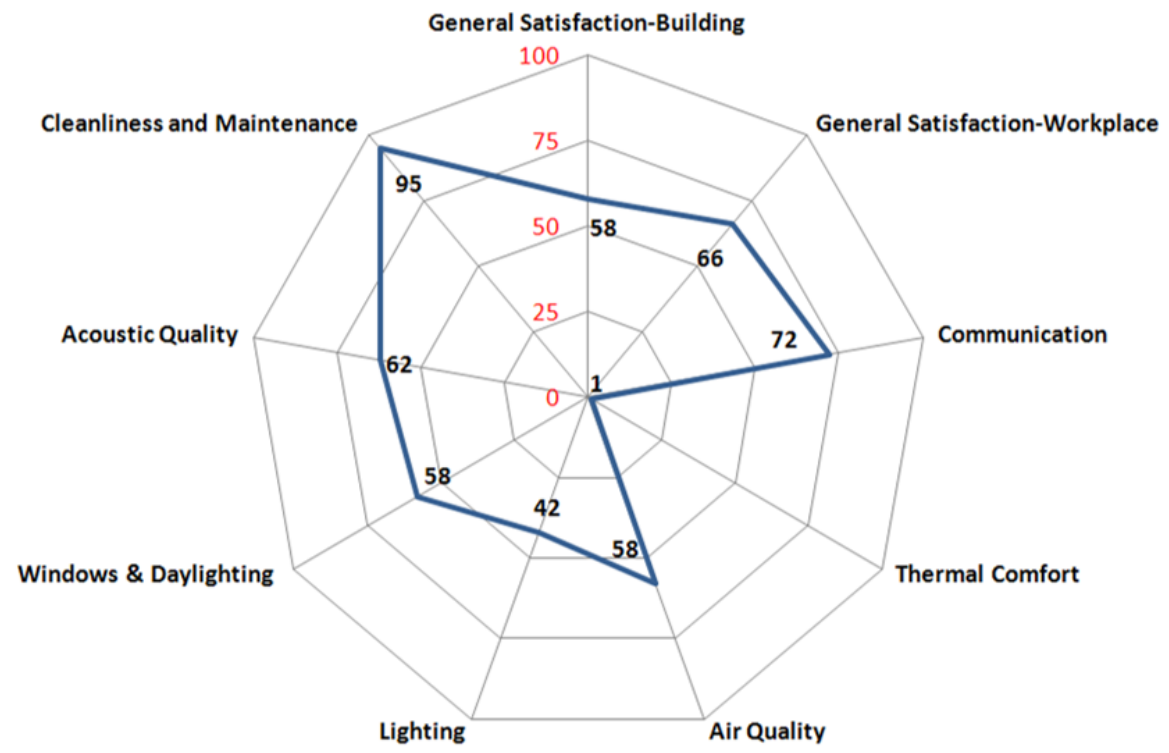




\section{Performance Data Summary}

The research team collected, normalized, and compared whole building performance data for the Youngstown CT \& FB to industry baselines. The following table summarizes the annual performance data collected and normalized.

\begin{tabular}{|c|c|c|c|c|}
\hline Metrics & \multicolumn{2}{|c|}{ Annual Performance Measurements } & \multicolumn{2}{|l|}{ Annual Performance Metrics } \\
\hline & Water Use (gal) & 418,880 & Gallons per occupant & 1,727 \\
\hline & Process Water Use (gal) & 0 & Water Cost per occupant & $\$ 16.27$ \\
\hline & Outdoor Water Use (gal) & 0 & Gallons per GSF & 8.02 \\
\hline & Water Cost & $\$ 3,945$ & Water Cost per RSF & $\$ 0.09$ \\
\hline & Energy Star Score & 50 & Energy Use (kBTU) per GSF & 79 \\
\hline & Total Energy Use (kBtu) & $4,152,436$ & Energy Cost per RSF & $\$ 2.44$ \\
\hline & Energy Cost & $\$ 108,647$ & Building Emissions per Occupant $\left(\mathrm{MTCO}_{2} \mathrm{e}\right)$ & 2.64 \\
\hline & General Maintenance Cost & $\$ 124,875$ & General Maint Cost per RSF & $\$ 2.81$ \\
\hline & Janitorial Services Cost & $\$ 99,267$ & Janitorial Services Cost per RSF & $\$ 2.23$ \\
\hline & Grounds Maintenance Cost & $\$ 37,300$ & Grounds Maint Cost per RSF & $\$ 0.84$ \\
\hline & Quantity of Maint Requests & 232 & Ratio of Maint Regurests to Total Maint Johs & 020 \\
\hline & Quantity of Prev Maint Jobs & 579 & Katio or Maint Requests to lotal Maint joos & 0.29 \\
\hline & Solid Waste Generated (tons) & 17 & Solid Waste (lb) per occupant & 139 \\
\hline & Solid Waste Cost & $\$ 1,530$ & Solid Waste Cost per RSF & $\$ 0.03$ \\
\hline & Quantity Recycled (tons) & 28.80 & Solid Waste Cost per occupant & $\$ 6.31$ \\
\hline & Recycling Cost & $\$ 0$ & $\%$ Recycle of Total Waste Generation & $63 \%$ \\
\hline & $\begin{array}{l}\text { Survey \# of Invitees } \\
\text { Survey \# of Respondents (n) }\end{array}$ & 45 & Survey Return Rate & $62 \%$ \\
\hline & Commute Miles per occ (avg) & 29 & Commute Emmisions per occ $\left(\mathrm{MTCO}_{2} \mathrm{e}\right)$ & 1.78 \\
\hline & $\begin{array}{l}\text { \# of Occupants using mass transit/walk/bike } \\
\text { \# of Respondents to Commute Question }\end{array}$ & $\begin{array}{r}0 \\
28\end{array}$ & $\begin{array}{l}\% \text { of Occupants who commute using mass } \\
\text { transit, biking and/or walking }\end{array}$ & $0 \%$ \\
\hline
\end{tabular}




\section{Cape Girardeau Courthouse}

\section{Description}

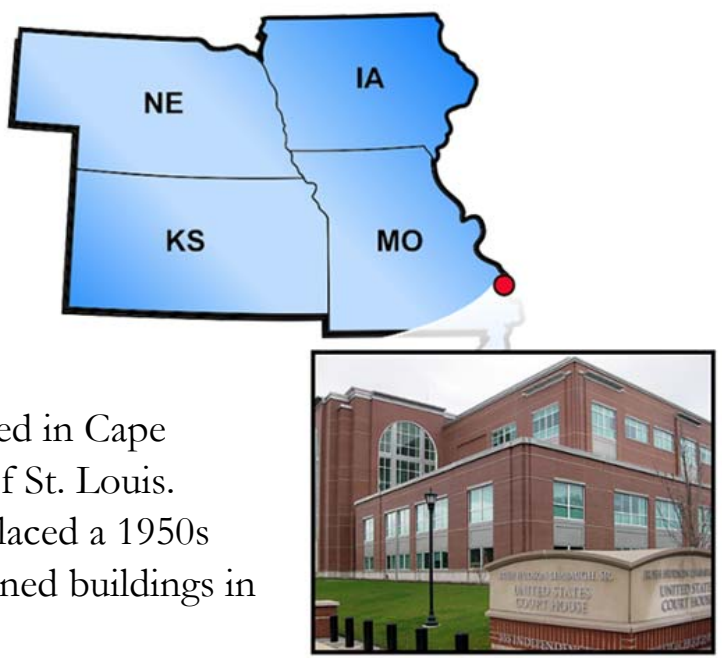

The Rush H. Limbaugh U.S. Courthouse is located in Cape Girardeau, Missouri, about 115 miles southeast of St. Louis. Completed in 2008, this LEED Silver facility replaced a 1950s era building and one of the first sustainably designed buildings in the area.

To increase the energy efficiency a $30 \%$ energy reduction from the ASHRAE 90.1-1999 standard was built into the design. Energy-efficient features of the building include occupancy sensors, daylight sensors, a white roof, Lighting Control System control of lighting, and Building Automation System (BAS) control of HVAC systems.

The building houses three courtrooms and sees a significant fluctuation in visitors depending on the need for those courtrooms.

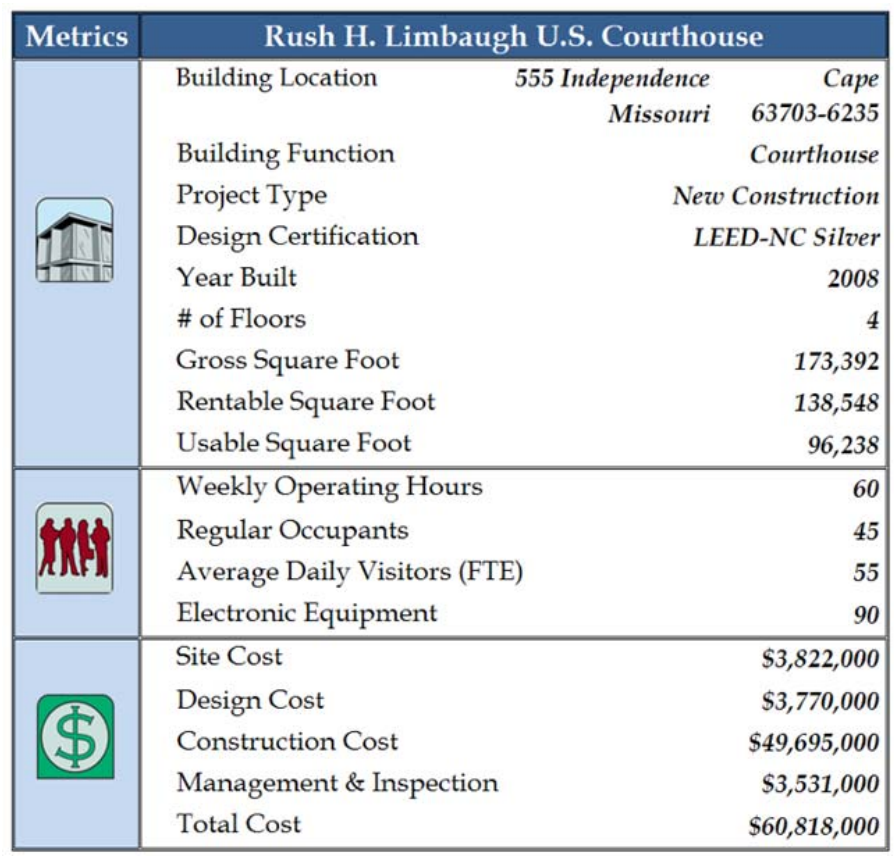

Cape Girardeau is a small town with a population of about 36,600 , and public transportation is not widely used.

The landscape includes a grassy area and small trees. An automatic irrigation system is in place that includes rain sensors and drip zones. Low flow fixtures add to the water efficiency of the building.

Each building in the study had operational highlights and potential opportunities for improvement. Although it was not the focus of this study to investigate and/or document operational highlights and opportunities, the research team observed:

- The automatic controls of the building are still being commissioned to ensure proper functionality. Once operating correctly, the lighting and HVAC controls in the courthouse offer opportunities for future energy reductions. 


\section{Certifications}

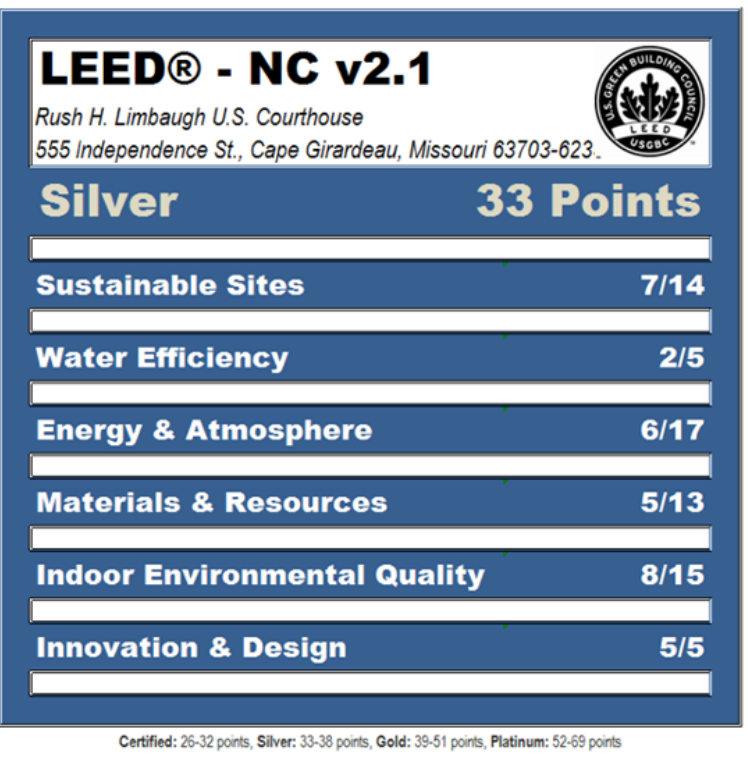

\section{Whole Building Performance}

The Limbaugh Courthouse operating costs are lower than the industry baseline for all metrics other than maintenance. The higher than average maintenance costs are attributed in part to flooding in the main atrium that occurred in the winter of 2008. Overall, the building costs less to operate than a baseline building.

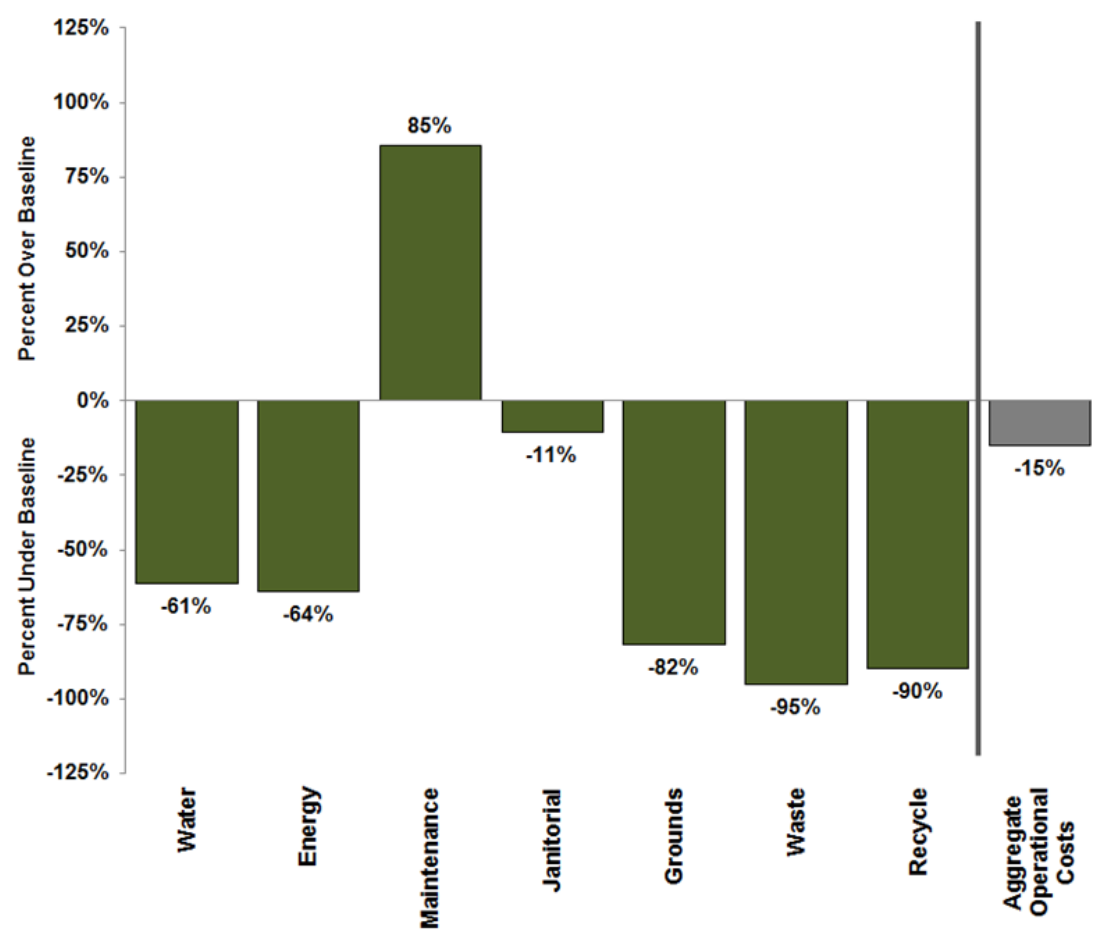




\section{Occupant Satisfaction Survey}

All of the 45 occupants in the Limbaugh Courthouse were surveyed and 26 responded. All of the main survey categories had positive average scores.

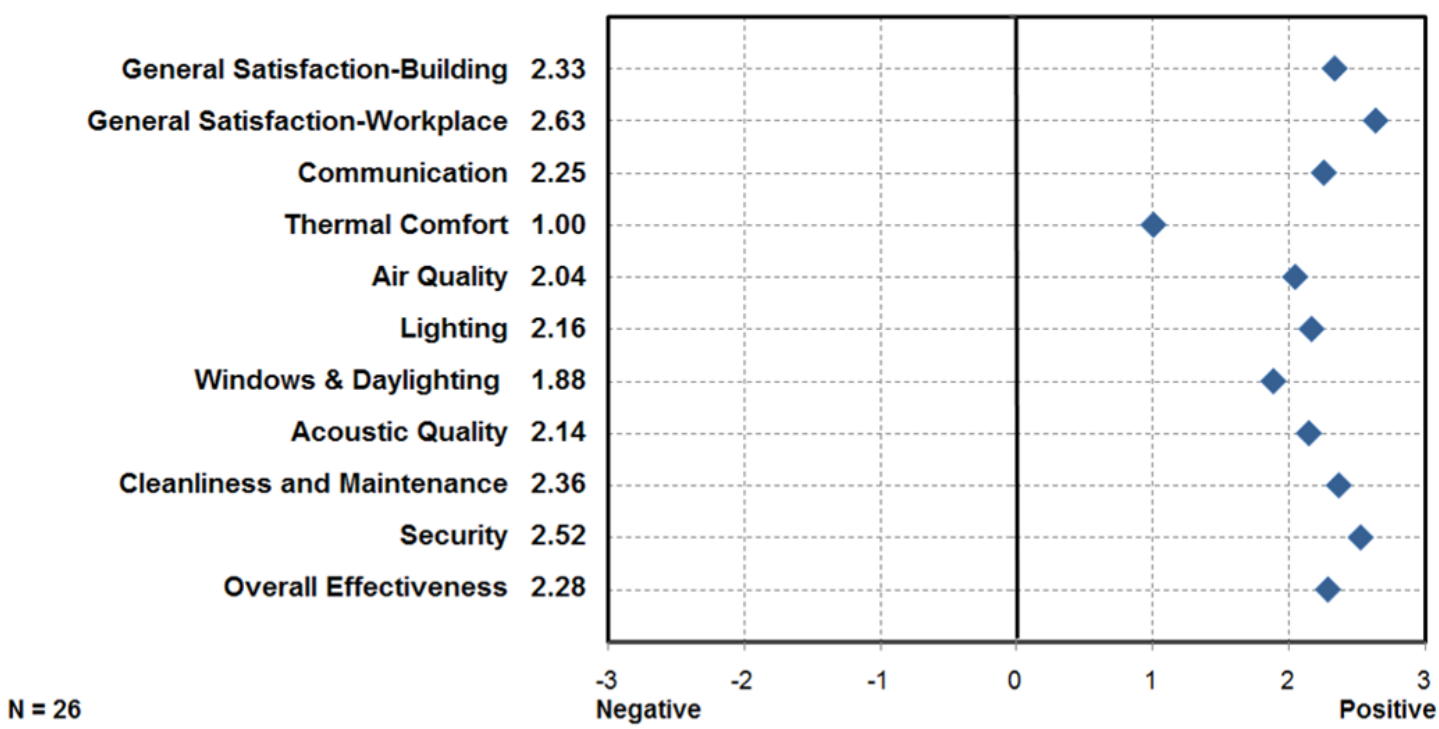

The results indicated that occupants of the Limbaugh Courthouse are more satisfied with their building than occupants in the CBE baseline ( $97^{\text {th }}$ percentile). In all of the key measurements - acoustic quality, air quality, cleanliness and maintenance, thermal comfort and lighting - Limbaugh occupants scored above the $90^{\text {th }}$ percentile of the CBE buildings surveyed.

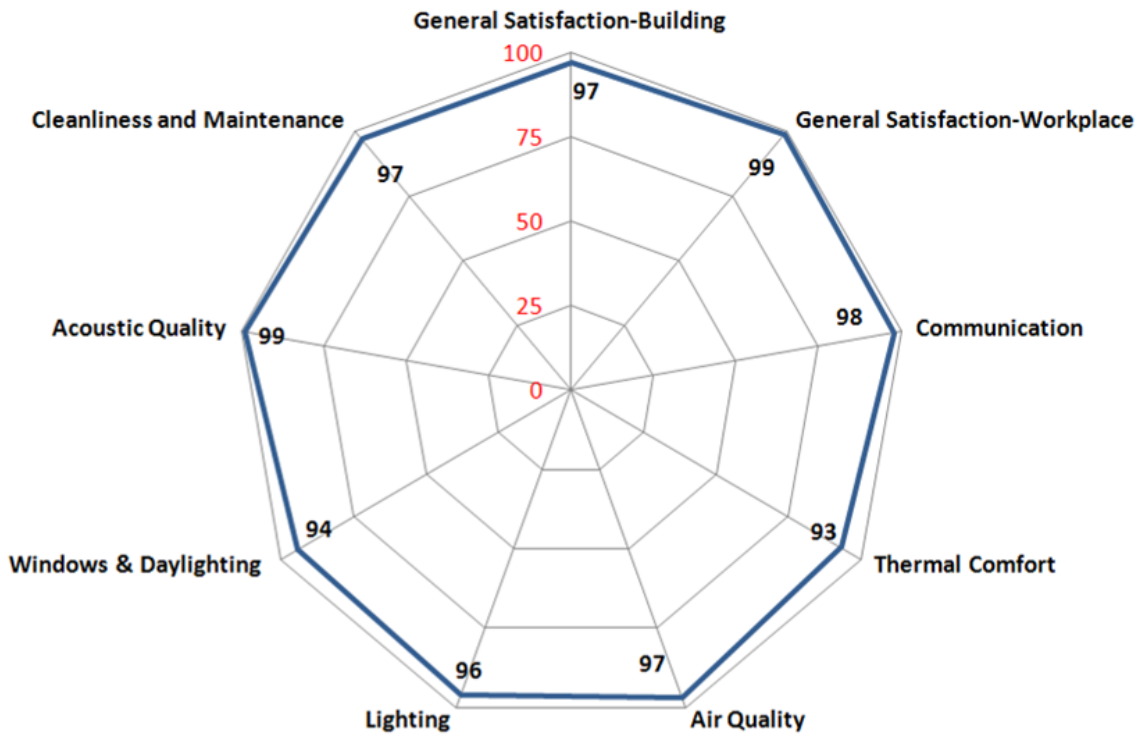




\section{Performance Data Summary}

The research team collected, normalized, and compared whole building performance data for the Rush H. Limbaugh Courthouse to industry baselines. The following table summarizes the annual performance data collected and normalized. The facility uses watercooled chillers for its air-conditioning system; therefore, the cooling tower water use was estimated using the "rule-of-thumb" that $27 \%$ of total water use is process water. Outdoor water use was estimated using the "rule-of-thumb" that $20 \%$ of total water used is for landscaping.

\begin{tabular}{|c|c|c|c|c|}
\hline Metrics & \multicolumn{2}{|c|}{ Annual Performance Measurements } & \multicolumn{2}{|l|}{ Annual Performance Metrics } \\
\hline & Water Use (gal) & 385,170 & Gallons per occupant & 2,041 \\
\hline & Process Water Use (gal) & 103,996 & Water Cost per occupant & $\$ 101.55$ \\
\hline & Outdoor Water Use (gal) & 77,034 & Gallons per GSF & 2.22 \\
\hline & Water Cost & $\$ 10,155$ & Water Cost per RSF & $\$ 0.07$ \\
\hline & Energy Star Score & 64 & Energy Use (kBTU) per GSF & 78 \\
\hline & Total Energy Use (kBtu) & $13,546,955$ & Energy Cost per RSF & $\$ 0.91$ \\
\hline & Energy Cost & $\$ 125,431$ & Building Emissions per Occupant $\left(\mathrm{MTCO}_{2} \mathrm{e}\right)$ & 23.62 \\
\hline & General Maintenance Cost & $\$ 411,651$ & General Maint Cost per RSF & $\$ 2.97$ \\
\hline & Janitorial Services Cost & $\$ 172,282$ & Janitorial Services Cost per RSF & $\$ 1.24$ \\
\hline & Grounds Maintenance Cost & $\$ 11,318$ & Grounds Maint Cost per RSF & $\$ 0.08$ \\
\hline & Quantity of Maint Requests & $N / A$ & & N/A \\
\hline & Quantity of Prev Maint Jobs & $N / A$ & Ratio of Maint Requests to lotal Maint Jobs & N/A \\
\hline & Solid Waste Generated (tons) & 2 & Solid Waste (lb) per occupant & 48 \\
\hline & Solid Waste Cost & $\$ 325$ & Solid Waste Cost per RSF & $\$ 0.00$ \\
\hline & Quantity Recycled (tons) & 0.33 & Solid Waste Cost per occupant & $\$ 3.25$ \\
\hline & Recycling Cost & $\$ 144$ & $\%$ Recycle of Total Waste Generation & $12 \%$ \\
\hline & $\begin{array}{l}\text { Survey \# of Invitees } \\
\text { Survey \# of Respondents (n) }\end{array}$ & $\begin{array}{l}45 \\
26\end{array}$ & Survey Return Rate & $58 \%$ \\
\hline & Commute Miles per occ (avg) & 41 & Commute Emmisions per occ $\left(\mathrm{MTCO}_{2} \mathrm{e}\right)$ & 1.47 \\
\hline & $\begin{array}{l}\text { \# of Occupants using mass transit/walk/bike } \\
\text { \# of Respondents to Commute Question }\end{array}$ & $\begin{array}{r}2 \\
26\end{array}$ & $\begin{array}{l}\% \text { of Occupants who commute using mass } \\
\text { transit, biking and/or walking }\end{array}$ & $8 \%$ \\
\hline
\end{tabular}




\section{Davenport Courthouse}

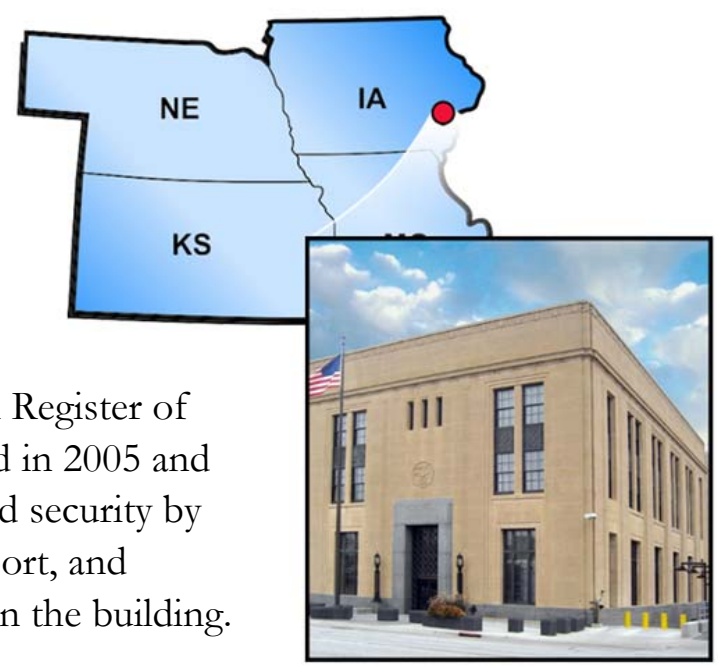

\section{Description}

The Davenport Courthouse is on the National Register of Historic Places. The renovation was completed in 2005 and increased the number of courtrooms, improved security by building new holding cells and a vehicle sally port, and updated the mechanical systems and controls in the building.

The remodel retained the historic integrity of the original the courtroom, the main lobby, staircases, windows, and hallways throughout the building.

\begin{tabular}{|c|c|c|c|}
\hline Metrics & \multicolumn{3}{|c|}{ Davenport U.S. Courthouse } \\
\hline & Building Location & $\begin{array}{r}131 \text { E. 4th Street } \\
\text { Iowa }\end{array}$ & $\begin{array}{r}\text { Davenport } \\
52801-1516\end{array}$ \\
\hline & Building Function & & Courthouse \\
\hline & Project Type & & Renovation \\
\hline & Design Certification & LEED-1 & C Registered \\
\hline & Year Built & & 1933 \\
\hline & \# of Floors & & 4 \\
\hline & Gross Square Foot & & 79,872 \\
\hline & Rentable Square Foot & & 68,391 \\
\hline & Usable Square Foot & & 48,836 \\
\hline & Weekly Operating Hours & & 70 \\
\hline & Regular Occupants & & 45 \\
\hline & Average Daily Visitors (FTE) & & 18 \\
\hline & Electronic Equipment & & 60 \\
\hline & Site Cost & & N/A \\
\hline & Design Cost & & N/A \\
\hline & Construction Cost & & N/A \\
\hline & Management \& Inspection & & N/A \\
\hline & Total Cost & & $\$ 20,000,000$ \\
\hline
\end{tabular}

The new courtrooms incorporate daylighting and the mechanical systems use variable frequency drives. The HVAC system consists of water-cooled chillers, boilers, and air handling units. The mailroom was specifically remodeled with high-efficiency particulate air filters for HAZMAT purposes.

Each building in the study had operational highlights and potential opportunities for improvement. Although it was not the focus of this study to investigate and/or document operational highlights and opportunities, the research

team observed the following:

- Two third-party commissioning studies have been performed at the Davenport Courthouse to investigate operational challenges related to the mechanical equipment. Reevaluating the energy performance, maintenance costs, and occupant satisfaction following the implementation of the studies' recommendations would offer tangible evidence of the impact.

- Mechanical equipment is difficult to access. Future Federal design projects should carefully evaluate mechanical room space to enable easy access for maintenance. 
- Based on the CBE survey results and site visit, it appears that issues exist with lighting, acoustics, and some security features. Interviews of the occupants and design team regarding these issues may result in a more detailed understanding of how future designs might be adjusted to improve occupant satisfaction.

\section{Certifications}

\section{LEED-NC Registered}

\section{Whole Building Performance}

The Davenport Courthouse operating costs are lower than the industry baseline for water, energy, grounds, and waste costs. The general maintenance, and janitorial costs are higher the industry baseline. Overall, the building costs less to operate than a baseline building. Because parts of the facility are still original (dating back to 1933) and the building flooded in April 2006, maintenance and janitorial cost could be expected to be more than industry baseline.

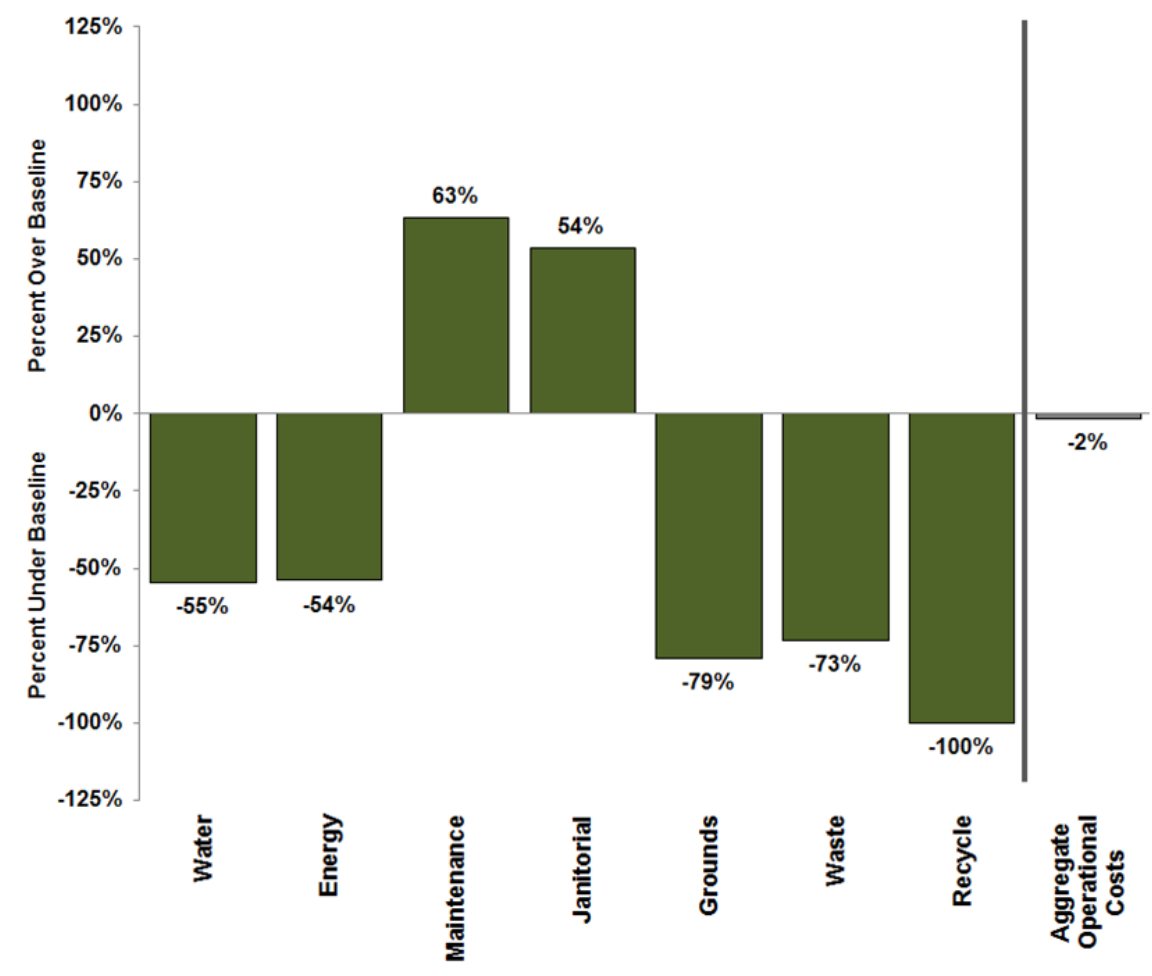




\section{Occupant Satisfaction Survey}

All 45 of the Davenport Federal Building occupants were surveyed and 22 responded. All of the main survey categories had positive average scores.

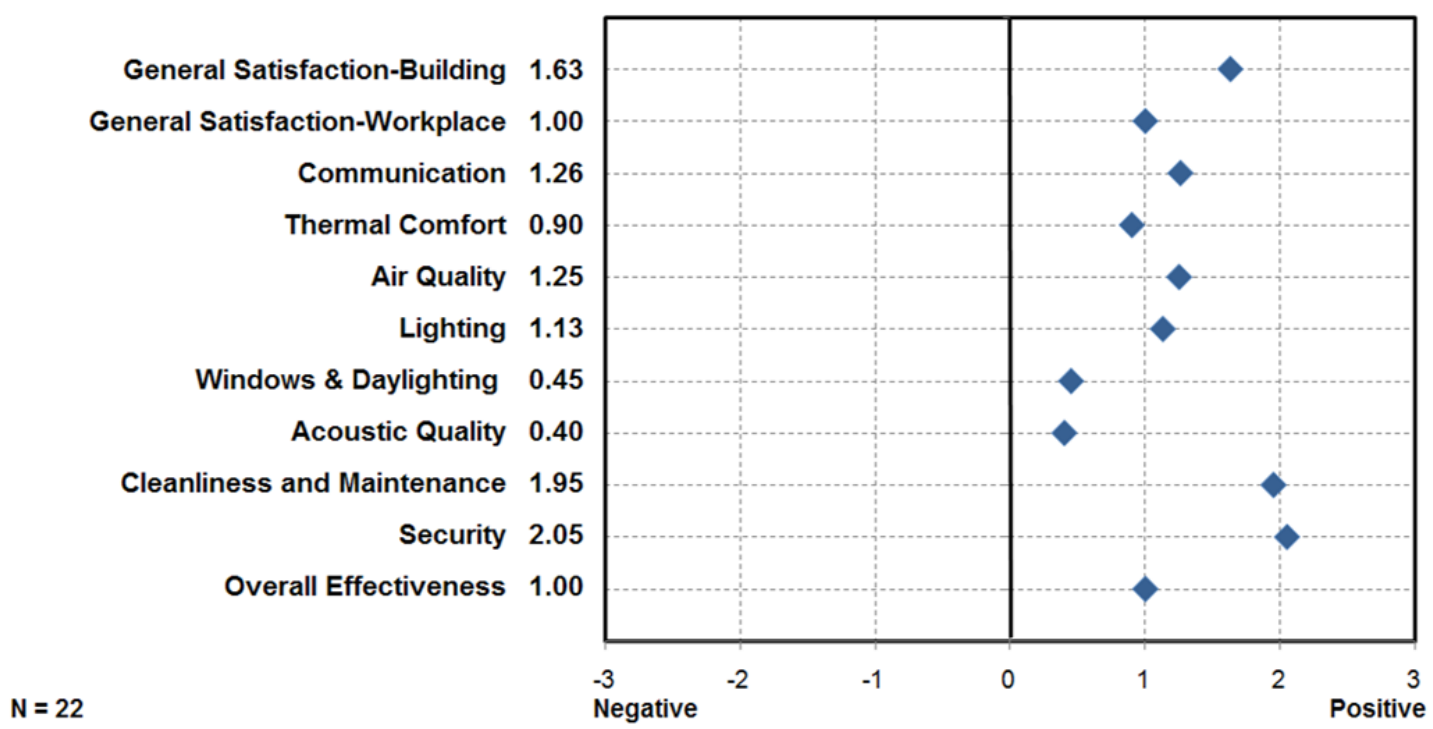

The results indicated that the occupants of the Davenport Courthouse are generally more satisfied with their building than occupants in the CBE baseline ( $77^{\text {th }}$ percentile). Lighting quality, general satisfaction with the workplace, and windows and daylighting scored below the $50^{\text {th }}$ percentile of the CBE buildings surveyed. Acoustic quality, thermal comfort, cleanliness and maintenance, and air quality all scored above the $50^{\text {th }}$ percentile.

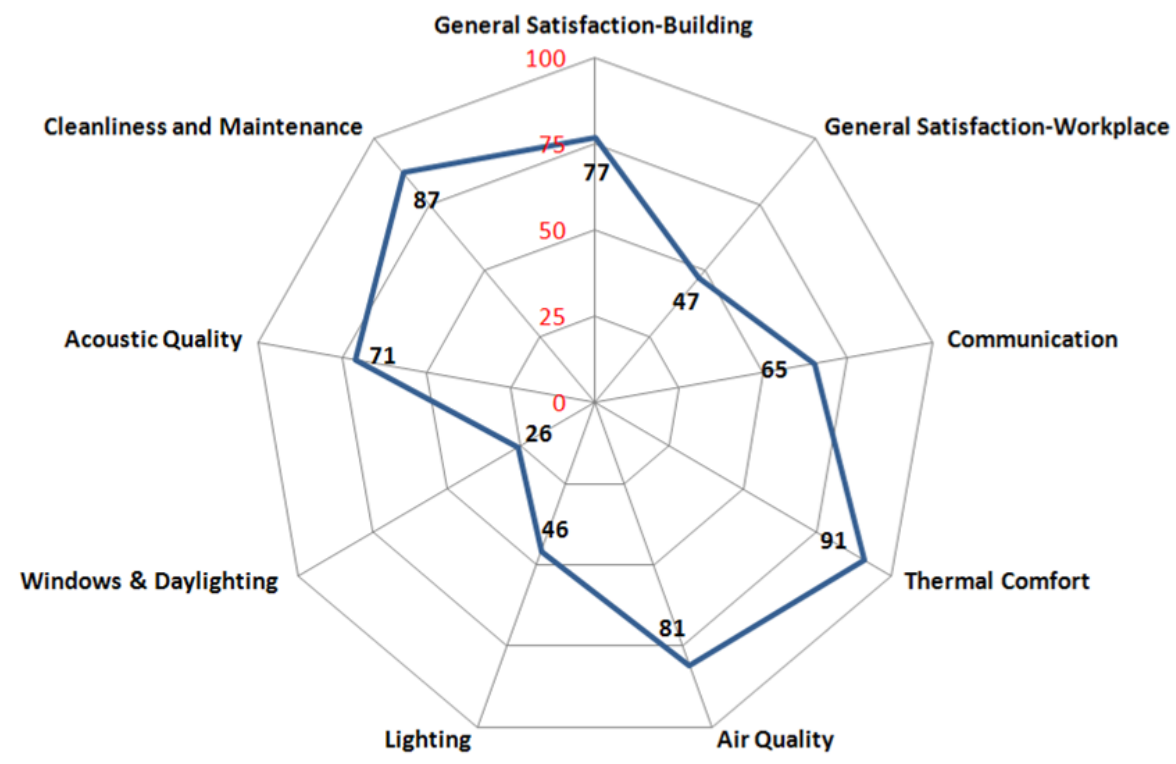




\section{Performance Data Summary}

The research team collected, normalized, and compared whole building performance data for the Davenport Courthouse to industry baselines. The following table summarizes the annual performance data collected and normalized. The facility uses water-cooled chillers for its air-conditioning system; therefore, the cooling tower water use was estimated using the "rule-of-thumb" that $27 \%$ of total water use is process water.

\begin{tabular}{|c|c|c|c|c|}
\hline \multirow[t]{2}{*}{ Metrics } & \multicolumn{2}{|c|}{ Annual Performance Measurements } & \multicolumn{2}{|l|}{ Annual Performance Metrics } \\
\hline & Water Use (gal) & 530,250 & Gallons per occupant & 6,144 \\
\hline & Process Water Use (gal) & 143,168 & Water Cost per occupant & $\$ 93.65$ \\
\hline & Outdoor Water Use (gal) & 0 & Gallons per GSF & 6.64 \\
\hline & Water Cost & $\$ 5,900$ & Water Cost per RSF & $\$ 0.09$ \\
\hline & Energy Star Score & 80 & Energy Use (kBTU) per GSF & 65 \\
\hline & Total Energy Use (kBtu) & $5,193,993$ & Energy Cost per RSF & $\$ 1.16$ \\
\hline & Energy Cost & $\$ 79,627$ & Building Emissions per Occupant $\left(\mathrm{MTCO}_{2} \mathrm{e}\right)$ & 13.22 \\
\hline & General Maintenance Cost & $\$ 179,011$ & General Maint Cost per RSF & $\$ 2.62$ \\
\hline & Janitorial Services Cost & $\$ 145,990$ & Janitorial Services Cost per RSF & $\$ 2.13$ \\
\hline & Grounds Maintenance Cost & $\$ 6,421$ & Grounds Maint Cost per RSF & $\$ 0.09$ \\
\hline & Quantity of Maint Requests & 520 & Ratio of Maint Requests to Total Maint Jobs & 0.31 \\
\hline & Quantity of Prev Maint Jobs & 1,179 & Ratio of Maint Requests to Iotal Maint jobs & 0.31 \\
\hline & Solid Waste Generated (tons) & 59 & Solid Waste (lb) per occupant & 1886 \\
\hline & Solid Waste Cost & $\$ 907$ & Solid Waste Cost per RSF & $\$ 0.01$ \\
\hline & Quantity Recycled (tons) & 2.40 & Solid Waste Cost per occupant & $\$ 14.39$ \\
\hline & Recycling Cost & $\$ 0$ & $\%$ Recycle of Total Waste Generation & $4 \%$ \\
\hline & $\begin{array}{l}\text { Survey \# of Invitees } \\
\text { Survey \# of Respondents (n) }\end{array}$ & $\begin{array}{l}36 \\
22\end{array}$ & Survey Return Rate & $61 \%$ \\
\hline & Commute Miles per occ (avg) & 27 & Commute Emmisions per occ $\left(\mathrm{MTCO}_{2} \mathrm{e}\right)$ & 2.85 \\
\hline 8 & $\begin{array}{l}\text { \# of Occupants using mass transit/walk/bike } \\
\text { \# of Respondents to Commute Question }\end{array}$ & $\begin{array}{r}0 \\
22\end{array}$ & $\begin{array}{l}\% \text { of Occupants who commute using mass } \\
\text { transit, biking and/or walking }\end{array}$ & $0 \%$ \\
\hline
\end{tabular}




\section{Manhattan Federal Building}

\section{Description}

The USDA Service Center in was completed in 2006 and is the smallest building in the study. Some of the energy-efficiency features in the building include a well-insulated white roof, efficient lighting, heat recovery, and occupancy sensors.

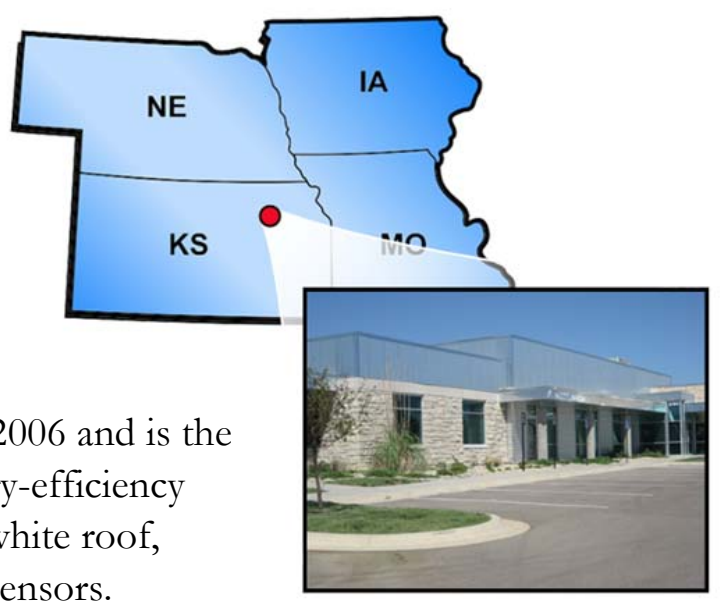

The landscape includes low water buffalo grass with native prairie grasses around the perimeter of the parking lot. There have been challenges with erosion of the buffalo grass

\begin{tabular}{|c|c|c|}
\hline Metrics & \multicolumn{2}{|c|}{ USDA Service Center } \\
\hline & Building Location & $\begin{aligned} 3705 \text { Miller } & \text { Manhattan } \\
\text { Kansas } & 66503-7600\end{aligned}$ \\
\hline & Building Function & Federal Building \\
\hline & Project Type & New Construction \\
\hline & Design Certification & LEED-NC Silver \\
\hline 14 & Year Built & 2006 \\
\hline & \# of Floors & 1 \\
\hline & Gross Square Foot & 13,500 \\
\hline & Rentable Square Foot & 12,262 \\
\hline & Usable Square Foot & 10,800 \\
\hline & Weekly Operating Hours & 60 \\
\hline & Regular Occupants & 28 \\
\hline & Average Daily Visitors (FTE) & 2 \\
\hline & Electronic Equipment & 35 \\
\hline & Site Cost & $\$ 361,333$ \\
\hline & Design Cost & N/A \\
\hline & Construction Cost & $\$ 1,989,400$ \\
\hline & Management \& Inspection & . \\
\hline & Total Cost & $\$ 2,350,733$ \\
\hline
\end{tabular}
and invasive weeds in the prairie. The buffalo grass has been reseeded several times. Some green cleaning products are being used, but not all products would have been considered "green." The building has a waterless urinal and low flow fixtures.

Each building in the study had operational highlights and potential opportunities for improvement. Although it was not the focus of this study to investigate and/or document operational highlights and opportunities, the research team observed the following:

- High levels of humidity were cited as a frequent complaint of the occupants. The set-back on the system had been overridden to condition the space during unoccupied hours. Building management has a contract in place to modify the HVAC system to address these problems. Recommissiong of the HVAC equipment and controls is recommended after modifications are complete.

- During the site visit, researchers noticed that the occupants had their shades closed to control for glare from the windows. Most of the lights were on in these spaces, not taking full advantage of the daylighting. Building management may want to consider installing shading devices that allow some of the light through the material. 


\section{Certifications}

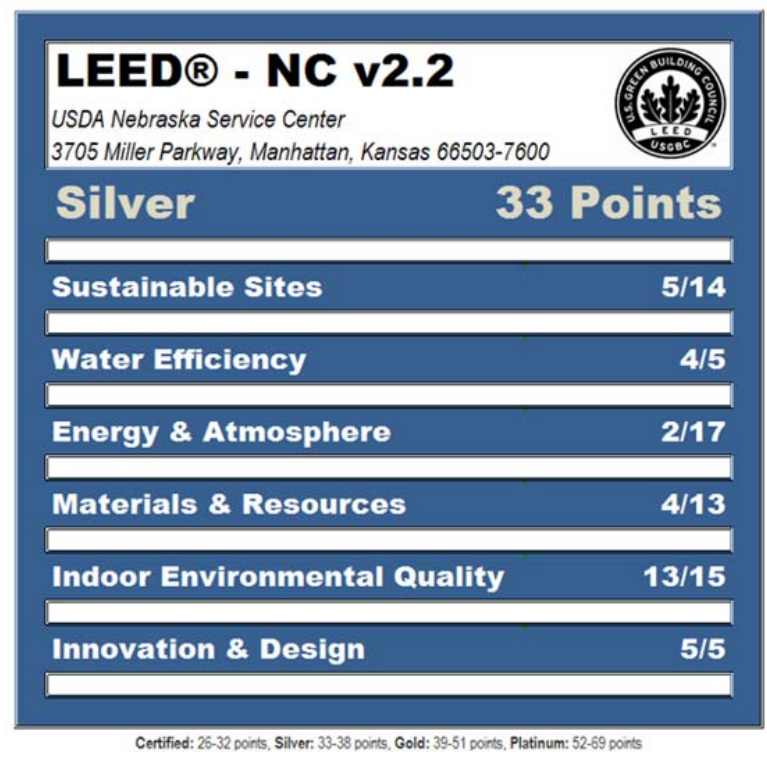

\section{Whole Building Performance}

The USDA Service Center operating costs are lower than the industry baseline for water, energy, general maintenance, and janitorial costs. The grounds maintenance, waste, and recycling costs are higher than the industry baseline. Overall, the building costs less to operate than a baseline building.

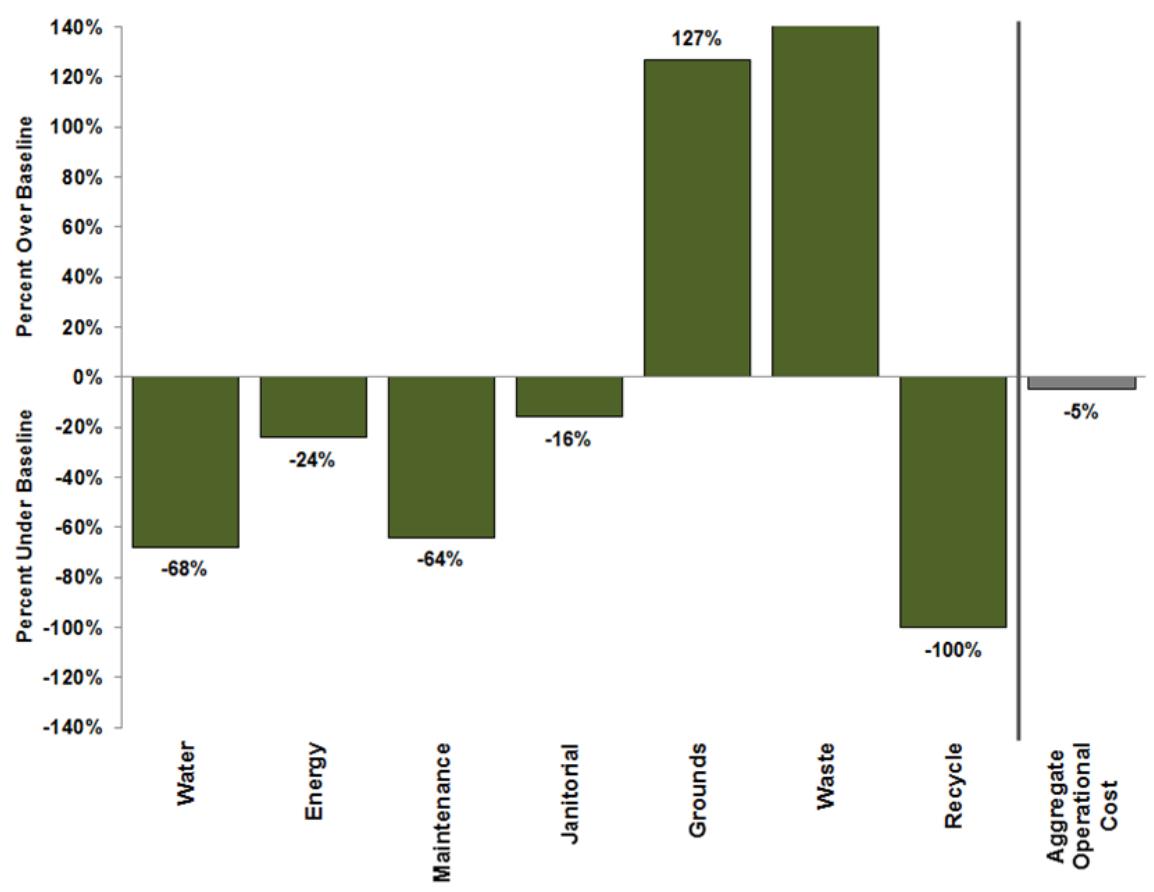




\section{Occupant Satisfaction Survey}

Occupants in the USDA Service Center occupants were surveyed by GSA in 2006 and 13 responded. A comparison of questions between the GSA survey and the CBE survey was made, and for available categories the values were translate to the $\mathrm{CBE}$ scale and are shown below.

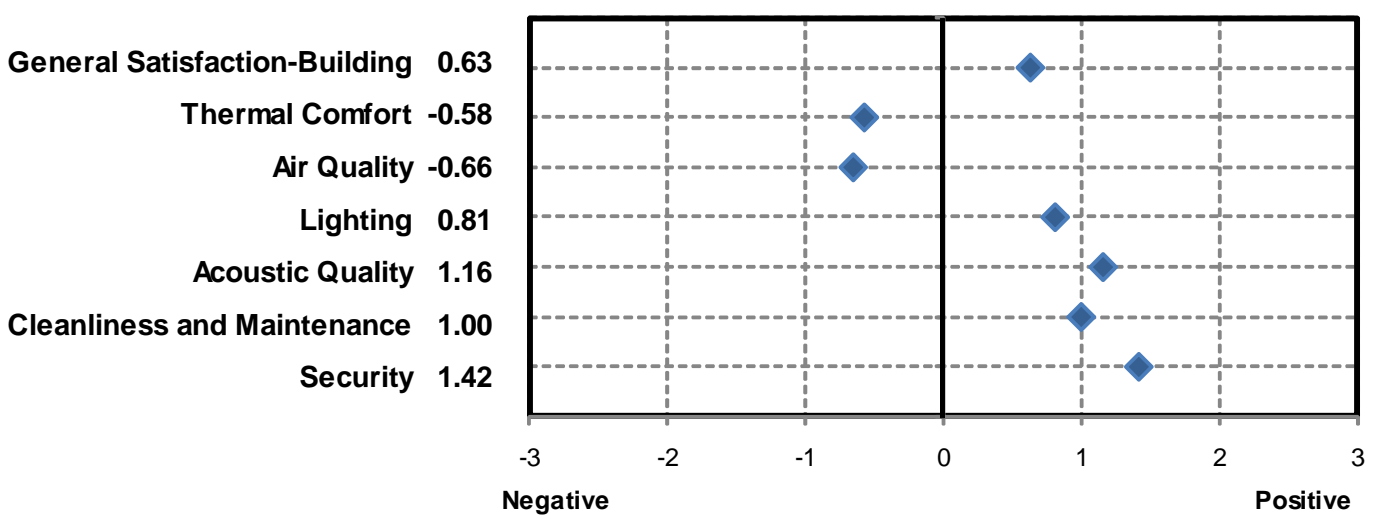

The results indicated that the occupants of the USDA Service Center occupants are generally less satisfied with their building than occupants in the CBE baseline ( $31^{\text {st }}$ percentile). Thermal comfort, cleanliness and maintenance, air quality, lighting quality, and general satisfaction scored below the $50^{\text {th }}$ percentile of the CBE buildings surveyed. Acoustic quality scored in the $90^{\text {th }}$ percentile, one of the highest scoring buildings in the study.

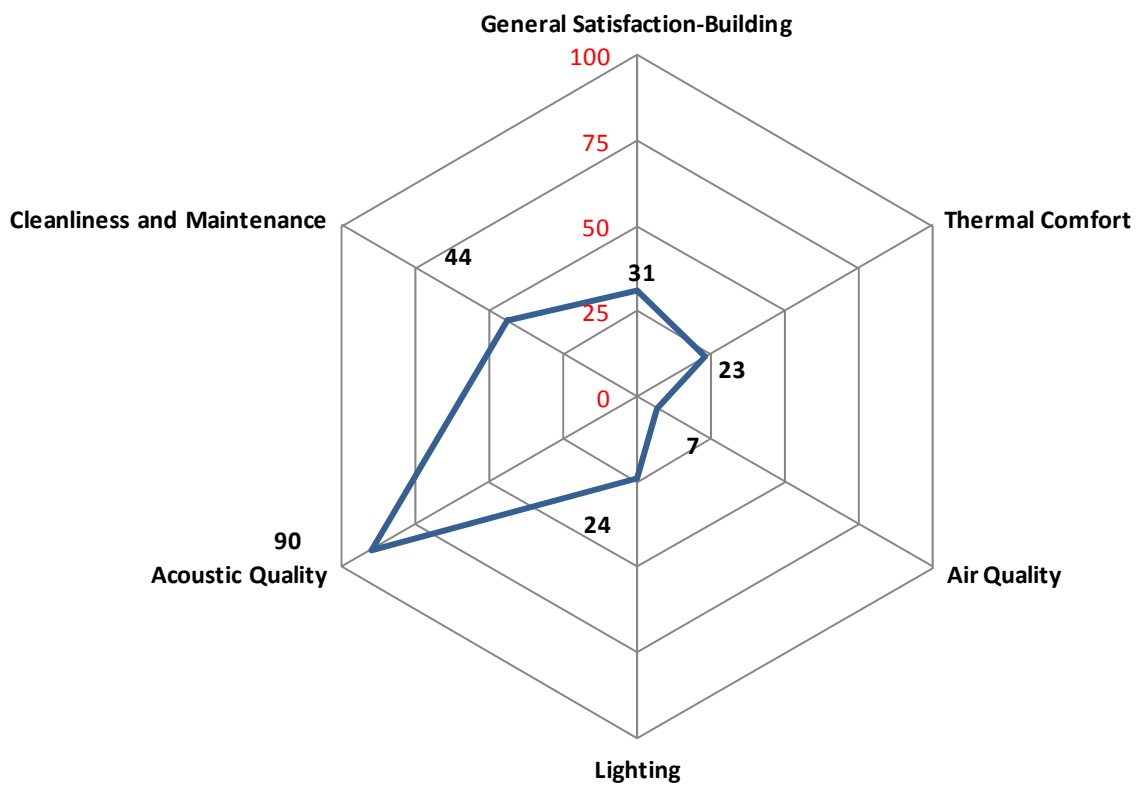




\section{Performance Data Summary}

The research team collected, normalized, and compared whole building performance data for the USDA Service Center to industry baselines. The following table summarizes the annual performance data collected and normalized.

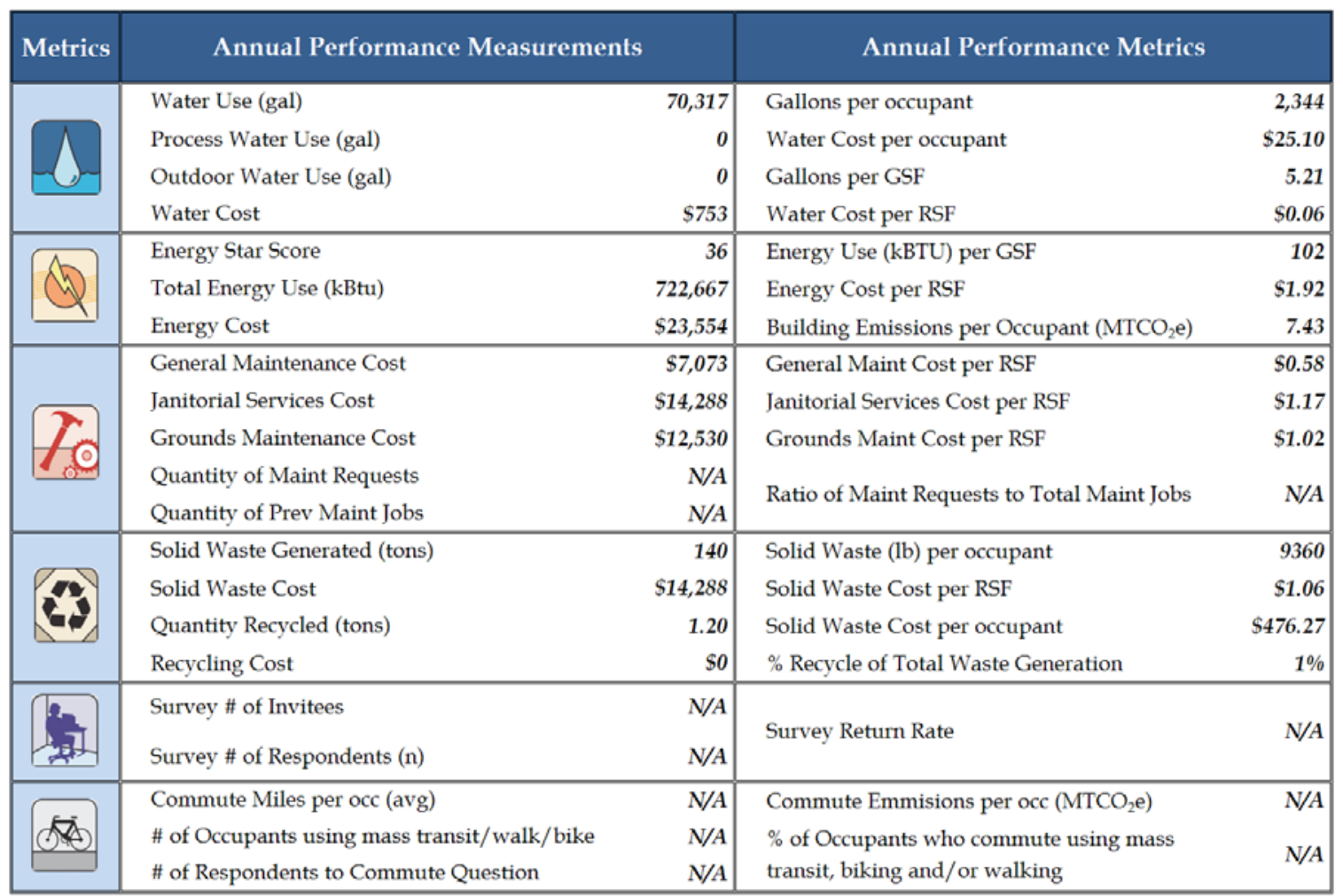




\section{Omaha DHS Federal Building}

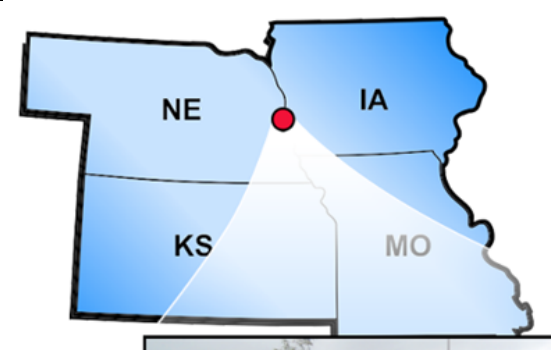

\section{Description}

The Omaha Department of Homeland Security (DHS)

Federal Building was designed to accommodate the varying needs of multiple DHS agencies and is the central facility for all immigration services.

The LEED Gold certified building uses a ground

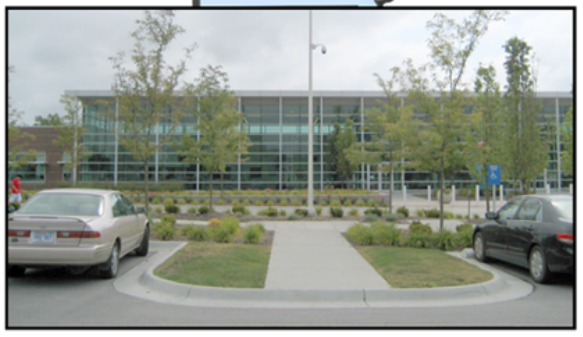
source heat pump system, and in combination with the building envelope and daylightharvesting system, the building energy model predicted a 66\% energy reduction over ASHRAE 90.1-1999. Water efficiency features include a rainwater-harvesting system, and low-flow and auto-flow lavatory fixtures. The building recently won the 2007 American Council of Engineering Award for its design.

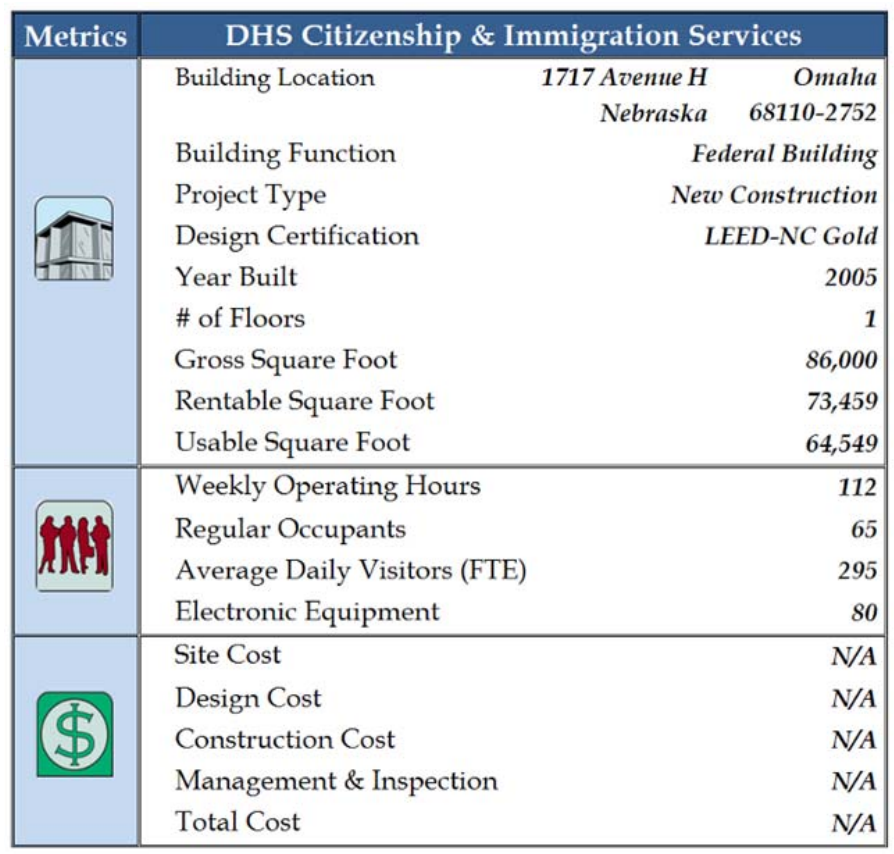

The majority of the building square footage is devoted to detention, courthouse, public, or unoccupied space. The occupied office portion of the building consumes approximately $40 \%$ of the gross square footage.

Each building in the study had operational highlights and potential opportunities for improvement. Although it was not the focus of this study to investigate and/or document operational highlights and opportunities, the research team observed:

- Erosion from the construction fill and clogged filters from the roof runoff have resulted in maintenance challenges with the rainwater-harvesting system.

Investigating strategies to address the current issues and communicating the lessons learned from this operations challenge will improve future implementations.

- The ground source heat pump system (GSHP) is innovative as well, resulting in a low energy use intensity for the building. Connecting the high level of satisfaction with the building's thermal comfort $\left(89^{\text {th }}\right.$ percentile on the CBE Survey) enhances 
that success. Communicating this operational success improves the chances of the GSHP technology being implemented effectively on future building projects.

\section{Certifications}

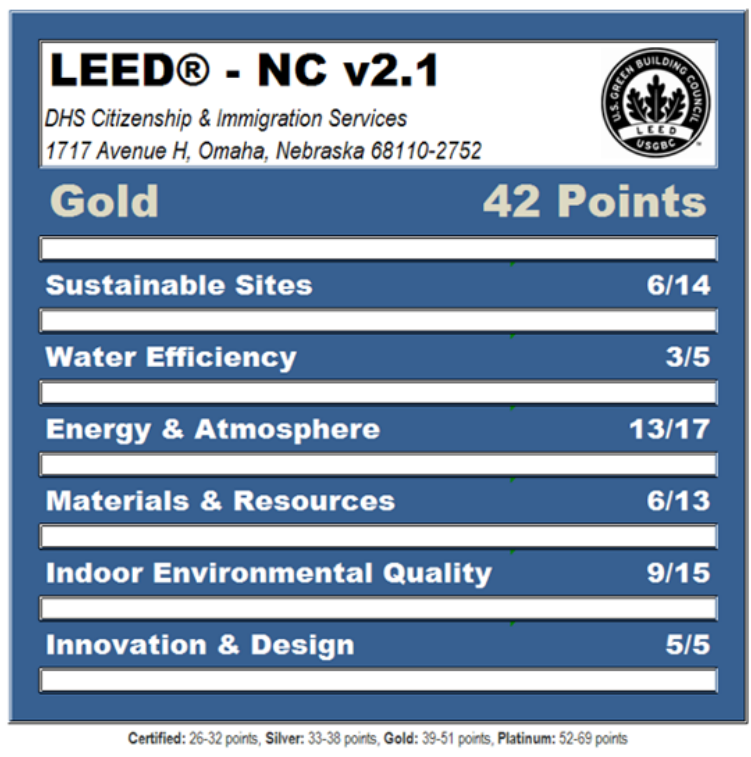

\section{Whole Building Performance}

The Omaha DHS Federal Building operating costs are lower than the industry baseline for all key metrics.

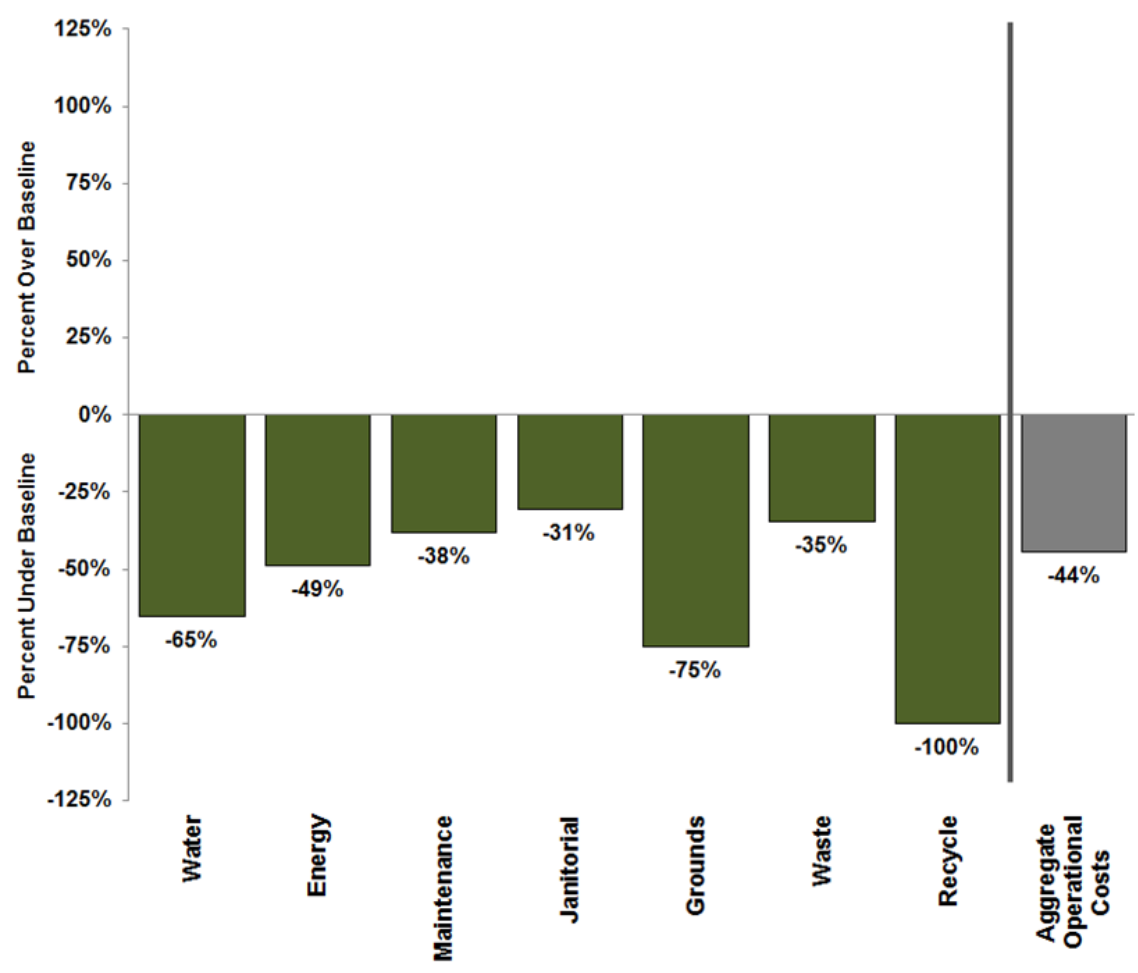




\section{Occupant Satisfaction Survey}

Of the 65 regular occupants in the Omaha DHS Federal Building, 18 were surveyed and 16 responded. It is unknown why such a small percentage of the occupants were invited to take the survey.

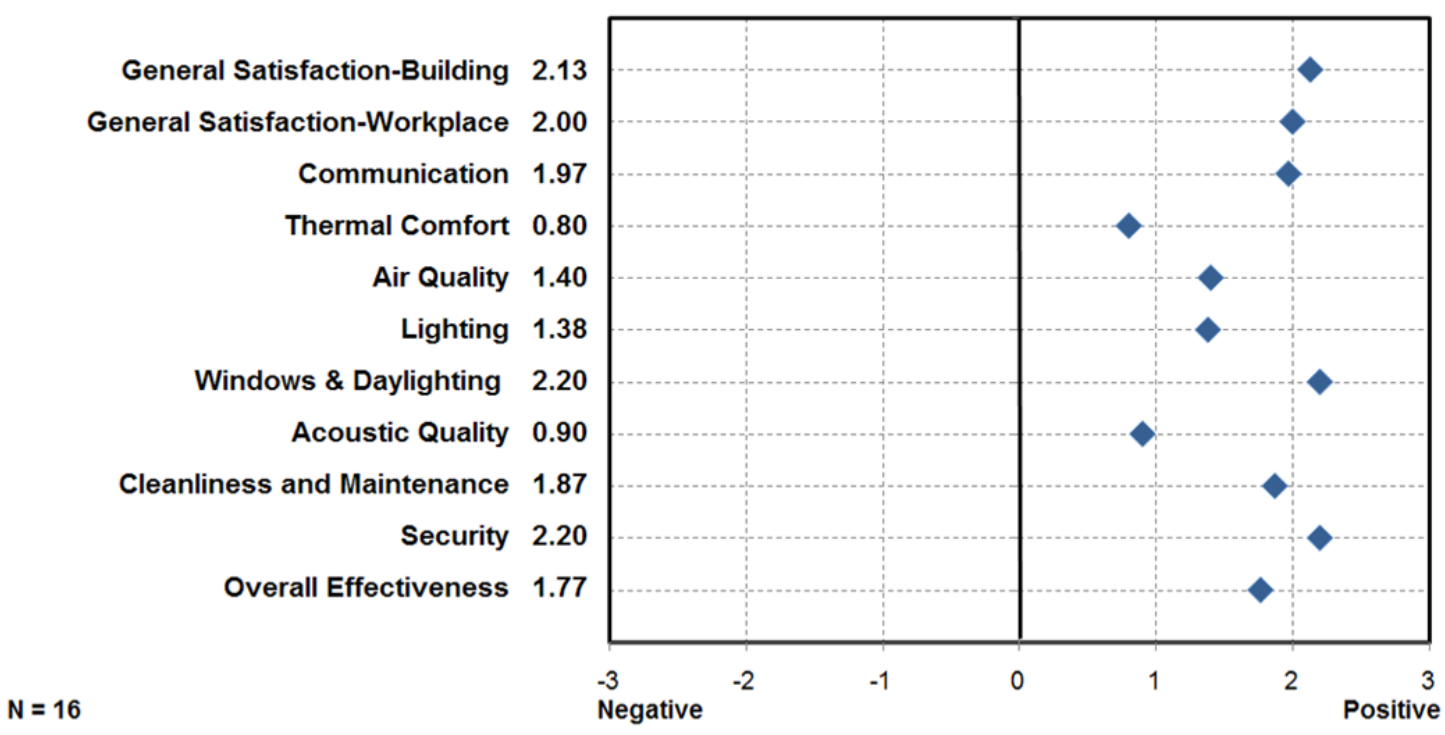

The survey results indicated that building occupants are significantly more satisfied with their building than occupants in the CBE baseline $\left(95^{\text {th }}\right.$ percentile). Acoustic quality, air quality, cleanliness and maintenance, and thermal comfort scored in the $80^{\text {th }}$ percentile or above. Occupant satisfaction with lighting scored in the $65^{\text {th }}$ percentile, which is in the top half of the buildings in this study.

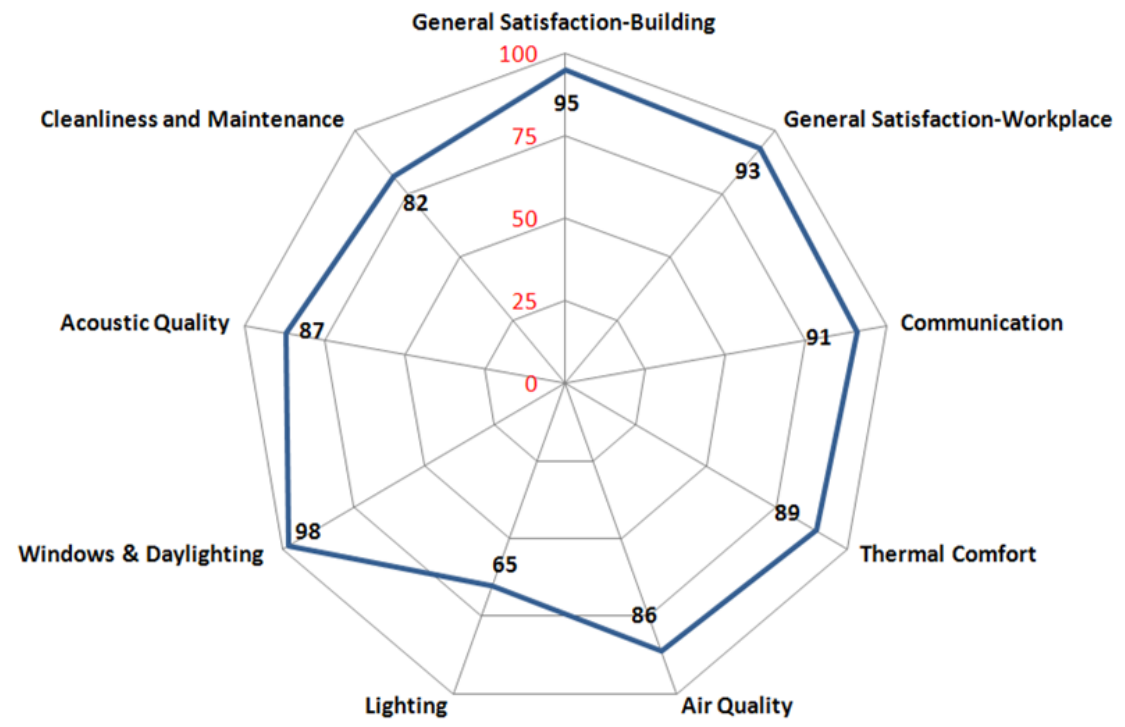




\section{Performance Data Summary}

The research team collected, normalized, and compared the whole building performance data for the Omaha DHS Federal Building to industry baselines. The following table summarizes the annual performance data that were collected and normalized. The rainwater-harvesting system that was intended for landscaping and nonpotable water use, was not functioning properly at the time of the site visit. No outdoor potable water use was estimated because researchers assumed that the system was functioning during the period of time that water use data were collected and that the system would be repaired.

\begin{tabular}{|c|c|c|c|c|}
\hline Metrics & \multicolumn{2}{|c|}{ Annual Performance Measurements } & \multicolumn{2}{|l|}{ Annual Performance Metrics } \\
\hline & Water Use (gal) & $2,252,228$ & Gallons per occupant & 6,256 \\
\hline & Process Water Use (gal) & 0 & Water Cost per occupant & $\$ 13.42$ \\
\hline & Outdoor Water Use (gal) & 0 & Gallons per GSF & 26.19 \\
\hline & Water Cost & $\$ 4,831$ & Water Cost per RSF & $\$ 0.07$ \\
\hline & Energy Star Score & 74 & Energy Use (kBTU) per GSF & 57 \\
\hline & Total Energy Use (kBtu) & $4,923,107$ & Energy Cost per RSF & $\$ 1.29$ \\
\hline & Energy Cost & $\$ 95,017$ & Building Emissions per Occupant $\left(\mathrm{MTCO}_{2} \mathrm{e}\right)$ & 3.33 \\
\hline & General Maintenance Cost & $\$ 72,632$ & General Maint Cost per RSF & $\$ 0.99$ \\
\hline & Janitorial Services Cost & $\$ 70,800$ & Janitorial Services Cost per RSF & $\$ 0.96$ \\
\hline & Grounds Maintenance Cost & $\$ 8,200$ & Grounds Maint Cost per RSF & $\$ 0.11$ \\
\hline & Quantity of Maint Requests & 260 & Ratio of Maint Requests to Total Maint Jobs & 0.35 \\
\hline & Quantity of Prev Maint Jobs & 482 & 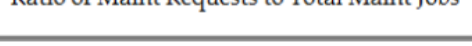 & \\
\hline & Solid Waste Generated (tons) & 113 & Solid Waste (lb) per occupant & 625 \\
\hline & Solid Waste Cost & $\$ 2,400$ & Solid Waste Cost per RSF & $\$ 0.03$ \\
\hline & Quantity Recycled (tons) & 23.53 & Solid Waste Cost per occupant & $\$ 6.67$ \\
\hline & Recycling Cost & $\$ 0$ & $\%$ Recycle of Total Waste Generation & $17 \%$ \\
\hline & $\begin{array}{l}\text { Survey \# of Invitees } \\
\text { Survey \# of Respondents (n) }\end{array}$ & $\begin{array}{l}18 \\
16\end{array}$ & Survey Return Rate & $89 \%$ \\
\hline & Commute Miles per occ (avg) & 30 & Commute Emmisions per occ $\left(\mathrm{MTCO}_{2} \mathrm{e}\right)$ & 2.09 \\
\hline & $\begin{array}{l}\text { \# of Occupants using mass transit/walk/bike } \\
\text { \# of Respondents to Commute Question }\end{array}$ & $\begin{array}{r}0 \\
16\end{array}$ & $\begin{array}{l}\% \text { of Occupants who commute using mass } \\
\text { transit, biking and/or walking }\end{array}$ & $0 \%$ \\
\hline
\end{tabular}




\section{Omaha NPS Federal Building Description}

The Carl T. Curtis Midwest Regional National Park Service (NPS) Headquarters Federal Building in Omaha was built on a brownfield as part of an urban redevelopment effort. This LEED Gold-certified building uses passive solar design; daylighting for $75 \%$ of building occupants; daylight harvesting; lightshelves; high-efficiency windows; heating, ventilation, and air-

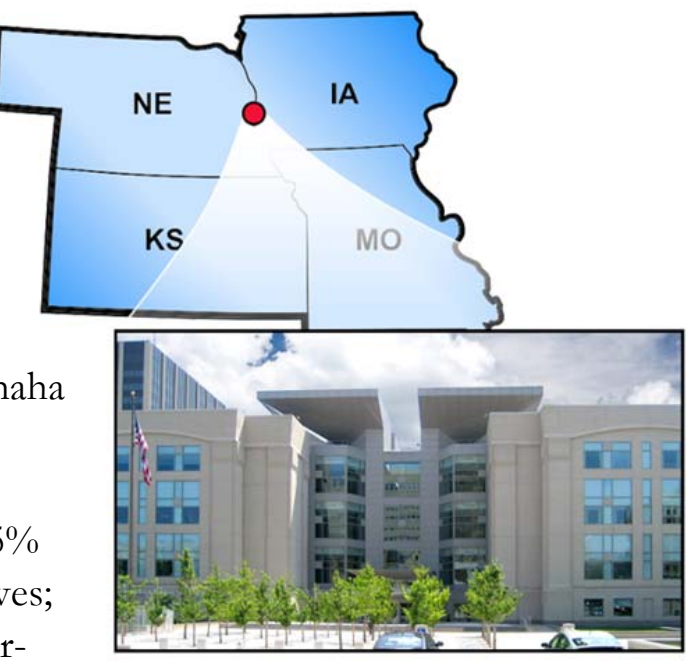
conditioning (HVAC) occupancy sensors; and underfloor air distribution. Use of native and adaptive vegetation eliminated the need for irrigation water, and use of a composting toilet, waterless urinals, low-flow fixtures, and water-efficient appliances resulted in a projected reduction of $39 \%$ of potable water use.

\begin{tabular}{|c|c|c|}
\hline Metrics & \multicolumn{2}{|c|}{ Carl T. Curtis NPS Midwest Regional Headquarters } \\
\hline & Building Location & $\begin{array}{rr}\text { 601 Riverfront } & \text { Omaha } \\
\text { Nebraska } & 68102-4226\end{array}$ \\
\hline & Building Function & Federal Building \\
\hline & Project Type & New Construction \\
\hline & Design Certification & LEED-NC Gold \\
\hline 1017 & Year Built & 2004 \\
\hline & \# of Floors & 3 \\
\hline & Gross Square Foot & 68,000 \\
\hline & Rentable Square Foot & 62,772 \\
\hline & Usable Square Foot & 0 \\
\hline & Weekly Operating Hours & 70 \\
\hline & Regular Occupants & 125 \\
\hline & Average Daily Visitors (FTE) & 9 \\
\hline & Electronic Equipment & 140 \\
\hline & Site Cost & N/A \\
\hline & Design Cost & N/A \\
\hline & Construction Cost & $\$ 8,500,000$ \\
\hline & Management \& Inspection & $N / A$ \\
\hline & Total Cost & $\$ 27,864,000$ \\
\hline
\end{tabular}

The building occupants are aware of the "green" building features and were involved in selecting the office furniture. To minimize materials during construction, the building has exposed concrete interior walls and beams. Operation of the facility incorporates green janitorial practices.

Each building in the study had operational highlights and potential opportunities for improvement. Although it was not the focus of this study to investigate and/or document operational highlights

and opportunities, the research team observed the following:

- The acoustic quality CBE score for the Omaha NPS was the lowest of all the buildings in the study and well below the average building at the $8^{\text {th }}$ percentile. In an open office layout, it is important to offer small meeting spaces for staff to schedule and conduct impromptu meetings. Identifying opportunities to increase alternative locations for staff to convene and investigating sound-masking technologies may improve the occupants' perception of the building's acoustic quality.

- Although considerable thought went into the daylighting design features, the CBE survey lighting score was below the $50^{\text {th }}$ percentile. Interviews of the occupants 
regarding these issues may result in a more detailed understanding of how operations might be adjusted to improve occupant satisfaction.

\section{Certifications}

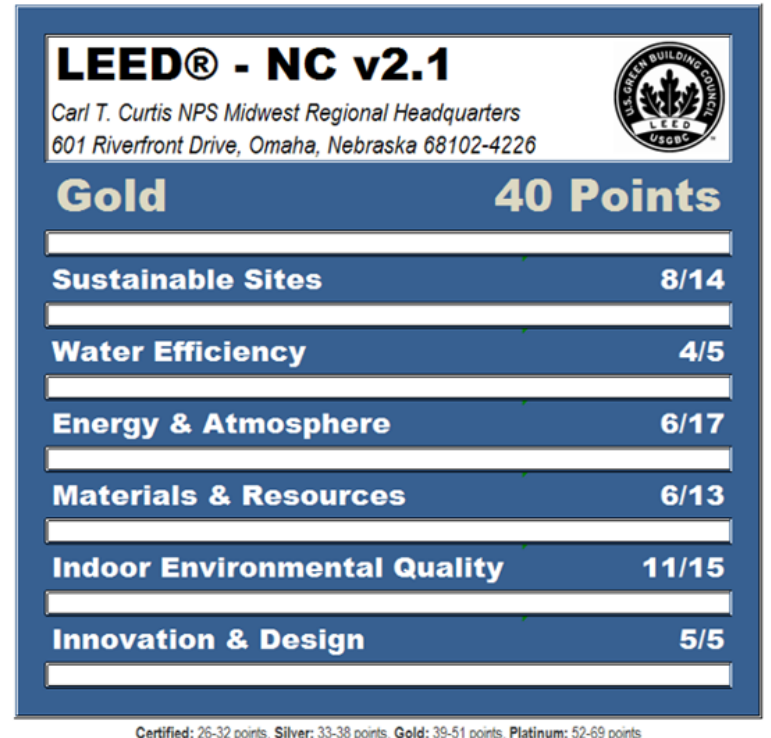

Certified: $26-32$ points, Silver: $33-38$ points, Gold: $39-51$ points, Platinum: $52-69$ points

\section{Whole Building Performance}

The Omaha NPS operating costs are lower than the industry baseline for all of the metrics except recycling.

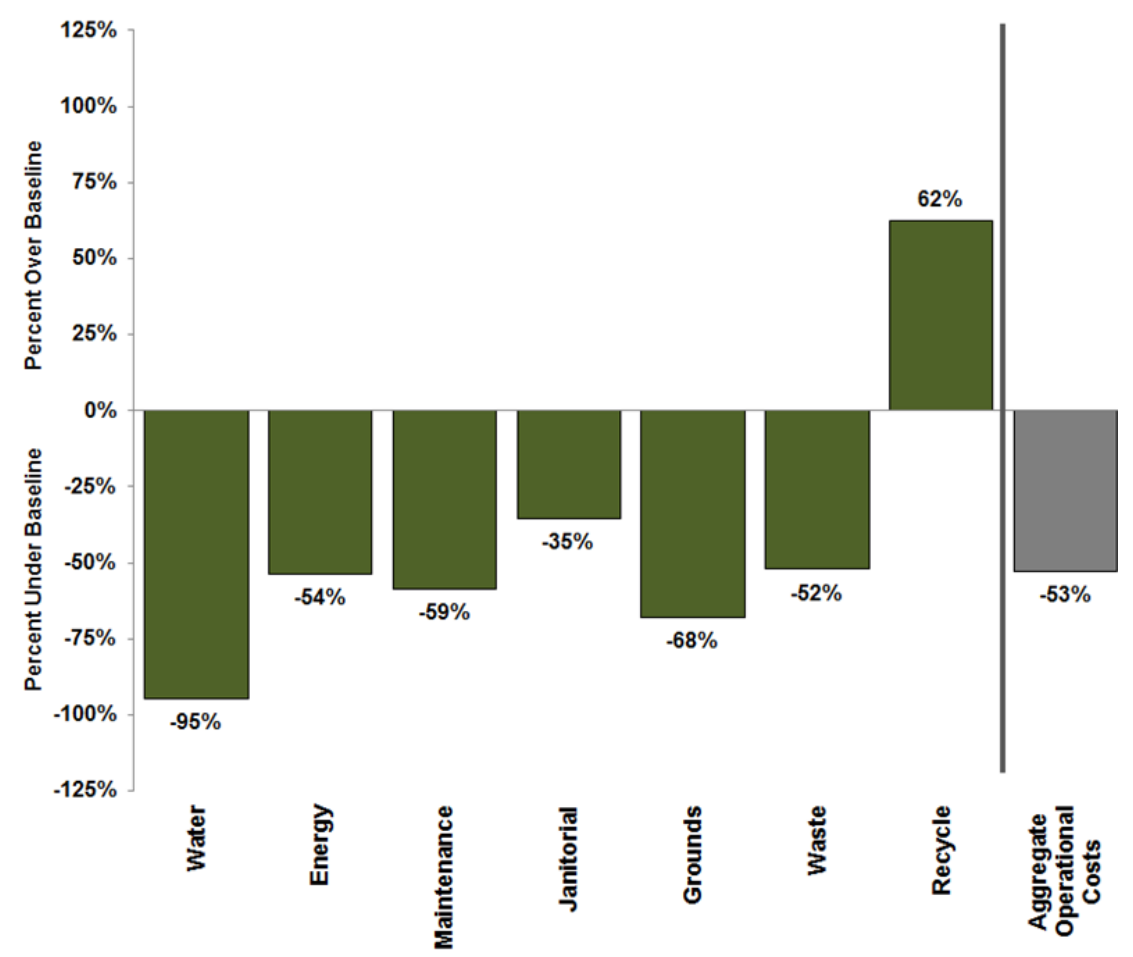




\section{Occupant Satisfaction Survey}

Of the 125 regular occupants in the Omaha NPS Federal Building, 120 were surveyed and 82 responded.

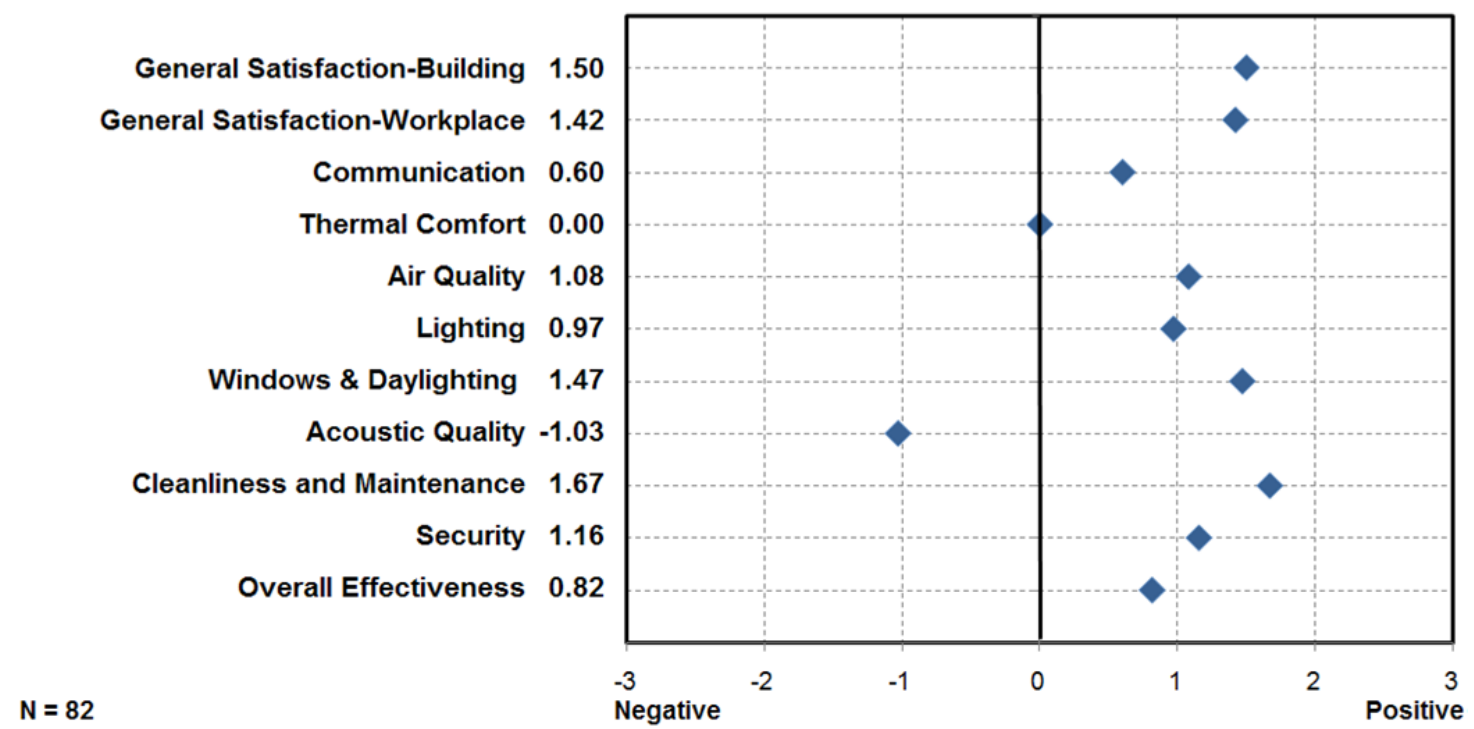

The results indicated that building occupants are more satisfied with their building than occupants in the CBE baseline $\left(70^{\text {th }}\right.$ percentile). Acoustic quality scored at the $8^{\text {th }}$ percentile of the CBE buildings database, which was the lowest score of all the buildings in the study. Lighting scored at the $32^{\text {th }}$ percentile, which was one of the lower scores of the buildings in the study. Thermal comfort, air quality, and cleanliness and maintenance scored above the $50^{\text {th }}$ percentile.

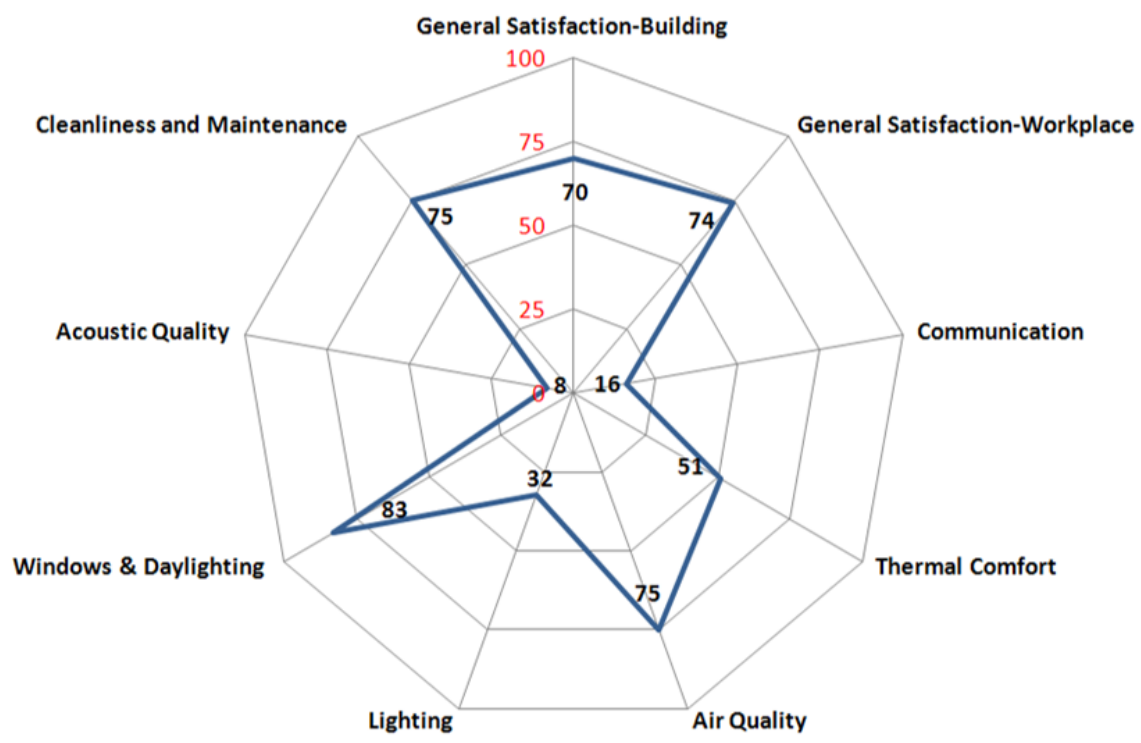




\section{Performance Data Summary}

The research team collected, normalized, and compared the whole building performance data for the Omaha NPS Federal Building to industry baselines. The following table summarizes the annual performance data collected and normalized.

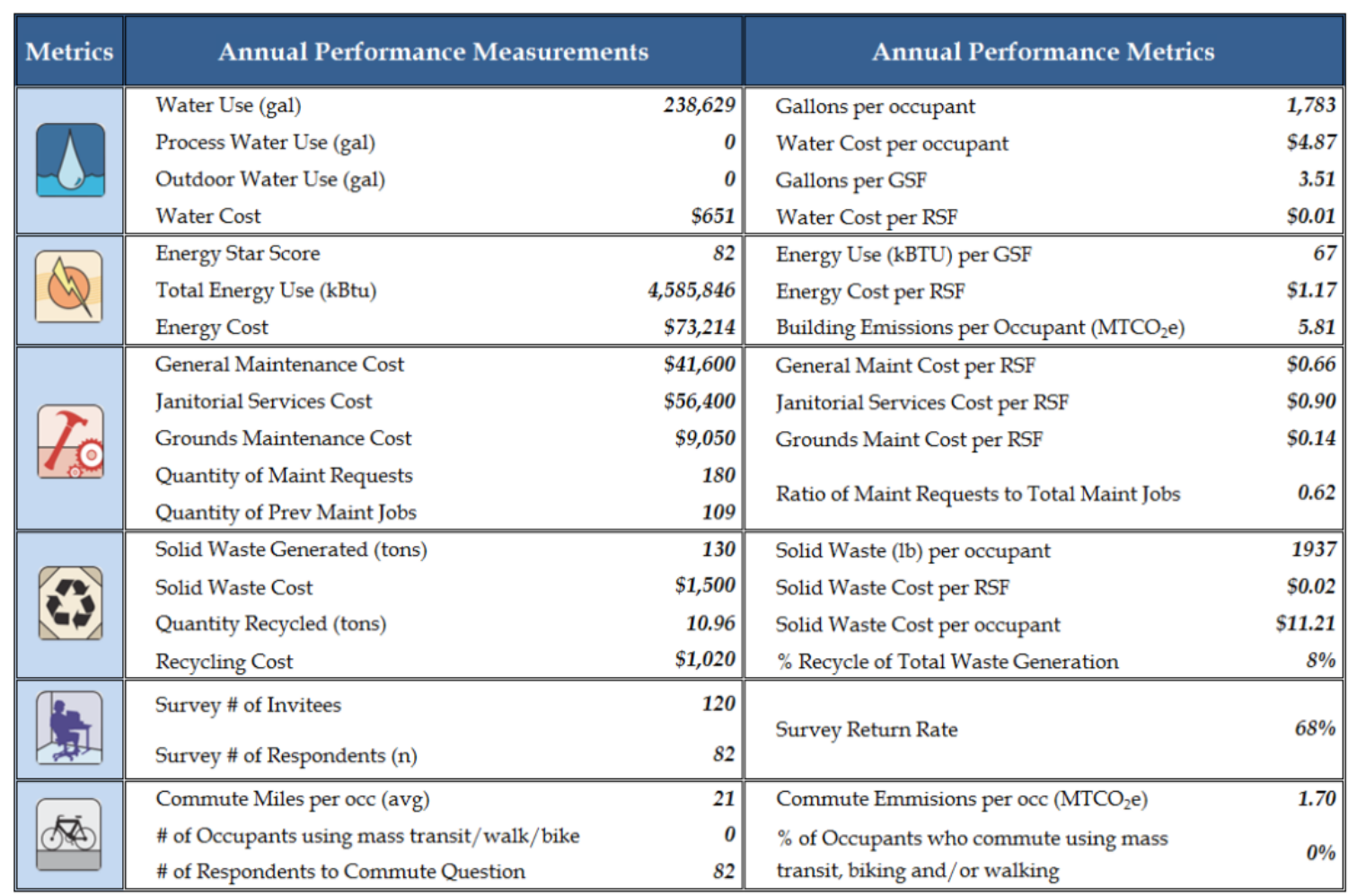




\section{Denver Courthouse}

\section{Description}

The Alfred A. Arraj Courthouse is the U.S. District Courthouse of Colorado, and it houses 15 courtrooms. The Arraj Courthouse was designed using the Green Building Challenge, and recently earned LEED-EB

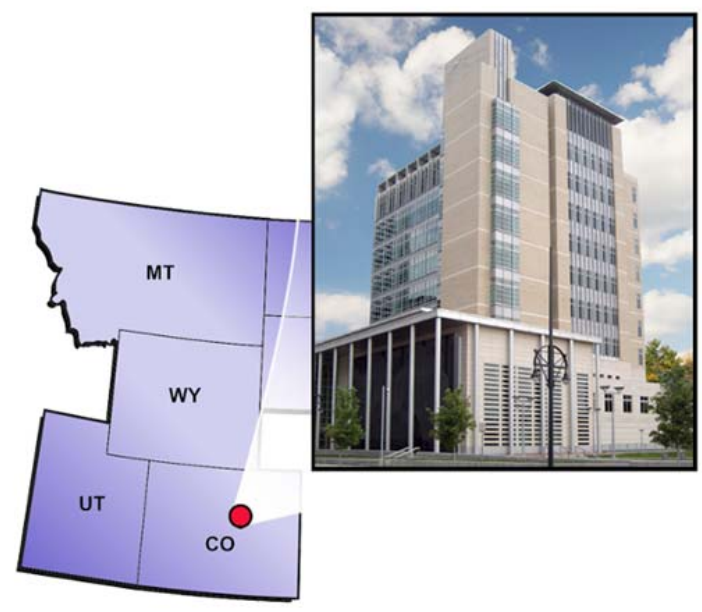

Silver certification. The building has an underfloor air distribution system on the first floor and in the courtrooms on the second floor, occupancy sensors for HVAC and lighting in the courtrooms, indirect T-5 fluorescent lamps, photocell controls, and electronic dimming

\begin{tabular}{|c|c|c|}
\hline \multirow{10}{*}{ Metrics } & \multicolumn{2}{|c|}{ Alfred A. Arraj U.S. Courthouse } \\
\hline & \multirow[t]{2}{*}{ Building Location } & $\begin{array}{rr}90119 \text { th Street } & \text { Denver } \\
\text { Colorado } & 80294-2500\end{array}$ \\
\hline & & Courthouse \\
\hline & Project Type & New Construction \\
\hline & Design Certification & ling Challenge, LEED-EB Silver \\
\hline & Year Built & 2002 \\
\hline & \# of Floors & 13 \\
\hline & Gross Square Foot & 327,103 \\
\hline & Rentable Square Foot & 256,718 \\
\hline & Usable Square Foot & 188,142 \\
\hline & Weekly Operating Hours & 70 \\
\hline & Regular Occupants & 170 \\
\hline & Average Daily Visitors (FTE) & 200 \\
\hline & Electronic Equipment & 185 \\
\hline & Site Cost & $N / A$ \\
\hline & Design Cost & $\$ 4,912,000$ \\
\hline & Construction Cost & $\$ 83,086,000$ \\
\hline & Management \& Inspection & N/A \\
\hline & Total Cost & $\$ 99,088,000$ \\
\hline
\end{tabular}
ballasts. Photovoltaic solar power panels are on the building roof, but they generate a low amount of energy.

The Court gives its occupants passes for mass transit and despite the availability of inexpensive parking within two blocks, the occupants have a smaller $\mathrm{CO}_{2}$-equivalent than the baseline and a smaller than would be expected based on the size of the community. The sanitary waste and recycling programs are combined with other federal buildings in the neighborhood. Currently, 900 tons of central chilled water per month must be purchased regardless of the quantity used. The values provided and used for this study were for only the quantity used, not the total purchased.

Each building in the study had operational highlights and potential opportunities for improvement. Although it was not the focus of this study to investigate and/or document operational highlights and opportunities, the research team observed:

- Energy use intensity (EUI) for the Arraj Courthouse is better than the Energy Star baseline; however, the courthouse has the second highest EUI of the courthouses in the study, and its EUI is higher than expected when considered against GSA's National Baseline. Sub-metering end uses and/or performing a re-commissioning study could be used to investigate and optimize building operations. 


\section{Certifications}

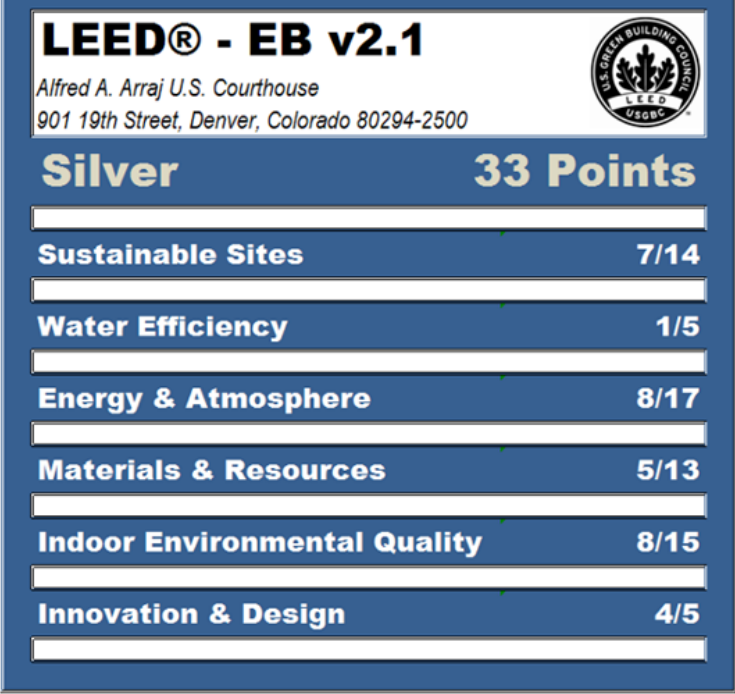

Certified: $26-32$ points, Silver: $33-38$ points, Gold: $39-51$ points, Platinum: $52-69$ points

\section{Whole Building Performance}

The Arraj Courthouse operating costs are higher than the industry baseline for energy and general maintenance costs. No building-specific recycling and waste costs were available for this courthouse, because waste and recycling services are combined with other nearby buildings. Overall, the building costs more to operate than a baseline building.

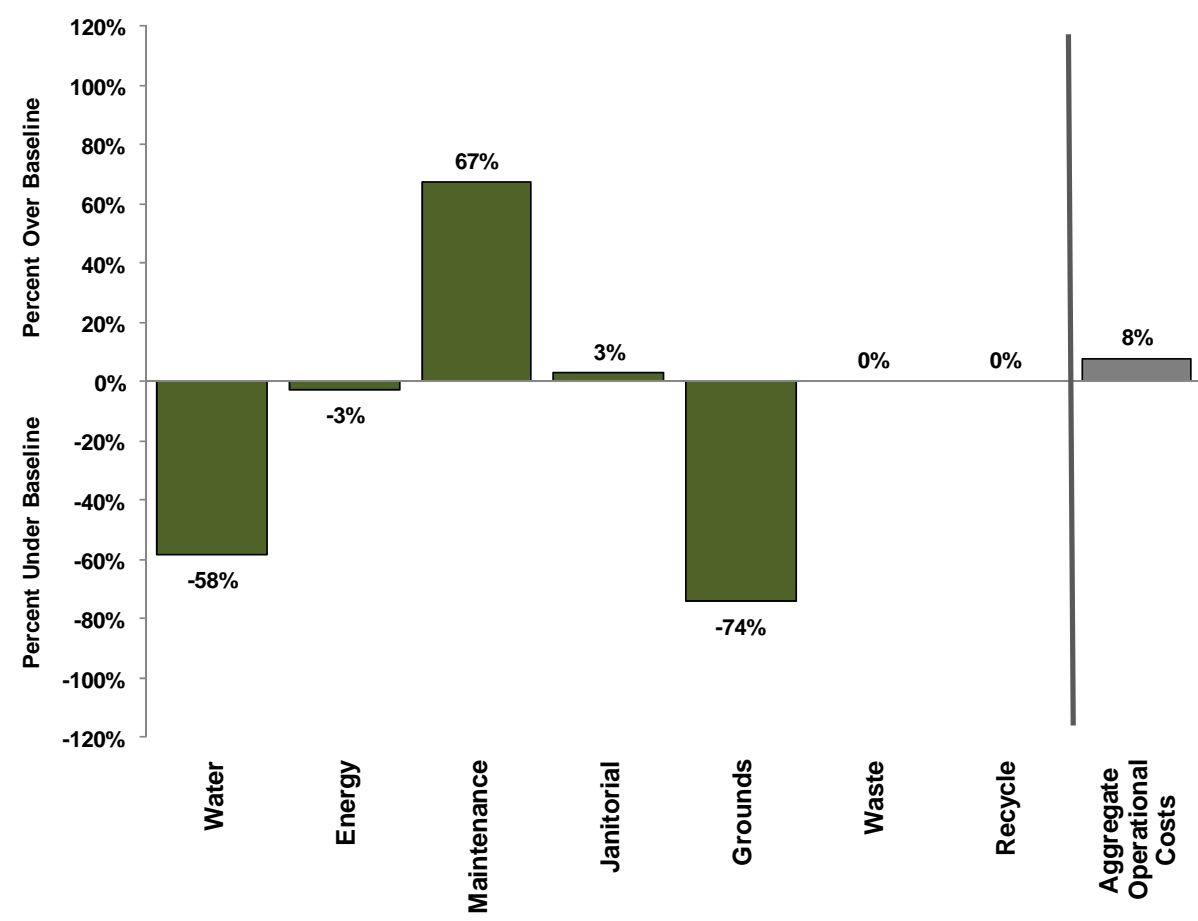




\section{Occupant Satisfaction Survey}

Of the 170 building occupants, 100 were surveyed and 58 responded. All of the main survey categories had neutral or positive average scores.

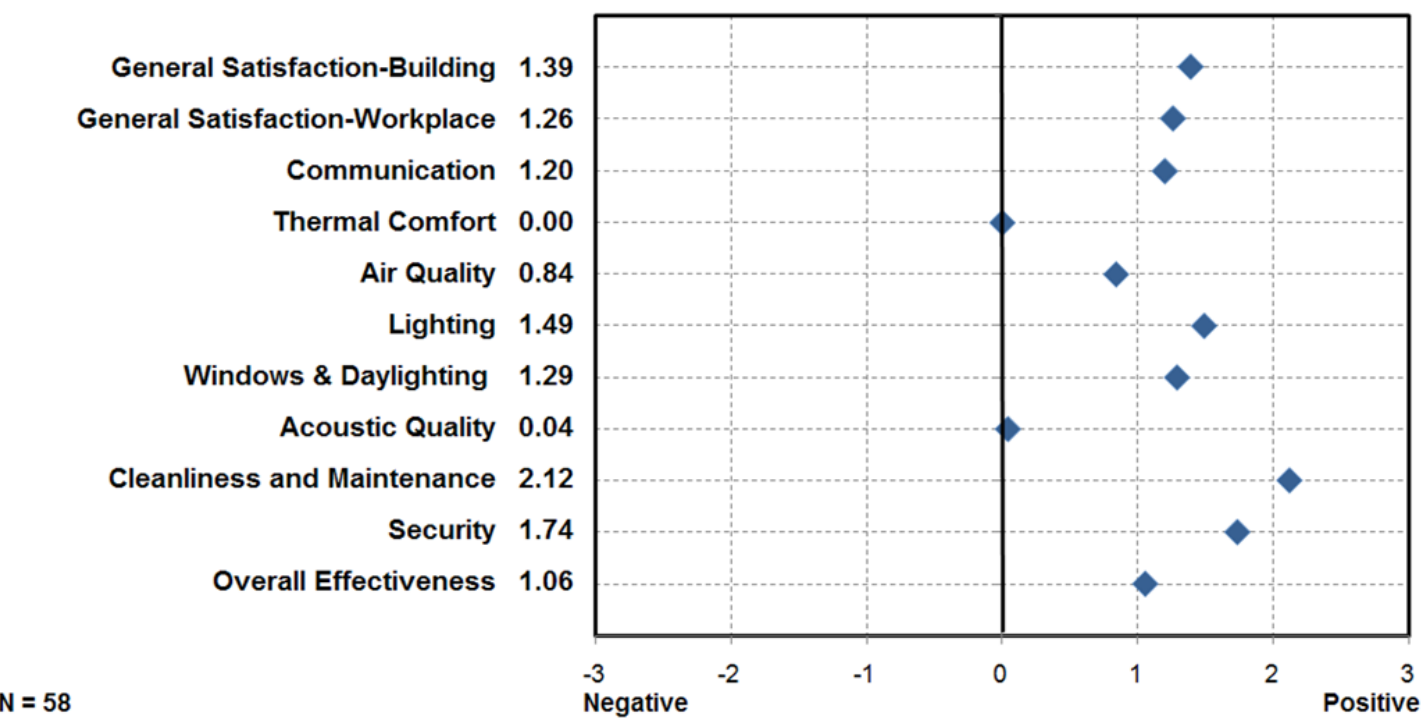

The results indicated that occupants of the Arraj Courthouse are more satisfied with their building than occupants in the CBE baseline ( $64^{\text {th }}$ percentile). For all of the survey categories that were the primary focus of this study — acoustic quality, air quality, lighting, cleanliness and maintenance, and thermal comfort - the Arraj Courthouse scored at the $50^{\text {th }}$ percentile or better.

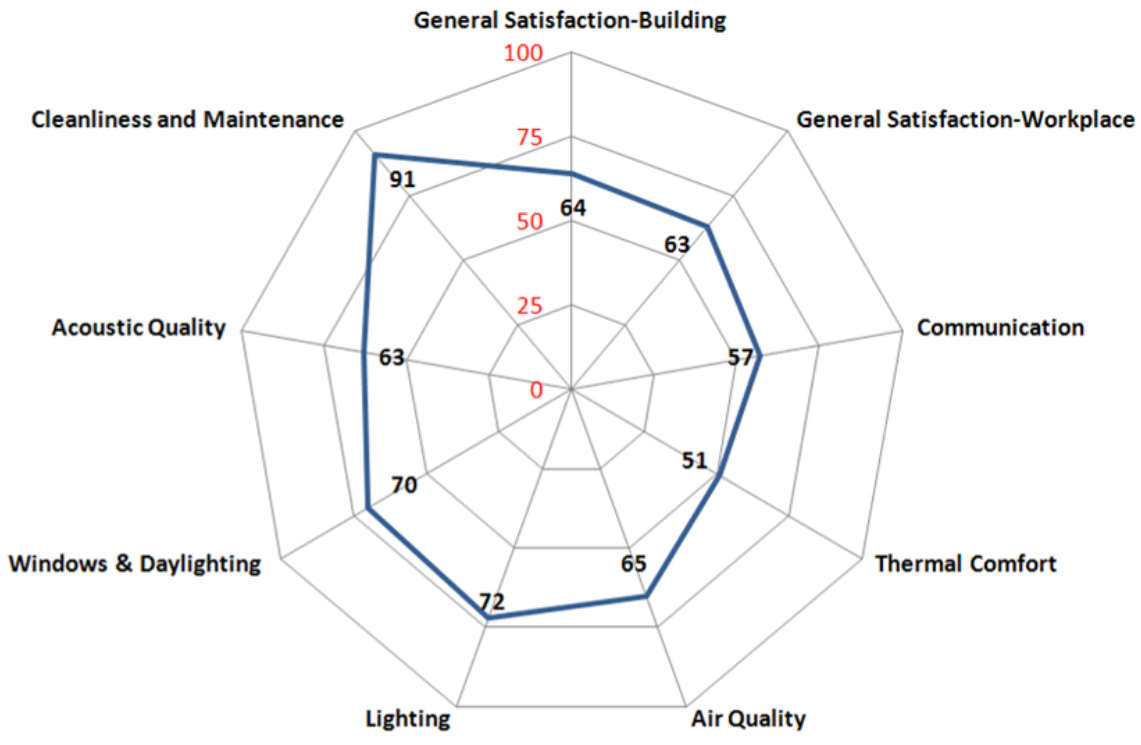




\section{Performance Data Summary}

The research team collected, normalized, and compared whole building performance data for the Arraj Courthouse to industry baselines. The following table summarizes the annual performance data collected and normalized. The facility uses evaporative cooling for its primary air-conditioning system; therefore, the evaporative cooling water use was estimated using the "rule-of-thumb" that $27 \%$ of total water use is process water.

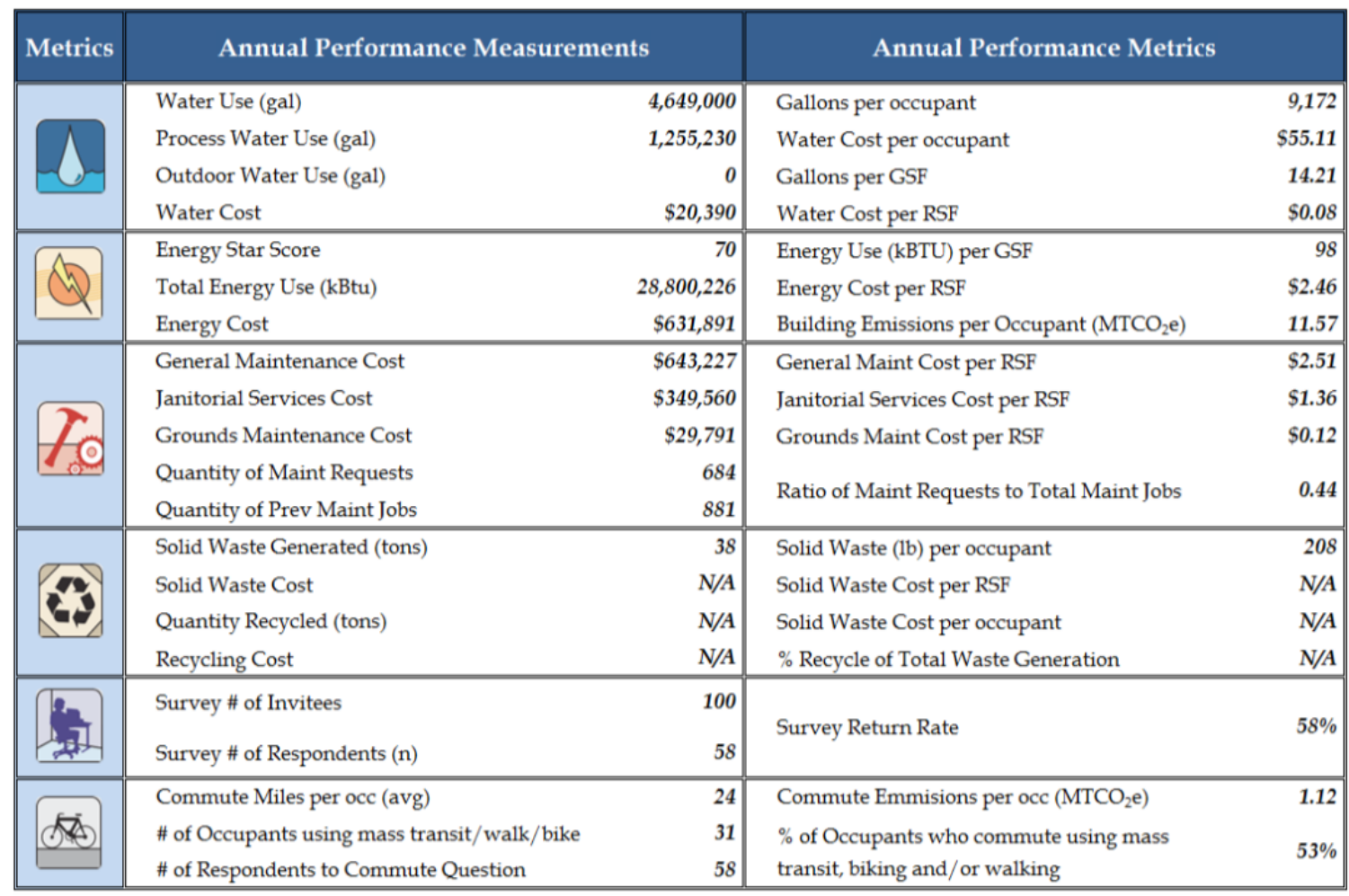




\section{Denver Federal Building}

\section{Description}

The EPA Region 8 Headquarters was built on a brownfield in the Denver Lower Downtown Historic District as part of an urban redevelopment effort. The proximity to public transport has enabled nearly $90 \%$

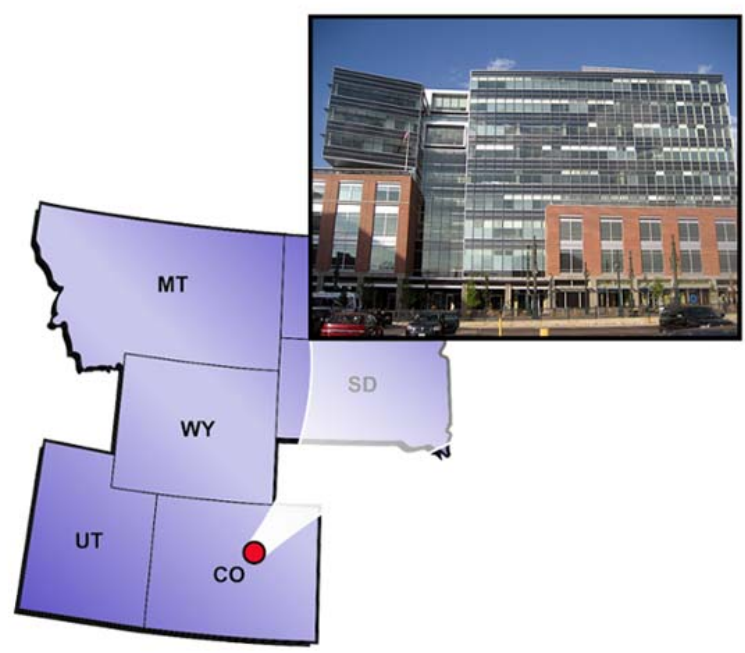
of the occupants surveyed to take some type of alternative transportation to their workplace.

This LEED-NC Gold-certified and Energy Star rated building uses a number of strategies contributing to a predicted 35\% energy savings from an ASHRAE 90.11999 energy model; daylighting for $85 \%$ of occupied spaces, daylighting dimmers, occupancy sensors, and underfloor air distribution HVAC system.

\begin{tabular}{|c|c|c|c|}
\hline Metrics & \multicolumn{3}{|c|}{ EPA Region 8 Headquarters } \\
\hline & Building Location & $\begin{array}{r}1595 \text { Wynkoop Street } \\
\text { Colorado }\end{array}$ & $\begin{array}{r}\text { Denver } \\
80202-9999\end{array}$ \\
\hline & Building Function & & eral Building \\
\hline & Project Type & $\mathrm{Ner}$ & Construction \\
\hline & Design Certification & LEED-NC Gold, Energy & $\operatorname{tar} 2008(96)$ \\
\hline 17 indive & Year Built & & 2006 \\
\hline & \# of Floors & & 9 \\
\hline & Gross Square Foot & & 301,292 \\
\hline & Rentable Square Foot & & 248,849 \\
\hline & Usable Square Foot & & 0 \\
\hline & Weekly Operating $\mathrm{Hc}$ & & 68 \\
\hline & Regular Occupants & & 922 \\
\hline & Average Daily Visito & FTE) & 71 \\
\hline & Electronic Equipment & & 1,289 \\
\hline & Site Cost & & $N / A$ \\
\hline & Design Cost & & $N / A$ \\
\hline & Construction Cost & & $\$ 90,400,000$ \\
\hline & Management \& Inspe & & $N / A$ \\
\hline & Total Cost & & $\$ 90,400,000$ \\
\hline
\end{tabular}

With respect to water, use of native and adaptive vegetation eliminated the need for irrigation water for landscaping. $51 \%$ of the roof is covered with a modular green roof system planted with sedum, and a portion of remainder is covered by 48 solar panels that generates $10 \mathrm{~kW}$ at peak output.

Each building in the study had operational highlights and potential opportunities for improvement. Although it was not the focus of this study to investigate and/or document

operational highlights and opportunities, the research team observed:

- Although considerable thought went into the daylighting design features, the CBE survey lighting score was below the $50^{\text {th }}$ percentile. Interviews of the occupants regarding these issues may result in a more detailed understanding of how operations might be adjusted to improve occupant satisfaction. 


\section{Certifications}

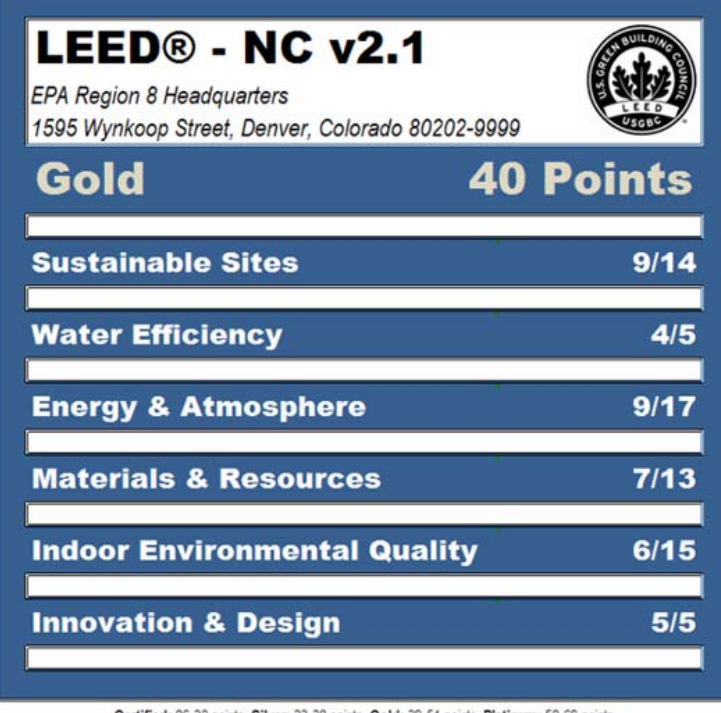

Certified: $26-32$ points, Silver: $33-38$ points, Gold: 39-51 points, Platinum: $52-69$ poirts

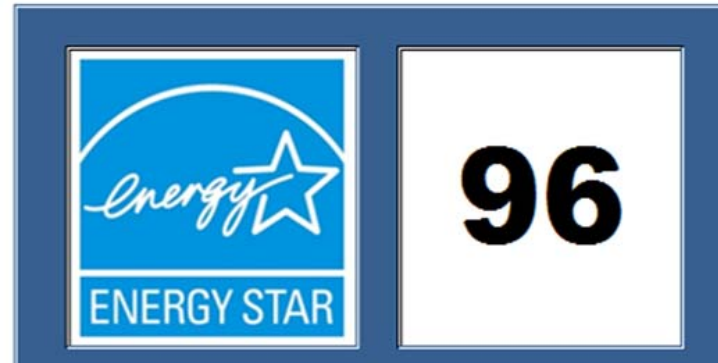

\section{Bulding Name}

\section{Denver (L) FB}

\section{Year Certified}

\section{8}

\section{Whole Building Performance}

The EPA Region 8 Headquarters operating costs are lower than the industry baseline for all metrics except waste and recycling.

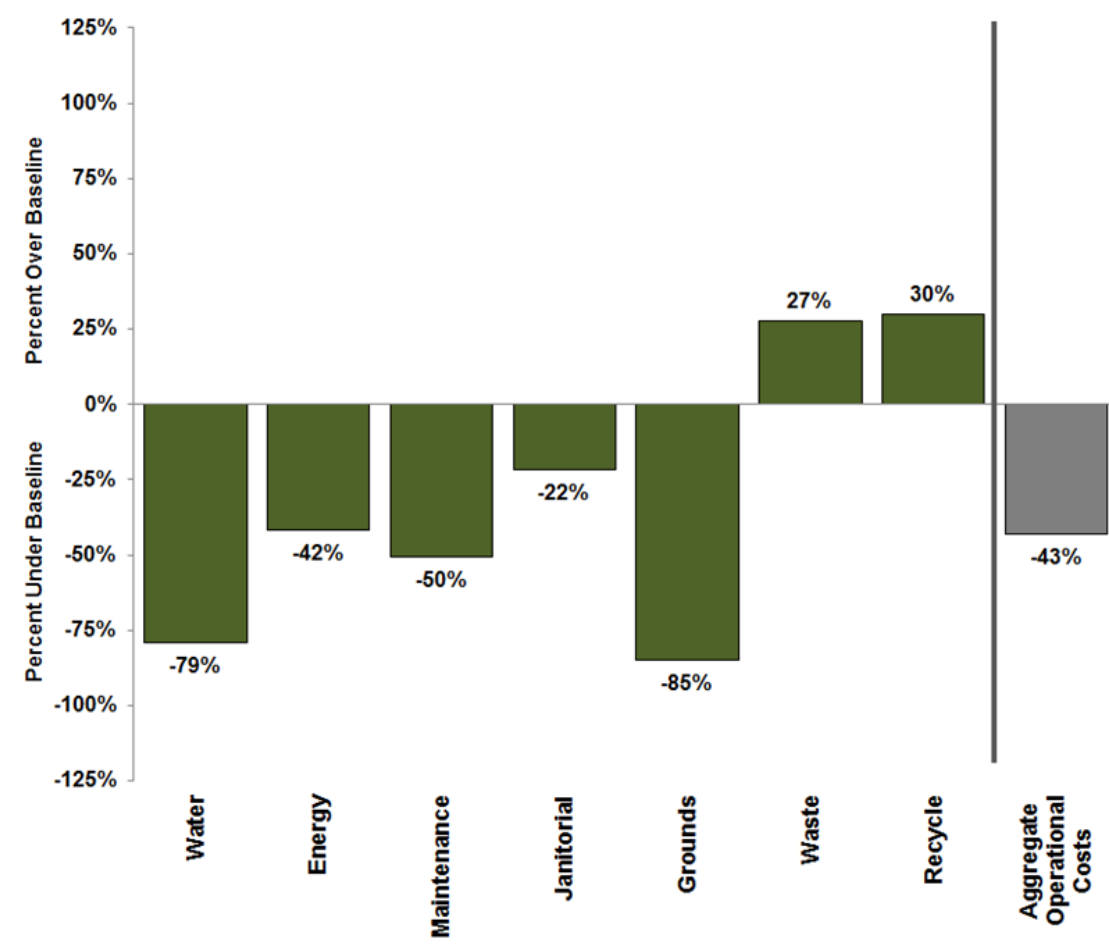




\section{Occupant Satisfaction Survey}

All 922 of the EPA Region 8 Headquarters occupants were surveyed and 340 responded. All of the main survey categories had positive average scores.

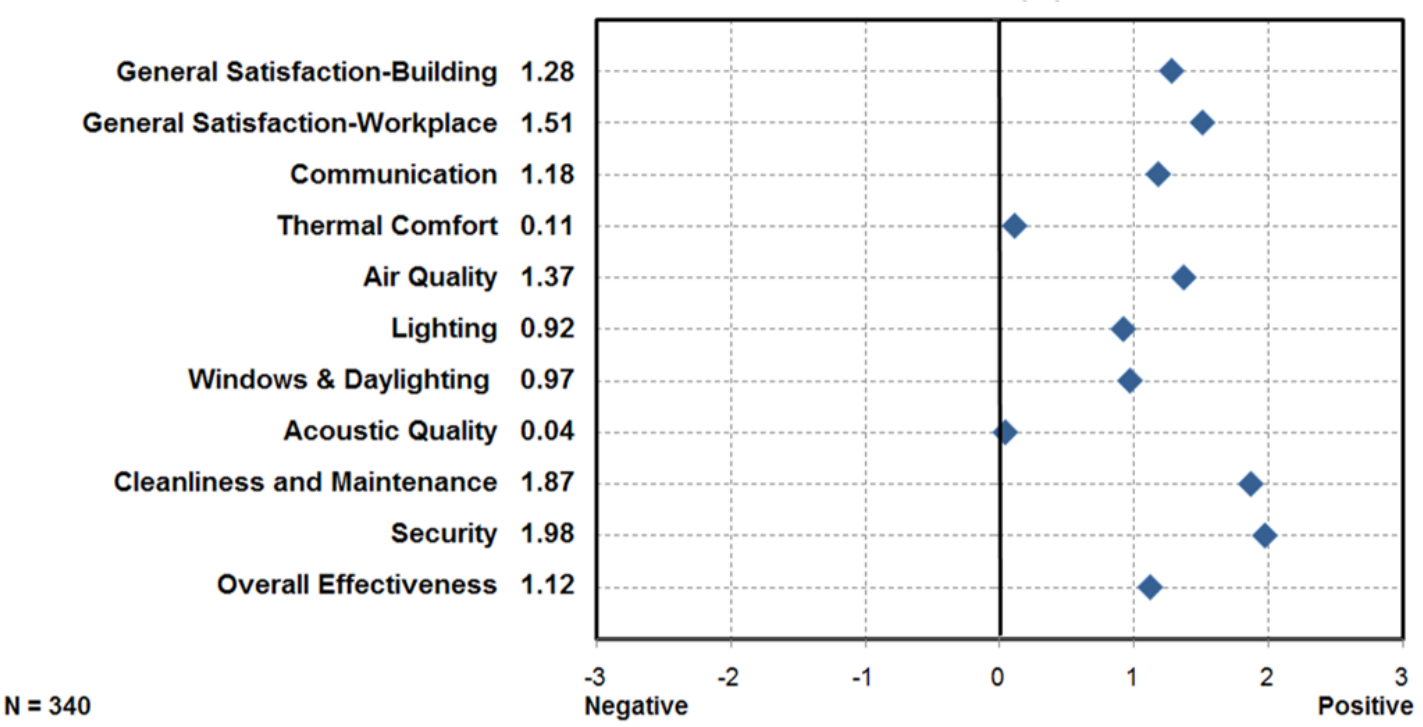

When the Denver EPA Federal Building survey responses are compared with the CBE database we see the occupants are more satisfied with their building ( $57^{\text {th }}$ percentile). Lighting was the only metric below the median $\left(30^{\text {th }}\right.$ percentile). For the other survey categories that were the primary focus of this study - acoustic quality, air quality, cleanliness and maintenance, and thermal comfort — the EPA Region 8 Headquarters scored above, or at, the $50^{\text {th }}$ percentile. Meaning the occupants were more satisfied with the building than those in the CBE baseline.

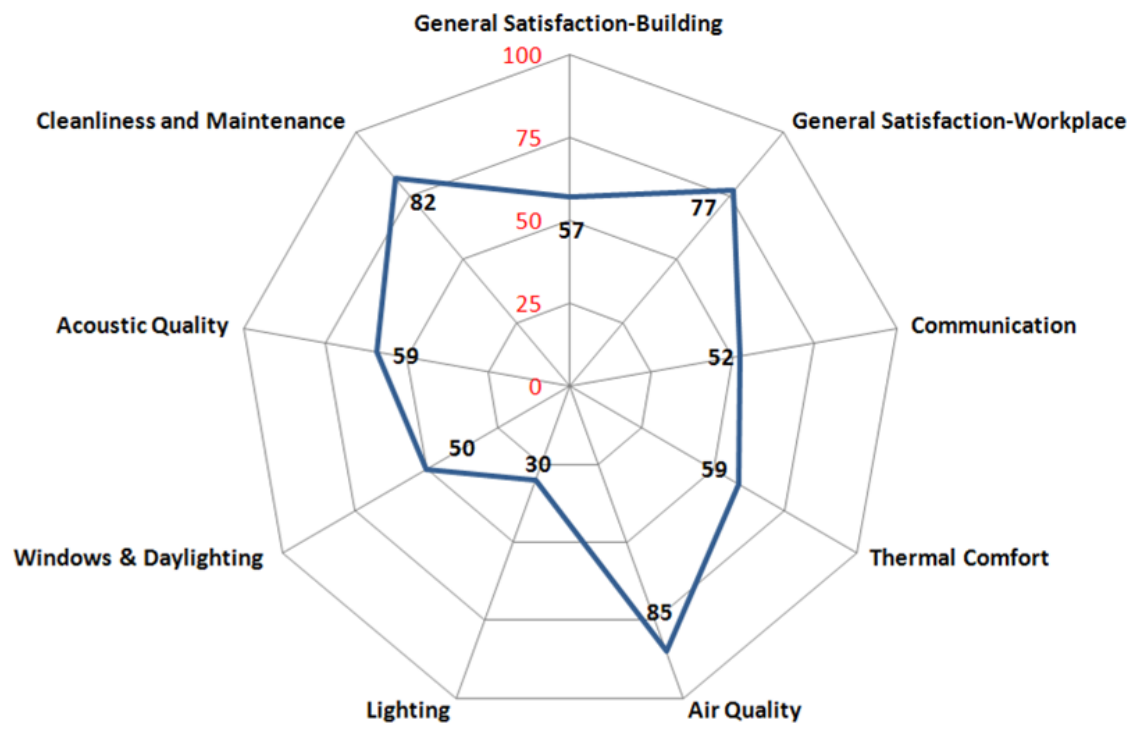




\section{Performance Data Summary}

The research team collected, normalized, and compared whole building performance data for the EPA Region 8 Headquarters to industry baselines. The following table summarizes the annual performance data collected and normalized. This is the only facility in the study that consistently records the potable water used for the water-cooled chillers and to irrigate the green roof.

\begin{tabular}{|c|c|c|c|c|}
\hline Metrics & \multicolumn{2}{|c|}{ Annual Performance Measurements } & \multicolumn{2}{|l|}{ Annual Performance Metrics } \\
\hline & Water Use (gal) & $3,970,000$ & Gallons per occupant & 3,500 \\
\hline & Process Water Use (gal) & 134,100 & Water Cost per occupant & $\$ 9.95$ \\
\hline & Outdoor Water Use (gal) & 358,962 & Gallons per GSF & 13.18 \\
\hline & Water Cost & $\$ 9,882$ & Water Cost per RSF & $\$ 0.04$ \\
\hline & Energy Star Score & 94 & Energy Use (kBTU) per GSF & 76 \\
\hline & Total Energy Use (kBtu) & $22,863,296$ & Energy Cost per RSF & $\$ 1.48$ \\
\hline & Energy Cost & $\$ 367,301$ & Building Emissions per Occupant $\left(\mathrm{MTCO}_{2} \mathrm{e}\right)$ & 4.09 \\
\hline & General Maintenance Cost & $\$ 184,607$ & General Maint Cost per RSF & $\$ 0.74$ \\
\hline & Janitorial Services Cost & $\$ 258,120$ & Janitorial Services Cost per RSF & $\$ 1.04$ \\
\hline & Grounds Maintenance Cost & $\$ 16,833$ & Grounds Maint Cost per RSF & $\$ 0.07$ \\
\hline & Quantity of Maint Requests & 1,120 & & \\
\hline & Quantity of Prev Maint Jobs & 200 & Ratio of Maint Requests to Total Maint Jobs & 0.85 \\
\hline & Solid Waste Generated (tons) & 290 & Solid Waste (lb) per occupant & 584 \\
\hline & Solid Waste Cost & $\$ 15,862$ & Solid Waste Cost per RSF & $\$ 0.05$ \\
\hline & Quantity Recycled (tons) & 177.00 & Solid Waste Cost per occupant & $\$ 15.97$ \\
\hline & Recycling Cost & $\$ 3,228$ & $\%$ Recycle of Total Waste Generation & $38 \%$ \\
\hline & $\begin{array}{l}\text { Survey \# of Invitees } \\
\text { Survey \# of Respondents (n) }\end{array}$ & $\begin{array}{l}830 \\
340\end{array}$ & Survey Return Rate & $41 \%$ \\
\hline & Commute Miles per occ (avg) & 26 & Commute Emmisions per occ $\left(\mathrm{MTCO}_{2} \mathrm{e}\right)$ & 0.58 \\
\hline & \# of Occupants using mass transit/walk/bike & 294 & $\%$ of Occupants who commute using mass & $87 \%$ \\
\hline & \# of Respondents to Commute Question & 339 & transit, biking and/or walking & \\
\hline
\end{tabular}




\section{Lakewood Federal Building}

\section{Description}

The Lakewood Department of Transportation (DOT) Federal Building is a leased facility designed by Opus Architects and Engineers, Incorporated. This LEED Silver-certified

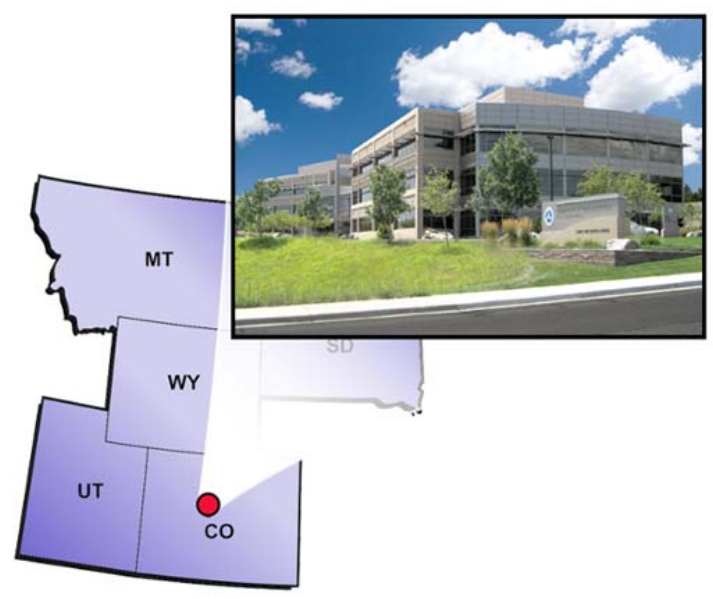
building incorporated low-emitting materials, adhesives, and sealants; daylight and views in 91\% of regularly occupied spaces; and recycled content materials. Seventy-two percent of the building materials were manufactured locally, and $41 \%$ of the materials were harvested locally. Additional features include light and

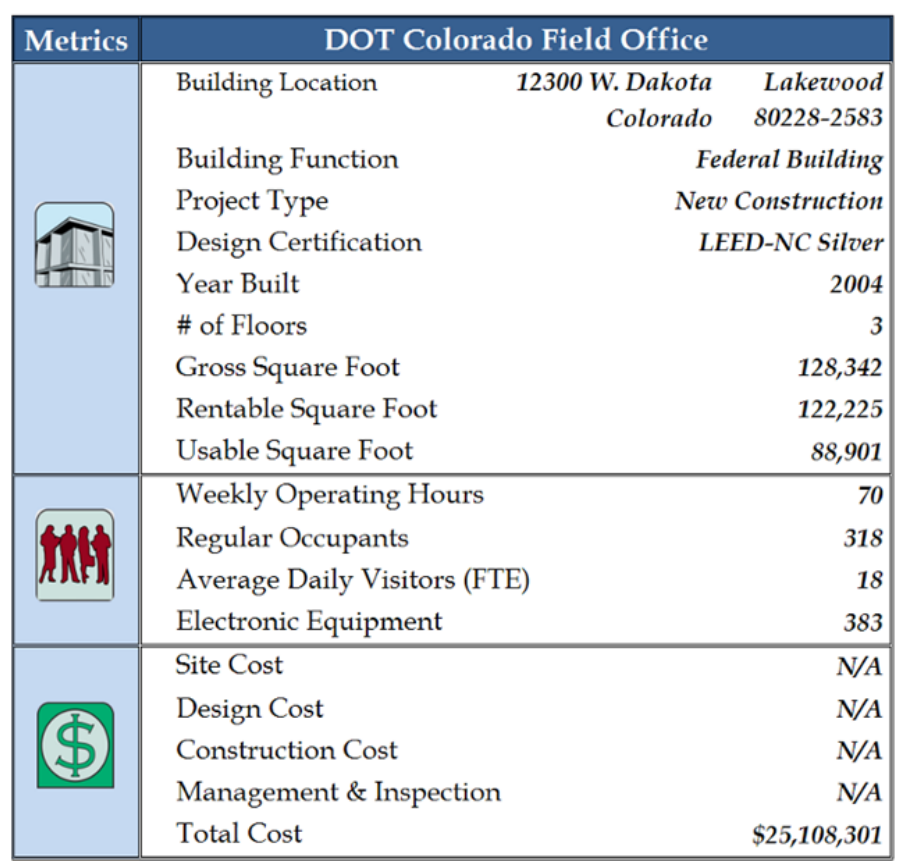

motion sensors, air-side economizers, and carbon dioxide $\left(\mathrm{CO}_{2}\right)$ monitors. Although the building is located on a large plot of land in a suburban community outside of Denver, a portion of the landscape is xeriscape.

All building occupants received a booklet about the design and operations of the building. The building was designed to house 400 occupants and currently has 318 occupants.

Each building in the study had operational highlights and potential opportunities for improvement.

Although it was not the focus of this study to investigate and/or document operational highlights and opportunities, the research team observed:

- The formal system for tracking service calls is not being regularly utilized. Using the service call tracking system is recommended to identify maintenance trends, and to anticipate future maintenance needs.

- Based on the CBE survey results, issues appear to exist with acoustics, air quality, and lighting. Interviews of occupants regarding these issues may result in a more detailed understanding of how operations might be adjusted to improve occupant satisfaction. 


\section{Certifications}

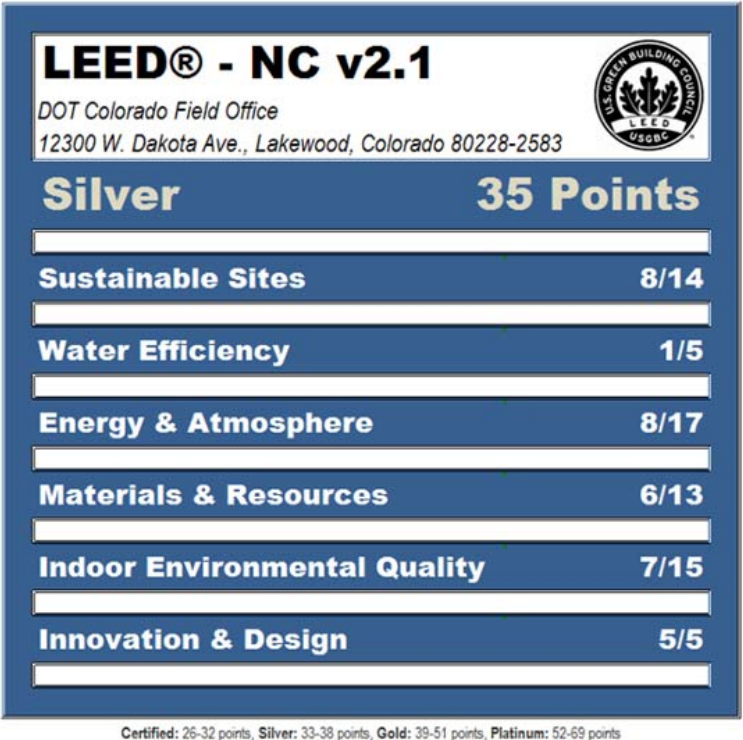

\section{Whole Building Performance}

The Lakewood Federal Building operating costs are lower than the industry baseline for all metrics.

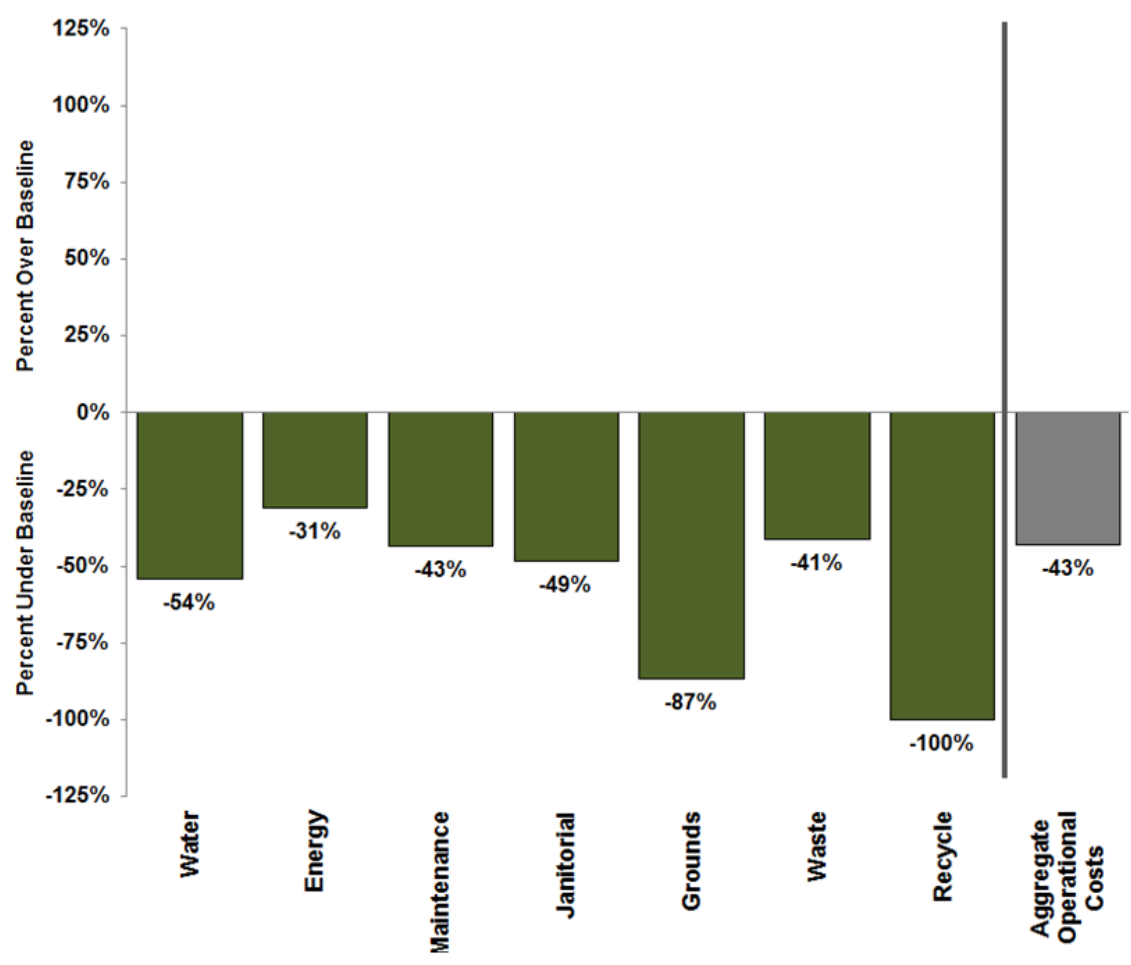




\section{Occupant Satisfaction Survey}

Of the 318 occupants in the building, 250 were surveyed and 103 responded.

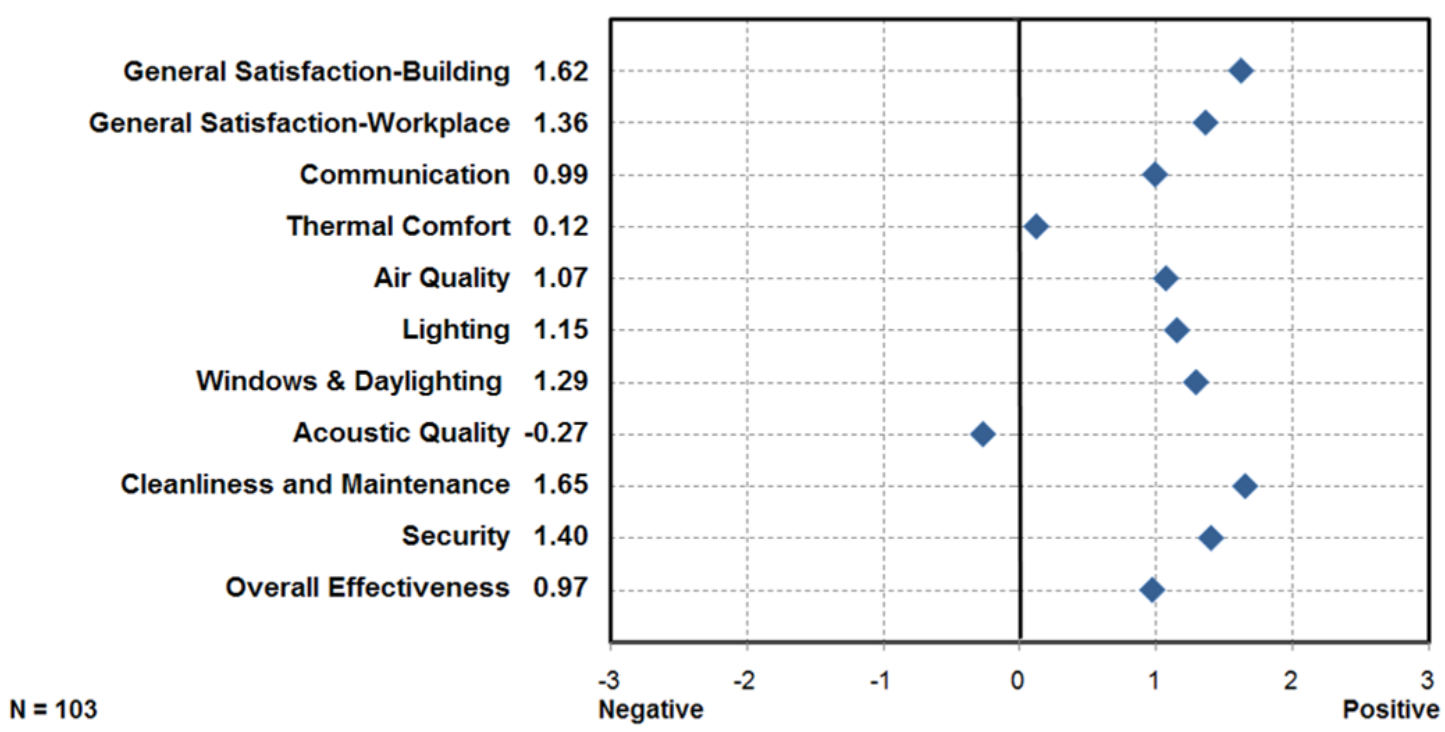

The result indicated that occupants of the Lakewood Federal Building are more satisfied with their building than occupants in the CBE baseline $\left(75^{\text {th }}\right.$ percentile). Acoustic quality, and lighting scored below the $50^{\text {th }}$ percentile of the CBE buildings surveyed. Cleanliness and maintenance, air quality, and thermal comfort scored above the $50^{\text {th }}$ percentile.

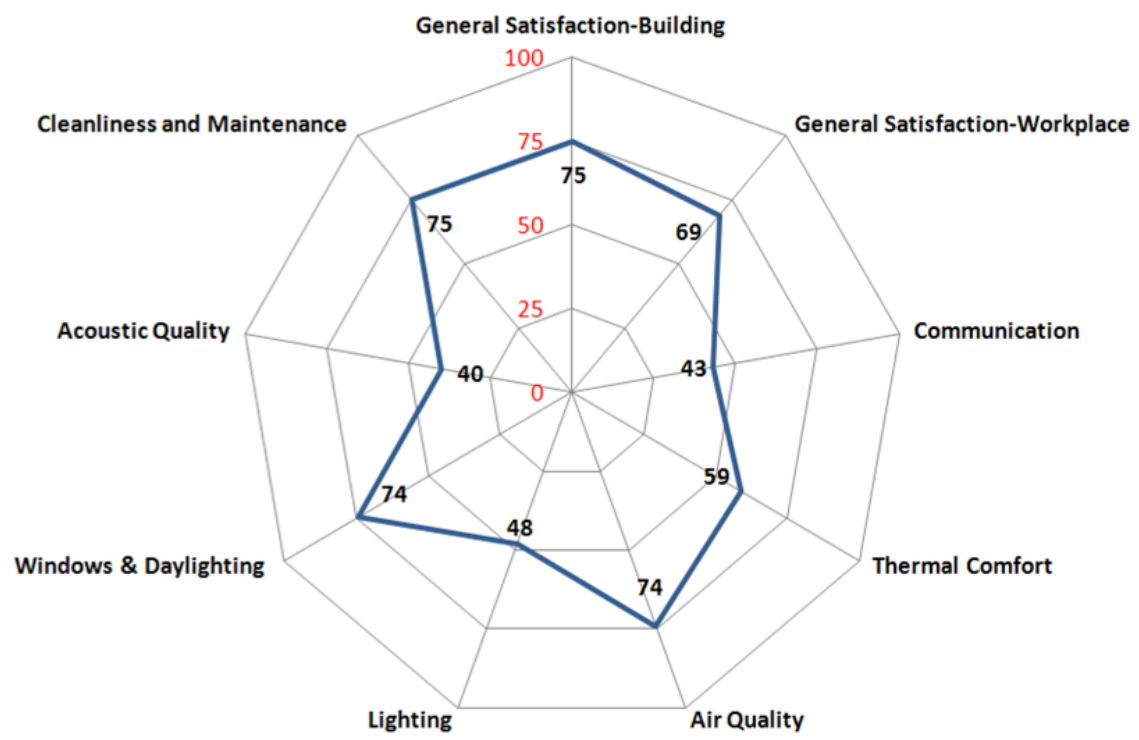




\section{Performance Data Summary}

The research team collected, normalized, and compared the whole building performance data for the Lakewood DOT Federal Building to industry baselines. The following table summarizes the annual performance data collected and normalized. The facility uses watercooled chillers for its air-conditioning system; therefore, the cooling tower water use was estimated using the "rule-of-thumb" that $27 \%$ of total water use is process water. Outdoor water use was estimated using the "rule-of-thumb" that $20 \%$ of total water use is for landscaping.

\begin{tabular}{|c|c|c|c|c|}
\hline Metrics & \multicolumn{2}{|c|}{ Annual Performance Measurements } & \multicolumn{2}{|l|}{ Annual Performance Metrics } \\
\hline & Water Use (gal) & $2,928,000$ & Gallons per occupant & 4,625 \\
\hline & Process Water Use (gal) & 790,560 & Water Cost per occupant & $\$ 31.65$ \\
\hline & Outdoor Water Use (gal) & 585,600 & Gallons per GSF & 22.81 \\
\hline & Water Cost & $\$ 10,617$ & Water Cost per RSF & $\$ 0.09$ \\
\hline & Energy Star Score & 84 & Energy Use (kBTU) per GSF & 65 \\
\hline & Total Energy Use (kBtu) & $8,810,081$ & Energy Cost per RSF & $\$ 1.74$ \\
\hline & Energy Cost & $\$ 213,099$ & Building Emissions per Occupant $\left(\mathrm{MTCO}_{2} \mathrm{e}\right)$ & 5.02 \\
\hline & General Maintenance Cost & $\$ 103,644$ & General Maint Cost per RSF & $\$ 0.85$ \\
\hline & Janitorial Services Cost & $\$ 83,220$ & Janitorial Services Cost per RSF & $\$ 0.68$ \\
\hline & Grounds Maintenance Cost & $\$ 7,394$ & Grounds Maint Cost per RSF & $\$ 0.06$ \\
\hline & Quantity of Maint Requests & 25 & Ratio of Maint Reguects to Total Maint Jobs & 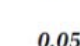 \\
\hline & Quantity of Prev Maint Jobs & 528 & Katio of Maint Requests to Iotal Maint jobs & \\
\hline & Solid Waste Generated (tons) & 374 & Solid Waste (lb) per occupant & 2230 \\
\hline & Solid Waste Cost & $\$ 3,600$ & Solid Waste Cost per RSF & $\$ 0.03$ \\
\hline & Quantity Recycled (tons) & 204.21 & Solid Waste Cost per occupant & $\$ 10.73$ \\
\hline & Recycling Cost & $\$ 0$ & $\%$ Recycle of Total Waste Generation & $35 \%$ \\
\hline & $\begin{array}{l}\text { Survey \# of Invitees } \\
\text { Survey \# of Respondents (n) }\end{array}$ & $\begin{array}{l}250 \\
103\end{array}$ & Survey Return Rate & $41 \%$ \\
\hline & Commute Miles per occ (avg) & 23 & Commute Emmisions per occ $\left(\mathrm{MTCO}_{2} \mathrm{e}\right)$ & 1.88 \\
\hline & $\begin{array}{l}\text { \# of Occupants using mass transit/walk/bike } \\
\text { \# of Respondents to Commute Question }\end{array}$ & $\begin{array}{r}9 \\
103\end{array}$ & $\begin{array}{l}\% \text { of Occupants who commute using mass } \\
\text { transit, biking and/or walking }\end{array}$ & $9 \%$ \\
\hline
\end{tabular}




\section{Ogden Federal Building}

\section{Description}

Prior to its transformation to a four-story office building, the Scowcroft Internal Revenue Service (IRS) Federal Building was a warehouse. The original main staircase and middle stairs have been preserved, and an

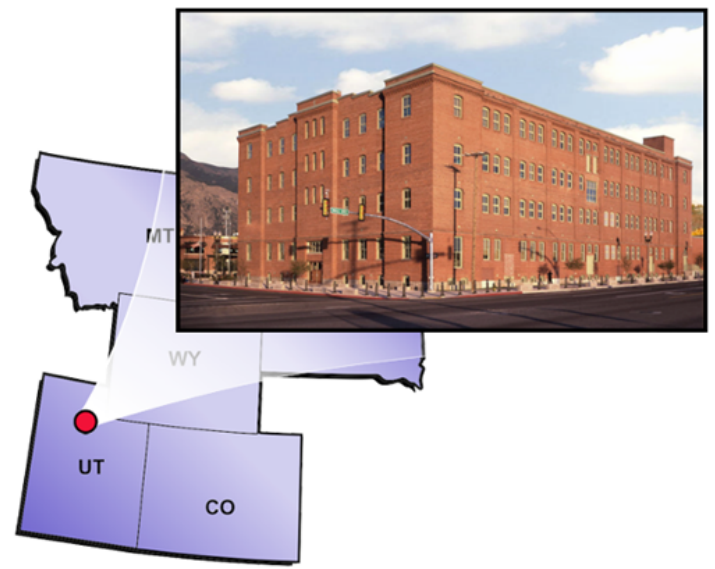
office suite has been restored. The renovation cost included costly earthquake prevention upgrades and tenant specific requests.

The Scowcroft Federal Building remodel incorporated improved roof insulation, radiant baseboard heating, variable speed condensers, and improved lighting power density. The underfloor air distribution system was coupled with indirect/direct evaporative cooling.

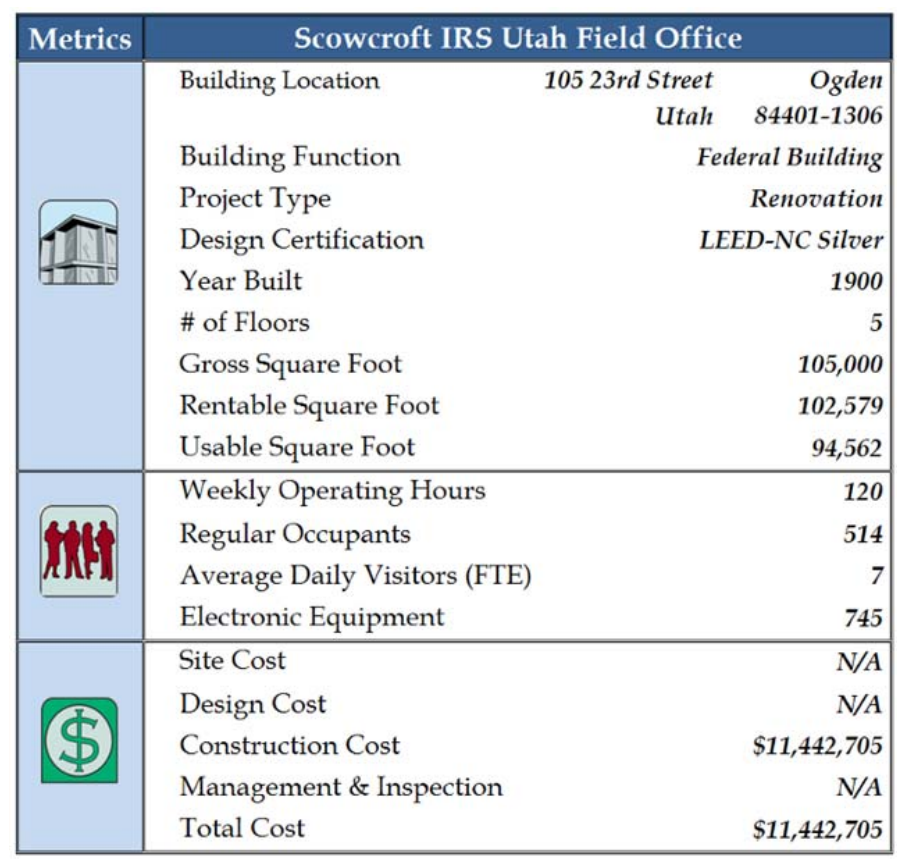

These systems allowed for increased ventilation effectiveness and temperature controllability for nonperimeter spaces. Presently, the building and operates 22 hours a day, 350 days a year. Office space includes a high number of cubicles with varying heights (6 to 10 feet).

Each building in the study had operational highlights and potential opportunities for improvement. Although it was not the focus of this study to investigate and/or document operational highlights and opportunities, the research team observed:

- Based on the CBE survey results, it appears that issues exist with thermal comfort, daylighting, lighting, cleanliness and maintenance, and acoustics. Interviews of occupants regarding these issues may result in a more detailed understanding of how operations might be adjusted to improve occupant satisfaction.

- Separately metering the process water would allow for the comparison of Scowcroft Federal Building domestic water use to a comparable baseline. Once measured domestic water use data are available, potential water conservation opportunities could be identified. 


\section{Certifications}

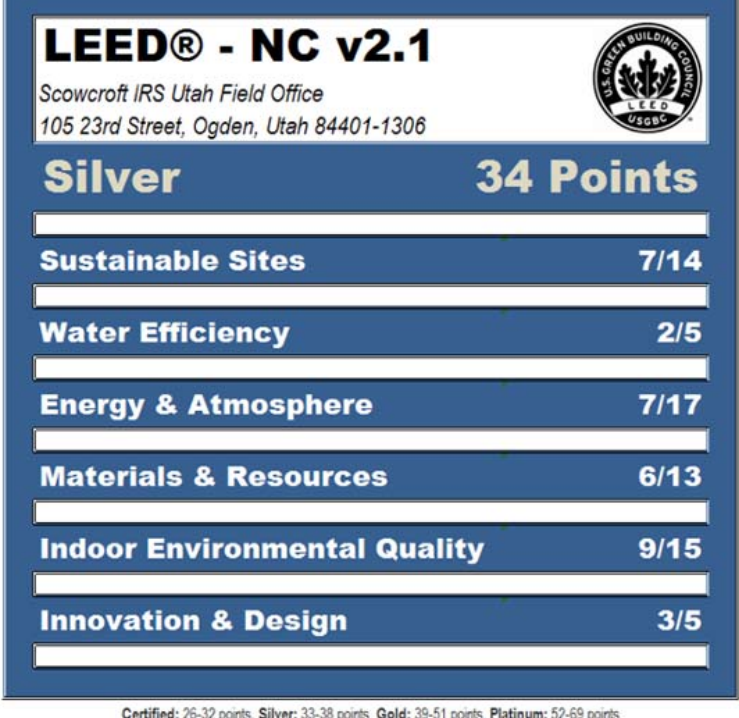

\section{Whole Building Performance}

The costs of operating the Scowcroft Federal Building are lower than the industry baseline for energy, water, waste, general maintenance, and janitorial costs. The recycling costs are higher than the industry baseline. Overall, the building costs less to operate than a baseline building.

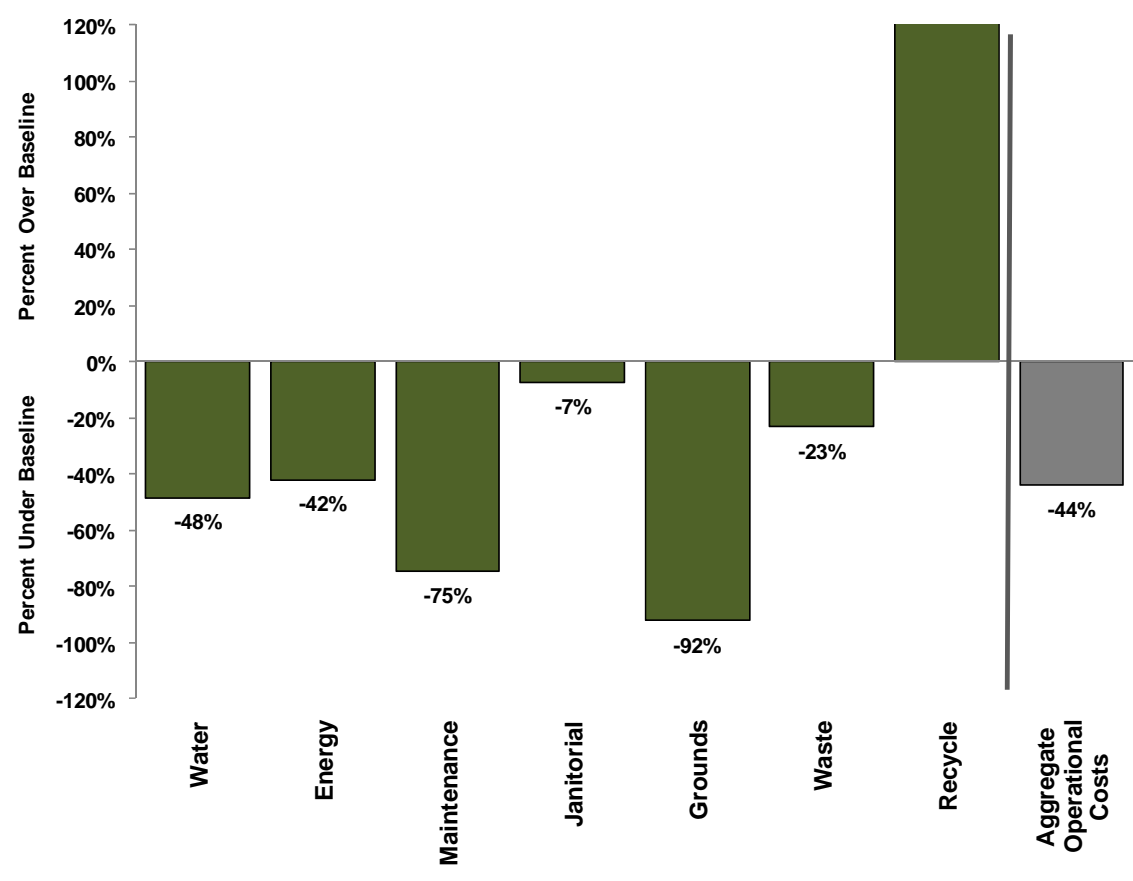




\section{Occupant Satisfaction Survey}

All 514 of the Scowcroft Federal Building occupants were surveyed and 151 responded. In addition to the electronic survey, GSA representatives issued the survey in hardcopy form because many staff did not have electronic access to the survey.

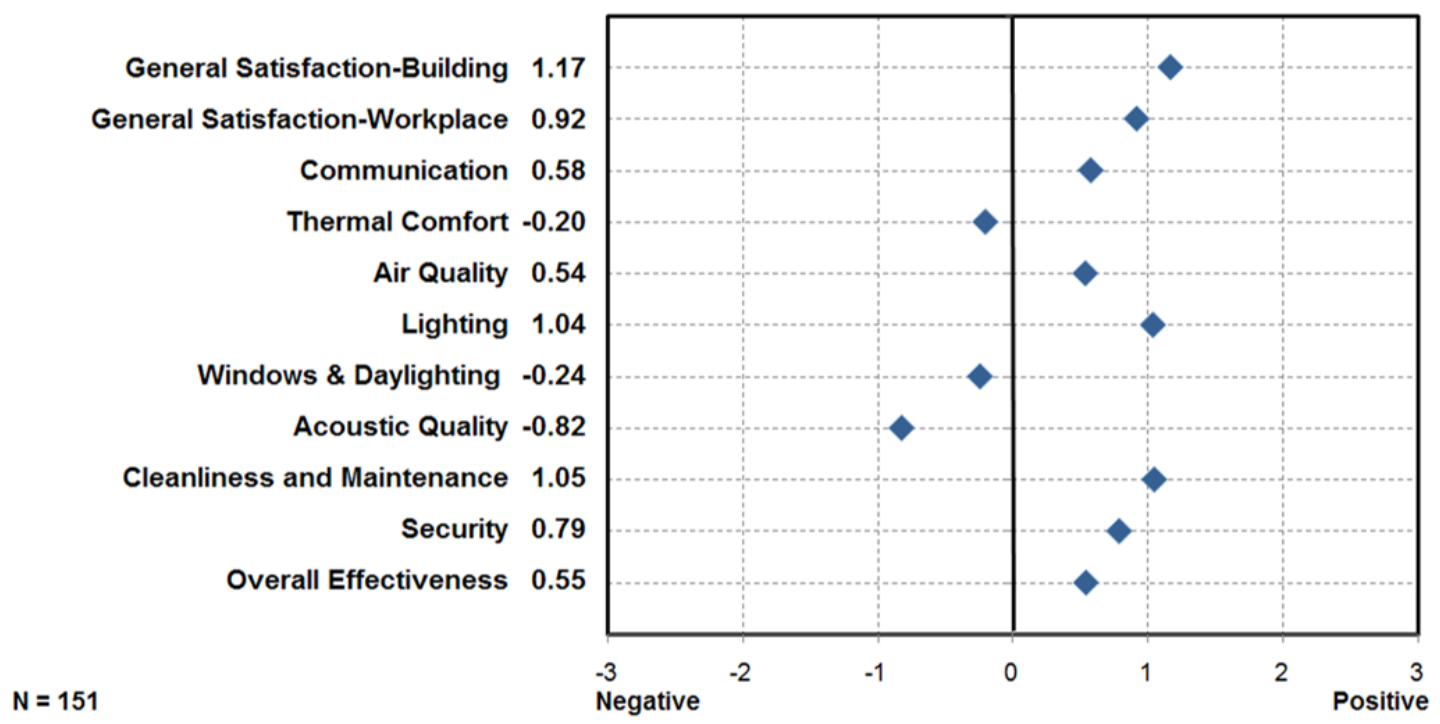

The results indicated that occupants are generally more satisfied with their building than occupants in the CBE baseline ( $52^{\text {nd }}$ percentile). The acoustic quality, thermal comfort, lighting, and cleanliness and maintenance all scored below the $50^{\text {th }}$ percentile of the CBE buildings surveyed. Frequently clogged toilets were identified as a persistent maintenance issue, and a large number of snack tables located throughout the building may be impacting the occupant satisfaction ratings.

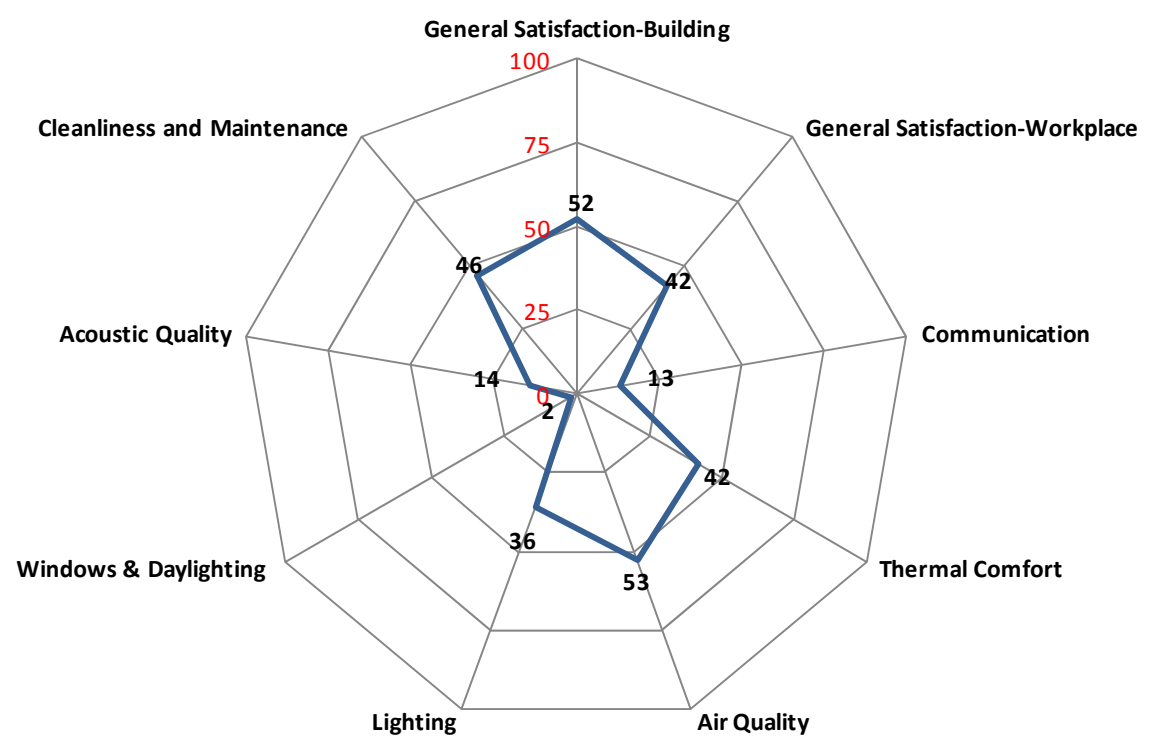




\section{Performance Data Summary}

The research team collected, normalized, and compared the whole building performance data for the Scowcroft Federal Building to industry baselines. The following table summarizes the annual performance data that were collected and normalized. The facility uses evaporative cooling for its air conditioning system; therefore, the amount of water used for evaporative cooling was estimated using the "rule-of-thumb" that $27 \%$ of total water use is process water.

\begin{tabular}{|c|c|c|c|c|}
\hline Metrics & \multicolumn{2}{|l|}{ Annual Performance Measurements } & \multicolumn{2}{|l|}{ Annual Performance Metrics } \\
\hline & Water Use (gal) & $3,619,100$ & Gallons per occupant & 5,071 \\
\hline & Process Water Use (gal) & 977,157 & Water Cost per occupant & $\$ 19.36$ \\
\hline & Outdoor Water Use (gal) & 0 & Gallons per GSF & 34.47 \\
\hline & Water Cost & $\$ 10,088$ & Water Cost per RSF & $\$ 0.10$ \\
\hline & Energy Star Score & 83 & Energy Use (kBTU) per GSF & 89 \\
\hline & Total Energy Use (kBtu) & $9,347,524$ & Energy Cost per RSF & $\$ 1.47$ \\
\hline & Energy Cost & $\$ 150,700$ & Building Emissions per Occupant $\left(\mathrm{MTCO}_{2} \mathrm{e}\right)$ & 1.86 \\
\hline & General Maintenance Cost & $\$ 39,068$ & General Maint Cost per RSF & $\$ 0.38$ \\
\hline & Janitorial Services Cost & $\$ 125,892$ & Janitorial Services Cost per RSF & $\$ 1.23$ \\
\hline & Grounds Maintenance Cost & $\$ 3,584$ & Grounds Maint Cost per RSF & $\$ 0.03$ \\
\hline & Quantity of Maint Requests & 0 & & $\mathrm{~N} / \mathrm{A}$ \\
\hline & Quantity of Prev Maint Jobs & 0 & Ratio of Maint Requests to Iotal Maint Jobs & N/A \\
\hline & Solid Waste Generated (tons) & 220 & Solid Waste (lb) per occupant & 845 \\
\hline & Solid Waste Cost & $\$ 3,940$ & Solid Waste Cost per RSF & $\$ 0.04$ \\
\hline & Quantity Recycled (tons) & 67.00 & Solid Waste Cost per occupant & $\$ 7.56$ \\
\hline & Recycling Cost & $\$ 16,081$ & $\%$ Recycle of Total Waste Generation & $23 \%$ \\
\hline & $\begin{array}{l}\text { Survey \# of Invitees } \\
\text { Survey \# of Respondents (n) }\end{array}$ & $\begin{array}{l}514 \\
151 \\
\end{array}$ & Survey Return Rate & $29 \%$ \\
\hline & Commute Miles per occ (avg) & 20 & Commute Emmisions per occ $\left(\mathrm{MTCO}_{2} \mathrm{e}\right)$ & 1.88 \\
\hline & $\begin{array}{l}\text { \# of Occupants using mass transit/walk/bike } \\
\text { \# of Respondents to Commute Question }\end{array}$ & $\begin{array}{r}5 \\
151\end{array}$ & $\begin{array}{l}\% \text { of Occupants who commute using mass } \\
\text { transit, biking and/or walking }\end{array}$ & $3 \%$ \\
\hline
\end{tabular}




\section{Sweetgrass Port}

\section{Description}

The Shared Port-of-Entry, bordering the towns of Sweetgrass, Montana and Coutts, Alberta, Canada was constructed as a facility jointly shared between GSA, the Canada Border Services Agency, and the regional

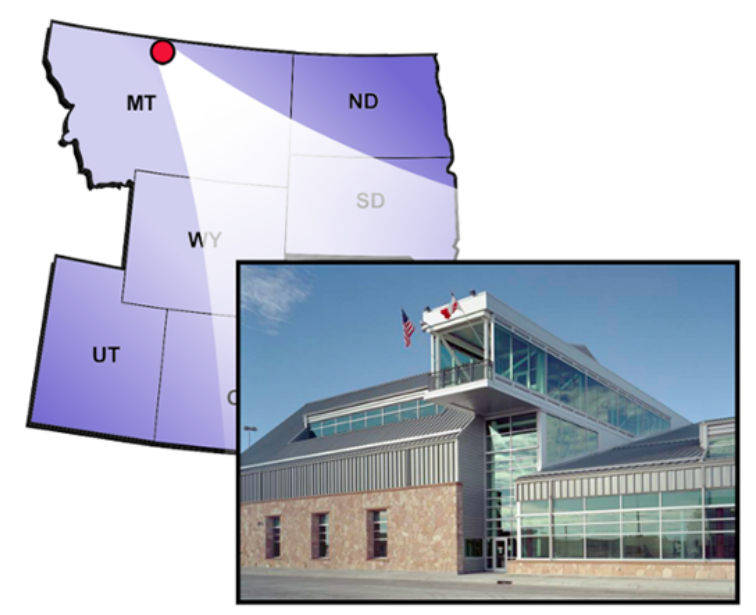
U.S. and Canadian highway departments. This is the nation's first LEED Certified Port, and it has won GSA's Environmental Award because of its water-efficiency features, indoor air

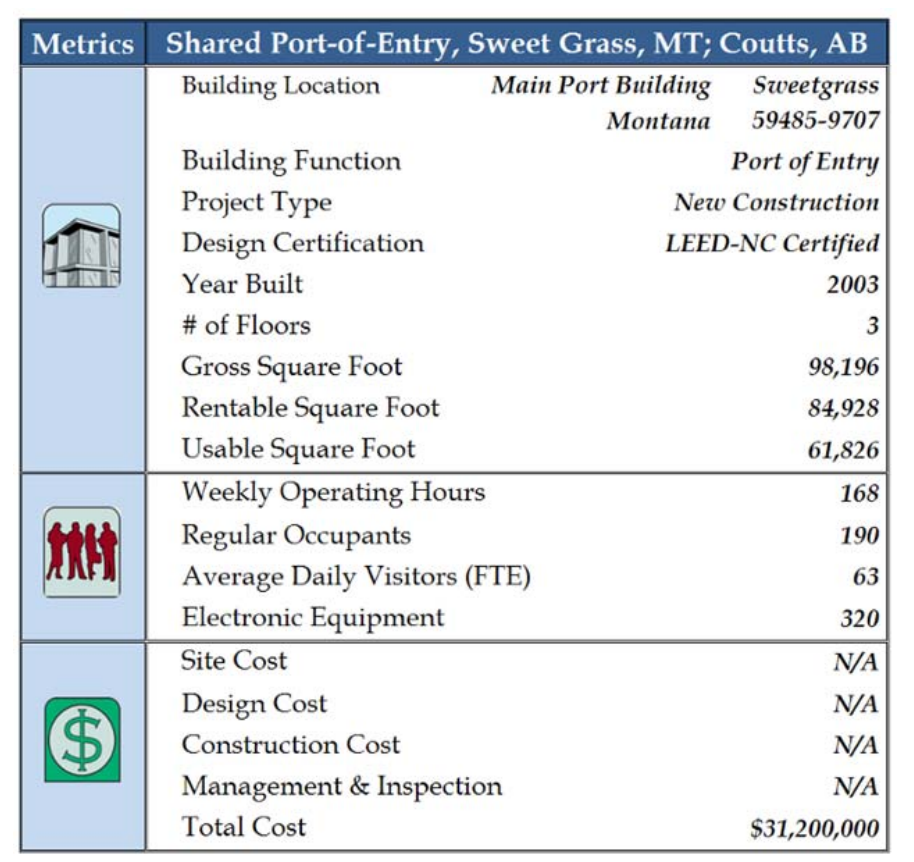
quality, sustainable siting, and green housekeeping features.

This study included the main port building as well as two commercial inspection bays, two vehicle inspection bays, and two hazardous materials inspection bays. Half of these facilities are located in the United States and half are in Canada, resulting in contracting challenges for the maintenance and operations of the facilities.

The design incorporated the security function of the building with the goal of $96 \%$ of all occupants having

a direct line of sight to the outdoors. Because of Sweetgrass' northern location and function, snow removal is critical to building operations. Glycol loops are used to heat the traffic areas and inspection facilities during the winter.

Each building in the study had operational highlights and potential opportunities for improvement. Although it was not the focus of this study to investigate and/or document operational highlights and opportunities, the research team observed:

- The primary challenge facing the Sweetgrass Port is available labor for operations and maintenance tasks. Joint ownership by Canada and the United States requires two contracts for each task. An agreement between the two governments to resolve the citizenship related contracting requirements would decrease operating costs and improve operations. 


\section{Certifications}

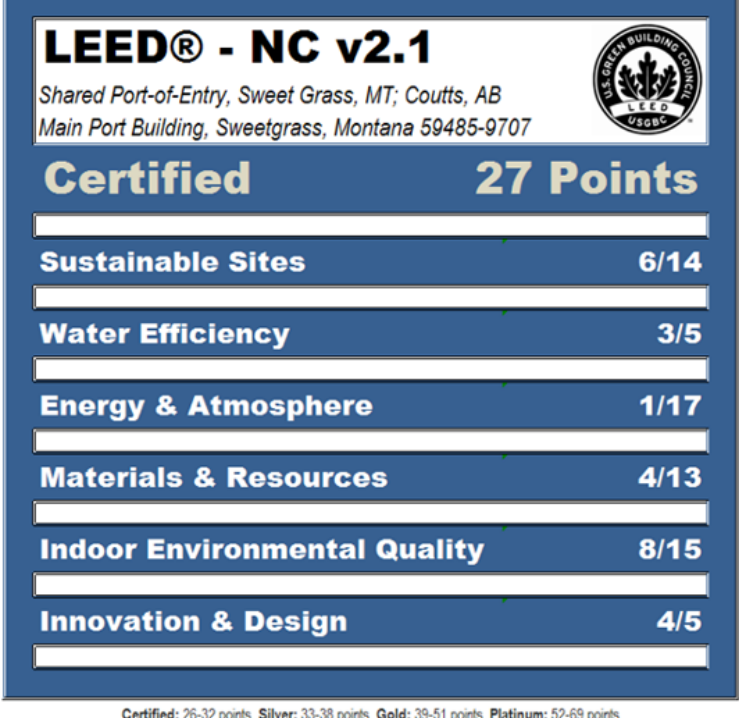

\section{Whole Building Performance}

The Sweetgrass Port operating costs are generally higher than the industry baseline for general maintenance, janitorial, and grounds. The energy, water, waste, and recycling costs were lower than the industry baseline. Overall, the building costs more to operate than a baseline building. The baseline used for this analysis was an office building, because no equivalent to Ports is available for comparison. Significant consideration must be given to the building's operational function and remote location when reviewing these costs.

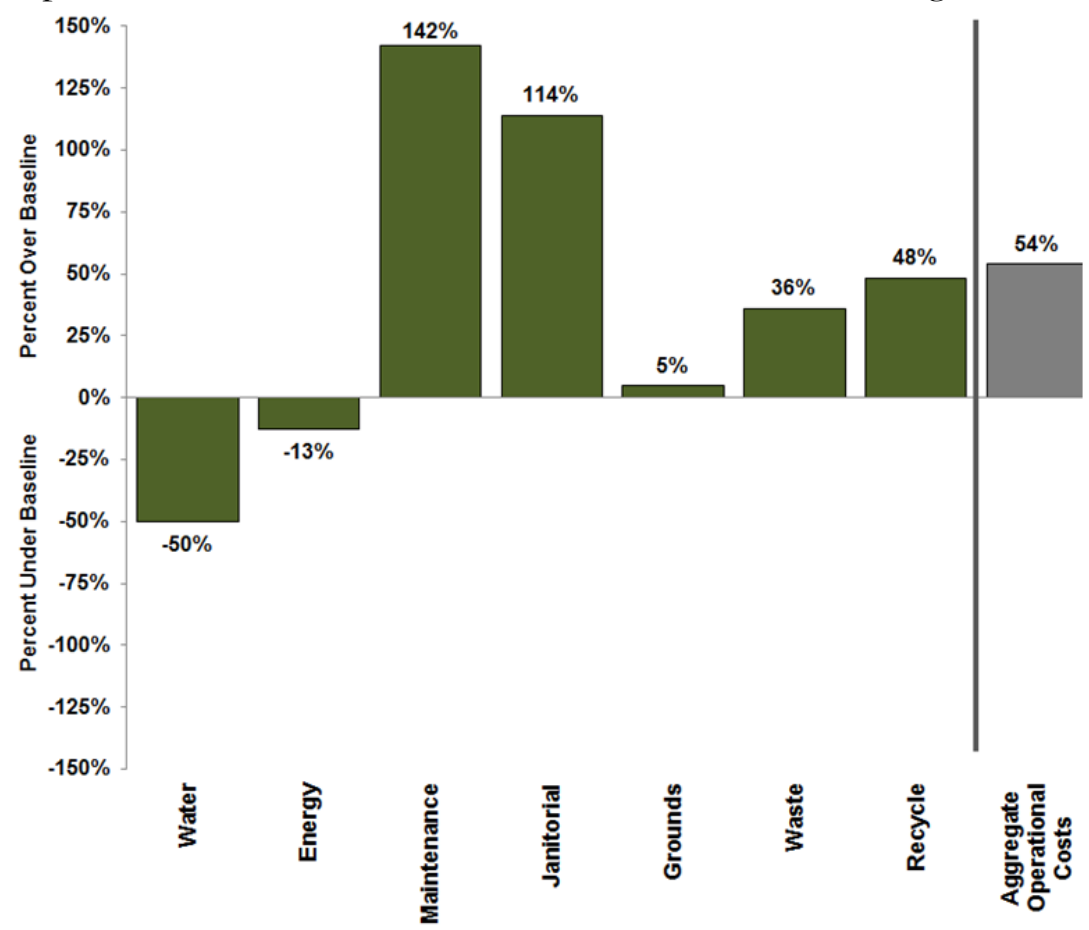




\section{Occupant Satisfaction Survey}

Of the 190 building occupants, 70 were surveyed and 42 responded.

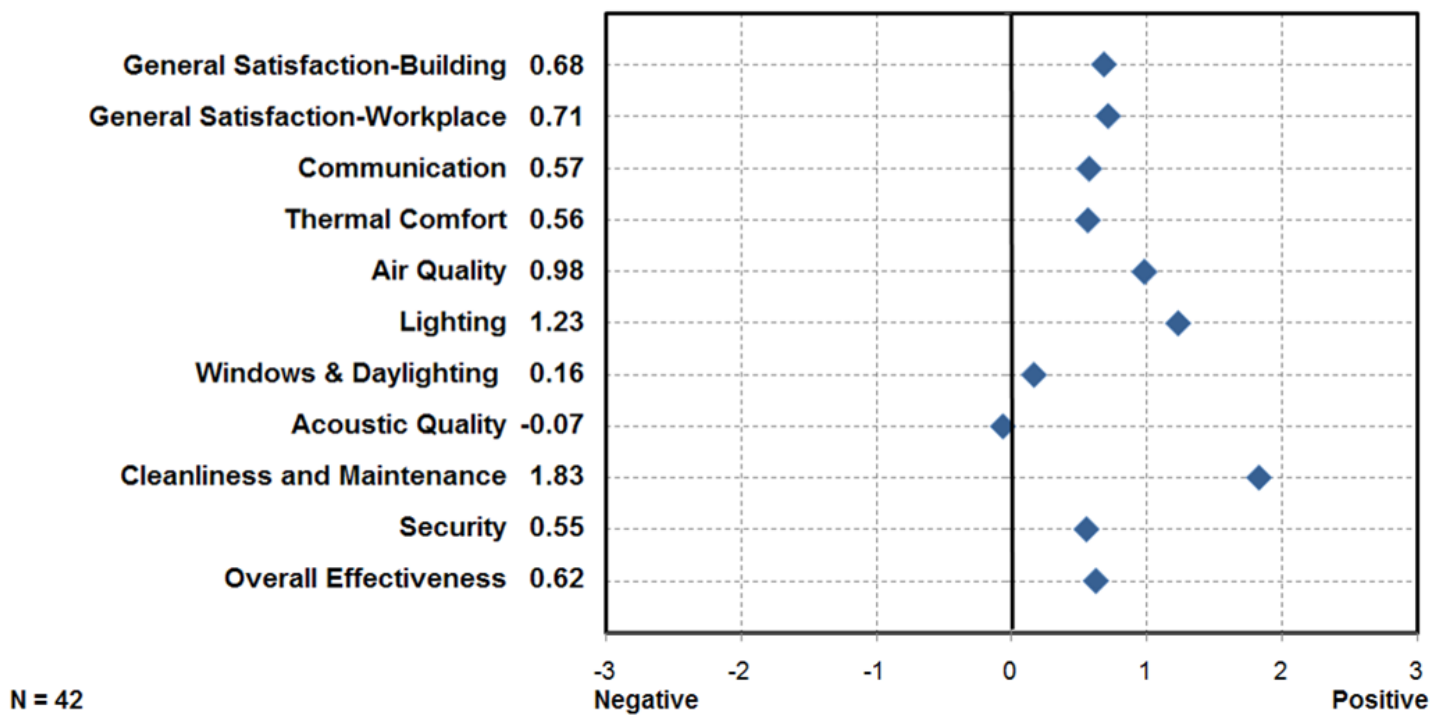

The results indicated that occupants of the Sweetgrass Port are less satisfied with their building than occupants in the CBE baseline ( $32^{\text {nd }}$ percentile), yet all of the major satisfaction metrics scored above the CBE baseline buildings. Acoustic quality and lighting scored in the $52^{\text {th }}$ and $55^{\text {th }}$ percentile respectively, while air quality, cleanliness and maintenance, and thermal comfort all scored in or above the $70^{\text {th }}$ percentile.

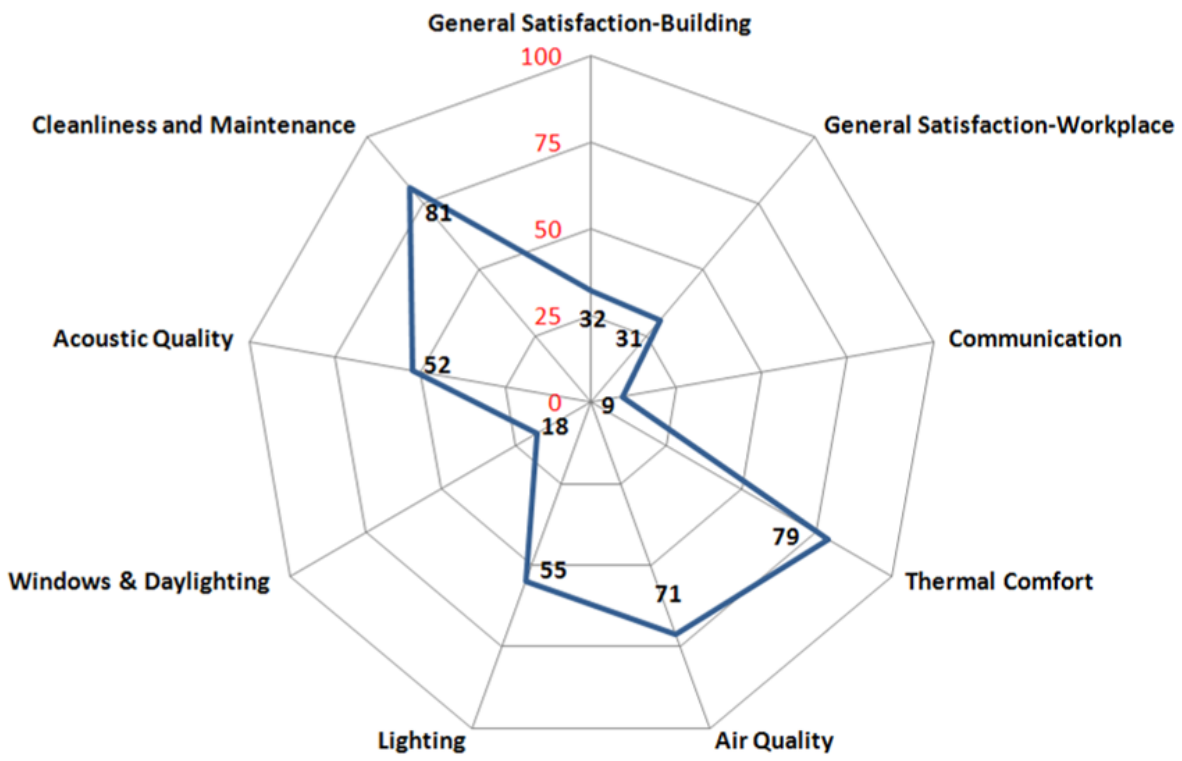




\section{Performance Data Summary}

The research team collected, normalized, and compared whole building performance data for the Sweetgrass Port to industry baselines. The following table summarizes the annual performance data collected and normalized.

\begin{tabular}{|c|c|c|c|c|}
\hline Metrics & \multicolumn{2}{|c|}{ Annual Performance Measurements } & \multicolumn{2}{|l|}{ Annual Performance Metrics } \\
\hline & Water Use (gal) & 123,144 & Gallons per occupant & 488 \\
\hline & Process Water Use (gal) & 0 & Water Cost per occupant & $\$ 31.97$ \\
\hline & Outdoor Water Use (gal) & 0 & Gallons per GSF & 1.25 \\
\hline & Water Cost & $\$ 8,073$ & Water Cost per RSF & $\$ 0.10$ \\
\hline & Energy Star Score & 19 & Energy Use (kBTU) per GSF & 193 \\
\hline & Total Energy Use (kBtu) & $20,583,129$ & Energy Cost per RSF & $\$ 2.20$ \\
\hline & Energy Cost & $\$ 187,253$ & Building Emissions per Occupant $\left(\mathrm{MTCO}_{2} \mathrm{e}\right)$ & 6.21 \\
\hline & General Maintenance Cost & $\$ 308,055$ & General Maint Cost per RSF & $\$ 3.63$ \\
\hline & Janitorial Services Cost & $\$ 240,630$ & Janitorial Services Cost per RSF & $\$ 2.83$ \\
\hline & Grounds Maintenance Cost & $\$ 40,035$ & Grounds Maint Cost per RSF & $\$ 0.47$ \\
\hline & Quantity of Maint Requests & 9 & Ratio of Maint Reguests to Total Maint Jobs & 0.04 \\
\hline & Quantity of Prev Maint Jobs & 228 & 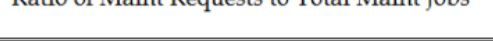 & \\
\hline & Solid Waste Generated (tons) & $N / A$ & Solid Waste (lb) per occupant & $N / A$ \\
\hline & Solid Waste Cost & $\$ 5,770$ & Solid Waste Cost per RSF & $\$ 0.06$ \\
\hline & Quantity Recycled (tons) & N/A & Solid Waste Cost per occupant & $\$ 22.85$ \\
\hline & Recycling Cost & $\$ 1,260$ & $\%$ Recycle of Total Waste Generation & $N / A$ \\
\hline & $\begin{array}{l}\text { Survey \# of Invitees } \\
\text { Survey \# of Respondents (n) }\end{array}$ & $\begin{array}{l}70 \\
42\end{array}$ & Survey Return Rate & $60 \%$ \\
\hline & Commute Miles per occ (avg) & 39 & Commute Emmisions per occ $\left(\mathrm{MTCO}_{2} \mathrm{e}\right)$ & 3.57 \\
\hline & $\begin{array}{l}\text { \# of Occupants using mass transit/walk/bike } \\
\text { \# of Respondents to Commute Question }\end{array}$ & \begin{tabular}{r||r}
0 \\
43
\end{tabular} & $\begin{array}{l}\% \text { of Occupants who commute using mass } \\
\text { transit, biking and/or walking }\end{array}$ & $0 \%$ \\
\hline
\end{tabular}




\section{Fresno Courthouse and Federal Building}

\section{Description}

The Fresno Courthouse and Federal Building is a part of the urban revitalization of the city's downtown district. There are 14 courtrooms that house district, magistrate and bankruptcy courts, and eight elevators in the tallest building in Fresno.

The facility was designed under California's Title 24 energy standards and incorporates highefficiency lighting (T5s, T8s and CFLs), underfloor air distribution systems for floors 1 through 4, water-cooled chillers, natural gas boilers, and variable speed drives. The lighting

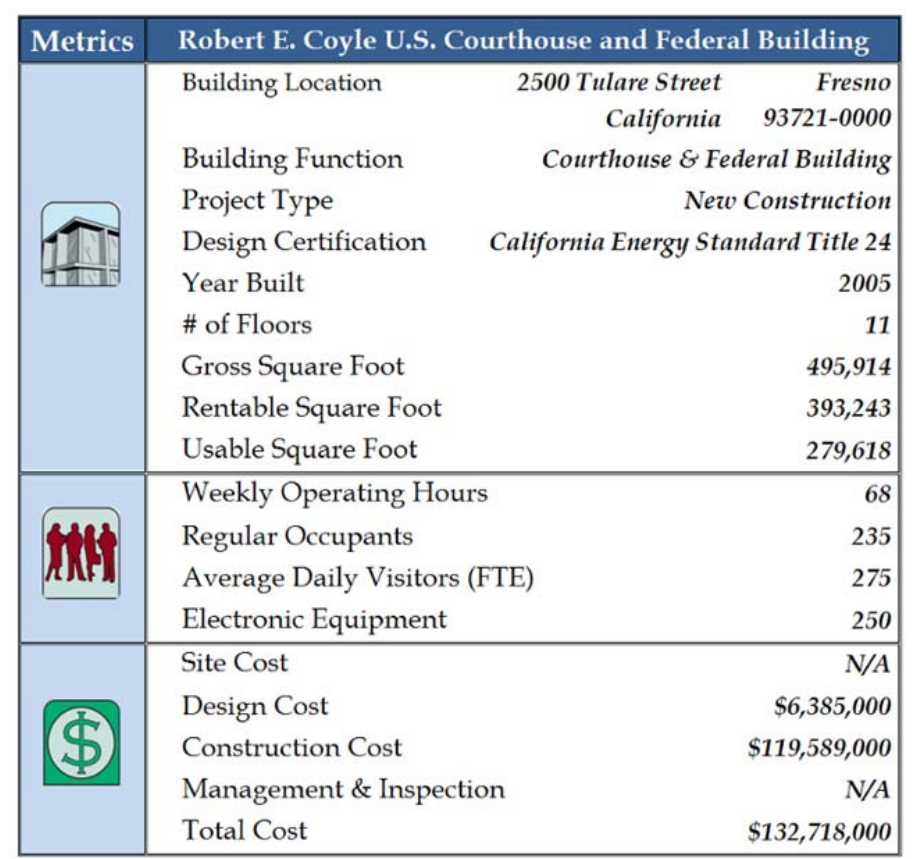

controls operate both on occupancy and time-of-day routines.

There are five primary federal agency tenants in the building. Unique features include a nurse's station that is supported by the tenants, a fitness room, underground parking, a public garden, and a library with original Ansel Adams photographs of the Yosemite Valley.

Each building in the study had operational highlights and potential opportunities for improvement.

Although it was not the focus of this study to investigate and/or document operational highlights and opportunities, the research team observed the following:

- The building landscaping is attractive, but water intensive. There is a large public garden (1.5 acres of the total 3.9-acre property size). The outdoor pond and waterfall, native plants, and conifers along with the indoor water feature offer a gathering space and a key attribute to the urban revitalization.

- A project is underway to purchase new window blinds with reflective backing to block heat and glare. 


\section{Design Certification}

California Energy Standard Title 24

\section{Whole Building Performance}

The costs of operating the Fresno CT \& FB are lower than the industry baseline for water, energy, grounds, and waste costs. The general maintenance and janitorial costs were higher than the industry baseline. Overall, the building costs slightly more to operate than a baseline building.

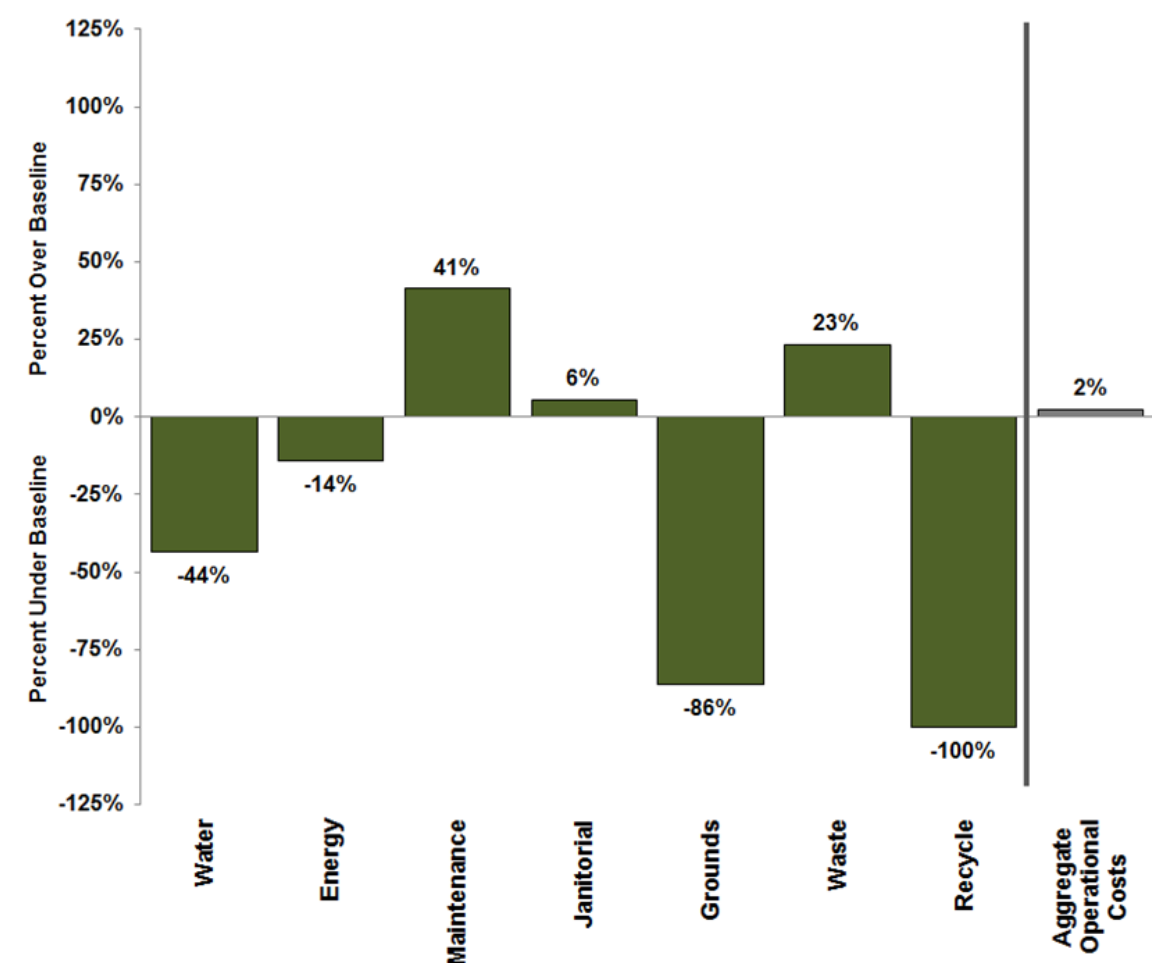




\section{Occupant Satisfaction Survey}

All 235 of the Fresno CT \& FB occupants were surveyed and 73 responded.

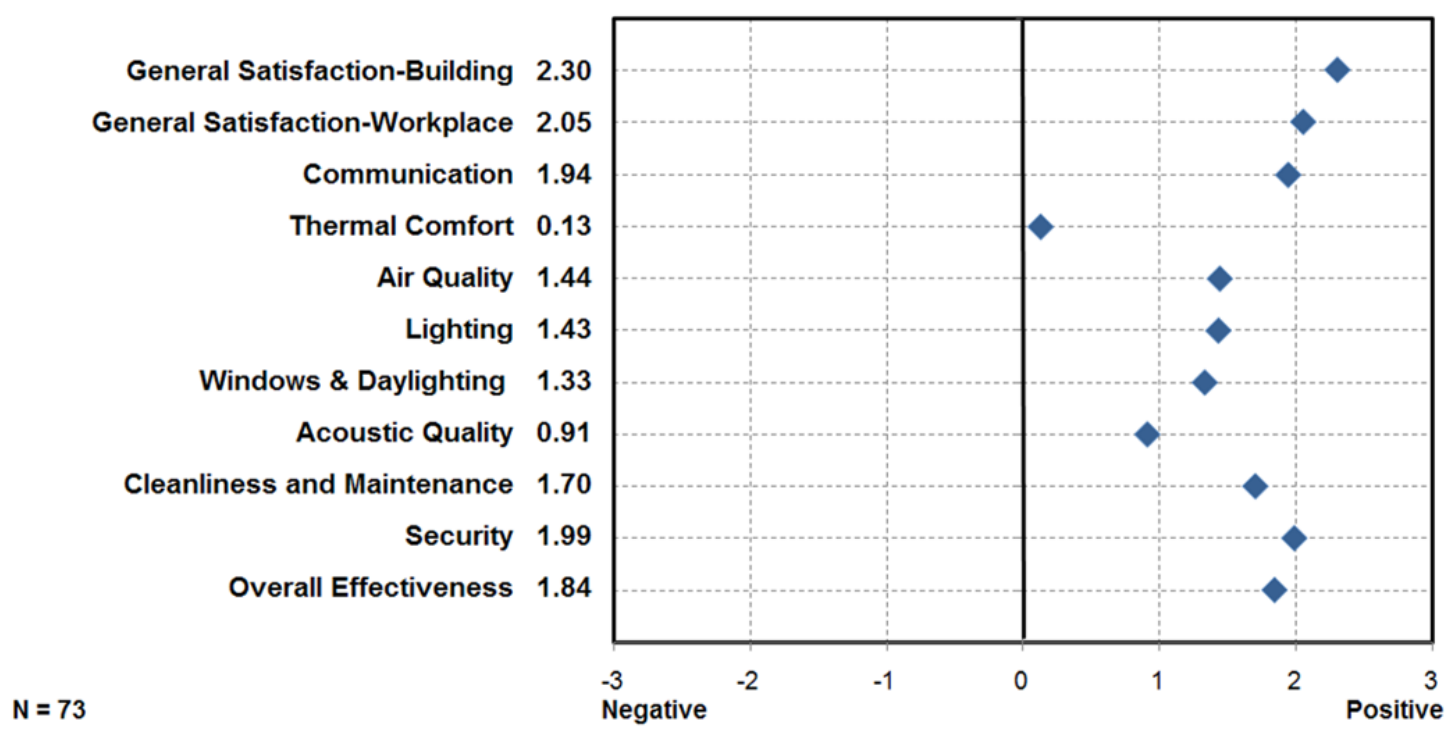

The result indicated that occupants of the Fresno CT \& FB are significantly more satisfied with their building than occupants in the CBE baseline $\left(97^{\text {th }}\right.$ percentile). Acoustic quality, air quality, and cleanliness and maintenance scored in the $75^{\text {th }}$ percentile or above. Occupant satisfaction with lighting and thermal comfort scored above the $50^{\text {th }}$ percentile.

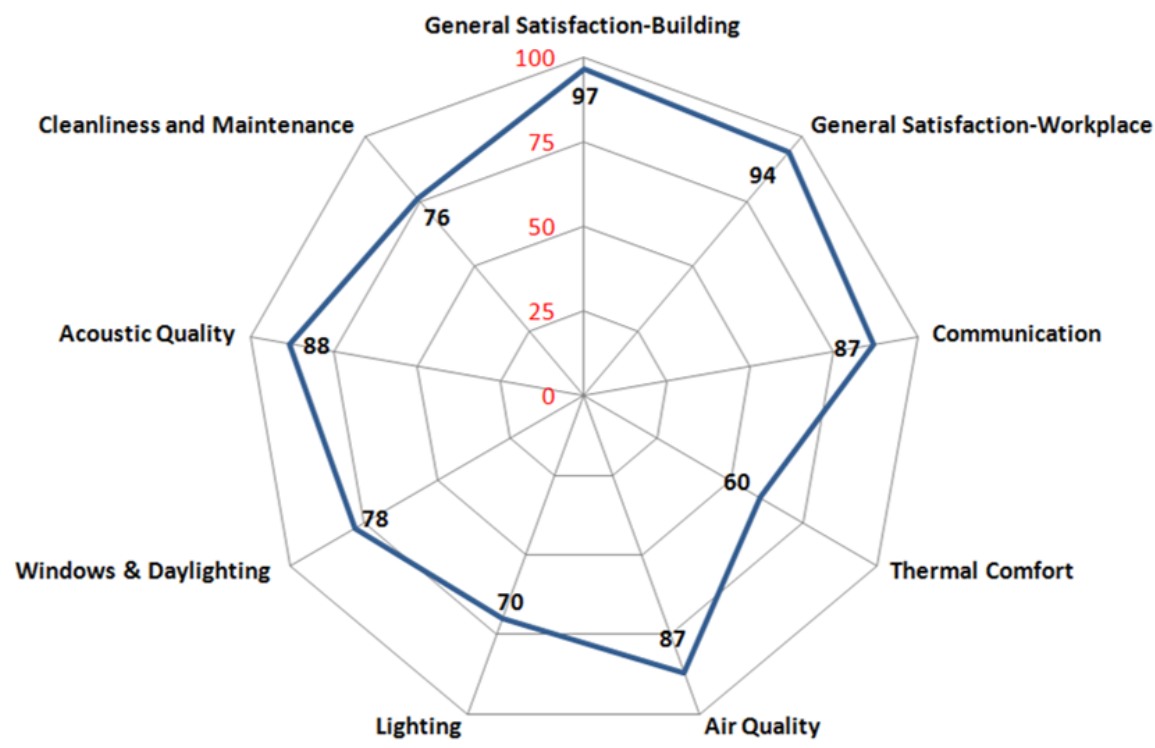




\section{Performance Data Summary}

The research team collected, normalized, and compared whole building performance data for the Fresno CT \& FB to industry baselines. The following table summarizes the annual performance data collected and normalized. The facility uses water-cooled chillers for its airconditioning system; therefore, the cooling tower water use was estimated using the "rule-ofthumb" that $27 \%$ of total water use is process water. Outdoor water use was estimated using the "rule-of-thumb" that $20 \%$ of total water use is for landscaping.

\begin{tabular}{|c|c|c|c|c|}
\hline Metrics & \multicolumn{2}{|c|}{ Annual Performance Measurements } & \multicolumn{2}{|l|}{ Annual Performance Metrics } \\
\hline & Water Use (gal) & $11,344,916$ & Gallons per occupant & 11,790 \\
\hline & Process Water Use (gal) & $3,063,127$ & Water Cost per occupant & $\$ 82.65$ \\
\hline & Outdoor Water Use (gal) & $2,268,983$ & Gallons per GSF & 22.88 \\
\hline & Water Cost & $\$ 42,150$ & Water Cost per RSF & $\$ 0.11$ \\
\hline & Energy Star Score & 87 & Energy Use (kBTU) per GSF & 54 \\
\hline & Total Energy Use (kBtu) & $26,629,363$ & Energy Cost per RSF & $\$ 2.17$ \\
\hline & Energy Cost & $\$ 854,680$ & Building Emissions per Occupant $\left(\mathrm{MTCO}_{2} \mathrm{e}\right)$ & 4.58 \\
\hline & General Maintenance Cost & $\$ 1,194,365$ & General Maint Cost per RSF & $\$ 3.04$ \\
\hline & Janitorial Services Cost & $\$ 821,414$ & Janitorial Services Cost per RSF & $\$ 2.09$ \\
\hline & Grounds Maintenance Cost & $\$ 24,236$ & Grounds Maint Cost per RSF & $\$ 0.06$ \\
\hline & Quantity of Maint Requests & 1,200 & & \\
\hline & Quantity of Prev Maint Jobs & 4,932 & Ratio of Maint Requests to Total Maint Jobs & 0.20 \\
\hline & Solid Waste Generated (tons) & 16 & Solid Waste (lb) per occupant & 64 \\
\hline & Solid Waste Cost & $\$ 24,236$ & Solid Waste Cost per RSF & $\$ 0.05$ \\
\hline & Quantity Recycled (tons) & 18.00 & Solid Waste Cost per occupant & $\$ 47.52$ \\
\hline & Recycling Cost & $\$ 0$ & $\%$ Recycle of Total Waste Generation & $53 \%$ \\
\hline & $\begin{array}{l}\text { Survey \# of Invitees } \\
\text { Survey \# of Respondents (n) }\end{array}$ & $\begin{array}{r}235 \\
73\end{array}$ & Survey Return Rate & $30 \%$ \\
\hline & Commute Miles per occ (avg) & 26 & Commute Emmisions per occ $\left(\mathrm{MTCO}_{2} \mathrm{e}\right)$ & 2.40 \\
\hline & $\begin{array}{l}\text { \# of Occupants using mass transit/walk/bike } \\
\text { \# of Respondents to Commute Question }\end{array}$ & $\begin{array}{r}0 \\
64\end{array}$ & $\begin{array}{l}\% \text { of Occupants who commute using mass } \\
\text { transit, biking and/or walking }\end{array}$ & $0 \%$ \\
\hline
\end{tabular}




\section{Las Vegas Courthouse}

\section{Description}

The Lloyd George U.S. Courthouse creates a federal presence in downtown Las Vegas as part of an urban redevelopment effort. The courthouse was competed in 2000 and received Energy Star recognition in 2007. The

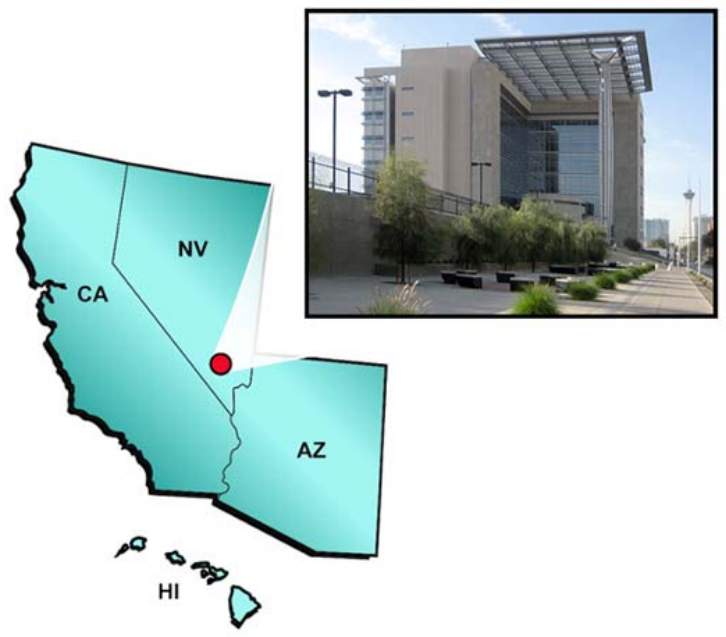
Lloyd George Courthouse was the first Federal Building built to the post-Oklahoma City blast resistant standards. In 2000 the Lloyd George Courthouse won GSA's honor award for design excellence.

There are 12 courtrooms that house district courts, and office spaces house various other agencies. The building sees a significant fluctuation in visitors depending on the need for

\begin{tabular}{|c|c|c|c|}
\hline \multirow[t]{2}{*}{ Metrics } & \multicolumn{3}{|c|}{ Lloyd D. George U.S. Courthouse } \\
\hline & Building Location & $\begin{array}{r}333 \text { Las Vegas } \\
\text { Nevada }\end{array}$ & $\begin{array}{r}\text { Las Vegas } \\
89101-7065\end{array}$ \\
\hline & Building Function & & Courthouse \\
\hline & Project Type & New & Construction \\
\hline & Design Certification & Energy & tar 2007 (77) \\
\hline & Year Built & & 2000 \\
\hline & \# of Floors & & 8 \\
\hline & Gross Square Foot & & 454,877 \\
\hline & Rentable Square Foot & & 368,969 \\
\hline & Usable Square Foot & & 281,049 \\
\hline & Weekly Operating Hours & & 55 \\
\hline & Regular Occupants & & 321 \\
\hline & Average Daily Visitors (FTE) & & 107 \\
\hline & Electronic Equipment & & 242 \\
\hline & Site Cost & & $\$ 3,030,000$ \\
\hline & Design Cost & & $\$ 1,200,000$ \\
\hline & Construction Cost & & $\$ 92,598,000$ \\
\hline & Management \& Inspection & & $\$ 3,500,000$ \\
\hline & Total Cost & & $\$ 100,328,000$ \\
\hline
\end{tabular}
those courtrooms. The design features high efficient lighting, a well-utilized EMCS system, watercooled chillers, natural gas boiler with variable speed drives. The occupancy sensors on the lighting were removed because of complaints that they were malfunctioning. The landscaping is xeriscape, but still requires some level of daily irrigation depending on weather conditions.

Each building in the study had operational highlights and potential opportunities for improvement. Although it was not the focus of

this study to investigate and/or document operational highlights and opportunities, the research team observed:

- Building management has identified several projects to improve the operations in the HVAC area. Challenges have been cited with maintain temperatures in the entryway, and revolving doors may be one solution. Additionally, there is no smaller "pony" chiller to condition the spaces that require 24-7 cooling. 


\section{Certifications}

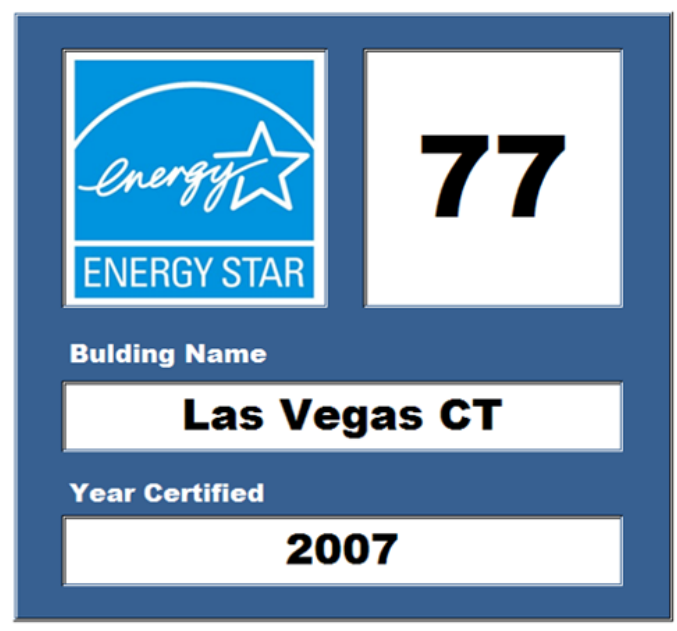

\section{Whole Building Performance}

The Lloyd George Courthouse operating costs are lower than the industry baseline in all categories.

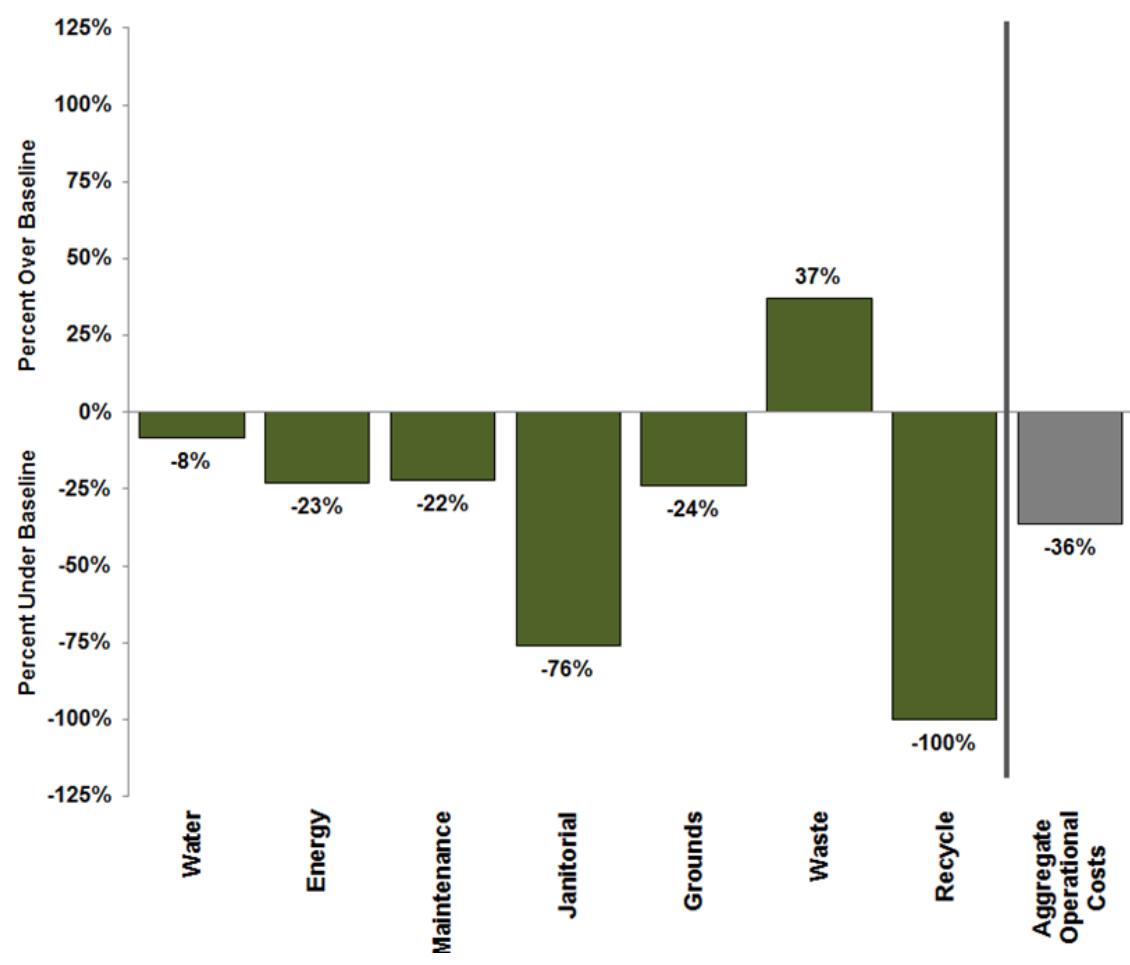




\section{Occupant Satisfaction Survey}

All 321 of the Lloyd George Courthouse occupants were surveyed and 65 responded. In addition to the electronic survey, GSA representatives issued the survey in hardcopy form as many staff did not have electronic access to the survey.

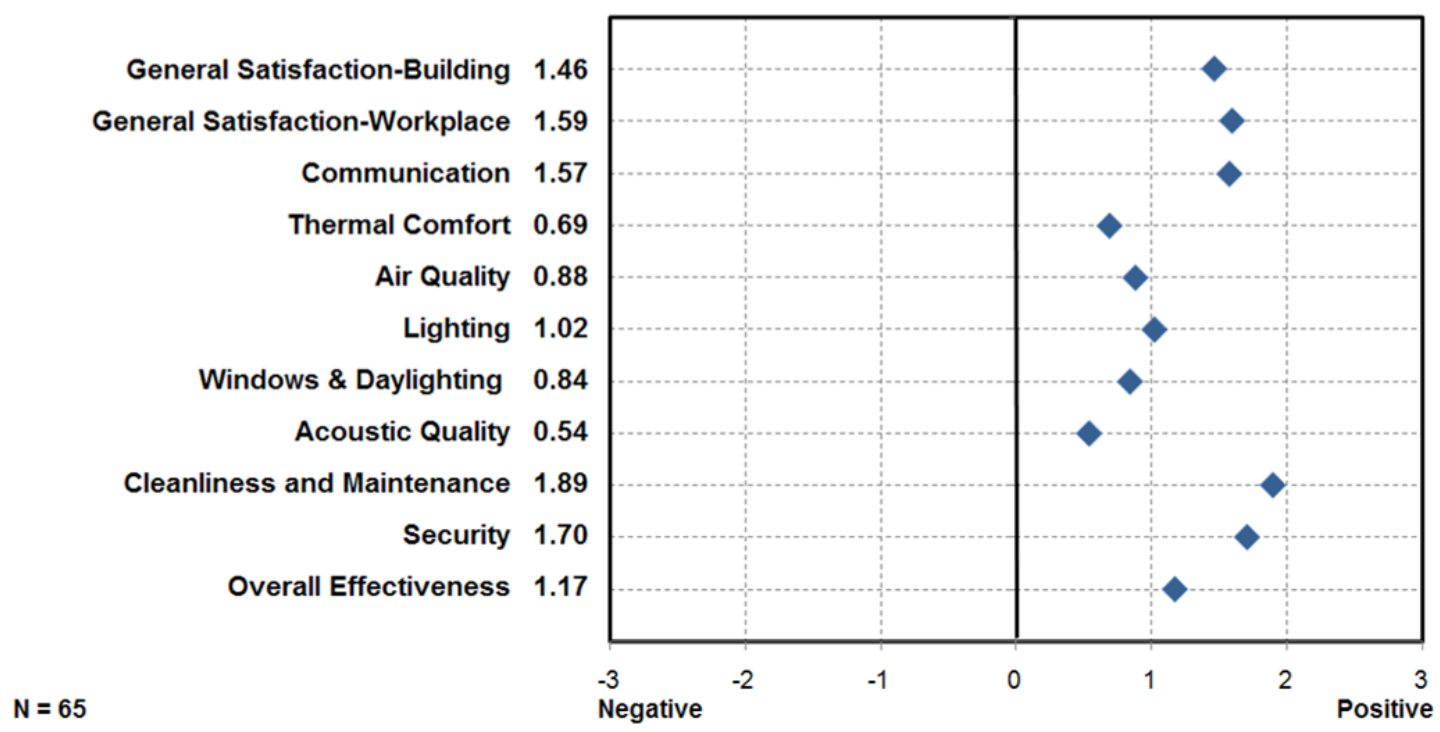

The results indicated that occupants of the Lloyd George Courthouse are more satisfied with their building than occupants in the CBE baseline $\left(69^{\text {th }}\right.$ percentile). For the other survey categories that were the primary focus of this study - acoustic quality, air quality, cleanliness and maintenance, and thermal comfort - the Lloyd George Courthouse scored above the $65^{\text {th }}$ percentile. Lighting satisfaction was the only metric scoring below the $50^{\text {th }}$ percentile.

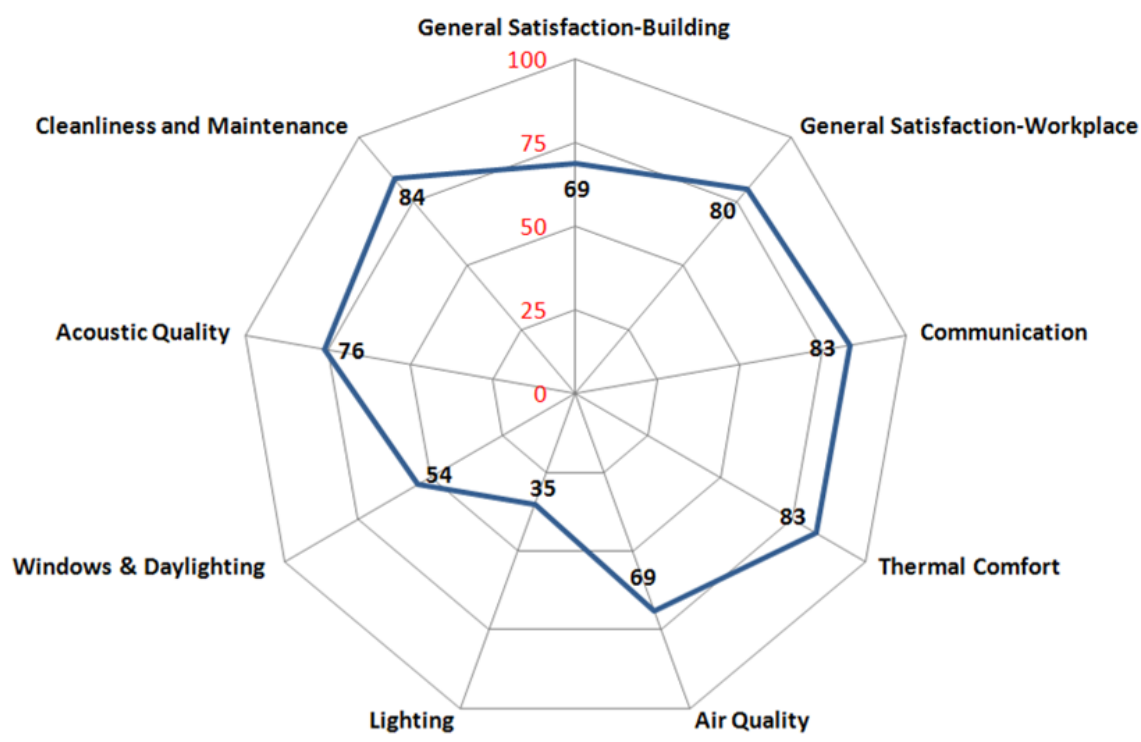




\section{Performance Data Summary}

The research team collected, normalized, and compared whole building performance data for the Lloyd George Courthouse to industry baselines. The following table summarizes the annual performance data collected and normalized. The facility uses water-cooled chillers for its air-conditioning system; therefore, the cooling tower water use was estimated using the "rule-of-thumb" that $27 \%$ of total water use is process water. Outdoor water use was estimated using the "rule-of-thumb" that $20 \%$ of total water use for landscaping.

\begin{tabular}{|c|c|c|c|c|}
\hline \multirow[t]{2}{*}{ Metrics } & \multicolumn{2}{|c|}{ Annual Performance Measurements } & \multicolumn{2}{|l|}{ Annual Performance Metrics } \\
\hline & Water Use (gal) & $10,413,000$ & Gallons per occupant & 12,905 \\
\hline & Process Water Use (gal) & $2,811,510$ & Water Cost per occupant & $\$ 150.54$ \\
\hline & Outdoor Water Use (gal) & $2,082,600$ & Gallons per GSF & 22.89 \\
\hline & Water Cost & $\$ 64,381$ & Water Cost per RSF & $\$ 0.17$ \\
\hline & Energy Star Score & 77 & Energy Use (kBTU) per GSF & 60 \\
\hline & Total Energy Use (kBtu) & $27,254,598$ & Energy Cost per RSF & $\$ 1.95$ \\
\hline & Energy Cost & $\$ 720,041$ & Building Emissions per Occupant $\left(\mathrm{MTCO}_{2} \mathrm{e}\right)$ & 10.72 \\
\hline & General Maintenance Cost & $\$ 616,845$ & General Maint Cost per RSF & $\$ 1.67$ \\
\hline & Janitorial Services Cost & $\$ 174,441$ & Janitorial Services Cost per RSF & $\$ 0.47$ \\
\hline & Grounds Maintenance Cost & $\$ 126,328$ & Grounds Maint Cost per RSF & $\$ 0.34$ \\
\hline & Quantity of Maint Requests & 962 & Ratio of Maint Requests to Total Maint Jobs & 0.40 \\
\hline & Quantity of Prev Maint Jobs & 1,430 & Kauo or Maint Kequests to Total Maint joos & \\
\hline & Solid Waste Generated (tons) & $N / A$ & Solid Waste (lb) per occupant & $N / A$ \\
\hline & Solid Waste Cost & $\$ 25,266$ & Solid Waste Cost per RSF & $\$ 0.06$ \\
\hline & Quantity Recycled (tons) & 24.00 & Solid Waste Cost per occupant & $\$ 59.08$ \\
\hline & Recycling Cost & $\$ 0$ & $\%$ Recycle of Total Waste Generation & $N / A$ \\
\hline & $\begin{array}{l}\text { Survey \# of Invitees } \\
\text { Survey \# of Respondents (n) }\end{array}$ & $\begin{array}{r}321 \\
65\end{array}$ & Survey Return Rate & $20 \%$ \\
\hline & Commute Miles per occ (avg) & 25 & Commute Emmisions per occ $\left(\mathrm{MTCO}_{2} \mathrm{e}\right)$ & 1.15 \\
\hline 00 & $\begin{array}{l}\text { \# of Occupants using mass transit/walk/bike } \\
\text { \# of Respondents to Commute Question }\end{array}$ & $\begin{array}{r}3 \\
62\end{array}$ & $\begin{array}{l}\% \text { of Occupants who commute using mass } \\
\text { transit, biking and/or walking }\end{array}$ & $5 \%$ \\
\hline
\end{tabular}




\section{San Francisco Federal Building}

\section{Description}

The San Francisco Federal Building (SFFB) was completed in 2007 and consists of an 18 story tower, four story annex, day care center, and cafeteria. The tower has a thin footprint

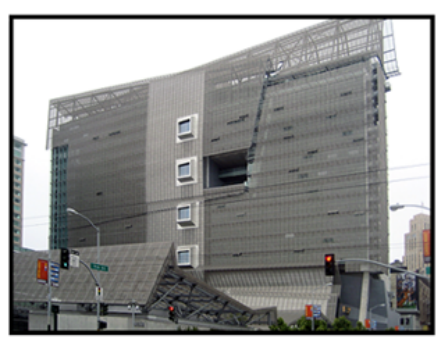
at 65 feet wide, with floors six through 18 using natural ventilation strategies to minimize mechanical heating and cooling. A three story open air sky garden is located on the $11^{\text {th }}$ floor to offer an outdoor venue for the building occupants and visitors without having to leave the building.

Features highlighted through the LEED Silver certification include: all on-site parking is underground reducing the urban heat-island effect, drip irrigation and dual-flush valves were

\begin{tabular}{|c|c|c|}
\hline Metrics & \multicolumn{2}{|c|}{ San Francisco Federal Building } \\
\hline & Building Location & $\begin{array}{l}907 \text { th Street San Francisco } \\
\text { California } \quad 94103-1516\end{array}$ \\
\hline & Building Function & Federal Building \\
\hline & Project Type & New Construction \\
\hline & Design Certification & LEED-NC Silver \\
\hline 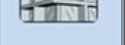 & Year Built & 2007 \\
\hline & \# of Floors & 18 \\
\hline & Gross Square Foot & 652,433 \\
\hline & Rentable Square Foot & 523,208 \\
\hline & Usable Square Foot & 406,475 \\
\hline & Weekly Operating Hours & 70 \\
\hline & Regular Occupants & 1,314 \\
\hline & Average Daily Visitors (FTE) & 130 \\
\hline & Electronic Equipment & 1,400 \\
\hline & Site Cost & $\$ 2,000,000$ \\
\hline & Design Cost & $\$ 9,200,000$ \\
\hline & Construction Cost & $\$ 143,180,204$ \\
\hline & Management \& Inspection & $\$ 6,100,000$ \\
\hline & Total Cost & $\$ 160,480,204$ \\
\hline
\end{tabular}

used to reduce potable-water consumption. Low- or zerotoxicity building materials were used during construction, and green cleaning custodial products are used during building operation. During construction, over $90 \%$ of construction waste was diverted from landfill through separation and recycling. The proximity to mass transit enables $94 \%$ of the building occupants to use some form of transit to get to the workplace. Most occupants use the BART, buses, or walk to SFFB

Each building in the study had operational highlights and potential opportunities for improvement. Although it was not the focus of this study to investigate and/or document operational highlights and opportunities, the research team observed:

- Commissioning of the building is still underway, specifically for the building automation system and HVAC balancing. The operations team has a plan in place for fine tuning of the building systems to optimize the functionality and reduce operations cost. 


\section{Certifications}

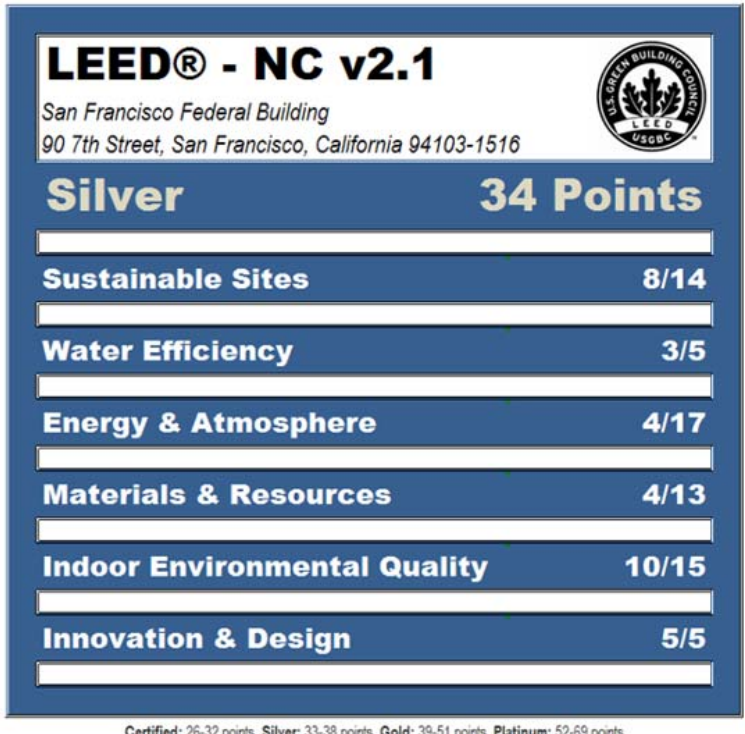

Certified: $26-32$ points, Silver: $33-38$ points, Gold: $39-51$ point, Platinum: $52-69$ points

\section{Whole Building Performance}

The San Francisco Federal Building operating costs are lower than the industry baseline for water, energy, grounds maintenance, waste, and recycling costs. The general maintenance and janitorial costs are higher than the industry baseline. Overall, the building costs less to operate than a baseline building.

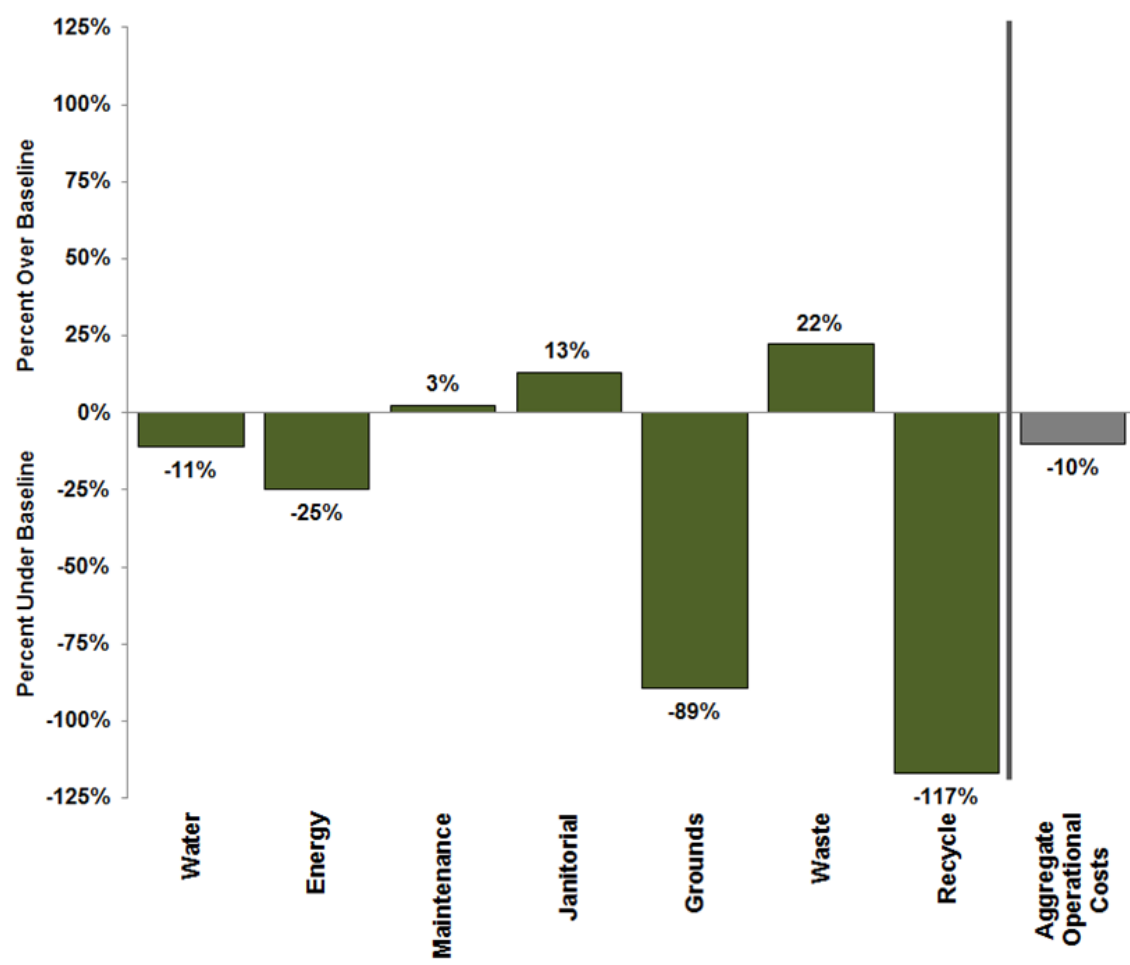




\section{Occupant Satisfaction Survey}

Of the 1314 occupants at the San Francisco Federal Building, 1244 were surveyed and 497 responded. In addition to the electronic survey, GSA representatives issued the survey in hardcopy in the lobby of the building.

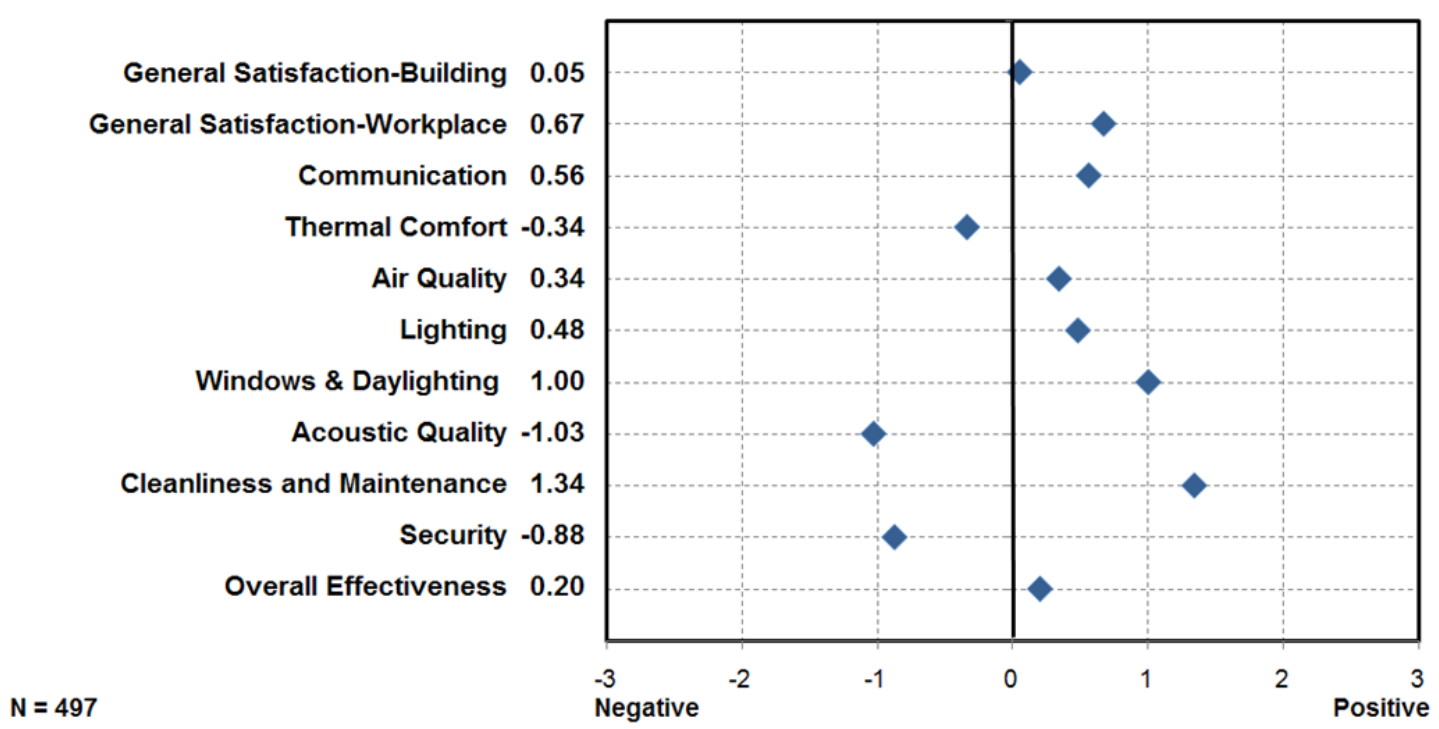

The results indicated that occupants of the San Francisco Federal Building are less satisfied with their building than occupants in the CBE baseline $\left(12^{\text {th }}\right.$ percentile). The acoustic quality, thermal comfort, and lighting all scored below the $50^{\text {th }}$ percentile of the CBE buildings surveyed. The San Francisco Federal Building had cleanliness and maintenance and windows and daylighting scores above the $60^{\text {th }}$ percentile.

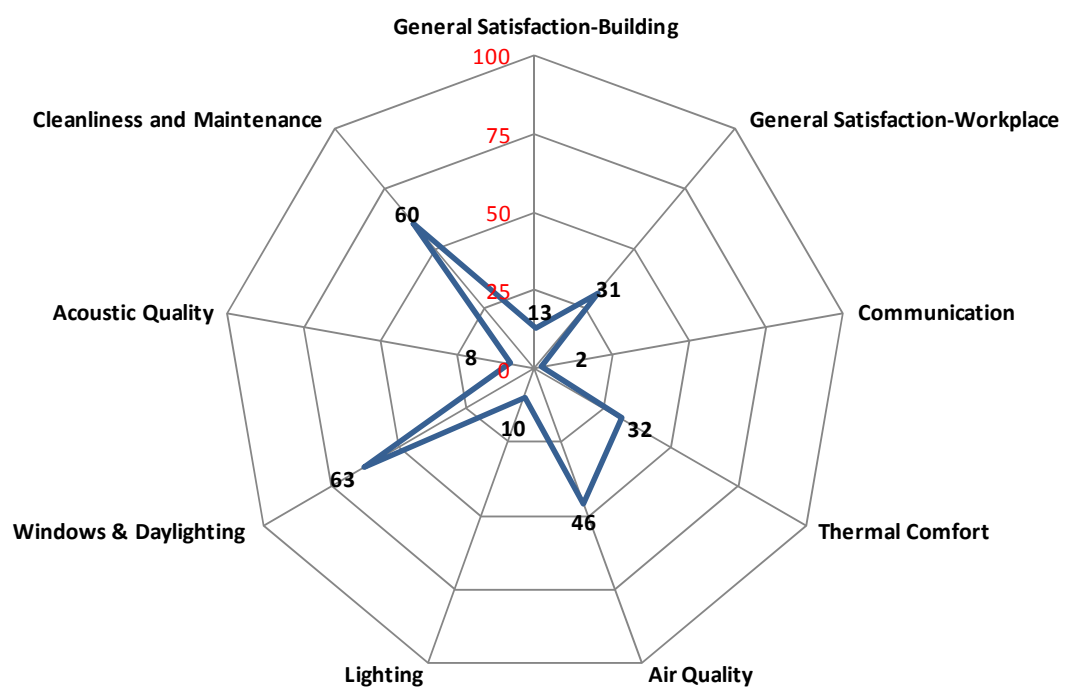




\section{Performance Data Summary}

The research team collected, normalized, and compared whole building performance data for the San Francisco Federal Building to industry baselines. The following table summarizes the annual performance data collected and normalized. The facility uses watercooled chillers for a portion of its air-conditioning system; therefore, the cooling tower water use was estimated using the "rule-of-thumb" that $27 \%$ of total water use is process water.

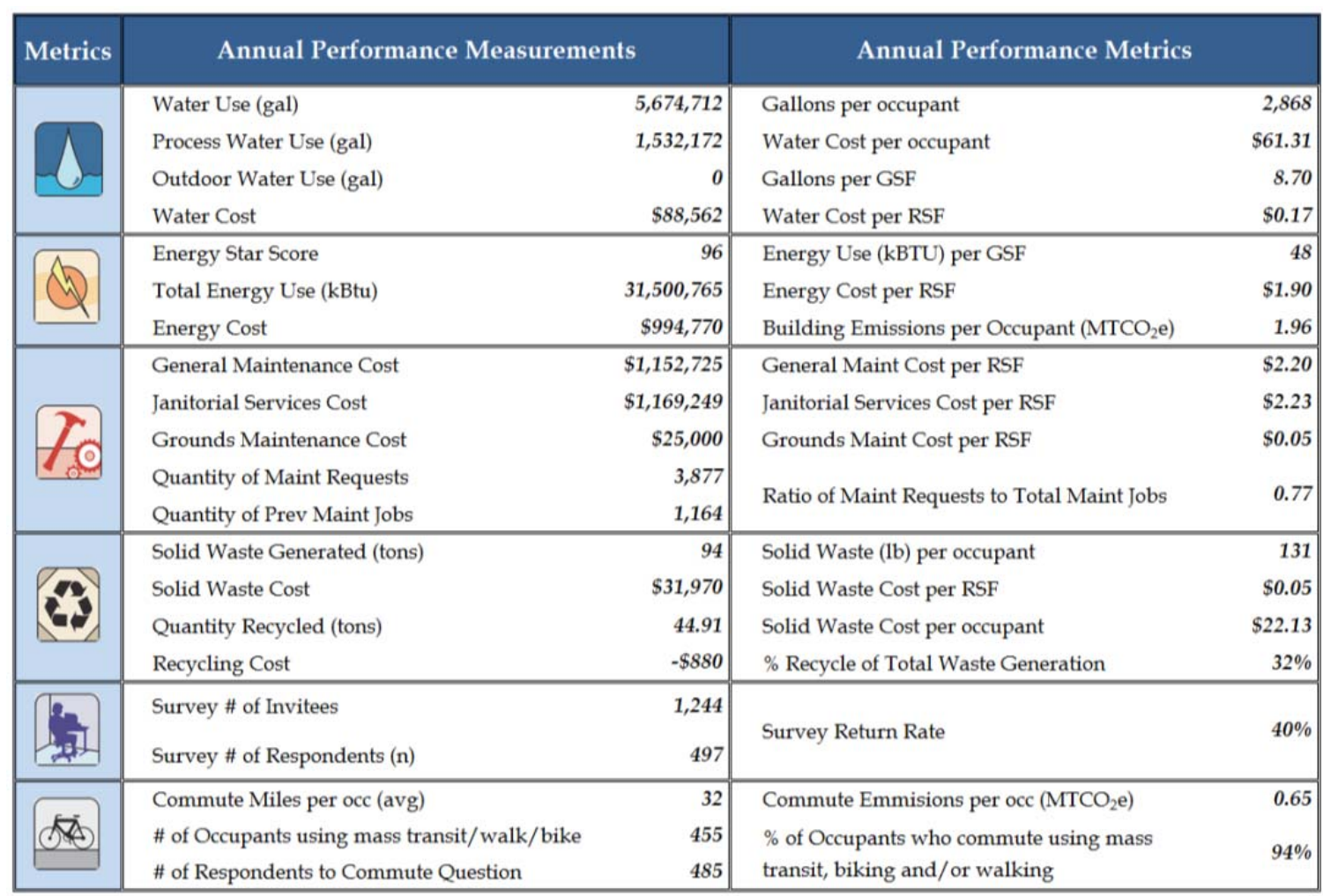




\section{Santa Ana Federal Building}

\section{Description}

The Santa Ana Federal Building was remodeled in 2005, incorporating new lighting and HVAC systems, a new roof, variable frequency drives, energy-efficient elevators, occupancy temperature control, and light-level sensors. All major commodities used in the building are

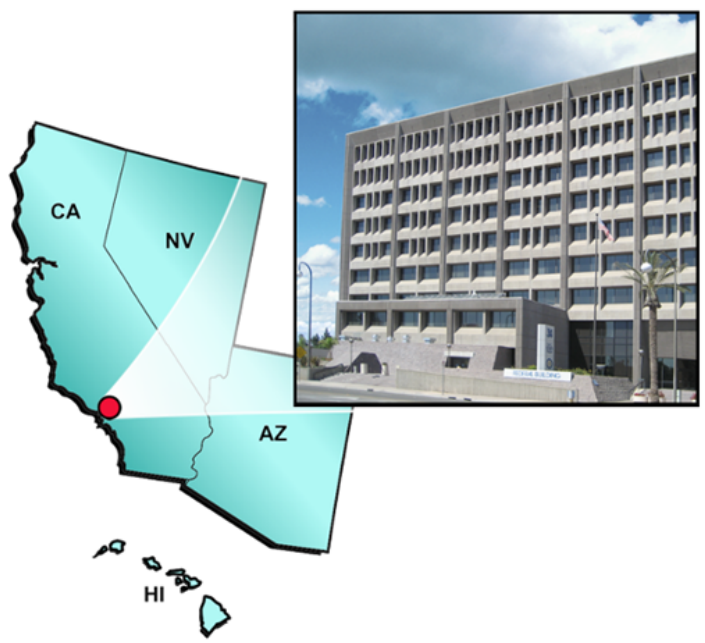
recycled, including plastic, glass, cans, batteries, paper, and cardboard. A concrete and steel high-rise building originally built in 1975, the Santa Ana Federal Building is located in the

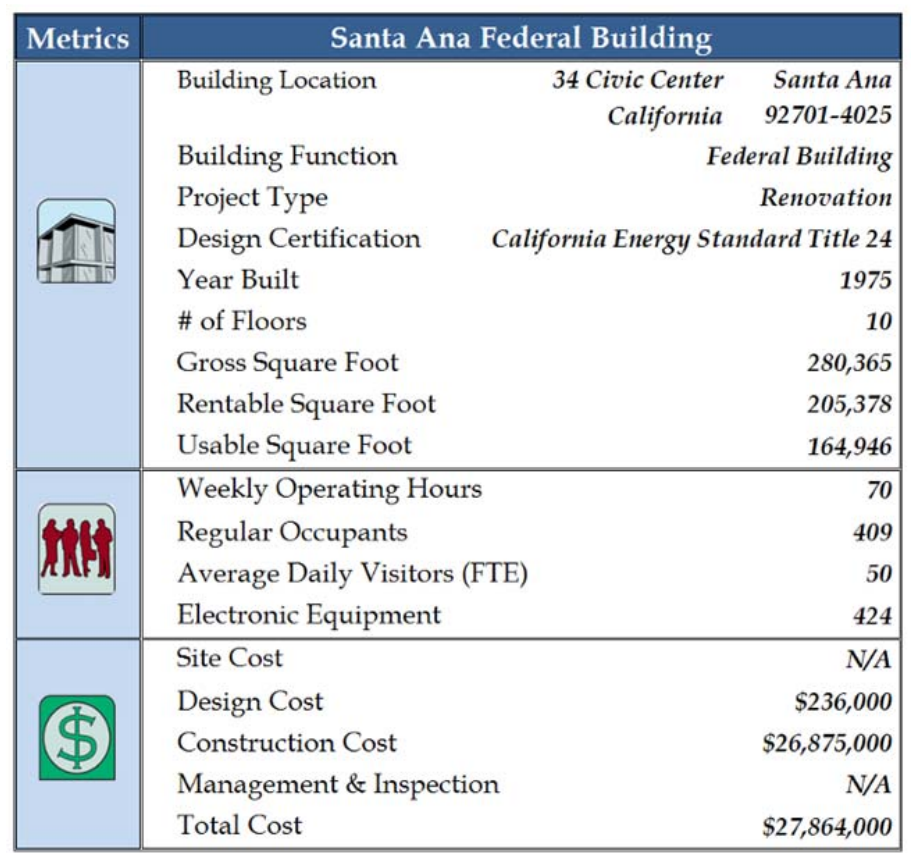
heart of the civic center district. The landscaping requires minimal maintenance and attractive.

The building currently houses five federal agencies. One of those offices serves approximately 300 customers daily and another office processes 75 to 100 detainees daily. The family-owned, full-service restaurant has an estimated 250 to 300 customers per day.

Each building in the study had operational highlights and potential opportunities for improvement. Although it was not the focus of this study to investigate and/or document operational highlights and opportunities, the research team observed the following:

- The Santa Ana Federal Building has a low energy use intensity and thus is performing well from an energy performance perspective. Applying for an Energy Star rating and/or LEED Existing Building certification would formally document the impact of this building.

- Thermal comfort scored high ( $87^{\text {th }}$ percentile) and acoustic quality, cleanliness and maintenance, and lighting scored below the $50^{\text {th }}$ percentile on the CBE buildings survey. Interviews of occupants regarding these issues may result in a more detailed understanding of how operations might be adjusted to improve occupant satisfaction and what to communicate regarding the thermal comfort success. 


\section{Certifications}

California Energy Standard Title 24

\section{Whole Building Performance}

The Santa Ana Federal Building operating costs are lower than the industry baseline for water, grounds maintenance, janitorial, waste, and recycling costs. Overall, the building costs slightly more to operate than a baseline building.

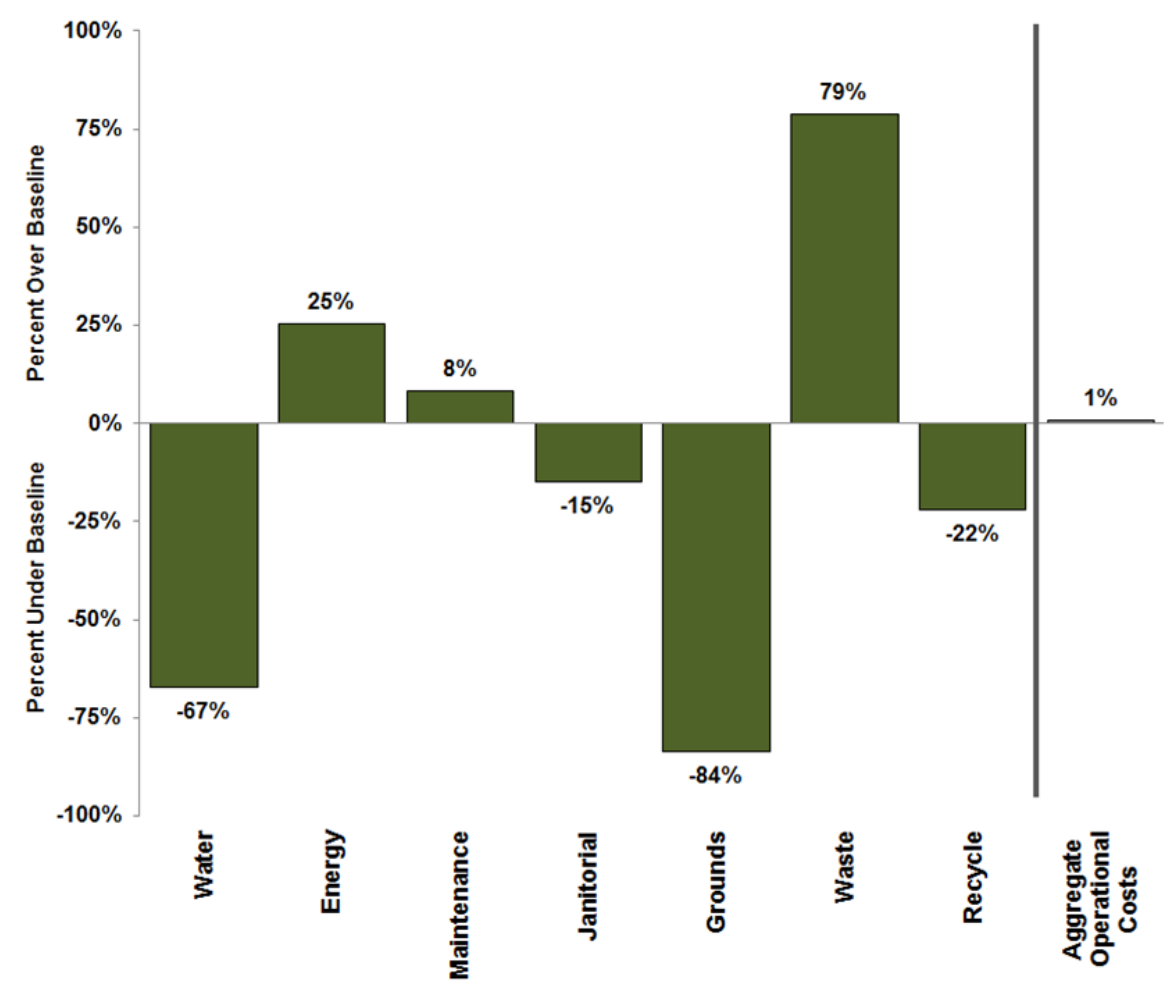




\section{Occupant Satisfaction Survey}

Of the 409 occupants in the Santa Ana Federal Building, 336 were surveyed and 118 responded.

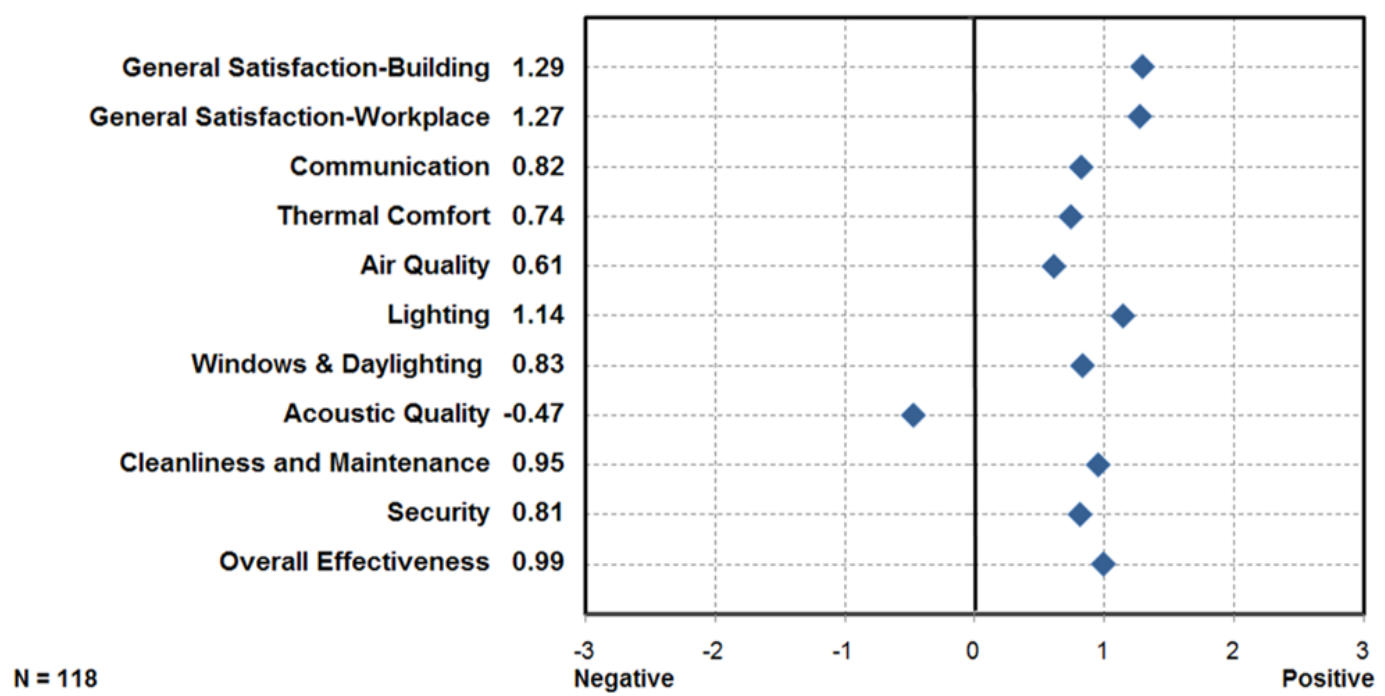

The results indicated that occupants of the Santa Ana Federal Building are generally more satisfied with their building than occupants in the CBE baseline $\left(58^{\text {th }}\right.$ percentile). The acoustic quality, cleanliness and maintenance, and lighting scored below the $50^{\text {th }}$ percentile of the CBE buildings surveyed. Thermal comfort and air quality scored above the $50^{\text {th }}$ percentile, with thermal comfort at the $87^{\text {th }}$ percentile (one of the highest scoring buildings in the study).

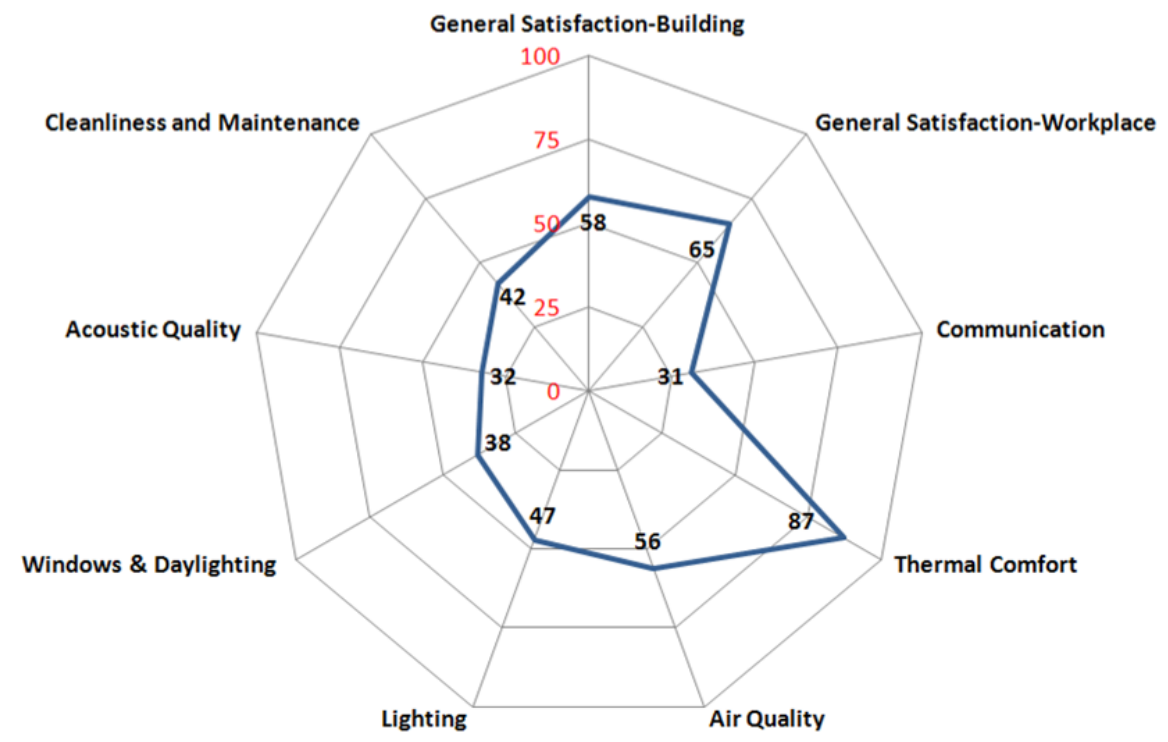




\section{Performance Data Summary}

The research team collected, normalized, and compared the whole building performance data for the Santa Ana Federal Building to industry baselines. The following table summarizes of the annual performance data collected and normalized.

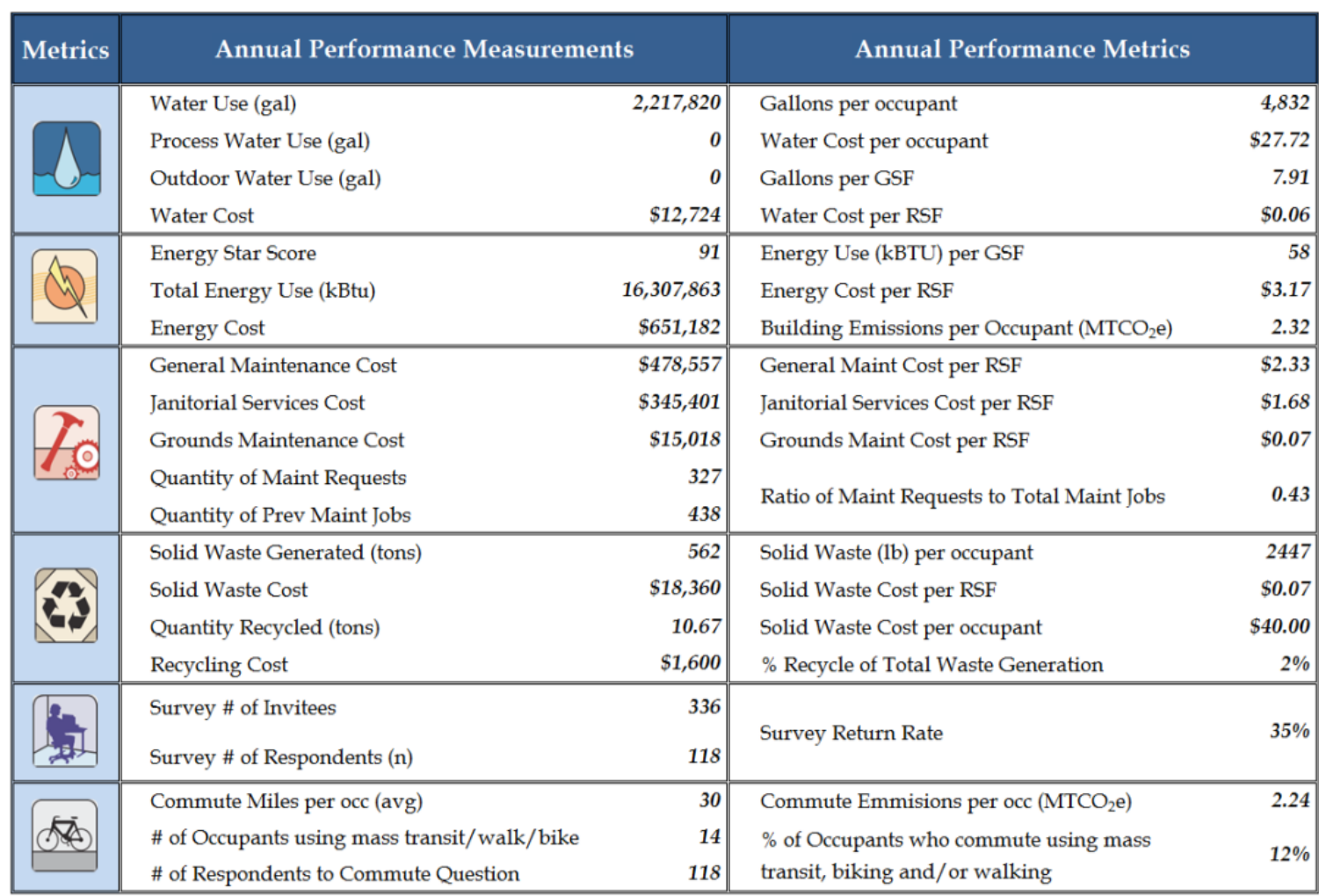




\section{Auburn Federal Building}

\section{Description}

Prior to its transformation to a office building, the Social Services Administration (SSA) Teleservice Center was a warehouse. The LEED Silver-certified remodel incorporated improved thermal envelope,

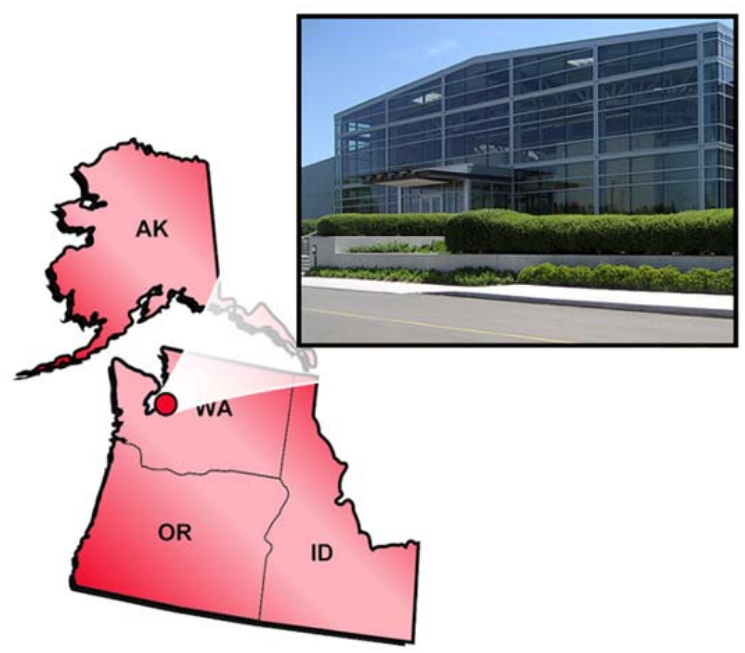
high efficiency windows, reduced lighting power density, occupancy sensors, daylighting controls, and variable speed drives. The underfloor air distribution system was coupled with high efficiency chillers and boilers with night flush and demand control ventilation. The

\begin{tabular}{|c|c|c|c|}
\hline Metrics & \multicolumn{3}{|c|}{ Auburn SSA Teleservice Center } \\
\hline & Building Location & $\begin{array}{r}1901 \text { C St Sw } \\
\text { Washington }\end{array}$ & $\begin{array}{r}\text { Auburn } \\
98001-7426\end{array}$ \\
\hline & Building Function & & ral Building \\
\hline & Project Type & & Renovation \\
\hline & Design Certification & & D-NC Silver \\
\hline Hintint & Year Built & & 1944 \\
\hline & \# of Floors & & $1+M e z z$ \\
\hline & Gross Square Foot & & 205,354 \\
\hline & Rentable Square Foot & & 201,003 \\
\hline & Usable Square Foot & & 189,249 \\
\hline & Weekly Operating Hours & & 70 \\
\hline & Regular Occupants & & 675 \\
\hline & Average Daily Visitors (FTE) & & 0 \\
\hline & Electronic Equipment & & 675 \\
\hline & Site Cost & & $N / A$ \\
\hline & Design Cost & & $\$ 1,134,000$ \\
\hline & Construction Cost & & $\$ 16,943,000$ \\
\hline & Management \& Inspection & & $\$ 1,372,000$ \\
\hline & Total Cost & & $\$ 19,449,000$ \\
\hline
\end{tabular}
building management is actively involved with the electric utility in their demand response program.

The open floor plan with cubicles offers relatively high acoustic quality ratings by the occupants $\left(70^{\text {th }}\right.$ percentile).

Use of native and adaptive vegetation reduced the need for irrigation water by $50 \%$. The use of dual flush toilets, and low-flow fixtures, resulted in a projected reduction of $39 \%$ of potable water use.

Each building in the study had

operational highlights and potential opportunities for improvement. Although it was not the focus of this study to investigate and/or document operational highlights and opportunities, the research team observed the following:

- The building management staff reported challenges in keeping temperatures within acceptable ranges. The CBE survey thermal comfort score was below the $50^{\text {th }}$ percentile. Recommisioning of the systems may alleviate some of these problems.

- The CBE survey lighting score was below the $50^{\text {th }}$ percentile. Interviews of the occupants regarding these issues may result in a more detailed understanding of how operations might be adjusted to improve occupant satisfaction. 


\section{Certifications}

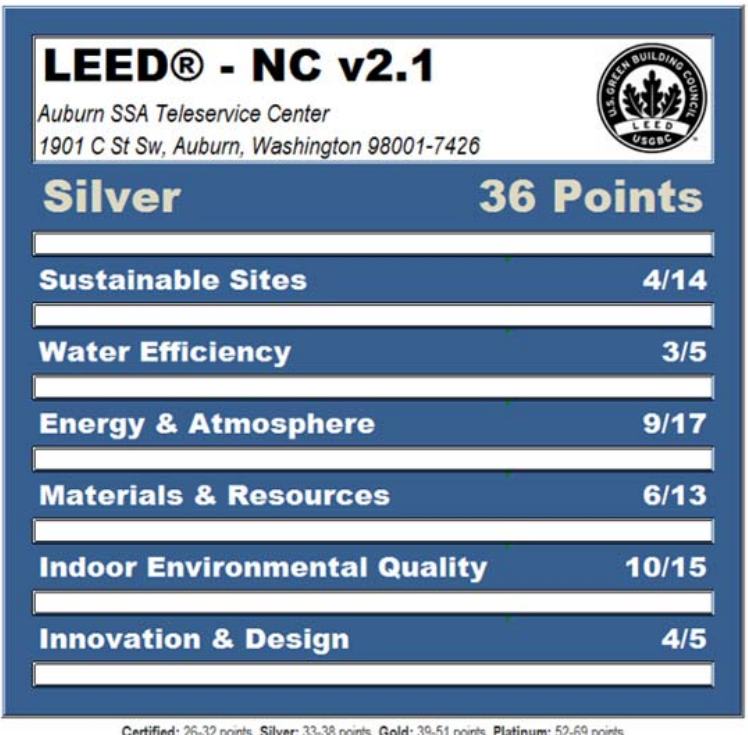

Certified: $26-32$ ponts, Silver: $33-38$ poins, Gold: $39-51$ point, Platinum: $52-69$ points

\section{Whole Building Performance}

The Auburn SSA Teleservice Center operating costs are lower than the industry baseline for water, energy, general maintenance, grounds maintenance, and waste. The janitorial costs are higher than the industry baseline, and recycling costs are not tracked for the building. Overall, the building costs less to operate than a baseline building.

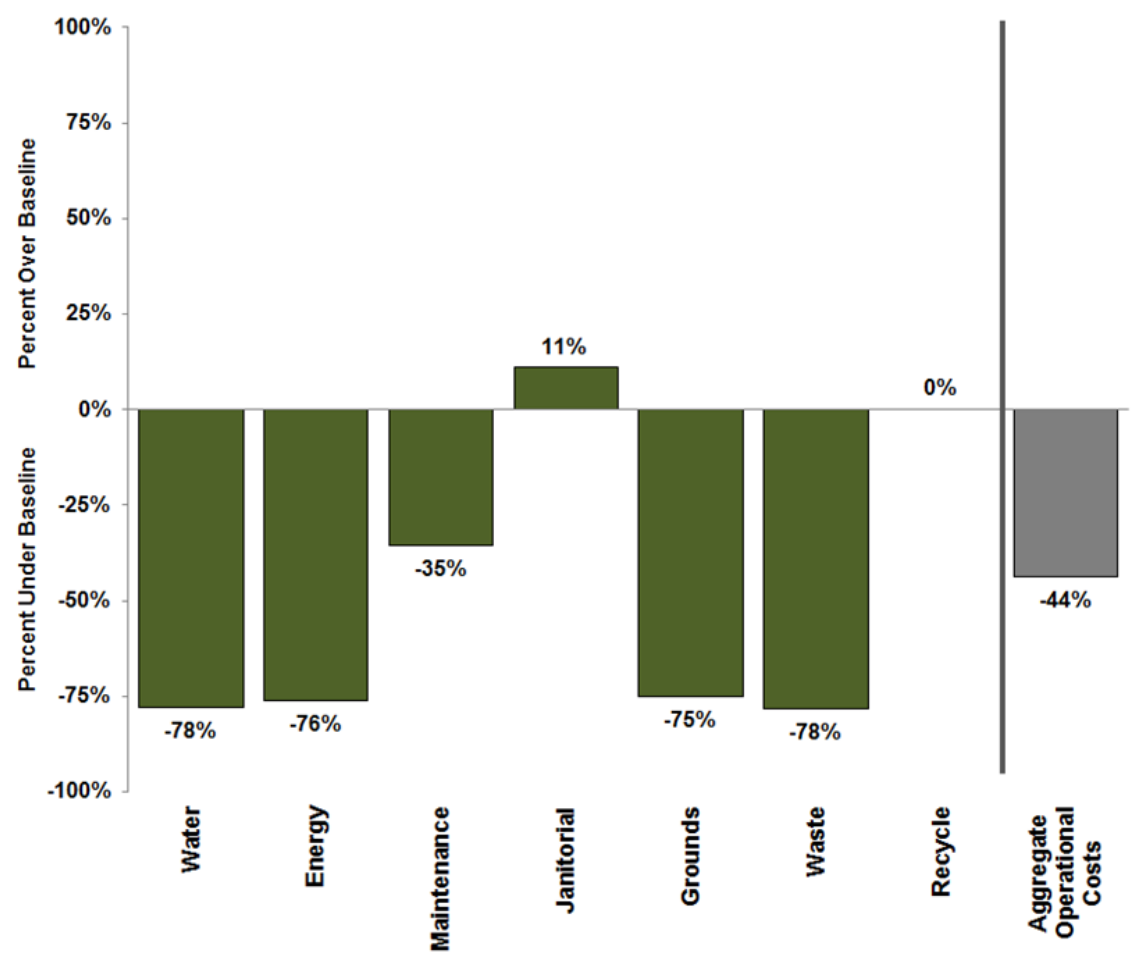




\section{Occupant Satisfaction Survey}

Of the 675 occupants at the Auburn SSA Teleservice Center, 600 were surveyed and 442 responded All of the main survey categories except thermal comfort had positive average scores.

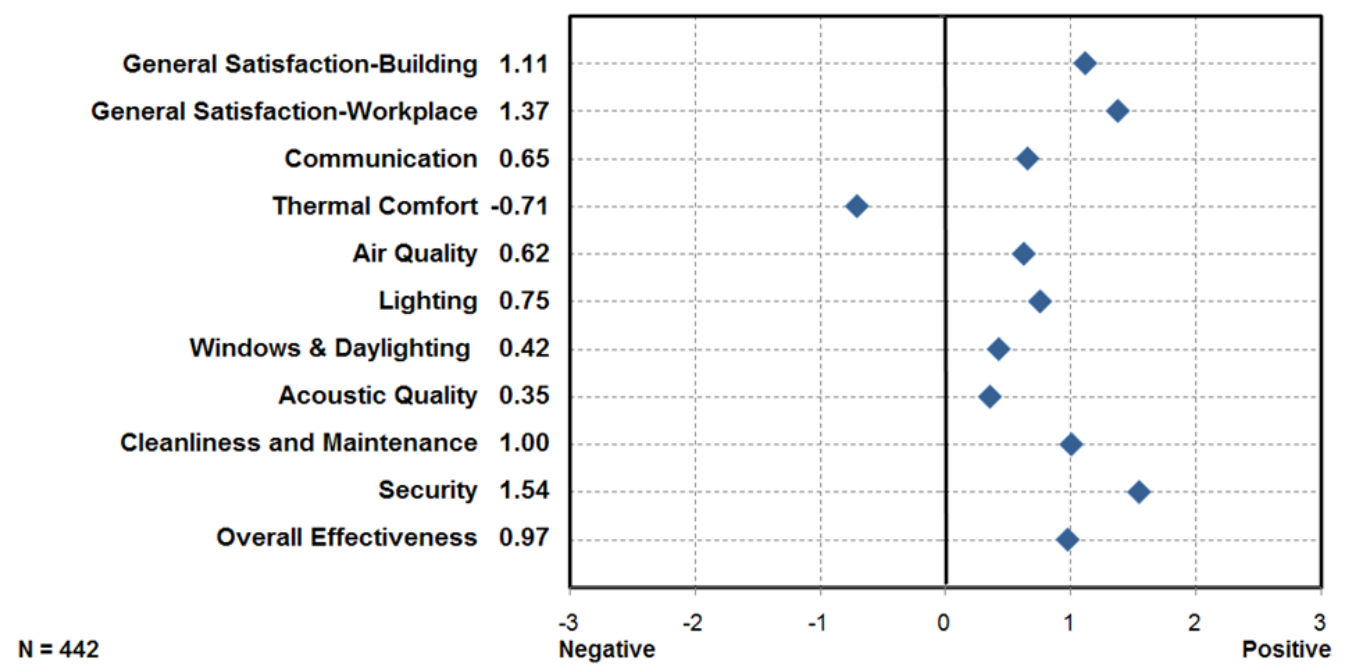

The results indicated that occupants of the Auburn SSA Teleservice Center are slightly less satisfied with their building than occupants in the CBE baseline $\left(49^{\text {th }}\right.$ percentile). The cleanliness and maintenance, lighting, and thermal comfort scored below the $50^{\text {th }}$ percentile of the CBE buildings surveyed. Acoustic quality and air quality scored above the $50^{\text {th }}$ percentile, with acoustic quality at the $70^{\text {th }}$ percentile (one of the highest scoring buildings in the study with an open plan design).

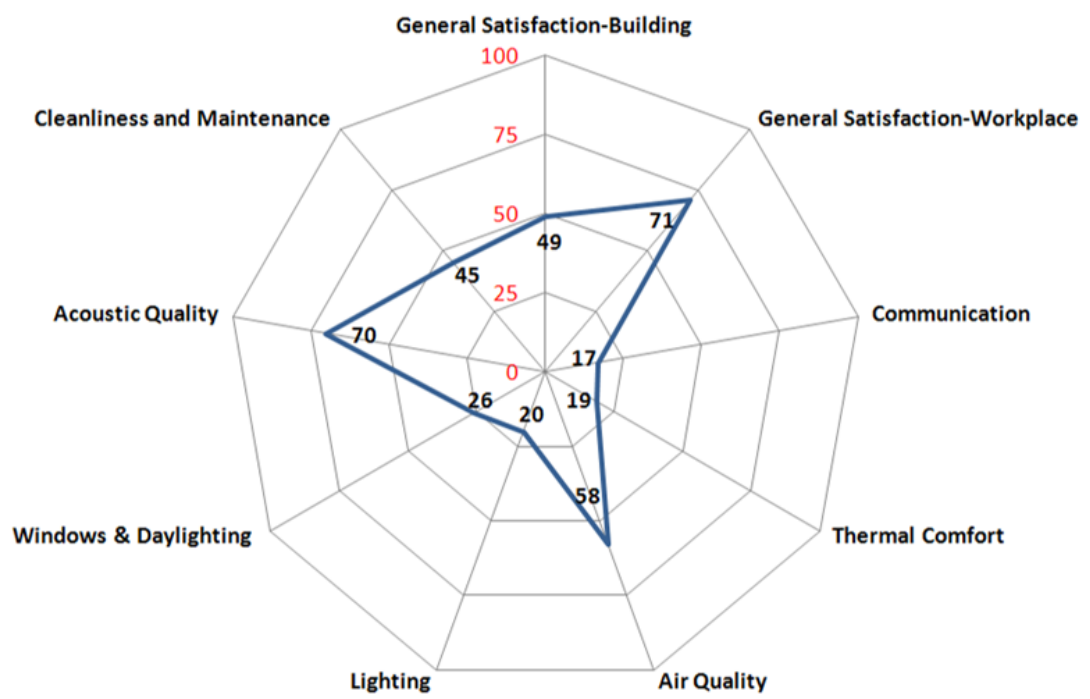




\section{Performance Data Summary}

The research team collected, normalized, and compared whole building performance data for the Auburn SSA Teleservice Center to industry baselines. The following table summarizes the annual performance data collected and normalized. The building is part of a campus and is not metered for water use. The water cost is estimated.

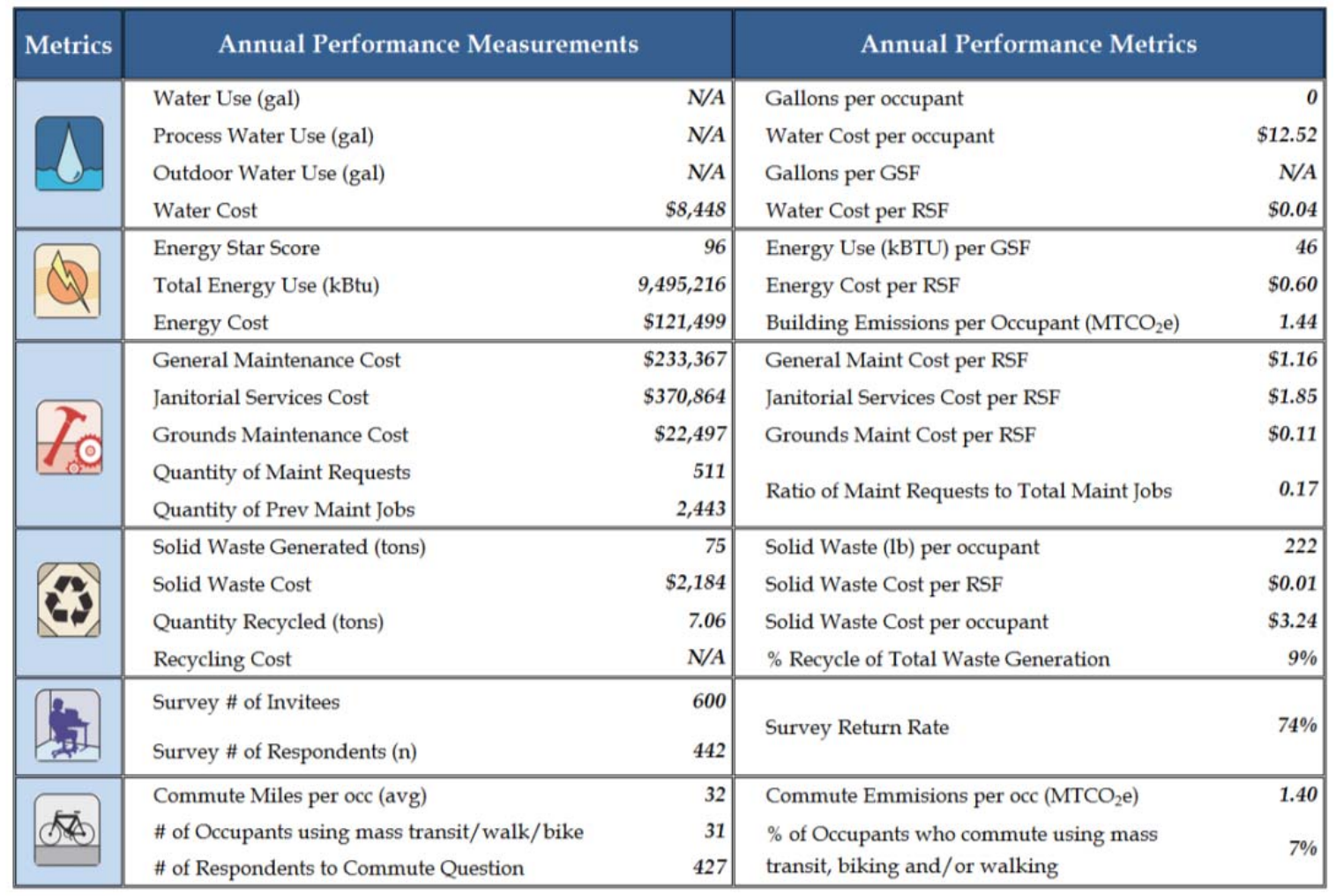




\section{Eugene Courthouse}

\section{Description}

The Wayne L. Morse U.S. Courthouse is located in Eugene, Oregon. Completed in 2006, this facility was the first LEED Gold courthouse in the U.S. The building houses six courtrooms and sees a significant

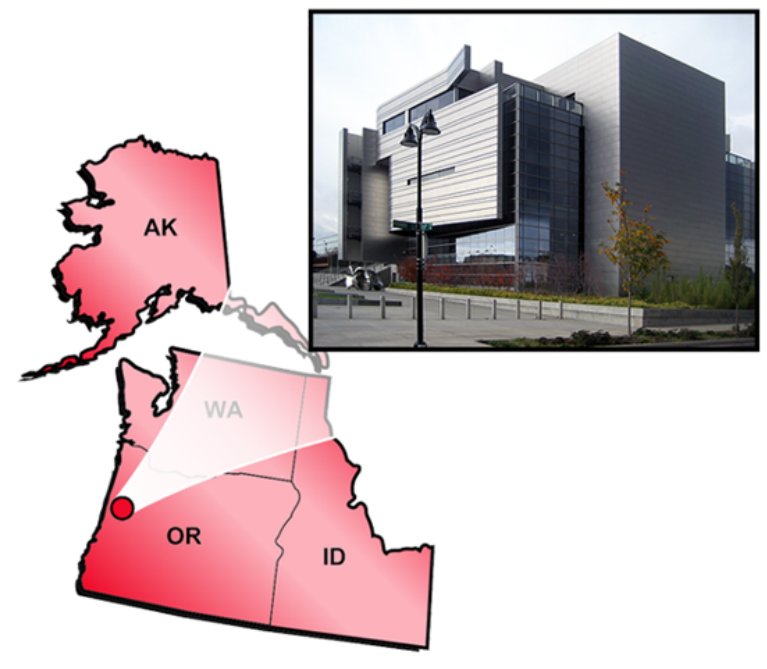
fluctuation in visitors depending on the need for those courtrooms.

Primary energy-efficient features include under floor air distribution (UFAD), fan wall

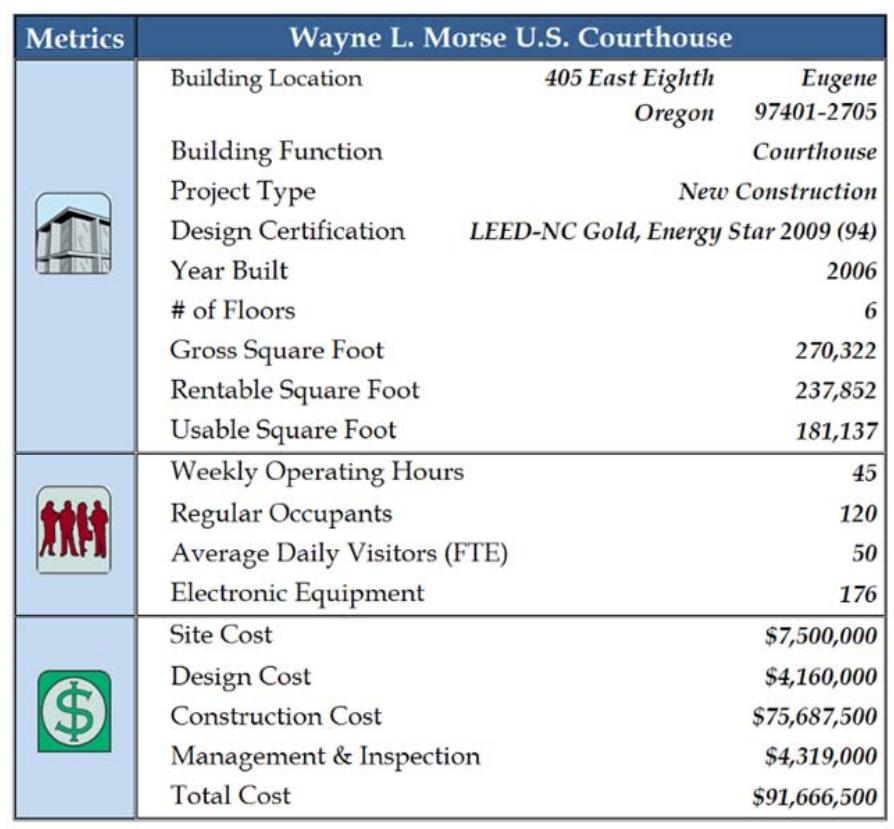
technology, heat reclaim chillers, radiant heating and cooling, condensing boilers, and daylight sensors.

Nearby access to the local bus line, secured bicycle storage, and preferred carpool parking encourage occupants to utilize alternative modes of transportation, although the courthouse's location near a main thoroughfare poses a hindrance for pedestrian traffic.

The Morse Courthouse was received multiple awards for the design, environmental elements, and

sustainability features implemented throughout the facility.

Each building in the study had operational highlights and potential opportunities for improvement. Although it was not the focus of this study to investigate and/or document operational highlights and opportunities, the research team observed:

- A smaller "pony chiller" was installed in 2009 which allowed building management to adjust the chiller operations to respond efficiently to the building loads. The building has received substantial rebates from state utilities and agencies.

- De-lamping during night-time hours while maintaining required lumen levels for security purposes could result in future energy savings. 


\section{Certifications}

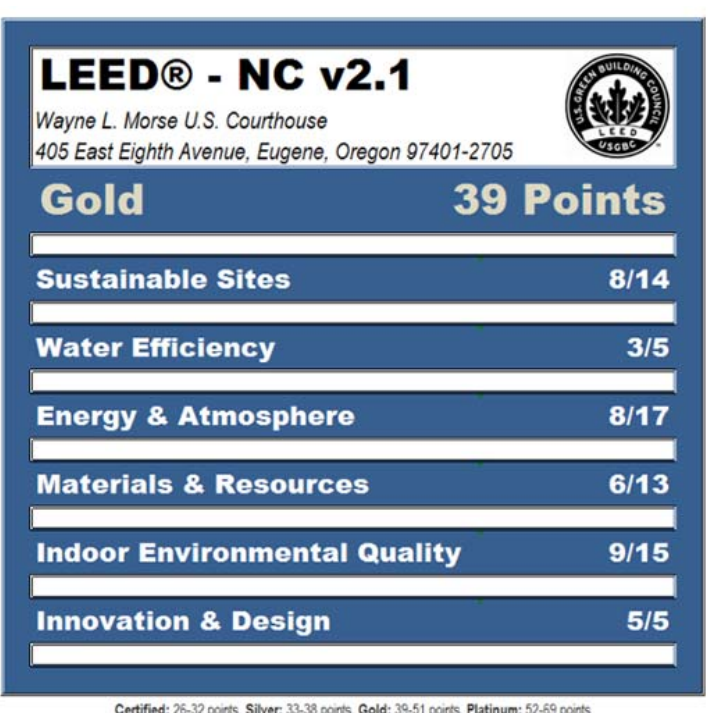

Certified: $26-32$ points, Silver: $33-38$ ponts, Gold: 39.51 poirs, Platinum: 52.69 ponts

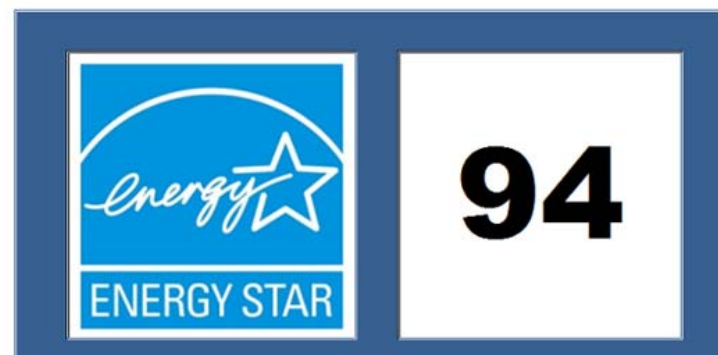

Bulding Name

\section{Eugene CT}

Year Certified

\section{9}

\section{Whole Building Performance}

The Morse Courthouse operating costs are lower than the industry baseline for all metrics. The waste and recycling costs are included in the janitorial cost reporting. Overall, the building costs less to operate than a baseline building.

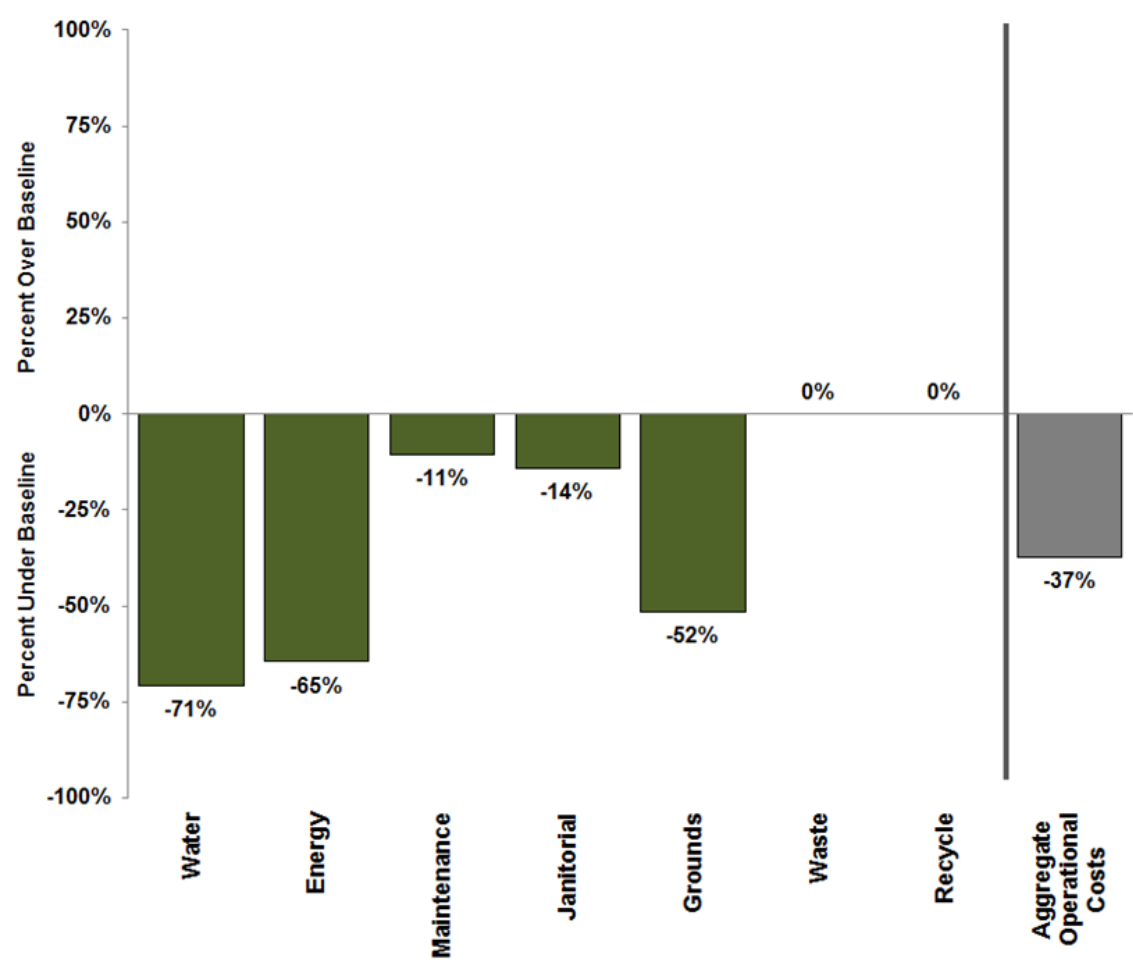




\section{Occupant Satisfaction Survey}

All 120 of the Morse Courthouse occupants were surveyed and 49 responded. All of the main survey categories except thermal comfort had positive average scores.

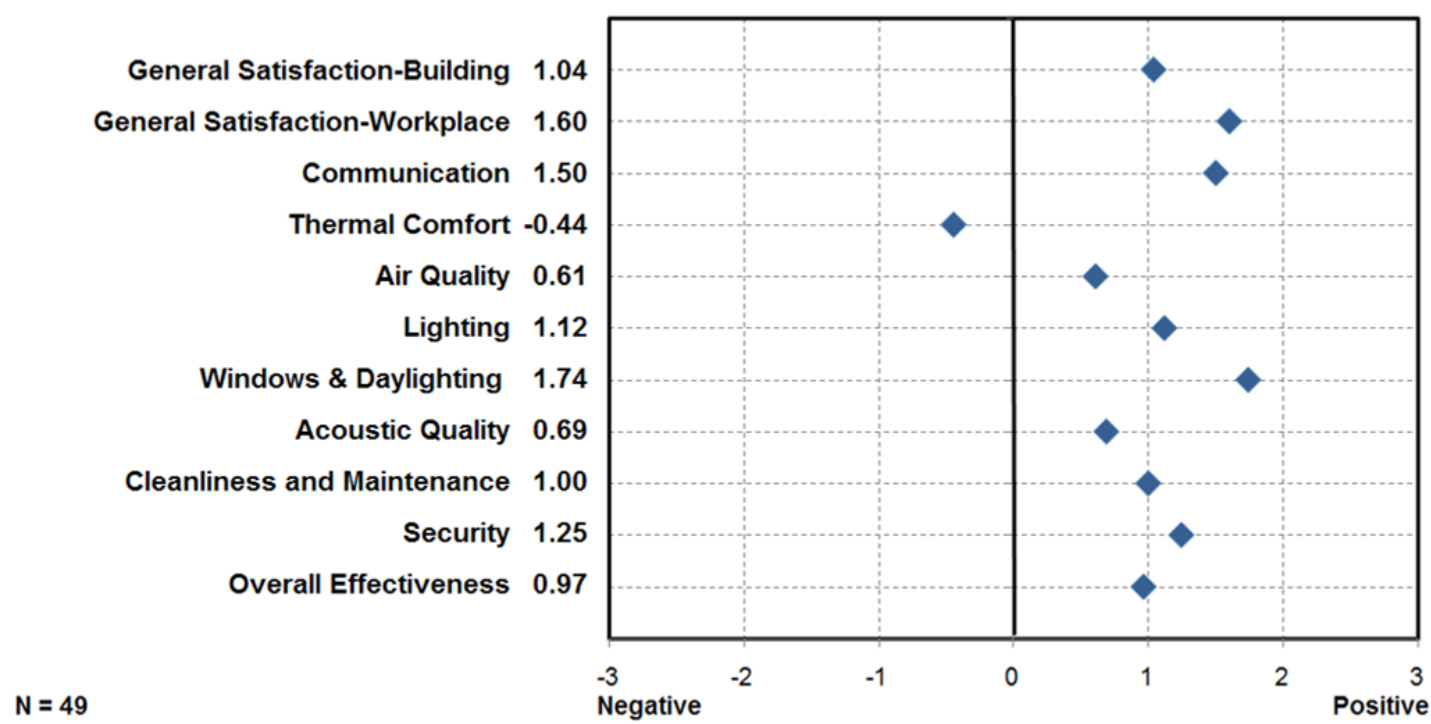

The results indicated that occupants of the Morse Courthouse are slightly less satisfied with their building than occupants in the CBE baseline ( $47^{\text {th }}$ percentile). The cleanliness and maintenance, lighting, and thermal comfort scored below the $50^{\text {th }}$ percentile of the CBE buildings surveyed. Acoustic quality and air quality in the Morse Courthouse scored above the $50^{\text {th }}$ percentile, with acoustic quality at the $81^{\text {st }}$ percentile (one of the highest scoring buildings in the study).

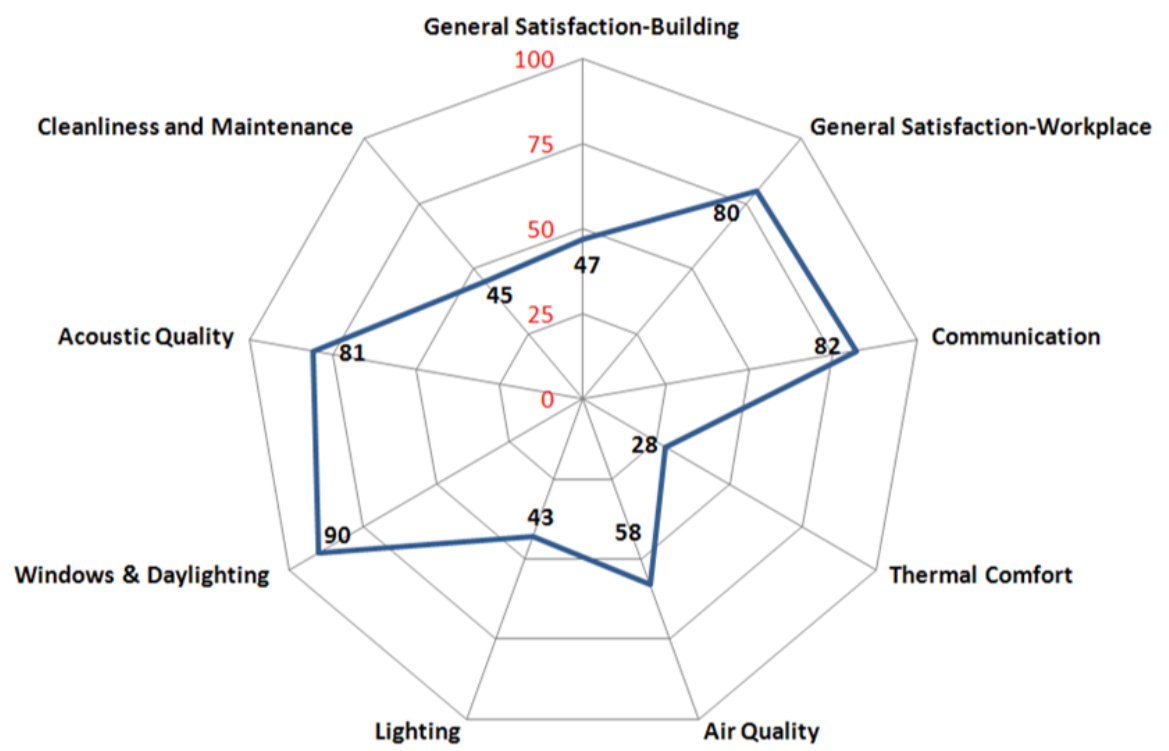




\section{Performance Data Summary}

The research team collected, normalized, and compared whole building performance data for the Morse Courthouse to industry baselines. The following table summarizes the annual performance data collected and normalized. The facility uses water-cooled chillers for its airconditioning system; therefore, the cooling tower water use was estimated using the "rule-ofthumb" that $27 \%$ of total water use is process water. Outdoor water use was estimated using the "rule-of-thumb" that $20 \%$ of total water used is for landscaping.

\begin{tabular}{|c|c|c|c|c|}
\hline Metrics & \multicolumn{2}{|c|}{ Annual Performance Measurements } & \multicolumn{2}{|l|}{ Annual Performance Metrics } \\
\hline & Water Use (gal) & $2,032,000$ & Gallons per occupant & 6,335 \\
\hline & Process Water Use (gal) & 548,640 & Water Cost per occupant & $\$ 77.69$ \\
\hline & Outdoor Water Use (gal) & 406,400 & Gallons per GSF & 7.52 \\
\hline & Water Cost & $\$ 13,208$ & Water Cost per RSF & $\$ 0.06$ \\
\hline & Energy Star Score & 92 & Energy Use (kBTU) per GSF & 48 \\
\hline & Total Energy Use (kBtu) & $13,020,236$ & Energy Cost per RSF & $\$ 0.90$ \\
\hline & Energy Cost & $\$ 213,279$ & Building Emissions per Occupant $\left(\mathrm{MTCO}_{2} \mathrm{e}\right)$ & 7.57 \\
\hline & General Maintenance Cost & $\$ 381,904$ & General Maint Cost per RSF & $\$ 1.61$ \\
\hline & Janitorial Services Cost & $\$ 339,996$ & Janitorial Services Cost per RSF & $\$ 1.43$ \\
\hline & Grounds Maintenance Cost & $\$ 51,808$ & Grounds Maint Cost per RSF & $\$ 0.22$ \\
\hline & Quantity of Maint Requests & 450 & Ratio of Maint Reguests to Total Maint Jobs & $N / A$ \\
\hline & Quantity of Prev Maint Jobs & 0 & 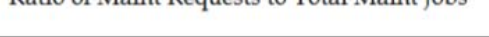 & \\
\hline & Solid Waste Generated (tons) & 5 & Solid Waste (lb) per occupant & 53 \\
\hline & Solid Waste Cost & Included & Solid Waste Cost per RSF & $N / A$ \\
\hline & Quantity Recycled (tons) & 5.70 & Solid Waste Cost per occupant & $N / A$ \\
\hline & Recycling Cost & $N / A$ & $\%$ Recycle of Total Waste Generation & $56 \%$ \\
\hline & $\begin{array}{l}\text { Survey \# of Invitees } \\
\text { Survey \# of Respondents (n) }\end{array}$ & $\begin{array}{r}120 \\
49\end{array}$ & Survey Return Rate & $38 \%$ \\
\hline & Commute Miles per occ (avg) & 18 & Commute Emmisions per occ $\left(\mathrm{MTCO}_{2} \mathrm{e}\right)$ & 0.78 \\
\hline & $\begin{array}{l}\text { \# of Occupants using mass transit/walk/bike } \\
\text { \# of Respondents to Commute Question }\end{array}$ & $\begin{array}{r}9 \\
48\end{array}$ & $\begin{array}{l}\% \text { of Occupants who commute using mass } \\
\text { transit, biking and/or walking }\end{array}$ & $19 \%$ \\
\hline
\end{tabular}




\section{Seattle Courthouse}

\section{Description}

Located in downtown Seattle, the courthouse has been deemed one of the safest structures ever built. There are 18 courtrooms that house district courts. It features radiant floor heating, high efficient lighting, a well-

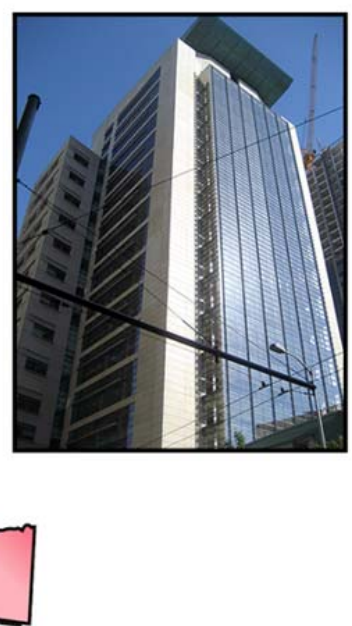
utilized EMCS system, water-cooled chillers, natural gas boiler with variable speed drives, waterless urinals, and photovoltaic panels. The lighting controls operate both on occupancy and time-of-day routines. A small "pony" chiller was recently added to the HVAC system to condition the spaces that require 24-7 cooling.

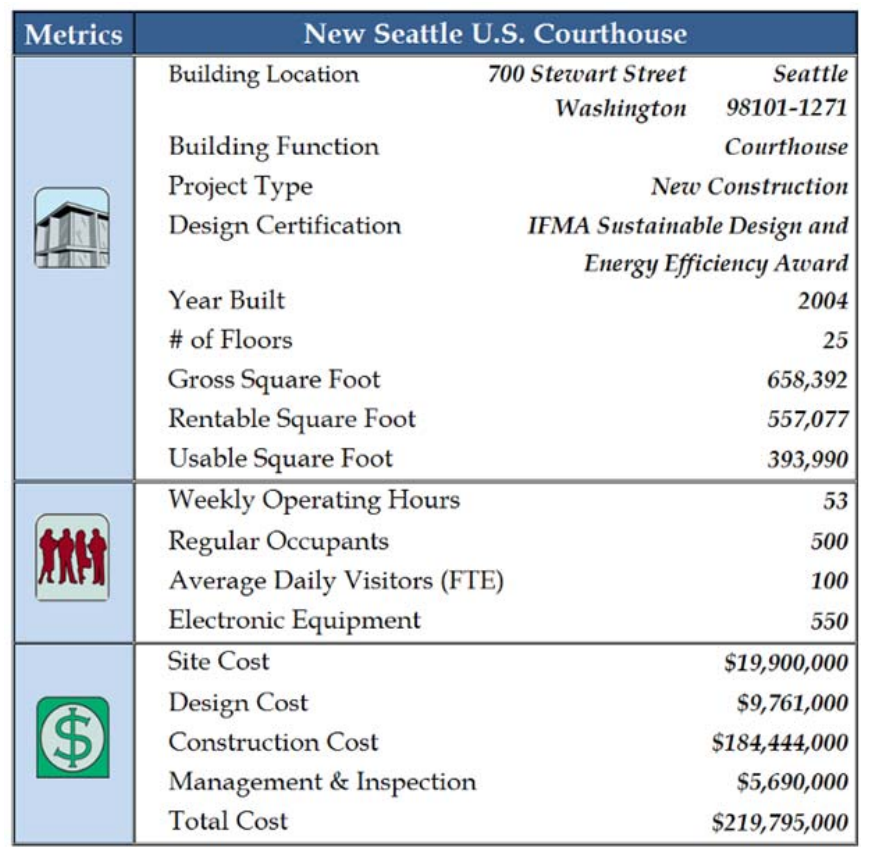

Unique features include a fitness room, underground parking, a public garden, and a library.

In 2004 the Seattle Courthouse won GSA's award for construction excellence, and in 2006 was named the most impressive engineering achievement at the $40^{\text {th }}$ Annual Engineering Excellence Awards, sponsored by the American Council for Engineering Companies.

Each building in the study had operational highlights and potential opportunities for improvement. Although it was not the focus of this study to investigate and/or document operational highlights and opportunities, the research team observed the following:

- Building management has identified several projects to improve the operations in the HVAC area. Challenges have been cited with boiler fouling, simultaneous heating and cooling, and pressurization imbalances. Recommisioning of the entire system is recommended after specific projects are completed.

- A study in underway to evaluate the building for daylighting controls to take advantage of the high amount of glazing. 


\section{Certifications}

IFMA Sustainable Design and Energy Efficiency Award

\section{Whole Building Performance}

The Seattle Courthouse operating costs are lower than the industry baseline for water, energy, general maintenance, grounds maintenance, and recycling costs. The janitorial costs are higher than the industry baseline and waste is included in this cost. Overall, the building costs less to operate than a baseline building.

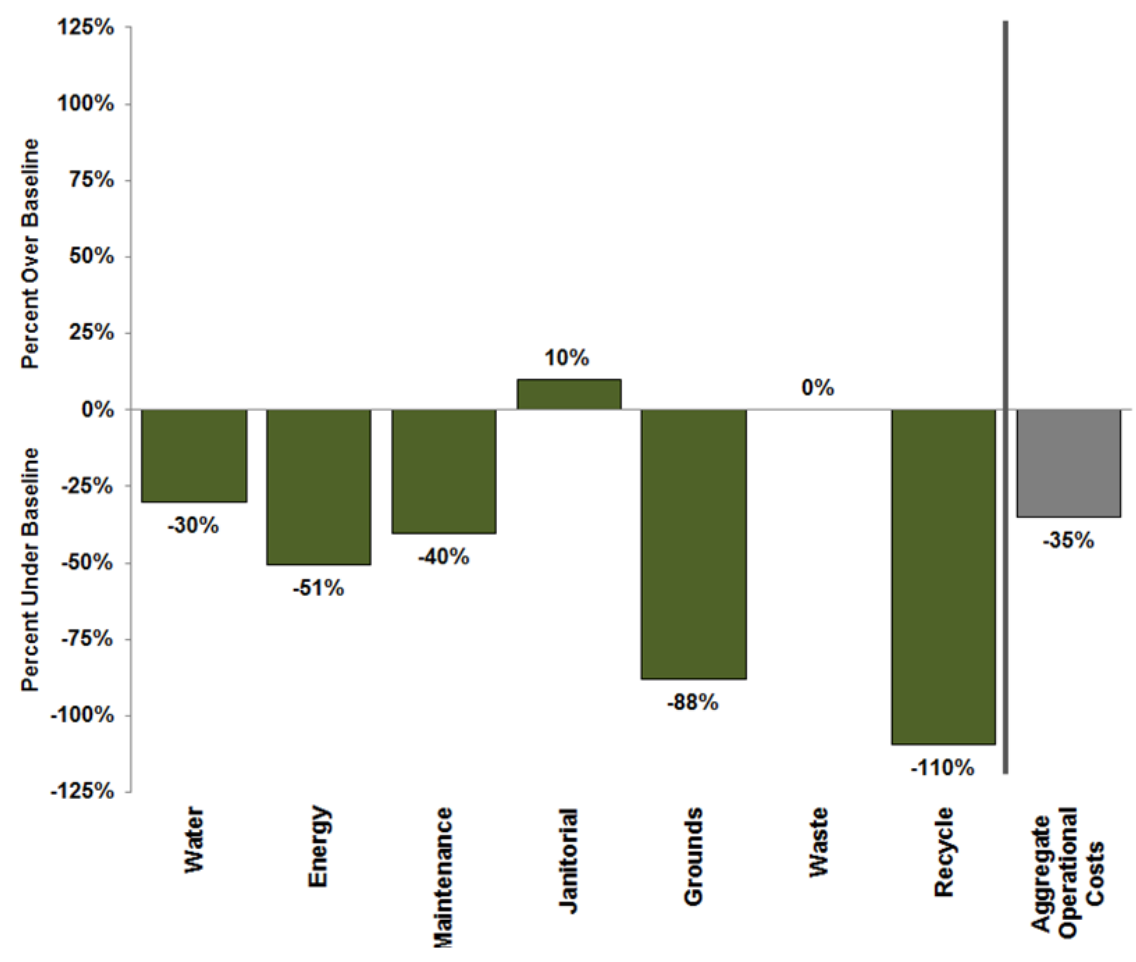




\section{Occupant Satisfaction Survey}

Occupants in the Seattle Courthouse occupants were surveyed by GSA in 2006 and 103 responded. A comparison of questions between the GSA survey and the CBE survey was made, and for available categories the values were translate to the CBE scale and are shown below.

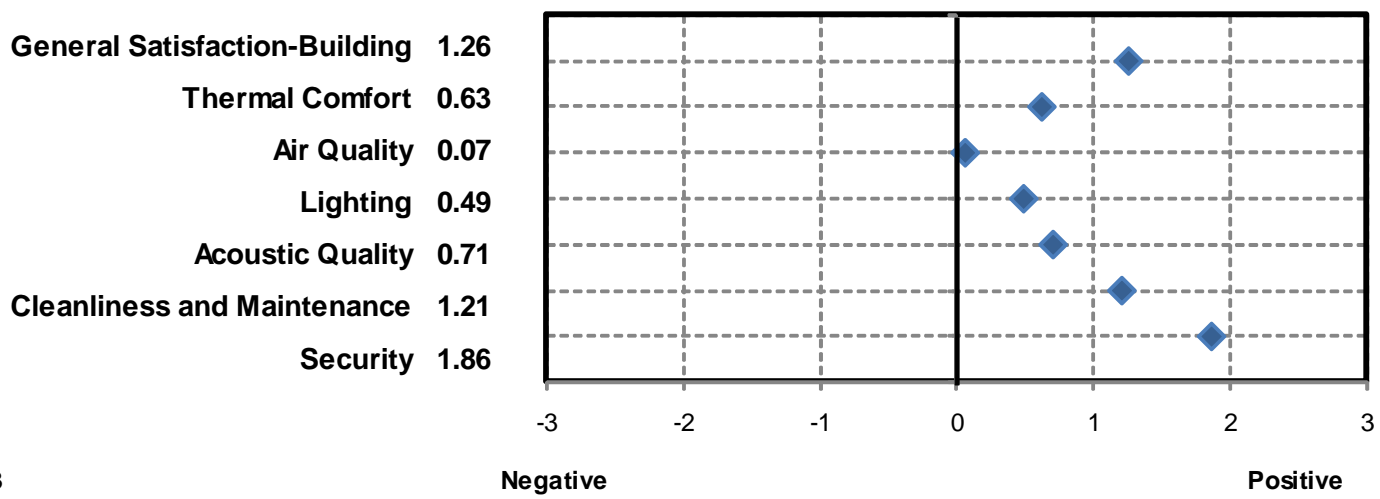

The results indicated that occupants of the Seattle Courthouse are satisfied with their building than occupants in the CBE baseline ( $57^{\text {th }}$ percentile). For the other survey categories that were the primary focus of this study - acoustic quality, cleanliness and maintenance, and thermal comfort - the Seattle Courthouse scored above the $60^{\text {th }}$ percentile. The courthouse scored below the $50^{\text {th }}$ percentile in the lighting and air quality categories.

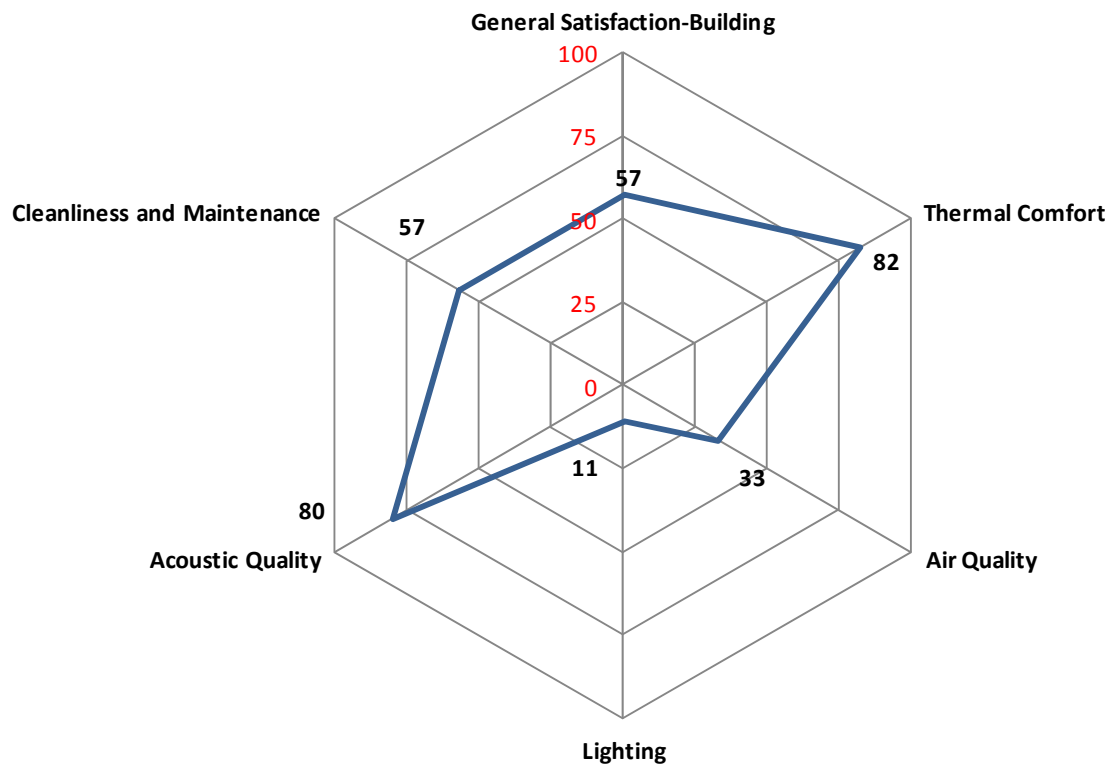




\section{Performance Data Summary}

The research team collected, normalized, and compared whole building performance data for the Seattle Courthouse to industry baselines. The following table summarizes the annual performance data collected and normalized. The facility uses water-cooled chillers for its airconditioning system; therefore, the cooling tower water use was estimated using the "rule-ofthumb" that $27 \%$ of total water use is process water. Outdoor water use was estimated using the "rule-of-thumb" that $20 \%$ of total water use if for landscaping.

\begin{tabular}{|c|c|c|c|c|}
\hline Metrics & \multicolumn{2}{|c|}{ Annual Performance Measurements } & \multicolumn{2}{|l|}{ Annual Performance Metrics } \\
\hline & Water Use (gal) & $4,973,452$ & Gallons per occupant & 4,393 \\
\hline & Process Water Use (gal) & $1,342,832$ & Water Cost per occupant & $\$ 123.36$ \\
\hline & Outdoor Water Use (gal) & 994,690 & Gallons per GSF & 7.55 \\
\hline & Water Cost & $\$ 74,016$ & Water Cost per RSF & $\$ 0.13$ \\
\hline & Energy Star Score & 85 & Energy Use (kBTU) per GSF & 70 \\
\hline & Total Energy Use (kBtu) & $45,809,870$ & Energy Cost per RSF & $\$ 1.25$ \\
\hline & Energy Cost & $\$ 695,685$ & Building Emissions per Occupant $\left(\mathrm{MTCO}_{2} \mathrm{e}\right)$ & 7.18 \\
\hline & General Maintenance Cost & $\$ 597,755$ & General Maint Cost per RSF & $\$ 1.07$ \\
\hline & Janitorial Services Cost & $\$ 1,016,574$ & Janitorial Services Cost per RSF & $\$ 1.82$ \\
\hline & Grounds Maintenance Cost & $\$ 29,635$ & Grounds Maint Cost per RSF & $\$ 0.05$ \\
\hline & Quantity of Maint Requests & 1,419 & & \\
\hline & Quantity of Prev Maint Hours & 2,922 & Ratio of Maint Requests to Total Maint jobs & $N / A$ \\
\hline & Solid Waste Generated (tons) & 59 & Solid Waste (lb) per occupant & 196 \\
\hline & Solid Waste Cost & Included & Solid Waste Cost per RSF & $N / A$ \\
\hline & Quantity Recycled (tons) & 38.02 & Solid Waste Cost per occupant & $N / A$ \\
\hline & Recycling Cost & $-\$ 533$ & $\%$ Recycle of Total Waste Generation & $39 \%$ \\
\hline & $\begin{array}{l}\text { Survey \# of Invitees } \\
\text { Survey \# of Respondents (n) }\end{array}$ & $\begin{array}{r}500 \\
103\end{array}$ & Survey Return Rate & $21 \%$ \\
\hline & Commute Miles per occ (avg) & $N / A$ & Commute Emmisions per occ $\left(\mathrm{MTCO}_{2} \mathrm{e}\right)$ & $N / A$ \\
\hline & $\begin{array}{l}\text { \# of Occupants using mass transit/walk/bike } \\
\text { \# of Respondents to Commute Question }\end{array}$ & $\begin{array}{l}N / A \\
N / A\end{array}$ & $\begin{array}{l}\% \text { of Occupants who commute using mass } \\
\text { transit, biking and/or walking }\end{array}$ & $N / A$ \\
\hline
\end{tabular}




\section{Rockville Federal Building}

\section{Description}

The Substance Abuse and Mental Health Services Administration (SAMSHA) Federal Building was designed to accommodate the needs of the Metropolitan Service Center.

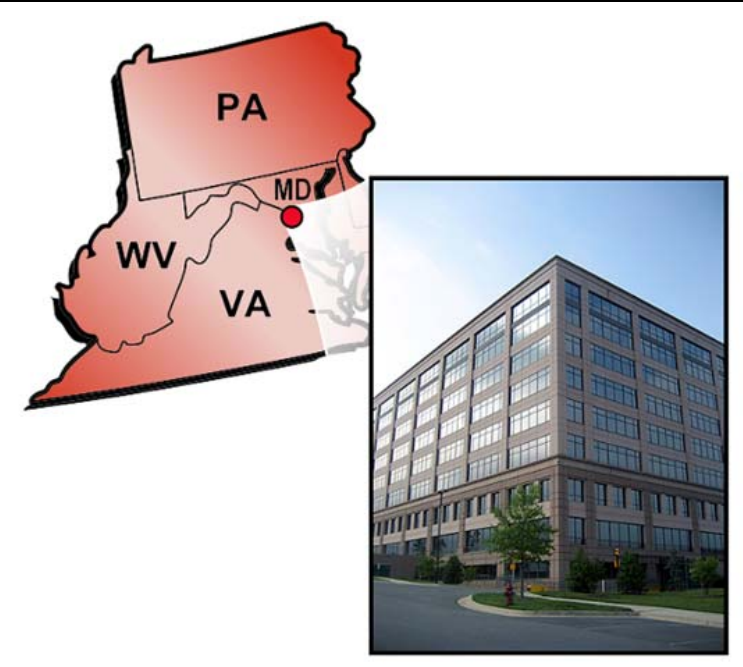

The LEED Silver-registered building features include a reflective white roof, 90\% daylighting factor in occupied spaces, occupancy sensors, and use of renewable, local, and recovered materials in both interior finishes and furniture. The building also earned an Energy Star certification in 2009.

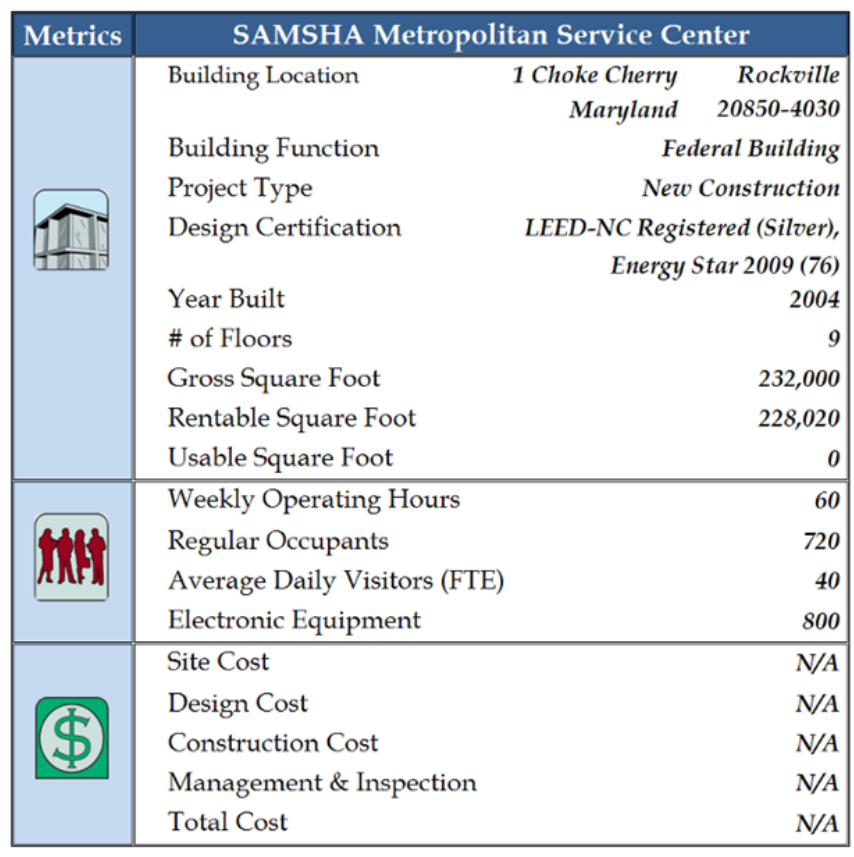

The landscaping incorporates the native and drought tolerant species of plants and trees. While originally designed without an irrigation system, recently hose bibs have been installed for watering during dry periods.

The building houses conference and training rooms that see a fluctuation in visitors. Unique features include a fitness center, locker room, library, and tenant supported nurse's office. The SAMSHA Service Center is within close proximity to the train, and the building management provides a bus shuttle from the station to the building for the occupants.

Each building in the study had operational highlights and potential opportunities for improvement. Although it was not the focus of this study to investigate and/or document operational highlights and opportunities, the research team observed the following:

- Building management has plans to perform a LEED feasibility study mid-2010 and register with the U.S. Green Building Council for LEED-EB certification. 


\section{Certifications}

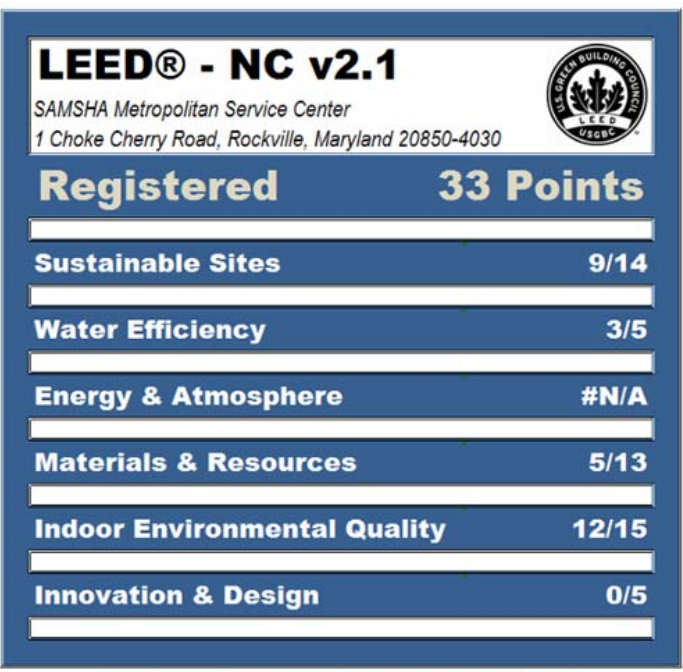

Certificed: 26.32 ponts, Silver: 33.38 poirts, Gold: 39.51 ports, Platinum: 52.69 ponts

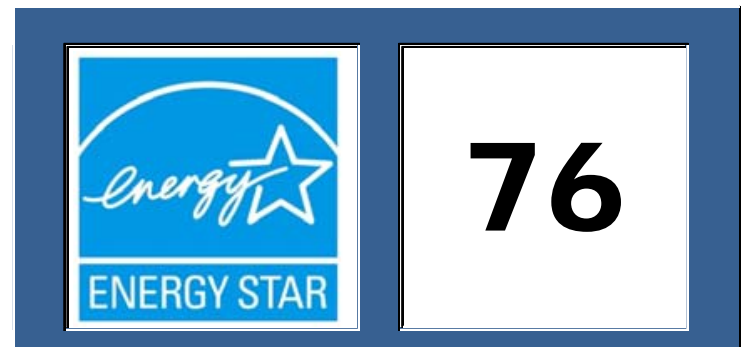

Bulding Name

Rockville (L) FB

Year Certified

\section{Whole Building Performance}

The SAMSHA Service Center operating costs are lower than the industry baseline for water, general maintenance, grounds maintenance, janitorial and waste costs. The energy costs are higher than the industry baseline. Overall, the building costs less to operate than a baseline building.

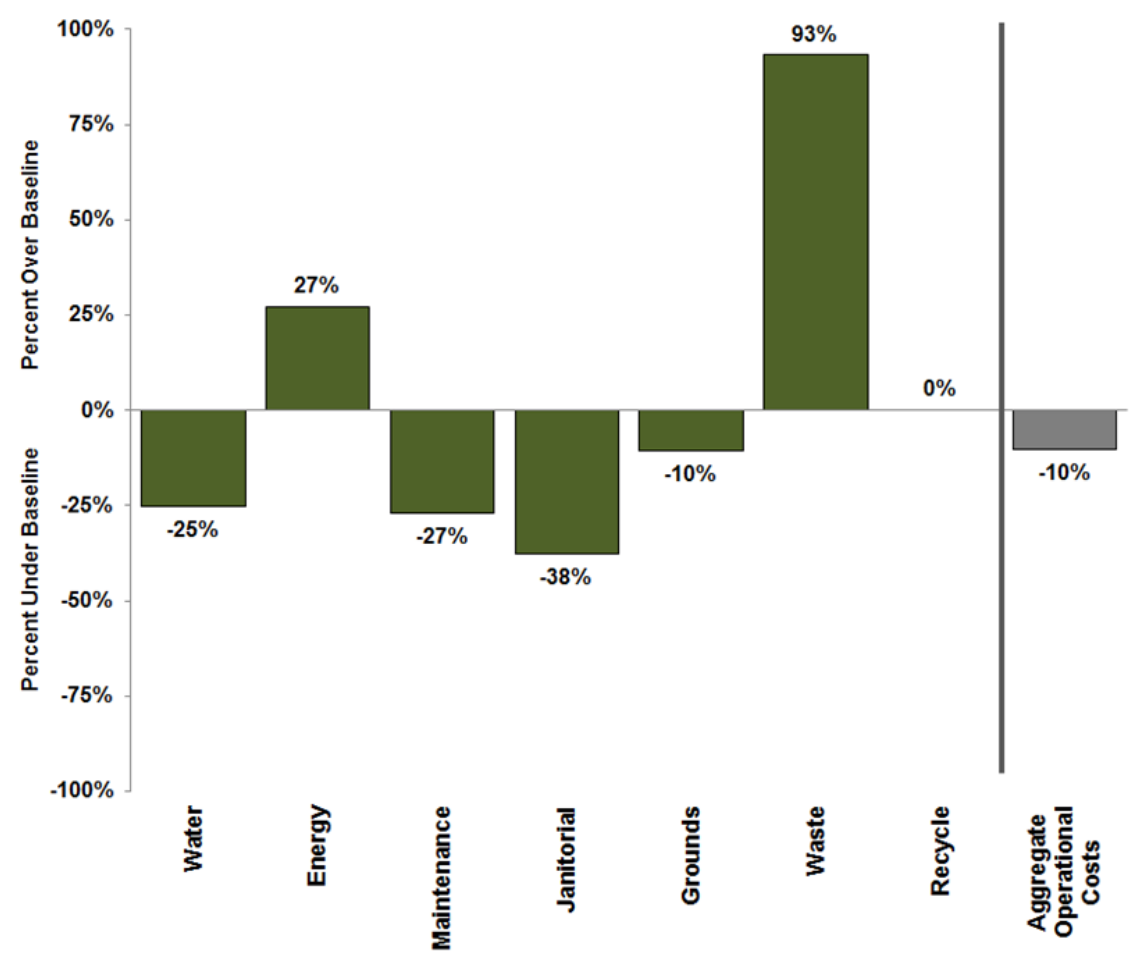




\section{Occupant Satisfaction Survey}

All 430 of the SAMSHA Service Center occupants were surveyed and 235 responded. All of the main survey categories had positive average scores.

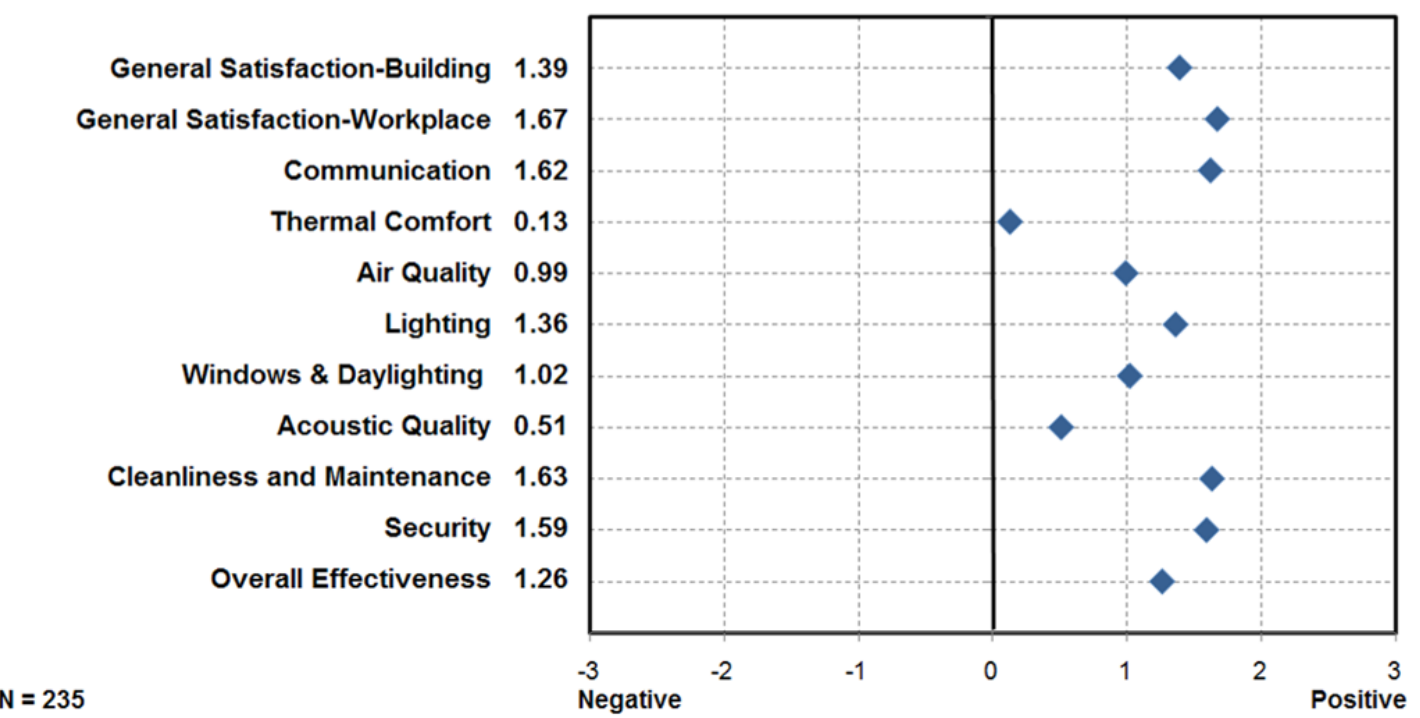

The results indicated that occupants of the SAMSHA Service Center are more satisfied with their building than occupants in the CBE baseline ( $64^{\text {th }}$ percentile). For the other survey categories that were the primary focus of this study - acoustic quality, air quality, cleanliness and maintenance, and thermal comfort- the SAMSHA Service Center scored above the $60^{\text {th }}$ percentile.

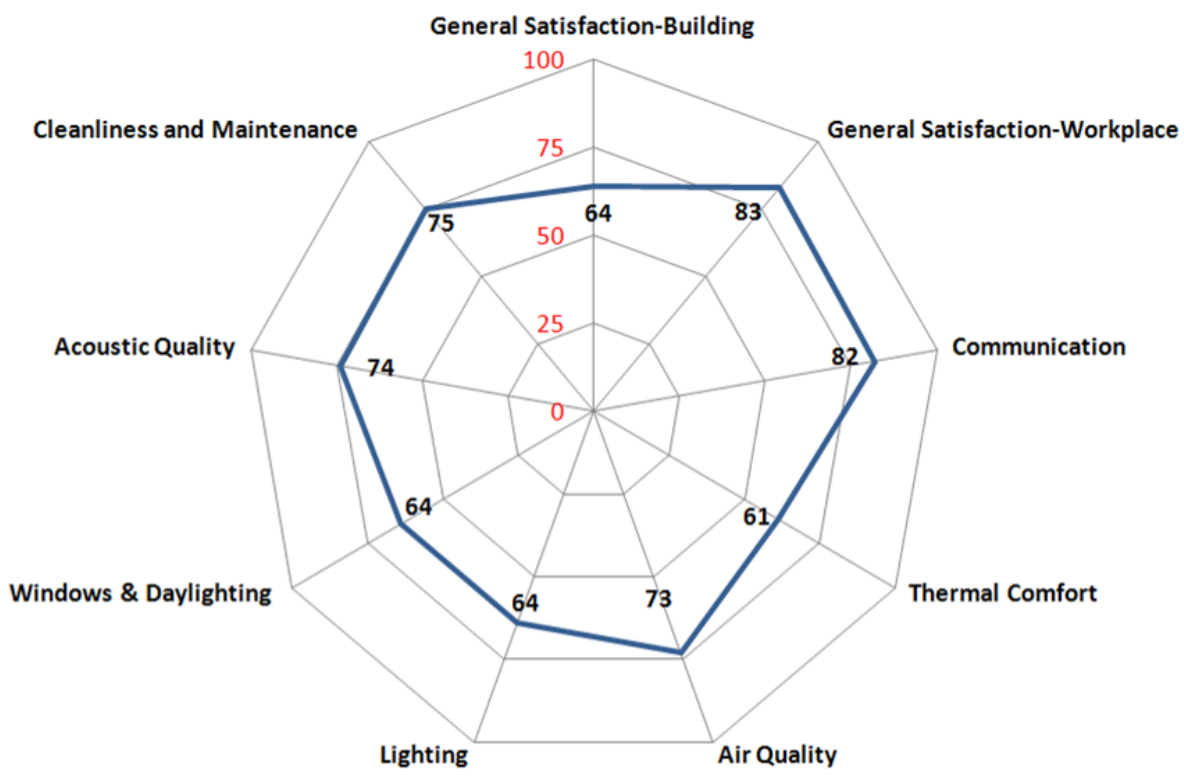




\section{Performance Data Summary}

The research team collected, normalized, and compared whole building performance data for the SAMSHA Service Center to industry baselines. The following table summarizes the annual performance data collected and normalized. The facility uses water-cooled chillers for its air-conditioning system; therefore, the cooling tower water use was estimated using the "rule-of-thumb" that $27 \%$ of total water use is process water.

\begin{tabular}{|c|c|c|c|c|}
\hline Metrics & \multicolumn{2}{|c|}{ Annual Performance Measurements } & \multicolumn{2}{|l|}{ Annual Performance Metrics } \\
\hline & Water Use (gal) & $2,680,000$ & Gallons per occupant & 2,574 \\
\hline & Process Water Use (gal) & 723,600 & Water Cost per occupant & $\$ 42.64$ \\
\hline & Outdoor Water Use (gal) & 0 & Gallons per GSF & 11.55 \\
\hline & Water Cost & $\$ 32,406$ & Water Cost per RSF & $\$ 0.14$ \\
\hline & Energy Star Score & 80 & Energy Use (kBTU) per GSF & 69 \\
\hline & Total Energy Use (kBtu) & $16,638,123$ & Energy Cost per RSF & $\$ 3.22$ \\
\hline & Energy Cost & $\$ 733,918$ & Building Emissions per Occupant $\left(\mathrm{MTCO}_{2} \mathrm{e}\right)$ & 3.33 \\
\hline & General Maintenance Cost & $\$ 370,782$ & General Maint Cost per RSF & $\$ 1.63$ \\
\hline & Janitorial Services Cost & $\$ 301,832$ & Janitorial Services Cost per RSF & $\$ 1.32$ \\
\hline & Grounds Maintenance Cost & $\$ 91,858$ & Grounds Maint Cost per RSF & $\$ 0.40$ \\
\hline & Quantity of Maint Requests & 937 & & \\
\hline & Quantity of Prev Maint Jobs & 179 & Ratio of Maint Requests to Total Maint Jobs & 0.84 \\
\hline & Solid Waste Generated (tons) & $N / A$ & Solid Waste (lb) per occupant & $N / A$ \\
\hline & Solid Waste Cost & $\$ 22,056$ & Solid Waste Cost per RSF & $N / A$ \\
\hline & Quantity Recycled (tons) & $N / A$ & Solid Waste Cost per occupant & $N / A$ \\
\hline & Recycling Cost & Included & \% Recycle of Total Waste Generation & $N / A$ \\
\hline & $\begin{array}{l}\text { Survey \# of Invitees } \\
\text { Survey \# of Respondents (n) }\end{array}$ & $\begin{array}{l}430 \\
235\end{array}$ & Survey Return Rate & $55 \%$ \\
\hline & Commute Miles per occ (avg) & 31 & Commute Emmisions per occ $\left(\mathrm{MTCO}_{2} \mathrm{e}\right)$ & 1.35 \\
\hline & $\begin{array}{l}\text { \# of Occupants using mass transit/walk/bike } \\
\text { \# of Respondents to Commute Question }\end{array}$ & $\begin{array}{r}42 \\
230\end{array}$ & $\begin{array}{l}\% \text { of Occupants who commute using mass } \\
\text { transit, biking and/or walking }\end{array}$ & $18 \%$ \\
\hline
\end{tabular}




\section{Suitland Federal Building}

\section{Description}

The Census Bureau Office Complex in Suitland is the largest building in the study at 2.3 million square feet. This LEED

Registered building has a curved design with shallow floor plate that takes advantage of the

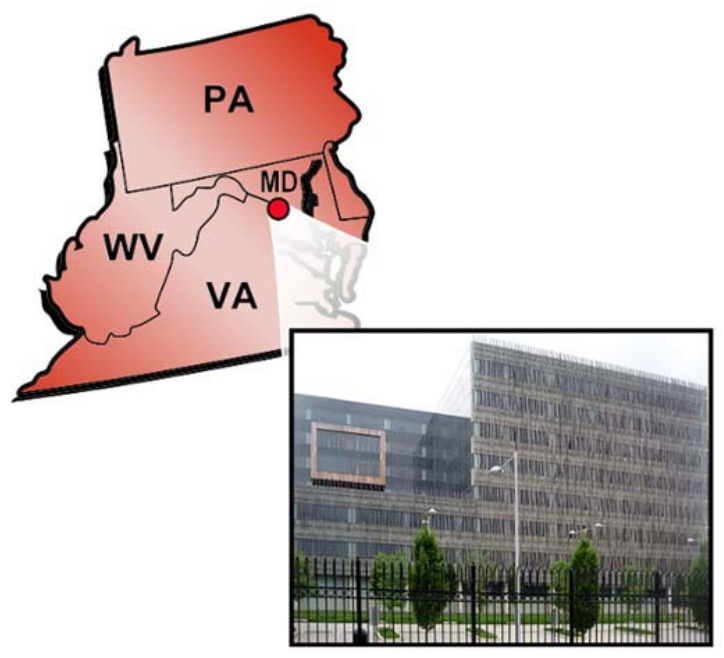
natural daylighting. Unique design features include underfloor air distribution, vertically mounted wood fins shades the curtain wall to reduce the solar glare, vegetative roofs, and a retention pond with bioswales.

Waterless urinals, low-flow fixtures, and water-efficient appliances resulted in a projected reduction of more than $30 \%$ of potable water use. Operation of the facility incorporates

\begin{tabular}{|c|c|c|c|}
\hline \multirow[t]{4}{*}{ Metrics } & \multicolumn{3}{|c|}{ Census Bureau Office Complex } \\
\hline & Building Location & $\begin{array}{r}\text { 4600a Silver Hill } \\
\text { Maryland }\end{array}$ & $\begin{array}{r}\text { Suitland } \\
20746-2402\end{array}$ \\
\hline & Building Function & & eral Building \\
\hline & Project Type & Neu & Construction \\
\hline & Design Certification & LEED-NCReg & stered (Gold) \\
\hline & Year Built & & 2006 \\
\hline & \# of Floors & & 8 \\
\hline & Gross Square Foot & & $2,340,988$ \\
\hline & Rentable Square Foot & & $1,410,988$ \\
\hline & Usable Square Foot & & $1,195,551$ \\
\hline & Weekly Operating Hours & & 119 \\
\hline & Regular Occupants & & 5,360 \\
\hline & Average Daily Visitors (FTE) & & 65 \\
\hline & Electronic Equipment & & 5,500 \\
\hline & Site Cost & & $N / A$ \\
\hline & Design Cost & & $\$ 8,013,000$ \\
\hline & Construction Cost & & $\$ 306,372,000$ \\
\hline & Management \& Inspection & & $\$ 16,998,000$ \\
\hline & Total Cost & & $\$ 331,383,000$ \\
\hline
\end{tabular}
green janitorial practices.

The complex is located next to commuter train station enabling alternative commuting. Unique features include amenities such as cafeteria, banks, fitness center, health clinic, and retail stores.

Each building in the study had operational highlights and potential opportunities for improvement. Although it was not the focus of this study to investigate and/or document operational highlights and opportunities, the research team observed the following:

- In an open office layout, it is important to offer small meeting spaces for staff to schedule and conduct impromptu meetings. The acoustic quality CBE score for the Suitland Census was well below the average building at the $11^{\text {th }}$ percentile. Identifying opportunities to increase alternative locations for staff to convene and investigating sound-masking technologies may improve the occupants' perception of the building's acoustic quality. 


\section{Certifications}

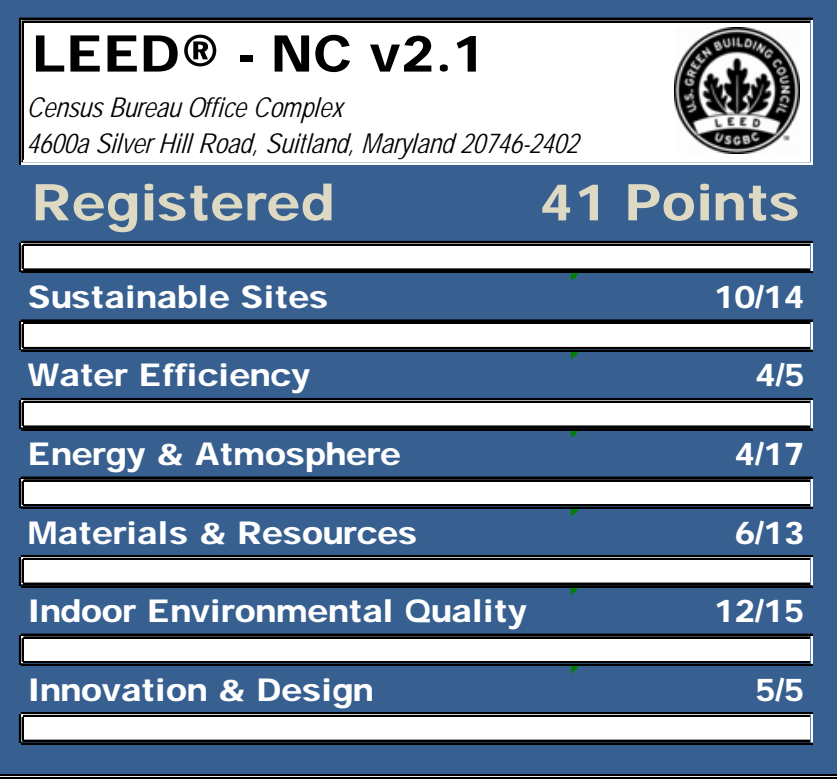

Certified: 26-32 points, Silver: 33-38 points, Gold: 39-51 points, Platinum: 52-69 points

\section{Whole Building Performance}

The Census Bureau Complex operating costs are lower than the industry baseline for general maintenance, grounds maintenance, waste, and recycling costs. The water, energy, and janitorial costs are higher than the industry baseline. Overall, the building costs slightly more to operate than a baseline building.

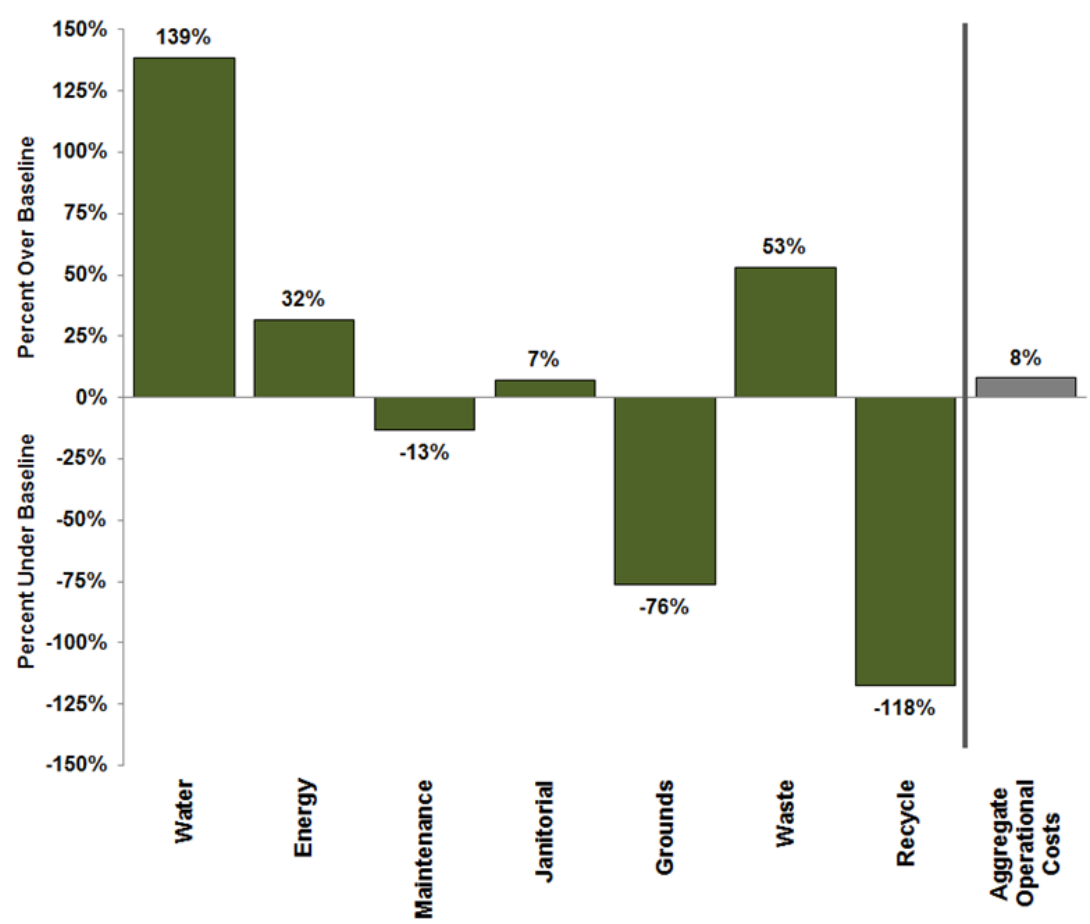




\section{Occupant Satisfaction Survey}

All 5,360 of the Census Bureau Complex occupants were surveyed and 955 responded. All of the main survey categories except thermal comfort and acoustic quality had positive average scores.

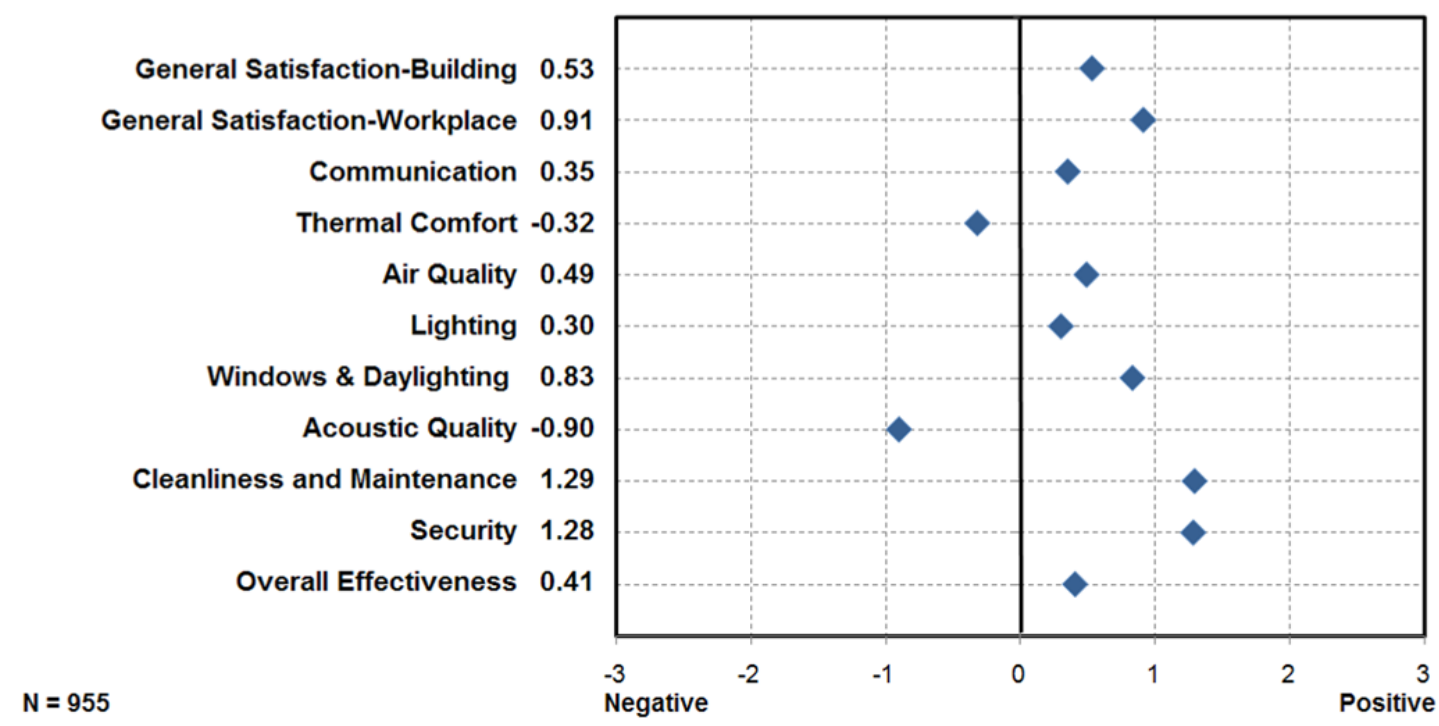

The results indicated that occupants of the Census Bureau Complex are less satisfied with their building than occupants in the CBE baseline $\left(26^{\text {th }}\right.$ percentile). The acoustic quality, lighting, and thermal comfort scored below the $50^{\text {th }}$ percentile of the CBE buildings surveyed. Cleanliness and maintenance and air quality in the Census Bureau Complex scored above the $50^{\text {th }}$ percentile.

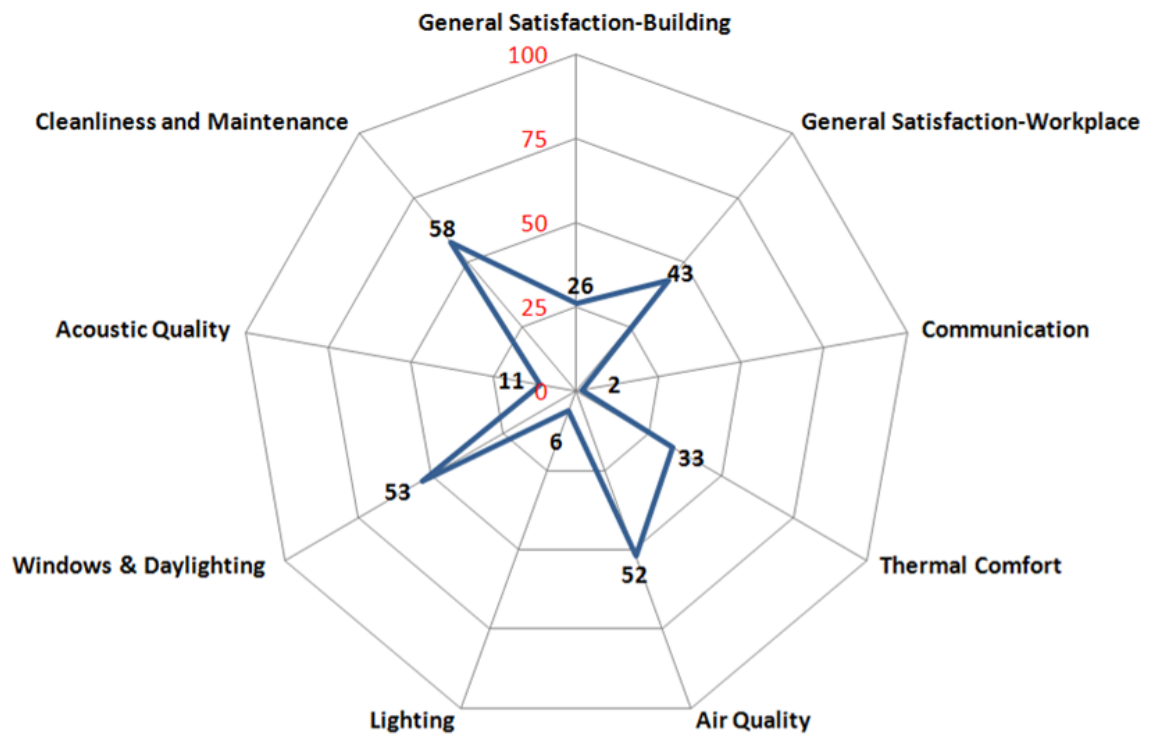




\section{Performance Data Summary}

The research team collected, normalized, and compared whole building performance data for the Census Bureau Complex to industry baselines. The following table summarizes the annual performance data collected and normalized. The facility uses water-cooled chillers for its air-conditioning system; therefore, the cooling tower water use was estimated using the "rule-of-thumb" that $27 \%$ of total water use is process water.

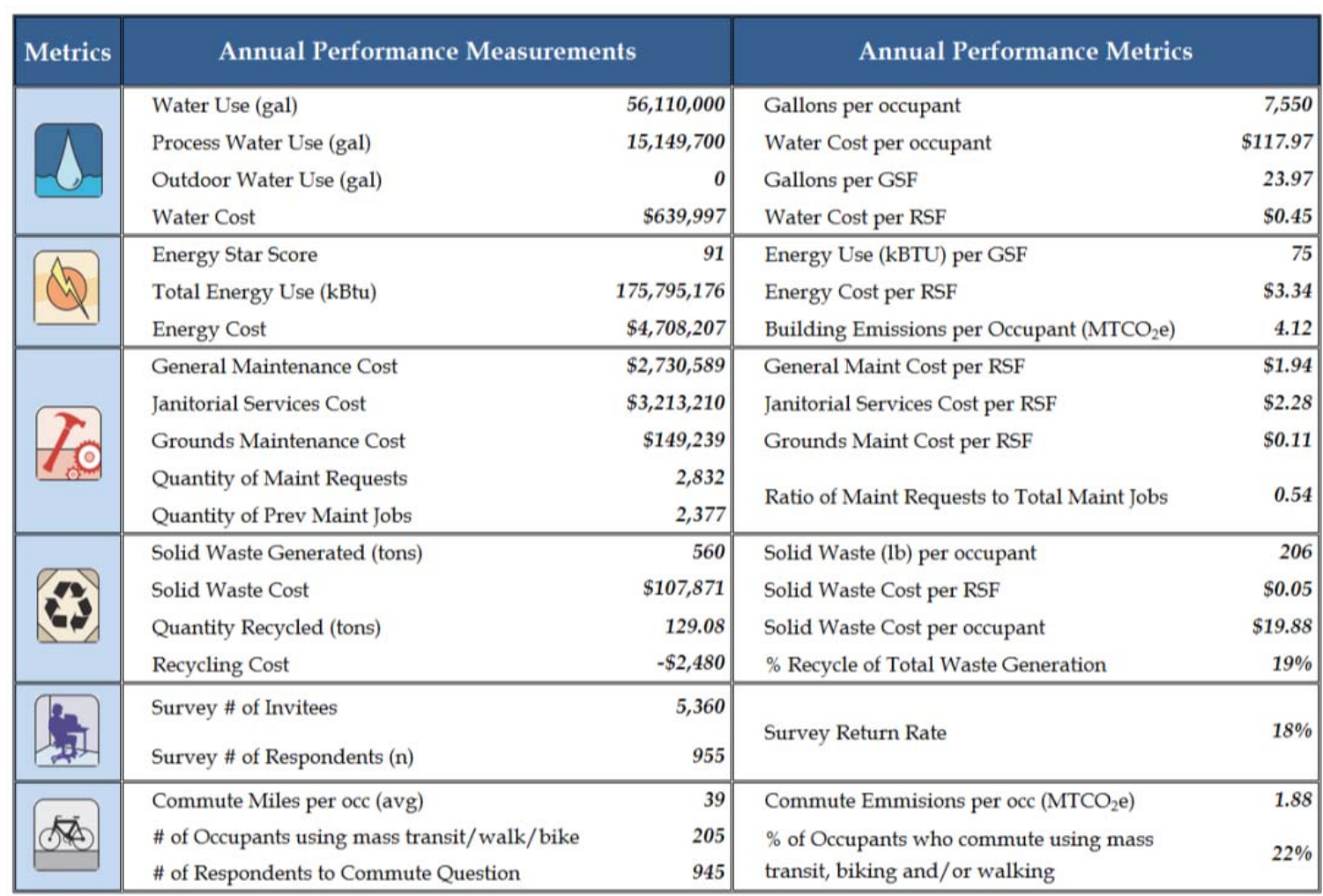




\section{Appendix B: Excluded Buildings}

This appendix includes data from two Port of Entry buildings and the Manhattan FB. Initial analysis of the Port of Entry data demonstrated that none of the commonly used baselines for office buildings would apply to Ports of Entry. During the site visit of the Manhattan $\mathrm{FB}$, researchers observed a number of significant operational problems assumed to be related to the building's HVAC system. Building management worked with a number of entities to engineer a solution and shortly after the site visit had signed a contract to implement solutions to improve building performance. For this study, the Manhattan FB was not included in the main body of the report as it was considered to be not fully commissioned. Some of the reasons for removing the Port of Entry buildings from the body of the report include

- Port of Entry buildings operate 24 hours a day for 365 days a year.

- Ports of Entry contain a considerable amount of electronic equipment (e.g., monitoring equipment, computers, etc.).

- A considerable number of public visitors impact the water use, energy use, and janitorial costs.

- The remote location of Ports of Entry tends to increase their associated labor costs.

- A portion of the space includes large heated garages for vehicle inspections.

For these reasons, a summary of the data for Manhattan FB, Sault Sainte Marie Port and Sweetgrass Port and are provided in this appendix.

\section{General Building Information}

The Manhattan FB is a leased facility in a medium-sized community in central Kansas. The Sault Sainte (Ste.) Marie Port of Entry is on the US-side of the US-Canadian border surrounded by a small community. The Sweetgrass, Montana/Coutts, Alberta (Sweetgrass) Port of Entry straddles the US-Canadian border in a remote location. Appendix A offers a detailed site summary for these facilities. 
For each of the key metrics in this study, the following table offers the summary results. The remaining tables in this appendix provide detail for each individual metric.

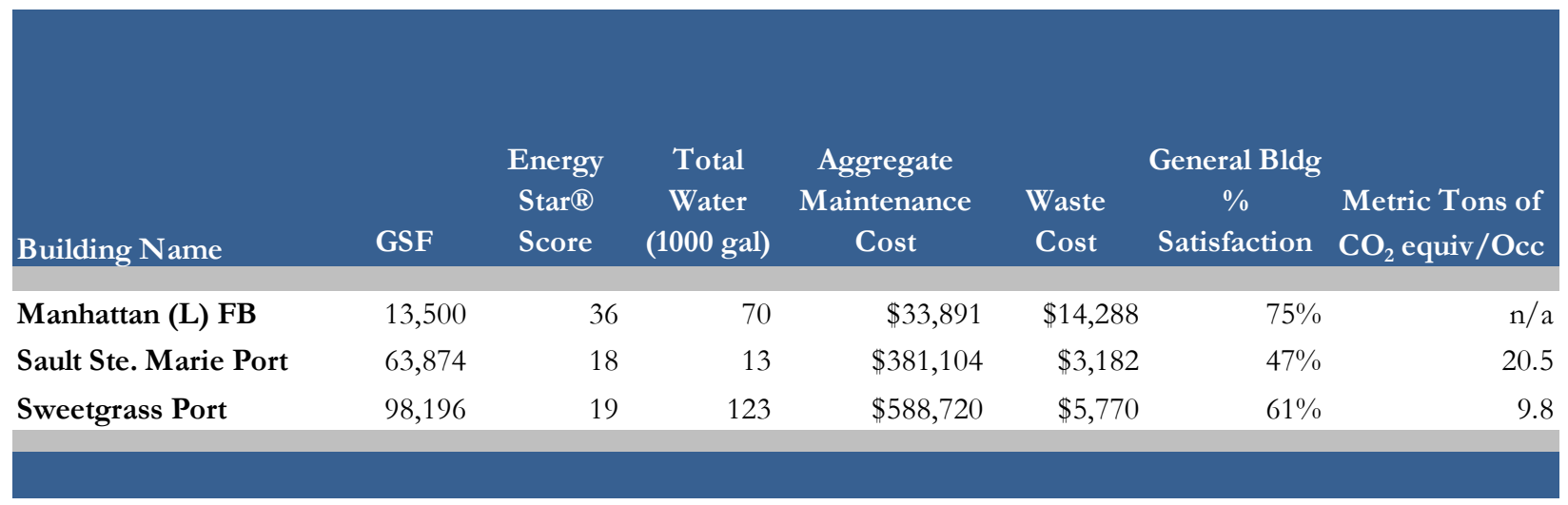

The Manhattan FB is the smallest building in the study. The Sweetgrass Port of Entry is larger than the Sault Sainte Marie Port of Entry and has more daily visitors that stopped to use the facilities.

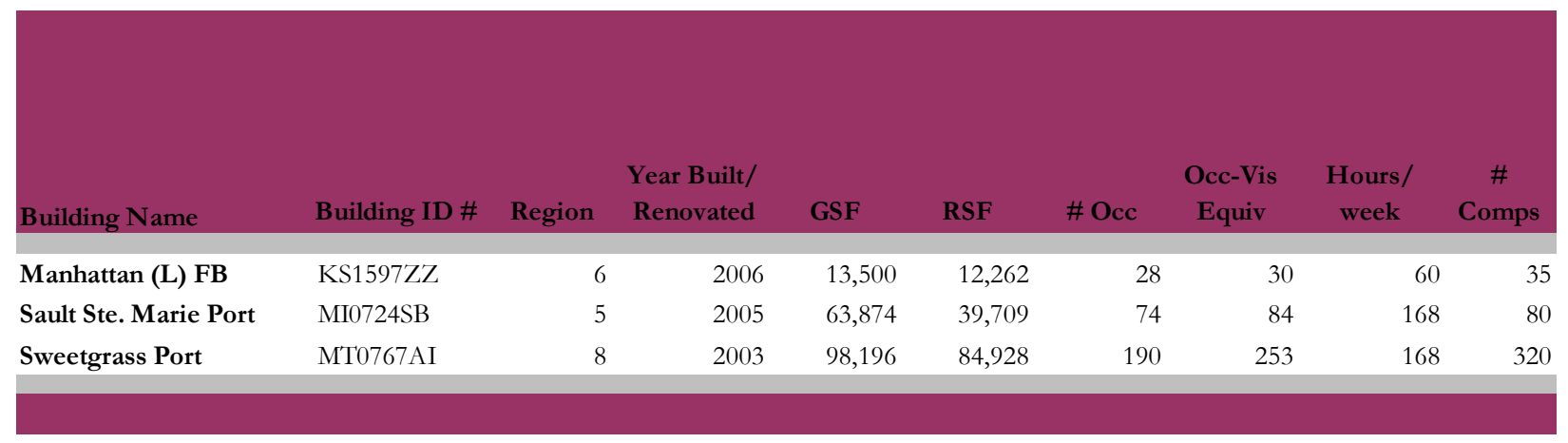

Manhattan is LEED-Silver certified with two Energy \& Atmosphere (EA) Optimize Energy Performance (EAc1) points and two Water Efficiency (WE) Water Use Reduction (WEc3) points. Sweetgrass is LEED-NC certified with no Energy EAc1 points and only one WEc3 point. Manhattan has an Energy Star score below 40, and both Port of Entry buildings have scores below 20. Manhattan and Sweetgrass also each have two points for Water-Efficient Landscaping (WEc1), and Sweetgrass has one EA point for Green Power (EAc6).

\begin{tabular}{|c|c|c|c|c|c|}
\hline Building Name & Certification Level & $\begin{array}{c}\text { LEED }^{\circledR} \\
\text { Total } \\
\text { Credits }\end{array}$ & $\begin{array}{c}\text { LEED® } \\
\text { EAc1 } \\
\text { Credits }\end{array}$ & $\begin{array}{c}\text { LEED® } \\
\text { WEc3 } \\
\text { Credits }\end{array}$ & $\begin{array}{c}\text { Energy } \\
\text { Star® } \\
\text { Score }\end{array}$ \\
\hline Manhattan (L) FB & LEED-NC Silver & 33 & 2 & 2 & 36 \\
\hline Sault Ste. Marie Port & LEED-NC Registered & $\mathrm{N} / \mathrm{A}$ & $\mathrm{N} / \mathrm{A}$ & $\mathrm{N} / \mathrm{A}$ & 18 \\
\hline Sweetgrass Port & LEED-NC Certified & 27 & 0 & 1 & 19 \\
\hline
\end{tabular}




\section{Water}

None of the sites use process water for cooling or potable water for landscaping. Manhattan has buffalo grass landscaping that has been a challenge to get established. Sault Ste. Marie has a vegetated roof, but no significant landscaping. Sweetgrass has minimal trees and native plants that require no additional water once they are established.

\begin{tabular}{|c|c|c|c|c|c|c|}
\hline \multirow[b]{2}{*}{ Building Name } & \multirow[b]{2}{*}{ Water Consuming Equipment } & \multicolumn{4}{|c|}{ Water Use (gallons) } & \multirow[b]{2}{*}{$\begin{array}{c}\text { Total } \\
\text { Water Cost }\end{array}$} \\
\hline & & Total Water & $\begin{array}{l}\text { Estimated } \\
\text { Landscape }\end{array}$ & $\begin{array}{l}\text { Estimated } \\
\text { Process }\end{array}$ & $\begin{array}{c}\text { Domestic } \\
\text { Portion }\end{array}$ & \\
\hline Manhattan (L) FB & - & 70,317 & 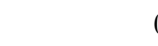 & 0 & 70,317 & $\$ 753$ \\
\hline Sault Ste. Marie Port & - & 13,000 & ( & 0 & 13,000 & $\$ 1,858$ \\
\hline Sweetgrass Port & - & 123,144 & ( & 0 & 123,144 & $\$ 8,073$ \\
\hline
\end{tabular}

\section{Energy}

None of the buildings have access to central steam or chilled water. All buildings use natural gas and electricity.

\begin{tabular}{|c|c|c|c|c|c|c|}
\hline \multirow[b]{2}{*}{ Building Name } & \multicolumn{6}{|c|}{ Energy Use } \\
\hline & $\begin{array}{l}\text { Electricity } \\
\text { (MWH) }\end{array}$ & $\begin{array}{l}\text { Nat Gas } \\
\left(1000 \mathrm{ft}^{3}\right)\end{array}$ & $\begin{array}{l}\text { Steam } \\
(\mathrm{kBtu})\end{array}$ & $\begin{array}{l}\text { Chilled Wate } \\
\text { (Ton Hr) }\end{array}$ & $\begin{array}{c}\text { Total Energy } \\
\text { (mbtu) }\end{array}$ & $\begin{array}{c}\text { Total Energy } \\
\text { Cost }\end{array}$ \\
\hline Manhattan (L) FB & 210 & 661 & & 0 & 723 & $\$ 23,554$ \\
\hline Sault Ste. Marie Port & 1,918 & 3,982 & & 0 & 10,577 & $\$ 98,472$ \\
\hline Sweetgrass Port & 2,432 & 12,127 & & 0 & 20,583 & $\$ 187,253$ \\
\hline
\end{tabular}

The most comparable information for the energy use intensity (EUI) is information specific to the GSA information. Manhattan is above all of the comparable values, which is not surprising given that the HVAC equipment has been operated 24-7 in an attempt to address humidity problems. When all GSA Port of Entry energy use is averaged the EUI is 109 $\mathrm{kBTU} / \mathrm{gsf}$. When only the northern Port of Entry energy use is averaged, the EUI is 132 $\mathrm{kBTU} / \mathrm{gsf}$, which is closer to the measured use than the Commercial Buildings Energy Consumption Survey (CBECS) values by region. 


\begin{tabular}{|c|c|c|c|c|c|c|c|}
\hline \multirow[b]{2}{*}{ Building Name } & \multicolumn{7}{|c|}{ EUI (kBTU/gsf) } \\
\hline & $\begin{array}{c}\text { Current } \\
\text { EUI }\end{array}$ & $\begin{array}{c}\text { FY09 GSA } \\
\text { Regional } \\
\text { Averages }\end{array}$ & $\begin{array}{c}\text { FY09 GSA } \\
\text { Target }\end{array}$ & $\begin{array}{c}\text { Energy Star } \\
\text { Baseline } \\
(50 \%)\end{array}$ & $\begin{array}{l}\text { CBECS } \\
\text { Regional } \\
\text { Average }\end{array}$ & $\begin{array}{c}\text { CBECS } \\
\text { Office }\end{array}$ & $\begin{array}{c}\text { GSA } \\
\text { Northern } \\
\text { Port Average }\end{array}$ \\
\hline Manhattan (L) FB & 102 & 75 & 81 & 88 & 75 & 88 & $\mathrm{n} / \mathrm{a}$ \\
\hline Sault Ste. Marie Port & 165 & 84 & 86 & 114 & 108 & $\mathrm{n} / \mathrm{a}$ & 132 \\
\hline Sweetgrass Port & 193 & 89 & 92 & 133 & 104 & $\mathrm{n} / \mathrm{a}$ & 132 \\
\hline
\end{tabular}

\section{Maintenance and Operations}

The Manhattan building manager indicated that the HVAC maintenance cost was significantly higher than expected due to the number of problems with the system. The site personnel at the Sweetgrass Port of Entry indicated that they had considerable difficulty getting reasonably priced contractors on site because of their remote location of the site. The site does not routinely track maintenance calls, thus the estimated ratio of maintenance calls to preventative maintenance provided by site personnel.

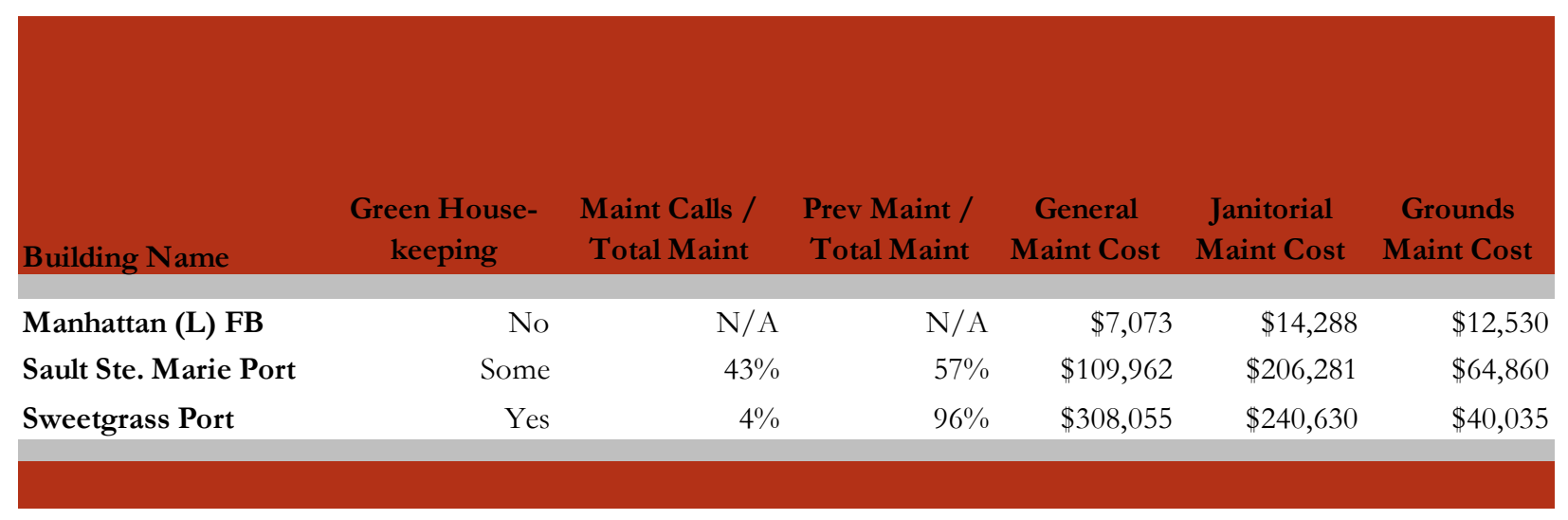

\section{Waste Disposal and Recycling}

Manhattan does have a recycling program that tracks quantity, and there is no cost to the site. Sault Ste. Marie did not have a recycling program, and although a recycling program exists at Sweetgrass, the PNNL research team was not able to obtain the numbers related to quantities of waste and recycled materials to enable a performance comparison. 


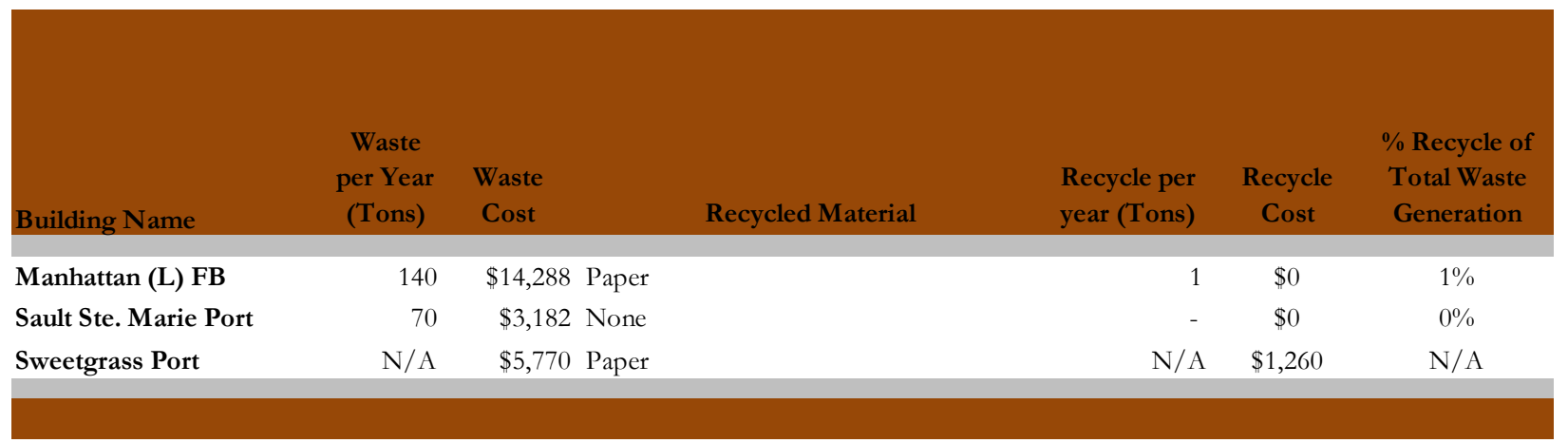

\section{Transportation}

The occupants of the Sault Ste. Marie Port of Entry building have the shortest average commute distances of all the buildings in the study, while Sweetgrass building occupants have the longest average commute distance. For both buildings, the majority of the building occupants drive trucks or sport utility vehicles. The occupants at Manhattan were not given the study specific survey that requested information on commute distance or type of vehicle driven. Alternatively the standard GSA survey had been administered earlier in the year and the occupants could not be re-surveyed.

\begin{tabular}{|c|c|c|c|c|c|c|c|}
\hline Building Name & $\begin{array}{c}\text { Survey N- } \\
\text { Value }\end{array}$ & \# Occ & $\begin{array}{l}\% \text { of Occupants } \\
\text { who commute } \\
\text { using mass transit, } \\
\text { biking and/or } \\
\text { walking }\end{array}$ & $\begin{array}{l}\text { Avg Daily } \\
\text { Roundtrip } \\
\text { Miles } \\
\text { Traveled/Occ }\end{array}$ & $\begin{array}{c}\text { Transportation } \\
\mathrm{CO}_{2} \text { Equiv/Occ } \\
\text { (metric tons) }\end{array}$ & $\begin{array}{c}\text { Baseline } \\
\text { Transportation } \\
\mathrm{CO}_{2} \text { Equiv/Occ } \\
\text { (metric tons) }\end{array}$ & $\begin{array}{c}\text { Bldg } \\
\text { Transportation } \\
\text { Performance }\end{array}$ \\
\hline Manhattan (L) FB & 13 & 28 & $\mathrm{~N} / \mathrm{A}$ & $\mathrm{N} / \mathrm{A}$ & $\mathrm{N} / \mathrm{A}$ & 2.3 & $\mathrm{~N} / \mathrm{A}$ \\
\hline Sault Ste. Marie Port & 16 & 74 & $0 \%$ & 16.7 & 2.0 & 2.3 & $-15 \%$ \\
\hline Sweetgrass Port & 43 & 190 & $0 \%$ & 38.6 & 3.6 & 2.3 & $55 \%$ \\
\hline
\end{tabular}

\begin{tabular}{|c|c|c|c|c|c|}
\hline \multirow[b]{3}{*}{ Building Name } & \multicolumn{5}{|c|}{ Aggregate $\mathrm{MTCO}_{2}$ Equivalent Emissions } \\
\hline & \multicolumn{3}{|c|}{ Transportation } & \multirow{2}{*}{$\begin{array}{l}\text { Building } \\
\text { Baseline }\end{array}$} & $\begin{array}{l}\text { Aggregate } \\
\mathrm{CO}_{2} \\
\text { Emissions }\end{array}$ \\
\hline & Transportation & Baseline & Building & & Performance \\
\hline Manhattan (L) FB & $\mathrm{N} / \mathrm{A}$ & 69 & 223 & 193 & $\mathrm{~N} / \mathrm{A}$ \\
\hline Sault Ste. Marie Port & 164 & 193 & 1,558 & 1,071 & $36 \%$ \\
\hline Sweetgrass Port & 902 & 581 & 1,568 & 1,079 & $49 \%$ \\
\hline
\end{tabular}

Recommissioning of the Manhattan Federal Building is recommended after modifications to the HVAC systems are incorporated. As more Port of Entry buildings are designed and built, the need to understand how to optimize the design and operation of this building type 
will become greater. A detailed analysis of a Port of Entry building's performance would offer additional insight into factors impacting the water and energy use, maintenance and waste costs, occupant commute, and occupant satisfaction considerations. This level of analysis would require sub-metered energy and water use and more detailed investigation into costs and occupant-related factors. 


\section{Appendix C: Building Selection Process}

The purpose of the study was to assess as many of GSA's sustainably designed buildings as possible. The GSA and PNNL research team identified buildings that had the potential for being included in the whole building performance measurement study. To identify the list of potential buildings a variety of resources were considered (see list of resources provided prior to the table of buildings). Once the list of buildings was identified, each was considered using the building selection criteria. The table in this appendix includes the list of buildings considered for this study, and the reason why a building was or was not included in the study.

(†) NREL. March 2008. Federal Building Projects Registered for LEED® Certification Partial Listing. http://www1.eere.energy.gov/femp/pdfs/fed leed bldgs reg.pdf Accessed October 2008.

(‡) NREL. March 2007. Federal Buidings Awarded LEED® Certification. www1.eere.energy.gov/femp/pdfs/fed leed bldgs sum.pdf Accessed October 2008.

(\#) GSA. LEED Certified Projects.

http://www.gsa.gov/Portal/gsa/ep/channelView.do?pageTypeld=17109\&channelP

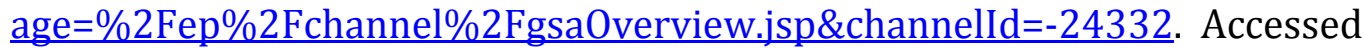
October 2008.

(*) Energy Star. 2008. ENERGY STAR Labeled Buildings \& Plants.

http://www.energystar.gov/index.cfm?fuseaction=labeled buildings.locator

Accessed October 2008.

OCA $=$ Office of the Chief Architect

PBS $=$ Public Buildings Service

R1 = Round 1 Assessing Green Building Performance Study

R2 = Round 2 Re-Assessing Green Building Performance Study

\begin{tabular}{|l|l|l|l|l|}
\hline \multicolumn{1}{|c|}{ Project Name } & $\begin{array}{c}\text { Building } \\
\text { Type }\end{array}$ & \multicolumn{1}{c|}{ Region } & Source & \multicolumn{1}{c|}{ Status } \\
\hline Quillen U.S. CT & Courthouse & Southeast Region 4 & PBS & Included R1 \\
\hline $\begin{array}{l}\text { John J. Duncan Federal } \\
\text { Building }\end{array}$ & Office & Southeast Region 4 & PBS & Included R1 \\
\hline Metzenbaum U.S. CT & Courthouse & Great Lakes Region 5 & PBS & Included R1 \\
\hline Scowcroft IRS Building & Office & Rocky Mountain Region 8 & PBS & Included R1 \\
\hline Lakewood DOT Office & Office & Rocky Mountain Region 8 & PBS & Included R1 \\
\hline DHS Omaha Office & Office & Heartland Region 6 & PBS & Included R1 \\
\hline $\begin{array}{l}\text { Curtis NPS Headquarters } \\
\text { Omaha }\end{array}$ & Office & Heartland Region 6 & PBS & Included R1 \\
\hline Santa Ana Federal Building & Office & Pacific Rim Region 9 & PBS & Included R1 \\
\hline
\end{tabular}




\begin{tabular}{|c|c|c|c|c|}
\hline Project Name & $\begin{array}{l}\text { Building } \\
\text { Type }\end{array}$ & Region & Source & Status \\
\hline Alfred Arraj U.S. CT & Courthouse & Rocky Mountain Region 8 & PBS & Included R1 \\
\hline Davenport CT & Courthouse & Heartland Region 6 & PBS & Included R1 \\
\hline $\begin{array}{l}\text { Jones Federal Building and } \\
\text { CT }\end{array}$ & $\begin{array}{l}\text { Office \& } \\
\text { Courthouse }\end{array}$ & Great Lakes Region 5 & PBS & Included R1 \\
\hline Coyle CT and Office & $\begin{array}{l}\text { Office \& } \\
\text { Courthouse }\end{array}$ & Pacific Rim Region 9 & PBS & Included R1 \\
\hline Sault Ste Marie Port & $\begin{array}{l}\text { Port of } \\
\text { Entry }\end{array}$ & Great Lakes Region 5 & PBS & Included R1 \\
\hline Sweetgrass Port & $\begin{array}{l}\text { Port of } \\
\text { Entry }\end{array}$ & Rocky Mountain Region 8 & PBS & Included R1 \\
\hline $\begin{array}{l}\text { U.S. Census Bureau } \\
\text { Headquarters }\end{array}$ & Office & National Capital Region 11 & $\neq$ & Included R2 \\
\hline $\begin{array}{l}\text { U.S. Department of } \\
\text { Agriculture Service Center }\end{array}$ & Office & Heartland Region 6 & \# & Included R2 \\
\hline $\begin{array}{l}\text { Social Services } \\
\text { Administration Telework } \\
\text { Center }\end{array}$ & Office & NW/Arctic Region 10 & $\#$ & Included R2 \\
\hline San Francisco FB & Office & Pacific Rim Region 9 & OCA & Included R2 \\
\hline Montgomery SAMHSA Lse & Office & National Capital Region 11 & OCA & Included R2 \\
\hline Las Vegas George CT & Courthouse & Pacific Rim Region 9 & OCA & Included R2 \\
\hline Seattle New CT & Courthouse & NW/Arctic Region 10 & OCA & Included R2 \\
\hline Jacksonville Bennett FB R & Office & Southeast Region 4 & OCA ${ }^{*}$ & Included R2 \\
\hline $\begin{array}{l}\text { Denver EPA Region } 8 \\
\text { Headq }\end{array}$ & Office & Rocky Mountain Region 8 & OCA/\# & Included R2 \\
\hline Eugene CT & Courthouse & NW/Arctic Region 10 & OCA/\# & Included R2 \\
\hline Cape Girardeau CT & Courthouse & Heartland Region 6 & PBS & Included R2 \\
\hline $\begin{array}{l}\text { Veterans Affairs Regional } \\
\text { Office }\end{array}$ & Office & Pacific Rim Region 9 & $\dagger$ & $\begin{array}{l}\text { Commissionin } \\
\text { g Underway }\end{array}$ \\
\hline $\begin{array}{l}\text { New Richmond U.S. } \\
\text { Courthouse }\end{array}$ & Courthouse & Mid-Atlantic Region 3 & $\neq$ & $\begin{array}{l}\text { Commissionin } \\
\text { g Underway }\end{array}$ \\
\hline $\begin{array}{l}\text { US CIS Detroit District } \\
\text { Office }\end{array}$ & $\begin{array}{l}\text { Cargo } \\
\text { Inspection }\end{array}$ & Great Lakes Region 5 & $\ddagger$ & $\begin{array}{l}\text { No Building } \\
\text { Type } \\
\text { Comparison }\end{array}$ \\
\hline NNSA Campus & $\begin{array}{l}\text { Production } \\
\text { Facility }\end{array}$ & Heartland Region 6 & $\ddagger$ & $\begin{array}{l}\text { No Building } \\
\text { Type } \\
\text { Comparison }\end{array}$ \\
\hline $\begin{array}{l}\text { Center for Devices and } \\
\text { Radiological Health }\end{array}$ & Laboratory & Mid-Atlantic Region 3 & $\neq$ & $\begin{array}{l}\text { No Building } \\
\text { Type } \\
\text { Comparison }\end{array}$ \\
\hline $\begin{array}{l}\text { David Skaggs Research } \\
\text { Center }\end{array}$ & Laboratory & Rocky Mountain Region 8 & $\neq$ & $\begin{array}{l}\text { No Building } \\
\text { Type } \\
\text { Comparison }\end{array}$ \\
\hline $\begin{array}{l}\text { NOAA Building } 1 \\
\text { Extension }\end{array}$ & Research & Rocky Mountain Region 8 & $\neq$ & $\begin{array}{l}\text { No Building } \\
\text { Type } \\
\text { Comparison }\end{array}$ \\
\hline $\begin{array}{l}\text { U.S. EPA Science and } \\
\text { Technology Center }\end{array}$ & $\begin{array}{l}\text { Laboratory } \\
\text { /Office }\end{array}$ & Heartland Region 6 & $\#$ & $\begin{array}{l}\text { No Building } \\
\text { Type } \\
\text { Comparison }\end{array}$ \\
\hline $\begin{array}{l}\text { Child Care Building for } \\
\text { Social Security }\end{array}$ & Child Care & Mid-Atlantic Region 3 & \# & $\begin{array}{l}\text { No Building } \\
\text { Type }\end{array}$ \\
\hline
\end{tabular}




\begin{tabular}{|c|c|c|c|c|}
\hline Project Name & $\begin{array}{l}\text { Building } \\
\text { Type }\end{array}$ & Region & Source & Status \\
\hline Administration & & & & Comparison \\
\hline $\begin{array}{l}\text { U.S. EPA New England } \\
\text { Regional Laboratory }\end{array}$ & Laboratory & New England Region 1 & \# & $\begin{array}{l}\text { No Building } \\
\text { Type } \\
\text { Comparison }\end{array}$ \\
\hline $\begin{array}{l}\text { OSHA Salt Lake Technical } \\
\text { Center }\end{array}$ & $\begin{array}{l}\text { Laboratory } \\
\text { /Office }\end{array}$ & Rocky Mountain Region 8 & \# & $\begin{array}{l}\text { No Building } \\
\text { Type } \\
\text { Comparison }\end{array}$ \\
\hline OKC Federal Campus & Campus & Greater Southwest Region 7 & OCA & $\begin{array}{l}\text { No Building } \\
\text { Type } \\
\text { Comparison }\end{array}$ \\
\hline Suitland NOAA Satellite 0 & $\begin{array}{l}\text { Research/ } \\
\text { Satellite } \\
\text { Operations }\end{array}$ & Mid-Atlantic Region 3 & OCA/\# & $\begin{array}{l}\text { No Building } \\
\text { Type } \\
\text { Comparison }\end{array}$ \\
\hline 536 S. Clark FB & $\begin{array}{l}\text { Office/Labo } \\
\text { ratory }\end{array}$ & Great Lakes Region 5 & & $\begin{array}{l}\text { No Building } \\
\text { Type } \\
\text { Comparison }\end{array}$ \\
\hline $\begin{array}{l}\text { Concord Cleveland FB-PO- } \\
\text { C }\end{array}$ & $\begin{array}{l}\text { Office/Post } \\
\text { Office/ } \\
\text { Courthouse }\end{array}$ & New England Region 1 & OCA & $\begin{array}{l}\text { No Building } \\
\text { Type } \\
\text { Comparison, } \\
\text { Not LEED }\end{array}$ \\
\hline Courthouse Square & Courthouse & Rocky Mountain Region 8 & $\ddagger$ & $\begin{array}{l}\text { Not } \\
\text { Cooperative }\end{array}$ \\
\hline $\begin{array}{l}\text { Potomac Yard } 1 \text { and } \\
\text { 2/EPA }\end{array}$ & Office & Mid-Atlantic Region 3 & † & $\begin{array}{l}\text { Not } \\
\text { Cooperative }\end{array}$ \\
\hline $\begin{array}{l}\text { Newport News Federal } \\
\text { Courthouse }\end{array}$ & Courthouse & Mid-Atlantic Region 3 & $\neq$ & $\begin{array}{l}\text { Not } \\
\text { Cooperative }\end{array}$ \\
\hline IRS Service Center & Office & Heartland Region 6 & $\#$ & $\begin{array}{l}\text { Not } \\
\text { Cooperative }\end{array}$ \\
\hline $\begin{array}{l}\text { CIS Nebraska Service } \\
\text { Center }\end{array}$ & Office & Heartland Region 6 & \# & $\begin{array}{l}\text { Not } \\
\text { Cooperative }\end{array}$ \\
\hline Wash DC ATF HQ & Office & National Capital Region 11 & OCA & $\begin{array}{l}\text { Not } \\
\text { Cooperative }\end{array}$ \\
\hline Liberty IV at Park Place & Office & Great Lakes Region 5 & $\dagger$ & Not GSA \\
\hline $\begin{array}{l}\text { DEA Pittsburgh District } \\
\text { Office }\end{array}$ & Office & Mid-Atlantic Region 3 & t & Not GSA \\
\hline $\begin{array}{l}\text { The Bureau of the Public } \\
\text { Debt }\end{array}$ & Office & Mid-Atlantic Region 3 & $\ddagger$ & Not GSA \\
\hline $\begin{array}{l}\text { USDA Headquarters } \\
\text { Modernization: South }\end{array}$ & Office & National Capital Region 11 & $\ddagger$ & Not GSA \\
\hline NIH Building 3 & Office & National Capital Region 11 & $\neq$ & Not GSA \\
\hline $\begin{array}{l}\text { U.S. District Court, District } \\
\text { of Montana }\end{array}$ & Courthouse & Rocky Mountain Region 8 & $\ddagger$ & Not GSA \\
\hline CIS Denver District Office & Office & Rocky Mountain Region 8 & $\neq$ & Not GSA \\
\hline US CIS West Palm Beach & Office & Southeast Region 4 & $\neq$ & Not GSA \\
\hline GSA Building Manager & Office & National Capital Region 11 & $\neq$ & $\begin{array}{l}\text { Not GSA } \\
\text { Building } \\
\end{array}$ \\
\hline $\begin{array}{l}\text { Hoover Building } \\
\text { Modernization }\end{array}$ & Office & National Capital Region 11 & $\ddagger$ & $\begin{array}{l}\text { Not LEED, no } \\
\text { Sustainable } \\
\text { Design } \\
\text { Features }\end{array}$ \\
\hline
\end{tabular}




\begin{tabular}{|c|c|c|c|c|}
\hline Project Name & $\begin{array}{l}\text { Building } \\
\text { Type }\end{array}$ & Region & Source & Status \\
\hline $\begin{array}{l}\text { U.S. District Courthouse, } \\
\text { SLC }\end{array}$ & Courthouse & Rocky Mountain Region 8 & $\neq$ & $\begin{array}{l}\text { Not LEED, no } \\
\text { Sustainable } \\
\text { Design } \\
\text { Features }\end{array}$ \\
\hline White Federal Bldg & $\begin{array}{l}\text { Office/Cour } \\
\text { thouse }\end{array}$ & Greater Southwest Region 7 & Region & $\begin{array}{l}\text { Not LEED, no } \\
\text { Sustainable } \\
\text { Design } \\
\text { Features }\end{array}$ \\
\hline Cleveland Stokes CT & Courthouse & Great Lakes Region 5 & OCA & $\begin{array}{l}\text { Not LEED, no } \\
\text { Sustainable } \\
\text { Design } \\
\text { Features }\end{array}$ \\
\hline San Antonio FB LEASE & Office & Greater Southwest Region 7 & OCA & $\begin{array}{l}\text { Not LEED, no } \\
\text { Sustainable } \\
\text { Design } \\
\text { Features }\end{array}$ \\
\hline Laredo New FB-CT & $\begin{array}{l}\text { Courthouse } \\
\text { /Office }\end{array}$ & Greater Southwest Region 7 & OCA & $\begin{array}{l}\text { Not LEED, no } \\
\text { Sustainable } \\
\text { Design } \\
\text { Features } \\
\end{array}$ \\
\hline Rockville AHRQ Lease & Office & National Capital Region 11 & OCA & $\begin{array}{l}\text { Not LEED, no } \\
\text { Sustainable } \\
\text { Design } \\
\text { Features }\end{array}$ \\
\hline $\begin{array}{l}\text { Wash DC } 20 \text { Mass Ave } \\
\text { LEASE }\end{array}$ & Office & National Capital Region 11 & OCA & $\begin{array}{l}\text { Not LEED, no } \\
\text { Sustainable } \\
\text { Design } \\
\text { Features }\end{array}$ \\
\hline Wash DC FTC Lease & Office & National Capital Region 11 & OCA & $\begin{array}{l}\text { Not LEED, no } \\
\text { Sustainable } \\
\text { Design } \\
\text { Features }\end{array}$ \\
\hline CB King CT & Courthouse & Southeast Region 4 & OCA & $\begin{array}{l}\text { Not LEED, no } \\
\text { Sustainable } \\
\text { Design } \\
\text { Features }\end{array}$ \\
\hline Orlando FB-CT & Courthouse & Southeast Region 4 & OCA & $\begin{array}{l}\text { Not LEED, no } \\
\text { Sustainable } \\
\text { Design } \\
\text { Features }\end{array}$ \\
\hline Hammond CT & Courthouse & Great Lakes Region 5 & OCA/* & $\begin{array}{l}\text { Not LEED, no } \\
\text { Sustainable } \\
\text { Design } \\
\text { Features } \\
\end{array}$ \\
\hline Corpus Christi FB-CT & Courthouse & Greater Southwest Region 7 & OCA/* & $\begin{array}{l}\text { Not LEED, no } \\
\text { Sustainable } \\
\text { Design } \\
\text { Features }\end{array}$ \\
\hline Jacksonville CT & Courthouse & Southeast Region 4 & OCA/* & $\begin{array}{l}\text { Not LEED, no } \\
\text { Sustainable } \\
\text { Design } \\
\text { Features }\end{array}$ \\
\hline
\end{tabular}




\begin{tabular}{|c|c|c|c|c|}
\hline Project Name & $\begin{array}{l}\text { Building } \\
\text { Type }\end{array}$ & Region & Source & Status \\
\hline $\begin{array}{l}\text { Annex Building for Social } \\
\text { Security Administration }\end{array}$ & Office & Mid-Atlantic Region 3 & \# & $\begin{array}{l}\text { Not Separately } \\
\text { Metered }\end{array}$ \\
\hline $\begin{array}{l}\text { Byron G. Rogers U.S. } \\
\text { Courthouse }\end{array}$ & $\begin{array}{l}\text { Courthouse } \\
\text { /Office }\end{array}$ & Rocky Mountain Region 8 & $\#$ & $\begin{array}{l}\text { Not Separately } \\
\text { Metered }\end{array}$ \\
\hline Arlington One Liberty Cen & Office & National Capital Region 11 & OCA & $\begin{array}{l}\text { Not Separately } \\
\text { Metered }\end{array}$ \\
\hline Wash DC NPS Lease & Office? & National Capital Region 11 & OCA & $\begin{array}{l}\text { Not Separately } \\
\text { Metered }\end{array}$ \\
\hline Gulfport FB-CT & Courthouse & Southeast Region 4 & OCA $/^{*}$ & $\begin{array}{l}\text { Not Separately } \\
\text { Metered }\end{array}$ \\
\hline $\begin{array}{l}\text { Federal Office Building } \\
\text { No.8 }\end{array}$ & Office & National Capital Region 11 & $\neq$ & $\begin{array}{l}\text { Project on } \\
\text { Hold }\end{array}$ \\
\hline GSA $1800 \mathrm{~F}$ & Office & National Capital Region 11 & $\neq$ & $\begin{array}{l}\text { Project on } \\
\text { Hold }\end{array}$ \\
\hline $\begin{array}{l}\text { Lafayette Building } \\
\text { Modernization }\end{array}$ & Office & National Capital Region 11 & $\neq$ & $\begin{array}{l}\text { Project on } \\
\text { Hold }\end{array}$ \\
\hline $\begin{array}{l}\text { Minton-Capehart Federal } \\
\text { Building }\end{array}$ & Office & Great Lakes Region 5 & $\neq$ & $\begin{array}{l}\text { Under } \\
\text { Construction }\end{array}$ \\
\hline $\begin{array}{l}\text { New United States } \\
\text { Courthouse }\end{array}$ & Courthouse & Great Lakes Region 5 & $\neq$ & $\begin{array}{l}\text { Under } \\
\text { Construction }\end{array}$ \\
\hline $\begin{array}{l}\text { U.S. District Court, Toledo, } \\
\mathrm{OH}\end{array}$ & Courthouse & Great Lakes Region 5 & $\neq$ & $\begin{array}{l}\text { Under } \\
\text { Construction }\end{array}$ \\
\hline $\begin{array}{l}\text { Anthony J. Celebrezze } \\
\text { Federal Building }\end{array}$ & Office & Great Lakes Region 5 & $\neq$ & $\begin{array}{l}\text { Under } \\
\text { Construction }\end{array}$ \\
\hline $\begin{array}{l}\text { Birch Bayh Federal } \\
\text { Building and U.S. } \\
\text { Courthouse }\end{array}$ & $\begin{array}{l}\text { Office/Cour } \\
\text { thouse }\end{array}$ & Great Lakes Region 5 & $\neq$ & $\begin{array}{l}\text { Under } \\
\text { Construction }\end{array}$ \\
\hline GT Mickey Leland R\&A & Office & Greater Southwest Region 7 & $\neq$ & $\begin{array}{l}\text { Under } \\
\text { Construction }\end{array}$ \\
\hline $\begin{array}{l}\text { San Antonio Federal } \\
\text { Building }\end{array}$ & Office & Greater Southwest Region 7 & $\neq$ & $\begin{array}{l}\text { Under } \\
\text { Construction }\end{array}$ \\
\hline $\begin{array}{l}\text { New Jefferson City } \\
\text { Courthouse }\end{array}$ & Courthouse & Heartland Region 6 & $\neq$ & $\begin{array}{l}\text { Under } \\
\text { Construction }\end{array}$ \\
\hline $\begin{array}{l}\text { John F. Kennedy Federal } \\
\text { Building }\end{array}$ & Office & New England Region 1 & $\neq$ & $\begin{array}{l}\text { Under } \\
\text { Construction }\end{array}$ \\
\hline $\begin{array}{l}\text { J.W. McCormack Repair } \\
\text { and Alterations }\end{array}$ & Office & New England Region 1 & $\neq$ & $\begin{array}{l}\text { Under } \\
\text { Construction }\end{array}$ \\
\hline $\begin{array}{l}\text { M.C. Smith Federal Bldg. \& } \\
\text { Courthouse }\end{array}$ & $\begin{array}{l}\text { Office/Cour } \\
\text { thouse }\end{array}$ & New England Region 1 & $\neq$ & $\begin{array}{l}\text { Under } \\
\text { Construction }\end{array}$ \\
\hline $\begin{array}{l}\text { Thurgood Marshall U.S. } \\
\text { Courthouse }\end{array}$ & Courthouse & $\begin{array}{l}\text { Northeast and Caribbean } \\
\text { Region } 2\end{array}$ & $\neq$ & $\begin{array}{l}\text { Under } \\
\text { Construction }\end{array}$ \\
\hline $\begin{array}{l}\text { GSA Coeur D'Alene Federal } \\
\text { Courthouse }\end{array}$ & Courthouse & NW/Arctic Region 10 & $\neq$ & $\begin{array}{l}\text { Under } \\
\text { Construction }\end{array}$ \\
\hline $\begin{array}{l}\text { Sam Nunn Atlanta Federal } \\
\text { Center }\end{array}$ & Office & Southeast Region 4 & $\neq$ & $\begin{array}{l}\text { Under } \\
\text { Construction }\end{array}$ \\
\hline United States Courthouse & Courthouse & Southeast Region 4 & $\neq$ & $\begin{array}{l}\text { Under } \\
\text { Construction }\end{array}$ \\
\hline $\begin{array}{l}\text { Modernization of the U.S. } \\
\text { Courthouse }\end{array}$ & Courthouse & Southeast Region 4 & $\neq$ & $\begin{array}{l}\text { Under } \\
\text { Construction }\end{array}$ \\
\hline $\begin{array}{l}\text { Nashville Federal } \\
\text { Courthouse }\end{array}$ & Courthouse & Southeast Region 4 & $\neq$ & $\begin{array}{l}\text { Under } \\
\text { Construction }\end{array}$ \\
\hline
\end{tabular}




\begin{tabular}{|l|l|l|l|l|}
\hline \multicolumn{1}{|c|}{ Project Name } & \multicolumn{1}{c|}{$\begin{array}{c}\text { Building } \\
\text { Type }\end{array}$} & \multicolumn{1}{|c|}{ Region } & Source & \multicolumn{1}{|c|}{ Status } \\
\hline $\begin{array}{l}\text { Martin Luther King Jr. } \\
\text { Federal Building }\end{array}$ & Office & Southeast Region 4 & $\ddagger$ & $\begin{array}{l}\text { Under } \\
\text { Construction }\end{array}$ \\
\hline $\begin{array}{l}\text { Dr. A. H. McCoy Federal } \\
\text { Building }\end{array}$ & Office & Southeast Region 4 & $\ddagger$ & $\begin{array}{l}\text { Under } \\
\text { Construction }\end{array}$ \\
\hline $\begin{array}{l}\text { U.S. Citizen and } \\
\text { Immigration Services }\end{array}$ & Office & Southeast Region 4 & $\ddagger$ & $\begin{array}{l}\text { Under } \\
\text { Construction }\end{array}$ \\
\hline Chicago FBI Office LEASE & Office & Great Lakes Region 5 & OCA & $\begin{array}{l}\text { Under } \\
\text { Construction }\end{array}$ \\
\hline
\end{tabular}




\section{Appendix D: Baseline Development Documentation}

For each of the major whole building performance metrics, an industry baseline was determined for comparison purposes. The baselines were developed specifically for this study and should therefore be evaluated for applicability if they are considered for use in other performance measurement efforts.

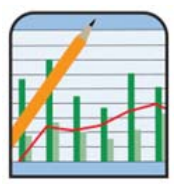

In addition to baseline calculations, some of the metrics needed additional values calculated and/or analyzed in order for the values to be useful in the analysis. The supporting values and baseline calculations included in this appendix are

- Occupant-Visitor equivalent

- Water baselines

o Indoor water use baseline

o Outdoor water use

- Monthly energy and water use

- Multiple year data analysis for energy, water, and maintenance

- Operations and maintenance baselines

- Operational cost baselines

\section{Occupant-Visitor Equivalent Calculations}

For each building, the number and type of visitors were requested in order to estimate visitor impact on water and energy use. The building contacts typically provided the number of visitors per day, the typical length of stay for each visitor, and the reason for the visit. Depending on the type and length of visit, the number of visitors was assigned from 25$100 \%$ of a regular building occupant. The sum of the regular building occupants and the visitor value is the occupant-visitor equivalent, which is intended to represent the number of people using contributing to the building's performance during a typical workday. 


\begin{tabular}{|c|c|c|c|c|c|c|c|c|}
\hline Building Name & $\begin{array}{l}\text { Regular } \\
\text { Occupant } \\
\text { s per Day }\end{array}$ & $\begin{array}{l}\text { Detainees } \\
\text { per year }\end{array}$ & $\begin{array}{c}\text { Oc } \\
\text { Detainees } \\
\text { per day }\end{array}$ & $\begin{array}{l}\text { Visitors } \\
\text { per year }\end{array}$ & $\begin{array}{l}\text { Visitors } \\
\text { per day }\end{array}$ & $\begin{array}{c}\text { Hours per Visitor } \\
\text { Estimate }\end{array}$ & $\begin{array}{l}\text { Visitor } \\
\text { FTE }\end{array}$ & $\begin{array}{l}\text { Occupant } \\
\& \text { Visitor } \\
\text { Equivalent }\end{array}$ \\
\hline Greeneville CT & 85 & - & - & 9,000 & 36 & half & 18 & 103 \\
\hline Jacksonville FB & 1000 & - & - & 75,000 & 300 & half & 150 & 1,150 \\
\hline Knoxville FB & 285 & - & - & 25,250 & 101 & 1 use & 25 & 310 \\
\hline Cleveland CT & 105 & - & - & 18,750 & 75 & half & 38 & 143 \\
\hline Youngstown CT \& FB & 45 & - & - & 61,750 & 247 & half \& 1 use & 198 & 243 \\
\hline Cape Girardeau CT & 45 & - & - & 27,500 & 110 & half & 55 & 100 \\
\hline Davenport CT & 45 & - & - & 9,000 & 36 & half & 18 & 63 \\
\hline Omaha DHS (L) FB & 65 & 2,750 & 7.86 & 65,250 & 250 & NA & 295 & 360 \\
\hline Omaha NPS (L) FB & 125 & - & - & 8,800 & 35 & 1use & 9 & 134 \\
\hline Denver CT & 170 & - & - & 100,000 & 400 & half & 200 & 370 \\
\hline Denver (L) FB & 922 & - & - & 35,700 & 143 & half & 71 & 993 \\
\hline Lakewood (L) FB & 318 & - & - & 9,900 & 40 & 1 use for $7500+$ meetings for 2400 & 18 & 336 \\
\hline Ogden (L) FB & 514 & - & - & 1,800 & 7 & equiv to occ & 7 & 521 \\
\hline Fresno CT \& FB & 235 & - & - & 275,000 & 1,100 & 1 use & 275 & 510 \\
\hline Las Vegas CT & 321 & - & - & 53,333 & 213 & half & 107 & 428 \\
\hline San Francisco FB & 1314 & - & - & See Note & See Note & $\begin{array}{r}\text { Confr. Cetner } 1500 / \text { month at } 8 \text {, } \\
\text { Tours } 345 / \text { month at } 1.5 \text {, Visitors } \\
75 / \text { day at } 1.5 \text {, SSA } 200 / \text { day at } 1.5 \text {, } \\
\text { DOL } 12 / \text { month at } 8\end{array}$ & 130 & 1,444 \\
\hline Santa Ana FB & 409 & 250 & 0.71 & 50,000 & 200 & 1use & 50 & 459 \\
\hline Auburn FB & 675 & - & - & - & - & - & - & 675 \\
\hline Eugene CT & 120 & - & - & 25,000 & 100 & half & 50 & 170 \\
\hline Seattle CT & 500 & - & - & 50,000 & 200 & half & 100 & 600 \\
\hline Rockville (L) FB & 720 & - & - & 20,000 & 80 & half & 40 & 760 \\
\hline Suitland FB & 5360 & - & - & 32,500 & 130 & half & 65 & 5,425 \\
\hline
\end{tabular}




\section{Water Baseline Calculations}

Water consumption in a commercial office building typically consists primarily of domestic use (i.e., faucet, toilet, and urinal use), landscape irrigation, and process water (i.e., cooling and/or heating processes). ${ }^{34}$

\section{Water Distribution in a Typical Office Building}

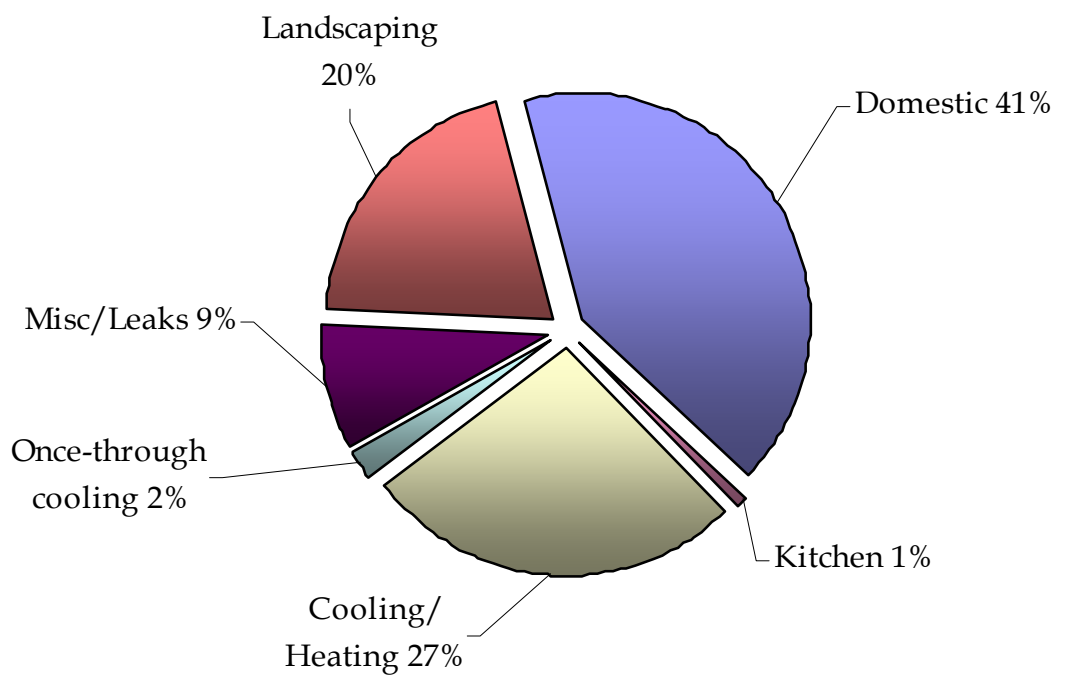

These three primary uses of water were separated for each building. Domestic water consumption depends on human operation and fixed equipment efficiency. Therefore, typical indoor water consumption is best expressed as per occupant. For water use comparisons to the baseline, gallons per occupant per year is used. Occupancy gender data allow for a more accurate comparison of indoor water use, because the quantity and type of water-using fixtures vary by gender. Many of these buildings also have a large number of visitors, who are likely to contribute to the total domestic water consumption. To address this, an estimate of visitor water use was added to the total based on expected quantities of visitors and an appropriate gallon also compared to a visitor-adjusted baseline in gallons used per occupant and visitor per year value.

For water use analysis, the indoor potable water use data had to be estimated from the water utility bills. The baselines for comparison include indoor potable water use per occupant per day, total water use per gross square footage, and water cost per rentable square foot. Process and landscape water analysis were not performed as detailed water use information was not available. 


\section{Indoor Water Use Per Occupant}

The reference data used for calculating the water use baseline was the federal Water Use Indices (Indices). ${ }^{35}$ The Indices provide basic guidance on typical water usage for different building types. Indoor water use for office buildings is estimated at an average of 15 gallons per occupant per day (gpd/occupant), with a range of 8 to $20 \mathrm{gpd}$.

When landscape irrigation water and process water have been removed from the total water consumption, the majority of the building water consumption is from "domestic uses." Due to the difference in fixture type (i.e., urinals and toilets), occupant gender plays a role in the quantity of water used in a typical federal building, courthouse, or port of entry building. However, the federal Indices do not provide detail on use for male and female building occupants. The following assumptions were made to support the adjustment of the Indices and develop a gender-specific water use baseline:

- The federal Indices were developed with a 50-50 ratio of male-to-female building occupants.

- In an office building, $61 \%$ of the domestic water use is for toilets, $17 \%$ for urinals, and $22 \%$ for faucets.

- On average, females use toilets three times per day with males only once per day plus urinals two times per day. ${ }^{36}$

- Faucet use is equal for males and females.

- $15 \mathrm{gpd} /$ occupant is the average between male and female water use.

Based on these assumptions, the following calculations were made:

$$
\begin{aligned}
& \text { Domestic Water Use }=\text { Female Toilet Use }+ \text { Male Toilet Use + Female Fancet Use + Male Fancet } \\
& \text { Use + Male Urinal Use } \\
& \text { Toilet Use }=\text { Female Use }(75 \%)+\text { Male Use }(25 \%) \\
& \text { Fancet Use }=\text { Female Use }(50 \%)+\text { Male Use (50\%) } \\
& \text { Female Use }=[(75 \% \text { Toilet }) *(61 \% \text { Water Use for Toilets })]+[(50 \% \text { Fancets }) *(22 \% \text { Water use } \\
& \text { for Faucets)] } \\
& \text { Female Use }=57 \% \text { Total Water Use or } 17.1 \mathrm{gpd} / \text { occupant } \\
& \text { Male Use }=[(25 \% \text { Toilet }) *(61 \% \text { Water Use for Toilets })]+[17 \% \text { Urinal }]+[(50 \% \text { Faucets }) * \\
& \text { (22\% Water use for Faucets)] } \\
& \text { Male Use }=43 \% \text { Total Water Use or } 12.9 \text { gpd/ occupant }
\end{aligned}
$$


Thus, the quantity of male and female occupants was used to adjust the Indices for the Indoor Water Use baseline as follows:

$$
\begin{aligned}
\text { Water Use Baseline }(g \mathrm{gd} / \text { occupant })= & (\text { Total Occupants *\% Female * } 17.1 \mathrm{gpd} / \text { occupant })+(\text { Total } \\
& \text { Occupants *\% Male* } 12.9 \mathrm{gpd} / \text { occupant })
\end{aligned}
$$

The Port of Entry buildings, the Department of Homeland Security federal building, and the Santa Ana courthouse and federal building also included inmates. Inmate water use was assumed to be $120 \mathrm{gpd} /$ occupant. Although several buildings had showers and a few buildings had a small restaurant, those water usages were not included in the baseline calculations. And finally, in all but the Port of Entry buildings, it was assumed the water use would occur 250 days per year (i.e., five workdays a week and fifty workweeks per year).

\begin{tabular}{|c|c|c|c|c|c|c|c|c|c|c|c|}
\hline \multirow[b]{2}{*}{ Building Name } & \multirow[b]{2}{*}{$\begin{array}{l}\text { Occupant \& } \\
\text { Visitor } \\
\text { Equivalent }\end{array}$} & \multicolumn{3}{|c|}{ \# of Occupants by Type } & \multicolumn{3}{|c|}{ Gallons Per Occupant Type } & \multicolumn{4}{|c|}{ Baseline Comparison } \\
\hline & & Male & Female & Detainees & $\begin{array}{c}\text { Male } \\
(12.9 \mathrm{gal} / \text { day })\end{array}$ & $\begin{array}{c}\text { Female } \\
\text { (17.1gal/day) }\end{array}$ & $\begin{array}{c}\text { Detainee } \\
\text { (120 gal/day) }\end{array}$ & $\begin{array}{l}\text { Baseline } \\
\text { gal per } \\
\text { Occ-Vis } \\
\text { Equiv }\end{array}$ & $\begin{array}{l}\text { Building } \\
\text { gal per } \\
\text { Occupant } \\
\text { Equiv }\end{array}$ & $\begin{array}{r}\text { Bu } \\
\text { W } \\
\text { Perfo }\end{array}$ & $\begin{array}{l}\text { ding } \\
\text { ter } \\
\text { mance }\end{array}$ \\
\hline Greeneville CT & 103 & 52 & 52 & - & 166,088 & 220,163 & - & 3,750 & 7,082 & & $89 \%$ \\
\hline Jacksonville FB & 1150 & 575 & 575 & - & $1,854,375$ & $2,458,125$ & - & 3,750 & 2,544 & & $-32 \%$ \\
\hline Knoxville FB & 310 & 155 & 155 & - & 500,278 & 663,159 & - & 3,750 & 5,299 & & $41 \%$ \\
\hline Cleveland CT & 143 & 71 & 71 & - & 229,781 & 304,594 & - & 3,750 & 3,160 & & $-16 \%$ \\
\hline Youngstown CT \& FB & 243 & 121 & 121 & - & 391,031 & 518,344 & - & 3,750 & 1,727 & & $-54 \%$ \\
\hline Cape Girardeau CT & 100 & 60 & 40 & - & 193,500 & 171,000 & - & 3,645 & 2,041 & & $-44 \%$ \\
\hline Davenport CT & 63 & 32 & 32 & - & 101,588 & 134,663 & - & 3,750 & 6,144 & & $64 \%$ \\
\hline Omaha DHS (L) FB & 360 & 176 & 176 & 7.86 & 567,830 & 752,705 & 235,714 & 4,323 & 6,256 & & $45 \%$ \\
\hline Omaha NPS (L) FB & 134 & 74 & 60 & - & 237,328 & 257,398 & - & 3,698 & 1,783 & & $-52 \%$ \\
\hline Denver CT & 370 & 185 & 185 & - & 596,625 & 790,875 & - & 3,750 & 9,172 & & $145 \%$ \\
\hline Denver (L) FB & 993 & 497 & 497 & - & $1,601,858$ & $2,123,393$ & - & 3,750 & 3,500 & & $-7 \%$ \\
\hline Lakewood (L) FB & 336 & 201 & 134 & - & 649,193 & 573,705 & - & 3,645 & 4,625 & & $27 \%$ \\
\hline Ogden (L) FB & 521 & 52 & 469 & - & 168,023 & $2,004,548$ & - & 4,170 & 5,071 & & $22 \%$ \\
\hline Fresno CT \& FB & 510 & 255 & 255 & - & 822,375 & $1,090,125$ & - & 3,750 & 11,790 & & $214 \%$ \\
\hline Las Vegas CT & 428 & 214 & 214 & - & 689,613 & 914,138 & - & 3,750 & 12,905 & & $244 \%$ \\
\hline San Francisco FB & 1444 & 578 & 867 & - & $1,863,272$ & $3,704,878$ & - & 3,855 & 2,868 & & $-26 \%$ \\
\hline Santa Ana FB & 459 & 229 & 229 & 0.71 & 738,986 & 979,586 & 21,429 & 3,791 & 4,832 & & $27 \%$ \\
\hline Auburn FB & 675 & 236 & 439 & - & 761,906 & $1,875,656$ & - & 3,908 & $\mathrm{~N} / \mathrm{A}$ & & $\mathrm{N} / \mathrm{A}$ \\
\hline Eugene CT & 170 & 68 & 102 & - & 219,300 & 436,050 & - & 3,855 & 6,335 & & $64 \%$ \\
\hline Seattle CT & 600 & 300 & 300 & - & 967,500 & $1,282,500$ & - & 3,750 & 4,393 & & $17 \%$ \\
\hline Rockville (L) FB & 760 & 266 & 494 & - & 857,850 & $2,111,850$ & - & 3,908 & 2,574 & & $-34 \%$ \\
\hline Suitland FB & 5425 & 1,628 & 3,798 & - & $5,248,688$ & $16,234,313$ & - & 3,960 & 7,550 & & $91 \%$ \\
\hline
\end{tabular}
The following table provides the baseline values for each of the buildings.

\section{Indoor Water Use Baseline Observations}

The Indices have not been updated since 1996. The last federal ruling on flow rates of water-consuming technologies was in the Energy Policy Act (EPAct) of 1992. As buildings update their faucets, toilets, urinals, and showerheads, it is conceivable that a savings of $50 \%$ could be achieved. When the Indices are updated, it is likely that the average use per occupant will decrease. Rather than updating the water baseline to an assumed use under 
the EPAct standard, the documented FEMP Water Use Indices baseline were used, which may represent a greater savings than current practice would offer.

\section{Outdoor Water Use}

Irrigation water use depends on the size of the irrigated area, as well as the climate and type of plants or turf being watered. A water-thirsty landscape (appropriate for climates with 40+ inches of annual precipitation) in a dry climate typically uses about 25 gallons of water per square foot per season. However, use of native and drought-tolerant plants can reduce irrigation needs to about 5 to 10 gallons per square foot per season. ${ }^{37}$

Only one of the buildings in the study had separately metered landscape irrigation (Denver FB). Many of the buildings had minimal landscaping. For those it was easy to dismiss landscape water use as minimal (see Jacksonville, FB, Ogden FB, Cleveland CT, Davenport CT, San Francisco FB, and Santa Ana FB). Other buildings have rainwater capture systems or bioswales that are used to store irrigation water (Knoxville FB, Omaha Department of Homeland Security FB, and Suitland FB), and Omaha National Park Service's FB, Youngstown CT \& FB, Rockville FB properties only has native trees, plants, and grasses that do not require any irrigation. However, several buildings had enough water-intensive landscaping that it was necessary to examine seasonal water use in order to estimate landscape irrigation use. A FEMP estimate of 20 percent of a building's water use being attributed to landscaping was applied to buildings with water-intensive landscaping. 


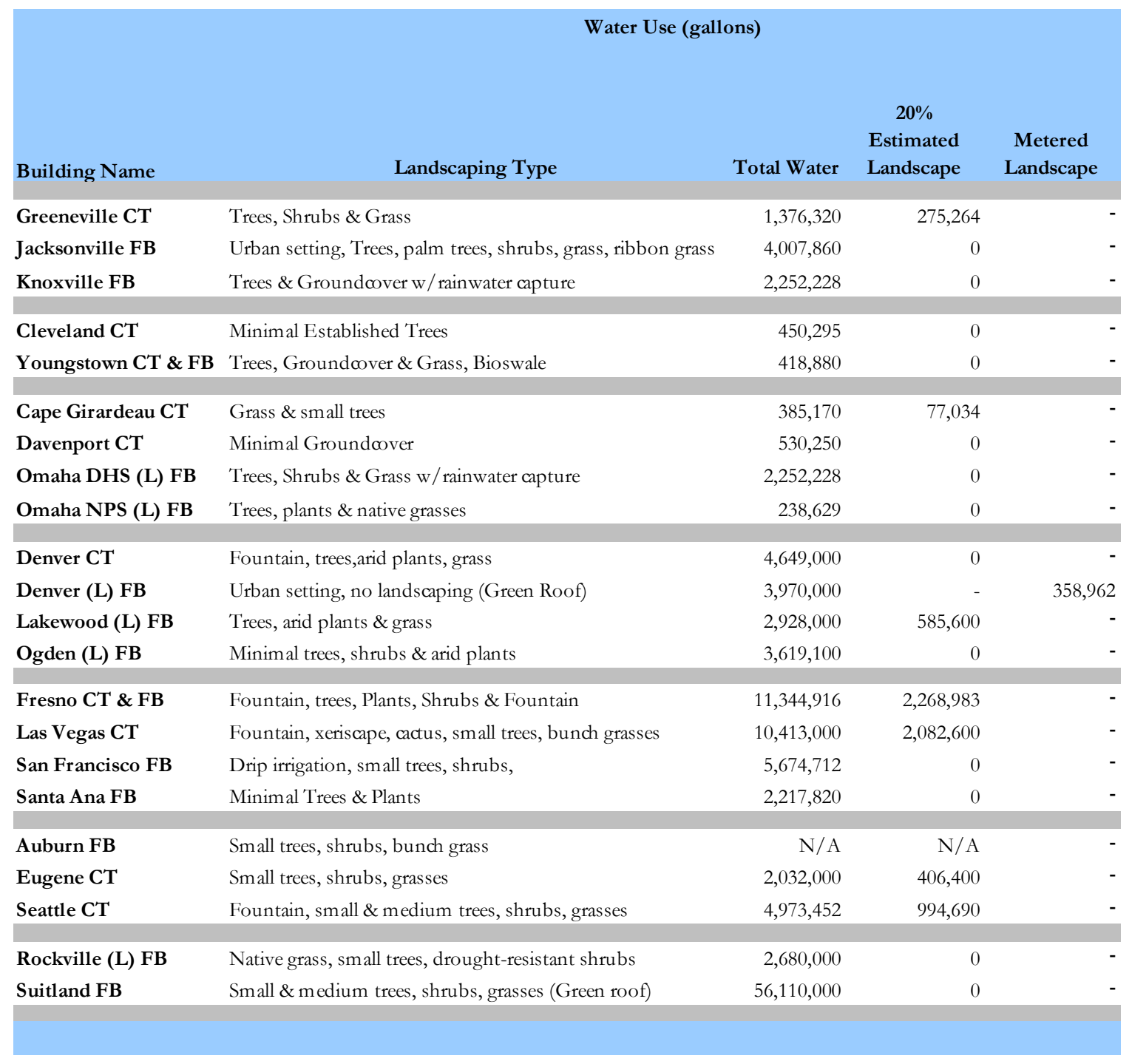


The summary of indoor and outdoor water uses is offered below.

\begin{tabular}{|c|c|c|c|c|c|}
\hline \multirow[b]{2}{*}{ Building Name } & \multicolumn{5}{|c|}{ Water Use (gallons) } \\
\hline & Water Consuming Equipment & Total Water & $\begin{array}{l}\text { Estimated } \\
\text { Landscape }\end{array}$ & $\begin{array}{c}\text { Estimated } \\
\text { Process }\end{array}$ & $\begin{array}{c}\text { Estimated } \\
\text { Domestic }\end{array}$ \\
\hline Greeneville CT & Cooling Towers & $1,376,320$ & 275,264 & 371,606 & 729,450 \\
\hline Jacksonville FB & Cooling Towers & $4,007,860$ & 0 & $1,082,122$ & $2,925,738$ \\
\hline Knoxville FB & Cooling Towers & $2,252,228$ & 0 & 608,102 & $1,644,126$ \\
\hline Cleveland CT & - & 450,295 & 0 & 0 & 450,295 \\
\hline Youngstown CT \& FB & - & 418,880 & 0 & 0 & 418,880 \\
\hline Cape Girardeau CT & Cooling Towers & 385,170 & 77,034 & 103,996 & 204,140 \\
\hline Davenport CT & Cooling Towers & 530,250 & 0 & 143,168 & 387,083 \\
\hline Omaha DHS (L) FB & - & $2,252,228$ & 0 & 0 & $2,252,228$ \\
\hline Omaha NPS (L) FB & - & 238,629 & 0 & 0 & 238,629 \\
\hline Denver CT & Evap Cooling & $4,649,000$ & 0 & $1,255,230$ & $3,393,770$ \\
\hline Denver (L) FB & Cooling Towers & $3,970,000$ & 358,962 & 134,100 & $3,476,938$ \\
\hline Lakewood (L) FB & Cooling Towers & $2,928,000$ & 585,600 & 790,560 & $1,551,840$ \\
\hline Ogden (L) FB & Evap Cooling & $3,619,100$ & 0 & 977,157 & $2,641,943$ \\
\hline Fresno CT \& FB & Cooling Towers & $11,344,916$ & $2,268,983$ & $3,063,127$ & $6,012,805$ \\
\hline Las Vegas CT & Cooling Towers & $10,413,000$ & $2,082,600$ & $2,811,510$ & $5,518,890$ \\
\hline San Francisco FB & Cooling Towers, Small Snack Bar & $5,674,712$ & 0 & $1,532,172$ & $4,142,540$ \\
\hline Santa Ana FB & - & $2,217,820$ & 0 & 0 & $2,217,820$ \\
\hline Auburn FB & - & $\mathrm{N} / \mathrm{A}$ & $\mathrm{N} / \mathrm{A}$ & $\mathrm{N} / \mathrm{A}$ & $\mathrm{N} / \mathrm{A}$ \\
\hline Eugene CT & Cooling Towers & $2,032,000$ & 406,400 & 548,640 & $1,076,960$ \\
\hline Seattle CT & Cooling Towers & $4,973,452$ & 994,690 & $1,342,832$ & $2,635,930$ \\
\hline Rockville (L) FB & Cooling Tower & $2,680,000$ & 0 & 723,600 & $1,956,400$ \\
\hline Suitland FB & Cooling Towers & $56,110,000$ & 0 & $15,149,700$ & $40,960,300$ \\
\hline
\end{tabular}

\section{Water \& Energy Use Profiles}

Monthly water and energy use were evaluated for seasonal trends. Seasonal energy use variations are observed at most of the buildings. The Energy Star Portfolio Manager accounts for annual weather patterns in the calculations of Energy Star scores. Seasonal water use can be observed for the Greenville CT, Jacksonville FB, Knoxville FB, Cape Girardeau CT, Davenport CT, Denver CT, Lakewood FB, Odgen FB, Fresno CT \& FB, Las Vegas CT, San Francisco, Eugene CT, Seattle CT, Rockville FB, and the Suitland FB. These buildings have evaporative cooling and/or cooling towers and/or landscaping that 
cause spikes in water use. The figures below show the water use by month for each building, with the summer months shaded gray.
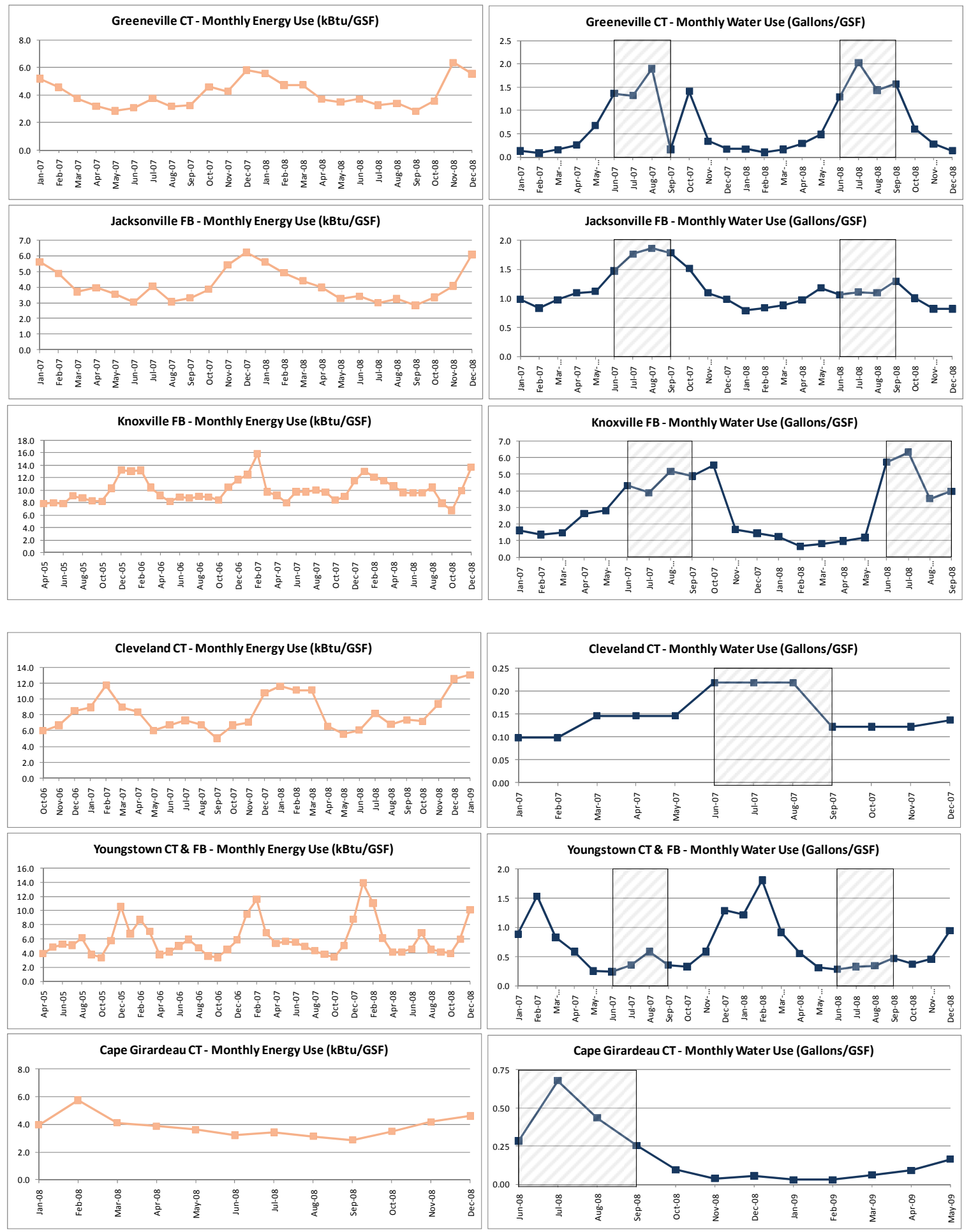

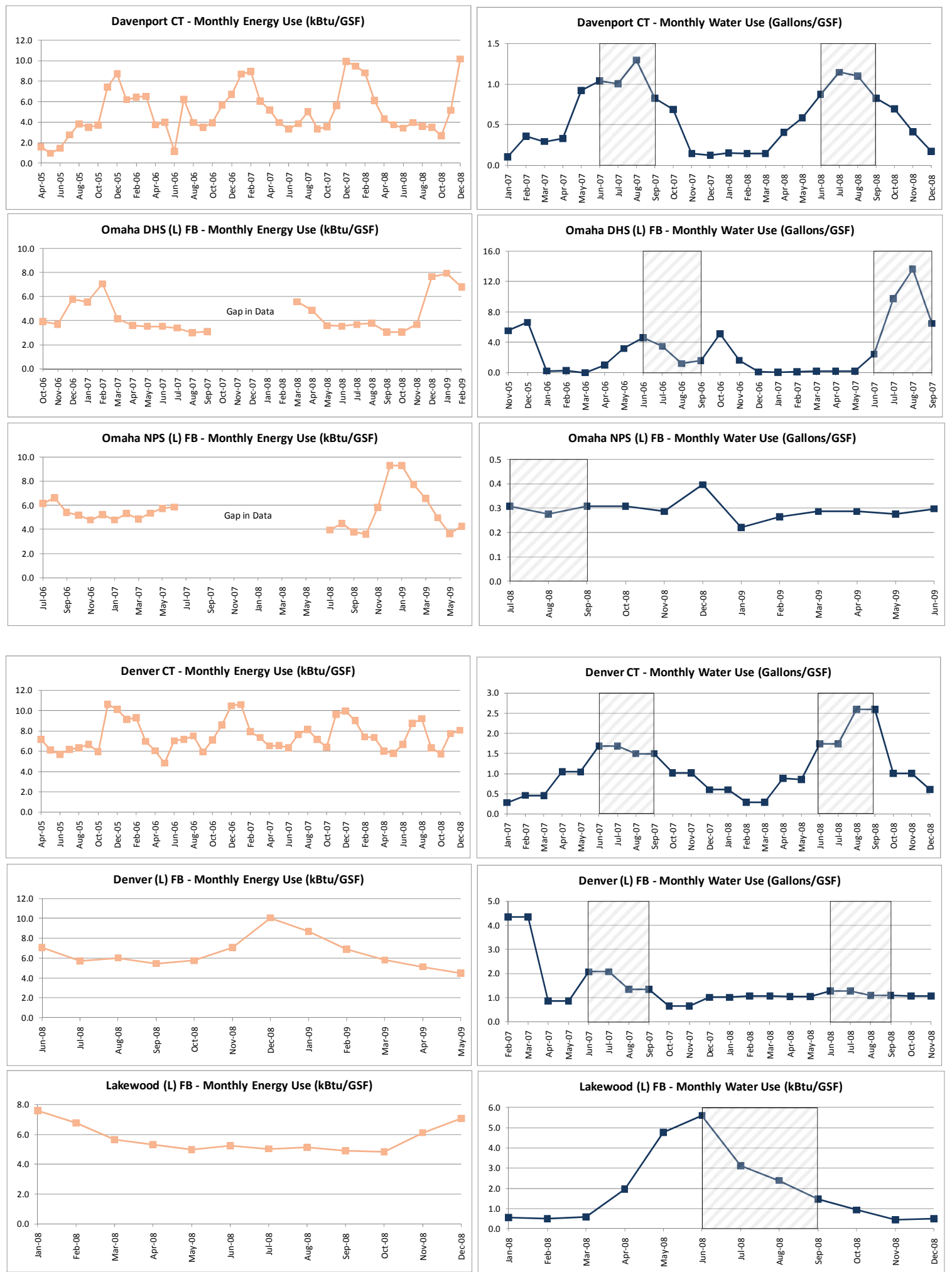

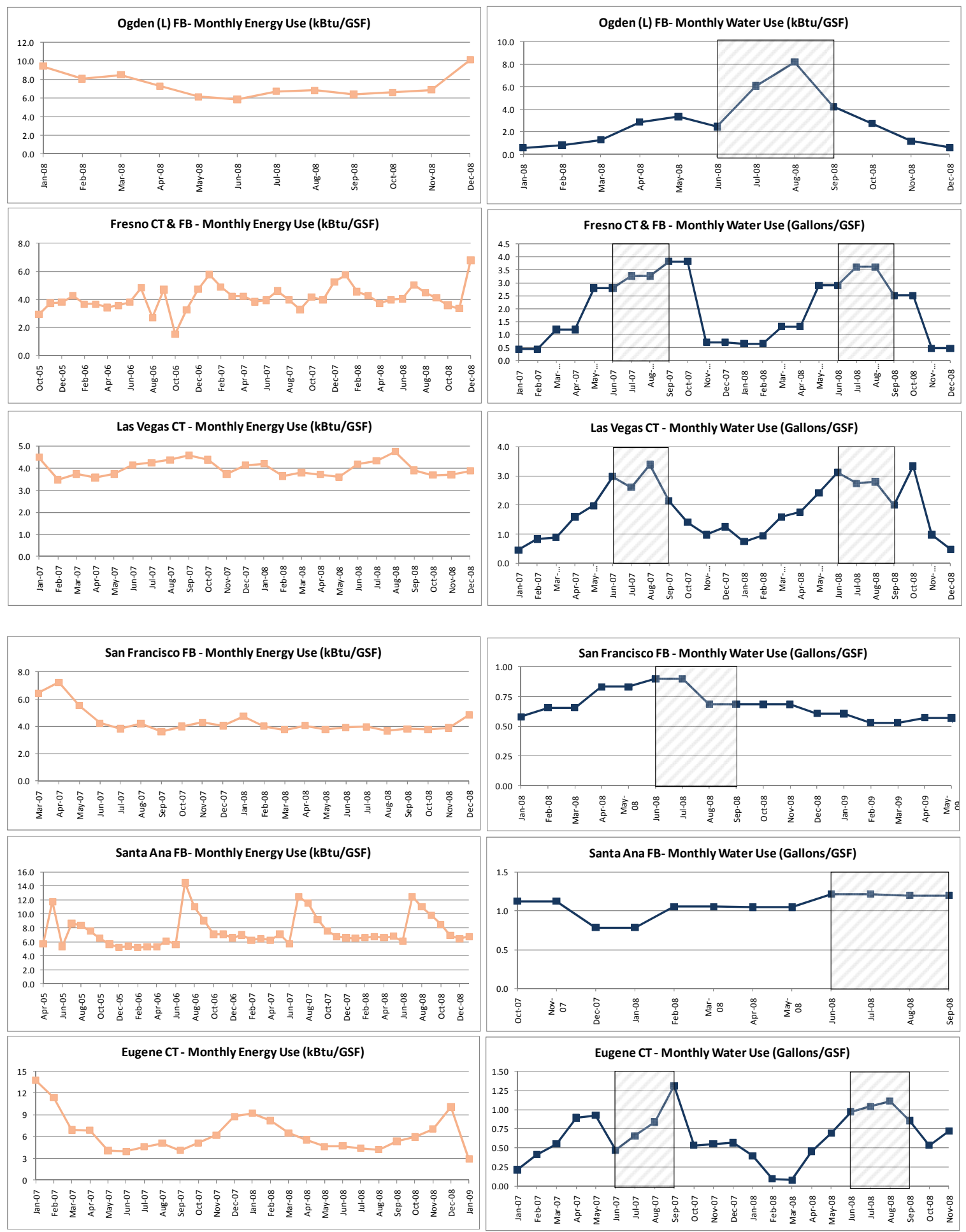

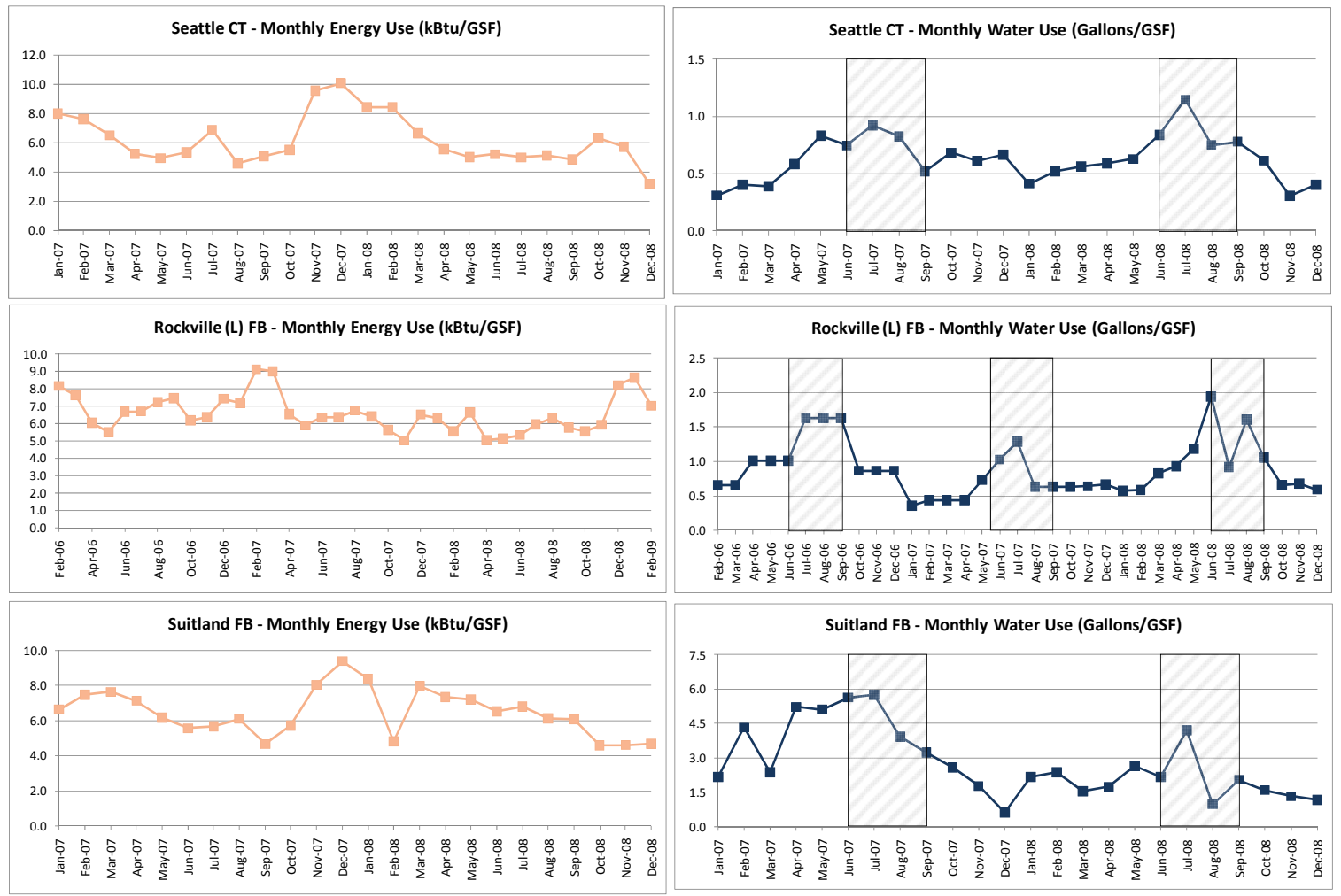


\section{Multiple Year Performance Analysis}

The graphs below compare energy and water consumption for consecutive years.

Maintenance costs can also change from year to year. For the buildings that provided two years of data, these variations are also shown below.

\section{Annual Water Consumption per GSF}

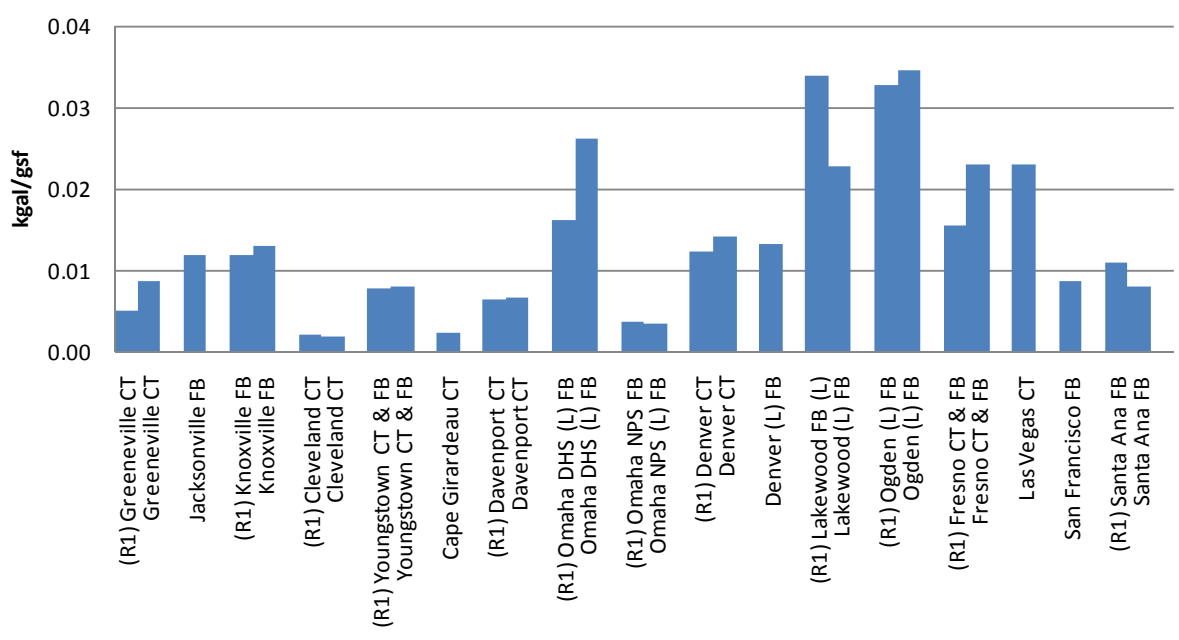

\section{Annual Water Cost per GSF}

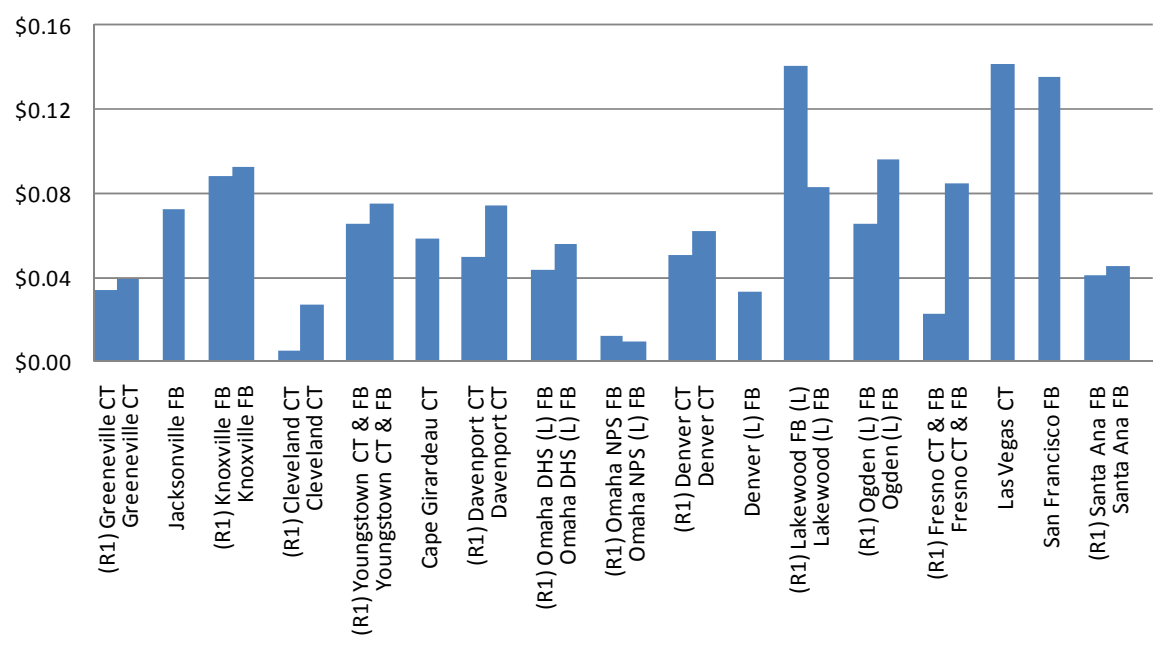




\section{Annual Energy Consumption (Kbtu/GSF)}

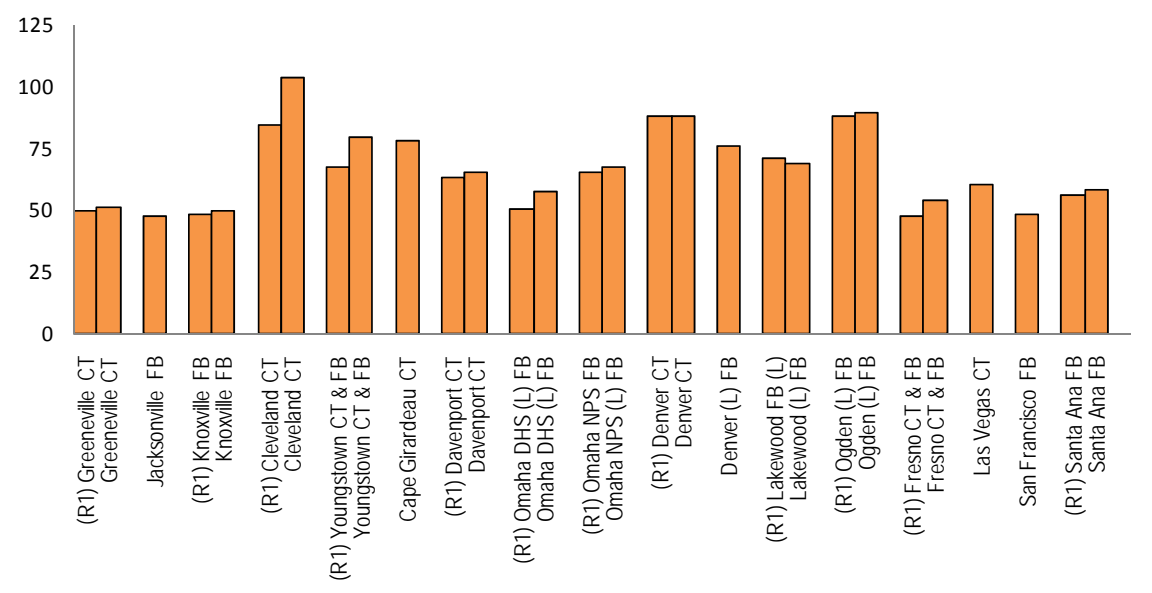

Annual Energy Star Scores

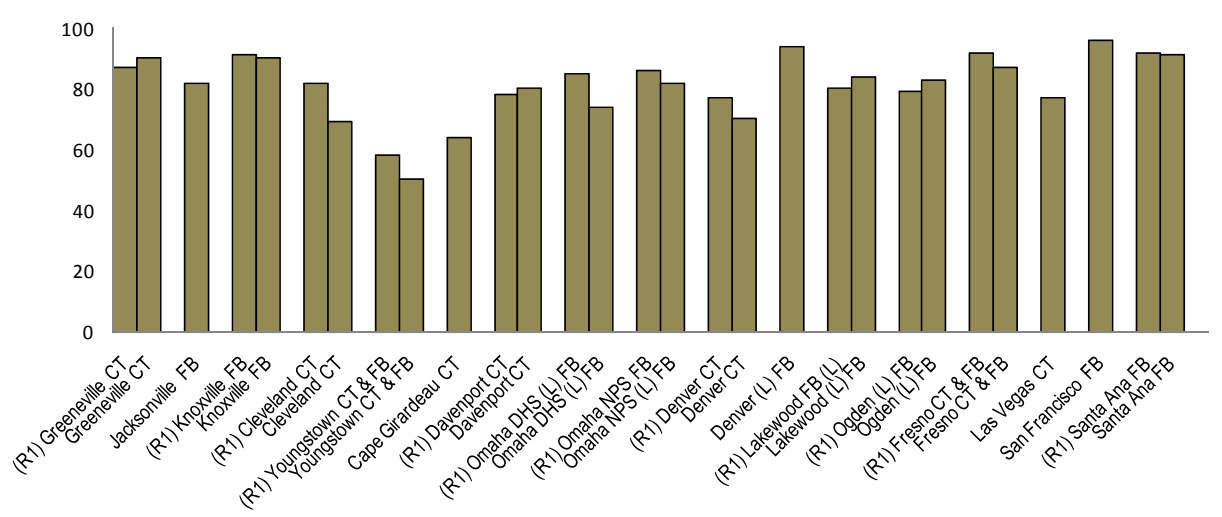

Annual Energy Cost per RSF

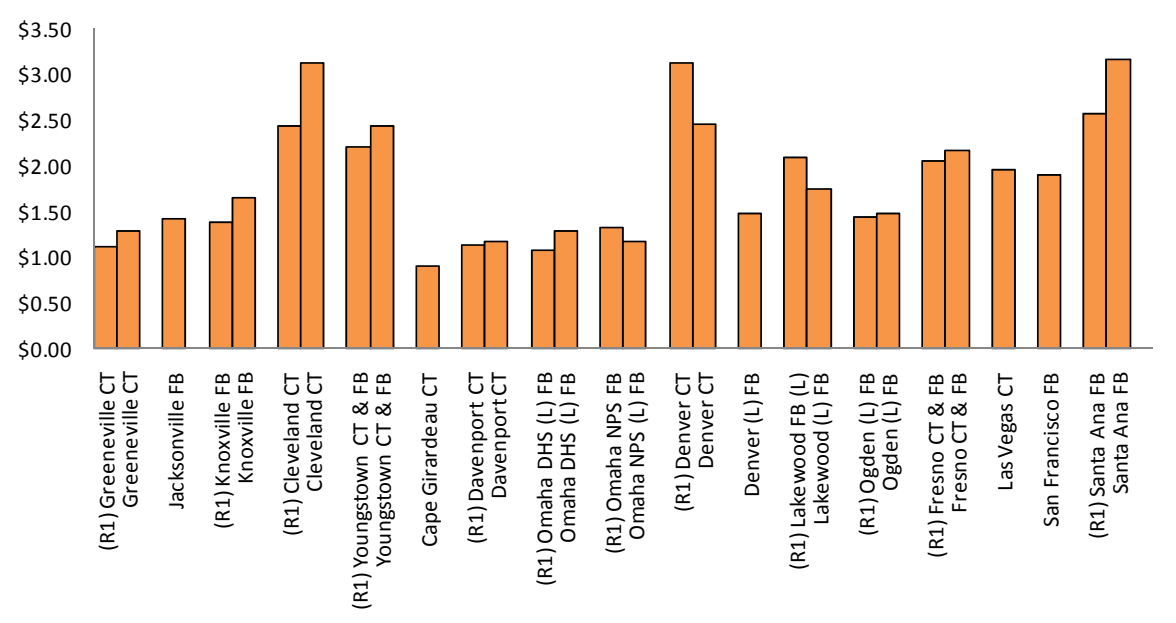




\section{General Maintenance - 2 Year Comparison}

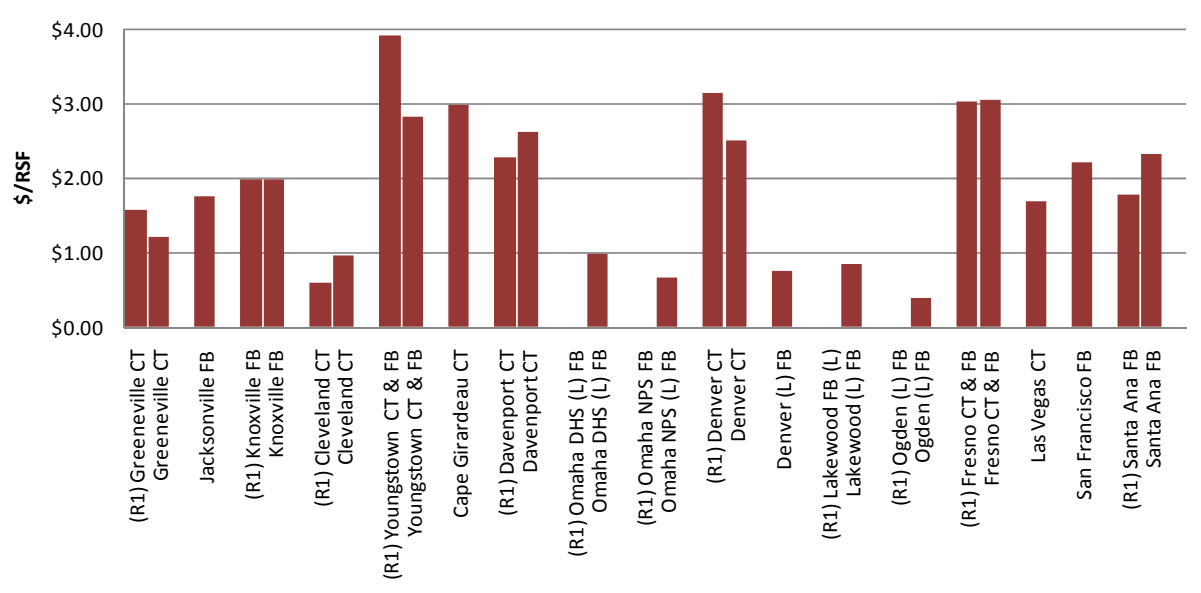

Janitorial Maintenance - 2 Year Comparison

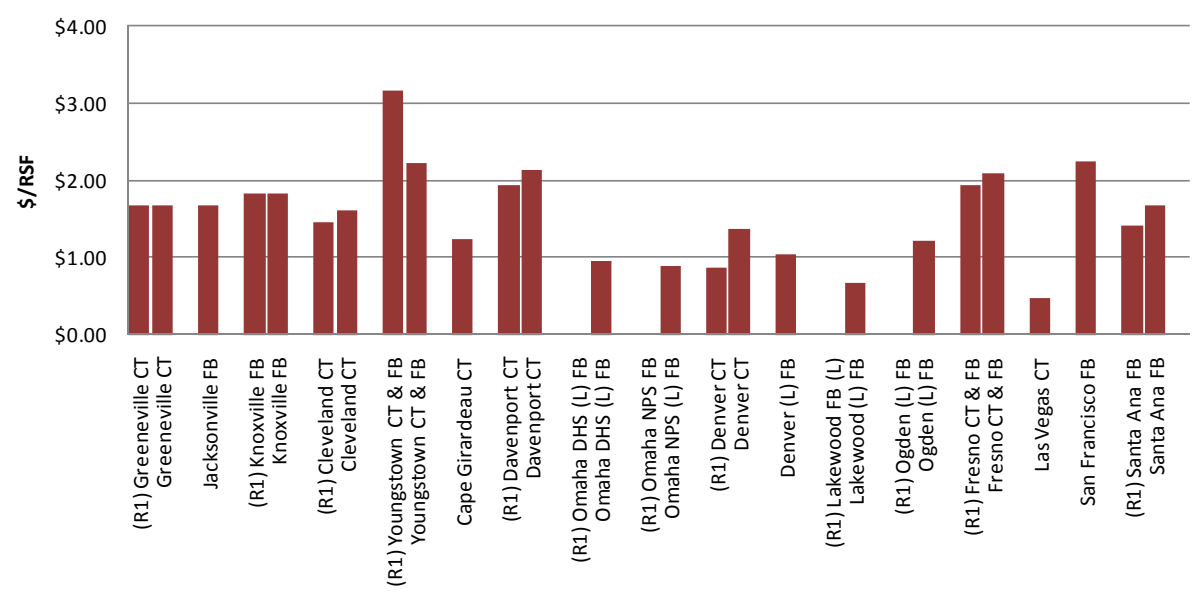

\section{Operations and Maintenance Baselines}

Comparable baselines were identified for each of the metrics. Where available, GSA, regional, and industry baselines are shown together. The following tables are summaries of the baselines used in the study. The first table includes the baselines that apply to all of the buildings, regardless of location, size, or number of occupants. The next includes baseline values that applied to specific GSA regions. The last shows building specific baselines that were calculated specifically for the building because of occupancy and/or location. 


\begin{tabular}{|c|c|c|c|}
\hline Metric & Value & Units & Source \\
\hline Water & $\begin{array}{c}15 \\
13 \\
0.19\end{array}$ & $\begin{array}{l}\mathrm{gal} / \mathrm{gsf} \\
\mathrm{gal} / \mathrm{gsf} \\
\$ / \mathrm{rsf}\end{array}$ & $\begin{array}{l}\text { IFMA \# } 32 \text { 50th Percentile ( } 2009 \text { pg 59) } \\
\text { GSA FY2015 Target } \\
\text { BOMA } 2008 \text { All Sector Total Building Rentable Area - Utility Water/Sewer }\end{array}$ \\
\hline Energy & $\begin{array}{c}2.53 \\
88\end{array}$ & $\begin{array}{c}\$ / \mathrm{rsf} \\
\mathrm{kBTU} / \mathrm{gsf}\end{array}$ & $\begin{array}{l}\text { BOMA } 2008 \text { All Sector Total Building Rentable Area - Utility (less water) } \\
\text { EIA CBECS Table C12 Office 1990-2003 }\end{array}$ \\
\hline $\begin{array}{l}\text { Maintenance - } \\
\text { Grounds } \\
\text { Maintenance - } \\
\text { Preventative } \\
\text { Maintenance - } \\
\text { Service }\end{array}$ & 0.45 & Ratio & $\begin{array}{l}\text { BOMA } 2008 \text { All Sector Total Building Rentable Area - Roads / Grounds } \\
\text { IFMA \#32 Facilities less than } 5 \text { years old ( } 2009 \text { pg. 47) } \\
\text { IFMA \#32 Facilities less than } 5 \text { years old ( } 2009 \text { pg. } 47 \text { ) }\end{array}$ \\
\hline $\begin{array}{l}\text { Waste } \\
\text { Recyding }\end{array}$ & $\begin{array}{l}0.05 \\
0.01\end{array}$ & $\begin{array}{l}\$ / \mathrm{rsf} \\
\$ / \mathrm{rsf}\end{array}$ & $\begin{array}{l}\text { IFMA \#25 (2004 pg. 27) } \\
\text { IFMA \#25 (2004 pg. 27) }\end{array}$ \\
\hline $\begin{array}{l}\text { Ocaupant } \\
\text { Satisfaction }\end{array}$ & $\begin{array}{l}1.13 \\
1.23\end{array}$ & & $\begin{array}{l}\text { CBE } 2009 \text { Survey Average Score - General Building Satisfaction } \\
\text { CBE } 2009 \text { Survey Average Score - LEED General Building Satisfaction }\end{array}$ \\
\hline Transportation & 2.3 & $\begin{array}{l}\text { MTCO2e/ } \\
\text { occ/year }\end{array}$ & EPA Climate Leaders Guidance (2008) and DOT Travel Survey (2001) \\
\hline
\end{tabular}

\begin{tabular}{|c|c|c|c|c|c|c|c|}
\hline \multirow[b]{6}{*}{ GSA Region } & \multicolumn{6}{|c|}{ Regional Baselines } & \\
\hline & \multicolumn{3}{|c|}{ Energy kBTU/gsf } & \multicolumn{4}{|c|}{ Maintenance \$/rsf } \\
\hline & GSA & GSA & & & Adapted & & Adapted \\
\hline & FY09 & FY09 & CBECS & GSA & BOMA & GSA & BOMA \\
\hline & Regional & Regional & Regional & General & General & Janitorial & Janitoria \\
\hline & EUI & Target & EUI & Maint & Maint & Maint & Maint \\
\hline 4 & 58 & 60 & 78 & $\$ 1.25$ & $\$ 1.23$ & $\$ 1.32$ & $\$ 1.25$ \\
\hline 5 & 84 & 86 & 113 & $\$ 1.23$ & $\$ 1.81$ & $\$ 1.91$ & $\$ 1.60$ \\
\hline 6 & 75 & 81 & 75 & $\$ 1.33$ & $\$ 1.60$ & $\$ 1.55$ & $\$ 1.39$ \\
\hline 8 & 89 & 92 & 81 & $\$ 1.79$ & $\$ 1.50$ & $\$ 1.33$ & $\$ 1.32$ \\
\hline 9 & 55 & 61 & 71 & $\$ 1.83$ & $\$ 2.15$ & $\$ 1.71$ & $\$ 1.98$ \\
\hline 10 & 63 & 64 & 71 & $\$ 1.37$ & $\$ 1.80$ & $\$ 1.34$ & $\$ 1.66$ \\
\hline 11 & 95 & 88 & 90 & $\$ 2.24$ & $\$ 2.23$ & $\$ 1.93$ & $\$ 2.12$ \\
\hline
\end{tabular}




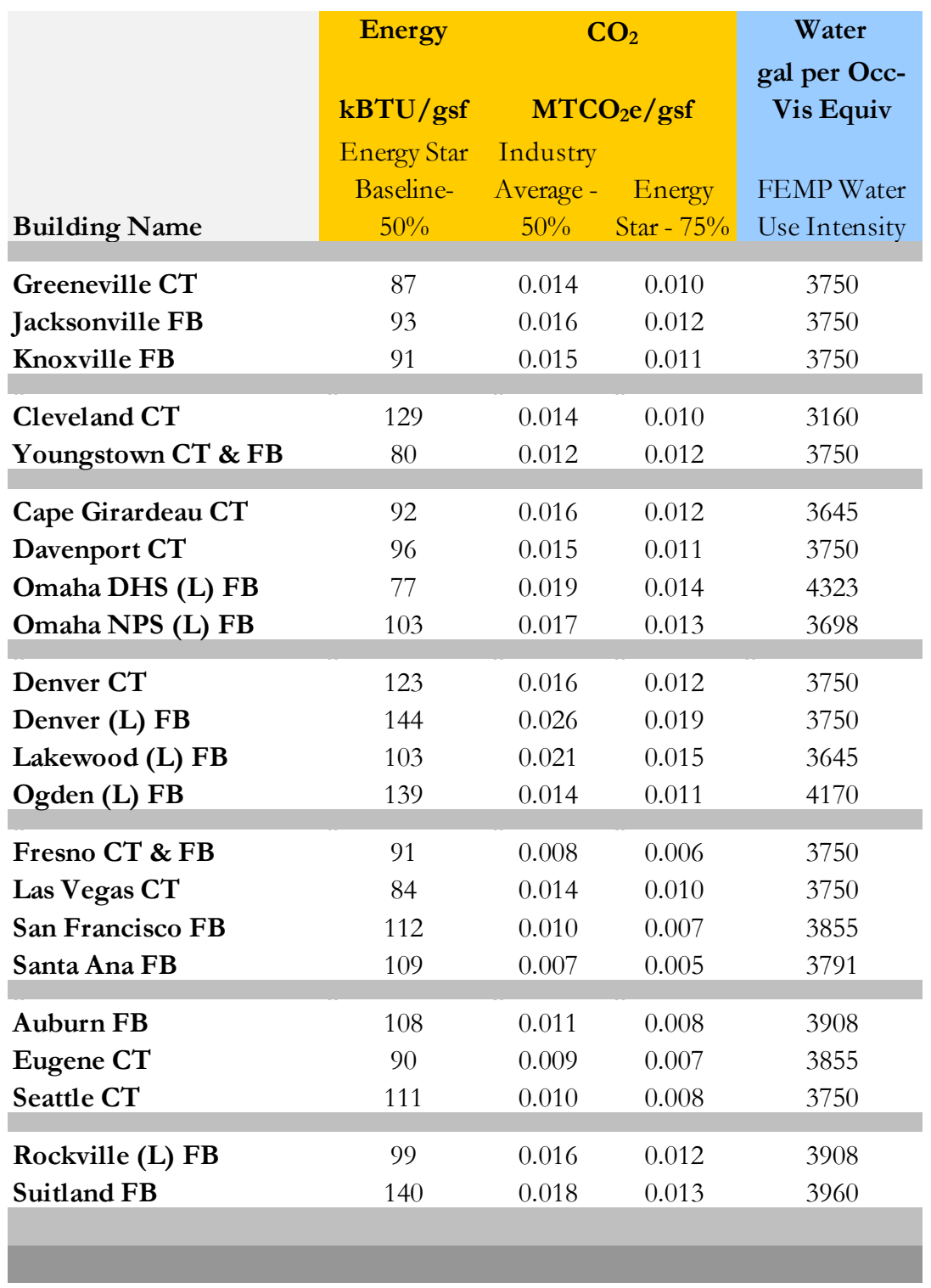




\section{Operational Costs Baselines}

Each of the baselines discussed above were applied to the buildings where a baseline cost was developed for every metric. The actual operational costs were compared and a building performance value was calculated. The following tables document these values.

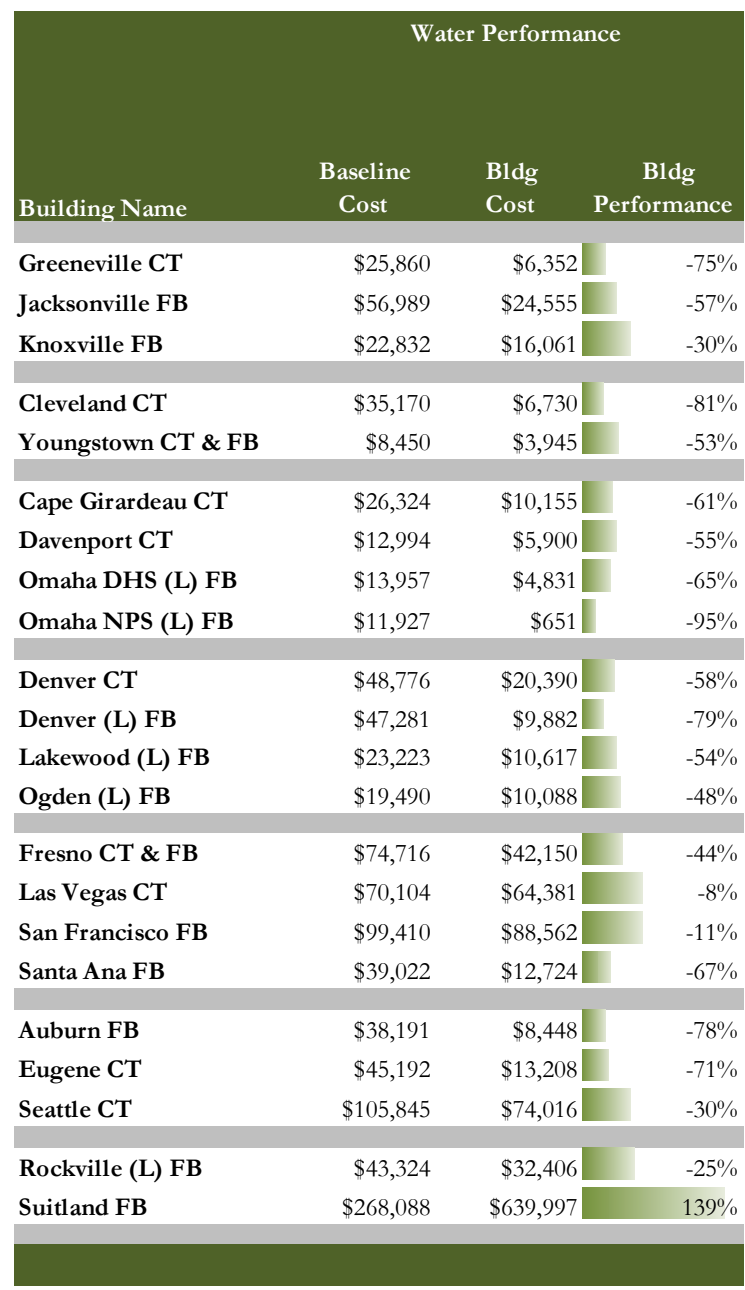

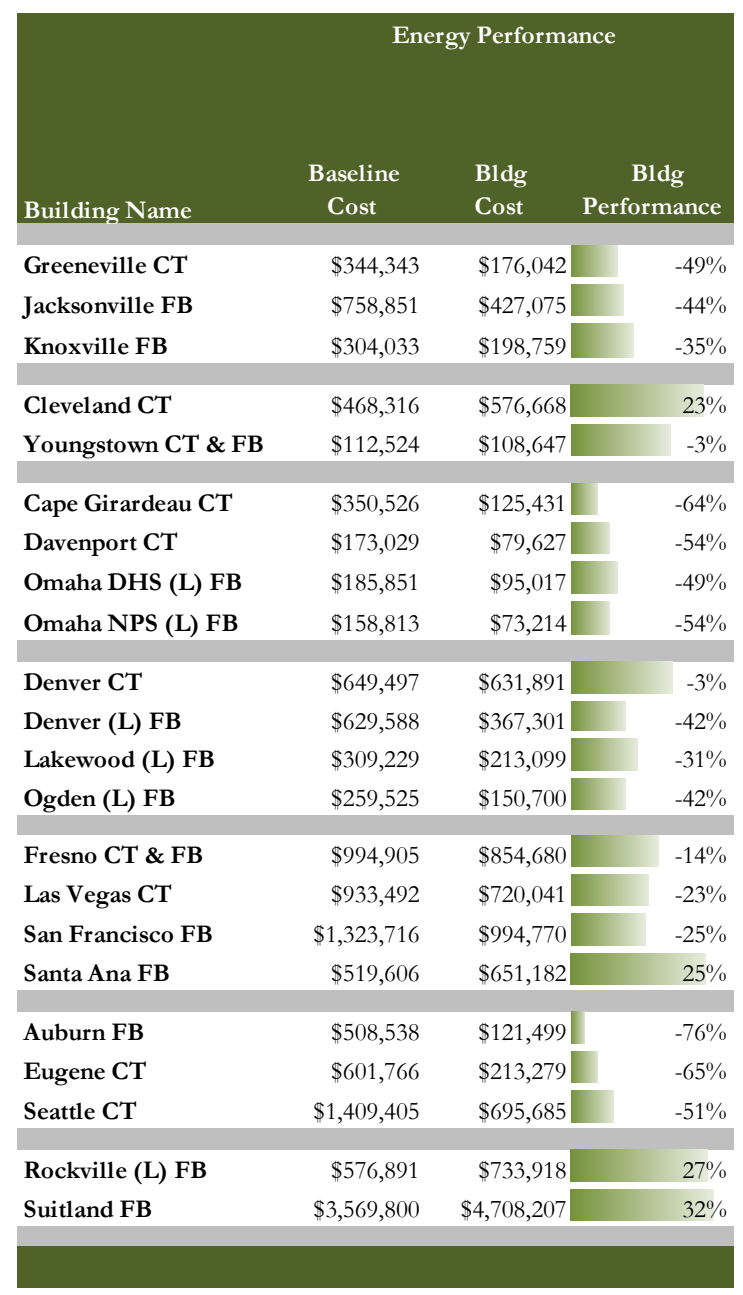




\begin{tabular}{|c|c|c|c|}
\hline \multirow[b]{2}{*}{ Building Name } & \multicolumn{3}{|c|}{ Maintenance Performance } \\
\hline & $\begin{array}{c}\text { Baseline } \\
\text { Cost }\end{array}$ & $\begin{array}{l}\text { Bldg } \\
\text { Cost }\end{array}$ & $\begin{array}{c}\text { Bldg } \\
\text { Performance }\end{array}$ \\
\hline Greeneville CT & $\$ 167,371$ & $\$ 163,419$ & $-2 \%$ \\
\hline Jacksonville FB & $\$ 368,845$ & $\$ 523,958$ & $42 \%$ \\
\hline Knoxville FB & $\$ 147,777$ & $\$ 237,836$ & $61 \%$ \\
\hline Cleveland CT & $\$ 334,683$ & $\$ 176,320$ & $-47 \%$ \\
\hline Youngstown CT \& FB & $\$ 80,416$ & $\$ 124,875$ & $55 \%$ \\
\hline Cape Girardeau CT & $\$ 222,089$ & $\$ 411,651$ & $85 \%$ \\
\hline Davenport CT & $\$ 109,629$ & $\$ 179,011$ & $63 \%$ \\
\hline Omaha DHS (L) FB & $\$ 117,753$ & $\$ 72,632$ & $-38 \%$ \\
\hline Omaha NPS (L) FB & $\$ 100,622$ & $\$ 41,600$ & $-59 \%$ \\
\hline Denver CT & $\$ 384,620$ & $\$ 643,227$ & $67 \%$ \\
\hline Denver (L) FB & $\$ 372,831$ & $\$ 184,607$ & $-50 \%$ \\
\hline Lakewood (L) FB & $\$ 183,120$ & $\$ 103,644$ & $-43 \%$ \\
\hline Ogden (L) FB & $\$ 153,686$ & $\$ 39,068$ & $-75 \%$ \\
\hline Fresno CT \& FB & $\$ 845,169$ & $\$ 1,194,365$ & $41 \%$ \\
\hline Las Vegas CT & $\$ 792,999$ & $\$ 616,845$ & $-22 \%$ \\
\hline San Francisco FB & $\$ 1,124,494$ & $\$ 1,152,725$ & $3 \%$ \\
\hline Santa Ana FB & $\$ 441,404$ & $\$ 478,557$ & $8 \%$ \\
\hline Auburn FB & $\$ 361,591$ & $\$ 233,367$ & $-35 \%$ \\
\hline Eugene CT & $\$ 427,880$ & $\$ 381,904$ & $-11 \%$ \\
\hline Seattle CT & $\$ 1,002,144$ & $\$ 597,755$ & $-40 \%$ \\
\hline Rockville (L) FB & $\$ 507,815$ & $\$ 370,782$ & $-27 \%$ \\
\hline Suitland FB & $\$ 3,142,358$ & $\$ 2,730,589$ & $-13 \%$ \\
\hline
\end{tabular}

\begin{tabular}{|c|c|c|c|}
\hline \multirow[b]{2}{*}{ Building Name } & \multicolumn{3}{|c|}{ Janitorial Performance } \\
\hline & $\begin{array}{c}\text { Baseline } \\
\text { Cost }\end{array}$ & $\begin{array}{l}\text { Bldg } \\
\text { Cost }\end{array}$ & $\begin{array}{c}\text { Bldg } \\
\text { Performance }\end{array}$ \\
\hline Greeneville CT & $\$ 170,704$ & $\$ 227,517$ & $33 \%$ \\
\hline Jacksonville FB & $\$ 376,192$ & $\$ 499,906$ & $33 \%$ \\
\hline Knoxville FB & $\$ 150,721$ & $\$ 220,948$ & $47 \%$ \\
\hline Cleveland CT & $\$ 296,271$ & $\$ 297,728$ & $0 \%$ \\
\hline Youngstown CT \& FB & $\$ 71,186$ & $\$ 99,267$ & $39 \%$ \\
\hline Cape Girardeau CT & $\$ 192,595$ & $\$ 172,282$ & $-11 \%$ \\
\hline Davenport CT & $\$ 95,070$ & $\$ 145,990$ & $54 \%$ \\
\hline Omaha DHS (L) FB & $\$ 102,115$ & $\$ 70,800$ & $-31 \%$ \\
\hline Omaha NPS (L) FB & $\$ 87,259$ & $\$ 56,400$ & $-35 \%$ \\
\hline Denver CT & $\$ 339,981$ & $\$ 349,560$ & $3 \%$ \\
\hline Denver (L) FB & $\$ 329,560$ & $\$ 258,120$ & $-22 \%$ \\
\hline Lakewood (L) FB & $\$ 161,867$ & $\$ 83,220$ & $-49 \%$ \\
\hline Ogden (L) FB & $\$ 135,849$ & $\$ 125,892$ & $-7 \%$ \\
\hline Fresno CT \& FB & $\$ 777,618$ & $\$ 821,414$ & $6 \%$ \\
\hline Las Vegas CT & $\$ 729,617$ & $\$ 174,441$ & $-76 \%$ \\
\hline San Francisco FB & $\$ 1,034,617$ & $\$ 1,169,249$ & $13 \%$ \\
\hline Santa Ana FB & $\$ 406,124$ & $\$ 345,401$ & $-15 \%$ \\
\hline Auburn FB & $\$ 334,139$ & $\$ 370,864$ & $11 \%$ \\
\hline Eugene CT & $\$ 395,396$ & $\$ 339,996$ & $-14 \%$ \\
\hline Seattle CT & $\$ 926,063$ & $\$ 1,016,574$ & $10 \%$ \\
\hline Rockville (L) FB & $\$ 484,222$ & $\$ 301,832$ & $-38 \%$ \\
\hline Suitland FB & $\$ 2,996,366$ & $\$ 3,213,210$ & $7 \%$ \\
\hline
\end{tabular}




\begin{tabular}{|c|c|c|c|}
\hline \multirow[b]{2}{*}{ Building Name } & \multicolumn{3}{|c|}{ Grounds Performance } \\
\hline & $\begin{array}{c}\text { Baseline } \\
\text { Cost }\end{array}$ & $\begin{array}{l}\text { Bldg } \\
\text { Cost }\end{array}$ & $\begin{array}{c}\text { Bldg } \\
\text { Performance }\end{array}$ \\
\hline Greeneville CT & $\$ 61,247$ & $\$ 4,000$ & $-93 \%$ \\
\hline Jacksonville FB & $\$ 134,973$ & $\$ 2,148$ & $-98 \%$ \\
\hline Knoxville FB & $\$ 54,077$ & $\$ 5,300$ & $-90 \%$ \\
\hline Cleveland CT & $\$ 83,297$ & $\$ 3,100$ & $-96 \%$ \\
\hline Youngstown CT \& FB & $\$ 20,014$ & $\$ 37,300$ & $86 \%$ \\
\hline Cape Girardeau CT & $\$ 62,347$ & $\$ 11,318$ & $-82 \%$ \\
\hline Davenport CT & $\$ 30,776$ & $\$ 6,421$ & $-79 \%$ \\
\hline Omaha DHS (L) FB & $\$ 33,057$ & $\$ 8,200$ & $-75 \%$ \\
\hline Omaha NPS (L) FB & $\$ 28,247$ & $\$ 9,050$ & $-68 \%$ \\
\hline Denver CT & $\$ 115,523$ & $\$ 29,791$ & $-74 \%$ \\
\hline Denver (L) FB & $\$ 111,982$ & $\$ 16,833$ & $-85 \%$ \\
\hline Lakewood (L) FB & $\$ 55,001$ & $\$ 7,394$ & $-87 \%$ \\
\hline Ogden (L) FB & $\$ 46,161$ & $\$ 3,584$ & $-92 \%$ \\
\hline Fresno CT \& FB & $\$ 176,959$ & $\$ 24,236$ & $-86 \%$ \\
\hline Las Vegas CT & $\$ 166,036$ & $\$ 126,328$ & $-24 \%$ \\
\hline San Francisco FB & $\$ 235,444$ & $\$ 25,000$ & $-89 \%$ \\
\hline Santa Ana FB & $\$ 92,420$ & $\$ 15,018$ & $-84 \%$ \\
\hline Auburn FB & $\$ 90,451$ & $\$ 22,497$ & $-75 \%$ \\
\hline Eugene CT & $\$ 107,033$ & $\$ 51,808$ & $-52 \%$ \\
\hline Seattle CT & $\$ 250,685$ & $\$ 29,635$ & $-88 \%$ \\
\hline Rockville (L) FB & $\$ 102,609$ & $\$ 91,858$ & $-10 \%$ \\
\hline Suitland FB & $\$ 634,945$ & $\$ 149,239$ & $-76 \%$ \\
\hline
\end{tabular}

\begin{tabular}{|c|c|c|c|}
\hline \multirow[b]{2}{*}{ Building Name } & \multicolumn{3}{|c|}{ Waste Performance } \\
\hline & $\begin{array}{c}\text { Baseline } \\
\text { Cost }\end{array}$ & $\begin{array}{l}\text { Bldg } \\
\text { Cost }\end{array}$ & $\begin{array}{c}\text { Bldg } \\
\text { Performance }\end{array}$ \\
\hline Greeneville CT & $\$ 10,815$ & $\$ 900$ & $-92 \%$ \\
\hline Jacksonville FB & $\$ 0$ & $\mathrm{~N} / \mathrm{A}$ & $0 \%$ \\
\hline Knoxville FB & $\$ 32,576$ & $\$ 4,380$ & $-87 \%$ \\
\hline Cleveland CT & $\$ 14,963$ & $\$ 3,067$ & $-80 \%$ \\
\hline Youngstown CT \& FB & $\$ 25,463$ & $\$ 1,530$ & $-94 \%$ \\
\hline Cape Girardeau CT & $\$ 10,500$ & $\$ 325$ & $-97 \%$ \\
\hline Davenport CT & $\$ 6,615$ & $\$ 907$ & $-86 \%$ \\
\hline Omaha DHS (L) FB & $\$ 37,800$ & $\$ 2,400$ & $-94 \%$ \\
\hline Omaha NPS (L) FB & $\$ 14,049$ & $\$ 1,500$ & $-89 \%$ \\
\hline Denver CT & $\$ 0$ & $\mathrm{~N} / \mathrm{A}$ & $0 \%$ \\
\hline Denver (L) FB & $\$ 104,307$ & $\$ 15,862$ & $-85 \%$ \\
\hline Lakewood (L) FB & $\$ 35,228$ & $\$ 3,600$ & $-90 \%$ \\
\hline Ogden (L) FB & $\$ 54,705$ & $\$ 3,940$ & $-93 \%$ \\
\hline Fresno CT \& FB & $\$ 53,550$ & $\$ 24,236$ & $-55 \%$ \\
\hline Las Vegas CT & $\$ 44,905$ & $\$ 25,266$ & $-44 \%$ \\
\hline San Francisco FB & $\$ 151,662$ & $\$ 31,970$ & $-79 \%$ \\
\hline Santa Ana FB & $\$ 48,195$ & $\$ 18,360$ & $-62 \%$ \\
\hline Auburn FB & $\$ 70,875$ & $\$ 2,184$ & $-97 \%$ \\
\hline Eugene CT & $\$ 17,850$ & Induded & $0 \%$ \\
\hline Seattle CT & $\$ 63,000$ & Induded & $0 \%$ \\
\hline Rockville (L) FB & $\$ 79,800$ & $\$ 22,056$ & $-72 \%$ \\
\hline Suitland FB & $\$ 569,625$ & $\$ 107,871$ & $-81 \%$ \\
\hline
\end{tabular}




\begin{tabular}{|c|c|c|c|}
\hline \multirow[b]{2}{*}{ Building Name } & \multicolumn{3}{|c|}{ Recycle Performance } \\
\hline & $\begin{array}{c}\text { Baseline } \\
\text { Cost }\end{array}$ & $\begin{array}{l}\text { Bldg } \\
\text { Cost }\end{array}$ & $\begin{array}{c}\text { Bldg } \\
\text { Performance }\end{array}$ \\
\hline Greeneville CT & $\$ 2,884$ & $-\$ 71$ & $-102 \%$ \\
\hline Jacksonville FB & $\$ 0$ & $\mathrm{~N} / \mathrm{A}$ & $0 \%$ \\
\hline Knoxville FB & $\$ 0$ & $\mathrm{~N} / \mathrm{A}$ & $0 \%$ \\
\hline Cleveland CT & $\$ 3,990$ & $-\$ 101$ & $-103 \%$ \\
\hline Youngstown CT \& FB & $\$ 6,790$ & $\$ 0$ & $-100 \%$ \\
\hline Cape Girardeau CT & $\$ 2,800$ & $\$ 144$ & $-95 \%$ \\
\hline Davenport CT & $\$ 1,764$ & $\$ 0$ & $-100 \%$ \\
\hline Omaha DHS (L) FB & $\$ 10,080$ & $\$ 0$ & $-100 \%$ \\
\hline Omaha NPS (L) FB & $\$ 3,746$ & $\$ 1,020$ & $-73 \%$ \\
\hline Denver CT & $\$ 0$ & $\mathrm{~N} / \mathrm{A}$ & $0 \%$ \\
\hline Denver (L) FB & $\$ 27,815$ & $\$ 3,228$ & $-88 \%$ \\
\hline Lakewood (L) FB & $\$ 9,394$ & $\$ 0$ & $-100 \%$ \\
\hline Ogden (L) FB & $\$ 14,588$ & $\$ 16,081$ & $10 \%$ \\
\hline Fresno CT \& FB & $\$ 14,280$ & $\$ 0$ & $-100 \%$ \\
\hline Las Vegas CT & $\$ 11,975$ & $\$ 0$ & $-100 \%$ \\
\hline San Francisco FB & $\$ 40,443$ & $-\$ 880$ & $-102 \%$ \\
\hline Santa Ana FB & $\$ 12,852$ & $\$ 1,600$ & $-88 \%$ \\
\hline Auburn FB & $\$ 0$ & $\mathrm{~N} / \mathrm{A}$ & $0 \%$ \\
\hline Eugene CT & $\$ 0$ & $\mathrm{~N} / \mathrm{A}$ & $0 \%$ \\
\hline Seattle CT & $\$ 16,800$ & $-\$ 533$ & $-103 \%$ \\
\hline Rockville (L) FB & $\$ 21,280$ & Induded & $0 \%$ \\
\hline Suitland FB & $\$ 151,900$ & $-\$ 2,480$ & $-102 \%$ \\
\hline
\end{tabular}

\begin{tabular}{|c|c|c|c|}
\hline \multirow[b]{2}{*}{ Building Name } & \multicolumn{3}{|c|}{ Aggregate Operational Performance } \\
\hline & $\begin{array}{c}\text { Baseline } \\
\text { Cost }\end{array}$ & $\begin{array}{l}\text { Bldg } \\
\text { Cost }\end{array}$ & $\begin{array}{c}\text { Bldg } \\
\text { Performance }\end{array}$ \\
\hline Greeneville CT & $\$ 783,224$ & $\$ 578,159$ & $-26 \%$ \\
\hline Jacksonville FB & $\$ 1,695,850$ & $\$ 1,477,642$ & $-13 \%$ \\
\hline Knoxville FB & $\$ 712,017$ & $\$ 683,284$ & $-4 \%$ \\
\hline Cleveland CT & $\$ 1,236,689$ & $\$ 1,063,512$ & $-14 \%$ \\
\hline Youngstown CT \& FB & $\$ 324,844$ & $\$ 375,564$ & $16 \%$ \\
\hline Cape Girardeau CT & $\$ 867,182$ & $\$ 731,306$ & $-16 \%$ \\
\hline Davenport CT & $\$ 429,878$ & $\$ 417,855$ & $-3 \%$ \\
\hline Omaha DHS (L) FB & $\$ 500,613$ & $\$ 253,880$ & $-49 \%$ \\
\hline Omaha NPS (L) FB & $\$ 404,664$ & $\$ 183,435$ & $-55 \%$ \\
\hline Denver CT & $\$ 1,538,397$ & $\$ 1,674,860$ & $9 \%$ \\
\hline Denver (L) FB & $\$ 1,623,364$ & $\$ 855,833$ & $-47 \%$ \\
\hline Lakewood (L) FB & $\$ 777,062$ & $\$ 421,574$ & $-46 \%$ \\
\hline Ogden (L) FB & $\$ 684,003$ & $\$ 349,351$ & $-49 \%$ \\
\hline Fresno CT \& FB & $\$ 2,937,198$ & $\$ 2,961,081$ & $1 \%$ \\
\hline Las Vegas CT & $\$ 2,749,128$ & $\$ 1,727,301$ & $-37 \%$ \\
\hline San Francisco FB & $\$ 4,009,785$ & $\$ 3,461,396$ & $-14 \%$ \\
\hline Santa Ana FB & $\$ 1,559,624$ & $\$ 1,522,842$ & $-2 \%$ \\
\hline Auburn FB & $\$ 1,403,785$ & $\$ 758,859$ & $-46 \%$ \\
\hline Eugene CT & $\$ 1,595,116$ & $\$ 1,000,195$ & $-37 \%$ \\
\hline Seattle CT & $\$ 3,773,941$ & $\$ 2,413,133$ & $-36 \%$ \\
\hline Rockville (L) FB & $\$ 1,815,940$ & $\$ 1,552,852$ & $-14 \%$ \\
\hline Suitland FB & $\$ 11,333,081$ & $\$ 11,546,632$ & $2 \%$ \\
\hline
\end{tabular}




\section{Appendix E: Occupant Satisfaction Key Survey Questions}

This appendix includes the key questions included in the GSA adaptation of the CBE survey, which was named the Sustainable Places and Organizational Trends "SPOT" survey and the GSA Customer Satisfaction survey questions.

\section{SPOT Survey}

\section{Part 1 - Background Information}

1. How would you describe the work you do?

2. Which organization do you work for?

3. How many years have you worked in this building?

4. How long have you been working at your present workspace?

\section{Part 2 - Commute}

1. On average, how many days per week do you travel to the office (i.e., commute)?

2. How far is your typical daily commute to and from this building? Miles Roundtrip

3. Please indicate the number of days per week you commute to and from this building for each mode of transportation that applies.

\begin{tabular}{|c|c|}
\hline \multirow{5}{*}{$\begin{array}{l}\text { Walk } \\
\text { Car, truck or } \\
\text { van - single } \\
\text { occupant } \\
\text { Bus }\end{array}$} & Bicycle \\
\hline & Car, truck or van - multiple \\
\hline & occupants (e.g. carpool, \\
\hline & vanpool or rideshare) \\
\hline & Train (including light rail) \\
\hline $\begin{array}{l}\text { Combination } \\
\text { ride share loc }\end{array}$ & $\begin{array}{l}\text { ultiple modes (e.g., driving to } \\
\text { is then taking mass transit) }\end{array}$ \\
\hline Other & \\
\hline
\end{tabular}

4. Please describe any other issues related to your commute to and from this building that are important to you; and/or provide additional detail on your modes of transportation as you see fit.

\section{Part 3 - Personal Workspace Location}

1. On which floor is your workspace located?

2. In which area of the building is your workspace located?

3. Are you near an exterior wall (within 15 feet)?

4. Are you near a window (within 15 feet)?

5. Describe your personal workspace. 


\section{Part 4 - Your Workstation}

In this section, please note your level of satisfaction with features and attributes of your workstation.

If any of these aspects are not important to you, please indicate so instead of answering with a level of satisfaction.

1. How satisfied are you with the comfort of your office furnishings (chair, desk, computer, equipment, etc.)? This is not important to me

\section{VERY SATISFIED RERY DISSATISHIED}

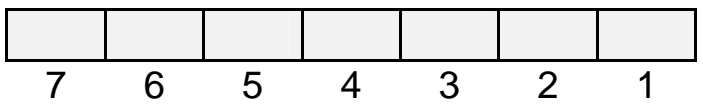

2. How satisfied are you with your ability to adjust your furniture to meet your needs?

This is not important to me

VERY SATISFIED

VERY DISSATISFHED

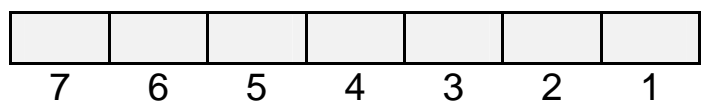

3. How satisfied are you with the colors and textures of flooring, furniture, and surface finishes?

This is not important to me

VERY SATISFIED

VERY DISSATISFIED

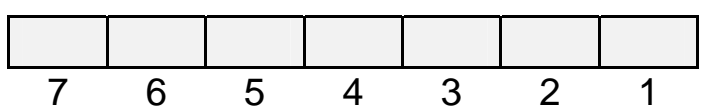

4. How satisfied are you with the amount of space available for individual work?

This is not important to me

VERY SATISEIED

VERY DISSATISEIED

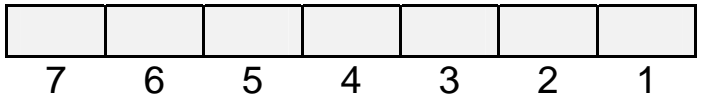


5. How satisfied are you with the level of visual privacy in your workspace?

This is not important to me

VERY SATISFIED

VERY DISSATISFIED

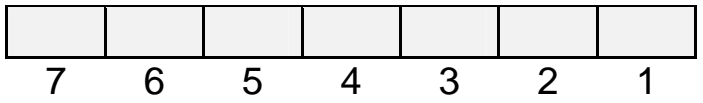

6. Please describe any other issues related to your personal workspace that are of importance to you.

\section{Part 5 - Communication}

1. How satisfied are you with your ability to communicate with co-workers in person (face to face)?

This is not important to me

VERY SATISFIED

VERY DISSATISFIED

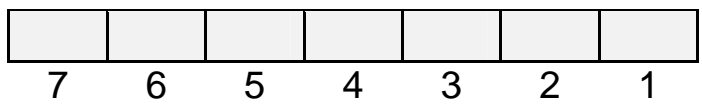

2. How satisfied are you with the ease of interaction with co-workers?

This is not important to me

VERY SATISFIED

VERY DISSATISFIED

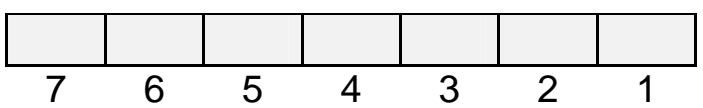

3. How satisfied are you with your ability to communicate in privacy?

This is not important to me

VERY SATISFIED

VERY DISSATISFIED

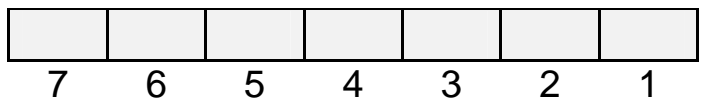


4. How satisfied are you with the availability of space where you and your colleagues can talk into a speaker phone together?

This is not important to me

\section{VERY SATISFIED VERY DISSATISHED}

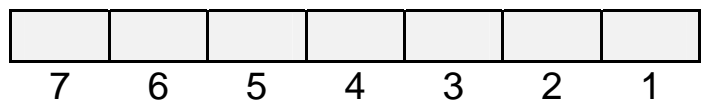

5. Please describe any other issues related to communication with others that are important to you.

\section{Part 6 - Meeting Facilities}

1. How satisfied are you with the availability of meeting rooms on short notice?

This is not important to me

VERY SATISFIED

VERY DISSATISEIED

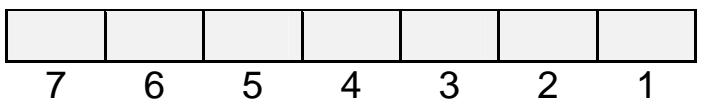

2. How satisfied are you with the availability of equipment in meeting rooms? (white boards, speaker phone, computer access, LCD projectors, etc.)

This is not important to me

VERY SATISFIED

VERY DISSATISFIED

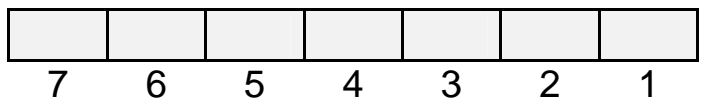

3. How satisfied are you with the temperature of meeting rooms?

This is not important to me

VERY SATISFIED VDVR DISSATISFIED

\begin{tabular}{|l|l|l|l|l|l|l|}
\hline & & & & & & \\
\hline 7 & 6 & 5 & 4 & 3 & 2 & 1
\end{tabular}


4. How satisfied are you with the acoustic quality of meeting rooms?

This is not important to me

VERY SATISHIIED

VERY DISSATISFIED

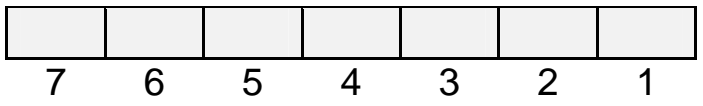

5. How satisfied are you with the variety of meeting rooms available to you?

This is not important to me

VERY SATISFIED

VERY DISSATISFIED

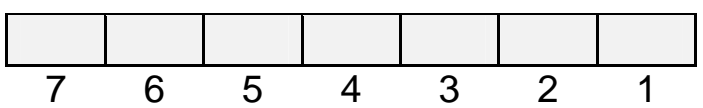

6. Please describe any other issues related to meeting facilities that are important to you.

\section{Part 7 - Work Experiences}

In this section, please rate your level of agreement with the following statements about experiences at work.

1. I look forward to working in the building.

STRONGLY AGREE

STRONGLY DISACREE

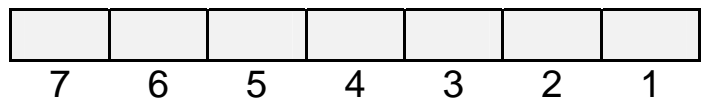

2. I am proud to show the office to visitors.

STRONGLY AGREE

STRONGLY DISAGREE

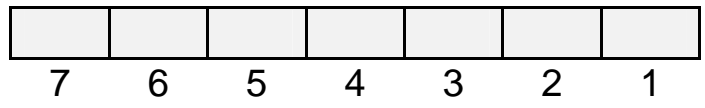

3. The overall appearance of the workplace is consistent with the mission of the agency.

STRONGLY AGREE

STRONGLY DISAGREE

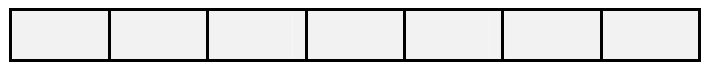




\begin{tabular}{lllllll}
\hline 7 & 6 & 5 & 4 & 3 & 2 & 1
\end{tabular}

4. There is a good sense of connection to the outdoors from inside the building.

STRONGLY AGREE

STRONGLY DISAGREE

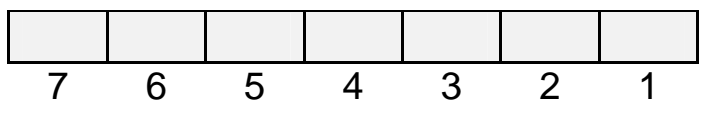

5. There is a definite space that is the 'heart' of the workplace.

STRONGLY AGREE

STRONGLY DISAGREE

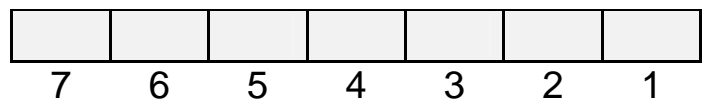

6. It is easy to locate other people and spaces (offices, meeting rooms, etc.) even when I have not been there before.

STRONGLY AGREE

STRONGIY DISAGREE

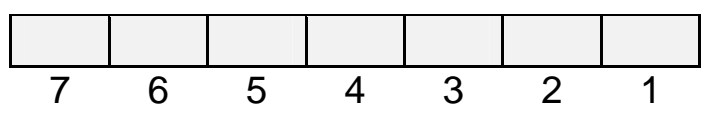

7. Communication within my group is good.

STRONGLY AGREE

STRONGLY DISAGREE

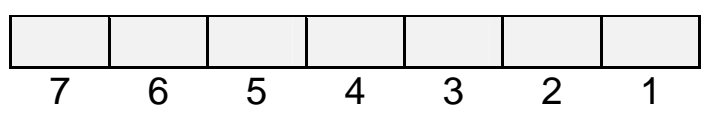

8. I learn a lot about what is going on by seeing and hearing others.

STRONGLY AGREE

STRONGLY DISAGREE

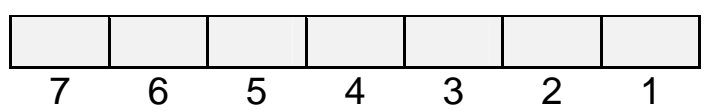

9. I often stop and talk to others in corridors or break areas.

STRONGIY AGREE

STRONGLY DISAGREE

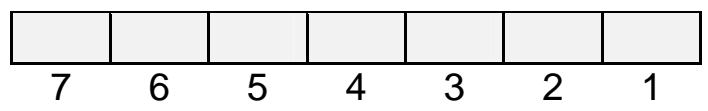


10. The security features of our building are adequate.

STRONGLY AGREE

STRONGLY DISAGREE

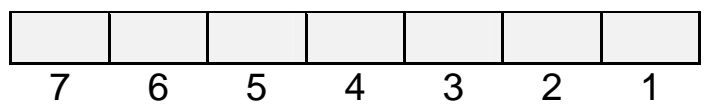

11. I feel safe walking to and from the building.

STRONGLY AGREE

STRONGLY DISAGREE

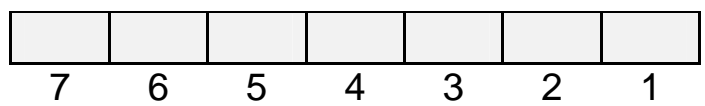

12. We have comfortable spaces to have lunch or takes breaks inside the building.

STRONGLY AGREE

STRONGLY DISAGREE

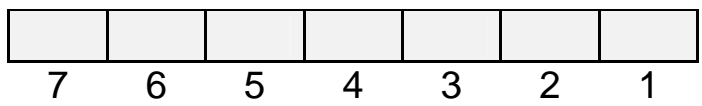

13. We have adequate restroom facilities in our offices.

STRONGLY AGREE

STRONGLY DISAGREE

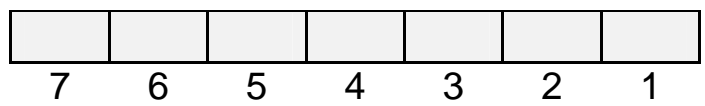

14. I use the building stairs rather than the elevator at least once a day.

STRONGLY AGREE

STRONGLY DISAGREE

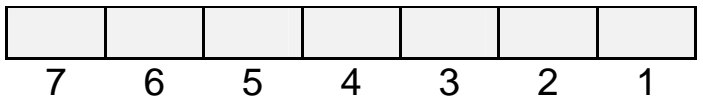




\section{Part 8 - Indoor Environmental Quality}

The following section of the survey focuses on your satisfaction with indoor environmental quality in your workplace. How important is each of the following items to doing your job well?

\section{Thermal Comfort}

1. Which of the following do you personally adjust or control in your workspace? (check all that apply)

\begin{tabular}{|c|c|}
\hline $\begin{array}{l}\text { Window blinds or } \\
\text { shades }\end{array}$ & Operable window \\
\hline Thermostat & Portable heater \\
\hline Permanent heater & Room air- \\
\hline Portable fan & Ceiling fan \\
\hline $\begin{array}{l}\text { Adjustable air vent in } \\
\text { wall or ceiling }\end{array}$ & $\begin{array}{l}\text { Ajustable air vent in } \\
\text { floor (diffuser) }\end{array}$ \\
\hline Door to interior space & $\begin{array}{l}\text { Door to exterior } \\
\text { space }\end{array}$ \\
\hline None of the above & Other \\
\hline
\end{tabular}

2. How satisfied are you with the temperature in your workspace?

VERY SATISFIED

VERY DISSATISFIED

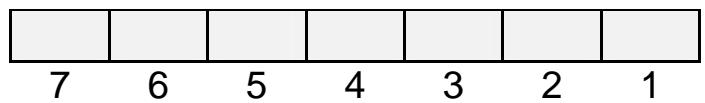

\section{Air Quality}

1. How satisfied are you with the air quality in your workspace (i.e. stuffy/stale air, cleanliness, odors)?

VERY SATISFIED VDR DISSATISHFIED

\begin{tabular}{|l|l|l|l|l|l|l|}
\hline & & & & & & \\
\hline 7 & 6 & 5 & 4 & 3 & 2 & 1 \\
\hline
\end{tabular}

\section{Lighting}


1. Which of the following controls do you have over the lighting in your workspace? (check all that apply)

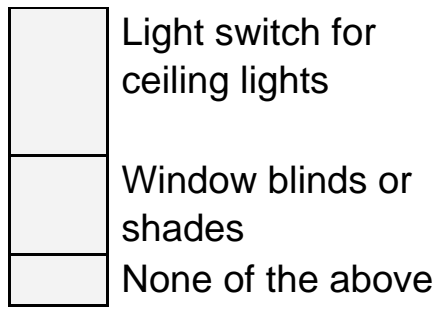

\begin{tabular}{|c|}
\hline $\begin{array}{l}\text { Dimmer switch for } \\
\text { ceiling lights }\end{array}$ \\
\hline Desk (task) light \\
\hline Other \\
\hline
\end{tabular}

2. How satisfied are you with the amount of light in your workspace?

VERY SATISFIED

VERY DISSATISFIED

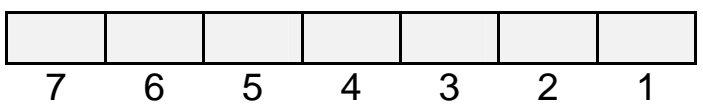

3. How satisfied are you with the visual comfort of the lighting (e.g., glare, reflections, contrast)?

VERY SATISFIED

VERY DISSATISFIED

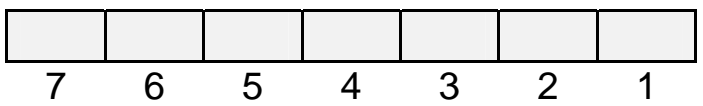

4. How satisfied are you with the degree of control you have over the lighting in your workspace?

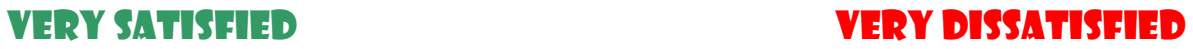

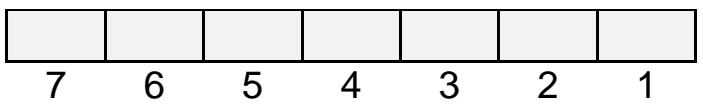

\section{Windows and Daylight}

1. How satisfied are you with the amount of daylight in your general office area?

VERY SATISFIED

VERY DISSATISEFIED

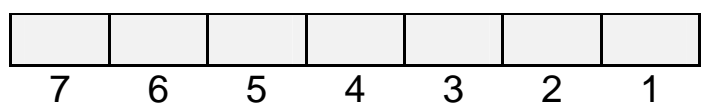


2. How satisfied are you with your access to a window view?

VERY SATISFIED

VERY DISSATISFIED

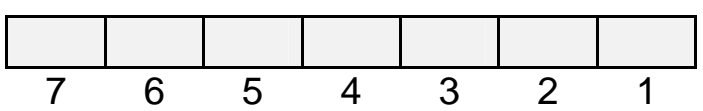

\section{Acoustic Quality}

1. How satisfied are you with the noise level in your workspace?

VERY SATISFIED

VERY DISSATISFIED

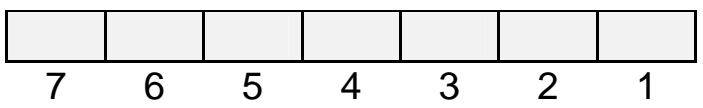

2. How satisfied are you with the speech privacy in your workspace (ability to have conversations without your neighbors overhearing and vice versa)?

VERY SATISFIED

VERY DISSATISFIIED

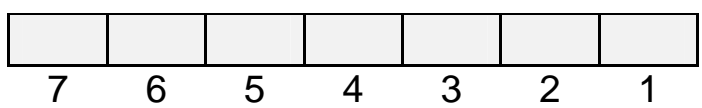

\section{Cleanliness and Maintenance}

1. How satisfied are you with the cleanliness and maintenance of the building?

VERY SATISFIED V VERY DISSATISFIED

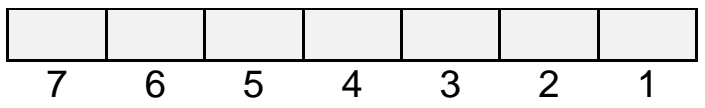

Please describe any other issues related to Indoor Environmental Quality that are important to you. 


\section{Part 9 - General Comments}

1. All things considered, how satisfied are you with your personal workspace?

VERY SATISFIED

VERY DISSATISFIED

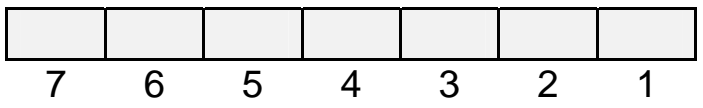

2. How satisfied are you with the building overall?

VERY SATISFIED

VERY DISSATISEFIED

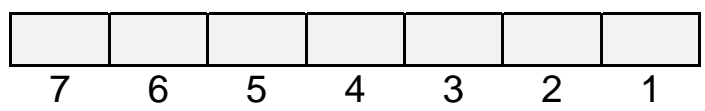

3. To what extent does your workplace enhance or interfere with your individual work effectiveness?

ENHANCES M INTERFERES

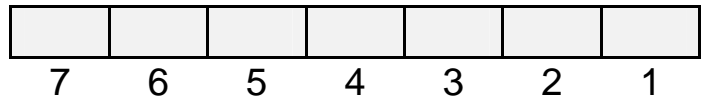

4. To what extent does your workplace enhance or interfere with your ability to work effectively with others?

ENHANCES MNTERFERES

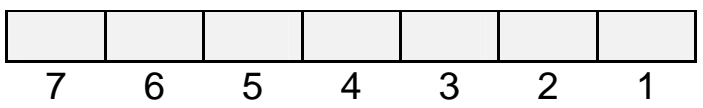

5. If you wanted to show a visitor around the building, but could only show one space, which space would you show?

6. Any additional comments or recommendations about your personal workspace or building overall? 


\section{Appendix F: GSA Customer Satisfaction Survey}
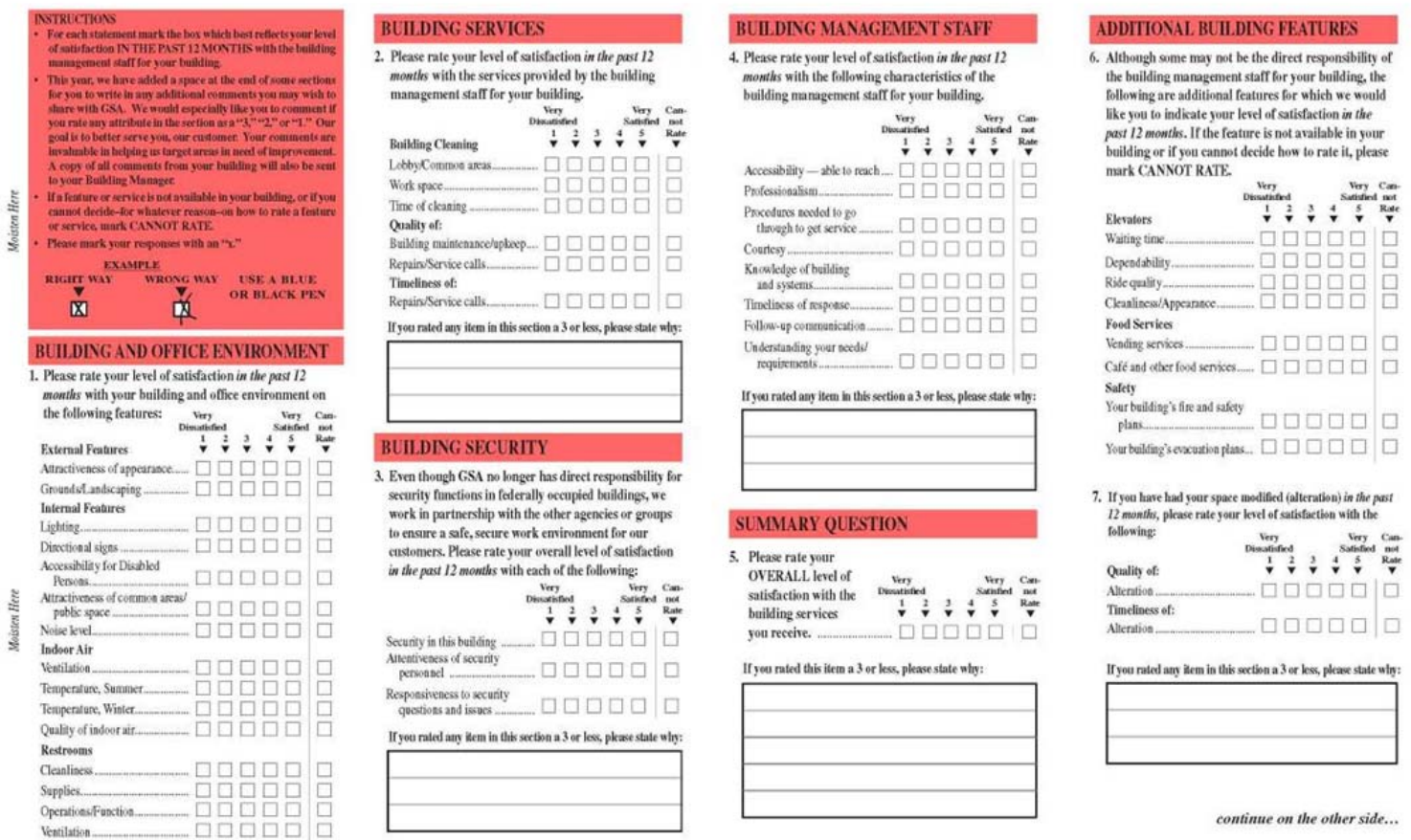

\section{SUMMARY QUESTION}

5. Pleses rate gour
OVERALLL leer of

ONERLLLL lect of
salisaction with the
builihing errices bililing service

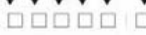

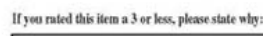
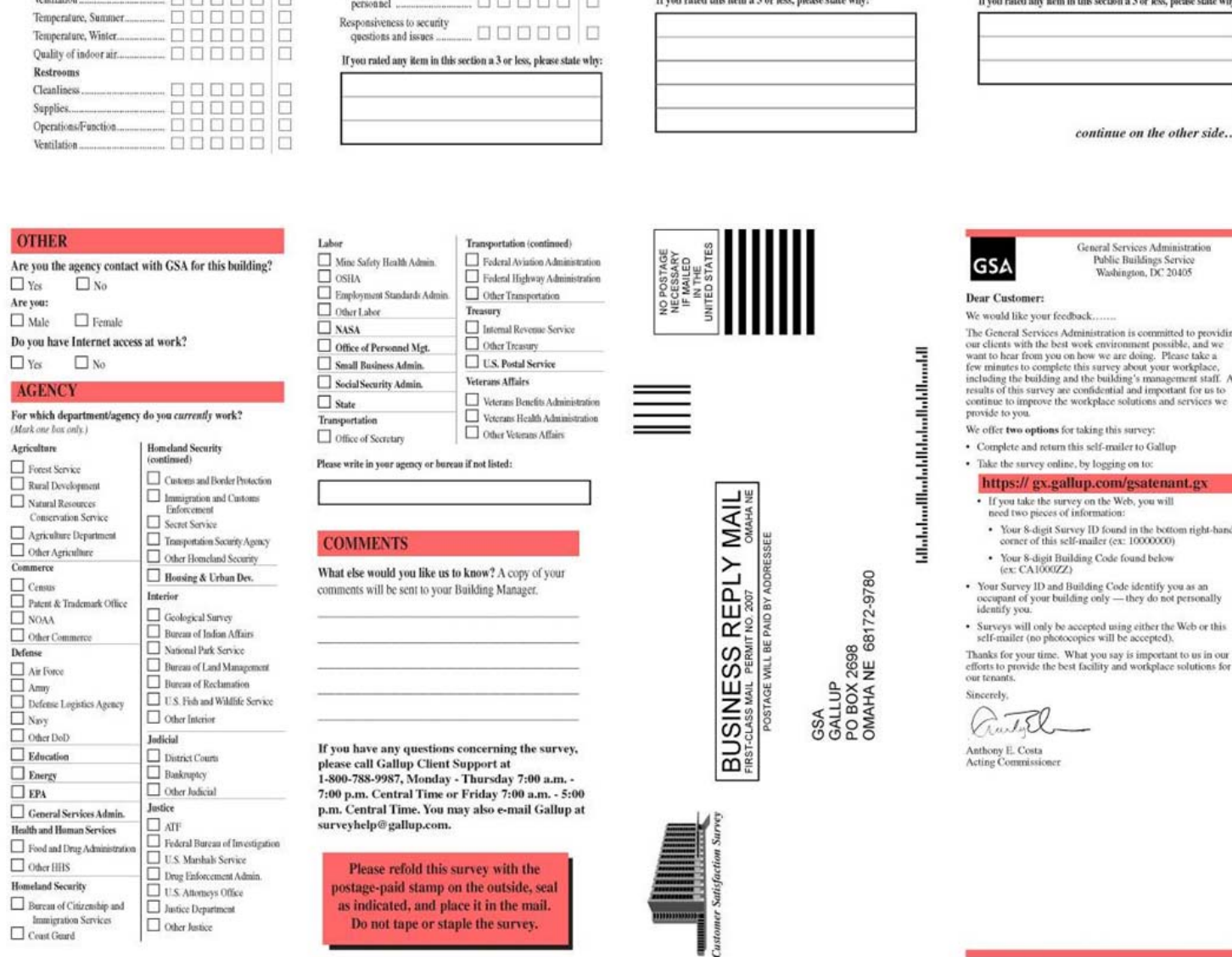

vear Customer:

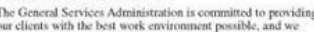
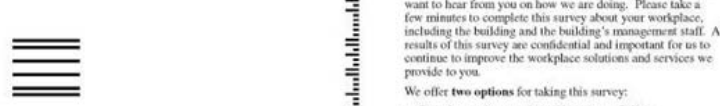

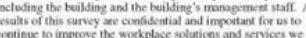
comines to imp

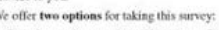

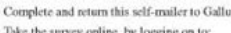

https:// gx.gallup.com/gsatenant.gx

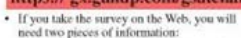

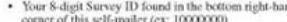

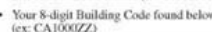

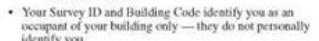

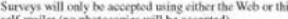

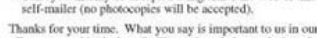

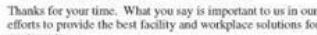

sincenty

Aural

Anthoy E Cooti 


\title{
Appendix G: Indoor Environmental Quality Assessment for Denver Federal Building
}

\section{Indoor Environmental Quality Measurements at the EPA Region VIII LEED Gold Certified Office Building}

\author{
Bradley P. Goodwin, Ian C. MacGregor, and Marcia G. Nishioka \\ Assessment Date: July 22, 2009 \\ Battelle, Columbus, $\mathrm{OH}$
}

\begin{abstract}
Indoor environmental quality (IEQ) measurements of temperature, relative humidity, atmospheric pressure, sound level, carbon dioxide, ozone, particulate matter, fungal spores, volatile organic compounds (VOCs), and semivolatile organic compounds (SVOCs) were performed at five indoor locations and one outdoor location at a Leadership in Energy and Environmental Design (LEED) Gold certified EPA Region VIII office building in Denver, Colorado. The goal of this assessment was to provide a rapid assessment of the indoor environmental quality of the building so that it could be compared to industry standards and the occupant satisfaction scores of the building's indoor environmental quality.
\end{abstract}

Compared to available standards, no acute hazards were identified given this was a oneday sampling of only five locations. All of the temperature and relative humidity combinations were within the acceptable range $\left(23-28^{\circ} \mathrm{C}\right)$ according to ASHRAE Standard 55-2004. However, temperatures measured in four of the indoor spaces exceeded the optimal temperature range $\left(20-23^{\circ} \mathrm{C}\right)$ for workplace productivity reported by Seppänen and Fisk (2006). The University of California - Berkeley's Center for the Built Environment (CBE) IEQ occupant satisfaction survey had occupant thermal comfort at $46 \%$ satisfied, which is the $59^{\text {th }}$ percentile in the CBE database of over 500 buildings.

To assess indoor air quality carbon dioxide, ozone, particulate matter, volatile organic compounds, semi-volatile organic compounds were measured. Carbon dioxide concentrations measured indoors (585-697 ppm) were acceptable based on the recommendation that indoor carbon dioxide levels not exceed outdoor levels by more than $650 \mathrm{ppm}$. Indoor ozone concentrations were all less than $27 \mathrm{ppb}$ and the indoor/outdoor ozone ratios were in the range of 0.09 to 0.17 which is comparable to the ratios observed in other indoor spaces with central air conditioning. Particulate matter concentrations were measured to be less than $25 \mu \mathrm{g} / \mathrm{m}^{3}$ in the indoor spaces and were less than half of the LEED new construction standard of $50 \mu \mathrm{g} / \mathrm{m}^{3}$. The occupant responses to the CBE survey had air quality at $76 \%$ satisfied, which is the $85^{\text {th }}$ percentile within the CBE database. 
Indoor fungal spore concentrations were measured to be less than $100 \mathrm{spores} / \mathrm{m}^{3}$ in all locations and were well below the $1000 \mathrm{spore} / \mathrm{m}^{3}$ level of concern. Indoor formaldehyde concentrations $\left(20-26 \mu \mathrm{g} / \mathrm{m}^{3}\right)$ were greater than the outdoor concentration $\left(5.3 \mu \mathrm{g} / \mathrm{m}^{3}\right)$ but still less than indoor air quality guidelines (the LEED new construction standard is 64.1 $\left.\mu \mathrm{g} / \mathrm{m}^{3}\right)$ and are below levels of concern. Ethanol (133-217 $\left.\mu \mathrm{g} / \mathrm{m}^{3}\right)$ and acetone (46-79 $\left.\mu \mathrm{g} / \mathrm{m}^{3}\right)$ were detected at levels higher than outdoor concentrations because of typical human activity in the building; HAPs 2-butanone $\left(6.8-11 \mu \mathrm{g} / \mathrm{m}^{3}\right)$, toluene $\left(7.3-13 \mu \mathrm{g} / \mathrm{m}^{3}\right)$, and hexane $\left(2.5-3.7 \mu \mathrm{g} / \mathrm{m}^{3}\right)$ were also detected at concentrations higher than the outdoor air.

Synthetic musks AHTN (3.7-23 ng/ $\left.\mathrm{m}^{3}\right)$ and HHCB (40-467 ng/m $\mathrm{m}^{3}$ ) were found in the indoor air with concentrations in one office approximately an order of magnitude higher than the other indoor locations. BDEs and phthalates were, in general, found at levels similar to those reported for other indoor environments. Limonene and its oxidation products were detected in the indoor samples, at relatively low concentrations. Samples collected from the copy room were found to have elevated concentrations of several polyaromatic hydrocarbons (PAHs) (predominantly the lower volatility PAHs). The concentration of total PAHs found in the copy room was higher than the other spaces measured in the building.

Sound levels measured indoors (61-65 dBa) did not exceed the range of normal conversation (60-70 $\mathrm{dBa}$ ). The occupant responses to the $\mathrm{CBE}$ survey had acoustic quality at $46 \%$ satisfied, which is the $59^{\text {th }}$ percentile within the CBE database.

In general, the various IEQ parameters measured during this limited study at the EPA Region VIII LEED Gold office building were within the ranges of applicable standards and were similar to the results of measurements in other indoor spaces, with the exception of PAH concentrations in the copy room.

\section{Introduction and Background}

Humans in modern society spend the bulk of their time indoors, and indoor environmental quality (IEQ) not only affects the health, comfort, and well-being of building occupants, but also their productivity and efficiency on the job in workplace environments. To assess the IEQ at the U.S. Environmental Protection Agency (EPA) Region VIII Headquarters, a U.S. Green Building Council Leadership in Energy and Environmental Design - New Construction (LEED-NC) Gold certified building, in Denver, Colorado, measurements were performed, on July 22, 2009, in six different locations throughout the building. Data collected during the field sampling event include continuous measurements of carbon dioxide, ozone, $\mathrm{PM}_{10}$ (particulate matter with an aerodynamic diameter of less than 10 microns), temperature, relative humidity, atmospheric pressure, and sound level. In addition, integrated samples were collected to quantify concentrations of fungal spores, volatile organic compounds (VOCs) and semivolatile organic compounds (SVOCs). 
Measurements of these various IEQ parameters are reported and compared to similar measurements conducted at other indoor locations. The goal of this assessment was to provide a rapid assessment of the indoor environmental quality of the building so that it could be compared to industry standards and the occupant satisfaction scores of the building's indoor environmental quality. The major source of indoor air quality reference measurements is the Building Assessment Survey and Evaluation Study (BASE). This study, conducted between 1994 and 1998, looked at indoor air quality in addition to other building parameters (HVAC, occupant satisfaction, etc.) at one hundred office buildings throughout the United States. Other sources of data used for comparison include standards for indoor environments published by the American Society of Heating, Refrigerating, and Air Conditioning Engineers (ASHRAE), LEED new construction standards, as well as data published in the peer-reviewed literature. Potential sources of VOCs and SVOCs are also discussed, as are implications of the findings, as are recommendations for improving the IEQ in this building.

\section{Methods}

$\underline{\text { Sampling locations }}$

Indoor sampling locations were selected throughout the building to characterize the IEQ in the different areas of the building where staff spend the bulk of their time. One location was outdoors on the roof of the building near the air intake for the HVAC system. This location was on a tiled path near the outer edge of the building. The sampling location was on the "green" portion of the roof (vegetation was present in close proximity to the sampling location). Of the five interior locations, four were located in office spaces while one was located in a dedicated copy room. Of the office spaces, two locations were closed offices and two were open offices. One each of the open and closed offices had underfloor ventilation, while the others had overhead ventilation. Table 1 lists the six sampling locations and specifies the location and ventilation conditions present in each. Figure 1 through Figure 6 show each of the sampling locations at various stages in the sampling process.

Table 1. Sampling Locations and Characteristics

\begin{tabular}{|l|l|l|l|l|}
\hline Location & Floor & Room Number & Office Type & Ventilation \\
\hline Roof & 9 (Outside) & NA & NA & Natural \\
\hline $\begin{array}{l}\text { Copy Room } \\
\text { (CR) }\end{array}$ & 8 & Copy Center & NA & Overhead \\
\hline Office 1 (O1) & 8 & 8271 & Closed & Underfloor \\
\hline Office 2 (O2) & 3 & 3153 & Closed & Overhead \\
\hline Office 3 (O3) & 3 & 3151 & Open & Overhead \\
\hline Office 4 (O4) & 7 & 7173 & Open & Underfloor \\
\hline
\end{tabular}




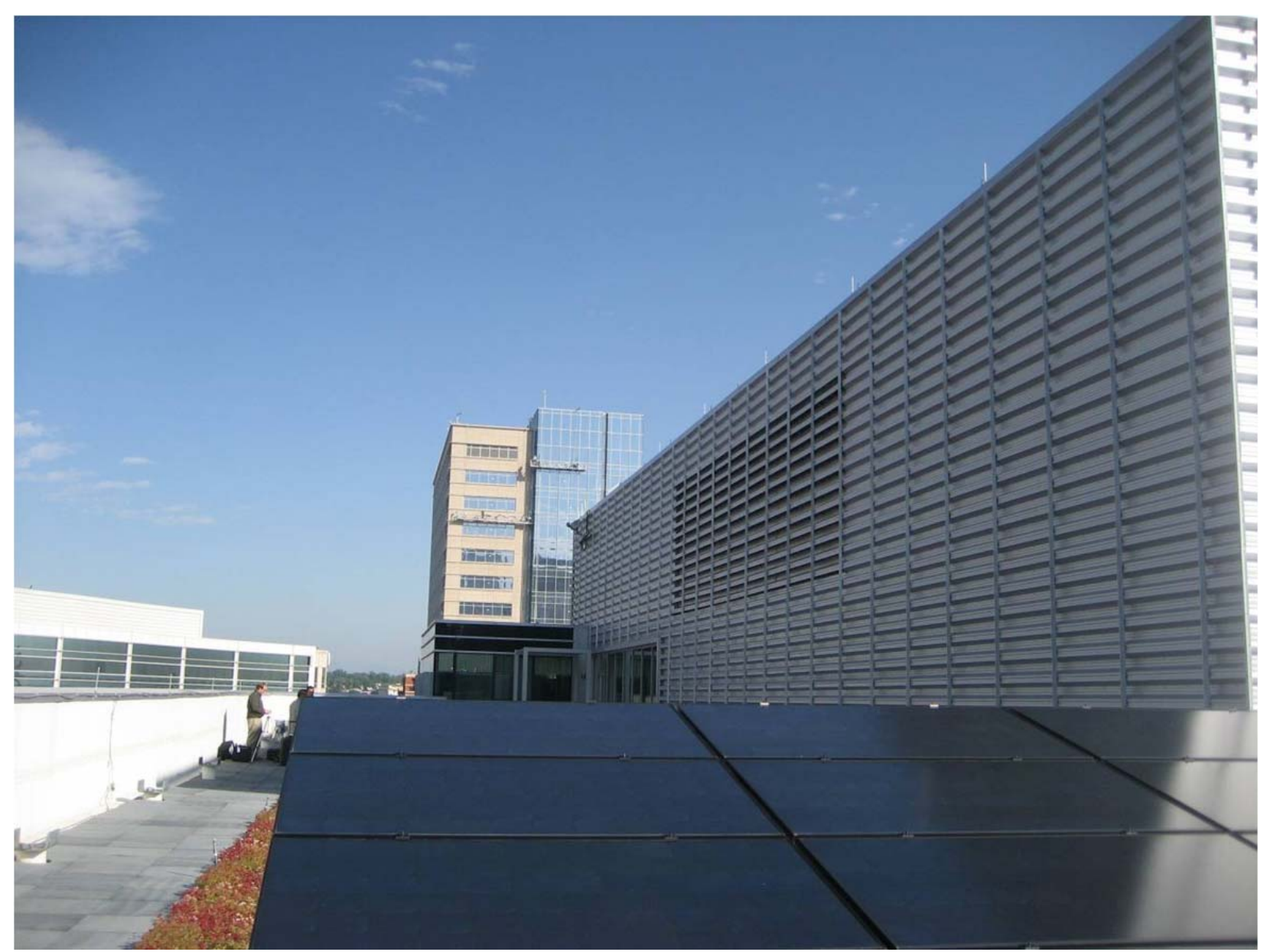

Figure 1. Roof sampling location. 


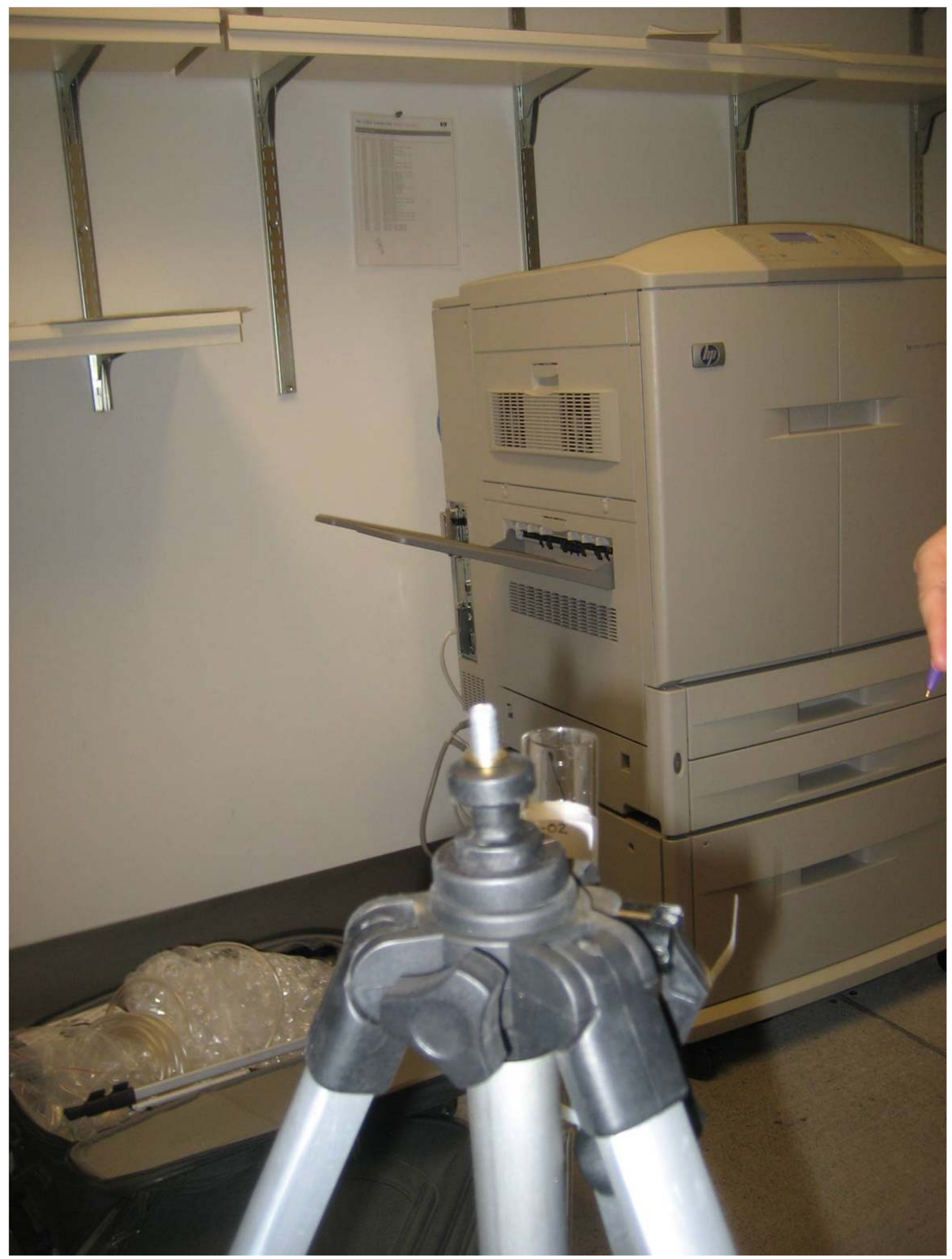

Figure 2. Copy Room (CR) sampling location and SVOC cartridge. 


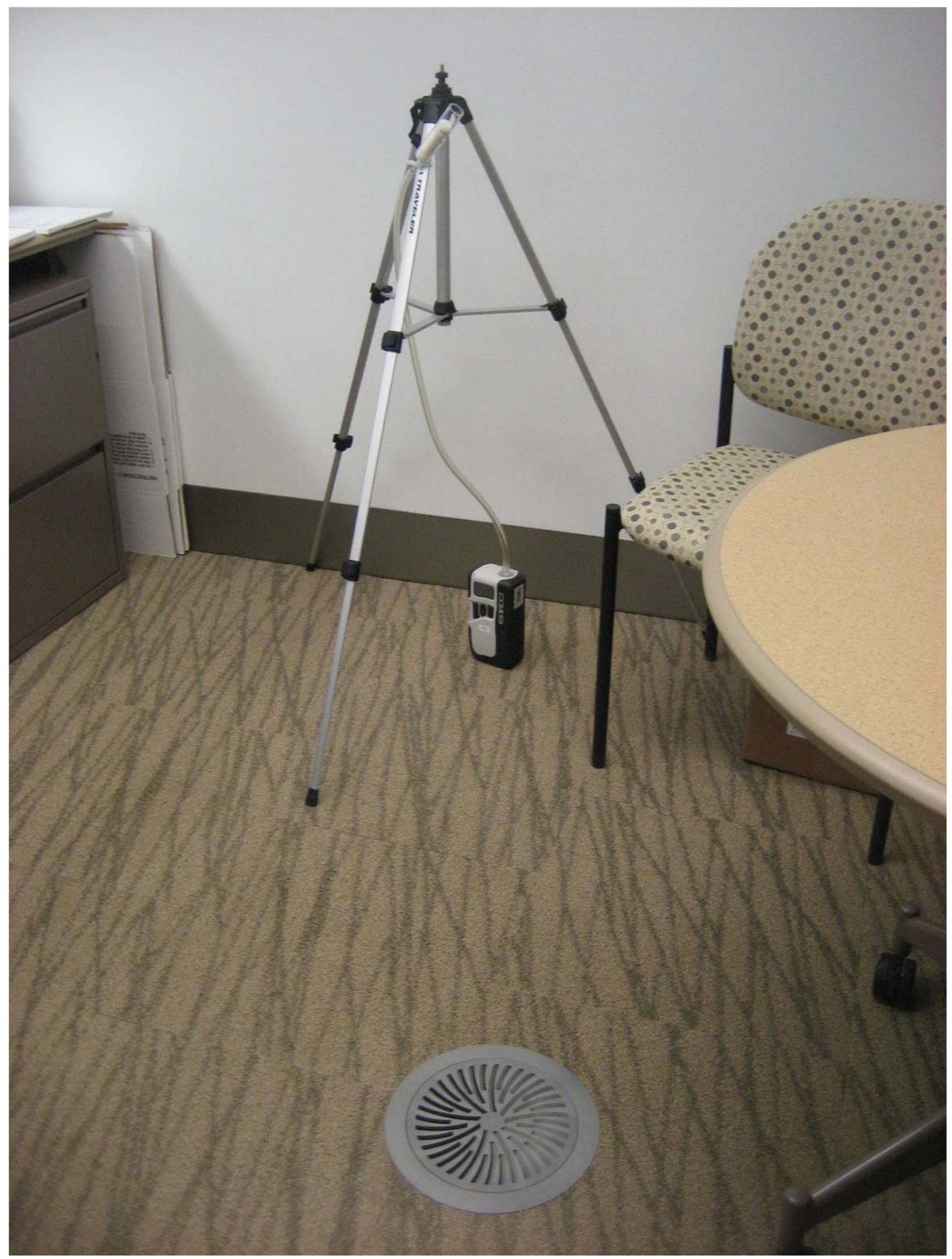

Figure 3. Office 1 (O1) sampling location and SVOC sampling setup. 


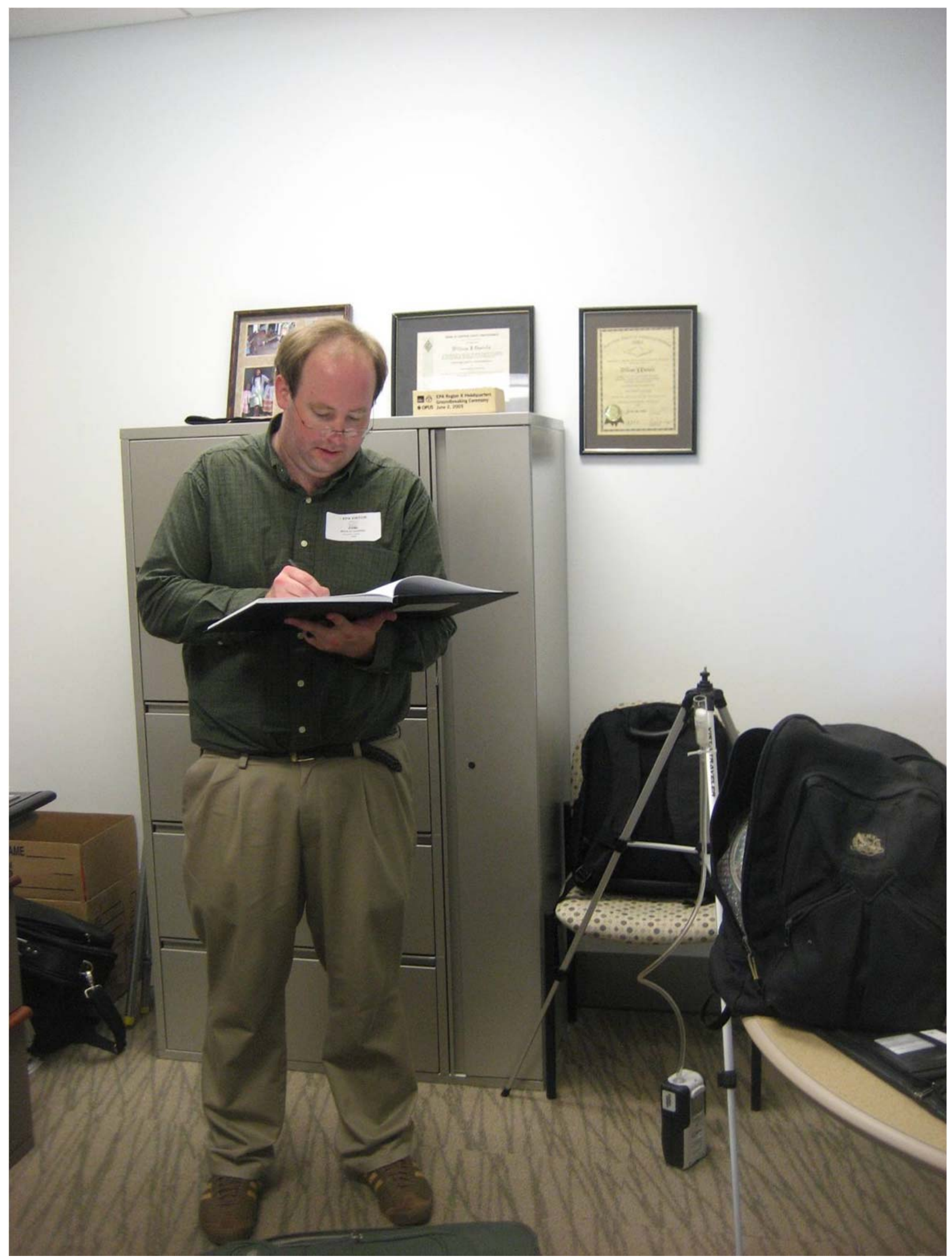

Figure 4. Office $2(\mathrm{O} 2)$ sampling location. 


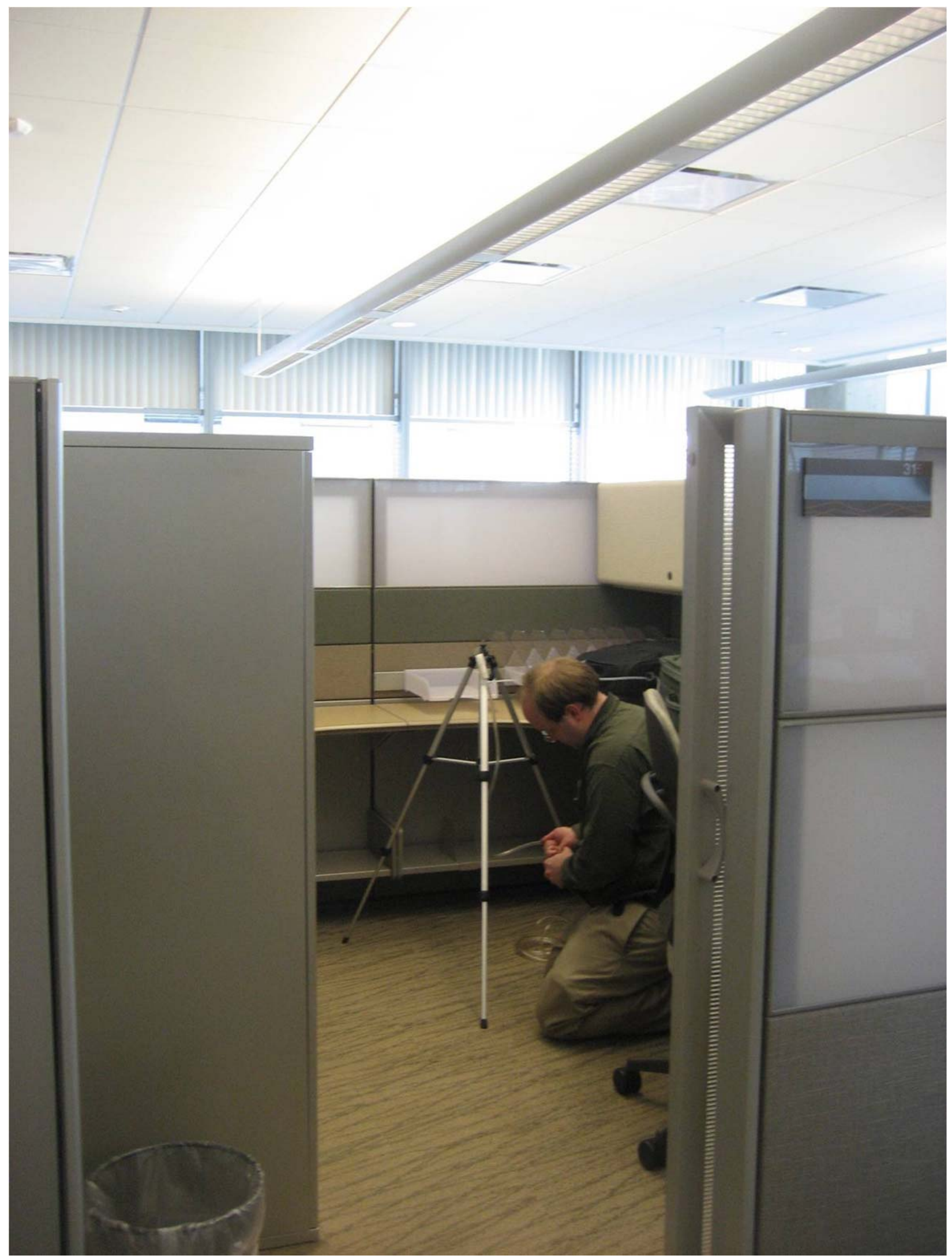

Figure 5. Office 3 (O3) sampling location. 


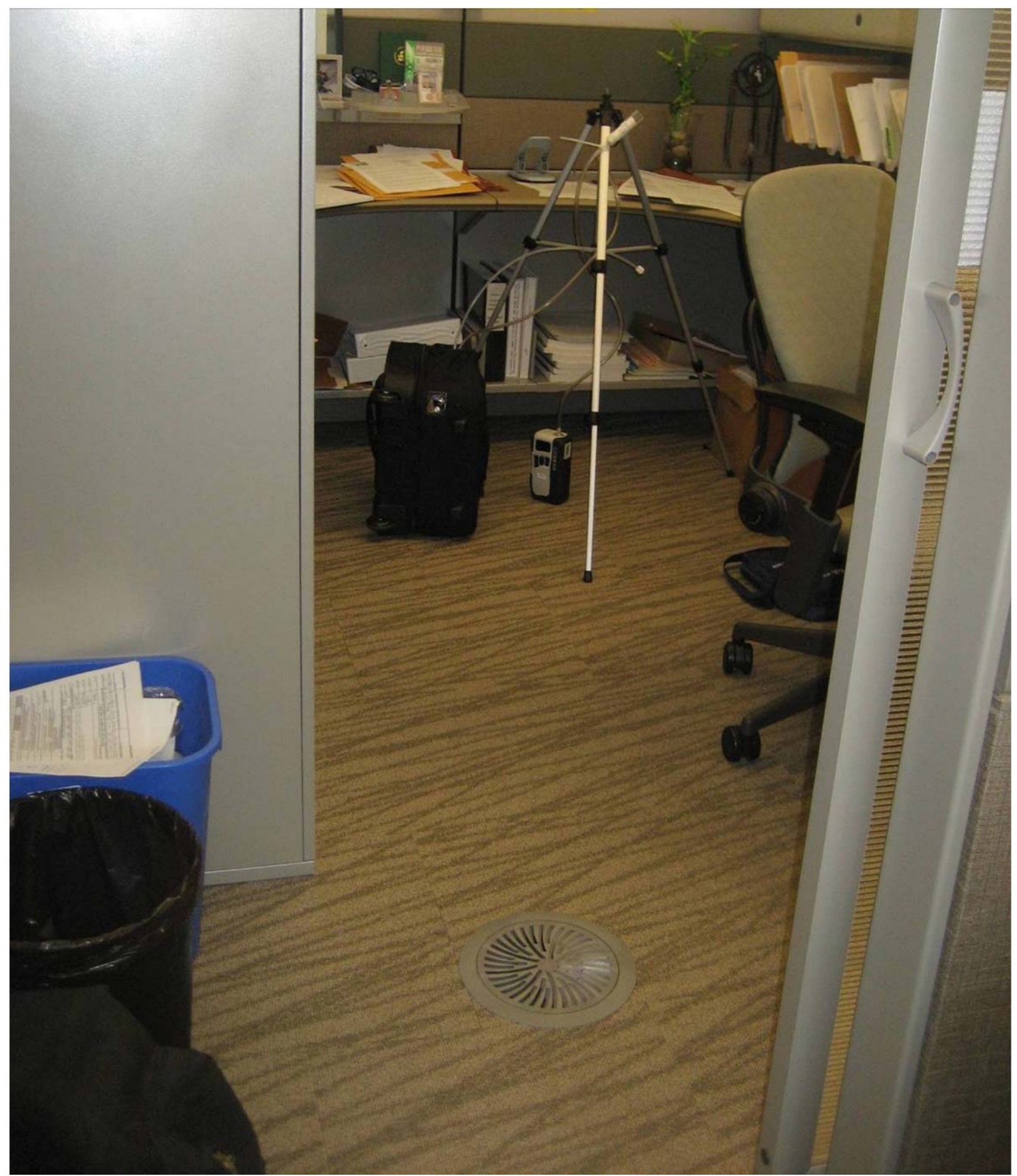

Figure 6. Office 4 (O4) sampling location with SVOC sampler and continuous instruments. 


\section{Field sampling}

Integrated VOC (canisters and cartridges), SVOC, and fungi samples were collected at each location in addition to continuous measurements of carbon dioxide, ozone, particulate matter, temperature, relative humidity, atmospheric pressure, and sound level. Selected VOCs were collected by sampling whole air into evacuated $400 \mathrm{~mL}$ passivated, stainless steel canisters. Grab samples were collected by simply opening the valve on each canister and allowing the canister to fill to atmospheric pressure over the course of approximately 30 seconds. Other VOCs (selected carbonyls) were collected using adsorbent cartridges containing silica gel coated with the derivitization agent 2,4dinitrophenyl hydrazine (DNPH) at a flow rate of 2 liters per minute for 10 minutes. The DNPH cartridges were purchased commercially from Supelco, and were shipped to the office building on ice, in individual sealed bags. Each SVOC cartridge consisted of $5 \mathrm{~g}$ of pre-cleaned styrene-divinyl benzene copolymer XAD-2 (Supelco) sandwiched between two plugs of polyurethane foam (PUF; Supelco), each plug being $22 \mathrm{~mm}$ in diameter and $19 \mathrm{~mm}$ in length. SVOC samples were collected at a flow rate of 8 liters per minute for a minimum of two hours. Fungi samples were collected on Air-O-Cell cassettes at a flow rate of 15 liters per minute for 10 minutes. Temperature, relative humidity, and sound level were measured by probes protruding from the side of the continuous instrument package (Figure 7). Atmospheric pressure was measured by a sensor housed inside the package. Concentrations of particulate matter, carbon dioxide, and ozone were determined by pulling air into instruments in the continuous instrument package. Air samples were collected at a height above the floor to approximate the height of the breathing zone of a seated individual $(\sim 1 \mathrm{~m})$.

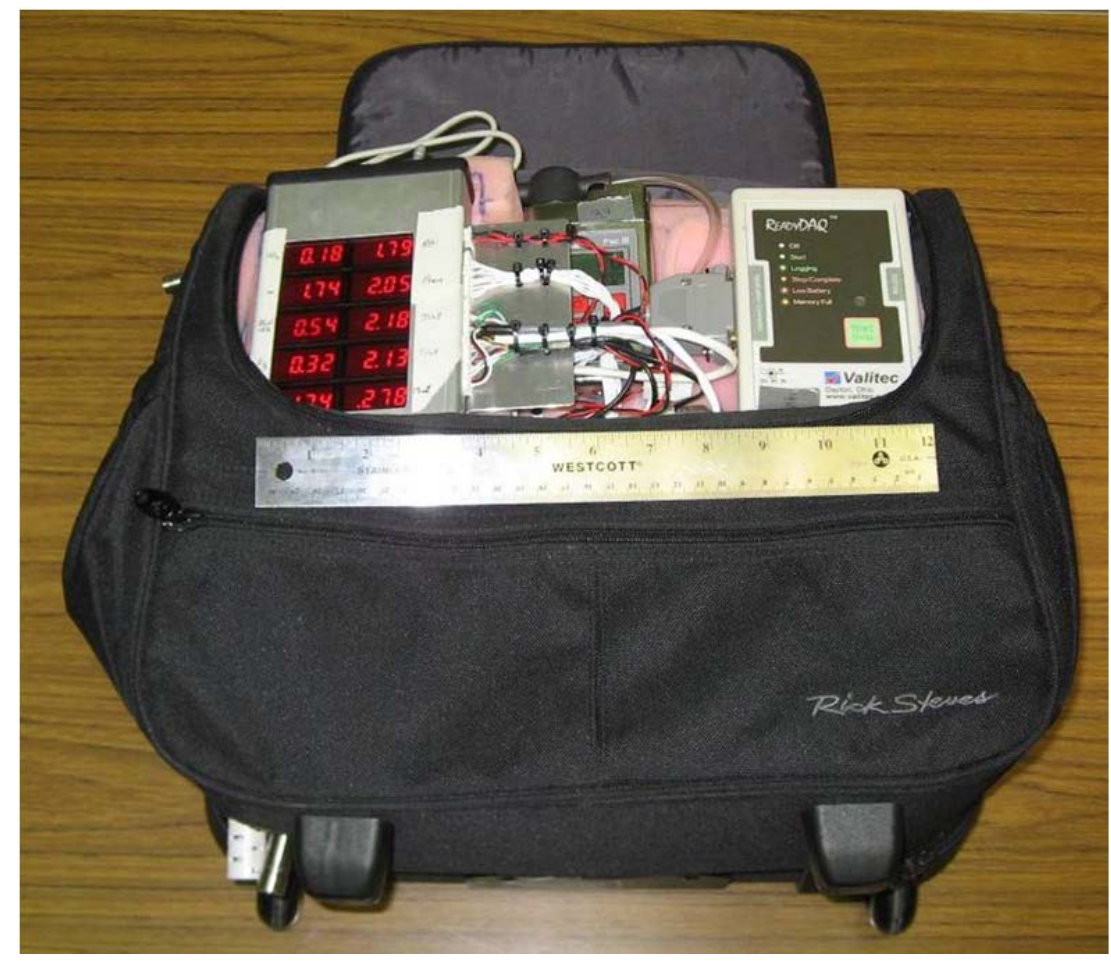

Figure 7. Continuous instrument package. 
The SVOC samples were deployed at each sampling location early in the day, beginning on the roof, to maximize the sampling duration at each location. Following deployment of these samples, the continuous package was moved to each location for 30 minute sampling events. During these events, the VOC, carbonyl, and fungi samples were collected and field blanks were generated. The SVOC sampling was concluded only after a minimum of 2 hours had elapsed. Continuous sampling was conducted a second time at the rooftop location at the end of the day.

\section{Calibration and Analysis}

\section{$\underline{\text { Continuous monitoring instrumentation }}$}

Table 2 lists the instrumentation contained in the continuous monitoring package. The table contains the parameter measured, manufacturer, and model number for each piece of equipment.

Table 2. Continuous Monitoring Instrumentation

\begin{tabular}{|l|l|l|}
\hline Parameter & Manufacturer & Model Number \\
\hline Carbon Dioxide & Li-Cor & LI-820 \\
\hline Ozone & 2B Technologies & Model 202 \\
\hline Particulate Matter & TSI & AM510 SidePak \\
\hline Temperature/RH & Vaisala & HMWY71 Humicap \\
\hline Atmospheric Pressure & Vaisala & PTB 100 \\
\hline Sound Level & Quest Technologies & 2100 \\
\hline
\end{tabular}

Prior to the field sampling event, calibrations were performed on the equipment in the continuous sampling package as well as the pumps used to collect the integrated samples. Flows for all pumps were verified with blank media to be within ten percent of the true value using a calibrated flow meter. The carbon dioxide instrument was calibrated using certified gas standards. The calibrations of the temperature, relative humidity, sound level, and pressure instruments were checked by comparison to calibrated instruments. The ozone and $\mathrm{PM}_{10}$ measurements were made using the factory supplied calibration for each instrument. The ozone instrument was compared to two other calibrated ozone measurements at concentrations below $50 \mathrm{ppb}$ and found to be acceptable. At concentrations above $50 \mathrm{ppb}$ the calibration is based on extrapolation. All data from the continuous instrumentation package were collected at $1 \mathrm{~Hz}$ as voltage outputs using a data logger and converted using the calibration information to the appropriate parameter values.

Data are reported for each sampling location as average values over the measurement interval in each location. Measurement intervals were approximately 30 minutes for all indoor office locations and approximately 15 minutes on the roof. At each location, the sampling interval started when the package was deployed and stopped when the package 
was moved. The start and stop times were recorded in the field and verified using data from a motion sensor incorporated into the sampling package.

\section{$\underline{\text { Fungal spore analysis }}$}

Fungal samples collected using Air-O-Cell cassettes were sent to EMSL Analytical Laboratory for analysis. Fungal analysis consisted of enumeration and identification of fungal spores present on the Air-O-Cell cassette using optical microscopy. Data were reported for both total fungal spores and for spores identified by type. A blank sample was included in the analysis batch for quality assurance purposes. No fungal spores were detected on the blank cartridge, so no blank correction was applied to the fungal data.

$\underline{\text { VOC analysis }}$

\section{Stainless steel canisters}

Air sampling canisters were cleaned and evacuated in the laboratory prior to field use. The cleaning/evacuation process involved a series of pressurization/evacuation steps incorporating heat treatment $\left(\sim 75^{\circ} \mathrm{C}\right)$ and humidification. The final evacuation step evacuated each canister to $\sim 20$ millitorr. After sample collection the canisters were packaged and delivered to Battelle's laboratories in Columbus, $\mathrm{OH}$. Upon receipt at the laboratory, the canister pressures were measured and recorded and the canisters were then filled to 30 psi absolute pressure (psia) with hydrocarbon-free, humidified air to facilitate analysis. Reported concentrations have been corrected by the dilution factor determined from the initial and final canister pressures. One field blank was generated by filling an evacuated canister with hydrocarbon-free, humidified air.

An Agilent 6890 gas chromatographic system equipped with a 5973 mass spectrometer (GC/MS) was used for the analysis of the VOCs present in the canister samples. The GC was connected to an Entech 7100A cryogenic preconcentration system with 7016C canister autosampler. Analysis generally followed the procedures as outlined in US EPA Compendium Method TO-15: http://www.epa.gov/ttnamtil/files/ambient/airtox/to15r.pdf. Briefly, the volatile compounds in a sample volume of $200 \mathrm{~mL}$ were concentrated and injected onto an 100\% polydimethylsiloxane fused silica capillary column, $60 \mathrm{~m}$ by $0.32 \mathrm{~mm}$ inner diameter (i.d.) (1 $\mu \mathrm{m}$ film thickness). Analytes were chromatographically resolved using helium carrier gas that was maintained at a constant flow rate of $1.2 \mathrm{~mL} / \mathrm{min}$. Optimal analytical results were achieved by temperature programming the GC oven from $35^{\circ} \mathrm{C}$ to $150^{\circ} \mathrm{C}$ at $6^{\circ} \mathrm{C} / \mathrm{min}\left(5\right.$ minute initial hold) followed by temperature ramping to $220^{\circ} \mathrm{C}$ at $15^{\circ} \mathrm{C} /$ minute. The mass spectrometer was operated in the full scan mode so that all masses between 35 and 300 atomic mass units (amu) were scanned at a rate of 1 scan per 0.4 seconds. The VOCs were identified by comparison of their retention times and their ion abundance ratios to those of known standards. Quantification of the analytes was based 
upon instrument response to known concentrations from a dilute calibration gas containing the target VOCs (traceable to a certified gas standard). Individual VOC detection limits were approximately 0.2 parts per billion (ppb). Blank concentration levels were typically below the $0.2 \mathrm{ppb}$ detection limit. No blank correction was applied to the data.

\section{DNPH cartridges}

Upon completion of the day's sampling activities, the DNPH cartridges were shipped to Battelle's laboratories in Columbus, $\mathrm{OH}$. Upon receipt in the laboratory, the cartridges were refrigerated until they were extracted with $2 \mathrm{~mL}$ of acetonitrile into a $2 \mathrm{~mL}$ volumetric flask. An aliquot of the sample solution was then transferred to a $1 \mathrm{~mL}$ vial and analyzed as described below. The remaining solution was refrigerated and archived.

The acetonitrile extracts were analyzed by an Agilent Series 1100 high performance liquid chromatograph equipped with an ultraviolet detector (HPLC-UV). Analytical procedures generally followed those outlined in US EPA Compendium Method TO-11A: http://www.epa.gov/ttn/amtic/files/ambient/airtox/to-11ar.pdf. Briefly, the instrument was equipped with an autosampler and was operated at a fixed wavelength of $360 \mathrm{~nm}$. Chromatographic separation of the carbonyl compounds was accomplished using two C-18 reversed phase columns (Supelcosil LC-18, $4.6 \mathrm{~mm}$ i.d. by $25 \mathrm{~cm}$ long) which were connected in series and maintained at room temperature. The solvent flow was 1.5 $\mathrm{mL} /$ minute, and the mobile phase was a 70/30 (volume/volume) mixture of acetonitrile/water. The analysis was carried out isocratically, with an injection volume of 20 $\mu \mathrm{L}$ and run time of 15 minutes. Cartridge blank levels ranged from less than $0.02 \mathrm{ug}$ (not detected) for propionaldehyde to no more than 0.04 ug for formaldehyde and acetaldehyde. The results reported here have been blank-corrected. Estimated carbonyl limits of detection are approximately $1 \mu \mathrm{g} / \mathrm{m}^{3}, 0.5$ to $1 \mathrm{ppb}$ depending on the compound.

\section{$\underline{\text { SVOC analysis }}$}

After assembly, the XAD-2 was spiked with the field recovery standards shown in Table 3.

Table 3. XAD-2 Field Recovery spikes

\begin{tabular}{|l|l|l|}
\hline $\begin{array}{l}\text { Field spike } \\
\text { amount }\end{array}$ & Compound & Function \\
\hline $100 \mathrm{ng}$ & $\mathrm{d} 8$-naphthalene & Retention efficiency of 1-2 ring compounds \\
\hline $100 \mathrm{ng}$ & $\mathrm{d} 10$-anthracene & Retention efficiency of 3 ring compounds \\
\hline $100 \mathrm{ng}$ & $\mathrm{d} 10$-fluoranthene & Retention efficiency of 4 ring compounds \\
\hline $100 \mathrm{ng}$ & $\mathrm{d} 12$-benzo(a)pyrene & Retention efficiency of 5 ring compounds \\
\hline $100 \mathrm{ng}$ & $\mathrm{d} 12$-indeno-(1,2,3-cd)pyrene & Retention efficiency of 6 ring compounds \\
\hline
\end{tabular}


The ends of each sampler cartridge were sealed with foil lined caps. The cartridge was placed in a polyethylene zip-seal bag, wrapped in bubble wrap and shipped to the field on ice. After use, each cartridge was recapped and wrapped as before and returned to the analysis lab. Cartridges were stored at $-20^{\circ} \mathrm{C}$ until analysis.

For analysis, the two sections of PUF and the $5 \mathrm{~g}$ of XAD-2 of each sample were transferred to a $22 \mathrm{~mL}$ accelerated solvent extractor (ASE; Dionex) cell and spiked with the following surrogate recovery standards (SRSs). SRSs are added just prior to extraction; their recovery is an indication of method performance on a sample-by-sample basis and indicates general compound class recovery through extraction and concentration steps. Spike amounts are similar to the levels anticipated for analytes of that compound class in field samples. Table 4 presents the surrogate recovery spikes.

Table 4. Surrogage Recovery Standards

\begin{tabular}{|l|l|l|}
\hline $\begin{array}{l}\text { Lab SRS } \\
\text { spike } \\
\text { amount }\end{array}$ & Compound & Function \\
\hline $750 \mathrm{ng}$ & $\begin{array}{l}\text { d4- Butyl benzyl } \\
\text { phthalate }\end{array}$ & SRS: method performance for phthalate esters \\
\hline $100 \mathrm{ng}$ & 13C6-phenanthrene & $\begin{array}{l}\text { SRS: method performance for diverse neutral } \\
\text { compounds }\end{array}$ \\
\hline $20 \mathrm{ng}$ & BDE 126 & SRS: method performance for BDEs 47, 99, 100 \\
\hline $40 \mathrm{ng}$ & $13 \mathrm{C} 12-\mathrm{BDE} 209$ & SRS: method performance for BDE 209 \\
\hline
\end{tabular}

The laboratory matrix spike sample was spiked with all analytes, in addition to the SRSs. The spike amounts of the analytes, by compound class, are indicated below. Laboratory matrix spikes are shown in Table 5.

Table 5. Laboratory Matrix Spikes

\begin{tabular}{|l|l|}
\hline Lab matrix spike amount & Compounds \\
\hline $10 \mathrm{ug}$ & All phthalate esters \\
\hline $150 \mathrm{ng}$ & All PAHs \\
\hline $200 \mathrm{ng}$ & All other neutral compounds (fragrances, pesticides, PCBs, etc) \\
\hline $50 \mathrm{ng}$ & BDEs 47, 99, 100 \\
\hline $100 \mathrm{ng}$ & BDE 209 \\
\hline
\end{tabular}

The ASE cells were extracted twice using dichloromethane (DCM) at $2000 \mathrm{psi}$ and $100^{\circ}$ $\mathrm{C}$, using 5 minute extraction cycles. The extract was transferred with two $5 \mathrm{~mL}$ DCM rinses to a Kuderna-Danish evaporator tube and concentrated at $45^{\circ} \mathrm{C}$ to $1 \mathrm{~mL}$. Then, 5 $\mathrm{mL}$ of methyl-t-butyl ether was added, and the extract was reconcentrated to $1 \mathrm{~mL}$. A 100 $\mathrm{uL}$ aliquot of the extract was removed to a $\mathrm{GC}$ vial, and spiked with $100 \mathrm{ng}$ of the internal standard (IS) bromobiphenyl. This fraction was analyzed for the phthalate esters using GC/MS in the multiple ion detection (MID) mode with electron impact ionization. The analyses were carried out using an Agilent 6890 GC interfaced to a 5973 MSD and an RTx-5ms capillary column ( $30 \mathrm{~m}, 0.25 \mathrm{~mm}$ if, $0.25 \mu \mathrm{m}$ film thickness; Restek), with 
the $\mathrm{GC}$ oven temperature programmed from 50-100 C @ $8^{\circ} \mathrm{C} / \mathrm{min}$, and then from 100$300^{\circ} \mathrm{C} @ 10^{\circ} \mathrm{C} / \mathrm{min}$.

The remaining $900 \mathrm{uL}$ extract was concentrated using a gentle stream of dry nitrogen to $0.1 \mathrm{~mL}$, spiked with $5 \mathrm{ng}$ of both bromobiphenyl and dibromobiphenyl and transferred to a GC vial. This fraction was analyzed first for the PAHs, PCBs, fragrances and other neutral compounds using conventional electron impact GC/MS/MID; the fraction was then reanalyzed using negative chemical ionization (NCI) GC/MS/MID for the selected brominated flame retardants (brominated diphenyl ethers, BDEs). The same instrument, GC column and temperature program as listed above was used for the EI GC/MS/MID analyses of the diverse neutral compounds. The BDEs were analyzed with the same instrument, albeit with a chemical ionization source, using a DB-5 GC column $(15 \mathrm{~m}$, $0.25 \mathrm{~mm}$ id, $0.10 \mu \mathrm{m}$ film thickness; Agilent), with the GC oven temperature programmed from 100-200 ${ }^{\circ} \mathrm{C} @ 10^{\circ} \mathrm{C} / \mathrm{min}$ and then $200-300^{\circ} \mathrm{C} @ 30^{\circ} \mathrm{C} / \mathrm{min}$.

The same approach to quantification was used for all $3 \mathrm{GC} / \mathrm{MS}$ analyses. For each analysis, a series of calibration solutions was prepared that spanned the linear range of the detector and the expected analyte concentrations in the extracts. The field recovery standards and the compound class SRSs were also included in these calibration solutions at levels which would bracket concentrations expected for these compounds; the IS for each method was held at a constant level in each solution. The phthalate ester calibration curve consisted of a 0 level standard and 5 other solutions spanning the range of 0.1-50 $\mu \mathrm{g} / \mathrm{mL}$. The diverse neutrals calibration curve consisted of a 0 level standard and 7 solutions spanning the range of $1-900 \mathrm{ng} / \mathrm{mL}$. The BDE calibration curve consisted of a 0 level standard and 5 solutions spanning the range of $2-1000 \mathrm{ng} / \mathrm{mL}$. The samples were run in an interspersed order with the calibration solutions. At the conclusion of data acquisition, linear regression analysis was used to generate the calibration curve for each analyte. The curve was applied to detected quantities using the internal standard method of quantification for the phthalate ester and diverse neutral analyses; the external standard method of quantification was used for the BDE analyses because of an interference to the IS from an unknown brominated compound. Solution concentration values were determined using the GC/MS software; concentration values were transferred to an Excel spreadsheet for further data processing.

Detection limits for SVOC compounds in air were estimated using the minimum amount (mass) of a compound detectable in a sample. These minimum detectable masses were treated as sample analysis results and corrected for surrogate recovery in the same way sample results were adjusted. The minimum air volume sampled from the six SVOC samples was used to determine a detection limit in mass per volume of air sampled. Only one detection limit (the most conservative, based on the lowest volume of air collected) is reported for each compound. 


\section{Results and Discussion}

Table 6 presents the sampling start and stop times for continuous measurements, SVOCs, carbonyls, and fungal sampling in each of the sampling locations. The collection time for each of the VOC samples is also shown. All times are in Mountain Daylight Time.

Table 6. Sampling Times

\begin{tabular}{|c|c|c|c|c|c|c|}
\hline \multirow[b]{2}{*}{ Parameter } & \multicolumn{6}{|c|}{ Location } \\
\hline & Roof & CR & O1 & O2 & O3 & O4 \\
\hline Continuous Start Time & $14: 57$ & $13: 16$ & $13: 55$ & $10: 37$ & 11:09 & 10:03 \\
\hline Continuous Stop Time & $15: 10$ & $13: 45$ & $14: 22$ & 11:07 & $13: 10$ & $10: 33$ \\
\hline SVOC Start Time & 08:39 & $09: 30$ & $09: 22$ & 09:39 & 09:48 & $10: 00$ \\
\hline SVOC Stop Time & $14: 57$ & $13: 46$ & $14: 22$ & $14: 41$ & $14: 37$ & $14: 29$ \\
\hline Carbonyl Start Time & $08: 45$ & $13: 30$ & $14: 02$ & $10: 52$ & $11: 25$ & $10: 19$ \\
\hline Carbonyl Stop Time & $08: 55$ & $13: 40$ & $14: 12$ & $11: 02$ & $11: 35$ & $10: 29$ \\
\hline Fungi Start Time & 09:00 & $13: 18$ & $13: 56$ & $10: 40$ & $11: 13$ & $10: 07$ \\
\hline Fungi Stop Time & $09: 10$ & $13: 28$ & $14: 06$ & $10: 50$ & $11: 23$ & $10: 17$ \\
\hline VOC Collection Time & $09: 15$ & $13: 21$ & $13: 58$ & $10: 43$ & $11: 15$ & $10: 09$ \\
\hline
\end{tabular}

\section{Continuous data}

Data for the continuously monitored chemical and physical parameters (carbon dioxide, ozone, $\mathrm{PM}_{10}$, temperature, humidity, sound level, and atmospheric pressure) were averaged over each measurement interval. Table 7 presents the average values for each of these parameters at each sampling location.

Table 7. Continuous Monitoring Results

\begin{tabular}{|c|c|c|c|c|c|c|c|}
\hline \multirow[b]{2}{*}{ Parameter } & \multicolumn{6}{|c|}{ Location } & \multirow{2}{*}{$\begin{array}{c}\text { Acceptable } \\
\text { Indoor Range }\end{array}$} \\
\hline & Roof & CR & O1 & $\mathrm{O} 2$ & O3 & O4 & \\
\hline $\mathrm{CO}_{2}(\mathrm{ppm})$ & 402 & 619 & 697 & 645 & 585 & 694 & $<1052^{\mathrm{a}}$ \\
\hline Ozone (ppb) & 157 & 14.2 & 17.7 & 19.5 & 17.1 & 26.8 & $75^{\mathrm{b}}$ \\
\hline $\mathrm{PM}_{10}\left(\mu \mathrm{g} / \mathrm{m}^{3}\right)$ & 33.9 & 20.6 & 22.3 & 18.6 & 18.6 & 13.8 & $<50^{c}$ \\
\hline Temperature $\left({ }^{\circ} \mathrm{C}\right)$ & 31.2 & 26.1 & 26.8 & 23.5 & 25.6 & 22.9 & $\begin{array}{c}20-23^{\mathrm{d}} \\
24-27^{\circ} \mathrm{C}^{\mathrm{e}}\end{array}$ \\
\hline Relative Humidity (\%) & 19 & 32 & 32 & 43 & 38 & 35 & $30-60 \%$ \\
\hline Sound Level $(\mathrm{dBa})$ & 61 & 65 & 62 & 61 & 62 & 62 & $60-70^{\mathrm{f}}$ \\
\hline Atm. Pressure (mbar) & 850 & 851 & 851 & 854 & 854 & 852 & NA \\
\hline
\end{tabular}

a ASHRAE 62.1-2007 standard of outdoor $\mathrm{CO}_{2}$ plus $650 \mathrm{ppm}$.

b 8-hour National Ambient Air Quality Standard (NAAQS) for ambient ozone.

c LEED new construction standard.

d Seppänen and Fisk (2006) optimal work performance range. 
e ASHRAE Standard 55-2004 acceptable temperature range for 0.5 Clo at measured humidity.

${ }_{\mathrm{f}}^{\mathrm{A}}$ range of normal conversation.

\section{$\underline{\text { Temperature and relative humidity }}$}

The day of the field measurement campaign was relatively warm with outdoor temperatures near $90^{\circ} \mathrm{F}\left(32^{\circ} \mathrm{C}\right)$. Temperatures at the five indoor measurement locations varied from $22.9^{\circ} \mathrm{C}$ to $26.8^{\circ} \mathrm{C}\left(73.3\right.$ to $\left.80.2^{\circ} \mathrm{F}\right)$. Relative humidity was $19 \%$ outdoors and ranged from 35 to $43 \%$ inside. As expected, the temperature steadily rose over the course of the day. The highest recorded indoor air temperature was found in Office 1 in the early afternoon. Each recorded indoor temperature/relative humidity combination falls within the acceptable ranges given in ASHRAE Standard 55-2004 (Thermal Environmental Conditions for Human Occupancy) (ASHRAE, 2004). The lower temperature environments (Office 2 and Office 4) fall within the occupant satisfaction range for a clothing insulation level of 1.0 (equivalent to trousers, long sleeve shirt, and sweater). The other environments fall within the occupant satisfaction range for a clothing insulation level of 0.5 (equivalent to trousers and a short sleeve shirt).

Even though the temperature/relative humidity combinations are acceptable under ASHRAE 55, the temperatures in the Copy Room, Office 1, and Office 3 exceed the $95^{\text {th }}$ percentile $\left(24.9^{\circ} \mathrm{C}\right)$ of the temperature measurements collected during the BASE study between 8:00 am and 5:00 pm (EPA, 2006) indicating that such temperatures are on the upper end of those typically encountered in office environments. In addition, Seppänen and Fisk (2006) found that optimal work performance occurs at temperatures between $20^{\circ} \mathrm{C}$ and $23^{\circ} \mathrm{C}$, with statistically significant decreases in work performance at temperatures greater than $23^{\circ} \mathrm{C}$. Only one of the five indoor locations had a temperature between $20^{\circ} \mathrm{C}$ and $23^{\circ} \mathrm{C}$, the remainder were higher.

\section{$\underline{\text { Carbon dioxide }}$}

The carbon dioxide measurements show that indoor levels of carbon dioxide were higher than outdoor levels, which is to be expected, given that sampling occurred on a weekday when the building was occupied. The levels measured in Office 1 and Office 4 were the highest, and those areas had the greatest density of people in the area while the measurements were being conducted. Measurements in Office 3 were conducted over lunch when the occupant density was low. This is reflected in the lower carbon dioxide measurements from Office 3 compared to the other indoor locations. Carbon dioxide levels in the Copy Room, Office 2 and Office 3 were between the $50^{\text {th }}(564 \mathrm{ppm})$ and $75^{\text {th }}$ (684 ppm) percentile of the measurements conducted during the BASE study between 8:00 am and 5:00 pm. Measurements from Office 1 and Office 4 were between the $75^{\text {th }}$ and $95^{\text {th }}(920 \mathrm{ppm})$ percentiles of the same subset of the BASE data (EPA, 2006).

All indoor carbon dioxide measurements were well below the OSHA and ACGIH indoor standards of $5000 \mathrm{ppm}$. The indoor carbon dioxide readings were also less than the ASHRAE 62.1-2007 standard which specifies that indoor carbon dioxide concentrations should be no more than 650 ppm greater than outdoor carbon dioxide levels. 
Ozone

Ozone is one of six criteria air pollutants whose outdoor concentrations are regulated by the US EPA (by way of National Ambient Air Quality Standards, NAAQS) because of its potential harm to human health and to the environment (http://www.epa.gov/air/urbanair/). In general, ozone encountered indoors is present because of transport from outdoors and indoor ozone concentrations are generally lower than outdoor levels (Weschler, 2000; Weschler, 2006). Nonetheless, minimizing indoor ozone concentrations is important given that ozone chemistry (reactions with VOCs and SVOCs, for instance) can generate sensory (eye and airway) irritants (Wolkoff et al., 2006).

On the day of the sampling event, outdoor ozone concentrations in Denver were very high. The outdoor concentration measured on the roof was $157 \mathrm{ppb}$. Indoor ozone concentrations were significantly lower, falling between 14 and $27 \mathrm{ppb}$. Indoor ozone concentrations are expected to be lower than outdoor concentrations due to losses during transport indoors. The indoor-to-outdoor $(\mathrm{I}: \mathrm{O})$ ratio was in the range of 0.09 to 0.17 for the sampling locations. These I:O ozone ratios are lower than the range of 0.22-0.9 for offices reported by Weschler (2000). I:O ratios of ozone have been found to be $<0.10$ for residences with central air conditioning (Weschler, 2006). The lower I:O ratios measured in this study may be due to more efficient removal of ozone in this building's HVAC system than in other buildings' HVAC systems. Ozone is very reactive and is often removed to a large degree by a HVAC system and other indoor surfaces. Ozone measurements were not among those performed during the BASE study so no comparison to BASE data can be performed.

\section{$\underline{\text { Particulate matter }}$}

Similar to ozone, outdoor particulate matter (PM) is a criteria pollutant and ambient PM concentrations governed by the NAAQS (http://www.epa.gov/air/particlepollution/). Exposure to particle pollution also occurs indoors. In this study, PM concentrations measured in the indoor spaces were generally low. Concentrations increased slightly over the course of the day, but this increase may be due to instrument drift observed in the measurements when particulate concentrations are low. Indoor particulate concentrations were lower than those measured in outdoor air $\left(13.8-22.3 \mu \mathrm{g} / \mathrm{m}^{3}\right.$ inside compared to $33.1 \mu \mathrm{g} / \mathrm{m}^{3}$ outside). All of the measured concentrations were well below the LEED new construction standard of $50 \mu \mathrm{g} / \mathrm{m}^{3}$ (LEED, 2005) but were elevated (between the $75^{\text {th }}$ and $95^{\text {th }}$ percentiles) compared to office buildings monitored in the BASE study. Outdoor particulate may be transported indoors through the HVAC system, although losses are expected. Resuspension may also cause elevated particulate matter levels (Ferro et al., 2004). In general, particulate matter concentrations are low and are not above levels of concern. 


\section{$\underline{\text { Sound levels }}$}

The sound levels measured at the various sampling locations showed little variability with all locations at either 61 or $62 \mathrm{dBa}$ except for the Copy Room which had a sound level of $65 \mathrm{dBa}$. These sound levels are likely to be slightly higher than actual ambient sound levels due to the operation of the monitoring equipment during the sound level measurements. This slight positive bias may account for the fact that all of the sound level measurements in the EPA Region VIII Headquarters building were between the $75^{\text {th }}$ $(59 \mathrm{dBa})$ and $95^{\text {th }}(68 \mathrm{dBa})$ percentiles of the BASE data collected between 8:00 am and 5:00 pm (EPA, 2006). For comparison, a whisper quiet library is typically $30 \mathrm{dBa}$, while normal conversation at three to five feet is in the range of 60 to $70 \mathrm{dBa}$. Nonetheless, excessive indoor noise is not a problem at this office building.

\section{Fungal spores}

Microbiological contamination in occupied buildings has been reported to cause respiratory symptoms and other negative health outcomes associated with Sick Building Syndrome (SBS) (see Wu et al., 2004 and references therein). Thus sampling for airborne fungi was undertaken as part of this IEQ survey. Data for the fungal spore traps are presented in Table 8. The table includes the total fungi count in number per cubic meter, as well as the raw counts of individual types of spores found on each spore trap. In addition to the types listed, 12 types of spores (Bipolaris ++ , Chaetomium, Curvularia, Epicoccum, Fusarium, Ganoderma, Rust, Scopulariopsis, Stachybotrys, Torula, Ulocladium, and Zygomycetes) were not detected in any of the samples. Levels of non-fungal material (skin fragments, fibrous particulate and background) were reported on a scale of 1 (low loading) to 5 (high loading). Background levels of 5 may interfere with spore identification and enumeration. All samples collected had background levels of 3 or lower.

Table 8. Concentrations of Fungal Spores

\begin{tabular}{|c|c|c|c|c|c|c|c|}
\hline \multirow{2}{*}{ Parameter } & \multicolumn{6}{|c|}{ Location } & \multirow{2}{*}{$\begin{array}{c}\text { Acceptable } \\
\text { Indoor Range }\end{array}$} \\
\hline & Roof & CR & O1 & $\mathbf{O} 2$ & $\mathbf{O 3}$ & $\mathbf{O 4}$ & \\
\hline Total Spores $\left(\# / \mathrm{m}^{3}\right)$ & 3510 & 84 & 84 & 63 & 42 & 42 & $<1000^{\mathrm{a}}$ \\
\hline Total Fungi (raw count) & 167 & 4 & 4 & 3 & 2 & 2 & \\
\hline Alternaria (raw count) & 3 & 2 & 0 & 0 & 0 & 0 & \\
\hline Ascospores (raw count) & 65 & 0 & 0 & 0 & 0 & 0 & \\
\hline $\begin{array}{l}\text { Aspergillus/Penicillium } \\
\text { (raw count) }\end{array}$ & 10 & 0 & 1 & 2 & 0 & 0 & \\
\hline Basidiospores & 37 & 0 & 1 & 0 & 0 & 0 & \\
\hline Cladosporium & 34 & 1 & 1 & 0 & 1 & 1 & \\
\hline Myxomycete & 16 & 1 & 1 & 1 & 1 & 1 & \\
\hline
\end{tabular}




\begin{tabular}{|l|l|l|l|l|l|l|l|}
\hline Pithomyces & 1 & 0 & 0 & 0 & 0 & 0 & \\
\hline Peronospora & 1 & 0 & 0 & 0 & 0 & 0 & \\
\hline
\end{tabular}
a Typical level of concern for fungi in indoor air (Wu et al., 2004)

Fungi measurements in the indoor spaces were very low. All of the sampling locations had fungi loading below the $50^{\text {th }}$ percentile of the BASE data $\left(121 \mathrm{spores} / \mathrm{m}^{3}\right)$. The indoor fungi concentrations were significantly lower than the outdoor concentration indicating that fungi in the outdoor air may be removed by the HVAC system or by deposition to surfaces. A typical threshold level of concern for fungi in indoor air is 1000 spores $/ \mathrm{m}^{3}$ (Wu et al., 2004). Daisey et al. (2003) performed fungi measurements in schools and found (1) at concentrations less than 700 spores $/ \mathrm{m}^{3}$, occupants did not voice complaints related to fungi; and (2) outdoor fungi concentrations were typically higher than those measured indoors. The concentrations of fungi measured in this office building are lower than in most other office buildings and are below typical levels of concern.

\section{$\underline{\text { VOC data }}$}

VOCs are organic compounds (compounds containing carbon and hydrogen) that have vapor pressures between 0.1 to $380 \mathrm{~mm} \mathrm{Hg}$ at $25^{\circ} \mathrm{C}$ (Spicer et al., 2002). A total of 67 VOCs and very volatile organic compounds (VVOCs, those with VPs $>380 \mathrm{~mm} \mathrm{Hg}$ at $25^{\circ} \mathrm{C}$; Spicer et al., 2002) were measured during this study -64 using stainless steel canisters and 3 by way of air sampling onto DNPH cartridges. (For the purpose of this study, the VVOCs and VOCs will be referred to together simply as VOCs.) Forty five of these 68 VOCs are classified by the US EPA under the US Clean Air Act Amendments of 1990 to be among the 187 hazardous air pollutants (HAPs), defined as "those pollutants that are known or suspected to cause cancer or other serious health effects, such as reproductive effects or birth defects, or adverse environmental effects" (http://www.epa.gov/ttn/atw/allabout.html). Given the prevalence and variety of indoor sources of VOCs, for instance, from adhesives, paints, consumer products, and furnishings, indoor concentrations of these compounds can in many cases be higher than outdoor concentrations.

Although most VOC levels found indoors are well below levels shown to demonstrate measureable (immediate or acute) health impacts (Jones, 1999), minimizing exposure to these compounds - given their toxicity and potential to cause cancer - is of great importance to promoting the health of building occupants. 
Of the 67 VOCs for which analysis was performed in the present work, 40 were monitored as part of the BASE study. A total of 25 of the 67 compounds measured in this study were detected in at least one sample, and concentrations of these 25 compounds for these VOCs are shown in Tables 9 and 10. Shown as well in these tables are corresponding BASE data and other typical indoor concentrations measured in other studies and applicable standards. In these and future tables, "benchmark" indoor air concentrations against which concentrations measured in this study are compared may be data from indoor air in residences, retail commercial buildings, office environments, or miscellaneous workplace environments.

Table 9. VOC Concentrations Compared to BASE Data and Other Benchmarks $\left(\mu \mathrm{g} / \mathrm{m}^{3}\right)$

\begin{tabular}{|c|c|c|c|c|c|c|c|c|c|c|c|}
\hline \multirow{2}{*}{ Compound } & \multicolumn{7}{|c|}{ Location } & \multicolumn{3}{|c|}{ BASE Data $^{a}$} & \multirow{2}{*}{$\begin{array}{c}\text { Other Benchmark } \\
\text { (reference) }\end{array}$} \\
\hline & DL & Roof & CR & O1 & $\mathrm{O} 2$ & O3 & O4 & $5^{\text {th }}$ & $50^{\text {th }}$ & $95^{\text {th }}$ & \\
\hline Acetone & 0.47 & 30 & 61 & 62 & 46 & 46 & 79 & 9.9 & 30 & 110 & \\
\hline Acrolein & 0.46 & $<\mathrm{DL}$ & 2.3 & 1.9 & 2.0 & $<\mathrm{DL}$ & $<\mathrm{DL}$ & $\mathrm{b}$ & & & $<\mathrm{DL}^{\mathrm{c}}, 0.59^{\mathrm{d}}, 5.54^{\mathrm{e}}(1)$ \\
\hline Benzene & 0.64 & 1.5 & 1.7 & 1.6 & 2.3 & 2.4 & 2.1 & 1.1 & 3.6 & 9.1 & \\
\hline 2-Butanone & 0.59 & 6.1 & 8.1 & 6.8 & 6.9 & 8.0 & 11 & 0.81 & 2.6 & 7.8 & \\
\hline Carbon disulfide & 0.62 & $<\mathrm{DL}$ & 0.65 & 0.68 & 0.72 & 0.68 & 0.65 & $\leq \mathrm{LOQ}^{\mathrm{f}}$ & $\leq \mathrm{LOQ}$ & 6.4 & \\
\hline Chloromethane & 0.41 & 1.3 & 1.3 & 1.4 & 1.2 & 1.3 & 1.4 & 1.8 & 2.5 & 4.3 & \\
\hline Cyclohexane & 0.69 & $<\mathrm{DL}$ & 0.93 & 0.86 & 1.1 & 1.2 & 0.96 & $\mathrm{~b}$ & & & $<0.054^{\mathrm{d}}, 26.8^{\mathrm{g}}(2)$ \\
\hline $\begin{array}{l}\text { Dichlorodifluoro- } \\
\text { methane }\end{array}$ & 0.99 & 2.6 & 2.7 & 2.6 & 2.6 & 2.7 & 2.6 & $\leq \mathrm{LOQ}$ & 6.8 & 36 & \\
\hline Ethanol & 0.38 & 34 & 204 & 217 & 133 & 168 & 158 & $\leq \mathrm{LOQ}$ & 79 & 260 & \\
\hline Ethylbenzene & 0.87 & $<\mathrm{DL}$ & $<\mathrm{DL}$ & $<\mathrm{DL}$ & 1.0 & 1.0 & 1.0 & 0.43 & 1.5 & 6.2 & \\
\hline Heptane & 0.82 & $<\mathrm{DL}$ & 1.0 & 0.94 & 1.4 & 1.5 & 1.4 & $\mathrm{~b}$ & & & $0.9^{\mathrm{d}}, 3.8^{\mathrm{h}}(3)$ \\
\hline Hexane & 0.70 & 2.2 & 3.1 & 2.5 & 3.4 & 3.7 & 2.9 & $\leq \mathrm{LOQ}$ & 2.5 & 12 & \\
\hline Isoprene & 0.56 & $<\mathrm{DL}$ & 2.3 & 4.0 & 0.75 & 1.6 & 3.1 & $\mathrm{~b}$ & & & i \\
\hline Isopropyl alcohol & 0.49 & $<\mathrm{DL}$ & 15 & 22 & 21 & 21 & 31 & $\mathrm{~b}$ & & & $6.2^{\mathrm{d}}, 676^{\mathrm{h}}(3)$ \\
\hline Methylene chloride & 0.69 & $<\mathrm{DL}$ & 0.90 & $<\mathrm{DL}$ & 0.83 & 0.73 & 0.83 & $\leq \mathrm{LOQ}$ & 2.9 & 16 & \\
\hline Propene & 0.34 & 7.1 & 8.3 & 6.6 & 9.5 & 10 & 8.6 & $\mathrm{~b}$ & & & $\mathrm{i}$ \\
\hline Toluene & 0.75 & 4.1 & 13 & 7.3 & 9.4 & 9.8 & 11 & 2.7 & 8.7 & 39 & \\
\hline $\begin{array}{l}\text { Trichloro- } \\
\text { fluoromethane }\end{array}$ & 1.1 & 1.3 & 1.4 & 1.4 & 1.5 & 1.4 & 1.5 & $\leq \mathrm{LOQ}$ & 3.9 & 51 & \\
\hline $\begin{array}{l}1,2,4- \\
\text { Trimethylbenzene }\end{array}$ & 0.98 & $<\mathrm{DL}$ & $<\mathrm{DL}$ & $<\mathrm{DL}$ & $<\mathrm{DL}$ & $<\mathrm{DL}$ & 1.03 & 0.61 & 1.9 & 12 & \\
\hline Vinyl acetate & 0.70 & $<\mathrm{DL}$ & $<\mathrm{DL}$ & 1.2 & $<\mathrm{DL}$ & $<\mathrm{DL}$ & $<\mathrm{DL}$ & $\mathrm{b}$ & & & i \\
\hline m- \& p-Xylenes & 0.87 & 1.5 & 1.9 & 1.8 & 2.6 & 2.8 & 2.6 & 1.3 & 5.1 & 24 & \\
\hline o-Xylene & 0.87 & $<\mathrm{DL}$ & $<\mathrm{DL}$ & $<\mathrm{DL}$ & 1.0 & 1.0 & 1.0 & 0.59 & 2.1 & 8.2 & \\
\hline $\begin{array}{l}\text { a BAS } \\
\text { b No B } \\
\text { c 5th, } \\
{ }^{\mathrm{f}} \text { Limi } \\
{ }_{\mathrm{g}}^{\mathrm{g}} \text { Maxi } \\
\text { h } 90 \text { th } \\
{ }^{\mathrm{i}} \text { Typic } \\
\text { (1) L } \\
\text { (2) J } \\
\text { (3) }\end{array}$ & $\begin{array}{l}\text { lata (pc } \\
\text { SE dat } \\
\text { th and } \\
\text { f quan } \\
\text { am. } \\
\text { rcentile } \\
\text { concen } \\
\text { et al., } \\
\text { et al., } \\
\text { und et }\end{array}$ & $\begin{array}{l}\text { centiles) } \\
\text { for these } \\
95^{\text {th }} \text { perc } \\
\text { fication } \\
\text { ations et } \\
006 \text {; dat } \\
\text { 08; data } \\
\text { l. 2008; }\end{array}$ & $\begin{array}{l}\text { ce availab } \\
\text { compoun } \\
\text { ntiles. } \\
\text { r BASE } \\
\text { ountered } \\
\text { from Rel } \\
\text { rom resi } \\
\text { ata from }\end{array}$ & $\begin{array}{l}\text { at http: } \\
\text { s. } \\
\text { ata. } \\
\text { ndoors r } \\
\text { tionship } \\
\text { ences. } \\
\text { ommerc }\end{array}$ & $\begin{array}{l}\text { t availab } \\
\text { of Indoo }\end{array}$ & Outdoor & and Pers & nal air $(\mathrm{R}$ & PA) stud & of resic & tial air. \\
\hline
\end{tabular}


Of the compounds listed in Table 9, only 2-butanone (methyl ethyl ketone) was measured at a concentration greater than the $95^{\text {th }}$ percentile of the BASE data, or similar upper limit from another benchmark study. 2-butanone is used as a solvent in resins, adhesives, and vinyl films. It is also present in some cleaning fluids and can be used as a printing catalyst. Levels of 2-butanone were measured above the $95^{\text {th }}$ percentile concentration in three locations (Copy Room, Office 3, and Office 4). The outdoor concentration of 2butanone was elevated, but was lower than all of the 2-butanone concentrations measured at the indoor locations. Higher indoor levels of 2-butanone may be the result of emissions from resins or adhesives in consumer products or may come from cleaning agents used in the indoor spaces. Longer term measurement, including observation of building occupant activity would be needed to determine if this was a one-time or sustained concentration.

Of the remaining compounds in Table 6 for which benchmarks are available, acetone, acrolein, cyclohexane, ethanol, heptane, hexane, isopropyl alcohol, toluene, and $\mathrm{m} / \mathrm{p}$ xylenes were detected at levels greater than the $50^{\text {th }}$ percentile concentrations reported from the BASE study. Ethanol and acetone are human bioeffluents (Fenske \& Paulson, 1999) so the presence of these compounds is expected in areas which are populated. Isopropyl alcohol is found in many surface and packaged hand cleaners, thus its presence at higher indoor concentrations than outdoor concentrations in office environments is not surprising. Acrolein is a toxic HAP and a severe lung irritant which may be formed indoors by reaction of VOCs offgassing from building materials, adhesives, and carpets (Seaman et al., 2007, and references therein). Hexane, toluene, and m\&p-xylenes are also HAPs and are indicative of the penetration of automobile exhaust into the building envelope, and may also be due to emissions from indoor sources such as solvents, cleaners, and office equipment (Destaillats et al., 2008). This is especially the case with the higher level of toluene in the Copy Room; toluene is emitted from photocopiers (Destaillats et al., 2008 and references therein).

Table 10 presents data for the three VOCs measured using the DNPH cartridges. Data have been blank corrected; blank corrections did not exceed the equivalent concentration of 1.85 $\mu \mathrm{g} / \mathrm{m}^{3}$. Detection limits for all three carbonyls are conservatively estimated to be $\sim 0.5$ $\mu g / \mathrm{m}^{3}$.

Table 10. Concentrations of Selected Carbonyls Compared to BASE Data and Other Benchmarks $\left(\mu \mathrm{g} / \mathrm{m}^{3}\right)$

\begin{tabular}{|c|c|c|c|c|c|c|c|c|c|c|c|c|c|}
\hline \multirow{2}{*}{ Compound } & \multicolumn{6}{|c|}{ Location } & \multicolumn{3}{|c|}{ BASE Data ${ }^{a}$} & \multirow{2}{*}{$\begin{array}{c}\text { LEED } \\
\mathrm{NC}^{\mathrm{b}}\end{array}$} & \multicolumn{3}{|c|}{ RIOPAc $^{c}$} \\
\hline & Roof & CR & O1 & $\mathrm{O} 2$ & O3 & O4 & $5^{\text {th }}$ & $50^{\text {th }}$ & $95^{\text {th }}$ & & $5^{\text {th }}$ & $50^{\text {th }}$ & $95^{\text {th }}$ \\
\hline Acetaldehyde & 4.3 & 11.3 & 10.8 & 8.9 & 9.2 & 8.6 & 2.6 & 7.2 & 15 & $\mathrm{~d}$ & 7.53 & 18.6 & 50.2 \\
\hline Formaldehyde & 5.3 & 20.4 & 20.9 & 21.3 & 20.6 & 26.1 & 4.4 & 15 & 32 & 61.4 & 12.5 & 20.1 & 32.5 \\
\hline Propionaldehyde & 1.5 & 2.3 & 2.2 & 1.9 & 2.0 & 1.8 & $\mathrm{e}$ & & & $\mathrm{d}$ & 0.23 & 1.74 & 3.65 \\
\hline
\end{tabular}

${ }^{a}$ BASE data (given as percentiles) are available at http://www.epa.gov/iaq/base/voc master list.html (EPA, 2006).

b LEED New Construction standard.

c Percentiles from Relationships of Indoor, Outdoor, and Personal Air (RIOPA) study of residential air; see Liu et al., 2006.

d No LEED standards for these compounds. 
${ }^{\mathrm{e}}$ No BASE data for this compound.

The concentrations of formaldehyde and acetaldehyde measured in the outdoor sample are typical of those found in urban atmospheres (Finlayson-Pitts \& Pitts, 2000). It is typical to see elevated indoor concentrations of the aldehydes in Table 10 due to the presence of indoor sources. Indoor concentrations for these compounds are between the $50^{\text {th }}$ and $95^{\text {th }}$ percentiles of the BASE or RIOPA (Relationships of Indoor, Outdoor, and Personal Air; Liu et al., 2006) data.

Formaldehyde is the most ubiquitous carbonyl found in the gas phase, and is a carcinogenic HAP (Liu et al., 2006). Indoor concentrations of formaldehyde throughout the EPA Region VIII office building were below the LEED new construction formaldehyde standard of $50 \mathrm{ppb}\left(61.4 \mu \mathrm{g} / \mathrm{m}^{3}\right)$ (LEED, 2005). Concentrations of indoor formaldehyde are also well below the American Conference of Governmental \& Industrial Hygienists (ACGIH) Threshold Limit Value (TLV) for occupational exposures of $300 \mathrm{ppb}\left(368 \mu \mathrm{g} / \mathrm{m}^{3}\right)$, a ceiling value which should not be exceeded at any time. The formaldehyde concentrations are somewhat elevated compared to measurements performed in other office buildings. This may be due to elevated outdoor ozone levels on the sampling day, as outdoor ozone penetrating indoors causes chemical reactions in which formaldehyde is formed, or may be due to the presence of indoor sources of formaldehyde, such as adhesives, insulation, and composite wood materials in the building. While the levels are somewhat elevated compared to concentrations measured in other office buildings and compared to outdoor concentrations, they do not reach levels of concern with respect to the health of the building occupants.

Forty-two of the 67 VOCs measured in this study were not detected in any of the six samples. Table 11 lists these compounds, estimated detection limits in $\mu \mathrm{g} / \mathrm{m}^{3}$ (based on $\sim 0.2 \mathrm{ppb}$ DL for each compound), and benchmark data for these compounds. Of note is that ethyl acetate was detected in $100 \%$ of the BASE samples but was not detected in any of the samples collected during this study. Ethyl acetate is a solvent found in consumer products.

For the 67 VOCs measured in this study, concentrations are low and similar to those found in other studies of indoor air in residences and office environments. Such indicates that, for the 67 VOCs measured, acute health hazards caused by high VOC concentrations are not a concern in this building. However, the presence of hazardous air pollutants at any concentration in indoor air represents a non-negligible long-term health concern for building occupants. At minimum, reducing indoor levels of HAPs to ambient outdoor levels either by source control or by filtration through activated carbon is a goal to be considered. 


\section{Table 11. VOCs Not Detected in Any Samples, Compared to BASE and Other Benchmark Data $\left(\mu \mathrm{g} / \mathrm{m}^{3}\right)$}

\begin{tabular}{|c|c|c|c|c|c|}
\hline \multirow{2}{*}{ Compound } & \multirow{2}{*}{ DL } & \multicolumn{3}{|c|}{ BASE Data $^{a}$} & \multirow{2}{*}{$\begin{array}{l}\text { Benchmark } \\
\text { (reference) }\end{array}$} \\
\hline & & $5^{\text {th }}$ & $50^{\text {th }}$ & $95^{\text {th }}$ & \\
\hline Benzyl chloride & 1.0 & $\mathrm{~b}$ & & & $<1^{\mathrm{c}}(1)$ \\
\hline Bromodichloromethane & 1.3 & $\mathrm{~b}$ & & & $<0.6^{\mathrm{d}}-5^{\mathrm{e}} ;<5^{\mathrm{f}}(1)$ \\
\hline Bromoform (Tribromomethane) & 2.1 & $\mathrm{~b}$ & & & $<^{\mathrm{c}}(1)$ \\
\hline 1,3-Butadiene & 0.44 & $\leq \mathrm{LOQ}$ & $\leq \mathrm{LOQ}$ & $\leq \mathrm{LOQ}$ & \\
\hline Carbon tetrachloride & 1.3 & $\leq \mathrm{LOQ}$ & $\leq \mathrm{LOQ}$ & 0.74 & \\
\hline Chlorobenzene & 0.92 & $\leq \mathrm{LOQ}$ & $\leq \mathrm{LOQ}$ & 0.26 & \\
\hline Chloroform (Trichloromethane) & 0.98 & $\leq \mathrm{LOQ}$ & $\leq \mathrm{LOQ}$ & 1.3 & \\
\hline Dibromochloromethane & 1.7 & $\mathrm{~b}$ & & & $<0.6^{c}(1)$ \\
\hline 1,2-Dibromoethane & 1.5 & $\leq \mathrm{LOQ}$ & $\leq \mathrm{LOQ}$ & $\leq \mathrm{LOQ}$ & \\
\hline 1,2-Dichlorobenzene & 1.2 & $\leq \mathrm{LOQ}$ & $\leq \mathrm{LOQ}$ & $\leq \mathrm{LOQ}$ & \\
\hline 1,3-Dichlorobenzene & 1.2 & $\mathrm{~b}$ & & & $<1.6^{\mathrm{d}}-5^{\mathrm{e}} ;<2^{\mathrm{f}}(1)$ \\
\hline 1,4-Dichlorobenzene & 1.2 & $\leq \mathrm{LOQ}$ & 0.54 & 13 & \\
\hline 1,1-Dichloroethane & 0.81 & LOQ & $\leq \mathrm{LOQ}$ & $\leq \mathrm{LOQ}$ & \\
\hline 1,2-Dichloroethane & 0.81 & $\leq \mathrm{LOQ}$ & $\leq \mathrm{LOQ}$ & $\leq \mathrm{LOQ}$ & \\
\hline 1,1-Dichloroethene & 0.79 & $\leq \mathrm{LOQ}$ & $\leq \mathrm{LOQ}$ & $\leq \mathrm{LOQ}$ & \\
\hline cis-1,2-Dichloroethene & 0.79 & $\mathrm{~b}$ & & & $<1^{\mathrm{c}}(1)$ \\
\hline trans-1,2-Dichloroethene & 0.79 & $\mathrm{~b}$ & & & $<4^{\mathrm{c}}(1)$ \\
\hline 1,2-Dichloropropane & 0.92 & $\mathrm{~b}$ & & & $<1^{\mathrm{c}}(1)$ \\
\hline cis-1,3-Dichloropropene & 0.91 & $\leq \mathrm{LOQ}$ & $\leq \mathrm{LOQ}$ & $\leq \mathrm{LOQ}$ & \\
\hline trans-1,3-Dichloropropene & 0.91 & $\leq \mathrm{LOQ}$ & $\leq \mathrm{LOQ}$ & $\leq \mathrm{LOQ}$ & \\
\hline 1,2-dichlorotetrafluoroethane & 1.4 & $\mathrm{~b}$ & & & $<1.6^{\mathrm{c}}(1)$ \\
\hline 1,4-Dioxane & 0.72 & $\mathrm{~b}$ & & & $\mathrm{~h}$ \\
\hline Ethyl acetate & 0.72 & 0.34 & 2.0 & 7.5 & \\
\hline Ethyl chloride (Chloroethane) & 0.53 & $\leq \mathrm{LOQ}$ & $\leq \mathrm{LOQ}$ & $\leq \mathrm{LOQ}$ & \\
\hline Hexachloro-1,3-butadiene & 2.1 & $\mathrm{~b}$ & & & $<2^{\mathrm{c}}(1)$ \\
\hline 4-Ethyl toluene & 0.98 & $\mathrm{~b}$ & & & $2.26^{\mathrm{f}}, 61.6^{\mathrm{e}}(2)$ \\
\hline 2-Hexanone & 0.82 & $\mathrm{~b}$ & & & $\mathrm{~h}$ \\
\hline Methyl bromide (Bromomethane) & 0.78 & $\leq \mathrm{LOQ}$ & $\leq \mathrm{LOQ}$ & 0.12 & \\
\hline Methyl isobutyl ketone & 0.82 & $\leq \mathrm{LOQ}$ & 1.0 & 7.2 & \\
\hline Methyl methacrylate & 0.82 & $\mathrm{~b}$ & & & $<0.17^{\mathrm{f}}, 26.8^{\mathrm{e}}(2)$ \\
\hline Methyl tert-butyl ether & 0.72 & $\leq \mathrm{LOQ}$ & $\leq \mathrm{LOQ}$ & 14 & \\
\hline Styrene & 0.85 & 0.091 & 0.91 & 3 & \\
\hline 1,1,2,2-Tetrachloroethane & 1.4 & $\mathrm{~b}$ & & & $<5^{c}(1)$ \\
\hline Tetrachloroethene & 1.4 & 0.3 & 1.5 & 18 & \\
\hline Tetrahydrofuran & 0.59 & $\mathrm{~b}$ & & & $<0.17^{\mathrm{f}}, 244^{\mathrm{e}}(2)$ \\
\hline 1,2,4-Trichlorobenzene & 1.5 & $\leq \mathrm{LOQ}$ & $\leq \mathrm{LOQ}$ & $\leq \mathrm{LOQ}$ & \\
\hline 1,1,1-Trichloroethane & 1.1 & 0.97 & 3.1 & 21 & \\
\hline 1,1,2-Trichloroethane & 1.1 & $\mathrm{~b}$ & & & $<1^{\mathrm{c}}(1)$ \\
\hline Trichloroethene & 1.1 & $\mathrm{~b}$ & & & $<0.6^{\mathrm{d}}-13^{\mathrm{e}} ;<2.8^{\mathrm{f}}(1)$ \\
\hline 1,1,2-Trichloro-1,2,2-Trifluoroethane & 1.5 & $\mathrm{~b}$ & & & $0.5^{\mathrm{f}}, 7^{\mathrm{e}}(3)$ \\
\hline 1,3,5-Trimethylbenzene & 0.98 & $\leq \mathrm{LOQ}$ & 0.54 & 3.9 & \\
\hline Vinyl chloride (Chloroethene) & 0.51 & $\leq \mathrm{LOQ}$ & $\leq \mathrm{LOQ}$ & $\leq \mathrm{LOQ}$ & \\
\hline
\end{tabular}

a BASE data (percentiles) are available at http://www.epa.gov/iaq/base/voc master list.html (EPA, 2006).

${ }^{\mathrm{b}}$ No BASE data for these compounds. ${ }^{\mathrm{c}}$ No detects above DL. ${ }^{\mathrm{d}}$ Minimum, ${ }^{\mathrm{e}}$ maximum, ${ }^{\mathrm{f}}$ median. 
${ }^{\mathrm{g}}$ Limit of quantification for BASE data. ${ }^{\mathrm{h}}$ Typical concentrations encountered indoors not available. (1) New York State Department of Health 1997 survey of residential indoor air. Available at: http://www.health.state.ny.us/environmental/investigations/soil_gas/svi_guidance/

(2) Jia et al., 2008; data from residences.

(3) Dawson and McAlary, 2009; data from residences.

\section{$\underline{\text { SVOC data }}$}

SVOCs are organic compounds that have vapor pressures generally between $10^{-7}$ and 0.1 $\mathrm{mm} \mathrm{Hg}$ at $25^{\circ} \mathrm{C}$ (Spicer et al., 2002). Few measurements of the large suite of SVOCs measured in this study have been made in office environments. For instance, of the 43 SVOCs measured in this study, only limonene and naphthalene were measured in the BASE study. Also, few single studies (with the exception of Rudel et al., 2003) have measured as many different classes of SVOCs during a single study. Many of the SVOCs measured here are considered to be among those known as endocrine disrupting compounds (EDCs) whose potential health effects have recently become the subject of intense scientific investigation (see Rudel et al., 2003, and references therein). In general, minimizing concentrations of such SVOCs in the workplace is becoming acknowledged as important for maintaining the long-term health of building occupants.

Tables 12, 13, and 14 present SVOC concentrations measured in this study, in the BASE study, as well as benchmark data from other studies. Table 12 presents data for the phthalate esters and BDEs; PAH concentrations are given in Table 13; and indoor air concentrations for a variety of different SVOCs such as pesticides, those found in fragranced consumer products, and phosphate flame retardants are shown in Table 14.

\section{Table 12. Phthalate and BDE Concentrations Compared to Benchmark Data $\left(\mathrm{ng} / \mathrm{m}^{3}\right)$}

\begin{tabular}{|c|c|c|c|c|c|c|c|c|}
\hline \multirow{2}{*}{ Compound } & \multirow{2}{*}{ DL } & \multicolumn{6}{|c|}{ Location } & \multirow{2}{*}{$\begin{array}{c}\text { Benchmark } \\
\text { (reference) }\end{array}$} \\
\hline & & Roof & CR & O1 & $\mathrm{O} 2$ & O3 & O4 & \\
\hline $\begin{array}{l}\text { Diethyl phthalate } \\
\text { (DEP) }\end{array}$ & 10 & 50 & 270 & 540 & 240 & 140 & 270 & $\begin{array}{c}130^{\mathrm{a}}-4300^{\mathrm{b}} ; 590^{\mathrm{c}}(1) \\
353^{\mathrm{c}}-5481^{\mathrm{b}}(2)\end{array}$ \\
\hline $\begin{array}{l}\text { Dibutyl phthalate } \\
\text { (DBP) }\end{array}$ & 10 & 2240 & 170 & 150 & 180 & 190 & 90 & $\begin{array}{l}52^{\mathrm{a}}-1100^{\mathrm{b}} ; 220^{\mathrm{c}}(1) \\
1083^{\mathrm{c}}-13305^{\mathrm{b}}(2)\end{array}$ \\
\hline $\begin{array}{l}\text { Butyl benzyl } \\
\text { phthalate (BBP) }\end{array}$ & 10 & $<\mathrm{DL}$ & 70 & $<\mathrm{DL}$ & 20 & 10 & 10 & $\begin{array}{c}<31^{\mathrm{a}}-480^{\mathrm{b}} ;<31^{\mathrm{c}}(1) \\
18^{\mathrm{c}}-575^{\mathrm{b}}(2)\end{array}$ \\
\hline $\begin{array}{l}\text { Di-2-ethyl hexyl } \\
\text { phthalate (DEHP) }\end{array}$ & 10 & 10 & 170 & 50 & 50 & 50 & 30 & $\begin{array}{c}<59^{\mathrm{a}}-1000^{\mathrm{b}} ; 77^{\mathrm{c}}(1) \\
156^{\mathrm{c}}-2253^{\mathrm{b}}(2)\end{array}$ \\
\hline BDE 47 & 0.01 & $<\mathrm{DL}$ & 0.01 & $<\mathrm{DL}$ & 0.22 & 0.08 & 0.01 & $\begin{array}{c}0.058^{\mathrm{a}}-7.14^{\mathrm{b}} ; 0.690^{\mathrm{c}}(3) \\
<0.062^{\mathrm{a}}-2.37^{\mathrm{b}} ; 0.145^{\mathrm{d}}(4)\end{array}$ \\
\hline BDE 100 & 0.01 & $<\mathrm{DL}$ & $<\mathrm{DL}$ & $<\mathrm{DL}$ & 0.03 & $<\mathrm{DL}$ & 0.07 & $\begin{array}{c}0.004^{\mathrm{a}}-1.45^{\mathrm{b}} ; 0.063^{\mathrm{c}}(3) \\
<0.010^{\mathrm{a}}-0.156^{\mathrm{b}} ; 0.012^{\mathrm{d}}(4)\end{array}$ \\
\hline BDE 99 & 0.03 & $<\mathrm{DL}$ & $<\mathrm{DL}$ & $<\mathrm{DL}$ & 0.07 & $<\mathrm{DL}$ & 0.28 & $\begin{array}{c}0.009^{\mathrm{a}}-6.51^{\mathrm{b}} ; 0.173^{\mathrm{c}}(3) \\
<0.049^{\mathrm{a}}-0.553^{\mathrm{b}} ; 0.060^{\mathrm{d}}(4)\end{array}$ \\
\hline BDE 209 & 0.78 & $<\mathrm{DL}$ & $<\mathrm{DL}$ & $<\mathrm{DL}$ & $<\mathrm{DL}$ & $<\mathrm{DL}$ & $<\mathrm{DL}$ & $\begin{array}{c}<0.048^{\mathrm{a}}-0.651^{\mathrm{b}} ; 0.094^{\mathrm{d}}(4) \\
0.058^{\mathrm{a}}-7.14^{\mathrm{b}} ; 0.690^{\mathrm{c}}(3)\end{array}$ \\
\hline
\end{tabular}

${ }^{\mathrm{a} M i n i m u m ;}$ ' ${ }^{\mathrm{M} M a x i m u m}$; ${ }^{\mathrm{c} M e d i a n}$; ${ }^{\mathrm{d}}$ Geometric mean

(1) Rudel et al., 2003; data from residences 
(2) Fromme et al., 2004; data from kindergartens and residences

(3) Harrad et al., 2004; data from workplace environments

(4) Allen et al., 2007; data from the main living area in residences

Phthalate esters are plasticizers used in the production of soft plastics such as softened polyvinyl chloride (PVC); other uses for phthalates are for dielectrics in electronics components, emulsifiers in personal care products, and as additives in glues, paints, and coatings (Fromme et al., 2004). Furthermore, as plasticizers, phthalates are only loosely bound in the polymer matrix; thus they slowly offgas into the environment over the lifetime of a plasticizer-containing product (evidence of which is the plastic becoming brittle over time). Phthalate esters are among compounds considered to be EDCs.

Airborne phthalate concentrations in residential environments have been reported previously; those in the present work may represent the first reported for office environments (see Table 12). Indoor air concentrations are available from Rudel et al. (2003) and Fromme et al. (2004), and are summarized in Weschler and Nazaroff (2008). Comparison to previous results indicates that phthalate concentrations in the various office locations in the EPA Region VIII building are in general on the lower end of the ranges reported for other indoor environments. This may indicate that the selection of building materials to meet LEED standards has resulted in smaller amounts of plasticizers being introduced into the built environment. In only three instances were phthalates found at concentrations above a benchmark study's medians, and in two such instances, the exceedances were in the copy room: butyl benzyl phthalate (BBP) at $70 \mathrm{ng} / \mathrm{m}^{3}$, and di(2-ethylhexyl)phthalate (DEHP) at $170 \mathrm{ng} / \mathrm{m}^{3}$. Offgassing of phthalates from copy equipment is a potential source for these elevated concentrations (see, for instance, Destaillats et al., 2008). Minimizing DEHP in the built environment - for instance, in PVC flooring materials - is also important given that it may hydrolyze under basic conditions to form 2-ethyl-1-hexanol, which is an odor nuisance and potentially one of the many causes of SBS (Sakai et al., 2009). It is unknown at the present time what caused the elevated level of dibutyl phthalate in the outdoor air.

The BDEs are typically used as flame retardants in office furniture such as polyurethane foam cushions and polymer enclosures for personal computers. The Penta BDE mixture, one of the most popular commercially available formulations for treatment of polyurethane foam, is composed primarily of tetra- to hexa-brominated congeners such as BDE 47 (2,2',4,4'-tetrabromodiphenyl ether), BDE 99 (2,2',4,4',5-pentabromodiphenyl ether), and BDE 100 (2,2',4,4',6-pentabromodiphenyl ether), and is primarily BDE 47 $(\sim 40 \%)$ and BDE 99 ( 46\%) (Allen et al., 2007). OctaBDE and DecaBDE products are mainly used in electronics; DecaBDE is composed wholly of the fully brominated congener, BDE 209. Studies in animals have shown that BDEs are endocrine disrupters, and very recently studies have shown that exposure to BDEs leads to adverse health effects in humans such as hormone problems and low birth weights (Stapleton et al., 2009, and references therein).

These compounds were detected only at low levels in the indoor air samples, and in many instances concentrations were not above the relatively modest detection limits that can be achieved by only sampling several cubic meters of air (See Table 12). In general, the 
BDEs are found at low concentrations in air primarily because they preferentially partition to surfaces and dust, rather than remain airborne. Weschler and Nazaroff (2008) have reviewed and presented summaries of BDE indoor air measurements, which have only been performed in the past decade. In two instances, the concentrations of BDE 47 (in Office 2) and BDE 99 (in Office 4) at the EPA Region VIII building exceeded the median concentration of BDEs in benchmark studies (Harrad et al., 2004 and Allen et al., 2007). Such concentrations could be indicative of the presence of office equipment treated with a BDE-containing flame retardant. BDE 209 was not detected in this study.

Table 13. PAH Concentrations Compared to BASE and Other Benchmark Data $\left(\mathbf{n g} / \mathbf{m}^{3}\right)$

\begin{tabular}{|c|c|c|c|c|c|c|c|c|}
\hline \multirow{2}{*}{ Compound } & \multirow{2}{*}{ DL } & \multicolumn{6}{|c|}{ Location } & \multirow{2}{*}{ Benchmark Data (reference } \\
\hline & & Roof & $\mathbf{C R}$ & 01 & $\mathrm{O} 2$ & O3 & O4 & \\
\hline Naphthalene & 0.03 & 147 & 301 & 252 & 338 & 271 & 348 & $\leq \mathrm{LOQ}^{\mathrm{a}}, 730^{\mathrm{b}}, 2600^{\mathrm{c}}(1)$ \\
\hline Biphenyl & 0.07 & 14 & 29 & 25 & 25 & 23 & 24 & d \\
\hline Acenaphthylene & 0.07 & 1.5 & 1.9 & 0.34 & 1.3 & 1.7 & 1.0 & d \\
\hline Acenaphthene & 0.07 & 23 & 21 & 17 & 20 & 22 & 18 & d \\
\hline Fluorene & 0.07 & 30 & 27 & 27 & 24 & 23 & 22 & $\mathrm{~d}$ \\
\hline Phenanthrene & 0.04 & 81 & 36 & 27 & 26 & 34 & 25 & $13^{\mathrm{e}}-330^{\mathrm{f}} ; 33^{\mathrm{g}}(2)$ \\
\hline Anthracene & 0.04 & 0.60 & 0.32 & 0.28 & 0.78 & 1.2 & $<\mathrm{DL}$ & $<1^{\mathrm{e}}-3.7^{\mathrm{e}} ;<1^{\mathrm{h}}(3)$ \\
\hline Fluoranthene & 0.04 & 19 & 8.3 & 0.91 & 2.4 & 5.0 & 0.73 & $\mathrm{~d}$ \\
\hline Pyrene & 0.04 & 7.9 & 7.3 & 0.71 & 2.1 & 3.8 & 0.38 & $<1^{\mathrm{e}}-3.4^{\mathrm{f}} ;<1^{\mathrm{h}}(3)$ \\
\hline Benzo(a)anthracene & 0.05 & $<\mathrm{DL}$ & 4.8 & $<\mathrm{DL}$ & 0.32 & 1.5 & $<\mathrm{DL}$ & d \\
\hline Chrysene & 0.05 & 0.35 & 4.1 & $<\mathrm{DL}$ & 0.21 & 1.4 & $<\mathrm{DL}$ & $\mathrm{d}$ \\
\hline Benzo(b)fluoranthene & 0.09 & $<\mathrm{DL}$ & 4.5 & $<\mathrm{DL}$ & $<\mathrm{DL}$ & 2.1 & $<\mathrm{DL}$ & d \\
\hline Benzo(k)fluoranthene & 0.09 & $<\mathrm{DL}$ & 2.5 & $<\mathrm{DL}$ & 0.10 & 1.6 & $<\mathrm{DL}$ & d \\
\hline Benzo(e)pyrene & 0.09 & $<\mathrm{DL}$ & 3.8 & $<\mathrm{DL}$ & $<\mathrm{DL}$ & 2.1 & $<\mathrm{DL}$ & d \\
\hline Benzo(a)pyrene & 0.09 & 0.85 & 3.8 & $<\mathrm{DL}$ & 0.35 & 1.6 & $<\mathrm{DL}$ & $0.0055^{\mathrm{e}}-0.23^{\mathrm{f}} ; 0.055^{\mathrm{g}}(2)$ \\
\hline Dibenzo (a,h)anthracene & 0.08 & $<\mathrm{DL}$ & 0.54 & $<\mathrm{DL}$ & $<\mathrm{DL}$ & 0.21 & $<\mathrm{DL}$ & d \\
\hline Indeno(1,2,3-cd)pyrene & 0.08 & $<\mathrm{DL}$ & 3.1 & $<\mathrm{DL}$ & 0.14 & 1.3 & $<\mathrm{DL}$ & $\mathrm{d}$ \\
\hline Benzo(ghi)pyrelene & 0.08 & $<\mathrm{DL}$ & 3.7 & $<\mathrm{DL}$ & 0.11 & 2.3 & $<\mathrm{DL}$ & d \\
\hline$\Sigma \mathrm{PAH}^{\mathrm{i}}$ (incl napthalene) & $\mathrm{NA}$ & 325 & 463 & 351 & 441 & 399 & 439 & $22^{e}-350^{f}(2)$ \\
\hline$\Sigma \mathrm{PAH}^{\mathrm{i}}$ (w/o napthalene) & $\mathrm{NA}$ & 178 & 162 & 99 & 103 & 128 & 91 & $2^{\mathrm{e}}-147^{\mathrm{f}} ; 30^{\mathrm{h}}(4)$ \\
\hline
\end{tabular}

a,b,c BASE $5^{\text {th }}, 50^{\text {th }}$ (median), and $95^{\text {th }}$ percentile data, respectively.

dData for all individual PAHs not provided here; they are available elsewhere, i.e. references (2) and (4) below.

eMinimum, ${ }^{\mathrm{f}}$ maximum, ggeometric mean, ${ }^{\mathrm{h}}$ median.

${ }^{\mathrm{i}} 1 / 2$ DL substituted for non-detects to calculate $\Sigma \mathrm{PAH}$; thus this sum is an upper bound.

(1) BASE data are available at http://www.epa.gov/iaq/base/voc master list.html (EPA, 2006).

(2) Naumova et al., 2002; data from residences in Elizabeth, NJ.

(3) Rudel et al., 2003; data from residences.

(4) Li et al., 2005; data from Chicago residences.

Concentrations of polycylic aromatic hydrocarbons (PAHs) are given in Table 13. PAHs are byproducts of incomplete combustion of all variety of organic matter, including gasoline, diesel fuel, coal, and wood. Indoor sources relevant to modern office environments include transport from outdoors through open windows or the building ventilation system, boiler/heating operations, and potentially from the resuspension of particles generated from 
office equipment (Naumova et al., 2002; Ren et al., 2006). Many of the PAHs are known, probable, or possible human carcinogens (Li et al., 2005).

PAHs in Table 12 are given in order of decreasing volatility. As volatility decreases, airborne concentrations should decrease, and the indoor PAH concentrations measured follow this generate trend. Naphthalene concentrations are the highest of all the PAHs, consistent with its high volatility. In addition, naphthalene concentrations are higher indoors than outdoors, indicating an indoor source for this compound. Considering the identity of a potential indoor source for naphthalene leads to discussion of perhaps the most striking feature of the PAH data in Table 12: the elevated concentration of PAHs found in the Copy Room. For instance, in the Copy Room, total PAH concentrations $(\Sigma \mathrm{PAH})$, with and without naphthalene, and of pyrene and benzo[a]pyrene, are higher than the maxima measured in benchmark studies. Furthermore, the concentration of benzo[a]pyrene in the Copy Room is an order of magnitude higher than the maximum concentration observed in Elizabeth, NJ, residences by Naumova et al. (2002), and is similar to the maximum concentration found in Chicago homes by Li et al. (2005). Emissions from copy room equipment may be responsible for the elevated PAHs concentrations (Ren et al., 2006); however, no study has been performed to quantify PAH emissions from office equipment (Destaillats et al., 2008).

Table 14. SVOC Concentrations Compared to BASE and Other Benchmark Data $\left(\mathrm{ng} / \mathrm{m}^{3}\right)$

\begin{tabular}{|c|c|c|c|c|c|c|c|c|}
\hline \multirow{2}{*}{ Compound } & \multirow{2}{*}{ DL } & \multicolumn{6}{|c|}{ Location } & \multirow{2}{*}{$\begin{array}{c}\text { Benchmark Data } \\
\text { (reference) }\end{array}$} \\
\hline & & Roof & CR & O1 & $\mathrm{O} 2$ & O3 & O4 & \\
\hline \multicolumn{9}{|l|}{ Pesticides } \\
\hline cis-permethrin & 0.08 & 0.43 & $<\mathrm{DL}$ & $<\mathrm{DL}$ & $<\mathrm{DL}$ & $<\mathrm{DL}$ & $<\mathrm{DL}$ & $<1^{\mathrm{a}}-3.7^{\mathrm{b}} ;<1^{\mathrm{c}}(1)$ \\
\hline trans-permethrin & 0.08 & 0.55 & 0.08 & $<\mathrm{DL}$ & 0.08 & $<\mathrm{DL}$ & 0.08 & $<1^{\mathrm{a}}-5.4^{\mathrm{b}} ;<1^{\mathrm{c}}(1)$ \\
\hline Sumithrin & 0.08 & $<\mathrm{DL}$ & $<\mathrm{DL}$ & $<\mathrm{DL}$ & $<\mathrm{DL}$ & $<\mathrm{DL}$ & $<\mathrm{DL}$ & $\mathrm{NA}^{\mathrm{d}}$ \\
\hline \multicolumn{9}{|c|}{ Fragrance Compounds } \\
\hline Limonene & 0.13 & 42 & 2323 & 2086 & 2774 & 2598 & 2155 & $1100^{\mathrm{e}}, 7100^{\mathrm{f}}, 44000^{\mathrm{g}}(2)$ \\
\hline Carvone & 1.3 & 5.0 & 78 & 69 & 74 & 76 & 81 & $\mathrm{~h}$ \\
\hline cis-limonene oxide & 0.65 & 41 & 230 & 222 & 241 & 244 & 217 & $\mathrm{~h}$ \\
\hline trans-limonene oxide & 0.65 & 24 & 127 & 115 & 139 & 141 & 113 & $\mathrm{~h}$ \\
\hline Benzyl acetate & 6.5 & $<\mathrm{DL}$ & 70 & 103 & 60 & 90 & 61 & $\mathrm{NA}^{\mathrm{d}}$ \\
\hline Hexyl cinnemal & 0.04 & $<\mathrm{DL}$ & 53 & 90 & 74 & 61 & 63 & $\mathrm{NA}^{\mathrm{d}}$ \\
\hline Phenethyl alcohol & 13 & $<\mathrm{DL}$ & $<\mathrm{DL}$ & $<\mathrm{DL}$ & 82 & 109 & $<\mathrm{DL}$ & $\mathrm{NA}^{\mathrm{d}}$ \\
\hline AHTN & 0.04 & 0.20 & 3.7 & 23 & 5.1 & 5.0 & 4.4 & $\begin{array}{l}44^{\mathrm{c}}-107^{\mathrm{b}}(3) \\
0.6^{\mathrm{a}}-13.4^{\mathrm{b}}(4)\end{array}$ \\
\hline HHCB & 0.04 & 0.21 & 45 & 467 & 43 & 62 & 40 & $\begin{array}{c}15^{\mathrm{a}}-299^{\mathrm{b}} ; 101^{\mathrm{c}}(3) \\
2.5^{\mathrm{a}}-44.3^{\mathrm{b}}(4)\end{array}$ \\
\hline \multicolumn{9}{|c|}{ Other Semivolatile Compounds } \\
\hline PCB 11 & 0.03 & $<\mathrm{DL}$ & 0.33 & 0.55 & 0.37 & 0.75 & 0.30 & $\mathrm{NA}^{\mathrm{d}}$ \\
\hline PCB 52 & 0.04 & 0.07 & 0.31 & 0.25 & 0.16 & 0.14 & $<\mathrm{DL}$ & $\begin{array}{c}<1^{\mathrm{a}}-25^{\mathrm{b}} ;<1^{\mathrm{c}}(1) \\
0.154^{\mathrm{a}}-14.8^{\mathrm{b}}(5)\end{array}$ \\
\hline $\begin{array}{l}4,4 \text { 'methylene bis } \\
\text { (o-chloroaniline) }\end{array}$ & 0.38 & $<\mathrm{DL}$ & $<\mathrm{DL}$ & $<\mathrm{DL}$ & $<\mathrm{DL}$ & $<\mathrm{DL}$ & $<\mathrm{DL}$ & $80,000(6)$ \\
\hline
\end{tabular}




\begin{tabular}{|l|r|r|r|r|r|r|r|c|}
\hline $\begin{array}{l}\text { Tris(2-chloroethyl) } \\
\text { Phosphate (TCEP) }\end{array}$ & 0.26 & 0.77 & 5.6 & 2.1 & 4.6 & 12 & 0.91 & $\begin{array}{c}6.1^{\mathrm{a}}-56^{\mathrm{b}}(7) \\
<5^{\mathrm{a}}-6000^{\mathrm{b}} ; 10^{\mathrm{c}}(8)\end{array}$ \\
\hline $\begin{array}{l}\text { Tris(1,3-dichloro-2- } \\
\text { propyl) phosphate } \\
\text { (TDCPP) }\end{array}$ & 0.08 & 0.21 & 0.23 & 2.0 & 1.1 & 0.48 & 0.34 & $\mathrm{NA}^{\mathrm{i}}$ \\
\hline
\end{tabular}

${ }^{a}$ Minimum, bmaximum, ${ }^{\mathrm{c}}$ median.

dTypical indoor air concentration has not been measured or is not available in the published literature.

e,f,gBASE $5^{\text {th }}, 50^{\text {th }}$ (median), and $95^{\text {th }}$ percentile data, respectively.

hIndoor air concentrations of these limonene oxidation products measured as part of recently completed study conducted

by Battelle. We are currently awaiting client permission to share these results.

${ }^{\mathrm{i} C o n c e n t r a t i o n s ~ h a v e ~ n o t ~ b e e n ~ m e a s u r e d ~ i n ~ a i r, ~ b u t ~ a r e ~ a v a i l a b l e ~ f o r ~ h o u s e ~ d u s t ; ~ s e e ~ S t a p l e t o n ~ e t ~ a l . ~(2009) . ~}$

(1) Rudel et al., 2003; data from residences.

(2) BASE data are available at http://www.epa.gov/iaq/base/voc master_list.html (EPA, 2006).

(3) Fromme et al., 2004; data from kindergartens.

(4) Kallenborn and Gatermann, 2004; data from various indoor locations.

(5) Currado and Harrad, 1998; data for office environments.

(6) OSHA 8-h workday Permissible Exposure Limit (PEL)

(7) Hartmann et al., 2004; data from office environments.

(8) Ingerowski et al., 2001; various indoor locations sampled.

Concentrations of numerous different additional SVOCs are given in Table 14.

Permethrin and sumithrin are synthetic pyrethroid pesticides used for indoor insect

control. These pesticides were only found indoors right at or below the detection limit of $\sim 0.08 \mathrm{ng} / \mathrm{m}^{3}$; these low concentrations are consistent with those measured by Rudel et al. (2003). Airborne pesticide contamination does not appear to be a problem in this building, although given the low volatility of these pyrethroid pesticides, it is more likely for them to be adhered to surfaces and dust. Concentrations of SVOCs adhered to interior surfaces and associated with settled dust were not measured in the present work.

Concentrations of limonene fall between the $5^{\text {th }}$ and $50^{\text {th }}$ percentiles of concentrations measured in indoor spaces in the BASE study. Limonene is found in a wide variety of fragranced consumer products and reacts with ozone indoors to form various irritant species (e.g., Wolkoff et al., 2006) that can cause degradation in perceived indoor air quality (Tamas et al., 2006). Such reaction products include cis- and trans-limonene oxide and carvone (Uhde and Salthammer, 2007). Benzyl acetate, hexyl cinnemal, and phenethyl alcohol are also found in fragranced consumer products and essential oils; hexyl cinnemal may undergo similar indoor chemistry as limonene. Concentrations for these various fragrance compounds and reaction products are low (sub parts per billion by volume), but indoor concentrations are higher than outdoor concentrations. As such, indoor sources such as volatilization from consumer products and indoor air chemistry are the most likely sources for these compounds.

To the best of our knowledge, this study is the first to measure the three limonene oxidation products and three other fragrance compounds in indoor air in occupied buildings. We have also measured concentrations of the three limonene reaction products in another indoor environment as part of a Battelle-funded independent research program; the results are roughly comparable. These results will be made known if permission of the owner of the indoor space is granted. 
The compounds AHTN (7-acetyl-1,1,3,4,4,6-hexamethyl-1,2,3,4-tetrahydronapthalene; Tonalide $\AA)$ and HHCB (1,3,4,6,7,8-hexahydro-4,6,6,7,8,8-hexamethylcyclopenta[g]-2benzopyran; Galaxolide $\AA$ ) are synthetic musk fragrances found in numerous household and personal care products and cleaning agents. Their toxicological properties are not fully known, although these compounds may affect human health (Fromme et al., 2004). Outdoor concentrations reported here are similar to those measured in other urban areas (Peck and Hornbuckle, 2006). Indoor concentrations are one to three orders of magnitude greater, indicating strong indoor sources for these compounds. Such sources may include laundry detergents, deodorants, and perfumes. AHTN concentrations were below the median found by Fromme et al. (2004). HHCB concentrations are in general greater than AHTN; both were highest in Office 1, and the concentration of HHCB in Office 1 was higher than the maximum concentration reported by Fromme et al. (2004). This office remained occupied during sampling, and offgassing of AHTN and HHCB from personal care products worn by the office occupant may be responsible for the elevated concentrations of these synthetic musk fragrances.

In general, minimizing the concentrations of fragrance compounds will lead to fewer potential indoor air quality problems. Preventing occupants from using fragranced personal care products is not feasible, but intelligent choices of cleaning products and enhanced ventilation and ozone removal during cleaning are possible methods for reducing concentrations of reactive and potentially irritant reaction byproduct species indoors.

The most important remaining SVOCs to discuss, based on concentrations measured, are the organophosphate flame retardants tris(2-chloroethyl)phosphate (TCEP) and tris(1,3dichloro-2-propyl)phosphate (TDCPP). As the Penta- and Octa-BDE flame retardants are phased out (they were banned or removed voluntarily from use in many countries worldwide beginning in 2002), alternative flame retardants for polyurethane foams such as TCEP and TDCPP have become more prevalent (Stapleton et al., 2009). These compounds also function as plasticizers and additives in textiles, paints, and certain wallpapers (Ingerowski et al., 2001). Some research suggests that organophosphates such as TCEP may be neurotoxic and carcinogenic (Hartmann et al., 2004, and references therein). Furthermore, hydrolysis of TDCPP forms the VOC 1,3-dichloro-2-propanol, a carcinogen (Uhde and Salthammer, 2007).

Indoor air concentrations of TCEP measured in the EPA Region VIII office building were in general similar to those found in other studies: concentrations were on the low end of those measured by Hartmann et al. (2004) and Ingerowski et al. (2001). Only the concentration in Office 3 exceeded the median found by Ingerowski et al. (2001). This study appears to be the first to report TDCPP concentrations in air; others such as Stapleton et al. (2009) have reported TDCPP concentrations in dust. As with many other species measured here, minimizing indoor concentrations of these organophosphate flame retardants may be important for maintaining the long-term health of building occupants. 


\section{Summary}

In general, the various IEQ parameters measured during this limited study at the EPA Region VIII LEED Gold office building were within the ranges of applicable standards and were similar to the results of measurements in other indoor spaces, with the exception of PAH concentrations in the copy room. Furthermore, no immediate and acute indoor environmental quality problems were identified in this short-term IEQ investigation, although it is not feasible nor was it attempted to measure every possible irritant compound or perform measurements in every possible indoor space.

This study did not formally assess the human exposure or health risks associated to the occupants of this building, nor did it intend to. However, steps can still be taken from a precautionary standpoint to ensure the overall long-term health of building occupants, given that concentrations of various compounds of known or potential concern were present indoors at elevated concentrations compared to outdoors. A broad recommendation for IEQ improvement is to minimize, through source control and filtration, the indoor concentrations of $\mathrm{PM}, \mathrm{O}_{3}$, and harmful and potentially harmful VOCs and SVOCs.

Results of the various measurements are summarized below.

- Temperature and Relative Humidity - All measurements were within ASHRAE occupant comfort range for the combination of temperature and relative humidity; several temperature measurements were above the optimal levels for worker performance $\left(20-23^{\circ} \mathrm{C}\right)$ reported by Seppänen and Fisk.

- Carbon Dioxide - All measurements were within ASHRAE, ACGIH, and OSHA limits for indoor concentrations. Indoor concentrations were elevated between 180 and $300 \mathrm{ppm}$ above outdoor concentrations, but fall within the recommendation that indoor concentrations of $\mathrm{CO}_{2}$ not exceed outdoor concentrations by more than $650 \mathrm{ppm}$.

- Ozone - indoor/outdoor ozone ratios were on the low end of ratios measured in indoor environments. All indoor concentrations were less than $30 \mathrm{ppb}$, which is less than half of the 8 hour NAAQS for outdoor ambient ozone.

- $\quad \mathbf{P M}_{10}$ - Indoor particulate matter concentrations were all less than $25 \mu \mathrm{g} / \mathrm{m}^{3}$, which is below the LEED new construction standard as well as lower than ambient outdoor levels.

- Sound Level - Sound level measurements in the indoor spaces did not exceed normal conversation levels of 60-70 dBa.

- Fungi - Concentrations of fungal spores were very low indoors (all indoor measurements were below 100 spores $/ \mathrm{m}^{3}$ ) and below levels of concern for indoor air $\left(1000\right.$ spores $\left./ \mathrm{m}^{3}\right)$.

- VOCs - Indoor formaldehyde $\left(20-26 \mu \mathrm{g} / \mathrm{m}^{3}\right)$ concentrations were greater than the outdoor concentration $\left(5.3 \mu \mathrm{g} / \mathrm{m}^{3}\right)$ but still less than indoor air quality guidelines (the LEED new construction standard is $64.1 \mu \mathrm{g} / \mathrm{m}^{3}$ ); ethanol $\left(133-217 \mu \mathrm{g} / \mathrm{m}^{3}\right.$ ) and acetone (46-79 $\mu \mathrm{g} / \mathrm{m}^{3}$ ) were detected at elevated concentrations due to human 
activity in the occupied building; HAPs 2-butanone $\left(6.8-11 \mu \mathrm{g} / \mathrm{m}^{3}\right)$, toluene $(7.3$ $\left.13 \mu \mathrm{g} / \mathrm{m}^{3}\right)$, and hexane $\left(2.5-3.7 \mu \mathrm{g} / \mathrm{m}^{3}\right)$ were detected in the indoor air.

- SVOCs - Synthetic musks AHTN (3.7-23 ng/m $\left.{ }^{3}\right)$ and HHCB (40-467 ng/m $\left.{ }^{3}\right)$ were found in the indoor air with concentrations in one office approximately an order of magnitude higher than the other indoor locations. BDEs and phthalates were in general found at levels similar to those reported for other indoor environments. Limonene and its oxidation products, potential sensory irritants, were detected in the indoor samples, albeit at low concentrations. Samples collected from the copy room were found to have elevated concentrations of several PAHs (predominantly the lower volatility PAHs). Concentrations of PAHs found in the copy room were higher than have been measured in other indoor environments. It is recommended the source of these compounds be investigated.

\section{References}

Allen, J. G., M. D. McClean, et al. (2007). Personal Exposure to Polybrominated Diphenyl Ethers (PBDEs) in Residential Indoor Air. Environmental Science \& Technology 41(13): 4574-4579.

ASHRAE, 2004. ASHRAE Stanadard 55-2004 Thermal Environmetnal Conditions for Human Occupancy. American Society of Heating, Refrigerating, and Air-Conditioning Engineers, January 29, 2009.

Currado, G. M. and S. Harrad (1998). Comparison of Polychlorinated Biphenyl Concentrations in Indoor and Outdoor Air and the Potential Significance of Inhalation as a Human Exposure Pathway. Environmental Science \& Technology 32(20): 3043-3047.

Daisey, J.M, W.J. Angell, M.G. Apte, 2003. Indoor air quality, ventilation and health symptoms in schools: an analysis of existing information. Indoor Air, Volume 13, 5364, February, 2003.

Dawson, H.E. and T. McAlary (2009). A Compilation of Statistics for VOCs from Post1990 Indoor Air Concentration Studies in North American Residences Unaffected by Subsurface Vapor Intrusion. Ground Water Monitoring \& Remediation 29(1): 60-69.

Destaillats, Hugo et al., 2008. Indoor pollutants emitted by office equipment: A review of reported data and information needs. Atmospheric Environment 42 (2008) 1371-1388.

Eklund, B. M., S. Burkes, et al. (2008). Spatial and temporal variability in VOC levels within a commercial retail building. Indoor Air 18(5): 365-374.

EPA, 2006. Building Assessment Survey and Evaluation Study, Data on Indoor Air Quality in Public and Commercial Buildings Data CD. EPA 402-C-06-002, January, 2006. 
Fenske, Jill D. and Suzanne E. Paulson, 1999. Human Breath Emissions of VOCs. Journal of the Air \& Waste Management Association, Volume 49, 594-598, May 1999.

Ferro, Andrea R. et al., 2004. Elevated personal exposure to particulate matter from human activities in a residence. Journal of Exposure Analysis and Environmental Epidemiology, Volume 14, S34-S40.

Finlayson-Pitts, Barbara J. and James N. Pitts, 2000. Chemistry of the Upper and Lower Atmosphere: Theory, Experiments and Applications. Academic Press, San Diego.

Fromme, H. et al., 2004. Occurrence of phthalates and musk fragrances in indoor air and dust from apartments and kindergartens in Berlin (Germany). Indoor Air, Volume 14, 188-195.

Harrad, S., R. Wijesekera, et al. (2004). Preliminary Assessment of U.K. Human, Dietary and Inhalation Exposure to Polybrominated Diphenyl Ethers. Environmental Science \& Technology 38(8): 188-195.

Hartmann, P. C., D. Bürgi, et al. (2004). Organophosphate flame retardants and plasticizers in indoor air. Chemosphere 57(8): 781-787.

Ingerowski, G., A. Friedle, et al. (2001). Chlorinated Ethyl and Isopropyl Phosphoric Acid Triesters in the Indoor Environment: An Inter-Laboratory Exposure Study. Indoor Air 11(3): 145-149.

Jia, C., S. Batterman, et al. (2008). VOCs in industrial, urban and suburban neighborhoods, Part 1: Indoor and outdoor concentrations, variation, and risk drivers. Atmospheric Environment 42(9): 2083-2100.

Jones, A. P. (1999). Indoor air quality and health. Atmospheric Environment 33(28): 4535-4564.

Kallenborn, R. and R. Gatermann (2004). Syntheric Musks in Ambient and Indoor Air. The Handbook of Environmental Chemistry. 3X: 85-104.

LEED, 2005. Leadership in Energy and Environmental Design for New Construction Reference Guide. Version 2.2, First Edition, October 2005.

Li, A., T. M. Schoonover, et al. (2005). Polycyclic aromatic hydrocarbons in residential air of ten Chicago area homes: Concentrations and influencing factors. Atmospheric Environment 39(19): 3491-3501.

Liu, W., J. Zhang, et al. (2006). Estimating contributions of indoor and outdoor sources to indoor carbonyl concentrations in three urban areas of the United States. Atmospheric Environment 40(12): 2202-2214. 
Naumova, Y.Y., S. J. Eisenreich, et al. (2002). Polycyclic Aromatic Hydrocarbons in the Indoor and Outdoor Air of Three Cities in the U.S. Environmental Science \& Technology 36(12): 2552-2559.

New York State Department of Health, "Guidance for Evaluatiing Soil Vapor Intrusion in the State of New York," Appendix C, "Volatile organic chemicals in air - summary of background databases." October 2006. Available at http://www.health.state.ny.us/environmental/investigations/soil_gas/svi/guidance/ accessed October 17, 2009.

Peck, Aaron M. and Keri C. Hornbuckle, 2006. Synthetic musk fragrances in urban and rural air of Iowa and the Great Lakes. Atmospheric Environment, Volume 40, 61016111.

Ren, Y., Cheng, T., Chen, J. (2006). Polycyclic aromatic hydrocarbons in dust from computers: one possible indoor source of human exposure. Atmospheric Environment 40: 6956-6965.

Rudel, R. A., D. E. Camann, et al. (2003). Phthalates, Alkylphenols, Pesticides, Polybrominated Diphenyl Ethers, and Other Endocrine-Disrupting Compounds in Indoor Air and Dust. Environmental Science \& Technology 37(20): 4543-4553.

Sakai, K., M. Kamijima, et al. (2009). Annual transition and seasonal variation of indoor air pollution levels of 2-ethyl-1-hexanol in large-scale buildings in Nagoya, Japan. Journal of Environmental Monitoring. DOI: 10.1039/b910558a.

Seaman, V. Y., D. H. Bennett, et al. (2007). Origin, Occurrence, and Source Emission Rate of Acrolein in Residential Indoor Air. Environmental Science \& Technology 41(20): 6940-6946.

Seppänen, Olli A. and William Fisk, 2006. Some Quantitative Relations between Indoor Environmental Quality and Work Performance or Health. HVAC\&R Research, Volume 12, 957-973, October 2006.

Spicer, Chester W. et al., 2002. Hazardous Air Pollutants Handbook: Measurement, Properties, and Fate in Ambient Air. Lewis Publishers, Boca Raton.

Stapleton, H. M., S. Klosterhaus, et al. (2009). Detection of Organophosphate Flame Retardants in Furniture Foam and US House Dust. Environmental Science \& Technology 43(19): 7490-7495.

Tamas, G., C. J. Weschler, et al. (2006). Influence of ozone-limonene reactions on perceived air quality. Indoor Air 16(3): 168-178. 
Uhde, E. and T. Salthammer (2007). Impact of reaction products from building materials and furnishings on indoor air quality - A review of recent advances in indoor chemistry. Atmospheric Environment 41(15): 3111-3128.

Weschler, Charles J., 2000. Ozone in Indoor Environments: Concentration and Chemistry. Indoor Air, Volume 10, 269-288, April 2000.

Weschler, Charles J., 2006. Ozone's Impact on Public Health: Contributions from Indoor Exposures to Ozone and Products of Ozone-Initiated Chemistry. Environmental Health Perspectives, Volume 114, Number 10, 1489-1496, October 2006.

Weschler, Charles J. and William W. Nazaroff, 2008. Semivolatile organic compounds in indoor environments. Atmospheric Environment, Volume 42, 9018-9040.

Wolkoff, P. et al., 2005. Organic compounds in office environments - sensory irritation, odor, measurements and the role of reactive chemistry. Indoor Air, Volume 16, 7-19, September, 2005.

Wu, P.-C. et al., 2004. Changing microbial concentrations are associated with ventilation performance in conditioned office buildings. Indoor Air, Volume 15, 19-26, October, 2004. 


\section{Appendix H: Conversion Factors}

\section{Volume Conversions ${ }^{38}$}

Water:

1 cubic feet $=7.48052$ gallons

1 cubic meter $=264.172$ gallons

Dry:

1 cubic yard $=27$ cubic feet

\section{Energy Utility Conversions}

Electricity:

$1 \mathrm{kwh}=3,413 \mathrm{Btu}$

Natural Gas:

1 cubic feet average $=1000 \mathrm{Btu}$

$1 \operatorname{ccf}=100$ cubic feet

$1 \mathrm{mcf}=1000$ cubic feet

1 gigajoule $=948$ cubic feet

1 therm $=100,000 \mathrm{Btu}$

1 decatherm $=10$ therms

Steam:

$1 \mathrm{lb}$. steam $=1,000 \mathrm{Btu}$

Chilled Water:

1 ton hour of chilled water $=12,000 \mathrm{Btu}$

\section{Material Conversions ${ }^{39}$}

Municipal Solid Waste:

1 cubic yard $=450$ pounds

Recycled Computer Paper:

1 cubic yard $=655$ pounds

\section{Monetary Conversions}

For purposes of this study, Canadian and American dollars were estimated to be at par.

Currency Exchange: $\quad 1$ U.S. $\$=1 \mathrm{CDN} \$$ 


\section{Appendix l: Building Contacts}

Many GSA and leased building site personnel assisted the PNNL research team with this study. The following is a list, in alphabetical order, of those that contributed time and data.

\begin{tabular}{|c|c|}
\hline \multirow[t]{2}{*}{ Laura Anderson } & Assistant Property Manager - JBG Companies \\
\hline & Rockville FB \\
\hline \multirow[t]{2}{*}{ Paul Anderson } & Senior Property Manager, Iowa Office \\
\hline & Davenport CT \\
\hline \multirow[t]{2}{*}{ Danielle Bogni } & Environmental Protection Specialist - Region 9 \\
\hline & Las Vegas CT \\
\hline \multirow[t]{2}{*}{ Alex Bonaparte } & Lead Engineer - JBG Companies \\
\hline & Rockville FB \\
\hline \multirow[t]{2}{*}{ Jonathan Bringewatt } & Public Buildings Service \\
\hline & Lakewood DOT FB \\
\hline \multirow[t]{3}{*}{ Jim Brown } & Building Engineer - Cottonwood \\
\hline & Management Services \\
\hline & Ogden FB \\
\hline \multirow[t]{3}{*}{ Gina Carter } & Assistant Property Manager - Cottonwood \\
\hline & Management Services \\
\hline & Ogden FB \\
\hline \multirow[t]{2}{*}{ Stephen Casey } & Operations Manager - Enovity Inc. \\
\hline & San Francisco FB \\
\hline \multirow[t]{2}{*}{ Diana Ciryak } & Property Manager \\
\hline & Cleveland CT \\
\hline \multirow[t]{2}{*}{ Chris Cockrill } & Energy Coordinator - Region 6 \\
\hline & Cape Girardeau CT, Manhattan FB \\
\hline Pamela Coleman & $\begin{array}{l}\text { IRS Real Estate and Facilities Management } \\
\text { Ogden FB }\end{array}$ \\
\hline Scott Crews & $\begin{array}{l}\text { Cottonwood Management Services } \\
\text { Ogden FB }\end{array}$ \\
\hline Mike Daniels & $\begin{array}{l}\text { Facilities Representative } \\
\text { Rockville FB }\end{array}$ \\
\hline Tim Essebaggers & Property Manager \\
\hline
\end{tabular}




\begin{tabular}{|c|c|}
\hline & Seattle CT \\
\hline Dan Fenner & $\begin{array}{l}\text { Building Manager - Michigan Service Center } \\
\text { Sault Ste. Marie Port }\end{array}$ \\
\hline John Garner & $\begin{array}{l}\text { Lease Management Representative } \\
\text { Omaha NPS FB and Omaha DHS FB }\end{array}$ \\
\hline Christopher Grigsby & $\begin{array}{l}\text { Asset Management Services } \\
\text { Denver CT }\end{array}$ \\
\hline Angel Gonzalez & $\begin{array}{l}\text { Building Management Specialist } \\
\text { San Francisco FB }\end{array}$ \\
\hline Richard Gordon & $\begin{array}{l}\text { Building Management Specialist } \\
\text { Auburn FB }\end{array}$ \\
\hline Scott Hawkins & $\begin{array}{l}\text { Building Engineer -Urban/Meridian Joint } \\
\text { Venture } \\
\text { Greeneville CT and Knoxville FB }\end{array}$ \\
\hline Sue Heeren & $\begin{array}{l}\text { Public Buildings Service } \\
\text { Davenport CT }\end{array}$ \\
\hline Tina Hingorani & $\begin{array}{l}\text { Property Manager } \\
\text { Santa Ana FB }\end{array}$ \\
\hline Richard Hosey & $\begin{array}{l}\text { Property Manager } \\
\text { Jacksonville FB }\end{array}$ \\
\hline Jason Hunt & $\begin{array}{l}\text { Property Manager } \\
\text { Fresno CT \& FB }\end{array}$ \\
\hline Nicholas Infantino & $\begin{array}{l}\text { Property Manager } \\
\text { Youngstown CT \& FB }\end{array}$ \\
\hline Mary Ann Kosmicki & $\begin{array}{l}\text { Deputy Director - Nebraska Office } \\
\text { Omaha NPS FB and Omaha DHS FB }\end{array}$ \\
\hline Kristina Lee & $\begin{array}{l}\text { Senior Property Manager - Grubb \& Ellis } \\
\text { Omaha NPS FB }\end{array}$ \\
\hline Chris Litsey & $\begin{array}{l}\text { Building Management Specialist - Region } 9 \\
\text { Auburn FB, Eugene CT, Seattle CT }\end{array}$ \\
\hline Jill McCormick & $\begin{array}{l}\text { Asset Services - CBRE } \\
\text { Omaha DHS FB }\end{array}$ \\
\hline Donald Murphy & $\begin{array}{l}\text { Property Manager } \\
\text { Eugene CT }\end{array}$ \\
\hline William Murphy & Assistant Property Manager \\
\hline
\end{tabular}




\begin{tabular}{|c|c|}
\hline & Auburn FB \\
\hline Lorento Neequaye & $\begin{array}{l}\text { Assistant Building Manager } \\
\text { Suitland FB }\end{array}$ \\
\hline J. Michael Ortega & $\begin{array}{l}\text { Public Buildings Service } \\
\text { Denver CT }\end{array}$ \\
\hline Peter Pocius & $\begin{array}{l}\text { Property Manager, Montana Field Office } \\
\text { Sweetgrass Port }\end{array}$ \\
\hline Cheri Sayer & $\begin{array}{l}\text { Energy Manager - Region } 9 \\
\text { Auburn FB, Eugene CT, Seattle CT }\end{array}$ \\
\hline Sharon Schuler & $\begin{array}{l}\text { Building Manager - St. Louis Field Office } \\
\text { Cape Girardeau CT }\end{array}$ \\
\hline Wendy Schuman & $\begin{array}{l}\text { Property Manager - NorthMarq } \\
\text { Lakewood FB }\end{array}$ \\
\hline Warren Sitterley & $\begin{array}{l}\text { Deputy Property Manager } \\
\text { San Francisco FB }\end{array}$ \\
\hline Sandy Sitton & $\begin{array}{l}\text { Program Analyst } \\
\text { Fresno CT \& FB }\end{array}$ \\
\hline C. Johnathan Sitzlar & $\begin{array}{l}\text { Property Manager } \\
\text { Greeneville CT and Knoxville FB }\end{array}$ \\
\hline Amy Smith & $\begin{array}{l}\text { Property Manger - NorthMarq } \\
\text { Denver FB }\end{array}$ \\
\hline Don Smyth & $\begin{array}{l}\text { NPS Property Management \& } \\
\text { Office Services } \\
\text { Omaha NPS FB }\end{array}$ \\
\hline Mark Stanford & $\begin{array}{l}\text { Site Engineer - Public Works and } \\
\text { Government Services Canada } \\
\text { Sweetgrass Port }\end{array}$ \\
\hline Joni Teter & $\begin{array}{l}\text { Green Build Education \& EMS Coordinator - } \\
\text { EPA Region } 8 \\
\text { Denver FB }\end{array}$ \\
\hline Tim Trubey & $\begin{array}{l}\text { Property Manager - McCullough Development } \\
\text { Manhattan FB }\end{array}$ \\
\hline Steven Underhill & $\begin{array}{l}\text { Assistant Property Manager } \\
\text { Las Vegas CT }\end{array}$ \\
\hline Christopher Wentzell & Property Manager - Public Works and \\
\hline
\end{tabular}




\begin{tabular}{|ll} 
& \\
& Government Services Canada \\
& Sweetgrass Port \\
Stephen West & Property Manager - Cottonwood \\
& Management Services \\
& Ogden FB \\
Ryan Wilcoxen & Senior Building Engineer - NorthMarq \\
& Denver FB \\
Bruce Williams & Building Management Specialist \\
& Las Vegas CT \\
\end{tabular}




\section{Appendix J : References}

${ }^{1}$ Fowler, K.M. and E.M. Rauch. 2008. Assessing Green Building Performance: A Post Occupancy Evaluation of 12 GSA Buildings. PNNL-17393. Pacific Northwest National Laboratory, Richland, Washington. URL:

http://www.gsa.gov/gsa/cm attachments/GSA DOCUMENT/oaspublications R2mQC1 $0 Z 5 R D Z-i 34 K-p R . p d f$

${ }^{1}$ U.S. General Services Administration (GSA). 2009. Public Buildings Service. Accessed: March 2010.

http://www.gsa.gov/Portal/gsa/ep/contentView.do?contentId=8062\&content'Type=GSA OVERVIEW

${ }^{3}$ U.S. Green Building Council (USGBC). 2010. "Green Building, USGBC, and LEED." Accessed: March 2010. http://www.usgbc.org/showfile.aspx?DocumentID=1991

${ }^{4}$ GSA. 2004. GSA LEED ${ }^{\mathrm{TM}}$ Cost Study. Accessed: September 2007. http://www.wbdg.org/

${ }^{5}$ Heerwagen, J. 2001. Do Green Buildings Enhance the Well Being of Workers? Environmental Design+Construction. 3(4):24-30. Accessed August 2007.

http://www.edcmag.com/CDA/ArticleInformation/coverstory/BNPCoverStoryItem/0,41 $\underline{18,19794,00 . h t m l}$

${ }^{6}$ Matthiessen, LF. 2004. Examining the Cost of Green. Greenbuild 2004 International Conference and Expo Proceedings, Portland, Oregon.

http://www.dladamson.com/Attachment $\% 20$ Files/Research/The $\% 20$ full $\% 20$ report.pdf

${ }_{7}^{7}$ Matthiessen, LF and P Morris. 2007. The Cost of Green Revisited. Davis Langdon, San Diego,

California. http://www.davislangdon.com/USA/Research/ResearchFinder/2007-The-Costof-Green-Revisited/

${ }^{8}$ U.S. Department of Energy (DOE). 2003. The Business Case for Sustainable Design in Federal Facilities. Interagency Sustainability Working Group, Federal Energy Management Program (FEMP), Washington, DC.

http://www.eere.energy.gov/femp/techassist/sustainability.html\#business

${ }^{9}$ Torcellini, P, S Pless, M Deru, B Griffith, N Long, and R Judkoff. 2006. Lessons Learned from Case Studies of Six High-Performance Buildings. NREL/TP-550-37542. National Renewable Energy Laboratory (NREL), Golden, Colorado.

${ }^{10}$ Diamond, R, M Opitz, B Von Neida, and S Herrera. 2006. Evaluating the Energy Performance of the First Generation of LEED-Certified Commercial Buildings. Published in the Proceedings of the 2006 Summer Study on Energy Efficiency in Buildings, American Council for an Energy Efficient Economy, Washington DC, August, 2006. LBNL-59853. Accessed June 2007. http://epb.lbl.gov/homepages/Rick Diamond/LBNL59853-LEED.pdf

${ }^{11}$ Turner, C, M Frankel, and B Owens. 2007. "The Energy Performance of LEED Buildings.” USGBC Greenbuild Conference 2007, Chicago, Illinois.

${ }^{12}$ Turner, C, and M Frankel. 2008. Energy Performance of LEED for New Construction Buildings. New Buildings Institute, White Swan, Washington. http://www.newbuildings.org/downloads/Energy Performance of LEED-NC BuildingsFinal 3-4-08b.pdf 
${ }^{13}$ GSA. 2009. LEED Certified Projects. GSA website. Accessed: March 2010. http://www.gsa.gov/Portal/gsa/ep/channelView.do?pageTypeId $=17109 \&$ channelPage $=\%$ $2 \mathrm{Fep} \% 2 \mathrm{Fchannel} \% 2 \mathrm{FgsaO}$ verview.jsp\&channelId $=-24332$

${ }^{14}$ Fowler, KM, EM Rauch, AR Kora, JE Hathaway, AE Solana, and KL Spees. 2009. Whole Building Cost and Performance Measurement: Data Collection Protocol, Revision 2.0. PNNL-18325, Pacific Northwest National Laboratory, Richland, Washington.

http://www1.eere.energy.gov/femp/pdfs/pnn115217.pdf

${ }^{15}$ USGBC. 2008. "US Building Impacts.” US Green Building Council website. Accessed: May 2008. http://www.usgbc.org/DisplayPage.aspx?CMSPageID=1720 ${ }^{16}$ DOE FEMP. 2007. "Federal Water Use Indices website.” Accessed: May 2010. http://www1.eere.energy.gov/femp/program/waterefficiency useindices.html

${ }^{17}$ Energy Information Administration (EIA). 2007. Official Energy Statistics from the U.S. Government. Accessed: August 2007. http://www.eia.doe.gov/

${ }^{18}$ EIA. 2007. "Table C12. Consumption and Gross Energy Intensity by Year Constructed for Sum of Major Fuels for Non-Mall Buildings, 2003." Accessed: October 2007. http://www.eia.doe.gov/emeu/cbecs/contents.html ${ }^{19}$ IFMA. 2004. Benchmarks Research IV Report \#25. IFMA. Houston, Texas.

${ }^{20}$ IFMA. 2006. Operations and Management Benchmarkes \#26. IFMA. Houston, Texas.

${ }^{21}$ IFMA. 2007. Space and Project Management Benchmarks \#28. IFMA. Houston, Texas. ${ }^{22}$ BOMA International. 2006. International Experience Exchange Report: Special Studies 2005, Agency Managed, Downtown all sizes, U.S. Government Sector. BOMA International, Washington, DC.

${ }^{23}$ EIA. 2010. “State Ranking 12. Electricity Residential Prices, March 2010” Accessed: May 2010. http://tonto.eia.doe.gov/state/state energy rankings.cfm?keyid=18\&orderid=1 ${ }^{24}$ IFMA. 2004.

25 IFMA. 2006.

26 IFMA. 2007.

${ }^{27}$ BOMA International. 2006.

${ }^{28}$ IFMA. 2006.

${ }^{29}$ GSA. 2006. Innovative Workplaces: Benefits and Best Practices. GSA Office of Government-wide Policy Office of Real Property Management and Public Buildings Service Office of Applied Science, Washington, DC.

${ }^{30}$ CBE. 2008. GSA Public Buildings Service Web Survey Final Report. University of California Berkeley.

${ }^{31}$ Goins, J, E Arens, A Allbee, and N Walter (CBE), M Moezzi (Portland State University), W Austin (Johns Hopkins University), and A Joseph and C Quist (Center for Health Design Research). May 2010. “Occupant IEQ Survey Research Program.” Presentation. Center for the Built Environment, Berkeley, California.

${ }^{32}$ Environmental Building News. September 2007. "Driving to Green Buildings: The Transportation Energy Intensity of Buildings.” Accessed: October 30, 2007 http://www.buildinggreen.com/auth/article.cfm?filename=160901a.xml 
${ }^{34}$ DOE FEMP. 2007. “U.S. Department of Energy - Energy Efficiency and Renewable Energy Federal Energy Management Program - Water Efficiency.” Accessed: October 28, 2007 http://www1.eere.energy.gov/femp/water/water faqs.html

${ }^{35}$ DOE FEMP. 2007. “Federal Water Use Indices website.” Accessed: May 2010. http://www1.eere.energy.gov/femp/program/waterefficiency useindices.html

${ }^{36}$ McMordie Stoughton, KL Solana, AE Elliott, DB Sullivan, GP Parker, GB. 2005. Update of Market Assessment for Capturing Water Conservation Opportunities in the Federal Sector, PNNL15320 Pacific Northwest National Laboratory Richland, Washington.

${ }^{37}$ New Mexico Office of State Engineer. 1999. A Water Conservation Guide for Commercial, Institutional and Industrial Users. Albuquerque, New Mexico.

${ }^{38}$ Bell, AA, Jr.. 2000. HVAC Equations, Data, and Rules of Thumb. McGraw-Hill. Available at http://www.knovel.com/knovel2/Toc.jsp?BookID $=585 \&$ VerticalID $=0$

${ }^{39}$ EPA. 1997. Measuring Recycling: Standard Volume-to-Weight Conversion Factors. EPA530-R-97-011. http://www.epa.gov/epaoswer/non-

hw/recycle/recmeas/docs/guide b.pdf 